\title{
ĖRIKS JĒKABSONS
}

pIESARDZíGĀ dRAUdZíEA: Latvijas un Polijas attiecibas 1919. un 1920. gadā 
ĖRIKS JĒKABSONS

\section{PIESARDZĪGĀ DRAUDZĪBA: Latvijas un Polijas attiecíbas 1919. un 1920. gadā}

LU Akadēmiskais apgāds 
UDK $327(474.3+438)(091)$

Je 304

Grāmatas izdošanu finansiāli atbalstījusi

Latvijas Republikas Aizsardzības ministrija

Grāmatas autors Ēriks Jēkabsons dzimis 1965. gadā Rīgā. Beidzis LU (1990), vēstures doktors (1995), LU asociētais profesors (2006). Specializējies Latvijas Republikas politiskās un militārās vēstures jautājumu izpētē, Latvijas mazākumtautību, Baltijas valstu, Polijas, Baltkrievijas un Ukrainas vēsturē. Sarakstījis monogrāfijas "Poḷi Latvijā" (1996), "Lietuvieši Latvijā" (2003) un vairāk nekā 150 zinātnisku rakstu. Viens no biogrāfisko vārdnīcu “Latvijas armijas augstākie virsnieki 1918-1940" (1998), "Latvijas ārlietu dienesta darbinieki 1918-1991” (2003), "Latgaliešu politiķi un politiskās partijas neatkarīgajā Latvijā" (2006) sastādītājiem. Vairāku zinātnisku izdevumu redakcijas kolēgijas un Latvijas Vēsturnieku komisijas loceklis. Apbalvots ar Eiropas Zinātņu un mākslu akadēmijas "Felix" veicināšanas balvu un Polijas Zelta nopelnu krustu.

Literārā redaktore Ruta Puriṇa

Maketu un vāka dizainu veidojis Arnis Čakstiņš 


\section{Saturs}

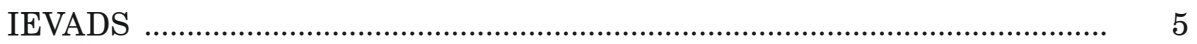

1. nodala

ATTIECİBU NODIBINĀŠANA (1919. gada marts-decembris) ..................... 21

Pirmie sakari f...................................................................................... 21

Militārā situācija Ilūkstes apriṇķ̣i 1919. gada augustā un septembrī ............. 34

Bermontiāde ............................................................................................... 41

Pastāvīgu attiecību nodibināšana ............................................................... 54

Militārās sadarbības līgums ............................................................................. 60

2. nodala

LATGALES ATBRĪVOŠANAS LAIKS (1920. gada janvāris-marts) ............. 71

Militārās operācijas norise .......................................................................... 71

Armiju sadarbība un apgāde operācijas laikā ................................................. 92

Poḷu karaspēks Latgalē un tā attiecības ar Latvijas iestādēm ....................... 97

Starptautiskā reakcija un Latvijas-Polijas starpvalstu attiecības................... 117

Varšavas konference un tās sekas .................................................................... 135

Latvijas un Polijas saimniecisko sakaru un satiksmes nodibināšana.

Bēg̣̣u un gūstekṇu atgriešanās no Polijas .................................................. 142

3. nodala

ATTIECĪBU SAREŽG̣ĪŠANĀS (1920. gada marts-jūnijs) ........................... 149

Polijas karaspēka lielākās daḷas izvešana no Latgales ................................... 149

Politiskās attiecības pēc Varšavas konferences neveiksmes .......................... 156

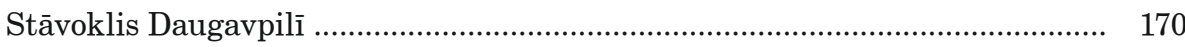


4. nodala

SAREŽĢ̄TITIE NOTIKUMI 1920. GADA OTRAJĀ PUSĒ UN LATVIJAS

ATZĪŠANA „DE IURE” (1920. gada jūlijs-1921. gada janvāris) ..................... 177

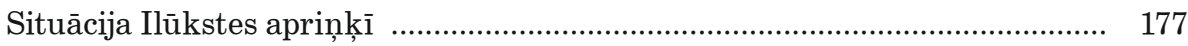

Starpvalstu attiecības reǵionā poḷu-padomju kara notikumu iespaidā ........... 183

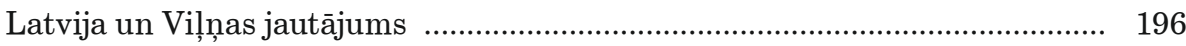

Latvijas starptautiskā atzīšana "de iure" .................................................... 208

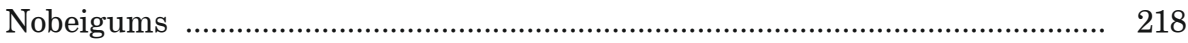

Avoti un literatūra ................................................................................. 223

Personu rāditājs ........................................................................................... 232 


\section{IEVADS}

Pirmā pasaules kara beigās, pakāpeniski sabrūkot impērijām - Krievijai, Austroungārijai un Vācijai - Baltijas jūras reǵionā izveidojās jaunas vai atjaunotas valstis: Polija, Lietuva, Igaunija, Latvija un Somija. Polija, jau sākot ar 1918. gadu, neapšaubāmi bija stabilākā un ietekmīgākā šĩ reğiona valsts iekšējo resursu un tai sniegtā Rietumu lielvalstu atbalsta ziṇā. Bijušā Žečpospoḷita (apvienotās Polijas-Lietuvas valsts oficiālais nosaukums) kopš 18. gadsimta beigām, kad notika Polijas dalīšana, atradās Prūsijas (vēlāk Vācijas), Austrijas (vēlāk - Austroungārijas) un Krievijas sastāvā. Visu 19. gadsimtu norisinājās poḷu tautas cīna par savas valsts atjaunošanu. Šì cīṇa Krievijas impērijas teritorijā izpaudās arī vairākās sacelšanās kustībās, kas tika asinaini apspiestas. Sākot ar 19. gadsimta otro pusi, arvien vairāk sāka izpausties poḷu atbrīvošanās kustības pretrunas ar lietuviešu nacionālo kustību. Galvenais pretrunu iemesls sakṇojās abu tautu kopīgajā vēsturē (līdz 18. gadsimta beigām tā bija vienota valsts, kurā neapšaubāmi un nepārprotami dominēja poliskums, bet, sākot ar 19.-20. gadsimtu, lietuviešu nacionālā valstiskuma izpratnei bija pilnīgi atškirīga nozīme un termins „lietuvietis” apzīmēja teritoriālo, nevis tautisko piederību). Lietuvieši arvien noteiktāk prasīja pilnīgu neatkarību (arī ievērojamas teritorijas), bet poḷu politiskās un saimnieciskās elites vairākums nespēja izprast jauno situāciju, kurā lietuvieši jeb poḷu izpratnē - zemnieki ar savu „zemnieku” valodu - bija izveidojušies par modernu nāciju.

Pirmā pasaules kara laikā poḷu politiskie grupējumi izvirzīja par savu politisko mērķi Polijas valsts atjaunošanu, turklāt J. Pilsudska vadītais novirziens atbalstīja bruṇotu cinnu Austroungārijas armijas sastāvā pret Krievijas impēriju (tika izveidoti t. s. poḷu leǵioni). Kara norisēm attīstoties, ASV prezidents V. Vilsons 1917. gada janvārī izteicās par neatkarīgas Polijas valsts izveidošanu. Par to viṇš runāja vēlreiz 1918. gada janvārī savos „četrpadsmit punktos”. Pašas poḷu zemes šajā laikā bija okupējusi Vācija un Austroungārija. Tikai 1918. gada 11. novembrī - pamiera parakstīšanas dienā - Rietumu frontē varu pārnẹēma poḷu iestādes, Varšavā proklamējot Polijas neatkarības atjaunošanu. 1919. gada sākumā Polijas valsti atzina Rietumu lielvalstis un tā piedalījās Parīzes Miera konferencē kā pilntiesīga miera sarunu dalībvalsts. Vienlaikus norisa jaunās Polijas valsts valdības, valsts priekšnieka un bruṇoto spēku virspavēlnieka J. Pilsudska cinna par atjaunotās Polijas robežām, un to veidošanās lıoti sarežğìtā procesā turpinājās līdz 1922. gadam. Polijas rietumu un dienvidu robežas noteica Versal̦as miera līgums. Polijas teritorijā tika iekḷautas kādreizējās poḷu zemes, kuras pirms tam bija piederējušas Vācijai. Daḷa no tām bija jau lielā mērā geermanizētas. Vairākas strīdīgas teritorijas poḷiem izdevās pievienot ar organizētu sacelšanos palīdzību. Savukārt austrumos Polijas robeža tika veidota vēl sarežg̀itākā ilgstošā militārā un politiskā cinnā. Tādējādi radās valsts, kur 1922. gadā bija 27,2 miljoni iedzīvotāju (apmēram 30\% no viniiem bija galvenokārt ukraiṇi, vācieši, baltkrievi, ebreji). Tās platība bija 388,6 kvadrātkilometri, un tajā bija 
izteikti rūpnieciski attīstīti reǵioni (rietumos un dienvidrietumos) un izteikti lauksaimnieciski un pat nepoliski reǵioni (austrumos un dienvidaustrumos). Polijai bija vislielākie bruṇotie spēki Austrumeiropā. Teritoriālu, politisku un citu iemeslu dēḷ Polijai bija l̦oti sarežǵitas un pat naidīgas attiecības gandrīz ar visām kaimiṇvalstīm (Vāciju, Čehoslovākiju, Padomju Savienību un Lietuvu), izṇemot Rumāniju un Latviju. Jau no pirmajām valsts pastāvēšanas dienām izpaudās arī iekšējās problēmas, kuras bija jāatrisina Polijas valdībai. Tās bija saistītas ar nacionālo minoritāšu (pirmkārt, ukraiṇu) neapmierinātību ar savu stāvokli, kā arī ar demokrātijas pieredzes trūkumu. Tas bija raksturīgi visām Austrumeiropas reǵiona valstīm, bet Polijas gadījumā izpaudās sevišķi spilgti.

Polijas austrumu politiku sākotnējā posmā noteica tās vadītāja J. Pilsudska un viṇa atbalstītāju nākotnes redzējums. Sakarā ar Krievijas pagaidu novājināšanos J. Pilsudskis izvirzīja plānu par tās sadrumstalošanu, pamatojoties uz baltkrievu, ukraiṇu, baltiešu un citu tautu nacionālismu. Sākotnēji šī t. s. federācijas ideja paredzēja Polijas ietekmes saglabāšanu teritorijās, kuras bija ietilpušas tās sastāvā līdz pirmajai dalīšanai 1772. gadā, vietējām tautām pieškirot zināmu autonomiju. Tomēr jau 1919. gadā kḷuva skaidrs, ka šādi îstenot ideju nav iespējams (lietuvieši un ukraiṇi bija skaidri pauduši vēlēšanos izveidot savu pilnīgi patstāvīgu valsti). Tāpēc Polijas valsts vadītājs J. Pilsudskis un viṇa nometne pakāpeniski radijja ideju izveidot valstu savienību, kas atrastos teritorijā no Baltijas jūras līdz pat Melnajai jūrai un nomināli būtu neatkarīga, taču vadošā valsts savienībā nepārprotami būtu Polija. Katrā ziṇā 1919. gada sākumā J. Pilsudskis plānoja radīt stāvokli, kurā Polija spētu koordinēt Somijas, Igaunijas, Latvijas, Lietuvas, Baltkrievijas, Ukrainas un pat Kaukāza valstu politiku pret Krieviju, tādējādi nodrošinot Poliju pret Krievijas varbūtējiem draudiem nākotnē un Krievijas iespaidu visā reǵionā. Diskusijās, kas notika poḷu vadošo politiķu aprindās, Polija parādīja sevi kā valsti, kas būs federatīvām saitēm saistīta ar Lietuvu un Baltkrieviju (retāk - arī ar Latviju un Ukrainu), bet militārām saitēm saistīta ar pārējām reǵiiona valstīm.

1919. gada aprīlī poḷu karaspēks ieṇēma Viḷṇu. Šo operāciju J. Pilsudska nometne uztvēra kā federācijas izveides koncepcijas iedzivināšanas sākumu. Taču patiesībā no šī brīža sākās ilgstošs konflikts ar lietuviešiem par šo pilsētu, bet ar ukraiṇiem - par Galīciju. Šis konflikts faktiski sagrāva minēto koncepciju. Poḷi mēǵināja izveidot sadarbību ar ukraiṇiem, baltkrieviem un lietuviešiem un balstīt to uz federatīviem principiem. Vienlaikus viṇi centās radīt savienību ar Latviju, Somiju un Igauniju un balstīt to uz formāli līdztiesīgiem pamatiem. Tas neizdevās pārāk atškirīgo šo valstu ārpolitisko interešu dēḷ. Tomēr šie mēǵinājumi turpinājās vairākus gadus un pakāpeniski pārauga centienos izveidot savienību, kas garantētu savas valsts austrumu robežas aizsardzību. Turklāt Polijas nostāju spēcīgi iespaidoja tās pastāvīgais un dziḷais teritoriālais konflikts ar Lietuvu Viḷnas dēl. Tādēḷ Polija (vismaz politiķu vairākums, kas bija varas pozīcijā) bija gatava atteikties no pretenzijām uz Latgali, kura arī līdz 1772. gadam ietilpa Polijas-Lietuvas valstī. 1920. gada aprīlī J. Pilsudskis vēlreiz mēǵināja iedzīvināt valstu federācijas ideju, uzsākot ofensīvu visā poḷu-padomju frontē un tādējādi cenšoties izveidot starp Poliju un Krieviju sev draudzīgu Ukrainas valsti. Ar šo mēǵinājumu viṇš arī centās novērst nopietnās briesmas, kas Polijai draudēja no Padomju 
Krievijas puses; faktiski Polija padomju pusi vienkārši apsteidza. Mēǵinājums beidzās ar neveiksmi un poḷu karaspēka atkāpšanos līdz pat Varšavai 1920. gada jūlijā un augustā. Varšavā tikai ar milzīgām grūtībām Sarkano armiju izdevās apturēt, tādējādi novēršot „pasaules revolūcijas” briesmas ne tikai pašai Polijai, bet arī Baltijas valstīm un pat Centrāleiropai un Rietumeiropai. 1920. gada septembrī Rīgā sākās poḷ-padomju miera sarunas, kas noslēdzās 1921. gada martā ar miera līguma parakstīšanu Melngalvju namā Latvijas galvaspilsētā. Tieši šis līgums izbeidza karadarbību Austrumeiropā un uz diviem gadu desmitiem noteica robežas starp reǵiona valstīm.

Viens no reǵiona nestabilitātes iemesliem bija minētais Polijas konflikts ar Lietuvu. Šì konflikta iespaidā Polijai veidojās īpatnējas attiecības ar visām kaimiṇvalstīm un Padomju Krieviju. 1918. gada 16. februārī vācu okupācijas apstākḷos un ar ievērojamu vācu atbalstu proklamētā Lietuvas valsts reāli eksistēt sāka tikai novembrī, taču jau pirms tam lietuviešu politiḳi iezīmēja gaidāmās pretrunas, izsakot l,oti ievērojamas pretenzijas pret teritorijām, kuras uzskatīja par savām ne tikai Polija, bet arī Latvija un Baltkrievija. 1918.-1920. gadā, karojot par savu neatkarību, lietuviešu karaspēks cīnījās pret lieliniekiem, bermontiešiem un poḷiem, taču ārpolitikā būtisks bija konflikts ar Poliju - tas lika pamatus t. s. Lietuvas horizontālajai ārpolitikai - orientācijai nevis uz pārējām Baltijas valstīm, bet gan uz Vāciju un Padomju Krieviju (vēlāk PSRS). Salīdzinoši vājā, iekšēji un ārēji nestabilā Lietuva, kuras politika pret Padomju Krieviju atškīrās no pārējo Baltijas valstu un Polijas politikas, 1919.-1920. gadā kḷuva par valsti, pret kuru dažkārt aizdomīgi un pat nedraudzīgi izturējās ne tikai Polija, bet arī Latvija, kā arī Igaunija un Somija. Tieši Lietuvas faktors kḷūs par izškirošo faktoru Latvijas un Polijas attiecībās, kā arī visa reǵiona starptautisko attiecību kontekstā.

Arī 1918. gada 24. februārī proklamētā Igaunijas valsts reālu neatkarību varēja iegūt tikai 1918. gada novembrī pēc Vācijas sakāves karā, jo pirms tam vācu okupācijas varas iestādes šo valsti vienkārši neatzina. Ar somu un Rietumu lielvalstu atbalstu Igaunijai samērā ātri izdevās padzīt no savas teritorijas lieliniekus, un 1919. gada pavasarī igaunu karaspēks piedalījās pat Latvijas teritorijas atbrīvošanā. No Igaunijas teritorijas 1919. gadā divas reizes Petrogradai mēǵināja uzbrukt pretlielinieciskā Krievijas Ziemel̦rietumu armija, kuru atbalstīja Lielbritānija un Francija (turklāt pirmajā reizē pašu igauṇu karaspēks arī aktīvi piedalījās šajā operācijā, ieņemot Pleskavu). Pašai Igaunijai šajā laikā izveidojās samērā spēcīgi bruṇotie spēki. Tomēr vienotības trūkuma dēḷ starp Baltijas valstīm 1919. gada nogalē un Sarkanās armijas spiediena dēḷ Igaunija pirmā uzsāka separātas miera sarunas ar Padomju Krieviju un noslēdza tās ar miera līguma parakstīšanu Tartu 1920. gada februārī. Kopš šì laika Igaunija vairāk formāli piedalījās sarunās ar Latviju, Somiju, Poliju un Lietuvu par iespējamās militārās un politiskās savienības izveidi.

Somija savu neatkarību no Krievijas bija proklamējusi jau 1917. gada rudenī. Vēlāk Somijā izraisījās asiṇains pilsoṇu karš, kurā uzvarēja „baltie” jeb Somijas Republikas valdība, kas atradās karastāvoklī ar Padomju Krieviju līdz pat 1920. gada decembrim. Kā jau minēts, Somija pauda samērā aktīvu atbalstu Igaunijai, kā arī piedalījās kopīgās sarunās ar pārējām Baltijas valstīm un Poliju par tādas kopīgas savienības izveidi, kurai būtu aizsardzības raksturs, taču somu politiskajās aprindās jau 1919.-1920. 
gadā bija acīmredzama tendence pārlieku nesaistīties ar Baltijas valstīm, kuras somu izpratnē apdraudēja Padomju Krievija. Somijas ārpolitikai bija raksturīga vēl viena tendence - simpātijas pret Vāciju. Ar to Somija atšḳīrās no pārējām potenciālajām savienības dalībvalstīm. Turklāt jau šajā periodā, gan tikai no Polijas puses, radās mēǵinājumi separāti vienoties ar Somiju par ietekmes vai aizbildniecības (faktiski - protekcionisma) sfēru sadali Baltijā.

Kamēr Latvija cīnījās par savu neatkarību, Pagaidu valdībai bija ārkārtīgi smags stāvoklis, kas ilga līdz pat 1919. gada jūnijam, kad Igaunijas armijas un Ziemeḷlatvijas brigādes uzvarēja vācu spēkus pie Cēsīm un beidzot Pagaidu valdība sāka daḷēji kontrolēt stāvokli valsts daḷā, kas bija atbrīvota no lieliniekiem. 1919. gada rudenī sekoja cīṇas ar Bermonta karaspēku, bet 1920. gadā - Latgales atbrīvošanas operācija, kas noslēdzās ar miera līguma parakstīšanu 1920. gada augustā. Visa Neatkarības kara laikā Latvijā seviškịi svarīga nozīme bija ne tikai Vācijas un Padomju Krievijas, bet arī Lietuvas, Igaunijas, Polijas un Antantes lielvalstu faktoram. Ārpolitikas pamatnostādnes paredzēja sabiedroto meklējumus cīnai ar daudzajiem ienaidniekiem, kā arī izveidot spēcīgu aizsardzības rakstura savienību un panākt starptautisko atzī̌anu „de iure”. Apstākḷos, kad kaimiņos norisinājās aktīvs Polijas un Lietuvas konflikts, kā arī kopumā ievērojami atšḳīās visu potenciālo savienības dalībvalstu ārējās intereses, tas bija sarežğìts uzdevums.

1918. gada 18. novembrī proklamētā Latvijas Republika par savu neatkarību bija spiesta ar ieročiem cīnīties līdz 1920. gada augustam, bet par valsts starptautisku atzīšanu - līdz 1921. gada janvārim. Cīṇa bija politiska un militāra, un abi tās veidi bija cieši savstarpēji saistīti. Atšḳirībā no Polijas un Lietuvas, kuras pilsoṇiem jau bija vēsturiskā valstiskuma apziṇa, latviešiem un igauṇiem tādas nebija, kaut arī vispārējais sabiedrības attīstības (pirmkārt, iedzīvotāju izglītības) līmenis Latvijā un Igaunijā bija ievērojami augstāks nekā kaimiṇvalstīs dienvidos un austrumos. Zināms izṇēmums Latvijā bija Latgale, kur īpašo vēsturisko apstākḷu iespaidā liela daḷa latviešu iedzīvotāju bija pilnībā zaudējuši nacionālo identitāti vai bija tuvu tam, bet sabiedrības sociālās attīstības līmenis bija līdzīgs Lietuvas līmenim. Galvenokārt šāds stāvoklis bija raksturīgs Dienvidlatgalei, kur inteliǵgencē un ierēdniecībā latviešu gandrīz nebija, bet zemnieku nacionālā pašapziṇa bija attīstīta l,oti vāji. Viṇi viegli pakḷāvās ārējai ietekmei, pieṇemot pat citu valodu (poḷu, baltkrievu vai krievu valodu vai dialektu, kas bija radies, sajaucoties visu šo valodu un arī latviešu valodas elementiem). Tādējādi viens no galvenajiem jaunās Latvijas valsts valdības uzdevumiem bija apvienot visus latviešu apdzīvotos novadus.

Sarežǵìto iekšpolitisko apstākḷu dēl Latvijas Pagaidu valdības ārpolitiskās aktivitātes 1918. gada beigās un 1919. gada sākumā aprobežojās gandrīz vienīgi ar centieniem gūt ārvalstu atbalstu un palīdzību naidīgu spēku aplenktajai un pat lielā mērā kontrolētajai valstij. 1918. gada 11. novembrī Polija bija atjaunojusi savu neatkarību, ko viṇa bija zaudējusi 18. gadsimtā. Polijas pirmie sakari īpaši iespaidoja tādus Latvijas vēsturē nozīmīgus notikumus kā cīṇa pret Bermonta komandēto Rietumkrievijas armiju, Latgales atbrīvošana, Baltijas valstu savienības izveides mēǵinājumi, Latvijas starptautiskās atzīšanas panākšana utt. Latviešu historiogrāfijā daudzi no šiem jautājumiem līdz šim aplūkoti nepietiekami (turklāt - arī faktoloğiski 
trūcīgi un pat kḷūdaini) un to vispusīgai analīzei ir liela nozīme, jo Polija bija Latvijas kaimin,valsts un attiecības ar Poliju veidoja vienu no Latvijas ārpolitikas stūrakmeṇiem, kā arī būtiski iespaidoja kopīgo stāvokli visā reǵionā.

Grāmata aptver laika posmu no 1919. gada marta, kad nodibinājās pirmie, vēl virspusējie sakari starp Latvijas un Polijas delegāciju Parīzes Miera konferencē, līdz 1921. gada janvārim, kad ar Latvijas starptautisko atzīšanu „de iure” noslēdzās arī starptautiski tiesiski pilnvērtīgas valsts veidošanās process. Sakarā ar straujajām militārpolitiskajām izmaiṇām Baltijas reǵionā minētais laika posms bija seviški bagāts ar militārpolitiskiem notikumiem un procesiem. Darba mērkiis ir uz vispārējās reǵiona militārpolitiskas situācijas fona no abu pušu viedokḷa vispusīgi parādìt Latvijas un Polijas attiecības, atsevišķus to posmus un tiem piemītošās īpatnības, abu valstu tuvināšanās cēloṇus un šīs tuvināšanās tālākās sekas līdz pat Latvijas starptautiskajai atzīšanai. Turklāt galvenā uzmanība pievērsta tieši attiecību politiskajam un militārajam aspektam, kas šajā laikā, norisinoties aktīvai cīṇai par valsts starptautisko atzīšanu un visu Latvijas zemju atbrīvošanu, bija sevišķi nozīmīgs. Uzmanība pievērsta arī Polijas īpatnējās austrumu politikas raksturojumam, kas l̦auj izprast Latvijas puses pastāvīgo piesardzību pret šo valsti, - sadarbība ar Poliju (īpaši grāmatā aplūkotajā laika posmā) bija nepieciešama ārpolitiskās un militārās situācijas dēḷ.

1. nodaḷa veltīta attiecību nodibināšanai un pirmo sakaru attīstībai 1919 . gadā. İsumā raksturota arī militārā situācija Polijas un Lietuvas armijas darbības rajonā Latvijas dienvidos (Ilūkstes apriṇķī). Tas l̦auj pilnīgāk izprast galvenos Latvijas-Polijas militārās sadarbības līguma noslēgšanas iemeslus 1919. gada decembrī. Lielāka uzmanība pievērsta tam, kādos apstākḷos un kā notika abu valstu tuvināšanās Bermonta karaspēka akcijas laikā un pēc tās. Nodaḷu noslēdz minētā Latvijas un Polijas militārās sadarbības līguma raksturojums un analīze.

Nākamajā nodaḷā aplūkots laika posms no 1920. gada janvāra līdz aprīlim - poḷu un latviešu karaspēka kopīgi veiktā Latgales atbrīvošana, kas noslēdzās ar pakāpenisku visas frontes pārṇemšanu Latvijas armijas pārziṇā. Atsevišķās apakšnodaḷās analizēta militārās operācijas gaita janvārī un februārī, Polijas armijas darbība tās atrašanās laikā Latvijas teritorijā un tās attiecības ar Latvijas varas iestādēm. Aplūkotas arī Latvijas un Polijas starpvalstu attiecības šajā laikā saistībā ar procesiem, kas notiek reǵionā, un ar Latgales atbrīvošanas operācijas gaitu. Īpaša uzmanība pievērsta tieši Polijas armijas darbībai Latvijā, jo šis jautājums latviešu historiogrāfijā līdz šim objektīvu iemeslu (attiecīgo avotu trūkuma) dēl skatīts nepietiekami.

3. nodaḷa veltīta laika posmam no 1920. gada aprīḷa (kad ar īpašu vienošanos sākās Polijas armijas izvešana no Latvijas) līdz 1920. gada jūlija sākumam, bet 4. nodaḷa - no 1920. gada vasaras (kad poḷu-padomju kara dēḷ Latvijas teritoriju atstāja vēl atlikušais poḷu karaspēks) līdz 1921. gada sākumam. Šajās nodaḷās aplūkots militārpolitiskais aspekts abu valstu attiecībās un skarti tādi būtiski jautājumi kā Latvijas nostāja Polijas un Lietuvas bruṇotā konflikta (ǵenerāla Žel̦igovska akcijas) laikā 1920. gada rudenī, Latvijas zemes reformas ietekme uz starpvalstu attiecībām, starptautiskās atzīšanas process un Polijas valsts nostāja tajā un citi jautājumi. 
Latvijas un Polijas attiecību detalizēta izpēte Latvijas historiogrāfijā lauj pilnveidot priekšstatus par Latvijas neatkarības sākumposma vēsturi, tajā skaitā - par sakariem ar kaimiṇvalstīm, pirmkārt, ar Poliju, kā arī Lietuvu un citām valstīm, un sniegt līdz šim pilnīgi nezināmu informāciju, kas dažos gadījumos maina vairākus līdzšinējos priekšstatus par Latvijas nozīmi reǵionā notiekošajos procesos (galvenokārt Lietuvas-Polijas attiecību dēl neīstenotās Baltijas valstu savienības kontekstā un citos aspektos). Pētījumam ir nozīme arī Polijas un Lietuvas vēsturē, jo savukārt šo valstu vēstures literatūrā praktiski nav izmantoti Latvijas puses avoti.

Nozīmīgākā avotu kopa, kas izmantota grāmatā, ir Latvijas un Polijas arhīvu un citu avotu krātuvju materiāli. Latvijas Valsts vēstures arhīvā (LVVA) ir daudzi līdz šim neizmantoti dokumenti par abu valstu attiecībām un to saistību ar kopējo stāvokli reǵionā, par abu armiju sadarbību frontē, situāciju atbrīvotajā un poḷu karaspēka ien,emtajā Latgalē, kā arī par Latvijas poḷu minoritātes stāvokli un darbību, kurai bỉja liela nozīme attiecībās ar kaimiņvalsti Poliju. Plaši izmantoti Latvijas Ārlietu ministrijas kancelejas (1313. f., 1. apr.), Ārlietu ministrijas Politiski ekonomiskā departamenta (2574. f., 3. apr.), Administratīvi juridiskā departamenta (2570. f., 1. un 2. apr.), kā arī Latvijas sūtniecības Polijā (2575. f., 15. apr.) un sūtniecības Lietuvā (2575. f., 11. apr.) materiāli. Tajos ietilpst oficiālā un neoficiālā korespondence starp amatpersonām, sarakste ar ārvalstu pārstāvjiem, diplomātu ziṇojumi utt. Šie dokumenti atspoguḷo oficiālo un neoficiālo valsts nostāju, un to ticamības pakāpe ir augsta. Ārlietu ministrijas materiālus būtiski papildina arī Latvijas armijas Virspavēlnieka štāba (3601. f., 1. un 9. apr.) dokumentācija, militāro pārstāvju Polijā un E. Ridza-Smiglija poḷu karaspēka grupas štāba ziṇojumi, Daugavpils latviešu komandanta, Dienvidlatgales apriņķu komandantu, kā arī Latvijas civilo varas iestāžu vadītāju ziṇojumi, apvienotās poḷu-latviešu karaspēka grupas pavēlnieka pavēles un citi materiāli, jo 1919.-1920. gadā tieši ar militāriestāžu starpniecību lielā mērā īstenojās abu valstu sadarbība. Šiem materiāliem tomēr dažkārt piemīt pārlieks subjektīvisms, jo attiecīgu dokumentu autori nav pārzinājuši politiskās norises.

Materiāli par politiskajiem un saimnieciskajiem sarežǵijumiem, kas saistīti ar Polijas armijas apgādi un ar tās atrašanos Latgalē, ir arī armijas Galvenās apgādības pārvaldes (3605. f., 1. apr.), Iekšlietu ministrijas Drošības policijas Politiskās pārvaldes (3235. f., 1/14. apr. - armijas Virspavēlnieka štāba Iekšējās izlūkošanas nodaḷas Daugavpils nodalas materiāli), Krāslavas (3479. f., 1. apr.), Grīvas (3461. f., 1. apr.) un Kalkūnes (3485. f., 1. apr.) komandantūras un citos fondos. Vērtīgas ziņas par Latvijas un citu valstu attiecībām apkopotas Kara vēstures komisijas (6033. f., 1. apr.) fondā. 30. gados komisija organizēja Neatkarības kara laika militāriestāžu dokumentācijas pārrakstīšanu un apkopošanu, kas diemžēl netika paveikta līdz galam, un tādēl dažos gadījumos ir grūti pilnīgi precīzi noteikt konkrēta mašīnrakstā pārrakstita dokumenta tapšanas laiku un izcelsmi.

Savukārt Polijā visvairāk materiālu, kas saistīti ar Latvijas starpkaru posma vēsturi, ${ }^{1}$ atrodas Jauno aktu arhīvā Varšavā (Archiwum Akt Nowych).

\footnotetext{
${ }^{1}$ Sīkāk sk.: Jēkabsons Ē. Latvijas 1919. un 1920. gada vēstures materiāli Polijas arhīvos//Latvijas Arhīvi. - 1995. - nr. 2, 79. - 81. lpp.
} 
Šeit glabājas vēsturnieka M. Serejska 30. gados tapušais nepublicētais darbs "Polijas un Latvijas attiecības 1919-1925”, kā arī tajā izmantotie „Dokumentu apstrādes rezultātu un norakstu kolekcijas par Polijas attiecībām ar Latviju, Lietuvu, Igauniju un Somiju" sējumi (Kolekcja opracowań i odpisów dokumentów dotyczacych stosunków Polski z Eotwa. Litwa, Estonia i Finlandia, t. 1-4). Tieši tiem ir îpaša vērtība, jo pašā darbā autors, izmantojot vienīgi poḷu puses avotus, pārliecīgu uzmanību pievērš, piemēram, no poḷu muižnieku viedokḷa "netaisnīgajai" Latvijas zemes reformai, dažkārt būdams l,oti subjektīiss. Diplomāta Leona Vasiḷevska personiskajā fondā (Akta L. Wasilewskiego) ir pirmo pastāvīgo Polijas un Latvijas sakaru liecības - pierakstītās sarunas ar Latvijas delegācijām Viḷnā 1919. gada rudenī u. c. Savukārt Polijas Ārlietu ministrijas (Ministerstwo Spraw Zagranicznych) fondā materiālu par Latviju 1919.-1920. gadā nav īpaši daudz. Tomēr arī diplomātisko pārstāvju ziṇojumi (kopā ar militāro pārstāvju raportiem) atrodami tā dēvētajā "Pie kapitālistisko valstu valdībām akreditēto militāro atašeju fondā" (Attachaty wojskowe RP akredytowane przy państwach kapitalistycznych 1920-1939), kur ir loti daudz materiālu par kopīgās militārās operācijas norisi Latgalē 1920. gadā un par stāvokli šīgada vasarā un rudenī, sākoties Želigovska akcijai Viḷnā, un citi materiāli. Militāra rakstura materiāli glabājas Galvenā štāba (Sztab Gtówny) un Militāro iestāžu (Instytucje wojskowe) fondā.

Polijas Centrālā kara arhīva (Centralne Archiwum Wojskowe) G̦enerālštāba Kara vēstures biroja (Wojskowe Biuro Historyczne) materiāli, kas veltīti Latgales operācijai, dod iespēju iepazìties ar Polijas un Latvijas armiju sadarbības un poḷu karaspēka darbības vēsturi Latgalē burtiski pa stundām, kā arī sniedz informāciju par stāvokli atbrīvotajā Daugavpilī un Latgalē 1920. gadā. Pamatojoties uz šiem un turpmāk minētajiem materiāliem, grāmatā, protams, sniegta maksimāli precīza kopaina par militārās operācijas gaitu. Informācija par Latviju (par sarunām ar vācu-krievu karaspēka pavēlnieka Baltijā Bermonta pārstāvi Polijā) atrodama arī Polijas armijas G̦enerālštāba Politiskās daḷas priekšnieka S. L,audaṇska fondā (Teki S. Laudańskiego), kā arī Polijas armijas virspavēlniecības II (Izlūkošanas) daḷas fondā (Oddziat II Naczelnego Dowództwa Wojska Polskiego). Starp materiāliem ir militārā pārstāvja ziņojumi no Rīgas, nedēlas ziṇojumi par stāvokli reǵionā kopumā, Latvijas un citu valstu preses apskati, izlūkošanas un pretizlūkošanas struktūru ziṇojumi no Latgales (arī Daugavpilī esošā 4. pretizlūkošanas postena atskaites ar apcietināto sarakstiem, kuros redzami poḷu iestāžu aizturēto daudzo Padomju Latvijas aktīvistu vārdi) un citi dokumenti.

Polijas Zinātṇu akadēmijas arhīvā (Archiwum Polskiej Akademii Nauk) atrodas Latgales muižnieka M. Svežbin,ska atmiṇas („Martyrologia Inflant Polskich” - „Poḷu Inflantijas moku cel̦š”). M. Svežbin,skis 20. gados bija Polijas konsuls Daugavpilī. Viña atmiņas tapušas 30. gados un pabeigtas 50. gados. Kaut arī autors daudzkārt pauž šauru šovinismu un pilnīgu analfabētismu latviešu tautas vēstures un poḷu vēsturiskās nozīmes traktējumā Latgalē (viṇa darbs ir šovinisma un personiska subjektīvisma pārpilns), tomēr atmiņas sniedz arī būtisku informāciju par norisēm Daugavpilī 1920. gadā, kuru tiešs vai netiešs liecinieks bija M. Svežbinsskis. Šajā pašā arhīvā glabājas arī Polijas Austrumzemju civilpārvaldes ǵenerālkomisāra vietnieka (vienlaikus Izlūkošanas daḷas priekšnieka) M. Kosakovska dienasgrāmata („Djarjusz M. S. Kossakowskiego"), kurā autors cita starpā stāsta par saviem sakariem 
ar Latgales muižniekiem un par savu darbu Polijas delegācijas sastāvā miera sarunās ar Padomju Krieviju Rīgā 1920. gada rudenī.

Kopumā Polijas arhīvu materiālu par Latvijas vēsturi ir l̦oti daudz, taču tie vienīgi ciešā sasaistē ar Latvijas puses avotiem (un otrādi) sniedz pilnvērtīgu un maksimāli objektīvu ieskatu abu valstu attiecībās. Polijā esošie Latvijas vēstures materiāli vēl l,oti lielā mērā nav izmantoti historiogrāfijā vai izmantoti virspusēji, vienīgi saistībā galvenokārt ar Polijas un Lietuvas attiecībām.

Nozīmīgi materiāli par aplūkojamo tēmu atrodas arī Lietuvas Centrālajā valsts arhīvā Viḷnā (Lietuvos Centrinis valstybinis archivas). Lietuvas Ārlietu ministrijas (383 f., 7 ap.), Apsardzības ministrijas (384 f., 3 ap.), Ministru kabineta (923 f., 1 ap.) un Armijas štāba (929 f., 1, 3 ap.) fondos esošie materiāli ḷoti būtiski papildina Latvijas, Polijas un Lietuvas attiecību kopainu 1919.-1921. gadā, sniedzot Latvijas un Polijas attiecībās iesaistītās faktiski trešās neatṇemamās puses redzējumu un viedokli. Seviški būtisks tas ir jautājumos un aspektos, kuri saistīti ar kopējo situāciju visā Baltijas jūras reǵionā, kā arī ar situāciju Ilūkstes apriņḳ̄ 1919.-1920. gadā. Tieši šajā reg̛ionā sadūrās visu triju valstu un vēl arī Padomju Krievijas intereses.

Otra nozīmīgākā izmantoto avotu kopa ir attiecīgā laika posma Latvijas un Polijas periodiskie preses izdevumi. Kopumā izmantoti 14 Latvijā un 25 Polijā un poḷu karaspēka ieṇemtajās teritorijās iznākušie laikraksti. Latvijas izdevumi attiecības ar kaimiņvalstīm atainoja diezgan detalizēti, ievērojot izdevēja politisko orientāciju. Tas uzskatāmi redzams Polijai visumā nelabvēlīgos Latvijas Sociāldemokrātiskās strādnieku partijas laikrakstos ("Sociāldemokrāts", "Strādnieku Avīze"). Sākoties Latvijas-Polijas attiecību atsalumam 1920. gada aprīlī, sociāldemokrāti kārtējo reizi centās pierādīt, ka Polijas nolūki ir Latvijai naidīgi. Samērā nelabvēlīgu nostāju pret Poliju ieṇēma arī latgaliešu laikraksti ("Latgalīts", "Latgolas Words"). Tas izskaidrojams ar vietējās latviešu inteliǵences un poḷu muižniecības dziḷajām pretrunām šajā novadā. Turpretī Latviešu zemnieku savienības laikraksts "Brīvā Zeme", valdības oficiozs "Valdības Vēstnesis", citas centrālās dienas avīzes ("Jaunākās Ziṇas", "Latvijas Sargs", "Baltijas Vēstnesis") bija pret Poliju kopumā labvēlīgas. Īpatnēja nostāja bija Latvijas armijas Virspavēlnieka štāba izdotajam laikrakstam "Latvijas Kareivis", ko sāka izdot no 1920. gada februāra. No vienas puses, tas pauda augstāko militāro aprindu labvēlību pret militāro sadarbību un pat savienību ar Poliju (piemēram, štāba priekšnieka - pulkveža, vēlāk ǵenerāla P. Radziņa - raksti). No otras puses, pārstāvot nacionāli noskan,oto virsniecību, laikraksts asi uzstājās pret poḷu šovinisma izpausmēm (piemēram, pret Polijas sūtṇa B. Boufala attiecīgajiem izteikumiem). Daudz informācijas par Latvijas attiecībām ar Poliju (kas dažkārt ievērojami atškīīās no latviešu preses sniegtajām ziṇām) sniedza Rīgas krievu dienas avīze „Сегодня”, kā arī mazākās „Воля” un vietējās pašvaldības avīze „Наша жизнь”, kas sāka iznākt Daugavpilī no 1920. gada marta.

Arī Polijas prese detalizētāk par Latvijas presi rakstīja līdzīgi atkarībā no izdevēja politiskās orientācijas. Visi poḷu laikraksti politisku iemeslu dēḷ bija labvēlīgi Latvijai 1919. gada rudenī, kad tā cīnījās ar reakcionāro Bermonta komandēto vācu-krievu karaspēku, kas apdraudēja arī Poliju vai tās intereses reǵionā. Savukārt, kad 1920. gada sākumā noskaidrojās, ka 
Polijas valsts vadība bez priekšnosacījumiem piekritusi Latgales, un ìpaši Daugavpils apriṇk,a, iekḷaušanai Latvijā, sekoja asi nacionāldemokrātu preses ("Gazeta Poranna", "Gazeta Warszawska", "Rzeczpospolita" u. c.) uzbrukumi savai valdībai un arī Latvijas valstij. Ši prese pārstāvēja nacionāldemokrātu intereses un pārmeta Latvijai poḷu minoritātes tiesību ierobežošanu Latgalē un nepateicību pret Poliju. Savukārt Polijas izdevumi, kas pārstāvēja valdības aprindas ("Gazeta Polska", "Kurjer Warszawski", "Kurjer Polski”, "Rząd i Wojsko", “Źołnierz Polski” u. c.), aizstāvēja ārpolitisko kursu attieksmē pret Latviju un visumā bija tai labvēlīgi. Dažāda attieksme pret Latviju polu presē bija vērojama pēc zemes reformas sākuma Latgalē 1920. gada rudenī, kad vienīgi sociālistu laikraksts "Robotnik" turpināja aizstāvēt (dažkārt pat pārspīlēti) Latviju pret “muižnieku tīkojumiem”. Samērā plaša informācija par norisēm Latgalē bija Viḷnas laikrakstos (nacionāldemokrātu avīzē "Ziemia Wileńska", "Nasz Kraj”, kas pauda valdības viedokli, politiski diezgan mērenajās "Dziennik Wileński”, "Tygodnik Wileński”, kā arī "Echo Litwy”, kas neoficiāli pārstāvēja Lietuvas intereses). Plaši Latgales notikumus atspoguḷoja arī Minskas laikraksti (“Goniec Miński”, “Минский курьер”). İpatnēju nostāju pret Latviju pauda Polijā iznākošie krievu laikraksti - daḷēji slēpti šovinistiskie „Варшавская речь”, „Варшавское слово”, kā arī B. Savinkova vadītās Krievu Politiskās komitejas izdotā avīze "Свобода". No vienas puses, šie izdevumi pauda nepatiku pret “jaunajām valstīm” kā Krievijas impērijas grāvējām, no otras puses, tie samērā objektīvi atainoja Baltijas notikumus un bija spiesti aprobežoties ar latviešu sarkano strēlnieku - "no dzimtenes aizklīdušo algotņu" - asu nosodījumu, ${ }^{2}$ jo nedrīkstēja atklāti propagandēt Krievijas impērijas atjaunošanu.

Latvijas-Polijas objektīvā attiecību atspoguḷjumā liela nozīme ir arī Lietuvas preses izdevumiem, kuri šajā jautājumā pārstāvēja savas valsts īpatnējās intereses attiecībās ar Latviju un Poliju, kā arī ar Vāciju un Padomju Krieviju. Grāmatā izmantota Lietuvas valsts centrālā laikraksta "Lietuva" un Kristīgo demokrātu partijas avīzes "Laisve" sniegtā informācija par militārajām norisēm Ilūkstes apriṇķ̄i, kur atradās Lietuvas armijas daḷas, un par Lietuvas valdības attieksmi pret Latvijas un Polijas attiecībām gan abu valstu tuvināšanās, gan nesaskaṇu laikā.

Nozīmīgākā izmantotā dokumentu publikācija ir Maskavā izdotais krājums par padomju-poḷu attiecībām (neraugoties uz zināmo tendenciozitāti materiālu atlasē). ${ }^{3}$ Materiāli par Latviju ir arī vairākos dokumentu krājumos, kas izdoti Polijā $\overline{4}^{4}$ un Rietumvalstīs poḷu valodā. ${ }^{5}$

\footnotetext{
2 Варшавская речь. - 1919. - 16 окт. Tomēr vienlaikus šis laikraksts izdarīja pārsteidzoši pareizu secinājumu, saskatot latviešu sarkano strēlnieku darbībā Krievijā arī vēlēšanos atriebties par kazaku soda ekspedīciju l̦aundarībām, kuras Latvija pieredzēja 1905. gada revolūcijas laikā.

3 Документы и материалы по истории советско-польских отношений. - Ч. II. - Москва, 1964 717 стр.

${ }^{4}$ Piłsudski J. Pisma zbiorowe. - T. V. - Warszawa, 1937. - 297 ss.; Deruga A. Nieznane dokumenty do dziejów polityki wschodniej Polski 1918 - 1919//Z dziejów stosunków polsko - radzieckich. T. VI. - Warszawa, 1970. - S. 231-246; Dokumenty z dziejów polskiej polityki zagranicznej 1918-1939. - T. I/ Red. T. Jędruszczak, M. Nowak - Kielbikowa. - Warszawa, 1989. - 540 ss.; Tajne rokowania polsko - radzieckie w 1919 r. - Warszawa, 1986. - 413 ss.

${ }^{5}$ Sąsiedzi wobec wojny 1920 roku. Wybór dokumentów/Oprac. J. Cisek. - Londyn, 1990. - 324 ss.
} 
Tēmas izpētē svarīgas ir laikabiedru atminas, kas tapušas pirms Otrā pasaules kara un trimdā Rietumos pēc kara. Pirmkārt, jāmin Latvijas pārstāvniecības (pēc tam - sūtniecības) darbinieka Varšavā, vēlākā konsula Viḷnā F. Donasa atminuu grāmata par savu darbību šajā pilsētā. ${ }^{6}$ Autors atturas no plašākas un dziḷākas notikumu analīzes un aprobežojas ar pieredzētā izklāstu, tomēr viṇš ir vienīgais no tiem diplomātiskās pārstāvniecības darbiniekiem, kuri strādāja Polijā 1919.-1920. gadā un arī atstāja atmiṇas. Analītiskāks ir valstsvīra un diplomāta K. Zariṇa raksts, ${ }^{7}$ kurā viṇš sīki apraksta arī savu komandējumu Polijā 1919. gada septembrī. Latvijas attieksmi pret Viḷnas piederības jautājumu fragmentāri un l̦oti neprecīzi piemin viens no Latvijas Sociāldemokrātiskās strādnieku partijas vadītājiem F. Cielēns. ${ }^{8}$ Unikālas un pārsteidzoši pilnīgas ir bijušā Latvijas armijas virspavēlnieka Jāṇa Baloža atmiṇas, kuras viņš rakstījis pēc atgriešanās Latvijā no ieslodzịjuma 50. gadu beigās un 60. gadu sākumā un kuras atklāj aprakstìto militāro un arī politisko norišu tiešā līdzdalībnieka redzējumu. ${ }^{9}$

Atmiṇas atstājis poḷu politiķis un diplomāts L. Vasiḷevskis. ${ }^{10}$ Tajās ir būtiskas liecības par Latvijas oficiālo pārstāvju viesošanos Polijā 1919. gadā, un to ticamību apstiprina arī Latvijas puses avoti. Kopumā L. Vasiḷevska objektivitāti un reālo situācijas redzējumu apliecina arī citi vina darbi, kuros tas aizstāv valsts vadītāja J. Pilsudska attieksmi pret Baltijas valstīm un nosoda poḷu šovinistu un muižnieku aprindas, ${ }^{11}$ kas izsaka zināmas pretenzijas uz Latgali. Situāciju Baltijā vērtēja arī otrais Polijas diplomātiskais pārstāvis Latvijā vēstures profesors V. Kameñeckis, ${ }^{12}$ kurš bija neapšaubāmi politiski apdomīgāks un Latvijai labvēlīgāks par savu priekšgājēju šajā amatā B. Boufalu. Latviešu valodā publicētas ìsas pirmā Polijas militārā pārstāvja Rīgā A. Miškovska un apvienotās poḷu-latviešu karaspēka grupas komandiera E. Ridza-Smiglija atmiṇas par savu darbību Latvijā. ${ }^{13}$ A. Miškovskis publicējis īsas, bet ārkārtīgi nozīmīgas atmiṇas par šo tēmu arī Polijā. ${ }^{14}$ No Latvijas vēstures viedokḷa ḷoti nozīmīga ir 1. Leǵionu kājnieku pulka rotas komandiera, vēlākā pazīstamā dzejnieka V. Broṇevska 1919.-1920. gadā rakstītā dienasgrāmata. ${ }^{15}$ Tā atklāj vienkāršā poḷu virsnieka skatījumu uz kaujām Latvijā un viṇa pieredzējumus Dienvidlatgalē 1920. gada ziemā. Kopumā V. Broṇevska notikumu redzējums raksturīgs cilvēkam, ko ilgie kara gadi padarījuši vienaldzīgu pret nāvi un dzīves apstākḷiem, taču

\footnotetext{
${ }^{6}$ Donass F. Politiskos krustcel̦os. - J. Šķirmanta apgāds, 1969. - 163 lpp.

${ }^{7}$ Zariņš K. 35 gadi Latvijas valsts darbā//Latviešu Almanahs 1954. gadam. - Londona, 1953. 66.-92. 1pp.

${ }^{8}$ Cielēns F. Laikmetu maiṇā. - 2. sēj. - Lidingo, 1963. - 510 lpp.

9 Balodis J. Ģenerāḷa Jāṇa Baloža atmiņu burtnīcas//Neatkarīgā Rīta Avīze. - 1997. - 22. febr., 22., 29. marts, 26. apr., 17. maijs.

${ }^{10}$ Wasilewski L. Józef Piłsudski. Jakim go znalem. - Warszawa, 1935. - 235 ss.

${ }^{11}$ Sk., piemēram: Wasilewski L. Wschodnia granica Polski// Bellona. - T. XVI. - 1922. S. $265-281$.

${ }^{12}$ Kamieniecki W. Polityka bałtycka//Przegląd Współczesny. - T. XVI. - S. 564 - 569.

${ }^{13}$ Smigły - Rydz E. Teicams karavīrs; Miškovskis A. Iz manām atmin̄ām no Latvijas//Ģenerālis Jānis Balodis. Atmiṇu krājums. - Rīga, 1931. - 68. - 69., 70. - 75. 1pp.

${ }_{14}$ Myszkowski A. Z moich łotewskich wspomnień//Polska Zbrojna. - 1933. - Nr. 320.

15 Broniewski W. Pamiętnik 1918 - 1922. - Warszawa, 1984. - 351 ss.
} 
tas nekādi nemazina atmiṇu nozīmi. Īpaši vērtīga ir V. Broṇevska liecība par pieredzēto tikko atbrīvotajā Daugavpilī - arī liecība par poḷu karavīru īstenoto marodierismu pret vietējiem ebreju iedzìvotājiem un nožēlojamajiem dzīves apstākḷiem izpostītajā pilsētā.

Zināmi avota (atmiṇu) elementi piemīt daudziem izmantotiem zinātniskās literatūras darbiem. To autori lielā mērā balstījušies uz savām atmiṇām un pieredzējumiem. Tieši viṇu līdzdalība vai vismaz klātbūtne aprakstāmajos notikumos un norisēs ir viens no galvenajiem šo darbu trūkumiem, jo bieži vien tādēḷ nav iespējama maksimāla objektivitāte. Tas lielā mērā attiecas arī uz ǵenerāḷa P. Radziṇa darbu "Latvijas atbrīvošanas karš". Šis darbs ir dziḷi analītisks no militārās vēstures viedokḷa. Tajā autors aplūko arī Latvijas armijas sadarbību ar Polijas karaspēku 1920. gadā. Visumā viṇš ir objektīvs, kaut arī ir noprotamas autora subjektīvās simpātijas pret Polijas armiju. Nozīmīgi ir arī P. Radziṇa spriedumi par politiskām problēmām. Viṇš vienkāršā veidā, kā jau tas raksturīgs profesionālam karavīram, izklāsta apsvērumus, kuru dēl valdība izšḳīās par sadarbību ar Poliju Latgales atbrīvošanā (9. lpp.). ${ }^{16}$ Atmiṇas, kas papildinātas ar teorētisku taktiskās situācijas analīzi, atstājuši arī citi Latvijas armijas virsnieki - Latgales atbrīvošanas kauju dalībnieki: bijušais 3. bruņotā vilciena komandieris pulkvedis-leitnants A. Paulockis, atsevišķās telegrāfa un telefona rotas komandieris pulkvedis P. Antens, Zemgales divīzijas atsevišķā eskadrona komandieris pulkvedis-leitnants A. Artum-Hartmanis. ${ }^{17}$ Līdzīgas liecības par poḷu karaspēka daḷu nomaiṇu frontē 1920. gada pavasarī, vēlāko situāciju reǵionā $\overline{1}^{18}$ atrodamas arī citos Latvijas Kara muzejā uzglabātajos materiālos, kā arī publicētajās vairāku Latvijas armijas pulku vēsturēs ${ }^{19}$ un Neatkarības karam veltītajos bijušo cīṇu dalībnieku sarakstītajos vispārīga rakstura darbos. ${ }^{20}$ Būtiskākais šo darbu trūkums ir ierobežots materiālu daudzums, ko izmantojuši autori, nepilnīga vispārējās politiskās situācijas izpratne, kā arī atsevišķu procesu nepietiekama analīze vai pat noklusēšana, ko izraisijjusi politiskā konjunktūra. Galvenokārt tiek runāts par Latvijas armijas nozīmi Latgales atbrīvošanā, vienīgi virspusēji pieminot arī sadarbību ar Polijas armiju. Līdzīgi politiski iemesli 20., un īpaši 30. gados, sekmēja arī Igaunijas armijas veikuma mazināšanas tendences Latvijā, kaut arī tās nebija tik spēcīgas kā gadījumā ar Poliju, kurai piedēvēja zināmus naidīgus nodomus attiecībā pret Latviju.

\footnotetext{
16 Radziņš P. Latvijas atbrīvošanas karš. - 2. daḷa. - Rīga, 1922. - 148 lpp.

${ }^{17}$ Latvijas Kara muzejs (turpmāk: LKM), 3. bruṇotā vilciena kaujas apraksts par laiku no 3. līdz 20. janvārim 1920. g.; Antens P. Pārskats par telegrāfa un telefona rotas darbību laikā no 1919. g. XI līdz 1921. g. IV; Artum-Hartmanis A. Zemgales divīzijas atsevišksā eskadrona vēsture.

${ }^{18}$ LKM, 12. Bauskas kājnieku pulka vēsture; Kalniņš T. Îss pārskats par 10. Aizputes pulka nodibināšanu, formēšanos un kara darbības gaitām atbrīvošanās cīṇu laikmetā 1919. un 1920. g. u. c. darbi

19 2. Ventspils pulks. - Liepāja, 1936. - 422 lpp.; Lavenieks J. Bruṇoto vilcienu pulks. - Izdevusi V. Laveniece, 1971. - 186 lpp.; Jātnieku pulks 10 gados. - Rīga, 1929. - 72 lpp.; 9. Rēzeknes k. p. gaitas. - Rīga, 1923. - 220 lpp.; 3. Jelgavas kājnieku pulks 1919. 16. VIII - 1929. - 3. Jelgavas k. p. izdevums, 1929. - 267 lpp.

${ }^{20}$ Apsītis A. Latgales atbrīvošana//Atbrīvošanās kara vēsture/Virsred. M. Peniķis. - Rīga, b. g. 256. - 325. lpp.; Latvijas armija 20 gados. - Rīga, 1940. - 217.-236. lpp., u. c. darbi
} 
Arī poḷu historiogrāfijā ir darbi, kurus var daḷēji uzskatīt par notikumu aculiecinieku atmiṇām, dalēji - par vairāk vai mazāk veiksmīgiem mēǵinājumiem sniegt kopīgo stāvokḷa vērtējumu (atkarībā no autoru izglītības un kompetences līmeṇa). Ziṇas par kaujām Latvijā 1919.-1920. gadā atrodamas visu Latvijā dislocēto karaspēka daḷu vēstures izdevumos (kopumā 19, neskaitot rakstus par atsevišḳu vienību piedalīšanos operācijās Latvijā), starp kuriem īpašu vietu ieṇem pulkveža A. Borkeviča sarakstītā 1. Leǵionu kājnieku pulka apjomīgā vēsture. ${ }^{21}$ Grāmatas pielikumā sniegti kritušo (arī Latvijā) pulka karavīru saraksts. Neliela šì darba daḷa (par Daugavpils atbrīvošanas operāciju) 30. gados iespiesta arī Latvijā. ${ }^{22}$ Diemžēl tā tulkota ar kḷūdām un tajā ir tikai neliels fragments no oriǵginālā ietvertā detalizētā kauju apraksta Latgalē. Par sadarbību ar Latvijas armiju rakstīja arī bijušais apvienotās karaspēka grupas štāba priekšnieks ǵenerālis T. Kučeba ${ }^{23}$ un 1. Leǵionu kājnieku brigādes (Latgales operācijas galvenā triecienspēka) komandieris S. Dombs-Bernackis. ${ }^{24}$ Arī šo darbu trūkums ir no mūsdienu viedokḷa nepietiekama politisko apstākḷu un fona analīze, kas izskaidrojama ar ierobežotajiem autoru mērk,iem un militārivēsturisko specifiku. Tomēr šie darbi sniedz informāciju, kuras nav politiku rakstos, tādēl ieṇem noteiktu vietu Latvijas un Polijas kopīgajā vēsturē. Jāpiezīmē, ka 20. gados radās diplomātiska nepieciešamība atzīmēt abu valstu kopīgās kaujas. Šajā sakarā tapa T. Kučebas raksts, kuram piemīt zināma āriškība un kurā jūtama autora vēlme izvairīties no attiecību sarežǵijumu analīzes, kaut gan tas uzrakstīts korekti un ar dziḷu militārās situācijas izpratni. Vienīgā nopietnā, acīm redzamā pārrakstīšanās kḷūda ir raksta beigās, kur minēts, ka poḷi Latgalē zaudējuši vairāk nekā 600 "nosalušo". Rakstu vairākus gadus vēlāk saīsināti pārpublicēja laikraksts "Latvijas Kareivis", diemžēl atkārtojot arī kḷūdu par neiedomājami milzīgo nosalušo skaitu (patiesībā šeit acīmredzot domāti nevis līdz nāvei nosalušie, kā to var saprast, bet kādas konkrētas karaspēka daḷas, visticamāk, 1. Leǵionu kājnieku brigādes, karavīri, kas guvuši dažādas pakāpes apsaldējumus). ${ }^{25}$

Vēl subjektīvāki ir daudzie darbi, kas veltīti Latvijai, īpaši Latvijas poḷu stāvokḷa tematikai, un izdoti Polijā 20. un 30. gados. Tādi ir bijušā Latgales muižnieka V. Studṇicka-Gizberta sacerējumi. ${ }^{26}$ Šis politiḳis Polijā pārstāvēja viedokli, kas Latvijai bija visnelabvēlīgākais. Tas lielā mērā bija saistīts ar viṇa labēji politisko radikālismu un aizvainojumu par „pārestībām”, kuras poḷu muižniecībai Latvijā nodarījuši latviešu „zemnieki”, kuriem, vinaprāt, ir daudz zemāks sociālās attīstības līmenis. 20. gadu sākumā viṇš atklāti

\footnotetext{
${ }^{21}$ Borkiewicz A. Dzieje 1-go pułku Legjonów. - Warszawa, 1929. - 1127 ss. Pats A. Borkēvičs 1920. gadā piedalījās Daugavpils atbrīvošanā un citās kaujās Latgalē.

22 Bebris R. Daugavpils atbrīvošana 1920. gada 3. janvārī//Militārais Apskats. - 1935. - Nr. 2. 214. - 229. lpp.

${ }^{23}$ Kutrzeba T. Wspomnienia źołnierskie w dzień swięta niepodległości Łotwy//Przegląd Współczesny. - 1927. - T. XX. - S. $113-120$.

${ }^{24} \mathrm{Dąb}$ - Biernacki S. Grupy oporowe w świetle działań pierwszej dywizji piechoty legjonów//Bellona. -1922 . - T. VIII. - Zesz. 3. - S. $230-246$.

${ }^{25}$ Latvijas Kareivis. - 1933. - 3. janv.

${ }^{26}$ Studnicki W. Zarys państw bałtyckich. Finlandja, Łotwa i Estonja. - Warszawa, 1924. - 188 ss.
} 
izteica nožēlu, ka Polija „darot pāri Latgales poḷiem”, 27 jo Polijas valdība nebija iekḷāvusi Polijā Daugavpili (nerunājot par 6 strīdīgajiem Ilūkstes apriņķa pagastiem), lai izveidotu labas attiecības ar Latviju. V. Studņicka un citu viṇam līdzīgi domājošo sacerējumus nevar salīdzināt ar inteliğentā un demokrātiskā J. Cinarska (literārais pseidonīms - Kšeslavskis) rakstiem un grāmatām par Latviju. ${ }^{28}$ No 1920 . gada līdz 20. gadu vidum viṇš strādāja par Polijas Telegrāfa ağentūras Rīgas biroja vadītāju. Notiekošo viṇš vērtē no Latvijai izteikti labvēlīgām pozīcijām un pat nosoda V. Studṇicka un citu paustos reakcionāros uzskatus.

Daudzi poḷu autori pievērsās poḷu minoritātes stāvokḷa analīzei Latvijā, skarot arī 1919.-1920. gada notikumus. Ar retiem izṇēmumiem (J. Cinarskis) viṇi centās saskatīt, pirmkārt, pierādījumus poḷu tiesību ierobežošanai Latvijā, ${ }^{29}$ cita starpā ievērojami un pilnīgi nepamatoti pārspīlējot Latvijā dzīvojošo poḷu skaitu (līdz 150000 cilvēku).

Pēc Otrā pasaules kara Baltijas valstu savienības problēmu Padomju Latvijā zinātniski pētīja K. Počs, ${ }^{30}$ kura darbi balstīti uz plašu avotu un literatūras bāzi. Viṇš neapšaubāmi sniedz svarīgu informāciju Latvijas un Polijas attiecību historiogrāfijā, lai gan atsevišknos vērtējumos un secinājumos ir zināma tendenciozitāte padomju vēstures zinātnes prasību un ierobežojumu dēḷ. Absolūti tendenciozs bija padomju vēsturnieks V. Sīpols, kurš, pētot Latvijas-Polijas attiecības, balstījās galvenokārt uz jau minēto, 1964. gadā Maskavā izdoto dokumentu krājumu par padomju-poḷu attiecībām, turklāt vienīgi savu politisko mērḳu kontekstā. ${ }^{31}$ Šo autoru darbos nav izmantoti Polijas avoti un literatūra, kas vēl vairāk padziḷina dokumentu atlases un uz to pamata izdarīto secinājumu subjektivitāti.

Līdzīgs trūkums piemīt arī latviešu izcelsmes ASV un latviešu trimdas vēsturnieka E. Andersona darbiem, ${ }^{32}$ kuros gan izmantota Rietumvalstīs pieejamā literatūra un daḷēji arī avoti. Tomēr dažas viṇa grāmatās un rakstos piel̦autās neprecizitātes un pat rupjas kḷūdas par aplūkojamo tēmu dažkārt grūti izskaidrot vienīgi ar Latvijas un Polijas avotu nepieejamību. Latvijas un Polijas attiecību problēmas 1919.-1920. gadā saistībā ar Padomju Krieviju skāris A. Stranga. Līdz šim viṇš tās atspoguḷojis vispilnīgāk, pamatojoties uz bagātīgu avotu materiālu bāzi un maksimāli objektīvi parādot, cik tās bija nozīmīgas visā Baltijas jūras reǵionā. Viṇš atklāja arī Latvijas valdības un

${ }^{27}$ Sīkāk sk.: Grzella J. Zaborcy i sąsiedzi w myśli politycznej Władysława Studnickiego (do 1939 roku). - Toruń, 1998. - S. 295-313.

${ }^{28}$ Cynarski J. Łotwa współczesna. - Warszawa, 1925. - 160 ss.; Cynarski J. Łotwa//Bellona. T. XIX. - Zesz. 1. - 1925. - S. 1 - 23; Krzesławski J. Stosunki polsko - łotewskie. - Kraków, 1925. - 18 ss., u. c.

${ }^{29}$ Piemēram: Maliszewski A. Polacy na Łotwie. - Kraków, 1922. - 35 ss.

${ }^{30}$ Počs K. Sanitārā kordona valgos. - Rīga, 1971. - 261 lpp.; Počs K. Pretpadomju Polijas-Baltijas valstu savienības jautājums buržuāziskās Latvijas ārpolitikā 1920.-1923. g.// Latvijas PSR Zinātṇu akadēmijas Vēstis. - 1966. - Nr. 1. - 21.-30. lpp.

${ }^{31}$ Sīpols V. Slepenā diplomātija. - Rīga, 1965. - 258 lpp.

32 Andersons E. Latvijas vēsture 1914-1920. - Daugava, 1967. - 755 lpp.; Andersons E. Sacensība par Daugavpili//Daugavas Vanagu Mēnešraksts. - 1965. - Nr. 2. - 46.-51. lpp.; Andersons E. Latvijas vēsture 1920-1940. - Daugava, 1982. - 704 lpp. 
politiķu nostāju konkrētajā vēsturiskajā situācijā. ${ }^{33}$ Par Latvijas un Polijas attiecībām rakstījis arī šì darba autors. ${ }^{34}$

Polijā visciešāk ar Baltijas valstu vēstures izpēti saistīts vēsturnieks P. Losovskis. Jau 60. gados vin,š rakstīja par Polijas attiecībām ar Lietuvu abu valstu neatkarības sākumposmā 1918.-1920. gadā. ${ }^{35}$ Šajā plašajā un analìtiskajā darbā, kas pamatojās uz bagātīgu faktu materiālu, viṇš sīki analizēja vispārējo stāvokli Baltijas reǵionā un pievērsās arī Polijas attiecībām ar Latviju. Tas ir pirmais nopietnais darbs par minēto tēmu Polijā, un 1996. gadā izdots tā pilnveidots variants. ${ }^{36}$ Sākoties Atmodas procesam Latvijā, Polijā tika publicēta neliela, bet faktoloǵiski bagāta P. Losovska grāmata par Polijas attiecībām ar Latviju starp abiem pasaules kariem. Grāmatas mērḳis bija iepazīstināt poḷu lasītājus ar atdzimstošo Latvijas valsti. ${ }^{37}$ Būtiskākais šì izdevuma trūkums gan ir zinātnisku atsauču trūkums.

Polijas attiecības ar Baltijas valstīm savā darbā aplūkojis arī poḷu vēsturnieks A. Skšipeks. Darbs veltìts Baltijas savienības izveides problēmai, ${ }^{38}$ un viņš analizē šìs savienības neizveidošanās cēloṇus, parādot visu ieinteresēto pušu motīvus. A. Skšipeks ir arī monogrāfijas autors. Tā veltīta tieši Polijas un Latvijas attiecībām 1918.-1939. gadā, un cita starpā monogrāfijā analizēts arī Latvijas poḷu minoritātes stāvoklis. ${ }^{39}$ Savukārt Polijas attieksmi pret P. Bermonta-Avalova vadītajiem reakcionārajiem vācu-krievu spēkiem pētījis A. Juzvenko ${ }^{40}$ un L. Kevišs. ${ }^{41}$ Viens no ievērojamākajiem poḷu vēsturniekiem V. Pobugs-Maḷinovskis emigrācijā, Londonā, izdotajā apjomīgajā "Polijas visjaunākajā politiskajā vēsturē"42 vispusīgi analizē arī attiecības ar Latviju un dara to ciešā kontekstā ar Polijas vispārējo vēstures kopainu. Darba tapšanas laikā nebija pieejama daḷa avotu, kas atradās Polijā. Līdz ar to atsevišķu detaḷu traktējums nav objektīvs. Latviešu valodā 1992. gadā tika iespiests A. Gizas raksts par Polijas un Latvijas attiecībām 1919.-1920. gadā, ${ }^{43}$ tomēr tas balstīts uz visai trūcīgas avotu un literatūras bāzes un norises aplūkotas tikai

\footnotetext{
${ }^{33}$ Stranga A. O niektórych problemach polsko - łotewskich stosunków (przełom 1919 - 1920 r.)// Przegląd Zachodniopomorski. - T. 4. - 1989. - Zeszyt 3 - 4. - S. 147-154; Stranga A. LatvijasPadomju Krievijas miera līgums 1920. gada 11. augustā. Latvijas-Padomju Krievijas attiecības 1919.-1925. gadā. - Rīga, 2000, u. c.

34 Jēkabsons Ē. Latvijas diplomātija Bermonta uzbrukuma laikā 1919. gadā//Militārais Apskats. - 1994. Nr. 2. - 73.-82. lpp.; Viḷnas jautājums un Latvija 1920. gada ruden̄̄//Latvija-Polija. Starptautiskas zinātniskas koferences materiāli. - Rīga, 1995. - 63.-88. lpp., u. c.

35 Łossowski P. Stosunki polsko-litewskie w latach 1918 - 1920. - Warszawa, 1966. - 413 ss.

36 Łossowski P. Konflikt polsko-litewski 1918 - 1920. - Warszawa, 1996. - 252 ss.

${ }^{37}$ Łossowski P. Łotwa nasz sąsiad. - Warszawa, 1990. - 63 ss.

38 Skrzypek A. Związek Bałtycki. - Warszawa, 1972. - 309 ss.

${ }^{39}$ Skrzypek A. Stosunki polsko-łotewskie 1918-1939. - Gdańsk, 1997. - 159 ss

40 Juzwenko A. Postawa Polski wobec akcji Von Der Goltza i Bermondt-Awałowa w krajach Bałtyckich w $1919 \mathrm{roku} / /$ Komunikaty Mazursko - Warmińskie. - 1969. - Nr. 4. - S. 571-580.

${ }^{41}$ Kiewisz L. Sprawy łotewskie w bałtyckiej polityce Niemiec w latach 1914-1919. - Poznań, 1970. 254 ss.

42 Pobóg -Malinowski W. Najnowsza historia polityczna Polski 1864-1945. - T. II. - Londyn, 1956. S. 665 .

${ }^{43}$ Giza A. Latvijas un Polijas attiecības 1919. un 1920. gadā//Latvijas Vēsture. - 1992. - Nr. 1. 14.-17. 1pp.
} 
virspusēji. Ievērojami dziḷāk jautājumu skāris poḷu vēsturnieks J. Paḷušiṇkis.. ${ }^{44}$ Viņš apkopojis lielāko daḷu avotu, kas bija pieejami Polijā poḷu valodā par Latvijas vēsturi attiecīgajā laika posmā. Tomēr T. Paḷušiņskis piel̦auj samērā daudz faktoloǵisku kḷūdu, jo gandrīz pilnībā trūkst Latvijas avotu un vietām viṇš paḷaujas uz Polijas preses izdevumu sniegto informāciju. Pieḷautās kḷūdas lielākoties gan neiespaido pamatā pareizos autora secinājumus. Minētais attiecas uz apjomīgo, faktiem bagāto un dziḷi analïtisko T. Paḷušin,ska doktora disertāciju "Cīṇa par Latvijas neatkarību 1916-1921". 1997. gadā viṇš to aizstāvēja Poznaṇas Universitātē, un 1999. gadā ar nosaukumu "Latvijas cīṇa par neatkarību 1914-1921” un ar Latvijas vēstniecības Varšavā atbalstu tā izdota atsevišḳā grāmatā. ${ }^{45}$ Tā kā latviešu avoti un literatūra valodas nezināšanas dēḷ autoram nav pieejami, viṇš atsevišķu Latvijas vēstures laika posmu apskatā kā Latvijas puses "literatūru" izmanto Latvijas PSR vēstures sējumus, kas 50. gadu sākumā izdoti krievu valodā, un pat vēsturnieku staḷinistu darbus. Pētāmās valsts pamattautas valodas gramatikas nezināšanas dēl autors raksta uzvārdus ǵenitīvā, nevis nominatīvā, kā arī izkroplo personu vārdu, uzvārdu un ǵeogrāfisko nosaukumu pareizrakstību. Diemžèl ḷoti kḷūdaini, neprecīzi un tendenciozi Polijas un Latvijas militāro sadarbību, kas notika 1919.-1920. gadā, aplūko Polijas vēstures speciālists angḷu vēsturnieks N. Deiviss, kas šodien pazīstams visā pasaulē. ${ }^{46}$

Kopumā visos poḷu vēsturnieku darbos praktiski nav izmantoti Latvijas avoti un literatūra. Tādējādi atkārtojas Latvijas historiogrāfijā vēl nesen vērojamā parādība - Polijas avotu neizmantošana - attiecībā uz abu valstu kopīgās vēstures izpēti. Lielāka uzmanība pievērsta Baltijas valstu savienības izpētei (K. Počs), kā arī šo valstu saistībai ar Rietumu lielvalstu ārpolitiku. Lielākoties šie pētījumi veikti padomju historiogrāfijas uzspiestā mērķa dēl parādìt Baltijas valstu atkarību no "Rietumiem", kas noteica to saistību ar "kordonvalsti" Poliju. Minētais mērķis iespaidoja vēsturnieku darbus, tomēr daži no tiem uzskatāmi par noteiktu ieguldijumu Latvijas un Polijas attiecību izpētē, pateicoties autoru sniegtajam faktoloǵiskajam materiālam un iespēju robežās arī objektīvajiem secinājumiem.

Līdz šim Latvijā nepietiekami analizēta sadarbība ar Polijas armiju Latgales atbrīvošanā; sarežğìjumi šajā sadarbībā, jo tie bija cieši saistīti ar Polijas armijas karavīru disciplīnas pārkāpumiem Latvijas teritorijā; šo pārkāpumu cēloṇi; Latvijas un Polijas teritoriālās domstarpības; Latvijas

44 Paluszyński T. Akcja polsko - łotewska w Łatgalii w styczniu 1920 roku//Wojskowy Przegląd Historyczny. - 1995. - Nr. 3-4. - S. 22-36; Paluszyński T. Podstawy polityki polskiej wobec Łotwy w latach 1919-1920//Łotwa-Polska. - Ryga, 1995. - S. 55-66; Paluzsyński T. Rola Leona Wasilewskiego w nawiązaniu stosunków pomiędzy Polską i państwami Bałtyckimi//Niepodległość Polski w 1918 roku a procesy państwowotwórcze w Europie Środkowo - Wschodniej/Red. Z. Mańkowski. Lublin, 1996. - S. 163-184; Paluszyński T. Konflikty graniczne pomiędzy państwami Bałltyckimi: Litwa, Łotwa i Estonia w dobie ich walki o niepodległość w latach 1919-1921//Studia z Dziejów Rosji i Europy Środkowo - Wschodniej. - T. XXX. - 1996. - S. 37-46.

45 Paluszyński T. Walka o niepodległość Łotwy 1916-1921. - Praca doktorska napisana pod kierunkiem naukowym prof. dr. hab. S. Sierpowskiego. - Poznań, 1997. - 401 ss.; Paluszyński T. Walka o niepodległość Łotwy. - Warszawa, 1999. - 448 ss.

${ }^{46}$ Davies N. Orzeł biały, czerwona gwiazda. Wojna polsko-bolszewicka 1919-1920. - Kraków, 1998. - 307 ss. 
nostāja Polijas un Lietuvas konfliktā Viḷnas dēḷ u. c. 30. gados Polijā atsevišḳi poḷu virsnieki, mācoties Augstākajā karaskolā, strādāja pie kopīgo militāro operāciju izpētes, taču viṇi izmantoja vienīgi poḷu avotus. Līdzīgs stāvoklis bija arī Latvijā. 1932. gadā Latvijas armijas kapteinis E. Ratnieks, beidzot kara akadēmiskos kursus, rakstīja diplomdarbu par Latgales atbrīvošanas operāciju. Viṇš lūdza Polijas militāro atašeju iegūt viṇam atlauju iepazìties ar poḷu puses materiāliem par minēto tēmu. Atašejs lūgumu atbalstīja un nosūtīja to Polijas armijas Kara vēstures birojam. Tā vadìtājs atbildēja, ka l,aus E. Ratniekam iepazìties ar materiāliem, taču viņam jāprot poḷu valoda, jo visa dokumentācija saprotamu iemeslu dēḷ ir poḷu valodā. Ar minēto sadarbības mēǵinājumu jautājuma izpēte beidzās, jo abu pušu militārie vēsturnieki turpināja strādāt nesaskaņoti, atseviškịi un katrs ar savām avotu grupām, kā arī savas valsts subjektīvā redzējuma iespaidā. Par nepilnībām šajā darbā liecina arī fakts, ka 30. gados Latvijas Kara muzejā par poḷu piedalīšanos Latgales atbrīvošanā bija tikai viens fotouzṇēmums (J. Pilsudskis un E. Ridzs-Smiglijs Daugavpils stacijā). ${ }^{47}$ Līdzīga un pat vēl sliktāka situācija bija arī Polijā.

Polijā minētie jautājumi skarti lielākā mērā (galvenokārt sakarā ar vēstures zinātnes nesalīdzināmi lielāko attīstības brīvību un atškíirīgo līmeni arī 60.-80. gados), tomēr saprotamu iemeslu dēḷ tas darīts vienīgi no Polijas interešu un redzes viedokḷa, kurš, kaut arī visumā labvēlīgs Latvijai, tomēr pilnvērtīgi neatspoguḷo Latvijas puses nozīmi un motīvus.

Šajā darbā iespēju robežās mēǵināts apkopot pieejamos abu pušu un Lietuvas avotus un literatūru un vispusīgi atspoguḷot Latvijas un Polijas attiecības, sākot ar pirmajiem sakariem 1919. gada martā un beidzot ar Latvijas atzīšanu „de iure” 1921. gada sākumā.

${ }^{47}$ AAN, Sztab Główny, t. 616/ 131, k. 521; t. 616/ 161, k. 238; t. 616/ 234, k. 132, 179. 


\section{1. nodalla \\ ATTIECİBU NODIBINĀŠANA \\ (1919. gada marts-decembris)}

\section{Pirmie sakari}

Latviešu sakari ar poliem neatkarīgas valsts idejas kontekstā iezīmējās jau 19. gadsimta beigās un 20. gadsimta sākumā. Viens no ievērojamākajiem 19.-20. gadsimta poḷu sociālistiskās kustības teorētiķiem, kā arī viens no nedaudzajiem Latgales muižniekiem, kurš saglabāja savu labvēlību pret Latvijas valsti līdz pat savai nāvei 1935. gadā - Daugavpils apriṇkī dzimušais Boḷeslavs L,imanovskis - jau 1878. gadā paredzēja, ka „poḷi, baltkrievi, lietuvieši, latvieši un ukraiṇi pēc sava nospiedošā jūga nomešanas vispārējās un brīvās vēlēšanās paši izlems, vai viṇiem jānorobežojas ar robežām vai jāpaliek saistītiem ciešā federācijā”. Nedaudz vēlāk - 1895. gadā - viens no poḷu sociālistu vadītājiem, nākamais Polijas valsts galva J. Pilsudskis rakstīja: „Par laimi, Krievijas valsts sastāvā bez pašas Krievijas ietilpst ar varu paverdzinātās un pie tās pieķēētās zemes. Šo zemju iedzīvotāji - poḷi, lietuvieši, latvieši, ukraiṇi - apdzīvo teritorijas, kas agrāk piederējušas Polijas-Lietuvas valstij. Tādējādi tiem ir pavisam cita vēsturiskā pagātne un tradīcijas; tie visi cieš no carisma nacionālās un reliǵiskās vajāšanas, kas tajos rada naidu pret pastāvošajiem politiskajiem apstākḷiem. [..] Visi šie apstākḷi lauj paredzēt, ka tieši no šejienes nāks tas spēks, kurš saberzīs pulverī carisma varenību. [..] Poḷu strādnieku šk̦ira, kura jau tagad carismam sagādā ne mazums raižu, vedīs aiz sevis cīṇā citu paverdzināto tautu strādājošo masas un, gūstot atbalstu no pašas Krievijas revolucionārās kustības, vedīs tos uz uzvaru, kas nodrošinās brīvību un atbrīvošanos ne tikai poliem, bet visiem pārējiem, kuri cietuši no carisma." Tajā pašā 1895. gadā Polijas Sociālistiskās partijas III kongress pieņēma lēmumu, ka partijai attiecībās ar citu tautību „opozicionārajām grupām jācenšas veicināt tajās separātistiskas tieksmes un pastāvīgi jārada nepieciešamība gāzt carismu, sadarbojoties visām tautām, kuras tas paverdzinājis". ${ }^{48}$ Tādējādi poḷu nacionālās atbrīvošanās kustības dalībnieki jau gadsimtu mijā ārējo apstākḷu iespaidā bija spiesti saskatīt latviešos potenciālo sabiedroto nākotnē.

19. gadsimta beigās latviešu sociāldemokrātiem izveidojās samērā pastāvīgi kontakti ar poḷu sociālistiem. Pirmkārt, tas notika Rīgā, kur Rīgas Politehnikumā (vēlāk Politehniskajā institūtā) darbojās l̦oti aktīvi poḷu sociālistu grupējumi (viena grupējuma vadītājs bija vēlākais Polijas valsts

\footnotetext{
${ }^{48}$ Boruta M. Wolni z wolnymi, równi z równymi, Polska i Polacy o niepodległośći wschodnich sąsiadów Rzeczypospolitej. - Kraków, 2002. - S. 45, 57.
} 
prezidents I. Moscickis). ${ }^{49}$ Ar tiem sakarus uzturēja un pat zināmā mērā sadarbojās latviešu kreisi noskaņotie studenti, kurus poḷi centās pārliecināt par nepieciešamību izvirzìt prasību pēc neatkarīgas Latvijas valsts, paredzot kara izcelšanos, kura laikā varēs īstenot šo prasību. Paši toreizējie latviešu studenti vēlāk atzina, ka šāda nostāja tiem tolaik škitusi nepamatota un neizprotama, tomēr uzskatīja, ka zināmu iespaidu uz viṇu domāšanu tā tomēr atstājusi. ${ }^{50}$ 1901. gadā latviešu sociāldemokrāti H. Punga un D. Bundža Londonā nodibināja sakarus ar vienu no vadošajiem Polijas Sociālistu partijas darbiniekiem J. Pilsudski, kurš bija tikko izbēdzis no cietuma slimnīcas Pēterburgā un centies latviešus pārliecināt par nepieciešamību cīnìties ne tikai par sociālismu un autonomiju Krievijas sastāvā, bet arī par pilnīgu neatkarību. H. Punga vēlāk citēja J. Pilsudska teikto: „Jūsu pienākums tagad nokratìt no saviem pleciem vāciešu politisko un ekonomisko slogu un izlabot tās kḷūdas, kuru dēḷ latviešu tauta cieta no vāciešiem. Esmu pārliecināts, ka nākotnes neatkarīgā Polija un brīvā Latvija ies roku rokā par svētību mūsu tautām." ${ }^{1}$ Turklāt Londonā J. Pilsudskis tikās ar latviešu sociāldemokrātu F. Vesmani un arī viṇu mēg̣ināja pārliecināt par nepieciešamību izvirzìt prasību par Latvijas neatkarību. ${ }^{52}$ 1905. gada revolucionāro notikumu laikā Latvijā poḷu sociālistu presē, kas iznāca Krakovā (Austroungārijā), rakstā „Lai dzīvo latvieši!” bija aprakstītas latviešu kaujinieku cīṇas ar cara karaspēku un secināts, ka poḷiem Latvija ir kḷuvusi par „svēto zemi”. ${ }^{53}$ Pēc 1905. gada revolūcijas latviešu sociāldemokrāts un aktīvs revolucionāro notikumu līdzdalībnieks Liepājā V. Smaren-Svarinskis, kas bija notiesāts uz sešiem ieslodzījuma gadiem, Rīgas un Irkutskas katorgas cietumā izcieta sodu kopā ar diviem poḷu revolucionāriem, kas bija notiesāti par piederību Polijas Sociālistiskajai partijai. Savstarpējās sarunās un kopīgi lasot attiecīgo poḷiem piesūtīto literatūru, V. Smaren-Svarinskis bija sācis apšaubīt savu līdzšinējo „revolucionāro uzskatu” un kopīgi ar viņiem nonācis pie slēdziena, ka Rietumkrievijas tautām jācīnās par neatkarību un ka skaitliski kopā tās līdzinās paverdzinātājai - krievu - tautai, tāpēc ,jāveicina separātistu kustība katrā Krievijas tautā” ${ }^{4}$ (drīzāk poḷi viṇu par to pārliecinājuši - $\bar{E}$. J.).

Galu galā pirmais no latviešu politiskajiem darbiniekiem, kurš pauda Latvijas neatkarības ideju vēl 1905. gada revolūcijas priekšvakarā kā Latviešu sociāldemokrātu savienības vadītājs Šveicē - M. Valters - , vēlāk atzīs, ka viṇa uzskatus šajā jautājumā iespaidojusi Poḷu sociālistiskā partija un pats J. Pilsudskis. M. Valters rakstīja: „Jau pirmie soḷi senākā emigrācijā pamudināja skatīties uz leišiem un poḷiem, ar kuriem satikās emigranti

\footnotetext{
49 Sk. sīkāk: Jēkabsons Ē. Poḷu studenti Rīgas Politehniskajā institūtā (19. gs. II puse - 1915. gads)// Latvijas Vēstures Institūta Žurnāls. - 2005. - Nr. 3. - 56.-83. lpp.

${ }^{50}$ Latvijas Valsts vēstures arhīvs (turpmāk: LVVA), 7473. f., 1. apr., 2. 1., 45.-46., 49. lp.

${ }^{51}$ Punga H. Polija un viņas valsts darbinieki//Darba Balss. - 1921. - 31. dec.; Pilsudskis kā revolucionārs un patriots// Latvijas Kareivis. - 1922. - 3. janv.

52 Krzesławski J. Stosunki polsko-łotewskie. - Kraków, 1925. - S. 5.

${ }^{53}$ Łossowski P. Łotwa nasz sąsiad. - Warszawa, 1991. - S. 5.

54 Smaren-Svarinskis V. Manas atmiņas//Latvju Nacionālā Kluba Bil̦etens. - 1924. - Nr. 7; Nr. 8.
} 
Londonā, Cīrihē, Bernē un no kuriem tie saṇēma tādu iespaidu, it kā latvju tauta būtu visu laiku aizsnaudusies un piemirsusi pavisam par sevi domāt." 55

Tādējādi jāsecina, ka vēl pirms 1918. gada poḷu politiskie centieni bija zināmi nelielā latviešu sabiedrības dal̦ā, taču ne par kādu plānveida sadarbību un pat nopietnu ieinteresētību no latviešu puses nevarēja būt runas. Kaut arī abu tautu stāvoklī bija kopīgas iezīmes, tomēr pārlieku atšķirīga bija abu tautu vēsture un tās izraisītās sekas, turklāt arī pastāvošie sakari jāuztver vienīgi kā individuālie kontakti. Kā jau minēts, tieši poḷu puse pastiprinātu vērību pievērsa sakariem, sadarbībai un attiecībām ar lietuviešiem. Saistībā ar viṇiem laiku pa laikam tika minēti arī latvieši. Piemēram, arī 1917. gadā poḷu zinātnieks V. Vakars rakstīja, ka nākamās Polijas interesēs ir lietuviešu un latviešu zemju apvienošanās vienā valstī. Tam ir zināms pamats: „Lietuviešulatviešu neatkarība Polijas interesēm atbilst vislielākā mērā. Tādējādi tieši tās kaimiṇos izveidotos neatkarīga valsts ar ievērojamu teritoriālo platību, dzīvotspējīga un izturīga, ar to mūs saistītu saimnieciskās intereses un kopīgi politiskie apdraudējumi. Nivelācijas vai kolonizācijas programmu attiecībā pret šìm zemēm Polija nelolo, bet par savu goda pienākumu uzskata veicināt ceturtā āriešu zara attīstību." ${ }^{\circ 6}$

Pirmā pasaules kara pēdējā posma notikumi skaidri liecināja, ka 1918. gadā bija gaidāmas pārmaiṇas Eiropas politiskajā kartē. Latviešu un poḷu politiķi šādos apstākḷlos saskatīja ekonomiskas un politiskas sadarbības iespējas vēl pirms formālas abu valstu neatkarības iegūšanas, lai gan abām tautām bija atšķirīgs militārpolitiskais, vēsturiskais, ǵeogrāfiskais stāvoklis, kā arī atšḳirīgs iedzīvotāju skaits un sastāvs. To noteica abu pušu militārpolitiskās un saimnieciskās intereses. Jau 1918. gada jūlija beigās Stokholmā pie J. Mokžiņska, kas bija Poḷu nacionālās komitejas pārstāvis Zviedrijā (šì komiteja darbojās Francijā), ieradās Latviešu Pagaidu nacionālās padomes Informācijas biroja pārstāvis Z. Meierovics un informēja to par Latvijas politiskajiem apstākḷiem un viņa pārstāvētās padomes mērķi nodibināt patstāvīgu Latvijas valsti. Abas puses sarunā secināja, ka "pēc kara" būs lietderīgi nodibināt ekonomiskus sakarus starp Latviju un Poliju (pirmkārt, poḷus interesēja Liepājas osta), tādēḷ būtu vēlams laikus apsvērt nākamās sadarbības formas. ${ }^{57}$ Jāpiezīmē, ka Poḷu Nacionālās komitejas paustā teritoriālā koncepcija šajā laikā un vēlāk bija Latvijai nelabvēlīga vai pat l,oti nelabvēlīga, taču minētā saruna apliecina, ka pat šajā komitejā dominējošie poḷu nacionāldemokrāti jau 1918. gadā uzskatīja Latvijas neatkarību par iespējamu un sadarbībā ar Latviju saskatīja ekonomisku izdevīgumu Polijai. Pastāvošajā militārpolitiskajā situācijā latviešu-poḷu sakari pagaidām tālāk neattīstījās. Līdzīga bija arī Igaunijas situācija attiecībās ar poḷu politiskajām aprindām. Igauṇu politiķis K. Pusta 1924. gadā gan rakstīja, ka jau 1918.

55 Valters M. Mūsu tautības jautājums//Daugavas gadagrāmata. 1932. - Rīga, 1932. - 128. lpp.; Cielēns F. dr. Miķelis Valters vēstures logatā. Viņa 90 gadu piemiņai//Brīvība. - 1964. - Nr. 4/5.

56 Wakar W. Rozwój terytorialny narodowości polskiej .-Cz. II. - Statystyka narodowościowa kresów wschodnich. - Kielce, 1917. - S. 154.

${ }^{57}$ Archiwum Akt Nowych (turpmāk: AAN), Kolekcja opracowań i odpisów dokumentów dotyczących stosunków Polski z Łotwą, Litwą, Estonią i Finlandią (turpmāk: Kod), t. 2, k. 7; Līgotṇu J. Latvijas valsts dibināšana. - Rīga, 1925. - 379. lpp. 
gada vasarā Parīzē, Poḷu Nacionālās komitejas namā, notikušas sarunas par nepieciešamību pēc kara veidot sadarbību starp Poliju, Lietuvu, Latviju, Somiju, Zviedriju un Igauniju, taču ne latviešu, ne lietuviešu pārstāvji tajās nav piedalïjušies. ${ }^{58}$

Reāla sadarbība kḷuva iespējama vienīgi pēc abu valstu faktiskas izveidošanās, turklāt ne uzreiz. Latvijas stāvoklis pirmajos neatkarības mēnešos bija politiski un militāri daudz nedrošāks nekā Polijai. Tas skaidri izpaudās Parīzes Miera konferencē 1919. gada pavasarī, kad nodibinājās pirmie Latvijas, kā arī Igaunijas sakari ar Polijas Republiku, kas 1918. gada 11. novembrī pasaules kara beigās bija atdzimusi un starptautiski atzìta.

1919. gada janvāra beigās Latvijas ārlietu ministrs Z. Meierovics Parīzē tikās ar Polijas valsts vadītāja J. Pilsudska pārstāvi K. Dluski, kurš tur bija ieradies, lai panāktu Polijas valdības saprašanos ar Poḷu Nacionālo komiteju, kurā, kā jau minēts, dominēja nacionāldemokrāti. Sarunā poḷu pārstāvis pauda savu un Polijas valdības labvēlību Latvijas neatkarības jautājumam (jo Polija bija ieinteresēta Krievijas "saskaldīšanā"), interesējās par Latvijas un Krievijas ekonomiskajām attiecībām nākotnē, kā arī runāja par nepieciešamību noslēgt militāru savienību, kura būtu vērsta pret Krieviju un kurā ietilptu Baltijas valstis, Somija, Polija un Rumānija. Tomēr K. Dluskis pagaidām atteicās runāt par Latgales valstisko piederību, aizbildinoties ar šì jautājuma neskaidrību, un noliedza Lietuvas tiesības uz neatkarību. Tam nepiekrita Z. Meierovics. ${ }^{59}$

1919. gada 26. martā Latvijas delegācijas sekretārs O. Grosvalds nodeva Polijas delegācijai notas norakstu ar lūgumu atzìt Latvijas neatkarību. ${ }^{60}$ Tajā pašā dienā Z. Meierovics un J. Čakste viesojās pie Polijas delegācijas un brokastu laikā pārrunāja abu valstu attiecības un pat diplomātisko pārstāvju apmaiṇas nepieciešamību un kandidatūras. ${ }^{61} 3$. aprīlī ziṇojumā savai valdībai Polijas delegācijas loceklis L. Vasiḷevskis uzsvēra, ka latvieši neatkarības jautājumā iesnieguši analoǵisku deklarāciju kā igauṇi, kaut arī politiski un militāri tie pagaidām ir daudz vājāki par igauṇiem. Savienību ar Poliju Latvija uzskata par vēlamu un piedāvā Polijai pieeju Baltijas jūras ostām, bet pretī prasa neatkarības atzīšanu un apmaiṇu ar diplomātiskajiem (pagaidām vismaz pusoficiāliem) pārstāvjiem. Arī Polijas Ārlietu ministrijas Austrumu nodaḷas vadītājs V. Jodko-Narkēvičs no Parīzes ziņoja, ka Latvija vēlas tuvināties Polijai, kaut arī apzinās, ka līdzšinējais vācu ietekmes faktors tajā "liek Polijai izturēties ar zināmu atturību". Gan Igaunijas, gan Latvijas pārstāvji atbalsta Baltijas savienības izveidošanu no Skandināvijas valstīm, Igaunijas, Latvijas, Lietuvas, Somijas un Polijas. ${ }^{62}$ Jāpiezīmē, ka tieši Parīzē Latvijas pārstāvji centās panākt Pagaidu valdības kā vienīgā likumīgā varas nesēja Latvijas teritorijā tiesību ievērošanu. Lielvalstis dažādu apstākḷu dēḷ ne

58 Pullat R. Od Wersalu do Westerplatte. Stosunki estońsko-polskie w okresie międzywojennym. Kraków, 2003. - S. 69.

${ }^{59}$ LVVA, 1313. f., 2. apr., 31. 1., 8.-9. 1p.

${ }^{60}$ AAN, Akta L. Wasilewskiego, t. 30, k. 113; Skrzypek A. Związek... - S. 28.

${ }^{61}$ LVVA, 1313. f., 2. apr., 31. 1., 48. 1p.

62 Deruga A. Nieznane dokumenty do dziejów polityki wschodniej Polski 1918 - 1919//Z dziejów stosunków polsko - radzieckich. - T. VI. - Warszawa, - 1970. - S. 241. 
vienmēr to darīja (savu nostāju lielvalstis mainīja tikai pēc konferences darba beigām 1919. gada vasarā, kad mainījās Pagaidu valdības stāvoklis Latvijā). Vienā notā, kas aprīla sākumā bija iesniegta Miera konferencei, Tautas Padomes priekšsēdētājs J. Čakste protestēja pret Vācijas mēǵinājumiem panākt poḷu karaspēka transportu no Francijas uz Poliju cauri Liepājas ostai, uzsverot, ka vienīgi Latvijas valdībai ir tiesības lemt par ārzemju karaspēka transportu cauri Latvijai. ${ }^{63}$

Polijas valsts galva un armijas virspavēlnieks J. Pilsudskis par Baltijas valstīm zināmu interesi izrādīja jau 1919. gada sākumā (7. februārī sarunā ar diplomātu V. Baranovski). ${ }^{64}$ 7. aprīlī viņš norādīja L. Vasil̨evskim Parīzē: "Vislabākais veids, kā ietekmēt lietuviešus [..], būtu latviešu spiediens uz viṇiem. Ja latvieši piekristu kaut kādai federācijai, nevaru iedomāties, ka lietuvieši spētu izturēt šādu divkāršu spiedienu [..]. Tas dotu mums Liepājas un Rīgas [ostu - E. . J.] formā vieglu kompensāciju par šaubīgo Gdaṇsku. Tāpēc spied, pirmkārt, uz latviešiem vai nu caur igauņiem, vai tieši!"65 Attiecības ar Lietuvu arvien vairāk sarežǵìjās (aprīlī poḷu karaspēks ieṇēma Viḷnu, uz ko pretendēja arī lietuvieši), un 4. maijā viņš bija vēl tiešāks: "Dieva dēl, cīnieties par to Latviju un nostipriniet ar viņiem attiecības. Atkārtoju, tas ir vienkāršākais veids, lai salauztu lietuviešu pretestību!" ${ }_{66}$ Aprīḷa sākumā Latvijas delegācijai Parīzē J. Pilsudska uzskatus atstāstīja Lielbritānijas valdības pārstāvis E. Hovards, kurš tikko bija atgriezies no Polijas. Saskaṇā ar vina teikto Polijas valsts vadītājs sarunā ar Hovardu uzsvēris nepieciešamību Latvijai noslēgt savienību ar Poliju. Teikto 14. aprīlī apstiprināja Polijas delegācijas loceklis Z. Zaḷeskis, kurš runāja par varbūtēju Latvijas un Polijas savienību (Latvijas pārstāvjus gan uzmanīgus darīja apstāklis, ka šajā savienībā nebūtu ietilpusi ne Igaunija, ne Somija). ${ }^{67}$ Ievērojot J. Pilsudska norādījumus, Polijas pārstāvji Parīzē nodibināja sakarus ar igauṇu un latviešu delegāciju. Îpaši sirsnīgi sakari poḷiem bija ar J. Poskas vadìto Igaunijas delegāciju, taču arī ar latviešiem viṇiem izveidojās labas attiecības. Latvijas un Polijas pārstāvjiem notika vairākas konsultatīvas apspriedes (piemēram, latviešu rīkotajās pusdienās 29. aprīlī), turklāt poḷus 19. aprīlī par patieso stāvokli Latvijā pēc vācu apvērsuma rakstiski informēja Tautas Padomes priekšsēdētājs J. Čakste. ${ }^{68}$ Vairāki poḷu delegācijas pārstāvji 1919. gada 12.jūlijā kopā ar Latvijas, Igaunijas, Gruzijas, Azerbaidžānas un Ziemeḷkaukāza pārstāvjiem parakstīja protesta deklarāciju pret Deņikina armijas iebrukumu Gruzijā un Ziemeḷkaukāzā. Tā tika iesniegta Francijas valdībai. ${ }^{69}$ Savukārt Lietuvas delegācijas loceklis Parīzē P. Kḷims savās atmiṇās uzsvēra, ka notikušas vairākas kopējas Lietuvas, Latvijas un Igaunijas delegāciju sēdes, kurās spriests par savstarpējo sadarbību. Tomēr tā kā lietuvieši vēlējušies, lai latvieši un igauṇi atbalstītu tos diplomātiskajā cīṇā pret Poliju, bet abu

\footnotetext{
${ }^{63}$ LVVA, 1313. f., 2. apr., 23. 1., 15. 1p.

${ }^{64}$ Baranowski W. Rozmowy z Piłsudskim 1916-1931. - Warszawa, 1990. - S. 137.

65 Wasilewski L. Józef Piłsudski... - S. 174, 176.

66 AAN, Kod, t. 1, k. 43.

${ }^{67}$ LVVA, 1313. f., 2. apr., 31. 1., 63., 74. lp.

${ }^{68}$ Turpat, Akta L. Wasilewskiego, t. 30, k. 114.

${ }^{69}$ LVVA, 1313. f., 2. apr., 26. 1., 26. lp. Poḷu pārstāvji deklarāciju gan parakstīja "ar speciālu piezīmi”.
} 
kaimiṇtautu pārstāvji "meklējuši poḷu palīdzību", plašāka sadarbība nenotika. Saskaṇā ar P. Kḷima vērtējumu "poḷi mācēja izmantot mūsu nesaskaṇas, afišēdami sevi par latviešu un igauṇu draugiem un glābējiem". ${ }^{70}$ Tādējādi jau Parīzē skaidri iezīmējās pretrunas, kuras traucēja Baltijas valstu un Polijas sadarbību arī turpmāk. Turklāt jau Parīzē izpaudās Lietuvas valsts augstās teritoriālās prasības, kuras skāra ne tikai Poliju un Baltkrieviju, bet arī Latviju. 1919. gada 22. aprīlī Lietuvas valdība pieņēma instrukciju Ārlietu ministrijai un delegācijai Miera konferencē. Instrukcijā, pirmkārt, tika paredzēts, ka galējais punkts, kas ietilpst Lietuvā, ziemeḷrietumos ir Liepāja, otrkārt, gadījumā, ja apstākḷi to noteiks, tika piẹ̦auta atkāpšanās no prasības iekḷaut Liepāju, taču vienīgi ar noteikumu, ka Lietuvas valsts varēs „brīvi” izmantot Liepājas ostu. Turklāt šīs prasības pilnībā sakrita ar P. Kḷima jau iepriekš izteiktajām un konferencei iesniegtajām prasībām par Lietuvas robežām kopumā. Tajās tika izteiktas pretenzijas uz ievērojamu Ilūkstes apriṇķa daḷu (arī uz teritoriju, kuru vēlāk savā valstī iekḷaus Polija; Polija un Lietuva izmantos sava karaspēka atrašanos šajā teritorijā no 1919. gada vasaras beigām). ${ }^{71}$ Tādējādi faktiski no šĩ laika Lietuvas puse pati radīja nopietnu škēēsli attiecībās ar Latviju. Tas veicināja Latvijas sadarbību ar Poliju un tuvināšanos Polijai. Turklāt tas padarīja būtībā neefektīvus lietuviešu pastāvīgos centienus panākt Latvijas nostāšanos Lietuvas pusē tās strīdā ar Poliju.

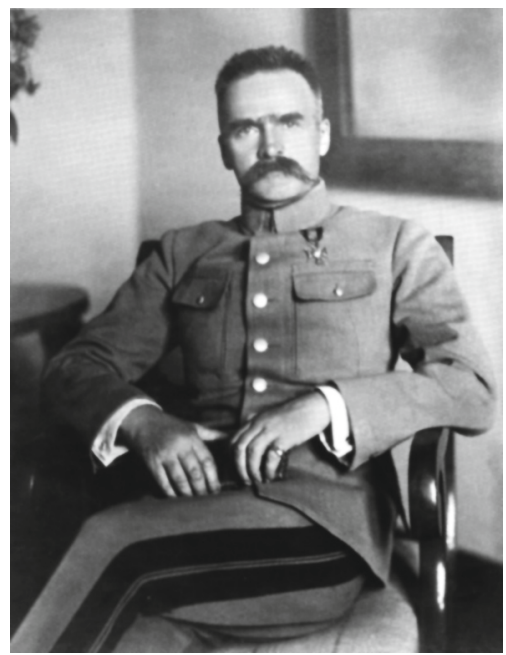

1. att.

\section{Polijas valsts priekšnieks un armijas virspavēlnieks Juzefs Pilsudskis}

Latvijas delegācijai Parīzē bija nopietni jārēḳinās ar viedokli, ko pauda R. Dmovska vadītā Poḷu Nacionālā komiteja un kas bija opozicionāra Polijas valdībai un personīgi J. Pilsudskim. Šì komiteja darbojās līdz 1919. gada jūlijam un prasīja iekḷaut Polijā arī Lietuvu, Palangu, Liepāju, Ilūkstes apriņķi, Latgales dienvidu dal̦u (Lietuvai ar Liepāju un apkārtni Polijas

\footnotetext{
${ }^{70}$ Klimas P. Lietuvos diplomatineje tarnyboje. - Vilnius, 1991. - P. $23-24$.

${ }^{71}$ LCVA, f. 383, ap. 7, b. 20, 1. 3.
} 
sastāvā paredzot pieškirt ierobežotu autonomiju). Ja 1918. gada 8. oktobrī memorandā ASV prezidentam R. Dmovskis pamatoja pretenzijas uz Liepāju ar ekonomisku nepieciešamību, tad viṇa 1919. gada 3. martā iesniegtajās prasībās Miera konferences Poḷu lietu komisijai teikts, ka Polijas robežai jābūt ziemelos no Liepājas ne tikai ǵeogrāfisku un ekonomisku apsvērumu dēḷ, bet arī tādēḷ, ka "puse Liepājas iedzīvotāju ir poḷi un lietuvieši”. Tas bija acīmredzams pārspīlējums (pirms Pirmā pasaules kara poḷi un lietuvieši veidoja $17 \%$ no pilsētas iedzīvotājiem, taču 1920. gadā šis skaitlis bija ievērojami mazāks). Pretēji J. Pilsudskim R. Dmovska nostājai bija raksturīga pietāte pret Krieviju. Viņš uzskatīja, ka poḷu bīstamākais ienaidnieks ir Vācija. Lai neitralizētu vācu spiedienu, ar Krieviju ir jāsadarbojas. Šì pietāte saglabājās arī pēc Krievijas revolūcijas pārliecībā, ka atdzims nelielinieciska Krievija, kas atkal pretendēs uz teritorijām pie Baltijas jūras. 1919. gada 29. maijā R. Dmovskis rakstīja, ka ir jārēḳinās ar Krieviju, tādēḷ nedrīkst „izvērst mūsu plānus uz Latviju un vispār Baltijas provincēm". ${ }^{72}$

Tā kā šajā laikā Krievijā darbojās krievu pretlielinieciskie spēki un šīs valsts tālākais liktenis nebija skaidrs, Miera konferences Poḷu lietu komisija jautājumu par Polijas austrumu robežu pagaidām atstāja atklātu. ${ }^{73}$

Tādējādi Latvijas pārstāvji pirmo reizi tieši saskārās ar divām iespaidīgākajām teritoriālajām programmām jautājumā par nākamo Polijas valsts austrumu robežu. Šìs programmas Polijā bija l,oti aktuālas. Minētā "inkorporatīvā programma", kuru pārstāvēja R. Dmovska vadītie nacionāldemokrāti, paredzēja iespēju robežās atjaunot Polijas 1772. gada robežas (izṇemot apgabalus, kur izteikts iedzīvotāju vairākums nebija poḷi), iekḷaujot Polijā Lietuvu ar ierobežotām autonomijas tiesībām (savukārt Lietuvā - arī minēto Kurzemes daḷu). Latgalei būtu jāiekḷaujas Polijā vai Krievijā. Savukārt J. Pilsudskis un viṇa piekritēji pārstāvēja "federatīvo" programmu, kas paredzēja panākt Krievijas pagātnē paverdzināto tautu ukraiṇu, baltkrievu, lietuviešu, latviešu un igauṇu - atbrīvošanos un to apvienošanos ūnijā ar Poliju uz vienlīdzīgas federācijas pamatiem, taču Polijas un poḷu tautas vadībā (turpretī $R$. Dmovskis uzskatīja, ka varbūtējie federācijas partneri austrumos ir pārāk vāji, savukārt Polija ir par vāju, lai nostātos visu Austrumeiropas zemju priekšgalā). Kamēr J. Pilsudska uzskati izslēdza jebkuru vienošanos ar Krieviju, R. Dmovska viedoklis to zināmos apstākḷos piẹ̦āva. Pats J. Pilsudskis vēl 1920. gadā pilnībā neatmeta domu par iespējamu iecerētās federatīvās valsts izveidi (vismaz ar ukraiṇiem, baltkrieviem un lietuviešiem), kaut arī jau 1919. gada sākumā bija kḷuvis skaidrs, ka ideja nav ìstenojama. Poḷu sabiedrībā federācijas ideja un pat tās galēji utopiski varianti bija populāra vēl ilgu laiku. Piemēram, 1920. gada janvārī nesenais Polijas delegācijas līdzstrādnieks Miera konferencē un Sorbonas Universitātes (no 1919. gada - arī Viḷnas Universitātes) docents V. Lutoslavskis plašā teorētiskā rakstā presē centās pierādīt, ka no Baltijas jūras līdz Melnajai jūrai jāizveido t. s. Tautu ūnija no visām „īstajām” slāvu

72 Juzwenko A. Polska a „biała” Rosja. - S. 144.

${ }^{73}$ Wasilewski L. Józef Piłsudski... - S. 126-127; Dmowski R. Polityka polska i odbudowanie państwa. - T. II. - Warszawa, 1988. - S. 307, 315-317; Dokumenty z dziejów polskiej polityki zagranicznej... - S. 35-37. 
tautām (izṇemot krievus un bulgārus, kuri gan runājot slāvu valodās, bet kuriem trūkstot „slāvu gara”) un no lietuviešiem un latviešiem. Jaunajā valstī visām tautām būtu pilnīga savas valodas, tradīciju, reliğijas brīvība, un tikai apvienojoties tās spētu nodrošināt sev politisku brīvību. Turklāt šajā koncepcijā galvenā loma atkal bija paredzēta Polijai. ${ }^{74}$ Tas viss - 1920. gada sākumā, kad bija jau acīmredzams, ka šis plāns ir utopisks.

Tomēr 1919.-1920. gadā Polijas ārpolitika bija agresīva - tā meklēja varbūtējos sabiedrotos austrumos. Bet šī ārpolitika nebija veiksmīga, jo pastāvošo savstarpējo pretrunu un dažādo militārpolitisko mērḳu dēḷ trūka partneru, lai federācijas ideju īstenotu. Polija potenciālajiem partneriem objektīvu iemeslu dēḷ "nespēja uzspiest savu Austrumeiropas nākotnes redzējumu" ${ }^{75}$ jo nenovērtēja to nāciju politiskā brieduma pakāpi, kuras dzīvoja Polijas austrumos. Jāatzīst, ka gan pats J. Pilsudskis, gan lielākā daḷa viṇa piekritēju samierinājās ar šo neveiksmi, un Latvijai tas bija ḷoti izdevīgi.

N̦emot vērā pagaidām nedrošo Latvijas valsts iekšpolitisko stāvokli, sarunām Parīzē 1919. gada pavasarī bija vienīgi informatīvs raksturs, tomēr tajās skaidri izpaudās abu pušu ieinteresētība attiecību nodibināšanā. Minētā apstākḷa dēḷ pagaidām sakari starp Poliju un Latviju attīstījās vienīgi pusoficiālā līmenī. Muižnieciskās Inflantijas (Latgales) Poḷu padomes ${ }^{76}$ iespaidā 1919. gada maijā Austrumu nomaḷu zemju G̦enerālkomisāra valdē tika izveidota Latvijas nodaḷa ar juristu, bijušo Rīgas advokātu un poḷu sabiedrisko darbinieku V. Soltanu priekšgalā. Viņš bija viens no nedaudzajiem Latgales muižniekiem, kurš jau 1919. gada janvārī paredzēja tikai vienu iespēju turpmākajā latviešu tautas vēsturē - patstāvīgas nacionālas valsts izveidi. Polijai ar to būtu jānoslēdz savienība, "atsakoties no poliskas Latvijas un pieṇemot nacionālu Latviju”. Pret šādu nostāju neapmierinātību izteica lielākā daḷa Latgales lielmuižniecības, kurai nebija skaidrs, kāda būs Polijas attieksme pret Latgali, ja savienību ar Latviju noslēgt neizdosies, un kura uzskatīja, ka brīvprātīgu "atteikšanos" no Latgales latvieši uztvers kā Polijas "vājuma pazīmi".77 Polijas Ārlietu ministrijas preses izdevumā 1919. gada februārī tika publicēts minētās padomes pārstāvja V. Dovgjalo raksts par Polijas Inflantiju. Rakstā viṇš no poḷu muižnieku redzes viedokḷa aplūkoja Latgales vēsturi un aktuālo stāvokli. Turklāt tajā bija īpaši uzsvērts Latgales latviešu zemais izglìtības līmenis un nacionālās pašapziṇas trūkums. V. Dovgjalo rakstīja, ka Latgales apvienošanā ar pārējo - "protestantisko" Latviju ir ieinteresēta tikai „neliela vietējās inteliğences daḷiņa”, bet lielākā daḷa neizglìtoto vai mazizglìtoto zemnieku esot pret to. Autors secināja, ka tādēḷ varētu panākt viṇu piekrišanu Latgales pievienošanai katoliskajai

\footnotetext{
${ }^{74}$ Lutosławski W. Unja Ludów//Kurjer Powszwechny. - 1920. - 9, 10 stycz.

75 Łukomski G. Walka Rzeczypospolitej o kresy północno - wschodnie 1918-1920. - Poznań, 1994. - S. 27-33; Szczepański J. Wojna 1920 roku na Mazowszu i Podlasiu. - Warszawa - Pułtusk, 1995. - S. 11; Dokumenty z dziejów polskiej polityki zagranicznej... - S. 8.

${ }^{76}$ Inflantijas Poḷu padome izveidojās 1917. gadā Latgalē no lielajiem zemes īpašniekiem. Vācu okupācijas laikā 1918. gadā tā aktīvi sadarbojās ar Latgales latviešiem novada administrācijā, kā arī atbalstīja ideju par Latgales atkalapvienošanos ar pārējo Latviju. No 1918. gada beigām padome darbojās Polijā, pakāpeniski ien̦emot naidīgu nostāju pret Latvijas valsti.

77 Archiwum Polskiej Akademii Nauk (turpmāk: APAN), Świerzbiński M. Martyrologia Inflant Polskich, s. 67.
} 
Lietuvai. ${ }^{78}$ Nemot vērā, ka savukārt Lietuvu Inflantijas Poḷu padome redzēja ciešā saistībā ar Poliju vai pat Polijā, top skaidri arī autora un viṇa domubiedru patiesie nodomi attiecībā uz Latgales nākotni.

1919. gada 31. martā J. Pilsudskis vēstulē premjerministram I. Paderevskim izvirzīja V. Soltanu un L. Vasil̨evski kā iespējamos kandidātus ziemel̦austrumu politikas pārzinātāja amatam (vēlāk tajā tika iecelts L. Vasiḷevskis).$^{79}$ Jūnijā V. Soltans Polijas valdības uzdevumā devās uz Latviju ar uzdevumu "nodibināt attiecības ar latviešu politiskajām aprindām", kaut gan oficiāli vin̄š pārstāvēja Polijas Sarkano Krustu, kura mērkịis bija noskaidrot, kāds ir to poḷu bēgḷu stāvoklis Latvijā, kuri ierodas no Ziemeḷkrievijas. 11. jūnijā V. Soltans ieradās vāciešu pārvaldītajā Liepājā (ar sarežğìjumiem izbraucot cauri vāciešu kontrolētajai Lietuvai). Sajā pilsētā ar savu pirmskara laika paziṇu - Latvijas Tiesu palātas prokurora K. Kvelberga un Pagaidu valdības kabineta kancelejas direktora D. Rudzīša - starpniecību V. Soltans nodibināja netiešus sakarus ar Ministru prezidentu K. Ulmani, kurš atradās uz tvaikoṇa "Saratov" klāja (D. Rudzītis uzturēja sakarus ar kug̣i, braukājot ar laivu). Pēc tam V. Soltans ieradās Rīgā, kur tikās ar provāciskās valdības vadītāju A. Niedru, zemkopības ministru J. Ansbergu, Tautas Padomes priekšsēdētāja vietnieku G. Zemgalu, publicistu J. Simsonu, Latgales politikiiem S. Kambalu un V. Seili, mācītāju J. Velkmi, kā arī ar baltvāciešu pārstāvjiem - advokātu Erdmani, baronu Lilienfeldu un grāfu Borhu (A. Niedras valdības Ārlietu ministrijas ierēdni). Gan K. Ulmaṇa, gan A. Niedras valdība izteica gatavību nodibināt diplomātiskas attiecības ar Poliju, garantēt dalēju poḷu kultūras autonomiju Latgalē un Polijai atvieglojumus tirdzniecībai caur Latvijas ostām ar noteikumu, ka Polija atzīst Latgali par Latvijas sastāvdaļu. Vienīgās bažas, ko pauduši V. Soltana sarunu biedri (gan Ulmaṇa, gan Niedras pārstāvji), saistījušās ar līdzšinējo Polijas agresīvo politiku Austrumos. ${ }^{80}$ Savā ziṇojumā, ko 10. jūlijā Soltans rakstīja Polijas Ārlietu ministrijai, viṇš uzsvēra, ka viens no sadarbības izveidošanas noteikumiem ir savstarpēju diplomātisko pārstāvniecību izveide un Latvijas valsts robežu atzīšana no Polijas puses. Viņš atzīmēja, ka bijis spiests „mierināt” savus latviešu sarunu biedrus, skaidrojot, ka „Polijas veidotā valstu sistēma, kas atdala Krieviju no Vācijas, izslēdz jebkādu agresīvu politiku no Polijas puses pret kaimiṇiem". Pēc atgriešanās Polijā V. Soltans publicēja periodikā rakstu, kurš bija labvēlīgs Latvijai un kurā viņš aplūkoja tās vēsturi un izdevīgo ǵeopolitisko stāvokli, kā arī uzsvēra nepieciešamību noslēgt Polijas-Latvijas savienību. ${ }^{81}$ Arī 1919. gada 22. augustā Polijas Ārlietu ministrijai adresētā rakstā viṇš ieteica nekavējoties nosūtīt uz Rīgu Polijas diplomātisko misiju. ${ }^{82}$ Tomēr, neraugoties uz V. Soltana 10. jūlijā tapušo ziṇojumu Ārlietu ministrijai par stāvokli Latvijā, kopumā šajā laikā poḷiem

\footnotetext{
${ }^{78}$ Dowgiałło W. Inflanty Polskie//Przegląd Dyplomatyczny. - 1919. - Nr. 1. - S. 29-36.

${ }^{79}$ Paluszyński T., Rola L. Wasilewskiego... - S. 172. Jau 1919. gada jūlijā L. Vasiḷevskis plānoja savā pārstāvja darbā Rīgā izmantot V. Soltanu kā vietējo apstākḷu pazinēju. - Seskis J. Latvijas valsts izcelšanās pasaules kara notikumu norisē. Atmiṇas un apcerējumi (1914-1921). - Rīga, 1991. 266. 1pp.

${ }^{80}$ AAN, Kod, t. 2, k. 41-44.

${ }^{81}$ Sołtan W. Polska a Łotwa//Przegląd Narodowy. - 1919. - Zesz. 5. - 1919. - S. 564-569.

82 Paluszyński T. Walka o niepodległość Łotwy 1914 -1921. - S. 236.
} 
izpratne par notiekošo bija ḷoti vāja. 12. jūlijā poḷu Lietuvas-Baltkrievijas frontes izlūkošanas dienesta vadītājs I. Berners rakstīja, ka līdz 1. jūlijam Latvijā valdījuši vācieši, kurus atbalstījusi „kāda Niedras” partija, kas savukārt cīnījusies ar „vairāk sociālistiski noskaṇotu grupējumu kāda Ulmaṇa vadībā. [..] Ulmaņa politiskais virziens ir tuvs krievu sociālistiem revolucionāriem". Tomēr, kā pamatoti atzīst poḷu vēsturnieki, līdz ar V. Soltana misijas izbeigšanos Polijas valsts vadītājs J. Pilsudskis un valdība sāka uzlūkot Latviju un Igauniju kā „neatkarīgus organismus”. ${ }^{83}$

Latvijas gadijumā šādas attieksmes maiṇas priekšnoteikums bija militārpolitiskās norises tās iekšienē. Jauns posms Latvijas attiecībās ar Poliju un arī citām valstīm sākās pēc Baltijas Landesvēra spēku sakāves kaujā ar Igaunijas armiju un tās pakḷautībā esošo latviešu Ziemeḷlatvijas brigādi pie Cēsīm 1919. gada jūnijā. K. Ulmaṇa valdība bija ieguvusi kontroli pār situāciju atbrīvotajos valsts novados (izṇemot Zemgales daḷu, kur evakuācijai paredzētā vācu karaspēka koncentrācijas vietās pakāpeniski sāka veidoties cits Latvijas valstij naidīgs spēks avantūristiskā P. Bermonta vadībā). Jau maijā Polijas valdība apsvēra iespēju iecelt L. Vasil̨evski par pārstāvi Baltijas valstīs (Somijā, Igaunijā un Latvijā). 15. un 16. jūlijā viņš Parīzē apmeklēja Latvijas delegācijas vadītāju J. Seski, informēja to par savu iecelšanu šajā amatā, saviem politiskajiem uzskatiem, galveno uzdevumu - nodibināt labas attiecības ar Latvijas valdību un noslēgt ar to militāru konvenciju -, kā arī par gaidāmo izbraukšanu uz Rīgu. ${ }^{84}$ 17. jūlijā L. Vasiḷevskis atgriezās Varšavā, tomēr uz Rīgu neizbrauca un augusta sākumā uzsāka strādāt Viḷnā par Ârlietu ministrijas pilnvaroto ziemeḷaustrumu lietās (faktiski par Polijas pārstāvi minētajās valstīs). J. Pilsudskis šajā laikā sarunā ar vinuu vēlreiz uzsvēra nepieciešamību tuvināties ar Latviju (pat lielākā mērā nekā Igauniju). ${ }^{85}$ Latvijā L. Vasiḷevska iecelšana amatā tika uzņemta atsaucīgi, bet ārlietu ministrs Z. Meierovics uzsvēra, ka attiecības ar Poliju ir labas un "pēc Latgales poḷi vairs netīko". ${ }^{86}$

5. augustā saskaṇā ar Polijas armijas virspavēlniecības rīkojumu tika norīkota četru lidotāju grupa poručņika L,. Rajska vadībā sakaru uzturēšanai ar Latvijas armijas virspavēlniecību Rīgā (lidojums - apmēram divas ar pusi stundas). ${ }^{87}$ Tieši ar šo lidotāju vadītajiem lidaparātiem jau jūlijā ${ }^{88}$ un pēc tam

\footnotetext{
83 Okulewicz P. Koncepcja „międzymorza”... - S. 55, 57.

${ }^{84}$ Seskis J. Latvijas valsts izcelšanās... - 266.-267. 1pp.

85 Wasilewski L. Józef Piłsudski... - S. 194-195, 197-199.

${ }^{86}$ Latvijas Sargs. - 1919. - 25. jūl., 5. aug.; Brīvā Zeme. - 1919. - 5. aug.

${ }^{87}$ Bukhman M. Baltic Civil War Calendar 1918 - 1920. Manuskripts autora rīcībā. - P. 27. Sākotnēji lidmašīnu satiksmē starp Viḷnu un Rīgu radās grūtības. Septembra sākumā poḷu lidotāji ziņoja, ka Rīgā 26. augustā varas iestādes un latviešu lidotāji viṇus uzņēmuši sirsnīgi, taču Latvijas varas iestāžu rīcībā nav bijis degvielas un el̦las krājumu, tādēḷ bijuši spiesti degvielu iepirkt aptieku noliktavās, bet eḷıu iegādāties Anglijas militārajā misijā. Poruçñiks J. Godḷevskis ziņoja: „Dzīves apstākḷi [Latvijā] l̦oti smagi dārdzības dēḷ. Pusdienas vienai personai 30 rbḷ. Latvija ir l̦oti nabadzīga valsts, trūkst visnepieciešamāko lietu. Valda pārsvarā angl̦i. Uz ielām var sastapt gan angḷu, igauņu, lietuviešu, Krievijas armijas, vāciešu formētās armijas (Kellera) virsniekus, gan karavīrus. Ostā stāv divi angḷu karakuǵi un viens franču karakuǵis." - CAW, Szefostwo lotnictwa, I. 301. 14. 29; Kopański T. 3. eskadra Wywiadowcza 1918-1920. - Warszawa, 1999. - S. 159.

${ }^{88}$ Skrzypek A. Związek... - S. 32.
} 
augusta vidū Polijas armijas Lietuvas-Baltkrievijas frontes štāba uzdevumā no Viḷnas Latvijā ieradās inženieris A. Luce-Birks, kas bija dzimis Rīgā, studējis Rīgas Politehniskajā institūtā un prata latviešu valodu. Viṇam bija jānodibina sakari ar latviešu politikiem, jānovērtē situācija, vācu karaspēkam pārtopot Bermonta vadìtajā "Rietumkrievijas armijā", un vietējās poḷu minoritātes stāvoklis. Rīgā A. Luce-Birks tikās ar Latgales poḷu muižnieku un Tautas Padomes locekli J. Salcēviču (nedaudzie Latgales vācu muižnieki bija lūguši J. Salcēviču aizstāvēt muižnieku mantiskās intereses Tautas Padomes Agrārlietu komisijā), citiem Latgales politiḳu pārstāvjiem un 23. augustā ar Z. Meierovicu un J. Caksti, ${ }^{89}$ kuri izteica gatavību nosūtīt uz Poliju oficiālu delegāciju, ja Polijas valdība būtu ar mieru to uzṇemt..$^{90}$

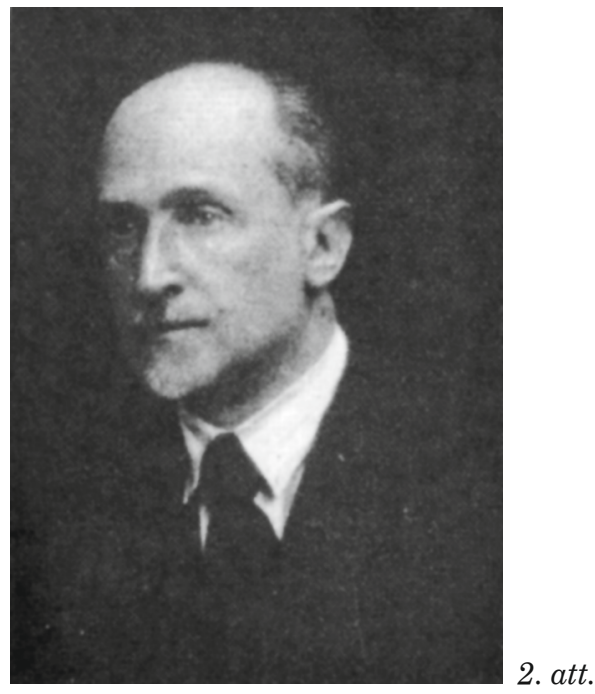

\section{Polijas pilnvarotais ziemeḷaustrumu lietās Leons Vasiḷevskis}

Šajā laikā - 1919. gada 15. augustā - Tautas Padomes sēdē Latvijas ārlietu ministrs Z. Meierovics savā runā par Latgali pirmo reizi oficiāli skāra jautājumu par attiecībām ar Poliju. Ministrs uzsvēra, ka uz Latgali savas pretenzijas izsaka Krievija, Polija un Lietuva. Viṇš atcerējās, ka 1919. gada sākumā un "vienā konferencē" (acīmredzot Parīzes Miera konferencē $\bar{E}$. J.) oficiāli Polijas pārstāvji iesniedza memorandus un runājuši par "Polijas garīgā un kultūras iespaidā" esošo Latgali kā "poḷu zemi”, kas pieder Polijai. Tālāk Z. Meierovics teica: "Ja pašlaik šīs valodas ir atbīdìtas pie malas, tad tas notiek tāpēc, ka Polijas un Latvijas intereses ir tādas, ka viṇas abējām šìm pusēm diktē zināmu saprašanos, bet tomēr vēlēšanās iegūt iespaidu Latgalē vienas daḷas Polijas valstsvīru starpā ir nenoliedzama.” Viṇš atklāti atzìmēja arī Lietuvas pretenzijas uz Latgali („bija laiks, kad arī viṇa uzskatīja, ka Latgale, ja viṇa nav patstāvīga republika, tad katrā ziṇā tā ir zeme, par

\footnotetext{
${ }^{89}$ AAN, Akta L. Wasilewskiego, t. 41, k. 11.

90 Turpat, Kod, t. 2, k. 103.
} 
kuras likteni Lietuvai ir līdzi jārunā").91 Vērtējums bija l̦oti precīzs, taču J. Pilsudskis, kas lielā mērā noteica Polijas ārējo politiku, šajā laikā aktīvi centās îstenot savu koncepciju attiecībā uz Baltijas valstīm. Lai to īstenotu, bija jāatsakās no jebkādām pretenzijām uz Latgali. Augustā, tiekoties ar Igaunijas armijas virspavēlniecības pārstāvi, kas bija nosūtīts uz Viḷnu, viņš runāja par nepieciešamību izveidot vienotu poḷu-latviešu-lietuviešuigauṇu fronti pret Padomju Krieviju. Poḷu militārā vadība savukārt piedāvāja pagaidām nosūtīt uz Viḷnu visu minēto zemju virspavēlniecību pārstāvjus, lai tur vienotos par kopdarbības plāniem. Turklāt kā pirmais šādas kopdarbības rezultāts tika minēta svarīgā dzelzceḷa mezgla - Daugavpils - ieņemšana. ${ }^{92}$

Saskaṇā ar šiem plāniem Polijas armijas virspavēlniecība 20. augustā iecēla par savu pārstāvi Latvijas armijas un Igaunijas armijas pavēlniecībā G̦enerālštāba II (Izlūkošanas) daḷas "Austrumu” sekcijas priekšnieku kapteini Á. Miškovski, kurš ieradās Rīgā93 (šis virsnieks līdz tam faktiski bija vadījis pret Padomju Krieviju un arī pret Lietuvu vērsto Polijas militāro izlūkdienestu ${ }^{94}$ ). 26.-27. augustā viṇš Rīgā piedalījās notikušajā pretlieliniecisko spēku (Latvijas, Lietuvas, Igaunijas, Polijas, P. Bermonta un N. Judeṇiča) pārstāvju apspriedē, kura notika pēc angḷu iniciatīvas un kurā parakstīja vienošanos, kas savstarpējo pretrunu dēḷ nekad neīstenojās. A. Miškovskis, kuru iespaidoja arī A. Luces-Birka ziṇojums par stāvokli Latvijā, sarunās ar angḷu pārstāvjiem par Bermonta karaspēku bija l̦oti piesardzīgs un, neraugoties uz savām plašajām pilnvarām, parakstīja kopējo vienošanos ar nosacījumu, ka tas vēl jāapstiprina Polijas armijas virspavēlniecībai. ${ }^{95}$ Pats A. Miškovskis vēlāk atcerējās, ka bijis pirmais (acīmredzot no ārvalstu pārstāvjiem $-\bar{E}$. J.), kurš sarunā ar Latvijas armijas virspavēlnieku D. Sīmansonu norādījis uz Bermonta patiesajiem nodomiem. ${ }^{96}$ Septembra sākumā Latvijā jau bija zināms, ka A. Miškovski norīkos par pastāvīgu Polijas militāro pārstāvi Latvijā un Igaunijā, ${ }^{97}$ bet 19. septembrī, kad viṇš atgriezās Rīgā no Tallinas, pēc Latvijas preses ziṇām, A. Miškovskis jau bija šajā amatā ${ }^{98}$ (pagaidām viņš palika vienīgais savas valsts oficiālais pārstāvis Latvijā). Vienlaikus A. Miškovskis 1919. gada rudenī uzsāka Polijas militārā izlūkošanas aǵentu tīkla veidošanu Latvijā. Šis tīkls bija vērsts pret Padomju Krieviju un Lietuvu, un drīz viṇš organizēja izlūkošanas punktus Rīgā un Liepājā. Tie piegādāja informāciju, kas tika nodota poḷu LietuvasBaltkrievijas frontes štāba Izlūkošanas daḷai Viḷnā..$^{99}$

\footnotetext{
91 Valdības Vēstnesis. - 1919. - 3. sept.

92 Pullat R. Od Wersalu do Westerplatte. - S. 71-72.

${ }^{93}$ CAW, Akta personalne A. Myszkowskiego, 1769/ 89/ 3610; Skrzypek A. Zagadnienie polskołotewskiej konwencji wojskowej//Z dziejów stosunków polsko - radzieckich. - T. VI. - Warszawa, 1970. - S. 218; Skrzypek A. Stosunki polsko-lotewskie 1918-1939. - S. 19. A. Skšipeks raksta, ka kopā ar A. Miškovski uz Rīgu tika komandēts arī podporučniks T. Vardejns-Zagurskis.

94 Pepłoński A. Wywiad polski na ZSSR 192-1939. - Warszawa, 1996. - S. 14.

95 Pobóg-Malinowski W. Najnowsza historia polityczna ... - 1956. - S. 194.; T. Paļušiņskis apgalvo, ka A. Miškovskis piedalījies sarunās vienīgi neoficiāli. - Paluszyński T. Walka o niepodległość Łotwy 1916-1921. - S. 238.

${ }^{96}$ Miškovskis A. Iz manām atmiṇām... - 71. lpp.

${ }^{97}$ Latvijas Sargs. - 1919. - 3. sept.

${ }^{98}$ LVVA, 6033. f., 1. apr., 24. 1., 3. 1p.; Jaunākās Ziṇas. - 1919. - 19. sept.

${ }^{99}$ Pepłoński A. Wywiad polski na ZSSR 1921-1939. - S. 25.
} 


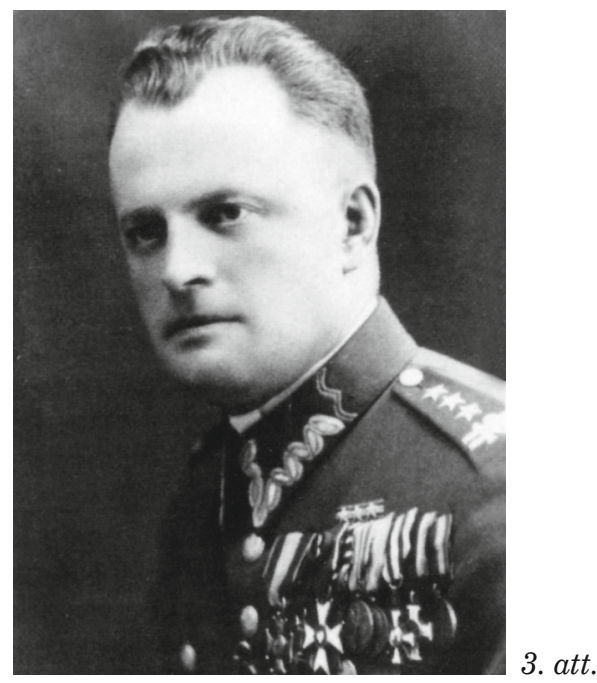

\section{Polijas armijas militārais pārstāvis Latvijā Aleksandrs Miškovskis}

Septembrī Latvijas valdībai kḷva pilnīgi skaidrs, ka gaidāmi nopietni sarežğìjumi ar reakcionārajiem Bermonta vācu-krievu spēkiem Zemgalē, tādēl sevišḳi aktuāla kḷuva sakaru nodibināšana ar varbūtējiem sabiedrotiem. Tūlìt pēc tam, kad L. Vasilevskis rakstiski paziṇoja J. Čakstem (savam "personīgam pazinam"), ka Polijas valdība labprāt uzṇems Latvijas pārstāvjus, ${ }^{100}$ septembra sākumā uz Poliju devās delegācija, ko vadīja Tautas Padomes loceklis K. Zariņš. Tajā ietilpa arī Ârlietu ministrijas pilnvarotais tirdzniecības jautājumos K. Spāde ${ }^{101}$ un armijas pārstāvis - Rīgas pilsētas komandants kapteinis O. Asmanis. ${ }^{102}$ Viṇi cauri Lietuvai un Austrumprūsijai (Vācijai) ar grūtībām nonāca Varšavā, bet no turienes 15. septembrī Viḷnā, kur atradās J. Pilsudskis. Sākotnējās sarunās ar L. Vasiḷevski latvieši centās noskaidrot Polijas nostāju pret Latgali un Daugavpili, uzzināt par iespējamo palīdzību Latvijai, kā arī par ekonomisko sadarbību. Sarunās piedalījās arī Lietuvas-Baltkrievijas frontes štāba II nodaḷas priekšnieks kapteinis V. Slaveks, sakaru virsnieks ar Ārlietu ministriju rotmistrs S. Radzivils un rotmistrs S. Pruss-Boguslavskis. L. Vasil̨evskis secināja, ka Latvijas "delegācija ir nopietna un tai ir informatīvs raksturs". Saskanāa ar J. Pilsudska norādijjumiem L. Vasilevskis paziṇoja, ka Polija nepretendē uz Latgali un Daugavpili, kā arī ir gatava sniegt Latvijai palīdzību bruṇojumā. Tika pārrunāta arī abu valstu attieksme pret Lietuvu, un L. Vasilevskis izteicās, ka Polijas puse būtu apmierināta, ja Latvijai izdotos "draudzīgā garā Lietuvu pārliecināt" mainīt savu ārpolitiku, kas ir naidīga Polijai. Savukārt pats J. Pilsudskis 16. septembrī izteica vēlmi panākt abu valstu

100 AAN, Kod, t. 2, k. 103.

${ }^{101}$ K. Spāde delegācijā tika iekḷauts pēc K. Zariṇa priekšlikuma, jo K. Spāde tikko bija atgriezies no Polijas un pazina turienes apstākḷus.

102 AAN, Akta L. Wasilewskiego, t. 41, k. 29 (D. Sīmansona parakstītā komandējuma apliecība O. Asmanim anglı valodā). 
militāru savienību un solīja ne tikai ieročus, bet nepieciešamības gadījumā arī Polijas karaspēka atbalstu cīṇā pret Bermonta spēkiem. K. Zariṇam Rīgā bija dots norādījums būt piesardzīgam - valdības vārdā neuzṇemties nekādas saistības, tādēl viṇš bija uzmanīgs un nekādus solījumus nedeva. ${ }^{103}$ Latvijas pārstāvji saṇēma apliecinājumu, ka pat Daugavpils ieņemšanas gadījumā poḷi uzskatīs to par Latvijas pilsētu. Tika pārrunāta arī kopīga uzbrukuma iespēja Daugavpilij, ko pagaidām vēl bija ieṇēmusi Sarkanā armija. ${ }^{104}$

16. septembrī delegācija kopā ar poḷu virsniekiem S. Prusu-Boguslavski un Puhaḷski ieradās Kauṇā un tikās (interesanti, ka kopā ar abiem poḷiem) ar Lietuvas armijas virspavēlnieku S. Žukausku un ārlietu ministru A. Voldemaru. Pēdējais izteica neapmierinātību ar to, ka Latvijas delegācija vispirms viesojusies Polijā, un pārliecību, ka poḷi Daugavpili ieņemt nespēj, jo pretējā gadījumā būtu to jau izdarījuši (tikko bija beidzies poḷu un lietuviešu lielā mērā kopīgais vai vismaz vienlaikus izdarītais neveiksmīgais mēǵinājums ieṇemt šo pilsētu - sk. turpmāk). Rīgā K. Zariṇš atgriezās 20. septembrī, ${ }^{105}$ presē uzsverot laipno uzņemšanu Polijā un J. Pilsudska labvēlību pret latviešiem, kā arī paužot pārliecību, ka Polija nepretendē uz Latvijas zemēm. Turklāt viṇš norādīja, ka Polijas domstarpībās ar Lietuvu "pie poḷu puses vaina vien nav meklējama". ${ }^{106}$ Vairāk nekā 30 gadus pēc šiem notikumiem K. Zariņš atcerējās J. Pilsudska vārdus, kurus viņš bija teicis Viḷnā: “[..] mums jāiet kopā. Jūs apdraud krievi, un mūs apdraud krievi. Jūs esat labi karotāji, un tādi esam arī mēs. Jums ir labas ostas, mums ir ogles, mēs viens otru varam tikai papildināt."107 Tādējādi Latvijas pretrunas ar Lietuvu 1919.-1920. gadā neizpaudās pēdējo reizi. Tās kḷuva par vienu no galvenajiem iemesliem turpmākajai sadarbībai ar Poliju.

\section{Militārā situācija Ilūkstes apriṇkīi 1919. gada augustā un septembrī}

Augusta beigās īpaši aktuāls kḷuva Daugavpils turpmākās valstiskās piederības jautājums, kaut arī runas par iespējamu Latvijas militāru sadarbību ar Poliju Parīzes Miera konferencē klīda jau agrāk (jau 2. jūnijā Z. Meierovics no turienes rakstīja, ka "baumas par poḷu karaspēka iešanu palīgā latviešiem pagaidām ir nedibinātas”, taču ir iespējams, ka pie Daugavpils "latviešu pulki stāvēs plecu pie pleca ar polu un lietuviešu karaspēku, aizstāvot mūsu zemes neatkarību pret Krieviju"). ${ }^{108}$ Lietuvas armija jau jūlijā bija ar kaujām šḳērsojusi bijušās Kauṇas un Kurzemes guberṇas robežu un iegājusi Ilūkstes apriṇkīi. Latvijas valdība šajā laikā bija informēta par

\footnotetext{
103 Zariņš K. 35 gadi... - 73.-75. 1pp.; LVVA, 5480. f., 1. apr., 60.1., 3.- 6. lpp. (K. Zariņa 1919. gada 20. septembra ziṇojums par komandējumu Polijā un Lietuvā); Latvijas Sargs. - 1919. - 17. sept.; AAN, Kod, t. 2, k. 103-104.

${ }^{104}$ Skrzypek A. Związek ... - S. 42-43; Łossowski P. Łotwa ... - S. 8.

105 Zariņš K. 35 gadi... - 75.-76. 1pp.; LVVA, 5480. f., 1. apr., 60. 1., 5.-6. 1p.

${ }^{106}$ Latvijas Sargs. - 1919. - 25. sept.; Brīvā Zeme. - 1919. - 26. sept.

107 Zariņš K. 35 gadi... - 76. lpp.

${ }^{108}$ LVVA, 1313. f., 1. apr., 5. 1., 188. 1p.
} 
lietuviešu nopietnajām teritoriālajām pretenzijām uz šo pilsētu, tādēl jau jūlijā K. Ulmanis Rīgā Lietuvas tirdzniecības un rūpniecības ministram J. Simkum skaidri lika noprast, ka nevēlas, lai lietuvieši ieņemtu Daugavpili. ${ }^{109}$ Jūlijā Lietuvas armijas aktīvās daḷas tika pārdēvētas: Ukmerğes grupa - par 1. brigādi, Panevēžas grupa - par 2. brigādi. 23. augustā Lietuvas armijas virspavēlniecība pavēlēja abām brigādēm sākt uzbrukuma operāciju pret Sarkano armiju. Operācijas galējais mērḳis bija Daugavpils ieṇemšana (turklāt 2. brigādei bija jāpārceḷas pāri Daugavai posmā no Kazimires līdz Poguḷankai - ap 20 kilometru lejpus Daugavpils - un jāien,em cietoksnis, bet 1. brigādei jāieṇem Kalkūnes dzelzceḷa stacija, Daugavas kreisā krasta nocietinājumi Grīvā, no kurienes jāpārceḷas pāri Daugavai un jāieṇem Daugavpils dzelzceḷa preču stacija). 25. augustā lietuviešu 1. brigāde ieṇēma Zarasus un tālāk ar kaujām uzbruka cauri Medumiem Daugavpils virzienā. Savukārt 2. brigāde 29. augustā ieṇēma Ilūksti. 30. augustā 1. brigāde devās uzbrukumā Kalkūnei, lai ienemtu Daugavpili (turklāt vēl 31. augustā 1. brigādes komandieris izdeva detalizētu pavēli ne tikai par pašas Daugavpils, bet arī par Augšguḷānu-Stropu līnijas ieņemšanu aiz pilsētas). ${ }^{110}$

Savukārt Polijas armija pēc sekmīgas ofensīvas Lietuvā un Baltkrievijā uzsāka uzbrukumu visā Daugavas frontē (viens no galamērkiem Daugavpils ieņemšana). Jāpiezīmē, ka tieši šajā laikā - 27. augustā - Polijas delegācijas pārstāvji Parīzē „konfidenciāli” informēja tur esošo Latvijas delegāciju, ka „pēc izlīgšanas ar ukrainiešiem poḷu Galvenais štābs ir nolēmis savu karaspēku virzìt pret ziemeḷiem un ieṇemt Dvinsku, varbūt arī Latgali". ${ }^{11}$ Daugavpils virzienā uzbruka poḷu karaspēka grupa, kas pagaidām zināmā mērā operatīvi sadarbojās ar Lietuvas armijas 1. brigādi, kura uzbruka šajā pašā virzienā kreisajā spārnā. Lietuvas armijas 1. brigādi veidoja 1. kājnieku pulks, uz laiku brigādei pakḷautais 2. kājnieku pulks, Viḷnas atsevišķais un Ukmerğes atsevišķais bataljons K. Ladigas vadībā. Poḷu karaspēka grupā ietilpa 6. Leǵionu kājnieku pulks un 1. Leǵionu divīzijas daḷas. Poḷu 6. Leǵionu pulks 27. augusta pēcpusdienā iegāja Turmantas dzelzceḷa stacijā uz bijušās Kurzemes guberṇas robežas (tajā jau atradās arī lietuvieši) un turpmākajās dienās kopīgi ar lietuviešiem atsita deviņus Sarkanās armijas daḷu pretuzbrukumus. Naktī uz 30. augustu poḷu trieciengrupa (1. un 6. Leǵionu kājnieku pulks majora B. Popoviča vadībā-3090 durkḷi, 59 ložmetēji, 8 lielgabali) gar Daugavpils-Viḷnas dzelzceḷu devās Daugavpils virzienā (vienlaikus Drujas virzienā no Opsas un Braslavas uzbruka 5. Leǵionu kājnieku pulks).

Daugavpils aizsardzību organizēja un vadīja latviešu komunists A. Daumanis. Viṇa rīcībā bez minētās brigādes bija cietokšṇa garnizons (500 durkḷi, 12 lielgabali), igauṇu padomju atsevišk,ā brigāde un 2. latviešu strēlnieku pulks (2 000 durkḷi, 8 lielgabali), kas tikko bija ieradies no Pleskavas

\footnotetext{
${ }^{109}$ LCVA, f. 923, ap. 1, b. 1588, 1. 11.

${ }^{110}$ Lietuva. - 1919. - 31 rugpj.; Jaunākās Ziṇas. - 1919. - 6. sept.; Brīvā Zeme. - 1919. - 11. sept.; Leščius V. Lietuvos kariuomene Nepriklausomybes kovose 1918-1920. Monografija. - Vilnius, 2004. - 154-169 p.; Jankauskas V. Kario kelias. Generolas Kazimieras Ladiga nepriklausobybes kovose. - Vilnius, 2004. - 97-133 p.

${ }^{111}$ LVVA, 2575. f., 7. apr., 6. 1., 397. 1p.
} 
frontes. ${ }^{112}$ Sākotnējais poḷu mērḳis bija Līksnas upes līnijas ieṇemšana aiz Daugavpils. Poḷu trieciengrupas uzdevums bija ieṇemt Kalkūnes dzelzcela staciju un uzbrukt abiem (dzelzceḷa un koka) tiltiem pār Daugavu. 27.-29. augustā nogurusī padomju 1. brigāde (1800 durkḷu, 120 zobenu, 32 ložmetēji, 8 lielgabali) bez kaujas atkāpās no vecajām krievu Pirmā pasaules kara pozīcijām uz priekštilta nocietinājumiem Grīvā pie dzelzceḷa tilta. 30. augustā plkst. 11.00 lietuviešu artilērija uzsāka Kalkūnes stacijas apšaudi, bet plkst. 16.00 lietuviešu 1. brigādes daḷas ieṇēma Grīvu un Liginišķus, apšaudot tiltus un Daugavpili aiz upes. 30. augusta pēcpusdienā tiltiem tuvojās arī poḷu 6. Leǵionu kājnieku pulka vienības, kopā ar lietuviešiem atklājot uguni pret padomju karaspēku. Sarkano armiju izglāba 2. padomju latviešu strēlnieku pulks, kas šajā dienā bija iebraucis no Pleskavas. Jau izkāpjot no vilciena Daugavpils stacijā, viens pulka karavīrs tika ievainots ar artilērijas lādiṇa škembu. Pulks ieradās 1. brigādes štābā netālu no koka tilta, kur saṇēma pavēli pāriet tiltu un apturēt poḷu un lietuviešu uzbrukumu. Latvieši sāka pretuzbrukumu brīdī, kad pāri tiltam lielā nekārtībā atkāpās pēdējie 1. brigādes karavīri no otra krasta. Tilts atradās zem šauteņu, artilērijas un bruṇotā vilciena uguns, tādēḷ, to pārejot, latviešiem bija lieli zaudējumi. Latvieši devās durkḷu triecienā lietuviešiem un piespieda tos steigšus atkāpties. Pēc tam uzbrucēji sadalījās divās grupās - labējā grupa pēc lietuviešu padzīšanas no Grīvas ieṇēma arī Kalkūnes staciju un muižu. Tādējādi poḷu rotas, kuras uzbruka priekštiltu nocietinājumiem un tiltiem, izrādījās atšķeltas no saviem galvenajiem spēkiem. Tāpēc poḷi pārgāja uzbrukumā Kalkūnei un ar bruṇotā vilciena uguns atbalstu piespieda latviešus atstāt Kalkūni un ieņemt aizsardzību Grīvas ziemel̦rietumu daḷā un gar Lauceses upīti. Kreisā latviešu grupa padzina poḷu 6. Leǵionu pulka rotu no Grīvas un sasniedza mežu pie Smilšinovkas (tag. Peski) dienvidrietumos no Grīvas, tomēr vakarā atkāpās uz kapsētu rajonu pie Grīvas. Šajā dienā latvieši bija saṇēmuši gūstā 20 polu karavīrus, ieguvuši 2 smagos ložmetējus, šautenes un munīciju. Pateicoties latviešu panākumiem, Daugavpilī tika sakārtoti divi aizbēgušie padomju strēlnieku pulki, kas tika piedalīti abām latviešu grupām. Cietokšna grupa A. Daumaña vadībā atradās priekštilta nocietinājumu fortā. Saskanāa ar 2. padomju latviešu strēlnieku pulka vēsturiskajā aprakstā sniegto informāciju poḷu gūstekṇi liecināja, ka katram karavīram par Daugavpils ieņemšanu esot apsolìta pudele degvīna un 500 cigarešu. Šajā dienā kaujas laukā bija palicis 30 kritušu poḷu un lietuviešu. 31. augustā poḷiem ar rezerves (77. kājnieku pulka) bataljonu izdevās nedaudz atspiest vienu padomju strēlnieku pulku un latviešus, taču vakarā latvieši prettriecienā atkal visu atguva. Šìs dienas vakarā no Pleskavas frontes Daugavpilī ieradās arī igauṇu padomju divīzija, un 1. septembrī latvieši, 1. igauņu pulks un krievi atkal uzbruka. Pēc stundu ilgas cīṇas latvieši atkal ieṇēma Kalkūni, pēc tam 5 stundas to aizsargāja pret poḷiem un lietuviešiem, bet vakarā atgriezās izejas pozīcijās, jo krievu pulki savas pozīcijas nebija noturējuši, arī cietokšṇa grupa tās bija zaudējusi (tāpat igauṇi šī iemesla dēl nevarēja sasniegt savu mērḳi - Skrudalienu). Latvieši 30. augusta-1. septembra kaujās bija zaudējuši 168 karavīrus (krituši, ievainoti un pazuduši bez vēsts), bet 7. septembrī latviešu pulku

112 Encyklopedja Wojskowa. - T. II. - Warszawa, 1932. - S. 408-409. 
frontē nomainīja 28. strēlnieku pulks. Latvieši tika nosūtīti uz Mogiḷevu un no turienes - uz Dienvidkrieviju. ${ }^{113}$ Kopumā, tieši pateicoties 2. latviešu pulka un igauṇu brigādes kaujas spējām, poḷiem un lietuviešiem neizdevās pāriet tiltus un Sarkanajai armijai - noturēt priekštilta nocietinājumu fortu Grīvā, Grīvas pilsētu un nelielu priekšlauku dienvidos no pilsētas.

1919. gada 2. septembrī priekštilta nocietinājumu kaujas iecirkṇa priekšnieks A. Daumanis, Daugavpils cietokšṇa garnizona štāba priekšnieks un komisārs parakstīja pavēli par „baltpoḷu un lietuviešu uzbrukuma atsišanu”. Tajā bija izteikta pateicība padomju karavīriem par 30. augusta-1. septembra kaujās parādīto varonību, kā arī izziņots, ka visi cietokšṇa nocietinājumu atjaunošanas darbos nodarbinātie strādnieki skaitās mobilizēti un, tāpat kā visas cietokšņa rajonā esošās personas, par pavēles neizpildīšanu tiks nodoti revolucionārajam tribunālam vai nošauti uz vietas. ${ }^{114}$

Poḷu daḷām dotā pavēle ieņemt Daugavpils cietoksni tika atcelta 3. septembrī, un sākās vairākus mēnešus ilgas pozicionālas ierakumu kaujas ar savstarpējām apšaudēm. ${ }^{115}$ Turklāt poḷu un lietuviešu artilērija pastāvīgi apšaudīja pilsētu ar artilēriju (aizstāvji atbildēja ar lielgabaliem, kas bija nostādīti pilsētas tirgus laukumā, Sabiedriskajā dārzā un Odesas ielā; slimnīcas un pārsienamie punkti Daugavpilī bija pārpildīti). ${ }^{116}$ Arī Drisas (1. kavalērijas brigāde) un Krāslavas (5. Leǵionu kājnieku pulks) iecirknī poḷiem neizdevās sasniegt plānoto. No 4. septembra notika asinainas kaujas Krāslavas un Kaplavas rajonā. 10. septembra naktī pretuzbrukumā pārgāja Sarkanās armijas 15. armijas sevišķu uzdevumu pulks, kas sastāvēja pārsvarā no latviešiem, un citas daḷas, pārraujot poḷu aizsardzību 30 kilometru dziḷumā. Tomēr 13. septembrī 5. Leğionu pulks slēdza sarkanarmiešiem atkāpšanās ceḷu, nodedzinot Daugavas tiltu pie Krāslavas, un līdz 16. septembrim padomju spēki upes kreisajā krastā tika likvidēti (sevišķu uzdevumu pulks gan paspēja atkāpties uz labo krastu). ${ }^{117}$ Tādējādi kreisajā krastā Sarkanās armijas rīcībā palika vienīgi priekštilta nocietinājumu forts Grīvā.

No 12. līdz 26. septembrim iecirkni gar Daugavu no Liellašiem līdz Vjatai ieṇēma 3. Leǵionu divīzija un visa 1. Leǵ̛ionu divīzija ar tai piekomandētajām daḷām tika koncentrēta uzbrukumam Daugavpilij (astoṇi bataljoni no 1., 6. un 5. pulka, trīs lauka un piecas smagās baterijas, sapieru rota, prožektoru vads,

113 Strauss A. 2. Latvju strēlnieku pulks revolūcijas cīṇās//Latvju strēlnieku vēsture. - II sēj. 2. daḷa. - Strēlnieki Padomju Latvijā. Atmiņas un apraksti. - Maskava, 1934. - 285.-295. lpp.; Andersons E. Sacensība par Daugavpili. - 49. lpp.; Andersons E. Latvijas vēsture... - 557. lpp.; Borkiewicz A. Dzieje 1 - go pułku... - S. 259-272 (šeit teikts, ka "palīgā boḷševiku 4. divīzijai ieradās latviešu-igauņu izlases brigāde", kuras karavīri bijuši liela auguma, labi apgādāti, labprāt gājuši kaujā. Naga cepuru vietā nēsājuši zaḷa auduma cepures); Skarbek E. Zarys historji wojennej 6-go pułku Legjonów. - Wilno, 1937. - S. 17 - 18; Latviešu strēlnieku vēsture (1915-1920). - Rīga, 1970. - 352. lpp.; Lietuva. - 1920. - 31 rugpj.

114 Социалистическая Советская республика Латвии в 1919 г. и иностранная интервенция. Документы и материалы. - Том 2. - Рига, 1960. - С. 326-327.

115 Borkiewicz A. Dzieje 1 - go pułku... - S. 277, 279.

116 Сегодня. - 1919. - 1919. - 25 сент.

117 Babiński K. Zarys historji wojennej 5 - go pułku piechoty Legjonów. - Warszawa, 1929. S. 41 - 42; Gazeta Polska. - 1919. - 17 wrz.; Źołnierz Polski. - 1919. - 24 wrz.; Latviešu strēlnieku vēsture... - 353. lpp. 
pontonu rota, divi bruṇuvilcieni un 1. Tanku pulka 2. rota (kas galvenokārt sastāvēja no frančiem) ar 20 „Renault” tankiem, no kuriem akcijā, kas bija pirmā tāda mēroga operācija ar tanku piedalīšanos poḷu-padomju kara gaitā, piedalījās 12 mašīnas $\left.{ }^{118}\right)$. Sākotnēji atkal bija paredzēts sasniegt Līksnas upi, taču pēc Antantes (pirmkārt, Anglijas) misiju iejaukšanās operācijas mērkis tika reducēts uz priekštilta forta ieņemšanu Grīvā un visu Daugavas tiltu iznīcināšanu. Bažas poḷiem sagādāja arī iespējamā lietuviešu karaspēka reakcija, jo bija pamats domāt, ka lietuvieši poḷu akcijas laikā centīsies ieṇemt teritorijas, ko poḷi uzskatīja par savām (savstarpējās attiecības šajā laikā bija ievērojami saasinājušās, un sīkas nesaskaņas frontes līnijā turpinājās jau no septembra sākuma ${ }^{119}$ ). Uzbrukums sākās 27. septembrī plkst. 4.30, un tieši pirms tam poḷu 1. Leǵionu brigādes komandieris informēja Lietuvas armijas 1. brigādes štābu par gaidāmo akciju, aicinot nemēǵināt uzbrukt poḷiem no aizmugures. Vienlaikus plkst. 00.30 tajā pašā naktī uz 27. septembri poli uzbruka lietuviešu 1. brigādes štābam un uz laiku aizturēja brigādes komandieri P. Latuku ${ }^{120}$ (acīmredzot lai šādi nodrošinātos pret lietuviešu darbību).

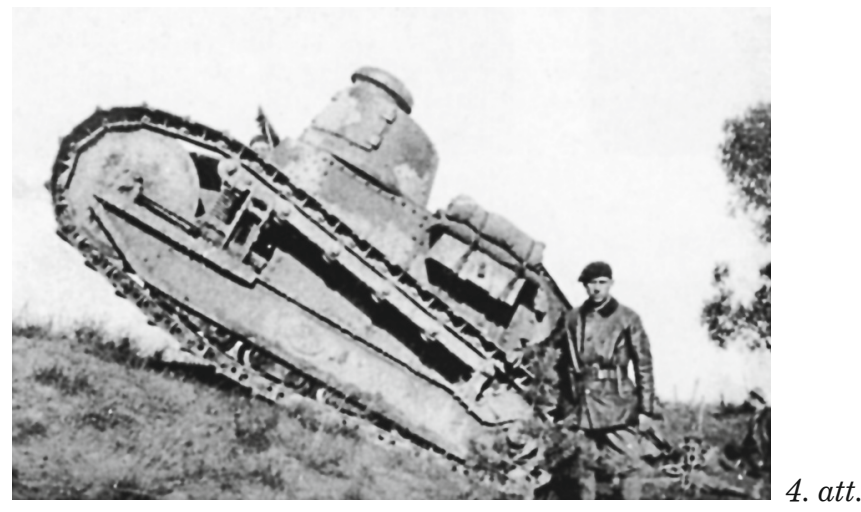

Poḷu tanks pie Daugavpils 1919. gada septembrī

Stāvokḷa nopietnību un abu pušu līdzvainību savstarpējā konflikta padziļināšanā apliecina Lielbritānijas militārās misijas majora H. B. Moketa telegramma Lietuvas armijas daḷu komandierim Daugavpils frontē (27. septembra vakarā H. B. Mokets atradās poḷu 1. divīzijas štābā). Telegrammā viṇš norādīja, ka poḷi dodas uzbrukumā, lai ien,emtu nevis Daugavpili, bet

118 Piwoszczyk M. Zarys historji wojennej 1 - go pułku czołgów. - Warszawa, 1935. - S. 20-30; Jeźewski B. Udział czolgów w akcji pod Dźwińskiem//Przegląd Wojskowo - Techniczny. T. V. - Zesz. 4. - 1929. - S. 738-748; Kochutnicki W. Przeszłość bojowa naszych czołgów w świetle krytyki//Przegląd Wojskowo - Techniczny. - T. IV. - Zesz. 6. - S. 243-249. Sīkāk sk.: Jēkabsons E. Polijas armijas kaujas ar Sarkano armiju Ilūkstes apriņķī 1919. gada septembrī//Latvijas Kara muzeja gadagrāmata. - Rīga, 2000, - 46.-58. lpp.; Jēkabsons Ē. Latvijas un Francijas militārie sakari//Militārais Apskats. - 1995. - Nr. 1. - 79.-82. lpp.

119 Sīkāk sk.: Ē. Jēkabsons. Latvijas attiecības ar Lietuvu 1919.-1921. gadā//Latvijas Vēsture. - 1997. Nr. 1. - 85.-91. lpp.

${ }^{120}$ LCVA, f. 384, ap. 3, b. 16, 1. 1, 10. P. L Latuks bija pārṇēmis 1. brigādes komandēšanu no K. Ladigas septembra sākumā. 
vienīgi priekštilta nocietinājumus Grīvā. Tā kā akcija tiek veikta pret kopējo ienaidnieku, angḷu majors pieprasīja lietuviešiem pārstāt apdraudēt poḷu aizmuguri ar varbūtēju uzbrukumu (šajā laikā lietuvieši bija aizturējuši poḷu munīcijas kolonnu). ${ }^{121}$

Neraugoties uz lieliem dzīvā spēka zaudējumiem un lielāko artilērijas uguns atbalstu līdzšinējā poḷu-padomju kara gaitā, 27. septembrī fortu Grīvā ieṇemt neizdevās. To izdarīja tikai 28. septembrī, iesaistot papildspēkus un tankus. 28. septembra naktī un dienā poḷu sapieri uzspridzināja abus (dzelzceḷa un koka) Daugavpils tiltus. Tādējādi poḷu kontrolē atradās viss Daugavas kreisais krasts līdz fortam, no kura pozīcijas gar Daugavu līdz Kazimirei bija ien̦ēmuši lietuvieši.

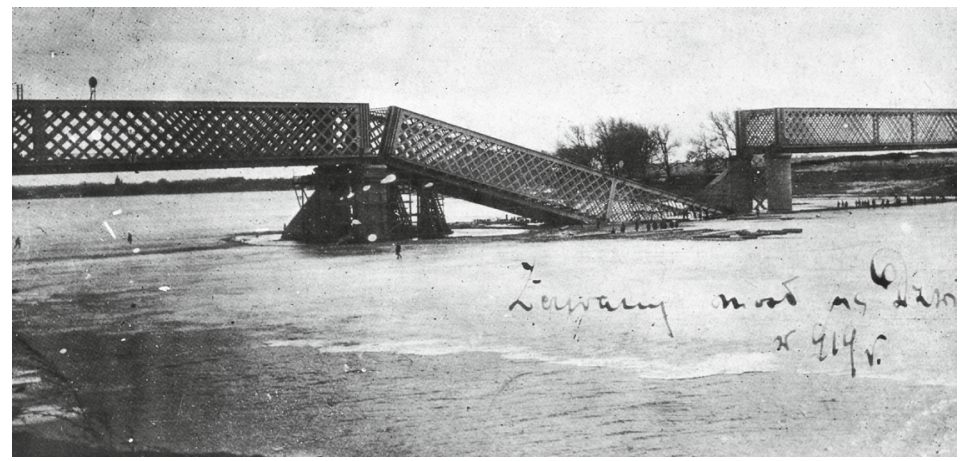

5. att.

\section{Uzspridzinātais dzelzceḷa tilts Daugavpilī 1919. gadā $\bar{a}^{122}$}

Kopumā augusta-septembra kaujās šodienas Latvijas teritorijā poḷi zaudēja 13 virsniekus un 253 kareivjus. Tajā skaitā 1. Leǵionu kājnieku pulks - 79 (kopā ar tiem, kas vēlāk mira no ievainojumiem), 5. Leǵionu kājnieku pulks 51, 6. Leǵionu kājnieku pulks - 75, 1. smagās artilērijas pulks - 4, 1. sapieru bataljona rota -2 un tanku rota -1 kritušo. Turklāt 9. Leǵionu kājnieku pulks pie Salienas zaudēja 41 kritušo. ${ }^{123}$ Lietuviešu 1. brigādes 1 . kājnieku

121 Turpat, 1. 17.

122 O niepodległość i granice 1914-1921. - Warszawa, 1990. - S. 153.

${ }^{123}$ K.L. Historja pulków i bataljonów saperskich w latach 1918-1928//Przegląd Wojskowo - Techniczny. - T. IV. - Zesz. 6. - 1928. - S. 345-346, 406-407; Wejtko T. Zarys historji wojennej 3-go pułku saperów wileńskich. - Warszawa, 1932. - S. 5; Polska w pierścieniu prób i ognia. Rok 1918-1926. Warszawa, 1933. - S. 139 (šeit norādīts, ka 27.-28. septembra kaujās poḷi zaudēja 123 kritušos un 371 ievainoto); Babiński K. Zarys historji... - S. 42; Pomarański S. Zarys historji wojennej 1-go pułku piechoty Legjonów. - Warszawa, 1931. - S. 54-56; Szatner Z. Zarys historji wojennej 9-go pułku piechoty Legjonów. - Warszawa, 1928. - S. 15-16; Skarbek E. Zarys historji... - S. 19 (vēlāk pulka karogā tika ierakstīts “Dyneburg 27 IX 1919”); Lewicki R. Zarys historji wojennej 1-go pułku artylerii polowej Legjonów. - Warszawa, 1929. - S. 25; Zaufał W. Zarys historji wojennej 3-go pułku artylerii cięźkiej im. króla Stefana Batorego. - Warszawa, 1930. - S. 12-13; Herzog S. Historja wojenna 5 pułku artylerii cięźkiej. - Warszawa, 1930. - S. 31 (par bijušā 1. smagās artilērijas pulka 1. divizionu); Centralne Archiwum Wojskowe (turpmāk: CAW), 400. 1. 495 (Piotrowski K. 6. p. p. Leg. Epizod bojowy z walk o Dźwińsk we wrześniu 1919 r.), 1893 (Riegert J. Przebieg bitwy pod Dyneburgiem w miesiącu wrześniu 1919 roku); Nasz Kraj. - 1919. - 2 paźdz.; Źołnierz Polski. - 1919. - 26 list. 
pulkā Zarasu-Kalkūnes operācijā līdz 5. septembrim bija 1 kritis virsnieks, 12 krituši un 9 bez vēsts pazuduši kareivji. Daudz upuru bija arī Viḷnas un Ukmerğes bataljonā. 2. brigādē - 2 krituši virsnieki un 20 kareivji, ievainoti 6 virsnieki un 115 kareivji, bez vēsts pazuduši 17 kareivji. Operācijas laikā abas puses bija spiestas zināmā mērā sadarboties pret kopējo ienaidnieku - Sarkano armiju. Tomēr poḷu un lietuviešu savstarpējās attiecības bija l̦oti piesardzīgas, abas puses centās ieṇemt pēc iespējas lielākas teritorijas, vienlaikus pat nodrošinoties pret varbūtēju otras puses rīcību. Pagaidām tās vēl nekḷuva atklāti naidīgas, un pēc tam, kad lietuviešu 1. brigādes komandieris bija ticies ar poḷu 1. Leǵionu brigādes komandieri Lauceses muižā (poḷu brigādes štābā), lietuvieši pat atdeva poḷiem poḷu karavīru pamestos ieročus, kas bija nonākuši lietuviešu rokās, kad notika kaujas par Kalkūni. Pēc tam saskaņā ar lietuviešu vēsturnieku viedokli „kādu laiku attiecības ar poḷiem bija normālas, kaut arī bija skaidri saskatāma poḷu vēlēšanās pārvaldīt Kalkūni un Turmantu". ${ }^{124}$

Turpmākajās dienās pēc forta ieṇemšanas poḷu 1. Leǵionu divīziju pie Daugavpils nomainìja 3. Leǵionu divīzijas daḷas (23. kājnieku pulks), kas kopā ar 7., 8. un 9. Leǵionu kājnieku pulku iesaistījās pozicionālā cīṇā. Nomainītā divīzija pagaidām tika atvilkta uz aizmuguri atpūtai un papildināšanai. ${ }^{125}$

Latvijas prese kaujas pie Daugavpils apgaismoja fragmentāri un dažkārt kḷūdaini (piemēram, ziņojot par Daugavpils krišanu poḷu rokās un Grīvas ieṇemšanu 29. septembrī, kaut gan faktiski tā tika ieṇemta agrāk), tomēr bija jūtama dzīva interese par notiekošo šajā frontes sektorā. ${ }^{126}$

Līdz ar to aktualizējās un pastiprinājās Latvijas puses bažas par Daugavpils valstisko piederību. Tādēl Z. Meierovics, mierinādams sabiedrisko domu un balstoties arī uz K. Zariņa apliecinājumiem, 7. oktobrī uzsvēra, ka Daugavpils kreisā krasta nocietinājumu ieņemšana notikusi saskaṇā ar vienošanos starp Latvijas un Polijas valdību un ka uz abu valstu labajām attiecībām tas iespaidu neatstās. ${ }^{127}$ N̦emot vērā šos apstākḷus, Latvijas valdība faktiski nereaǵēja uz Lietuvas delegācijas izteikto kārtējo lūgumu pēc atbalsta. Šis lūgums bija izteikts 4. septembrī Parīzē un pamatots ar apgalvojumu par Polijas mēǵinājumu ,atdalīt Lietuvu no pārējām Baltijas valstīm” un atjaunot Poliju „vēsturiskajās” robežās („Lietuvā Polijas armija neievēro demarkācijas līniju un uzsāk virzienu pret Kauṇu un tālāk uz Baltijas jūru”). ${ }^{128}$

\section{Bermontiāde}

\footnotetext{
${ }^{124}$ Leščius V. Lietuvos kariuomene... - 172-174 p.

${ }^{125}$ Witkowski S. Zarys historji wojennej 23-go pułku piechoty. - Warszawa, 1928. - S. 13; Markiewicz F. Zarys historji wojennej 7-go pułku piechoty Legjonów. - Warszawa, 1928. - S. 11; Targowski M. Zarys historji wojennej 8-go pułku piechoty Legjonów. - Warszawa, 1928. - S. 18.

126 Jaunākās Ziṇas. - 1919. - 17. sept., 2., 3. okt.; Latvijas Sargs. - 1919. - 27. sept.; Brīvā Zeme. 1919. - 2., 3., 4. okt.; Baltijas Vēstnesis. - 1919. - 2., 7. okt.

127 Jaunākās Ziṇas. - 1919. - 8. okt.

${ }^{128}$ LVVA, 2575. f., 7. apr., 6. 1., 393. lp.
} 
1919. gada septembrī visā Baltijas telpā priekšplānā izvirzījās vāciski krieviskās Rietumkrievijas brīvprātīgo armijas problēma. ${ }^{129}$ Šĩ armija bija izveidota Latvijas un Lietuvas teritorijā, un to vadija P. Bermonts. Bija skaidrs, ka bijušā vācu karaspēka un arī monarhistiski noskanoto krievu darbība var apdraudēt ne tikai jaunās Baltijas valstis, bet arī Poliju. Polijas vadošie politiķi šajā laikā joprojām nebija atmetuši cerību panākt Lietuvas piekāpšanos abu valstu federācijas jautājumā, lai gan lietuvieši konsekventi pauda noraidošu nostāju šajā jautājumā. Lietuva atdalīja Poliju no pārējām Baltijas valstīm, kā arī varēja teorētiski veidot „tiltu” starp Polijai naidīgo Vāciju un Padomju (vai jebkuru citu) Krieviju, vienlaikus pilnībā slēdzot Polijai pieeju tās potenciālajiem sabiedrotajiem - Latvijai un Igaunijai - un tādējādi radot reālus draudus arī pašas Polijas valsts drošībai. ${ }^{130}$

Jau augusta vidū Polijas Ārlietu ministrijā tika domāts par iespējamo "katastrofu", ko var izraisìt vācu un krievu spēku darbība Latvijā un Lietuvā. 23. augustā Polijas Kara lietu ministrija, aizbildinoties ar tehniskiem sarežǵījumiem, informēja Krievijas Ziemeļrietumarmijas (N. Judeņiča) pārstāvi šajā valstī, ka Polijas teritorijā tiek apturēta brīvprātīgo vervēšana un nosūtīšana uz krievu „baltajām” armijām ziemeḷos (šajā laikā lielākā daḷa krievu karavīru, galvenokārt bijušo kara gūstekṇu, kas tika sūtīti no Vācijas un Polijas uz Judeņiča armiju cauri Latvijai, tika aizturēti Jelgavā un iekḷauti Bermonta karaspēka daḷās). Augusta beigās poḷu G̦enerālštābs sāka apsvērt iespēju sākt karadarbību pret Bermonta armiju. Septembrī poḷu virspavēlniecība karaspēkam izstrādāja instrukciju šādai akcijai. Pret vācu un krievu monarhistisko spēku apvienošanos Baltijā bija arī Polijas nacionāldemokrāti, ${ }^{131}$ jo visas Baltijas iekḷaušana Krievijā apdraudētu arī tās Lietuvas un Baltkrievijas zemes, kurām, pēc vinu domām, vajadzēja kḷūt par Polijas sastāvdaḷ. ${ }^{132}$ Turklāt 1919. gada rudenī poḷu politiskajās aprindās pakāpeniski attīstījās koncepcija par Krievijas draudu novēršanu no sevis un mazinājās „federācijas idejas” iespaids (kaut arī minētais termins vēl zināmu laiku tiks izmantots poḷu politiķu retorikā, škiet, turpmāk ar to tiks domāta nevis „daudztautu” valsts, kas izveidota pēc viduslaiku un jauno laiku parauga, bet gan cieša militārpolitiska valstu savienība). Tagad poḷu presē arvien noteiktāk parādījās prasība atbalstīt arī to valstu neatkarību, kuras izveidojās ziemeḷos no Polijas-Lietuvas valsts 1772. gada robežām. Turklāt arvien izteiktāk tika argumentēta Polijas saimnieciskā sadarbība vai „kopība” ar Lietuvu, Latviju, Ukrainu un Baltkrieviju. ${ }^{133}$

Latvijā un Lietuvā esošo vācu-krievu spēku vadības pakāpeniskā nostāšanās arvien noteiktākās provāciskās pozīcijās izraisīja Antantes

\footnotetext{
129 Sīkāk sk.: Jēkabsons Ē. Latvijas diplomātija Bermonta uzbrukuma laikā 1919. gada ruden̄̄// Militārais Apskats. - 1994. - Nr. 2. - 73.-82. lpp.

130 Okulicz P. Koncepcja międzymorza. - S. 84.

131 Sk., piemēram, nacionāldemokrātu laikrakstu "Gazeta Polska”. - 1919. - 4 paźdz.

132 Juzwenko A. Postawa Polski... - S. 571, 576; Łukomski G., Polak B. W obronie Wilna, Grodna i Mińska. Front Litewsko - Białoruski wojny polsko - bolszewickiej 1918-1920. - Koszalin - Warszawa, 1994. - S. 57.

133 Okulicz P. Koncepcja międzymorza. - S. 82.
} 
lielvalstu, īpaši Lielbritānijas, augošu neapmierinātību un bažas. Reǵionā vienīgo reālo spēku, kurš būtu spējīgs ātri panākt vācu karaspēka atgriešanos Vācijā, Antante saskatīja Polijas armijā. Savukārt Polijas valdības apsvērumus šajā situācijā konstatē vēsturnieks T. Palušiṇskis: Polijas valdībai konflikts Baltijā varēja kḷūt izdevīgs ne tikai tāpēc, lai atrisinātu vācu karaspēka problēmu, kas bija bīstama Polijas valstij, bet arī lai īstenotu plašākus politiskos mērk,us, jo Bermonta uzbrukums Kauņai dotu pamatojumu poḷu karaspēka iesaistīšanai karadarbībā Lietuvā un tādējādi galīgi izšķirtu konfliktu ar Lietuvu par labu Polijai, un Lietuva pakḷautos Polijai. Turpretī Bermonta uzbrukums Rīgai l̦autu politiski un militāri piesaistīt sev Latviju. Briti izvirzīja priekšlikumu izmantot pret vācu karaspēku Baltijā Polijas armiju. Viṇi to izteica pēc apspriešanās ar Polijas pārstāvi Parīzē un viṇa formālas piekrišanas (gan izvirzot l,oti augstas pretprasības par Polijas rietumu robežas nodrošināšanu un materiālām kompensācijām). 15. septembrī Antantes Augstākā Padome Parīzē pienēma lēmumu par Polijas armijas iesaistīšanu problēmas risināšanā ar noteikumu, ka Polija tādējādi nemēǵinās iejaukties Lietuvas iekšējās lietās. Tomēr, tā kā I. Paderevskis bija izvirzījis pretprasības un Lietuvas puse kategoriski atteicās izlaist poḷus cauri savai teritorijai, 17. septembrī padome savu iepriekšejjo lēmumu atcēla. ${ }^{134}$ Taču J. Pilsudskis neatmeta domu par brunotas akcijas iespējamību. ${ }^{135}$ Vēl 29. septembrī viņš vēstulē I. Paderevskim uzsvēra, ka uzskata Bermonta armijas jautājuma atrisināšanu par svarīgāko Polijas ārpolitikas uzdevumu, jo šie spēki apdraud arī Poliju. ${ }^{136}$ 22. septembrī Parīzes Miera konferencē notika neoficiāla Latvijas un Polijas delegācijas pārstāvju tikšanās, kuras laikā tika saskaṇota principā vienota nostāja pret vācu-krievu spēku darbību Zemgalē. Tomēr poḷiem neizdevās iegūt no latviešiem tiešu piekrišanu poḷu karaspēka izmantošanai pret vācu spēkiem Baltijā. Latvijas delegācijas sekretārs O. Grosvalds pēc sarunas secināja, ka gadījumā, ja poḷiem "tiešām nav nekādu imperiālistisku nodomu [..], tad viṇi var būt mums spēcīgs atbalsta punkts [..]". ${ }^{137}$ Savukārt Latvijas delegācijas vadītājs Parīzes Miera konferencē J. Seskis 3. oktobrī ieradās uz pārrunām pie nacionāldemokrāta, Polijas delegācijas ǵenerālsekretāra vietnieka J. Bartoševiča, kurš bija l,oti "rezervēts un uzmanīgs". Tomēr arī viṇš atzina, ka par galveno Polijas ienaidnieku uzskata Vāciju (līdz ar to - arī Bermonta spēkus, kā arī Ukrainu un Lietuvu, kuras īstenojot "provācisku” politiku) un vēlas "sniegt draudzīgu roku Latvijai". ${ }^{138}$

Septembrī un oktobra sākumā gandrīz visa Polijas prese izturējās labvēlīgi pret Latviju un Igauniju. Īpaši ar to izcēlās valdībai tuvu stāvošā dienas avīze "Gazeta Polska". 20. septembrī šīs avīzes žurnālists T. Svencickis rakstīja, ka līdz ar Daugavpils ieņemšanu nodibināsies sakari ar Polijai draudzīgo Latviju. Gan ar Latviju, gan Igauniju Polijai nekad nebūšot domstarpību, bet

\footnotetext{
134 Paluszyński T. Walka o niepodległość Łotwy 1916-1921. - S. 237-238.

135 Łossowski P. Stosunki polsko - litewskie... - S. 180.

${ }^{136}$ Historia dyplomacji polskiej. Tom IV 1918-1939/Red. P. Łossowski. - Warszawa, 1995. - S. 125.

137 Paluszyński T. Walka o niepodległość Łotwy 1914 -1921. - S. 278; Kiewisz L. Sprawy łotewskie w bałtyckiej polityce Niemiec w latach 1914-1919. - Poznań, 1970. - S. 211.

${ }^{138}$ LVVA, 6033. f., 1. apr., 19. 1., 24. 1p.; Seskis J. Latvijas valsts izcelšanās... - 286. lp.
} 
sadarboties liek nepieciešamība stāties pretī iespējamiem Vācijas un Krievijas agresīvajiem nolūkiem. Savukārt 3. oktobrī avīze tieši atzina, ka Daugavpilī var apvienoties Polijas un Latvijas brunotie spēki, lai kopīgi cīnītos pret "krieviski vāciskajām briesmām", kas apdraud abas valstis.

Polijas valdības nostāju skaidri izteica J. Pilsudskis, septembra beigās paziṇojot, ka Polija gaida "tuvāko prūšu militārisma triecienu Baltijā". Vēstulē Polijas premjerministram I. Paderevskim viņš rakstīja: „Personiski tomēr uzskatu, ka no visām mūsu lietām šì [Baltijas valstu stāvokḷa lieta] mums ir vissvarīgākā, jo draud mums ar vislielākajām briesmām. Tur, ziemel̦os, šobrīd ir sakoncentrējušies visi „vecā” [Vācijas] režīma centieni, pagaidām tas spēlē dubultu spēli attieksmē pret Krieviju, no vienas puses atbalstot lieliniekus vinu cīn,ā pret Poliju, no otras - gatavojot monarhijas restaurāciju pašā Krievijā." 8. oktobrī britu laikraksta "Times" korespondentam J. Pilsudskis izteicās, ka šajā brīdī par bīstamāko uzskata Bermonta spēku darbību Polijas armijas kreisajā spārnā. To mērķis esot monarhijas atjaunošana Vācijā. J. Pilsudskis noraidīja iespēju, ka, vāciešiem atstājot Baltiju, tur triumfētu lieliniecisms, jo tas esot "tīri krieviska slimība" un nevar nostiprināties zemēs, kur sabiedriskā iekārta nav "krieviska" (acīmredzot cilvēka vērtības traktējuma un citā ziṇā - ÉE. J.). Gadījumā, ja vācieši paliktu Baltijā, J. Pilsudskis paredzēja viṇu nenovēršamo sadursmi ar Poliju, jo tur, "kur sastopas divi spēki, tiem ir vai nu jāsavienojas, vai savstarpēji jācīnās, bet mēs negribam savienoties ar vāciešiem”. Sākoties Bermonta spēku uzbrukumam, tieši Latvija varēja novērst tiešus Krievijas un Vācijas sakarus ziemel̦os. ${ }^{139}$

Arī Latvijas puses nostāja ārējo apstākḷu iespaidā šajā laikā bija Polijai īpaši labvēlīga (Lietuvas nostāja poḷiem bija naidīga). "Jaunākās Ziṇas" 22. un 23. septembrī publicēja interviju ar Polijas armijas rotmistru S. Prusu-Boguslavski, kurš atradās Rīgā un popularizēja visu Baltijas valstu savienības ideju (ar Polijas piedalīšanos tajā). Viṇš uzsvēra Polijas gatavību atbalstīt Latviju ar izejvielām un kā vienu no stabilu sakaru nodibināšanas priekšnoteikumiem minēja savstarpējas satiksmes noregulēšanu, kas kḷūs iespējama pēc Daugavpils atbrīvošanas (abu valstu bruṇotos spēkus šajā laikā vēl atdalīja Lietuvas armijas ien,emtās teritorijas josla Ilūkstes apriṇḳī). ${ }^{140}$

4. oktobrī uz Rīgu no Viḷnas bija atlidojis A. Luce-Birks ar oficiālu Polijas Ārlietu ministrijas uzdevumu uzlūgt Latvijas, Igaunijas un Somijas zinātniekus uz Viḷnas Universitātes atklāšanu, kā arī pagaidām aizvietot Polijas pilnvaroto pārstāvi Latvijā, bet no 6. oktobra - arī Igaunijā iecelto B. Boufalu, kurš kopā ar diplomātiskās misijas sekretāru J. Baḷin,ski 30. septembrī bija devies uz Latviju pa jūras cel̦u. Turklāt viens no A. LucesBirka galvenajiem patiesajiem uzdevumiem bija arī informācijas iegūšana par Bermonta komandētā vācu-krievu karaspēku Latvijā un sevišḳi Lietuvā. ${ }^{141}$

139 Piłsudski J. Pisma zbiorowe. - T. V. - Warszawa, 1937. - S. 108 - 111 (“Times” interviju publicēja 16. oktobrī); Okulicz P. Koncepcja międzymorza. - S. 91.

140 Jaunākās Ziṇas. - 1919. - 22., 23. sept. (interviju ar saviem komentāriem atreferēja Lietuvas prese. - Lietuva. - 1919. - 3 sp.); Ceḷotāji uz Poliju 1919. gada vasarā brauca cauri Jelgavai un Tilzītei. Rudenī kḷuva iespējama satiksme uz dzelzcel̦a Čarnibruda-Eglaine cauri Lietuvai, tomēr lietuvieši to dažādi traucēja. Oficiālie un neoficiālie Polijas pārstāvji 1919. gada otrajā pusē izmantoja gaisa un jūras satiksmi. - Brīvā Zeme. - 1919. - 6. sept.; Latvijas Sargs. - 1919. - 13. nov.; LVVA, 1313. f., 1. apr., 35. 1., 75. 1p. 
Poliskās Viḷnas Universitātes atklāšana, uz kuru tagad tika uzaicināti latvieši, poḷiem un viṇu nacionālpolitiskām ambīcijām bija īpaši svarīga. To plašākā nozīmē izteica valdības laikraksts „Rząd i Wojsko” vēl septembrī: „Šai universitātei jākḷūst par zinātnes un kultūras centru. Uz to ir jātiecas visām tautām, kuras drīzumā atradīsies Polijas iespaidā, vispirms kulturālā orbītā. Ukraiņiem, baltkrieviem, lietuviešiem, latviešiem šeit ir jāmeklē gaisma."142 A. Luce-Birks Rīgā tikās ar Z. Meierovicu, aicinot nosūtīt uz Viḷnnas Universitātes atklāšanu zinātniekus un liekot noprast, ka tie varētu būt cilvēki ar plašām pilnvarām runāt arī par abu valstu turpmāko politisko un militāro sadarbību. Z. Meierovics bija uzņēmis priekšlikumu ar "zināmu apjukumu", jo, kā bija informēts arī pats A. Luce-Birks, Baltijas valstu konferencē Tērbatā septembrī Latvija bija noraidījusi Lietuvas prasību pārējām dalībvalstīm (arī Igaunijai un Somijai) atbalstît Grodņas un Suvalku pievienošanu Lietuvai, taču neoficiāli piekritusi atbalstīt lietuviešu pretenzijas uz Viḷnu. (Patiesībā jau no 1919. gada Latvijas puse šajā jautājumā bija l,oti piesardzīga. To atsevišķos gadījumos kāda no iesaistītajām pusēm varēja pārprast. Iespējams, tas noticis arī šajā gadījumā - $\bar{E}$. J.) Tāpēc no Latvijas ārēji stingrās neitrālās nostājas viedokla Polijas un Lietuvas strīdā par Viḷnu oficiālas delegācijas nosūtīšana nebija iespējama. Tomēr Z. Meierovics diplomātiski atklāja, ka poḷi bija radījuši ieganstu, lai noraidījuma varbūtējās sekas neietekmētu attiecības ar Poliju. Tās šajā laikā bija sevišķi būtiskas. Sarunā ar A. Luci-Birku viņš lika noprast, ka Latvijas puse ir nedaudz aizvainota par to, ka Latvijas Augstskolas atklāšanā 28. septembrī nepiedalījās Polijas pārstāvji, lai gan bija nosūtīts ielūgums. Vienlaikus Z. Meierovics, acīmredzot reāli novērtējot situāciju, tomēr informēja sarunu biedru, ka tuvākā laikā uz Viḷnu dosies Tautas Padomes locekḷa J. Zālīša vadīta delegācija, kurai būs arī uzdevums piedalīties universitātes atklāšanā. Z. Meierovics pamatā atbalstīja A. LucesBirka priekšlikumu par varbūtējo abu valstu savienību pret Bermontu ar nosacījumu, ka tajā jāpiedalās arī Lietuvai, un piedāvāja Latvijas starpniecību Polijas un Lietuvas konflikta risinājumā. 7. oktobrī A. Luce-Birks devās uz Tallinu, ${ }^{143}$ bet dienu pirms tam -6 . oktobrī - Z. Meierovics, runājot Tautas Padomē par valsts ārpolitiku un savienības nepieciešamību starp Latviju, Igauniju, Lietuvu un Somiju, izteica pārliecību, ka tiks novērstas Lietuvas un Polijas savstarpējās nesaskaṇas un savienībai pievienosies arī Polija. Ministrs uzsvēra, ka tāda ir Latvijas valdības vēlme - "radīt lielāku sienu starp Vāciju un Krieviju vēl vairāk uz dienvidiem", jo "Krievijas un Vācijas ūnija Polijai nav mazāk bīstama kā mums. Polija kā daudz stiprāka valsts ar vecām tradīcijām, ar noorganizētu valsts aparātu ir šinī brīdī visstiprākā arī militārā ziṇā starp tiem, kuriem vajadzēs aizsargāties pret Krievijas-Vācijas apvienību".'144

Šajā laikā Latvijas valdībai jau bija pilnībā skaidrs, ka konflikts ar Bermonta spēkiem nav izbēgams. Tā kā frontē notika galveno Latvijas armijas

\footnotetext{
${ }^{141}$ Skrzypek A. Związek... - S. 38, 40; Skrzypek A. Stosunki polsko - łotewskie 1918-1939. - S. 23; AAN, Kod, t. 2, k. 79; Okulewicz P. Koncepcja międzymorza. - S. 85.

142 Turpat. - S. 80

143 AAN, Akta L. Wasilewskiego, t. 41, k. 19, 23. No Tallinas A. Luce-Birks 10. oktobrī ieradās Helsinkos, no kurienes 12. oktobrī atgriezās Igaunijas galvaspilsētā.

${ }^{144}$ Cielēns F. Laikmetu maiṇā. Atmiṇas un atziṇas. - 3. grām. - Stokholma, 1998. - 71.-72. 1pp.
} 
spēku koncentrācija pret Sarkano armiju, bija steidzami vajadzīgi sabiedrotie. Sakarā ar notikumu straujo attīstību Bermonta karaspēka dislokācijas vietās, jau 5. oktobrī145 uz Poliju un Lietuvu devās Tautas Padomes locekḷa un bijušā apsardzības ministra J. Zālīša vadītā delegācija, kurā bija arī Tirdzniecības un rūpniecības ministrijas Tirdzniecības departamenta direktors A. Launags, kapteinis M. Hartmanis (29. oktobrī vinuu apstiprināja par militāro pārstāvi Polijā $\left.{ }^{146}\right)$, Tautas Padomes sekretāra biedrs S. Kambala un Ārlietu ministrijas pārstāvis J. Grišāns (abi pēdējie, būdami Latgales latvieši, mācēja runāt poliski ${ }^{147}$ ). Polijā delegācijai pievienojās K. Spāde, kurš tur bija ieradies vēl kopā ar K. Zariṇu un palicis, kārtojot ekonomiskas sadarbības jautājumus (K. Spāde atgriezās Rīgā tikai decembrī). ${ }^{148}$

6. oktobrī Latvijas armijas virspavēlnieks D. Sīmansons šifrētā telegrammā pilnvaroja M. Hartmani lūgt Polijas armijas vadību atklāt karadarbību pret Bermonta daḷām, kas "virzās no Kurzemes un Lietuvas ziemel̦austrumu virzienā". ${ }^{149}$ 7. oktobrī delegācija iebrauca Viḷ,nā, ${ }^{150}$ bet 8. oktobrī sākās Bermonta spēku uzbrukums Rīgai, un drīzumā tie bija ieņēmuši Pārdaugavu. 10. oktobrī plkst. $11.00 \mathrm{~K}$. Ulmanis telegrafēja no Ropažiem uz Rīgu, ka nosūtīts lūgums pēc militāras palīdzības uz Tallinu un tiek gatavots līdzīgs lūgums nosūtīšanai uz Viḷnu (lai panāktu "Polijas un Baloža ${ }^{151}$ spēku savienošanos"). ${ }^{152}$ Tomēr Igaunijā izdevās panākt vienīgi divu bruṇuvilcienu pagaidu atsūtīšanu uz Rīgu, bet par lielāku palīdzību igauṇi izvirzīja nepien,emamas teritoriālas prasības. ${ }^{153}$

Tādējādi delegācija Viḷñā saṇēma plašas pilnvaras. Tūlīt pēc atbraukšanas tā tikās ar J. Pilsudsḱi un Ārlietu ministrijas valsts apakšsekretāru V. Skšin,ski, kurš apstiprināja galveno, ko Latvijas puse vēlējās dzirdēt - ka Polijai nav pretenziju uz Latgali. Savukārt J. Pilsudskis uzsvēra, ka Polija labprāt palīdzēs Latvijai, ja Lietuva piekritīs izlaist cauri savai teritorijai poḷu karaspēku. Latvijas delegācijai poḷu priekšlikumi šḳita pieņemami arī no Lietuvas redzes viedokḷ. Zināmā mērā to apliecināja 13. oktobra paziṇojums ārvalstu pārstāvjiem Varšavā. Paziņojumā Polija apṇēmās nepārkāpt demarkācijas līniju ar lietuviešiem un dot iespēju Lietuvas armijai koncentrēt spēkus pret Bermonta daḷām. ${ }^{154}$ Galu galā šajā brīdī Bermonta militārpolitisko mērḳu radītās briesmas arī Polijai lika mainīt tās plānus attiecībā pret

145 Pirms tam Z. Meierovics A. Lucem-Birkam kā delegācijas izbraukšanas laiku minēja 10. oktobri. - AAN, Akta L. Wasilewskiego, t. 41, k. 19.

146 LVVA, 5601. f., 1. apr., 1828. 1., 4. 1p. Kopš 1920. gada 1. februāra viṇa („kara pārstāvniecības”) rīcībā Varšavā bija arī no 3. Jelgavas kājnieku pulka piekomandētie kareivji Vilhelms Sparinš̌ un Jēkabs Kazens, kā arī latvietis Aleksandrs Legzdin̦š, kas bija brīvprātīgi pārnācis no dienesta poḷu žandarmērijā. - LVVA, 3601. f., 1. apr., 469. 1., 249. 1p.

147 Nasz Kraj. - 1919. - 9 paźdz.

${ }^{148}$ LVVA, 2574. f. 3. apr., 17. 1., 507. 1p.; Jaunākās Ziṇas. - 1919. - 7. okt., 24. dec.; Latvijas Sargs. 1919. - 26. okt.

${ }^{149}$ LVVA, 6033. f., 1. apr., 406. 1., 1. 1p.

150 Gazeta Warszawska. - 1919. - 7 paźdz.

151 Jānis Balodis šajā laikā vēl bija Kurzemes divīzijas komandieris, bet 1919. gada 16. oktobrī tika iecelts par armijas virspavēlnieku.

${ }^{152}$ LVVA, 6033. f., 1. apr., 406. 1., 4. 1p.

153 Turpat, 1313. f., 1. apr., 35. 1., 35. lp. 
Lietuvu (turklāt Bermonta panākumu gadījumā tieši Lietuva varēja kḷūt par iecerēto „tiltu”, kas savieno Krieviju un Vāciju. Latvijas delegācija 11. oktobrī piedalījās arī poliskās Viḷnas Universitātes atklāšanā (š̄ augstskola bija nosaukta karaḷa Stefana Batorija vārdā) un centās iepazīstināt daudzos viesus ar patieso stāvokli Latvijā. ${ }^{155}$ Faktiski šo brīdi var uzskatìt par pirmo, bet ne pēdējo reizi, kad Latvija pārkāpa savu oficiālā līmenī deklarēto neitralitāti Polijas un Lietuvas strīdā par Viḷnu.

Pēc sarunām Viḷnā J. Zālītis bija noskaņots optimistiski. 13. oktobrī viṇš ziņoja uz Rīgu, ka Polijas valdībā palīdzības jautājums Latvijai izšķirts labvēlīgi, un solìja darīt visu, lai "visdrīzākā laikā dabūtu Latvijas armijas karavīriem cīṇubiedrus". Tajā pašā dienā J. Zālītis devās uz Kauṇu, kur, pēc viṇa domām, nāksies "l,oti noteikti uzstāties", jo poḷu-lietuviešu attiecībās "ir sarežǵìti apstākḷi, kurus mēǵināsim no savas puses labot". ${ }^{156}$ Kopumā J. Zālīša delegācijas darbs un tam īpaši labvēlīgie apstākḷi (Bermonta radìtie draudi) pavēra ceḷu Latvijas un Polijas noteiktas tuvināšanās procesam.

Fakts, ka 13. oktobrī no Latvijas uz Lietuvu un Poliju devās arī pats ārlietu ministrs Z. Meierovics, liecina, cik lielu nozīmi šajā laikā varbūtējai Polijas un Lietuvas militārai palīdzībai pieškīra Latvijas valdība. Pārnakšṇojis Pḷavināās (šeit viṇš no Kurzemes divīzijas komandiera J. Baloža ieguva informāciju, kas bija nepieciešama sarunām Polijā), 14. oktobrī Z. Meierovics cauri lietuviešu karaspēka ieṇemtajai Eglainei Ilūkstes apriṇḳī (šeit lietuviešu karaspēks sarīkoja viņam godpilnu pavadīšanu ar kara orķestra piedalīšanos) ${ }^{157}$ un Panevēžai ieradās Kauṇā (sava adjutanta, Lietuvas diplomātiskā pārstāvja Rīgā J. Šḷūpa un militārā pārstāvja V. Natkeviča pavadībā $\left.{ }^{158}\right)$, kur jau atradās J. Zālītis un pārējie delegācijas pārstāvji. Delegācija tikās ar vairākiem Lietuvas politiķiem, arī ar prezidentu A. Smetonu. Lietuvas armijas daḷas šajā laikā tika koncentrētas pret Bermonta spēkiem, par ko Z. Meierovics 15. oktobrī ziṇoja uz Rīgu, izsakot cerību, ka iespējama "mūsu sabiedroto pavairošana ar Lietuvas un Polijas spēkiem". ${ }^{159}$ Tomēr konkrētus solïjumus Lietuvas puse nedeva, bet izlaist cauri savai teritorijai poḷu karaspēku kategoriski atteicās, "kamēr netiks noregulētas politiskās lietas".160 Lietuvieši aizbildinājās ar nevēlēšanos nonākt konfliktā ar vācu karavīriem, kas atradās Bermonta spēkos un gribēja atgriezties dzimtenē, un neievēroja Z. Meierovica iebildumus par vāciešu reakcionāro noskaṇojumu. 17. oktobrī Lietuvas valdības loceklis V. Čarnecks valdības sēdē atzina, ka Latvijas delegācija Kauṇā uzṇemta "vēsi". ${ }^{161}$ Lietuvas nostāja bija izskaidrojama ar valsts sarežǵìto stāvokli.

\footnotetext{
154 Документы и материалы... - 356 стр.; Brīvā Zeme. - 1919. - 26. okt.; Kurjer Lwowski. - 1920. 13 luty; Pobóg - Malinowski W. Najnowsza historia... - S. 191.

155 Latvijas Sargs. - 1919. - 31. okt.

${ }^{156}$ LVVA, 6033. f., 1. apr., 22. 1., 1.-2. 1p.

${ }^{157}$ Petruitis J. Mūsu žygiai. Atsiminimai iš kovu su bolševikas ir bermontininkais. - B. v., b. m. 182-183 p.; Balodis J. Ģenerāḷa Jāṇa Baloža atmiṇu burtnīcas//Neatkarīgā Rīta Avīze. - 1997. 22. febr.

${ }^{158}$ Lietuva. - 1919. - 15 spālis.

159 Turpat, 1313. f., 1. apr., 35. 1., 23. 1p.

${ }^{160}$ Gazeta Warszawska. - 1919. - 21 paźdz.
} 
Attiecības ar ievērojami spēcīgāko Poliju bija saspīlētas teritoriālo domstarpību dēḷ, bet Rietumlietuvā Bermonta spēki kontrolēja dzelzceḷu no Kurzemes līdz Austrumprūsijai. Turklāt šajā laikā jau skaidri izpaudās zināmā Lietuvas orientācija uz vienu no lielākajiem Polijas ienaidniekiem - Vāciju. Oktobrī Bermonta karaspēka vācu daḷas ienēma arī Linkuvas, Radvilišku un Biržu dzelzceḷa mezglu, tomēr sīkās sadursmes vēl nepārauga plašākā konfliktā Lietuvas valdības piesardzīgās nostājas dēḷ. Atklātā konfliktā ar Lietuvu sava karaspēka aizmugures nodrošināšanas nepieciešamības dēl pagaidām nebija ieinteresēts arī Bermonts, kurš jau augustā bija centies panākt Lietuvas valdības labvēlību. 11. oktobrī Bermonta armijas 2. Brīvprātīgo korpusa komandieris P. Virgoḷičs paziņojumā Lietuvas valdībai par savu spēku virzīšanos uz Šauliem šo kustību izskaidroja ar nepieciešamību savienoties ar Judeņiča spēkiem, vienlaikus uzsverot savu draudzīgumu ar Lietuvu. ${ }^{162} 15$. oktobrī pats Bermonts personiski solīja izmeklēt sava karaspēka izdarītos pārkāpumus Lietuvā, par ko viņu informēja lietuvieši, bet 16. oktobrī izteica izbrīnu par Lietuvas armijas pārgrupēšanos, apgalvodams, ka atzīst lietuviešu tautas pašnoteikšanās tiesības („,atbalsta tautu pašnoteikšanās tiesības”) un ir gatavs noslēgt ar to savienību pret lieliniekiem - cīna pret tiem esot vina vienīgais mērkis. Lietuvas valdība savā sēdē 17. oktobrī telegrammu apsprieda, un Lietuvas Ministru prezidents E. Galvanausks 18. oktobrī pieprasīja izvest no Lietuvas valsts visus vācu karavīrus. Nākamajā dienā Bermonts vēlreiz aicināja vienoties. E. Galvanausks 20. oktobrī atbildēja, ka sarunas nav iespējamas līdz visa vācu karaspēka izvešanai no Lietuvas. ${ }^{163}$ Turklāt latviešu konservatīvi provāciskais politiķis A. Niedra, kas atbalstīja Bermontu, arī aicināja lietuviešus sadarboties, solot atbalstu cīṇā ar poḷiem par Viḷnu (Bermonts pats solīja lietuviešiem pieeju Liepājas ostai). ${ }^{164}$

Šādos apstākḷos 19. oktobrī Latvijas delegācija no Kauṇas ieradās poḷu kontrolētajā Viḷnāā, kur to uzṇēma L. Vasilevskis, V. Slaveks un Polijas Ārlietu ministrijas pārstāvji. Z. Meierovics lūdza palīdzēt Latvijai ar munīciju, lielgabaliem un lidmašīnām. Poḷu puse atbildēja, ka attiecībā uz munīciju palīdzība iespējama, bet uz pārējo - ticama. ${ }^{165}$ Nākamajā dienā Z. Meierovics telegrafēja K. Ulmanim, ka centīsies “pēc iespējas” panākt palīdzību ieroču un munīcijas piegādē, un kopā ar adjutantu virsleitnantu H. Tepferu, M. Hartmani un K. Spādi devās uz Varšavu (L. Vasiḷevska pavadībā). Savukārt J. Grišāns devās uz Kauṇu kā pagaidu pārstāvis Lietuvā, bet S. Kambala 21. oktobrī (kopā ar bijušo Ukrainas Tautas Republikas armijas G̦enerālštāba priekšnieka palīgu pulkvedi P. Radziṇu, kurš atgriezās dzimtenē) - uz Rīgu. ${ }^{166}$

Z. Meierovics iebrauca Varšavā 20. oktobra vakarā, bet 22. oktobra pēcpusdienā Polijas valdības premjerministrs un ārlietu ministrs

\footnotetext{
${ }^{161}$ Butkus Z. Lietuvos ir Latvijos santykiai 1919-1929 metais. - Vilnius, 1993. - P. 33.

162 LCVA, 329 f., 3 ap., 39 b., 571.

${ }^{163}$ LVVA, 3301. f., 1. apr., 3. 1., 36., 46., 50., 52., 54. 1p.; Čepenas P. Naujuju laiku Lietuvos istorija. - Chikago, 1986. - P. 551.

164 Butkus Z. Lietuvos ir Latvijos... - P. 34.

${ }^{165}$ Łossowski P. Łotwa... - S. 9; LVVA, 2570. f., 2. apr., 18. 1., 3. 1p.; 3. apr., 1126. 1., 21. lp.; Jaunākās Ziņas. - 1919. - 28. okt.; Sk.: Dokumenti par Latvijas valsts starptautisko atzīšanu, neatkarības atjaunošanu un diplomātiskajiem sakariem 1918-1998. - Rīga, 1999. - 72. lpp.

${ }^{166}$ LVVA, 1313. f., 1. apr., 35. 1., 51. 1p.; 2570. f., 2. apr., 18. 1., 6. 1p.; Latvijas Sargs. - 1919. - 26., 31. okt. S. Kambala ieradās Rīgā 25 . oktobrī, J. Zālītis un citi - 30. oktobrī.
} 
I. Paderevskis bijušajā Karaḷa pilī svinīgi pasniedza viṇam Latvijas valsts "de facto" atzīšanas rakstu, kurā Polijas valdība atzina Latvijas Tautas Padomi „par neatkarīgu struktūru "de facto” līdz brīdim, kad Miera konference atzīs Latviju tādā statusā, kas atbilstu Latvijas tautas gribai" (faktiski šis teikums pauda visai piesardzīgu poḷu puses nostāju). Vienlaikus tika izteikta cerība, ka abu valstu kopējās intereses un „dziḷās savstarpējās simpātijas tuvākā nākotnē kḷūs par pamatu Latvijas un Polijas draudzības un sirsnīga [savstarpēja] atbalsta nostiprināšanai”, kā arī paziņots par diplomātiskā pārstāvja Latvijā B. Boufala iecelšanu amatā. ${ }^{167}$ Sarunā I. Paderevskis nevietā izteica nediplomātisku piezīmi, ka Polija būšot spiesta mainìt attieksmi pret Latvijas neatkarības jautājumu, ja to darīs Antante. Tēdējādi viņš pilnībā attaisnoja J. Pilsudska bažas, kuras Pilsudskis pirms tam bija izteicis Vasilevskim, un radijja nepatīkamu iespaidu latviešos, parādot Polijas valdības vadītāja nenoteikto nostāju pret Latvijas neatkarības jautājumu kopumā un viṇa pārspīlēto atkarību no Antantes lielvalstīm. Tās pašas dienas vakarā delegācija ieradās pie J. Pilsudska Belvederas pilī, kur viṇš mēǵināja labot premjera neveiklo izteicienu. Divas stundas notika saruna, kuru Z. Meierovics vērtēja kā "plašu un sirsnīgu”. Latvieši izskaidroja stāvokli Bermonta frontē, J. Pilsudskis apsolīja ievērojamu, neatmaksājamu palīdzību ieroču un munīcijas piegādēe $\overline{1}^{168}$ (12. novembrī 25000 šauteṇu un 5 miljoni patronu atradās Viḷnā un bija sagatavotas nosūtīšanai. 27. novembrī daḷu no šiem materiāliem divos dzelzceḷa vagonos no Čarnibrudas latviešu karavīru apsardzībā nogādāja Latvijā, bet 1. decembrī lietuvieši aizliedza Latvijas vilcienu tranzìtu. Tāpēc pārējais sūtījums sasniedza Latviju tikai pēc 12. decembra, ${ }^{169} \mathrm{kad}$ Lietuvas armijas Daugavpils grupas štābs atḷāva izmantot dzelzceḷa līniju militāru un citu misiju pārvadāšanai un militāro materiālu nogādei Latvijā. ${ }^{170}$ Turklāt 13. novembrī Polija pārdeva Latvijai kara lidmašīnu "Salmson", kura bija avarējusi pie Cēsīm un ar kuru bija lidojis A. Miškovskis ${ }^{171}$ ). Tikšanās ar J. Pilsudski un viṇa škietami nesavtīgie, Latvijai pilnīgi draudzīgie priekšlikumi un solījumi atstāja uz Z. Meierovicu un pārējiem latviešiem dziḷu iespaidu. ${ }^{172}$

Vēl Varšavā Z. Meierovics saṇēma apliecinājumu, ka Polijas armijas dalas tiks koncentrētas Svenčones apkārtnē un dienvidos no Daugavpils, un solījumu tūlìt pēc Versaḷas miera līguma ratificēšanas ieṇemt bijušos Vācijas apgabalus, kas piešķirti Polijai, tādējādi atškeḷot Austrumprūsiju no pārējās Vācijas (un šādi kavējot arī vācu daḷu apgādi Baltijā). Viṇš tikās ar ārlietu ministra vietnieku V. Skšin,ski, kara lietu ministru ǵenerāli J. L,esṇevski, armijas G̦enerālštāba priekšnieka vietas izpildītāju S. Halleru' ${ }^{173}$ un citām oficiālām personām. 24. oktobrī Z. Meierovics ar adjutantu devās uz Rīgu,

\footnotetext{
${ }^{167}$ Igauniju Polija "de facto" bija atzinusi jau 6. oktobrī.

168 Wasilewski L. Józef Piłsudski... - S. 212. M. Hartmanis 4. novembrī ziṇoja: "Lūdzām vācu patronas un tūliņ dabūjām. Lūdzām flintes, pat necerējām dabūt - arī dabūjām. Palikuši drošāki, lūdzām lielgabalus un arī tos mums apsolīja. Visu par velti, bez maksas." - LVVA, 6033. f., 1. apr., 24. 1., 2. lp.

169 LVVA, 2574. f., 3. apr., 1. 1., 26. 1p.; 2575. f., 15. apr., 11. 1., 81. 1p; 6033. f., 1. apr., 25.1., 25. 1p.

170 Turpat, 4592. f., 3. apr., 101. 1., 279. 1p.

171 Turpat, 1477. f., 1. apr., 464. 1., 4. 1p.

172 Łukomski G., Polak B. W obronie Wilna, Grodna i Mińska... - S. 58.
} 
kur ieradās 27. oktobrī. Jau Ikšḳilē viṇu sagaidīja Ministru prezidents K. Ulmanis un armijas virspavēlnieks J. Balodis. ${ }^{174}$ Arī tas apliecināja, cik lielu nozīmi Latvijas valdība piešķir vizìtei dienvidu kaimiņvalstīs (sevišḳi pēc neveiksmīgā mēǵinājuma iegūt atbalstu no Igaunijas; pēc šīs neveiksmes igaunu puse nekavējoties atsauca savus divus brunuvilcienus no Rīgas). Tūlìt pēc atgriešanās Z. Meierovics pauda presei apmierinājumu par vizīti Polijā un uzsvēra, ka Latvijas un Polijas kopējās intereses un abu tautu "dziḷās savstarpējās simpātijas" liek tām sadarboties. Viṇš arī paziṇoja, ka Polija piešḳīrusi Latvijai kara materiālus un iecēlusi diplomātisko pārstāvi, kurš drīz ieradīšoties. Turklāt Polija noraidījusi Bermonta priekšlikumu „atzìt Rietumkrieviju”, neraugoties uz piesolïto „kompensāciju”, un nosodijusi Bermonta agresiju pret Latviju. ${ }^{175}$

Z. Meierovica teiktajam par Polijas attieksmi pret Bermonta priekšlikumiem bija zināms pamats. Varšavā vienlaikus ar Latvijas delegāciju uzturējās arī Bermonta pārstāvji - bijušais cara valdības Rīgas apriṇḳa komisārs 1905. gada revolūcijas laikā kṇazs N. Kropotkins un grāfs Borhs, kas Rietumkrievijas apgabalu administratīvās padomes (Bermonta spēku kontrolētajā teritorijā izveidotās krievu civilpārvaldes) vārdā centās panākt labvēlīgu Polijas attieksmi pret struktūrām, kuras pārstāv Bermonta civilo un militāro pārvaldi (jau 9. oktobrī Jelgavā tika izlemts, ka Kropotkinam jādodas uz Vāciju un Poliju ar uzdevumu novērst „poḷu briesmas”, kuras draud Bermonta karaspēkam - sevišķi sakaru uzturēšanā ar Vāciju). Septembrī Rīgā notika Bermonta armijas izlūkdienesta pārstāvju sarunas ar A. Miškovski, un jau oktobra sākumā izlūkdienests principā kḷūdaini un nepamatoti konstatēja, ka Polija netraucēs vācu-krievu spēku darbību Baltijā, ja Vācija netraucēs poḷu plānus Lietuvā (jo poḷi apzinās, ka Vācija ir "pārāk spēcīga, lai ilgu laiku paliktu atgriezta no pasaules"). Acīmredzot A. Miškovskis, nebūdams pilnvarots šādām sarunām, vienkārši izvairījās dot konkrētus solījumus, skaidri nenoraidot arī iespēju izdarīt šādu "ietekmes sfēru" sadalīšanu. ${ }^{176}$ Labi apzinādamies, kādas briesmas draud no Polijas puses tās nelabvēlīgas nostājas gadījumā, 9. oktobrī Bermonts ar draudzīgā garā ieturētu vēstījumu griezās pie Polijas valdības, taču atbildi nesaṇēma. Oktobra vidū Bermonts nosūtīja Polijas valdībai telegrammu. Tajā viņš paziṇoja, ka viṇam nav naidīgu nodomu pret Poliju un viņš vēlas ar to sadarboties cīṇā pret lieliniekiem. Viņš lūdza l,aut Polijā esošajiem krievu gūstekṇiem iestāties viṇa armijā. ${ }^{177}$ Savukārt 22. oktobrī Bermonts, kārtējo reizi cenšoties panākt vismaz Polijas neitralitāti, pavēlēja savas armijas aviācijas priekšniekam, kara lidotājam apakšpulkvedim B. Firsovam, kas devās pie Dienvidkrievijas Brīvprātīgo armijas virspavēlniecības, pa ceḷam nogādāt poḷu pretlielinieciskās frontes virspavēlniekam vēstījumu, kurā skaidroti Bermonta mērki - vēlme cīnīties ar lieliniekiem - un izteikts aicinājums vienoties, pamatojoties uz panslāvisma

\footnotetext{
173 Jaunākās Ziņas. - 1919. - 28. okt.

${ }^{174}$ Latvijas Sargs. - 1919. - 28. okt.

175 LVVA, 2575. f., 1. apr., 169. 1., 29. 1p.

${ }^{176}$ Kurzemes muižniecības pilnvarotā - grāfa Paula Pālena - dienasgrāmata//Jaunākās Ziṇas. - 1921. 12. jūl.; LVVA, 2574. f., 4. apr., 83. 1., 10. lp.

177 Paluszyński T. Walka o niepodległość Łotwy 1914-1921. - S. 256.
} 
ideju. ${ }^{178}$ Radiogrammā Polijas Ārlietu ministrijai Bermonts vēlreiz deklarēja, ka viņš ir Polijas draugs. Uzbrukumu Latvijai viņš skaidroja vienīgi ar operatīvu nepieciešamību un lūdza nosūtīt uz viņa karaspēku bijušos krievu karagūsteknuus, kas atradās Polijā. Radiogramma palika bez atbildes, taču Kropotkinu 27. un 29. oktobrī pienēema Polijas armijas G̦enerālštāba Politiskās nodaḷas priekšnieks majors S. Laudan,skis. Kropotkins deva ziṇas par "Rietumkrievijas" armijas uzbūvi un sastāvu (melīgi apgalvojot, ka tajā esot tikai 20-25\% vāciešu), kā arī iesniedza plašu armijas "izcelšanās vēsturisku aprakstu”. Baltijas valstu neatzīšanu viṇš skaidroju ar Krievijas nepieciešamību pēc ostām (ieskaitot Tallinu), bet Polijai solīja brīvu pieeju pie tām, atkal piedāvājot sadalīt "ietekmes sfēras" (Latvija un JelgavasAustrumprūsijas dzelzcel̦š Bermontam, pārējā Lietuva - Polijai). ${ }^{179}$ Fakts, ka minētais priekšlikums par Lietuvu tika izteikts gandrīz reizē ar Bermonta apliecinājumiem Lietuvas valdībai, ka viņš pilnībā atzīst šīs valsts tiesības uz neatkarību, liecina par Bermonta piedāvājumu raksturu un nolūkiem. Atbildi Kropotkins Varšavā nesaṇēma, jo Polijā bija skaidri jaušams vispārējs naidīgs noskaṇojums pret vāciski krieviskajiem spēkiem Baltijā. Tas izpaudās gan poḷu politiķu runās, gan presē. T. Palušin,skis konstatēja, ka to noteica Bermonta izteiktais naidīgums pret Baltijas valstīm, kuru pastāvēšana palīdzētu Polijai īstenot savus mērķus - vājināt Krieviju un nodibināt savu kontroli reǵionā. Polija nevēlējās atbalstīt visu, kas varētu stiprināt savas tradicionālās ienaidnieces - Vācijas - pozīcijas, un bažìjās par iespējamo Antantes reakciju gadījumā, ja Polija uzsāktu kaut kādu sadarbību ar vāciešiem Baltijā. Sasniegt mērḳus Polijai palīdzētu arī Bermonta nenoteiktā nostāja Lietuvas jautājumā - no vienas puses, viṇš piedāvāja Polijai to sadalīt, no otras puses, - atzìt to par Krievijas sastāvdaḷu vai atzìt Lietuvas tiesības uz neatkarību. ${ }^{180}$

Pirms Bermonta spēku uzbrukuma Rīgai Polijas laikrakstu nostāja pret vinuu bija nelabvēlīga, tomēr piesardzīga. Pēc uzbrukuma sākuma prese gandrīz vienprātīgi aicināja savu valdību sniegt atbalstu Latvijai. Zināms izṇēmums bija sociālistu avīze "Robotnik", kas nevēlējās karot vienlaikus pret Padomju Krieviju un Bermontu, jo uzskatīja, ka visā notiekošajā vainīga Antante, kura vēlas labot savas kḷūdas ar poḷu karavīru asinīm. Tomēr arī "Robotnik" sevišǩi asi uzbruka Bermontam. ${ }^{181}$ Valdībai tuvu stāvošā "Gazeta Polska" 17. oktobrī pieprasīja nekavējoties palīdzēt Latvijai, jo uzbrukums apdraudēja arī Poliju. Nākamajā dienā šis laikraksts rakstīja, ka "uzbrukumam Rīgai jākḷūst par izšķirošo punktu mūsu attiecībās ar valstīm ziemeḷos", un vēlāk paziņoja, ka gandrīz visa poḷu sabiedriskā doma saprot Bermonta briesmas un nostājusies Latvijas pusē. ${ }^{182}$ Līdzīgas domas pauda arī Minskas poḷu laikraksts ${ }^{183}$ un citas avīzes. Pat nacionāldemokrātu "Gazeta Warszawska" ievietoja labvēlīgus aprakstus par Latvijas vēsturi un aktuālo stāvokli. ${ }^{184}$

\footnotetext{
${ }^{178}$ LVVA, 3301. f., 1. apr., 3. 1., 43.-44., 63.-64. 1p.

179 CAW, Teki Laudańskiego, 440. 12/2-3, k. 292-295.

180 Paluszyński T. Walka o niepodległość Łotwy 1916-1921. - S. 241.

181 Robotnik. - 1919. - 9, 19 paźdz. (sk. laikraksta redaktora vietnieka J. M. Borska ievadrakstus).

182 Gazeta Polska. - 1919. - 17, 18, 29 paźdz.
} 
25. oktobrī poḷu prese publicēja interviju ar Z. Meierovicu. Tajā viṇš analizēja vēlamās Baltijas valstu un Polijas savienības perspektīvas, ${ }^{185}$ bet dažas dienas vēlāk - aicinājumu tautiešiem Polijā. Šo dokumentu 26. oktobrī bija parakstījis K. Spāde un latviešu inženieris E. Ansons, kas dzīvoja Varšavā. Aicinājumā bija lūgums tautiešiem kopīgi apsvērt iespējas, kā veicināt Latvijas un Polijas tālāku tuvināšanos. ${ }^{186}$

Tādējādi ar Bermonta uzbrukumu skaidri iezīmējās attiecību aktivizēšanās starp Latviju un Poliju, turklāt izteikti pozitīvā gaisotnē. Īpaši tas bija saskatāms uz Latvijas un Lietuvas attiecību fona. Tajās bija jūtams saspīlējums, ko izraisīja Lietuvas vilcināšanās sniegt palīdzību Latvijai cīṇā ar Bermontu un pieaugošās domstarpības nākamās valsts robežas jautājumā. Savukārt Lietuvas politiķi bija neapmierināti ar Latvijas zināmo tuvināšanos Polijai. Tomēr 23. oktobrī Lietuva atzina Latviju "de facto", ${ }^{187}$ bet 8 . novembrī - Latvija atzina Lietuvu. ${ }^{188}$ Oktobra beigās abu armiju virspavēlnieki apmainījās sirsnīgiem apsveikumiem, uzsverot latviešu un lietuviešu tautu likteṇa kopību. ${ }^{189}$ Kauju laikā ar bermontiešiem Lietuvas pārstāvniecības pagaidu vadītājs K. Vizbars 21. oktobrī no Rīgas ziṇoja, ka Latvijas puse neatzīst Lietuvas pilsoṇu pases, mobilizē savā armijā un pat uz laiku apcietina Lietuvas pilsoņus. ${ }^{190}$

Attiecības ar Latviju vēl vairāk sarežǵīja 30. oktobrī noslēgtā Lietuvas valdības un Bermonta karaspēka pārstāvju vienošanās, ko parakstīja Šauḷos un kas noteica neitrālo joslu gar Šauḷu-Tauraǵes dzelzceḷa līniju, kā arī faktiski leǵitimēja piegādes Bermonta spēkiem Latvijā, nosakot vācu karaspēka "izvešanas un apgādes" maršrutus. ${ }^{191}$ Latvijas puses jūtīgums šajā jautājumā ir izprotams. Jau pirms šī līguma Bermonta karaspēks Latvijā netraucēti tika apgādāts ar kara materiāliem un dzīvā spēka resursiem cauri Lietuvas teritorijai: 13.-14. oktobrī caur Šauḷiem no Vācijas pienāca uniformu sūtījums, 17. oktobrī - 6 lidmašīnas, 19. oktobrī - 6 vagoni ar kājnieku ieroču munīciju, 20. oktobrī - 25 vagoni ar artilērijas lādiṇiem utt. ${ }^{192}$ Latvijas militārais pārstāvis Lietuvā virsleitnants A. Kraulis par šīm sarunām uzzināja jau 30. oktobrī (viṇš 31. augustā bija iecelts par sakaru virsnieku Lietuvā, 16. septembrī - formāli arī Polijā, bet no 13. novembra skaitījās kara lietu priekšstāvis Lietuvā). Līguma norakstu viṇš Lietuvas armijas štābā

\footnotetext{
183 Goniec Miński. - 1919. - 25 paźdz.

184 Gazeta Warszawska. - 1919. - 10 paźdz., 29 grudz.

185 Gazeta Polska. - 1919. - 25 paźdz.

${ }^{186}$ Robotnik. - 1919. - 29 paźdz.; Gazeta Polska. - 1919. - 31 paźdz. Šajā laikā Polijā atradās vairāki simti latviešu, neskaitot gūstā nokḷuvušos sarkanarmiešus latviešus.

${ }^{187}$ Sk.: Dokumenti par Latvijas valsts starptautisko atzišanu, neatkarības atjaunošanu un diplomātiskajiem sakariem... - 73. lpp.

${ }^{188}$ LVVA, 1313. f., 1. apr., 35. 1., 51. lp.

${ }^{189}$ Latvijas armijas virspavēlnieka 1919. gada pavēle Nr. 70 (atreferēta Lietuvas armijas virspavēlnieka P. L̦atuka 28. oktobra telegramma)//LVVA Zinātniskajā bibliotēkā.

${ }^{190}$ LCVA, 383 f., 7 ap., 108 b., 108 1. K. Vizbara ziņojums bija rakstīts 21. oktobrī - dienā, kad bermontiešu artilērijas lādiṇa sprādzienā cieta Lietuvas diplomātiskās pārstāvniecības ēka Rīgā un vairāki tās darbinieki tika kontuzēti. - LCVA, f. 383, ap. 7, b. 35, 1. 10-11.

${ }^{191}$ LVVA, 2575. f., 11. apr., 1. 1., 5.-6. 1p.

192 Čepenas P. Naujuju laiku Lietuvos istorija. - II t. - P. 549.
} 
pēc pieprasījuma saṇēma 3. novembrī. Nākamajā dienā A. Kraulis tikās ar Lietuvas armijas virspavēlnieku, viņa štāba priekšnieku un kara ministra palīgu, kuri skaidroja, ka līgums noslēgts Lietuvas armijas vājā bruṇojuma dēḷ (viṇi nespēja uzsākt aktīvu uzbrukumu bermontiešiem). Virspavēlnieks P. Latuks pat lūdza pieškirt lietuviešiem dalu no munīcijas, ko Polija bija dāvājusi Latvijai (paši lietuvieši par to ar poliem "negribēja runāt"). Gan A. Kraulim, gan pagaidu pārstāvim J. Grišānam Kauṇā tika pārmests, ka Latvija ved sarunas ar Poliju uz "Lietuvas rēķina". ${ }^{193}$

30. oktobra līguma būtība bija jānoskaidro Latvijas diplomātiskajam pārstāvim Lietuvā V. Bandrevičam, kurš ieradās Kauṇā 4. novembrī un iesniedza akreditācijas dokumentus. Lietuvas Ārlietu ministrijas pārvaldniekam P. Kḷimam un Ministru prezidentam E. Galvanauskam bija bažas par Polijas patiesajiem nodomiem pret Lietuvas valsti, tāpēc viṇi nevēlējās piel̦aut Polijas armijas iziešanu cauri Lietuvai. V. Bandrevičs konstatēja, ka panākt Lietuvas un Polijas saprašanos nav iespējams. Interesanti, ka L. Vasiḷevskis 7. novembrī ziņoja uz Varšavu: V. Bandrevičs jau ceḷā uz Kauṇu saṇēmis informāciju par 30. oktobra līgumu un tāpēc bijis spiests raudzìties pesimistiski uz vienu no saviem uzdevumiem - panākt lietuviešu piekrišanu poḷu karaspēka tranzìtam uz Latviju. ${ }^{194}$

Pakāpeniski militārais stāvoklis Latvijā stabilizējās. 11. novembrī Rīgā sākās Latvijas armijas izšķirošais uzbrukums, kas noslēdzās novembra beigās ar bermontiešu pilnīgu padzīšanu no Latvijas. 21. novembrī uzbrukumā Bermonta daḷām pie Radvilišķiem pārgāja arī Lietuvas armija, un decembrī vācu spēki bija spiesti atstāt Lietuvu. Jāpiezīmē, ka vēl 10. novembrī Bermonts kārtējo un pēdējo reizi mēǵināja nodrošināt lietuviešu neitralitāti - Lietuvas armijas 1. brigādes štābā Baisogalā ieradās Bermonta spēku delegācija ar K. Ziminu priekšgalā. Tā bija pilnvarota "noregulēt attiecības" un sarunā centās pārliecināt lietuviešus, ka Bermonts neatzīst K. Ulmaṇa Pagaidu valdību, kura "nepārstāv tautu un necīnās ar lieliniekiem, taču tas nenozīmē, ka viṇš neatzīst arī Latvijas valsti". Tika piedāvāts sadalìt darbības sfēras, lai lietuvieši varētu iegūt savā rīcībā arī dzelzceḷu uz Liepāju, kura „Lietuvai loti nepieciešama kā osta”. Lietuviešu brigādes komandieris K. Ladiga aizbildinājās, ka nav pilnvarots vest sarunas šajā jautājumā. ${ }^{195}$

Bermontiādes laikā Rīgā strādāja Polijas militārais pārstāvis A. Miškovskis. Pildot J. Pilsudska dotos norādījumus, viṇš vairākkārt latviešu presē deklarēja Polijas attieksmi pret Latgali kā Latvijas sastāvdaḷu. Sakarus ar Poliju A. Miškovskis uzturēja, lidojot uz Viḷṇu un no tās ar lidmašīnu. Jau 19. augustā ceḷā uz Rīgu viṇa lidaparāts bija apšaudīts no sarkanarmiešu pozīcijām pie Daugavpils, tāpēc viṇš bija spiests nolaisties ienaidnieka kontrolētajā teritorijā. A. Miškovskis kopā ar pilotu - 1. aviācijas pulka podporučniku V. Turovski ${ }^{196}$ - vairākas dienas klīda pa mežiem, kamēr ar latviešu zemnieka

\footnotetext{
${ }^{193}$ LVVA, 2574. f., 3. apr., 5. 1., 113. 1p.

194 Turpat, 2575. f., 11. apr., 6. 1. , 3.-4., 6., 9.-10. 1p.; AAN, Akta L. Wasilewskiego, t. 41, k. 7. Vienlaikus Kauņā no Rīgas bija ieradies arī sabiedroto misijas loceklis - angḷu ǵenerālis S. Talentss, lai noskaidrotu Lietuvas attieksmi pret Bermonta karaspēku un „,eventuālu poḷu karaspēka caurlaišanu”.

195 LCVA, f. 384, ap. 3, b. 17, 1. 5; Surgailis G. Lietuvas un Latvijas armiju sadarbība neatkarības cīn̨u gados// Latvijas armija vēstures griežos. - Rīga, 1993. - 34. lpp.; Jankauskas V. Kario kelias. - 163 p.
} 
palīdzību nokḷuva neitrālajā joslā, ko drīz ieṇēma Latvijas armijas vienības, un abi lidotāji tika nogādāti Rīgā. ${ }^{197}$ Savukārt naktī uz 15. oktobri A. Miškovskis Viḷnā saṇēma personisku J. Pilsudska pavēli (J. Pilsudskis tikko bija runājis ar Latvijas delegāciju) lidot uz Cēsīm (kur saskaṇā ar poḷu rīcībā esošajām ziṇām atradās Latvijas armijas virspavēlniecība) un paziṇot, ka divas poḷu divīzijas ir gatavas uzbrukt Bermonta spēkiem, ja lietuvieši izlaidīs tās cauri savai teritorijai. ${ }^{198}$ Vētras un negaisa dēḷ Polijas armijas 1. aviācijas eskadriḷas komandieris atteicās iecelt pilotu, un lidojumam brīvprātīgi pieteicās Francijas armijas leitnants M. Denīns. Lidmašīna avarēja mežā pie Nītaures, bet A. Miškovskis un pilots tika ievainoti un ar Latvijas armijas auto steidzami nogādāti Rīgā, kur A. Miškovskis sniedza attiecīgu ziṇojumu J. Balodim, kas tikko bija iecelts par Latvijas armijas virspavēlnieku. A. Miškovskis palika pilsētā arī turpmāko cīnu laikā ${ }^{199}$ un 18. oktobrī tikās arī ar K. Ulmani. ${ }^{200}$ 25. oktobrī A. Miškovskis telegrafēja uz Poliju, ka "Lietuvas nespēcība, Igaunijas pārspīlētās prasības, vācu uzbrukums, Antantes neizlēmība un mūsu lieliskā izturēšanās veicina uzticības pieaugumu un rēkināšanos ar Polijas atbalstu. Neticība un bažas, ko [pret Poliju] sējusi Lietuva, pazūd". ${ }^{201}$ A. Miškovska stāvokli un darbību Rīgā netieši atviegloja arī Lietuvas diplomātiskā pārstāvja J. Šlūpa un militārā pārstāvja V. Natkēviča prombūtne (bija sācies Bermonta karaspēka uzbrukums, tāpēc viṇi 12. oktobrī no Ieriķiem bija izbraukuši uz Lietuvu). Lietuvas pārstāvniecības darbu šajā laikā vadīja Rīgas lietuviešu sabiedriskais darbinieks K. Vizbars un kapteinis, militārā pārstāvja palīgs - krievs ar latvisku uzvārdu S. Lappa, kurš neprata lietuviešu valodu. Abiem trūka nepieciešamās autoritātes un diplomātiskās pieredzes. $^{202}$

\section{Pastāvīgu attiecību nodibināšana}

196 V. Turovskis vēlāk par to tika apbalvots ar "Virtuti Militari" ordeni. - Źołnierz Polski. - 1923. - 2 wrz.

197 Mączewski P. Misya kap. A. Myszkowskiego//Tygodnik Ilustrowany. - 1920. - Nr. 16. - 17 kw; Brīvā Zeme. - 1919. - 21. sept.; Myszkowski A. Z moich łotewskich wspomnień//Polska Zbrojna. $-1933 .-18$ list.

198 Pobóg - Malinowski W. Najnowsza historia... - S. 196.

199 CAW, Akta Personalne A. Myszkowskiego, 1969/89/3610. Miškovskis A. Iz manām atmiṇām... 70.-71. lpp.; Jaunākās Ziṇas. - 1919. - 17. okt.; Latvijas Sargs. - 1919. - 17. okt.; Brīvā Zeme. 1919. - 5., 18. okt. A. Miškovskis par lidojuma laikā parādīto pašaizliedzību vēlāk tika apbalvots ar Polijas Drošsirdīgo krustu.

${ }^{200}$ LVVA, 5969. f., 1. apr., 29. 1. (A. Miškovska vizītkarte ar veltījuma ierakstu K. Ulmanim). Sīkāk sk.: Jēkabsons Ē. Pirmais, kurš brīdināja [Polijas militārais pārstāvis A. Miškovskis]//Latvijas Avīze. Mājas Viesis. - 2004. - 12. nov.

201 AAN, Ministerstwo Spraw Zagranicznych (turpmāk: MSZ), t. 5197, k. 30.

${ }^{202}$ LCVA, f. 384, ap. 3, b. 73, 1. 159-160; f. 383, ap. 7, b. 35, 1. 118-119. Jāatzīmē, ka 20. gadu sākumā S. Lappa tika registrēts Latvijas politiskajā policijā kā "politiski neuzticams ar kriminālu pagātni”, vēlāk Lietuvā bija padomju izlūkdienesta rezidents, 1936. gada sākumā bēga uz Latviju, bet pēc gada tika apcietināts un notiesāts uz 4 gadiem spaidu darbos. - LVVA, Politiskās pārvaldes kartotēka (S. Lappas kartina). 
1919. gada 1. oktobrī Polijas diplomātiskās misijas vadītājs Latvijā un Igaunijā B. Boufals izbrauca no Polijas un cauri Stokholmai pa jūras ceḷu ieradās Liepājā, lai veiktu galveno uzdevumu - panāktu abu Baltijas valstu tuvināšanos Polijai, kā arī „pretdarbotos krievu-vācu kombinācijām” šajās valstīs. Tā kā notika karadarbība pret Bermontu, misija bija spiesta atgriezties Zviedrijā. Otru reizi tā iebrauca Liepājā 24. oktobrī, atstāja šeit jauniecelto Polijas konsulāro aǵentu šajā pilsētā Z. Daṇiḷēviču-Čečotu, ${ }^{203}$ apmeklēja Kurzemes apgabala priekšnieku A. Bērziṇu, kuram B. Boufals lūdza paziṇot Latvijas valdībai savu nožēlu par kara apstākḷu izraisīto misijas aizkavēšanos, bet 29. oktobrī ieradās Rīgā. ${ }^{204}$ Nākamajā dienā B. Boufals iesniedza akreditācijas dokumentus Latvijas valdībai un drīz pēc tam izbrauca uz Tallinu. Rīgā viṇš atgriezās 18. novembrī uz Latvijas valsts neatkarības gadadienas svinībām. B. Boufala uzdevums bija arī nepiel̦aut un kavēt Latvijas un Igaunijas miera sarunas ar Padomju Krieviju. ${ }^{205}$ Pēc ierašanās viņš presē paziņoja par Polijas gatavību sniegt Latvijai tūlìtēju palīdzību, kas pagaidām nav iespējama Lietuvas nostājas dēl. Viṇš arī atzinīgi novērtēja Latvijas valdības gatavošanos īstenot agrāro reformu, kas vērsta pret vācu muižniecību. ${ }^{206}$ Latvijas puse saprotamu iemeslu dēl B. Boufala misiju uztvēra nopietni. Par to liecina arī 1. novembrī dotais rīkojums armijas radiotelegrāfam pieņemt nosūtīšanai viņa šifrētās telegrammas. Oktobrī tika turpināti darbi pie Rīgas-Varšavas tiešās telegrāfa līnijas izbūves. 17. novembrī darbs Latvijā bija pabeigts, taču Lietuvā līnija lietuviešu noraidošās attieksmes dēḷ bija ierīkota tikai līdz Panevēžai. Turklāt pirmais Polijas diplomātiskais pārstāvis Latvijā acīmredzot nevēlējās izmantot netiešā Latvijas telegrāfa starpniecību konfidenciālu rakstu saņemšanai un nosūtīšanai, tāpēc B. Boufala darbs Rīgā bija ievērojami apgrūtināts. 22. novembrī viņš ziņoja uz Viḷnu, ka jau „septiṇas nedēlas ir pilnībā nogriezts no pasaules”, un ziṇojumu nosūtīšanai lūdza organizēt kurjeru-jātnieku satiksmi starp latviešu karaspēka rokās esošo Bebreni un Turmantu (vēlreiz to pašu viņš lūdza 20. decembrī). Tāpat viṇš nesagaidīja, kad tiks atsūtīts solìtais Polijas Preses biroja vadītājs, tādēḷ šo biroju Rīgā organizēja, noslēdzot līgumu ar Japānas laikrakstu korespondentu Latvijas galvaspilsētā - poli H. Klepacki kā tā pagaidu vadìtāju -, un birojs darbu tomēr sāka. ${ }^{207}$ Tādējādi pirmajā darbības laikā Rīgā B. Boufals sakaru trūkuma dēḷ darbojās faktiski bez Polijas norādījumiem un daudzos gadijjumos bija spiests rīkoties, pamatojoties uz dažkārt novecojušām norādēm, kuras viṇš bija saṇēmis pirms izbraukšanas, un uz savu situācijas novērtējumu.

Jau 1919. gadā Latvijā un Polijā izveidojās pretrunīgi viedokḷi par J. Boufala kvalifikāciju un politisko sagatavotību delikātajai misijai Latvijā.

\footnotetext{
${ }^{203}$ Polijas konsulāta izveidošanas nepieciešamību Liepājā L. Vasiḷevskis uzsvēra jau 1919. gada 15. jūlijā Parīzē. - Seskis J. Latvijas valsts izcelšanās... - 266. lpp.

${ }^{204}$ LVVA, 1313. f., 1. apr., 24. 1., 76. lp.; Latvijas Sargs. - 1919. - 7. nov.; Baltijas Vēstnesis. - 1919. 30. okt.; Brīvā Zeme. - 1919. - 2. nov.; Сегодня. - 1919. - 2 ноября.

${ }^{205}$ Łossowski P. Łotwa ... - S. 9; Skrzypek A. Związek... - S. 38; AAN, Kod, t. 2, k. 80; MSZ, t. 5197, k. 38; Latvijas Sargs. - 1919. - 18. nov.

206 Сегодня. - 1919. - 2 ноября. Sīkāk sk.: Jēkabsons Ē. Latvijas poḷi un Latgales poḷu muižniecība valsts neatkarības sākuma posmā (1918-1920)//Latvijas Vēstures Institūta Žurnāls. - 1995. Nr. 3.- 78.-108. lpp.

207 AAN, Akta L. Wasilewskiego, t. 43, k. 19, 21, 22.
} 
13. novembrī Latvijas militārais pārstāvis Varšavā ziṇoja, ka Latvijai draudzīgās poḷu politiskās aprindas raksturo viṇu kā cilvēku, kas "katrā ziṇā izpildīs savas valdības uzdevumus", bet var būt Latvijai nelabvēlīgs. ${ }^{208}$ Pats B. Boufals uzskatīja, ka atsūtīts strādāt uz "austrumiem" (š̄ vārda negatīvajā nozīmē) un tādēl vinam jāizturas ar noteiktību, kāda pienākas lielvalsts pārstāvim. ${ }^{209}$ Kaut arī misijas sekretārs J. Baḷiṇskis 1919. gada decembrī bija sajūsmināts par B. Boufalu, ${ }^{210}$ tomēr šovinistiski noskaṇotās aprindas Polijā visumā nepamatoti pārmeta viṇam nepietiekamu vietējo poḷu (pirmkārt, muižnieku) interešu aizstāvību. Lielā mērā tas notika tāpēc, ka viņš, pamatojoties uz savas valsts interesēm, atteicās iesniegt Latvijas valdībai muižniecības izstrādāto "projektu", kas paredzēja "poḷu zemes īpašumu neaizskaramību" Latgalē. ${ }^{211}$ Katrā ziṇā gan B. Boufals, gan A. LuceBirks, kura attieksme pret Latviju l,oti atškīinās no B. Boufala attieksmes, tika uzskatīti par J. Pilsudska politiskās programmas atbalstītājiem. ${ }^{212}$ Tas arī apliecina, kādu nozīmi Polijas valsts vadība 1919. gadā pieškīira attiecību nodibināšanai ar Latviju.

Patiesībā poḷu minoritātes darbības apstākḷi Rīgā un Liepājā šajā laikā bija pilnībā apmierinoši. ${ }^{213}$ Darbojās poḷu pamatskolas, patversmes, poḷiem bija pārstāvji Tautas Padomē - B. Nagujevskis, pieminētais J. Salcēvičs un V. Janovskis (abi Latgaliešu frakcijā), neskaitot poli V. Bžezinski, kurš kā substitūts darbojās Vācu demokrātu partijas frakcijā (B. Nagujevskis vienatnē veidoja t. s. Poḷu frakciju, turklāt darbojās Tautas Padomē jau 1919. gada pavasarī Liepājā. Jūlijā kopā ar K. Ulmaņa Pagaidu valdību viņš tvaikonī „Saratov” atgriezās no Liepājas ${ }^{214}$ ). Rīgā noorganizētā Poḷu lietu pagaidu komiteja ar zināmu Polijas valdības finansiālu atbalstu palīdzēja skolām un poḷu bēgḷiem, kas cauri Latvijai atgriezās dzimtenē no Ziemeļkrievijas. Sākotnēji tas notika pa jūras ceḷu, vēlāk - cauri Lietuvas armijas ieṇemtajai teritorijai. Būtisku atbalstu šiem bēgḷiem sniedza Latvijas varas iestādes. ${ }^{215}$ Tomēr vēsturnieks J. Aḷbins pamatoti secina, ka neatkarības pirmajos gados Polijas valdībai nebija noteiktas attieksmes pret poḷu minoritāti Latvijā. Tā bija "neskaidra un svārstīga" (stāvoklis mainījās pēc Polijas austrumu robežas izveidošanas 20. gadu sākumā). Savukārt Latvijas poḷu minoritāte šī vārda plašākā nozīmē neizrādīja gandrīz nekādu interesi par minēto attieksmi (tas izskaidrojams, pirmkārt, ar poḷu minoritātes organizētības pakāpi, kas šajā laikā bija lıti vāja. To savukārt iespaidoja samērā zemais poḷu minoritātes sociālais stāvoklis $-\bar{E}$. J.). Par to pagaidām, pirmkārt, savtīgu materiālo interešu vadīta, interesējās vienīgi neliela Latgales muižnieku grupa Polijā. ${ }^{216}$

\footnotetext{
${ }^{208}$ LVVA, 2574. f., 3. apr., 13. 1., 227., 242. 1p.; 1. 1., 38. 1p.

209 AAN, Akta L. Wasilewskiego, t. 43, k. 25.

${ }^{210}$ APAN, Djarjusz M. S. Kossakowskiego, t. 4, cz. 2, s. 288.

211 AAN, Kod, t. 4, k. 22.

212 Łaptos J. Organizacja, personel i funkcjowanie polskiego Ministerstwa Spraw Zagranicznych w latach 1918-1939//Z dziejów polityki i dyplomacji polskiej. - Warszawa, 1994. - S. 335.

213 Sīkāk sk.: Jēkabsons Ē. Poḷi Latvijā. - Rīga, 1996. - 27. lpp.

214 LVVA, 1468. f., 1. apr., 18. 1p.

215 AAN, Akta L. Wasilewskiego, t. 41, k. 13-15, 82, 84, 86; Źołnierz Polski. - 1919. - 4 paźdz.; Jaunākās Ziṇas. - 1919. - 12. sept.
} 
Neuzticību pret Poliju Latvijā lielā mērā radīja tieši Latgales muižnieku darbība šajā valstī, kur atradās šīs muižniecības lielākā un aktīvākā daḷa. Sākot ar 1919. gada jūniju, Inflantijas Poḷu padome regulāri iesniedza Polijas valdībai prasības vai nu pievienot Latgali Polijai, vai aktīvāk aizstāvēt poḷu muižnieku īpašuma tiesības tajā. ${ }^{217} \mathrm{~J}$. Aḷbins atzīst, ka liela Lietuvas, Latgales un citu zemju (tās atradās austrumos no etnogrāfiskās Polijas) poḷu muižniecības daḷu neapmierināja pat nacionāldemokrātu aizstāvētā "inkorporatīvā" teritoriālā programma, un viṇi atbalstīja nedaudzos tā dēvētos konservatīvos, kuri vēlējās pilnīgu Polijas 1772. gada robežu atjaunošanu (tātad arī Latgali un bijušās Kurzemes guberṇas daḷu tās sastāvā). ${ }^{218}$ Šīs muižniecības daḷas darbības rakstura dēḷ bieži vien tās paustās idejas tika un dažkārt historiogrāfijā vēl arvien tiek identificētas ar visas Latgales poḷu muižniecības politisko noskaņojumu, kaut arī tajā neapšaubāmi bija cilvēki, kas apveltīti ar dziḷu iekšēju inteliǵenci un arī nacionālos jautājumos noskan,oti demokrātiski.

Poḷu nacionāldemokrātu un "Austrumu nomaḷu" muižnieku uzskatus (šie muižnieki bija noskaņoti vēl šovinistiskāk) īpaši asi nosodīja poḷu sociālisti. ${ }^{219}$ Savukārt Polijas valdības viedokli 1919. gada nogalē atspoguḷoja Viḷnas laikraksts "Nasz Kraj”, uzsverot, ka Polijai ir jāpanāk kultūras autonomijas garantijas poliem Latgalē, taču "mēs nedrīkstam zem poḷu elementa aizsardzības saukḷa apdraudēt Latvijas valsts vienotību" un apšaubìt Daugavpils un Latgales piederību tai. ${ }^{220} 21$. novembra sarunā ar Z. Meierovicu līdzīgi izteicās B. Boufals, atzīmējot, ka Polija atzīst Latgali par Latvijas sastāvdaḷu, taču vēlas, lai Latgalē saglabātu poḷu kultūru, tādēl aizstāvēs mazākumtautību tiesības šajā novadā, pamatojoties uz Versaḷas miera līguma 93. punktu. ${ }^{221}$

Pēc B. Boufala ierašanās Rīgā arvien aktuālāks kḷuva jautājums par Latvijas diplomātiskās pārstāvniecības atklāšanu Polijā. J. Zālītis jau 13. oktobrī ziṇoja, ka bez tās "vairs nevar iztikt". Militārais pārstāvis M. Hartmanis un viṇa palīgs virsleitnants I. Ulmanis Varšavā 5. novembrī piedalījās Poḷu un latviešu draudzības kluba atklāšanā (tā izveidē iesaistījās arī vairāki Seima deputāti). M. Hartmanis izveidoja Latvijas Preses biroju, taču trūka informācijas un laika, ko aizṇēma tiešie pienākumi. Viṇš panāca Polijas Ârlietu ministrijas piekrišanu reizi mēnesī piešķirt vietu Latvijas kurjeram savā vilcienā uz Parīzes Miera konferenci, bet sūtījumus nogādāt neierobežotā daudzumā. ${ }^{222}$

\footnotetext{
216 Albin J. Polski ruch narodowy na Łotwie w latach 1919-1940. - Wrocław, 1993. - S. 46.

217 AAN, Kod, t. 2, k. 109-110 u. c.; Dziennik Wileński. - 1919. - 4 list.; Sīkāk sk.: Jēkabsons Ē Latvijas poḷi un Latgales poḷu muižniecība valsts neatkarības sākumposmā 1918.-1920. g.//Latvijas Vēstures Institūta Žurnāls. - 1995. - Nr. 3. - 78.-108. lpp. Jau 1918. gada 10. decembrī Inflantijas Poḷu padome iesniedza Polijas valdībai priekšlikumus panākt Latvijas piesaistīšanu Polijai, tādējādi iegūstot brīvu pieeju tās ostām. - Albin J. Polski ruch... - S. 48-49.

218 Albin J. Polski ruch... - S. 46.

${ }^{219}$ Robotnik. - 1919. - 1 paźdz.; Gazeta Warszawska. - 1919. - 14 paźdz.

${ }^{220}$ Nasz Kraj. - 1919. - 4 list.

${ }^{221}$ Łossowski P. Łotwa... - S. 11.
} 


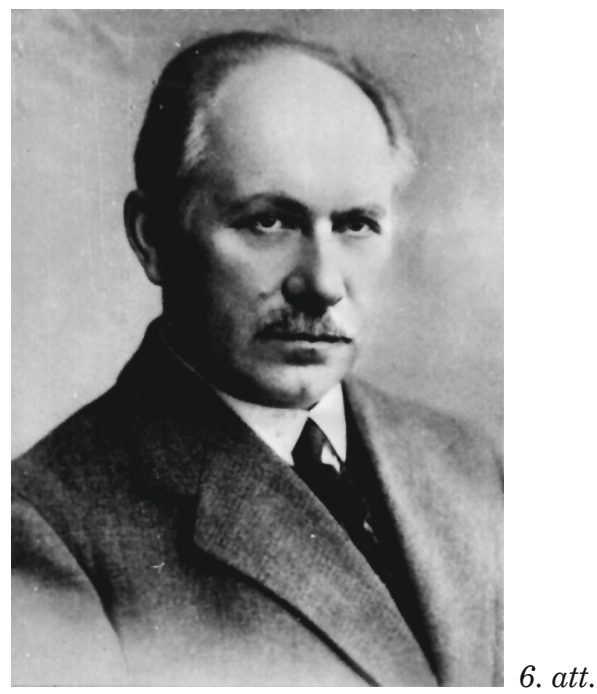

\section{Latvijas diplomātiskais pārstāvis Polijā Atis Ķeniṇš}

Jau savas viesošanās laikā Varšavā Z. Meierovics paziṇoja, ka par pirmo pārstāvi Polijā kḷūs dzejnieks A. Keniṇš, kurš novembra sākumā tika iecelts amatā. ${ }^{223}$ Tomēr ceḷā uz Poliju viṇš misijas priekšgalā izbrauca tikai 19. novembrī. Misijā bija pirmais sekretārs P. Oliṇš ar kundzi - kancelejas ierēdni, tirdzniecības atašejs H. Steinmanis un Informācijas biroja vadītājs, vēlākais ilggadējais konsuls Viḷnā F. Donass. Pārvarot ievērojamas ceḷa grūtības, misija cauri lietuviešu karaspēka ieṇemtajai teritorijai Sēlijā, cauri Turmantai, Dūkštai un Viḷnai naktī uz 26. novembri ieradās Varšavā. Dienā A. Keniṇu apmeklēja Polijas Ārlietu ministrijas Austrumu nodaḷas Baltijas lietu referents A. Tarnovskis, bet vakarā notika līdzšinējā Latvijas Ārlietu ministrijas pilnvarotā tirdzniecības jautājumos K. Spādes rīkotās pusdienas par godu sūtṇa atbraukšanai. 28. novembrī par misijas ierašanos tika informēts premjers I. Paderevskis, taču Ministru kabineta krīzes dēḷ audience notika vēlāk. Sūtnis uzturēja sakarus ar Ārlietu ministrijas Politiskā departamenta direktoru Z. Okencki, Ukrainas Tautas Republikas pārstāvjiem ${ }^{224}$ (kas savas valdības vārdā iesniedza Latvijas atzīšanas aktu ${ }^{225}$ ) un kārtoja citus jautājumus. Tikai decembrī misijas darbiniekiem ar grūtībām (privātas pazī̌anās ceḷā) izdevās atrast telpas birojam "Viktorijas" viesnīcā,

${ }^{222}$ LVVA, 2574. f., 3. apr., 13. 1., 234. 1p.; Latvijas Sargs. - 1919. - 23. nov.; Сегодня. - 1919. 2 ноября.

223 Gazeta Warszawska. - 1919. - 23 paźdz.; Jaunākās Ziṇas. - 1919. - 6. nov.; Latvijas Sargs. - 1919. 12. nov. Sīkāk sk.: Jēkabsons Ē. Latvijas un Polijas attiecības 1919. gadā//Latvijas Vēstures Institūta Žurnāls. - 1994. - Nr. 1. - 93.-111. lpp.; Jēkabsons Ė. Latvija un Polija 1919. gadā: pirmie sakari// Latvijas Zinātņu Akadēmijas Vēstis. - 2003. - Nr. 1.-2., 32.-53. lpp.

${ }^{224}$ Sīkāk sk.: Jēkabsons Ē. Latvijas attiecības ar Ukrainas Tautas Republiku (1919-1921)//Latvijas Vēsture. - 2003. - Nr. 4, 56.-72. lpp.

225 Sk.: Dokumenti par Latvijas valsts starptautisko atzī̌sanu, neatkarības atjaunošanu un diplomātiskajiem sakariem... - 75. lpp. 
bet šĩ mēneša vidū Polijas Ārlietu ministrija rekvizēja telpas Latvijas misijai prominentajā "Bristoles" viesnīcā. ${ }^{226}$

Arī A. Keniṇa darbība sūtṇa amatā izraisīja dažādus viedokḷus. Nevar piekrist poḷu historiogrāfijā izplatītajam uzskatam par viṇa pārliecīgo labvēlību Lietuvai un līdz ar to - nelabvēlību Polijai. Dal̦ēji šis uzskats balstīts uz B. Boufala 1. novembra telegrammu, kurā viṇš šĩ iemesla dēl prasīja noraidìt A. Keniņa kandidatūru sūtṇa amatam. Iegansts tam bija viṇa konflikts ar Francijas militārās misijas vadītāju E. Diparkēe227 (Francijas misija Polijai bija ìpaši labvēlīga). Tomēr A. Keniṇa ziņojumi bija objektīvi un balstījās uz faktiem. Savukārt pret Lietuvu viņš izturējās loti kritiski, ipaši uzsverot redzēto pa ceḷam uz Varšavu - Ilūkstes apriṇki bija ieṇēmis lietuviešu karaspēks, un bija radies iespaids, ka, pretēji Lietuvas valdības apgalvojumiem par okupācijas pagaidu raksturu, tie gatavojas tur palikt.228 Secinājuma pamatotību apliecināja tālākā notikumu gaita.

Viens no svarīgākajiem diplomātiskās misijas uzdevumiem bija nokārtot to Latvijas pilsoṇu atgriešanos dzimtenē, kuri dažādu iemeslu dēḷ atradās Polijā. Vairākums no viņiem bija sarkanarmieši, kas labprātīgi bija pārgājuši poḷu pusē vai bija saṇemti gūstā un atradās dažādās gūstekṇu nometnēs. Jau septembrī uz Poliju devās Iekšlietu ministrijas Karagūstekṇu un bēgḷu nodaḷas pārstāvis leitnants P. Strods, ${ }^{229}$ kurš novembrī kopīgi ar Polijas Austrumu zemju komisijas pārstāvjiem apmeklēja gūstekṇu nometnes un konstatēja tajās neapkurinātas barakas, nepietiekamu ēdināšanu un sliktu apǵērbu. Stšalkovas nometnē pie Krakovas ${ }^{230}$ latvieši tika pakḷauti miesassodiem un viens pat noslepkavots. Kopumā Polijā šajā laikā atradās apmēram 1300 latviešu karagūstekṇu. ${ }^{231}$

Polijas Kara lietu ministrija 25. novembrī, nesaskaņojot ar Latvijas pārstāvjiem, izdeva pavēli par Latvijai piederīgo gūstekṇu atbrīvošanu pēc vinuu iepriekšējās politiskās darbības pārbaudes. Vairāki simti cilvēku tika atlaisti bez pienācīga apǵērba un iztikas līdzekḷiem. Viena šāda 250 vīru grupa ieradās no Varšavas Viḷnā, kur Polijas Bēgḷu un gūstekṇu pārvalde tiem pirmo reizi izsniedza daḷu no nepieciešamā apgèērba un apaviem, kā arī izmitināja un pabaroja. Bijušo gūstekṇu nosūtīšanu sarežğīja normālas satiksmes trūkums ar Latviju, jo šaursliežu dzelzcel̦š Čarnibruda-Eglaine cauri Lietuvai nefunkcionēja, lai gan Latvijas puse bija vairākkārt lūgusi attiecīgās Lietuvas iestādes atjaunot dzelzceḷu un netraucēt Latvijas vilcienu satiksmi

${ }^{226}$ LVVA, 2575. f., 15. apr., 11. 1., 77. 1p.; 2570. f., 2. apr., 18. 1., 94. 1p.; 2574. f., 3. apr., 13. 1., 238. 1p.; Donass F. Politiskos krustceļos. - 8. lpp.

227 AAN, Akta L. Wasilewskiego, t. 41, k. 9.

${ }^{228}$ LVVA, 2575. f., 15. apr., 11. 1., 81.-82. lpp.

${ }^{229}$ Latvijas Sargs. - 1919. - 29. aug., 14. sept.

${ }^{230}$ Stšalkovas un Dombes nometnē vēl 1920. gada septembrī valdošie sliktie dzīves apstākḷi aprakstīti ar̄̄ ASV humanitāro organizāciju pārstāvju ziṇojumos. - Польско - советская война 1919-1920 (ранее не опубликованные документы и материалы). - Часть II. - Москва, 1994. - 29-30, 48-51 стр.

${ }^{231}$ LVVA, 2574. f., 3. apr., 13. 1., 43.-44. lp.; Jaunākās Ziṇas. - 1919. 28. nov.; 1920. - 12. marts. Sīkāk sk.: Jēkabsons Ē. Jeńcy - Łotysze w niewoli polskiej (1918-1921)//Zeszyt Naukowy Muzeum Wojska. - 13. - Białystok, 2000, s. 93-102. 
(3. decembrī Lietuvas Ārlietu ministrija atbildēja uz kārtējo 7. novembrī izsūtīto vēstuli, ka dzelzcel̦a atjaunošana būs iespējama vienīgi pēc Lietuvas attiecību uzlabošanās ar Poliju). ${ }^{232}$ Cilvēki no poḷu kontrolētās Turmantas stacijas bija spiesti vairākus desmitus kilometru noiet kājām. Latvijas misijai trūka līdzekḷu pilnvērtīgas palīdzības sniegšanai atbrīvotajiem. Decembrī tika panākta vienošanās ar Polijas armijas vadību, ka turpmāk latviešu tautības gūstekṇus uzreiz pēc nonākšanas gūstā nosūtīs uz Latviju. No novembra beigām arī Viḷn̄ā strādāja latviešu gūstekṇu lietu pārzinis - kapteinis A. Krūms (11. novembrī viṇu no Latvijas armijas Virspavēlnieka štāba Operatīvās dalas M. Hartmaṇa rīcībā bija nosūtījuši uz Varšavu, taču M. Hartmanis komandēja A. Krūmu uz Viḷnu „rūpēties par latviešu gūstekn,u partijām, kas brauks uz Latviju, uzturēt sakarus ar legāciju Varšavā un reǵistrēt vietējos latviešus"). ${ }^{233}$ Latviešu civilo bēgḷu kopskaits Polijā tika vērtēts ap 2000 cilvēku, un lielākā daḷa no viṇiem bija materiāli nenodrošināti. ${ }^{234}$ Runājot par turības līmeni, kāds kopumā bija latviešiem Polijā šajā laikā, kā iznēmums jāmin Olkušas fabrikas direktors P. Kroders, kurš 4. decembrī ziṇoja Latvijas valdībai, ka savu Latvijas propagandēšanas darbu Polijā veic brīvprātīgi. ${ }^{235}$

Latvijas un Polijas saimnieciskie sakari kopējas robežas trūkuma dēḷ 1919. gadā bija vēl vāji. Septembra beigās, lai runātu par preču apmaiṇu pēc Daugavpils ienemšanas, Polijas Tirdzniecības un rūpniecības ministriju apmeklēja K. Spāde, ${ }^{236}$ taču A. Keniņš uzskatīja, ka K. Spādes darbībai Polijā “pagaidām nav lielas izredzes". Jau septembrī K. Zariṇa delegācijai Polijas puse piedāvāja rūdu, degvielu un ogles apmaiṇā pret iespējamo Liepājas ostas izmantošanu (K. Spādem tika piedāvāta nafta, audumi un galantērijas preces apmaiñā pret Latvijas liniem, ādām un pārtiku). Novembrī poḷu puse piedāvāja sāli un petroleju. ${ }^{237}$ Tomēr viss bija atkarīgs no dzelzceḷa līnijas Eglaine-Čarnibruda. Tā atradās lietuviešu kontrolē un nefunkcionēja. Latvijas Satiksmes un darba ministrija jau septembra beigās un pēc tam novembra sākumā Ārlietu ministrijā interesējās, kas tiek darìts ogḷu, benzīna, naftas un citu produktu piegādes nodrošināšanā no Polijas, taču objektīvu apstākḷu dē konkrētu atbildi nesaṇēma. ${ }^{238}$ Pagaidām no Polijas Latvijā nelielā daudzumā pienāca vienīgi smērẹ̦la, lidmašīnu degviela, petroleja un citi materiāli armijai, taču lietuvieši kavēja arī šīs piegādes. ${ }^{239}$

Ar saimniecisko sakaru veidošanu 1919. gada nogalē nodarbojās galvenokārt privātuzṇēmēji. Varšavā šajā laikā ieradās vairākas personas,

\footnotetext{
${ }^{232}$ LCVA, f. 383 , ap. 7, b. 35, 1. 51; b. 36, 1. 75; f. 384, ap. 3, b. 358, 1. 5.

${ }^{233}$ LVVA, 2574. f., 3. apr., 13. 1., 46. 1p.; 2575. f., 15. apr., 11. 1., 77., 79. lp.; Jaunākās Ziṇas. - 1919. 28. nov., 22. dec.; Brīvā Zeme. - 1919. - 14. dec.

234 Jaunākās Ziņas. - 1919. - 11. dec.; Brīvā Zeme. - 1920. - 8. janv.

${ }^{235}$ LVVA, 2574. f., 3. apr., 13. 1., 248. 1p. P. Kroders jau 1919. gada 22. maijā iesniedza I. Paderevskim memorandu, kurā lūdza viṇu Parīzes Miera konferencē vērst uzmanību uz Latvijas Republikas neatkarības jautājumu (vienlaikus memoranda noraksts tika piesūtīts Anglijas pārstāvniecībai Polijā).

236 Kurjer Powszechny. - 1919. - 30 wrz.

${ }^{237}$ Latvijas Sargs. - 1919. - 25. sept.; Kurjer Polski. - 1919. 30 wrz.; Jaunākās Ziṇas. - 1919. - 24. nov.

${ }^{238}$ LVVA, 4592. f., 3. apr., 101. 1., 197.-199., 209. lp.

239 Počs K. Sanitārā kordona... - 45. lpp.
} 
kuras bija komandējusi Latvijas Apgādības ministrija un kuras darbojās "šauri tirdznieciskās interesēs". ${ }^{240}$ A. Keniņšs sūdzējās par J. Poli, kurš armijas Virspavēlnieka štāba uzdevumā centās iepirkt kara materiālus un kopā ar sev pazīstamo, minēto A. Luci-Birku apmeklēja vairākus ministrus un pat J. Pilsudski, kā arī nodibināja sakarus ar Varšavas Banku apvienību, lai veidotu kopuzṇēmumus. ${ }^{241}$ Turklāt Latvijas uzṇēmējs un arī Tautas Padomes loceklis E. Traubergs lūdza piešķirt Latvijas armijai izlūklidmašīnu, bet pats izgāja lidošanas apmācības kursu Varšavas kara lidlaukā. Katrā ziṇā A. Keniņš uzsvēra, ka Traubergs un vēl viens Latvijas tirgotājs L. Rapeports - ar Apgādības ministrijas pilnvarām slēdz līgumus, kuri var “ātri izvērsties par skandalozām afērām”. Visa šì darbība netika saskaṇota ar Latvijas diplomātisko misiju. ${ }^{242}$

Negatīvu iezīmi abu valstu attiecībās izraisīja 4. decembra incidents Liepājā, kur notika pilsētas skolēnu pateicības manifestācija par godu ASV Sarkanā Krusta misijai. Daži latviešu skolotāji pieprasīja novākt "Bermonta flagu", ar to domājot Polijas karogu, ko nesa poḷu pamatskolas skolnieki. Šìs dažu latviešu pedagogu neizglìtotības dēḷ aizsākās vairāku mēnešu ilga diplomātiska sarakste ar Polijas misiju Latvijā. ${ }^{243}$ Tomēr šādi nenozīmīgi pārpratumi nemainīja kopējo tuvināšanās tendenci Latvijas un Polijas attiecībās.

\section{Militārās sadarbības līgums}

1919. gada nogalē Latvijas un Polijas tuvināšanos noteica abu pušu intereses. Latvija dienvidos robežojās ar Lietuvu, un attiecības ar to bija loti sarežğìtas. Oktobrī Bermontiādes laikā gandrīz visi lietuviešu spēki tika atvilkti no Daugavpils frontes, tomēr tie joprojām kontrolēja daḷu Ilūkstes apriṇķa. Kaut arī Z. Meierovics Kauṇā saṇēma tikai nekonkrētus solījumus noslēgt militāru savienību nākotnē, tomēr Latvijas valdība saglabāja cerību

${ }^{240}$ Vienam no šādiem tirgotājiem - J. Treimanim - bija Apgādības ministrijas pilnvaras ievākt informāciju par tirdzniecības iespējām Polijā, Ukrainā un Rumānijā. Pēc atgriešanās Latvijā viņš piedāvāja manufaktūras preces no Polijas, taču priekšlikums nebija izdevīgs. - Brunners P. Panama. - Rīga, 1926. - 24. lpp. Nav izslēgts, ka P. Brunners kḷūdījies un patiesībā ir runa par turpmāk minēto Tautas Padomes locekli un uzņēmēju E. Traubergu.

241 J. Polis Rīgā atgriezās decembra vidū un sniedza presē visumā objektīvu raksturojumu par Latvijas attiecībām ar Poliju un latviešu stāvokli šajā valstī. - Brīvā Zeme. - 1919. - 14. dec. (rakstā J. Polis dēvēts par Latvijas "militārmisijas padomnieku ekonomiskos jautājumos".

${ }^{242}$ LVVA, 2575. f., 15. apr., 11. 1., 80. 1p. J. Poḷa nozīme nav skaidra. 6. novembrī B. Boufals ziṇoja, ka viņš ieradīsies "inkognito" Viḷñā A. Niedras uzdevumā, lai nodibinātu sakarus ar Poliju. Savukārt saskaņā ar 28. novembra A. Luces-Birka ziņojumu viņš bija ieradies Varšavā mēneša vidū Latvijas armijas virspavēlnieka uzdevumā un ar vairāku tirdzniecības firmu ieteikumiem (30. oktobrī J. Polis bija ieskaitīts kara dienestā kā kara ierēdnis Latvijas armijas Apgādības pārvaldē (armijas virspavēlnieka 1919. gada 31. okt. pavēle). Luce-Birks lūdza izpildīit viņa lūgumu par prožektora un 10 lauka virtuvju piegādi Latvijas armijai un aţ̦aut latviešu virsniekam un inženierim Ļvovā iepazīties ar armijas darbnīcām, kā arī piešķirt naudas pabalstu laikrakstiem "Brīvā Zeme" un "Latvijas Sargs", lai noskaņotu tos labvēlīgi pret Poliju (lūgums gan palika bez ievērības $-\bar{E}$. $J$.). - AAN, Akta L. Wasilewskiego, t. 41, k. 8-9, 44-46.

${ }^{243}$ LVVA, 2574. f., 3. apr., 13. 1., 27.-34. 1p.; AAN, Akta L. Wasilewskiego, t. 43, k. 25. 
vienoties ar tuvāko kaimiṇu dienvidos. 8. novembrī Z. Meierovics deva rīkojumu uzaicināt uz Rīgu Lietuvas armijas virspavēlniecības pārstāvjus. 11. novembrī uz Latvijas galvaspilsētu izbrauca generālleitnants J. Galvidis-Bikausks un majors A. Jakaitis. ${ }^{244}$ Viṇi 20. novembrī apspriedās ar Latvijas armijas vadību un valdības pārstāvjiem. Abas puses vienojās par nepieciešamību tuvākā laikā noslēgt militāru savienību. ${ }^{245}$ Jaunieceltais Latvijas diplomātiskais pārstāvis Lietuvā V. Bandrevičs šajā laikā Kauṇā sarunā ar avīzes "Lietuva" korespondentu uzsvēra, ka Latvija nav noslēgusi nekādus līgumus ar Poliju, bet Z. Meierovics viesojies Varšavā tāpēc, ka Latvija vēlas nodibināt labas attiecības ar visām valstīm, kurām ir līdzīgas intereses - arī ar Poliju, Somiju, Ukrainu. ${ }^{246}$ Kaut arī Latvijas un Lietuvas armija cīṇā ar bermontiešiem zināmā mērā sadarbojās, tomēr teritoriālo nesaskaṇu un atškirirīgo ārpolitisko nostādṇu dēl radītā savstarpējā neuzticība saglabājās. 22. novembrī Z. Meierovics informēja Lietuvas valdību, ka cīṇā ar bermontiešiem Latvijas armija stratēǵisku apsvērumu dēl pārgājusi Lietuvas robežu, ienemot Žeimju apdzīvoto vietu, bet Lietuvas Ārlietu ministrijas atbildē 25. novembrī bija stingri uzsvērta vēlme, lai latvieši nepārietu bijušo Kauņas guberņas robežu. ${ }^{247}$

Tomēr militārpolitiskie apstākḷi bija zināmā mērā labvēlīgi LatvijasLietuvas savienības noslēgšanai, kaut arī attiecības bojāja nesaskaņas par Ilūkstes apriņ̧̧a daḷu un Lietuvas noraidošā nostāja pret Latvijas sakariem ar Poliju. Novembrī Tērbatā, Baltijas valstu konferencē, uz dalībniekiem dziḷu iespaidu atstāja Lietuvas pārstāvja J. Šlūpa runa, kurā viňš Polijas neoficiālā pārstāvja S. Prusa-Boguslavska klātbūtnē apvainoja Poliju Lietuvas zemju sagrābšanā. ${ }^{248}$ Kaut arī S. Prusam-Boguslavskim bija dots rīkojums noskaidrot tuvināšanās iespējas ar Latviju, Igauniju un Somiju, tomēr Lietuvai pagaidām izdevās šo mēǵinājumu iztraucēt. Katrā ziṇā 9. decembrī Latvijas Ārlietu ministrijas pārskatā teikts, ka ir cerības saprasties ar Lietuvu robežas jautājumā un noslēgt militāru konvenciju. Šìs cerības palielināja abu valstu armiju virspavēlniecību slepenais līgums, ko parakstīja 8. decembrī Rīgā un kas paredzēja kopīgu uzbrukumu pret vācu spēkiem Lietuvā, ja tie laikus (līdz 13. decembrim) nepārietu Vācijas robežu ${ }^{249}$. Savukārt Polija šajā laikā aicināja sarīkot Viḷnā Baltijas valstu ārlietu ministru apspriedi bez Lietuvas piedalīšanās. Latvijas valdība tam nepiekrita, prasīja sarīkot to Tērbatā un uzskatīja ka jāpiedalās arī Lietuvai. ${ }^{250}$

6. decembrī Kauñā ieradās Latvijas delegācija V. Zāmuela un pulkvežaleitnanta V. Ozola vadībā ar pilnvarām līguma noslēgšanai. Līdz 12. decembrim ar grūtībām tika panākta vienošanās tikai vienā apspriežamo jautājumu daḷā. Galvenais nesaskaņu iemesls palika robeža un atšķirīgā attieksme pret Poliju. Lietuvieši pārmeta Latvijai vienaldzību pret Polijas agresīvajiem nolūkiem.

\footnotetext{
${ }^{244}$ LCVA, f. 383, ap. 7, b. 36, 1. 62.

245 Kurzemes Vārds. - 1919. - 25. nov.

${ }^{246}$ Lietuva. - 1919. - 22 lāpkr.

${ }^{247}$ LCVA, f. 384, ap. 3, b. 13, 1. 9, 13-14; Butkus Z. Lietuvos ir Latvijos... - P. 35.

${ }^{248}$ Łossowski P. Stosunki polsko - litewskie... - S. 189; Skrzypek A. Związek... - S. 36 -37.

${ }^{249}$ Sk.: LCVA, f. 383, ap. 7, b. 38, 1. 14. Līgums paredzēja Latvijas armijas uzbrukumu no Priekules uz Klaipēdu un no Mažeiķiem uz Pluṇgíi.

${ }^{250}$ LVVA, 2574. f., 4. apr., 7. 1., 36. lp.
} 
Savukārt Latvijas pusi neapmierināja lietuviešu nevēlēšanās deklarēt atbalstu Latvijai konfliktā ar Vāciju. Puses nevienojās Mažeiḳu dzelzceḷa posma piederības jautājumā, kā arī jautājumā par kopīgu virspavēlniecību frontē pret Sarkano armiju, jo lietuvieši atteicās operatīvas nepieciešamības gadījumā atstāt frontes iecirkni Kalkūne-Kazimire, kas atradās Ilūkstes apriṇkī un ko tie uzskatīja par savas valsts robežu. Stūrgalvīgi nepiekāpīga bija arī Latvijas puse. P. Radziņš, 12. decembrī atbildot uz V. Ozola telegrammu no Kauñas („Svarīgākais strīdus punkts - dzelzceḷa Mažeiķu posms, līguma noslēgšana - tikai piekāpšanās gadījumā”), uzsvēra, ka šādu lietuviešu prasību gadījumā "līguma noslēgšana nav vēlama" (Mažeik̦u dzelzceḷa mezgls militāru apsvērumu dēl Latvijai esot nepieciešams līdz kara beigām), un lūdza Ārlietu ministriju informēt par kaimiṇu nepiekāpību Antantes lielvalstis, tādējādi mēǵinot panākt, lai uz lietuviešiem izdara spiedienu Antantes lielvalstis ${ }^{251}$ ). Galu galā Lietuvas Ārlietu ministrijas pārvaldnieks P. Kḷims Kauṇā paziṇoja, ka Lietuvas delegācijai nemaz nav pilnvaru līguma noslēgšanai un sarunās ar latviešiem tā piedalās vienīgi informācijas iegūšanas nolūkos, jo par sabiedroto nevar uzskatît valsti, kura izturas vienaldzīgi pret Polijas tīkojumiem. Tādējādi sarunas beidzās faktiski bez rezultātiem. ${ }^{252}$

Šādos apstākḷos Latvijas valdība izšḳīās par noteiktu tuvināšanos Polijai, jo pēc Bermonta sakaušanas Latgales atbrīvošana bija kḷuvusi par aktuālāko jautājumu. Jau Tautas Padomes 1919. gada 15. jūlija sēdē Ministru prezidents K. Ulmanis paziņoja, ka „Latgales atbrīvošana stāv pirmā vietā un, pirms rudzi sāks dzeltēt, neviena ienaidnieka vairs nebūs mūsu zemē". 10. augustā Tautas Padomes Latgaliešu frakcija iesniedza valdībai jautājumus - ko tā ir darījusi Latgales atbrīvošanai un kādi ir panākumi šajā jautājumā. ${ }^{253}$ Tādē] problēma šajā situācijā bija jārisina. Savukārt Polijai, plānojot savas armijas tālāko operatīvo darbību austrumos, vajadzēja nodrošināt tās kreiso spārnu. To varēja izdarīt, savienojoties ar Latvijas armiju, turklāt gan militāri, gan politiski tiktu izolēta Lietuva, kas bija naidīga Polijai. Lietuvai tiktu atņemta arī tās īsā fronte pret Sarkano armiju. Tiktu izveidota kopēja PolijasLatvijas robeža, kas atšķeltu Lietuvu no Krievijas un novērstu pat netiešus krievu-vāciešu sakarus caur Lietuvu. Tādējādi būtu iespējams īstenot poḷu politiķu vēl arvien loloto plānu - no Baltijas jūras līdz Ukrainai izveidot vienotu fronti, kas būtu vērsta pret Padomju Krieviju. Savukārt, atzīstot Daugavpils piederību Latvijai, varēja cerēt, ka tiks iegūta Latvijas uzticība un padziḷināsies Latvijas un Lietuvas pretrunas. Turklāt tādējādi bija iespējams nodrošināties pret Krievijas un Vācijas puses varbūtēju apdraudējumu Polijai. Tas bija kḷuvis aktuāls jau Bermontiādes laikā. 27. novembrī Polijas armijas Galvenais štābs pārskatā par situāciju reǵionā uzsvēra: „Polijas diplomātijai jācenšas izveidot ciešas attiecības ar Baltijas valstīm, lai šīs attiecības radītu mums sabiedrotos vai pat savienību. Tā būtu vērsta, pirmkārt, pret Vāciju, bet pēc tam pret Krieviju. Šāda savienība būtu buferis starp Vāciju un topošo Krieviju un padarītu neiespējamu Vācijas kundzību pie Baltijas jūras

\footnotetext{
251 Turpat, 3. apr., 77. 1., 122. 1p.

252 Turpat, 11. 1., 154.-166. 1p.; Lietuva. - 1919. - 11 gruōdis.

${ }^{253}$ LVVA, 1468. f., 1. apr., 138. 1., 146. lpp. Viens no iniciatoriem, kas 1919. gada 10. augustā valdībai iesniedza pieprasījumu, bija „Latgaliešu frakcijas” loceklis polis J. Salcēvičs.
} 
un neiespējamus Krievijas imperiālistiskos centienus atjaunot valsts vecās robežas, kuras neatzīst jaunizveidotās valstis."254

21. novembrī Polijas valdības un J. Pilsudska uzdevumā Rīgā ieradās Lietuvas-Baltkrievijas frontes Pretizlūkošanas daḷas vadītājs kapteinis V. Slaveks un frontes sakaru virsnieks ar Ārlietu ministriju un J. Pilsudski rotmistrs S. Radzivils, lai sagatavotu militāras savienības noslēgšanu ar Latviju. ${ }^{255}$ Notika sarunas ar Latvijas armijas virspavēlniecību un ārlietu ministru. 23. novembrī viesi pirmoreiz Polijas armijas vēsturē nolika vainagu Brāḷu kapos Rīgā, ${ }^{256}$ bet 25 . novembrī Latvijas armijas kara laika ierēdnis A. Jakovḷevs tika iecelts par sakaru virsnieku poḷu 3. Leǵionu divīzijas štābā un komandēts uz Dūkštu. ${ }^{257}$ Visumā poḷi ar sarunu rezultātiem bija apmierināti, jo Latvijas puse izrādīja gatavību noteiktos apstākḷos noslēgt militāru savienību ar Poliju, ${ }^{258}$ kaut arī politiskajās aprindās uzskati šajā jautājumā bija atšḳirīgi. Sevišḳi asi pret Poliju nostājās sociāldemokrāti. Daḷa no tiem nepamatoti uzskatīja, ka Padomju Krievija atdos Latvijai Latgali pēc miera noslēgšanas ar Latviju. Par savienību bija liela daḷa Zemnieku savienības pārstāvju, kaut arī viṇiem bija šaubas par Polijas nodomiem attiecībā uz Latgali. Ŝ̀̃ šaubas lielā mērā izraisīja Polijas nacionāldemokrātu un Latgales muižniecības darbība. Lai gan padomju valdība novembrī un decembrī bija solījusi atdot Latgali Latvijai tūlīt pēc pamiera noslēgšanas, tomēr, kā atzīst vēsturnieks A. Stranga, igauṇu-padomju sarunu laikā Latvijas valdība pilnībā pārliecinājās, ka tas nenotiks labprātīgi259 (padomju puse izmantoja sarunas, lai ar operatīvu darbību frontē atbalstītu savas teritoriālās prasības). Rīgā V. Slaveks un S. Radzivils pagaidām vēl nebija sanēmuši konkrētus solījumus. 24. novembrī S. Radzivils atgriezās Polijā, bet V. Slaveks devās uz Tallinu, cauri Rīgai atgriežoties Viḷnā mēneša beigās. ${ }^{260}$

Turpmāko Latvijas nostāju izskaidro toreizējais Latvijas armijas Virspavēlnieka štāba priekšnieks P. Radziņš. Viņš liecina, ka Latvijas armija vēl nebija gatava sākt uzbrukumu Latgalē patstāvīgi, jo tādā gadījumā lietuvieši, kuri atradās Daugavpilij tuvāk, būtu iegājuši tajā ātrāk. N,emot vērā Polijas paziņojumu, ka tā piekritīs pilsētas iekḷaušanai tikai un vienīgi Latvijā, Polijas armija nekavējoties mēǵinātu lietuviešus padzìt no pilsētas un to, visticamāk, arī izdarìtu. Pēc tam poḷus "dabūt ārā" no Daugavpils būtu grūti vai pat neiespējami. ${ }^{261}$ Turklāt pats bijušais virspavēlnieks J. Balodis vēlāk uzsvēra, ka šajā laikā Latvijas valdībai un armijas vadībai bija nopietni jārēķinās, ka Igaunija un arī Lietuva noslēgs mieru ar Padomju Krieviju un ka tas vēl vairāk sarežǵīs Latvijas militāro situāciju. ${ }^{262}$ Savukārt Latvijas

\footnotetext{
254 Okulicz P. Koncepcja międzymorza. - S. 91, 114.

255 AAN, MSZ, t. 5197, k. 60.

${ }^{256}$ LVVA, 2574. f., 3. apr., 13. 1., 240. 1p.; Brīvā Zeme. - 1919. - 21., 22., 25. nov.

257 Turpat, 5601. f., 1. apr., 552. 1., 2. 1p. A. Jakovḷevs no šì komandējuma atgriezās tikai 1920. gada 8. janvārī.

258 AAN, MSZ, t. 5197, k. 60; Akta L. Wasilewskiego, t. 41, k. 51 (A. Luce-Birks decembrī rakstīja, ka S. Radzivils atgriezies sajūsmināts par latviešiem un nav sapratis, ka "viņi iet pa angḷu līniju”).

259 Stranga A. O niektórych problemach polsko - łotewskich stosunków... - S. 149.

${ }^{260}$ Brīvā Zeme. - 1919. - 25. nov.; Latvijas Sargs. - 1919. - 4. dec.

${ }^{261}$ Radziņš P. Latvijas atbrīvošanas karš. -9 . lpp.
} 
armijas kara ierēdnis, militārais vēsturnieks P. Bērziṇš papildus minētajam Lietuvas faktoram min arī tīri taktisku iemeslu - Latgale bija jāatbrīvo ziemā, jo, iestājoties pavasarim, dabas apstākḷi ievērojami apgrūtinātu uzbrūkošā karaspēka darbību. ${ }^{263}$

Polijas puse ar J. Pilsudski priekšgalā centās radīt priekšnoteikumus ciešākai un pat tiešai militārai sadarbībai ar Latviju jau ilgāku laiku. 3. un 26. novembrī padomju delegācijai, ar kuru poli veda slepenas sarunas Mikaševičos, tika paziņots, ka Polija atbalstīs Latvijas prasību pēc Daugavpils, un ieteica pilsētu latviešiem atdot. ${ }^{264}$ Vēl agrāk operatīvo apstākḷu iespaidā Polijas armijas vadība sāka apsvērt Daugavpils ieṇemšanu sadarbībā ar Latvijas armiju. 3. oktobrī Lietuvas-Baltkrievijas frontes virspavēlnieks S. Šeptickis saṇēma instrukciju paredzētajai operācijai Latgalē, ${ }^{265}$ bet 13 . novembrī G̦enerālštābs pavēlēja 1. un 3. Leǵionu divīzijai gatavoties Daugavpils operācijai, pēc kuras būs jāsavienojas ar Latvijas armiju. ${ }^{266} 16$. novembrī J. Pilsudskis lūdza Anglijas sūtnim Polijā H. Ramboldam viņa valsts labvēlību operācijai, bet 2. decembrī kā armijas virspavēlnieks izdeva instrukciju Latgales operācijai ar kodētu nosaukumu "Zima" ("Ziema"). 8. decembrī 1. Leǵionu divīzijas štābs saṇēma pavēli gatavoties operācijai ar saviem un 3. Leǵionu divīzijas spēkiem, kurus atbalstīs 1. jātnieku brigāde. 17. decembrī šì brigāde tika pārvietota uz 8. divīzijas iecirkni, kurš atradās gar Daugavu grupas labajā spārnā, lai gan pirms tam karaspēka grupas virspavēlnieks E. Ridzs-Smiglijs bija protestējis un argumentējis, ka neesot iespējams īstenot operāciju „Ziema” bez jātnieku vienībām, kas bloḳētu lietuviešu karaspēka pāriešanu pāri Daugavai. ${ }^{267}$

Poḷu karaspēka stāvokli apgrūtināja tīfa epidēmija, siltā apgèērba, apavu un dzelzceḷa ritošā sastāva trūkums, kaut arī 19. decembrī frontes štābs bija izdevis pavēli par karavīru apgādi ar nepieciešamo apǵērbu, ieročiem un pārtiku gaidāmajai akcijai. Vēlāk karavīri saṇēma silto veḷu, svìterus, cimdus, zeḳes, visiem izdalīja franču (virsniekiem - vācu) bruṇucepures un skotu cepures. Vezumniekiem, šoferiem un sargkareivjiem - arī kažokus un salmu veltenus, kurus Baltkrievijā bija iepirkusi frontes intendantūra. Bruṇojumā pārsvarā bija franču "Lebel” karabīnes, austriešu "Schwarzlose", trofeju - (vācu) "Maxim" un angḷu "Hotchkiss" - ložmetēji. ${ }^{268}$ Kopumā Polijas armija bija apgādāta ievērojami labāk nekā latviešu karavīri. 16. decembrī E. Ridza-Smiglija grupas štābs ziṇoja, ka karaspēku iespējams sakoncentrēt izejas pozīcijās deviṇās dienās, taču štāba priekšnieks T. Kučeba uzskatīja, ka tas būs gatavs uzbrukumam tikai 5.-10. janvārī. Savukārt Ridzs-Smiglijs Varšavā J. Pilsudskim kā iespējamo termiṇu minēja decembra beigas. ${ }^{269}$ Katrā

\footnotetext{
262 Balodis J. Ģenerāḷa Jāṇa Baloža atmiṇu burtnīcas//Neatkarīgā Rīta Avīze. - 1997. - 22. marts.

263 Bērziṇš P. Latvijas Brīvības cīṇas 1918-1920. - Rīga, 1928. - 75. lpp.

264 Tajne rokowania polsko - radzieckie w 1919 r. - Warszawa, 1986. - S. 204, 264.

265 Jędrzejewicz W. Kronika źycia Józefa Piłsudskiego 1867-1935. - T. 1. - Londyn, 1986. - S. 457. S. Šepticka izpratne par politiskajām norisēm bija vāja, jo vēstulē J. Pilsudskim viṇš runāja par sadarbību ar Igaunijas armiju Kurzemē, nevis ar Latvijas karaspēku Latgalē.

266 AAN, Kod, t. 2, k. 125.

${ }^{267}$ CAW, Wojskowe Biuro Historyczne (turpmāk: WBH), 341. 1. 153.

${ }^{268}$ Szeptycki S. Front Litewsko - Białoruski. - 10 marca 1919 - 30 lipca 1920. - Kraków, 1925. - S. 11; CAW, WBH, 341. 1. 150, 151; Merwin B. Wzięcie Dźwińska//Nasz Kraj. - 1920. - 15 stycz.
} 
ziṇā turpmākie notikumi frontē pie Daugavpils bija atkarīgi no A. Miškovska darbības Latvijas galvaspilsētā.

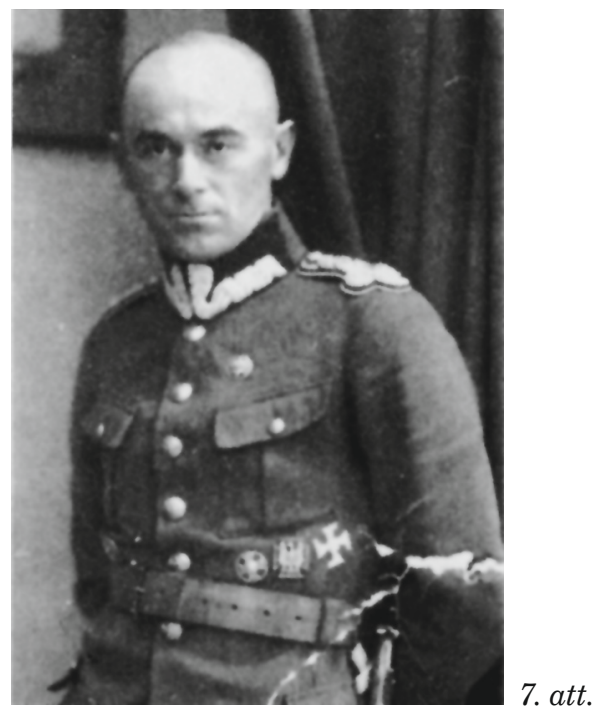

\section{Poḷu karaspēka grupas virspavēlnieks Eduards Ridzs-Smiglijs}

13. decembrī viņš ieradās Rīgā jau ar pilnvarām noslēgt vienošanos par militāru sadarbību (politiskus jautājumus iztirzāt viṇš izvairījās ${ }^{270}$ ). Gaidot Latvijas armijas virspavēlnieka atgriešanos no Liepājas, A. Miškovskis pārliecinājās, ka latvieši būs gatavi uzbrukumam ne ātrāk par 1920. gada 1. janvāri, jo Kurzemē (Liepājā) vēl tikai formējās Zemgales divīzija un artilērijas pulki. 19. decembrī viṇš ziṇoja, ka Rīgā vēl nav izstrādāts operatīvais plāns Latvijas armijas darbībai Latgales frontē. A. Miškovska 16.-17. decembra sarunās ar Latvijas armijas Virspavēlnieka štāba priekšnieku P. Radziṇu abas puses vienojās sākt uzbrukumu laikā no 4. līdz 10. janvārim, kā arī turēt gatavošanos pilnīgā slepenībā gan no Padomju Krievijas, gan Lietuvas, gan Antantes lielvalstīm. ${ }^{271}$ Virspavēlnieks J. Balodis vēlāk atcerējās - A. Miškovskis uzsvēris, ka izsaka priekšlikumus J. Pilsudska vārdā un viṇa sākotnēji piedāvātais uzbrukuma termiṇš bijis 20. decembris, kas vēlāk tika pārlikts uz 3. janvāri. ${ }^{272}$

Slepenība tiešām tika ievērota sekmīgi. Armijas Virspavēlnieka štāba virsnieki tikai decembra beigās nopratuši, ka tiek gatavota vienošanās ar Poliju. P. Radziṇš vairākkārt apspriedās ar A. Miškovski štāba karšu istabā, taču nekad nepieaicināja kādu trešo personu un nedeva pārrakstīšanai sarunu piezīmes. ${ }^{273}$ Tomēr Lietuvas armijas vadība, analizējot operatīvo stāvokli, nojauta varbūtējos poḷu operatīvos mērḳus un decembrī sāka koncentrēt

\footnotetext{
${ }^{269}$ CAW, WBH, 341. 1. 151, k. 153.

270 Skrzypek A. Stosunki polsko - łotewskie 1918-1939. - S. 25.

271 Документы и материалы... - 444-445 стр.

272 Balodis J. Ģenerāḷa Jāṇa Baloža atmiṇu burtnīcas//Neatkarīgā Rīta Avīze. - 1997. - 22. marts.
} 
savas karaspēka vienības Subates rajonā. Tas varēja nozīmēt nopietnu gatavošanos Daugavpils ieņemšanai (šīs aizdomas apstiprināja Ilūkstes apriṇkī koncentrētās Lietuvas karaspēka grupas nosaukums, kurā bija pilsētas lietuviskais nosaukums - "Daugapilis" grupa). Pēc tam kad Latvijas armijas virspavēlniecība divkārt bija prasījusi izbeigt minēto koncentrāciju, ko Lietuvas puse skaidroja ar "parastu pārgrupēšanos", Z. Meierovics 23. decembrī izteica oficiālu protestu pret lietuviešu veikto „Latvijas zemes okupāciju” un kategoriski pieprasīja atvilkt Lietuvas karaspēku divu nedēḷu laikā. Pretējā gadījumā viṇš Latvijas valdības vārdā solīja "paturēt sev rīcības brīvības tiesības", kas diplomātiskajā praksē skanēja jau ḷoti nopietni un patiesībā atgādināja ultimātu valstij, kura tiek uzskatīta par naidīgu. ${ }^{274}$ 30. decembrī A. Voldemars atbildēja, ka Lietuva "neizšķirs jautājumu vienpusēji", tā uzskata par savām "Kurzemes guberṇas lietuviskās daḷas" un pretendē uz Daugavpils cietoksni, kurš ir "Lietuvas galvaspilsētas Viḷnas atslēga" un ne no vēsturiskā, ne etnogrāfiskā viedokḷa nepiederot Latvijai. ${ }^{275}$ Tādējādi A. Voldemars praktiski pats, netieši iedalot Latviju vienā kategorijā ar Poliju (poḷi atṇēmuši Lietuvai Viḷnu, latvieši gatavojas atņemt tai Daugavpili), norādīja uz vienīgo potenciālo latviešu sabiedroto šajā periodā - tā bija Polija. Lietuviešu vēsturnieks Z. Butkus atzīst, ka A. Voldemars un daži citi Lietuvas politiḳi šajā laikā īstenoja nesaprātīgu, dažkārt izteikti ambiciozu politiku pret Latviju, izsakot pilnīgi nepamatotas pretenzijas uz Daugavpili un Latgali (A. Voldemars pat vairākkārt nebija saskaṇojis ar citiem savas valdības locekḷiem to notu saturu, kuras bija nosūtījis uz Latviju). ${ }^{276}$ Jāpiezīmē, ka 24. decembrī Ilūkstes apriņķa latviešu komandants informēja Lietuvas armijas 2. brigādes komandieri, ka lietuviešu daḷām apriṇkị jāatstāj, bet vēl 1920. gada 6. janvārī no šī komandiera saṇēma noraidošu atbildi un ieteikumu nodibināt sakarus ar Lietuvas armijas virspavēlniecību. ${ }^{277}$ Lietuviešu vēsturnieks Č. Laurinavičs konstatē, ka jau 1917. gadā politiki A. Voldemars un M. Ičs uzskatīja, ka Lietuvai ir nopietnāks pamats nekā Igaunijai un Latvijai nodibināt savu valsti, tādēl pat necentās noorganizēt sakarus ar šo tautu pārstāvjiem (savukārt M. Slezēvičs, P. Kḷims un citi lietuviešu politiķi pamatoti domāja, ka visu triju zemju vienotība var ievērojami stiprināt arī Lietuvas stāvokli). A. Voldemars, jau būdams atbildīgos amatos valdībā 1918.-1919. gadā, turpināja paust līdzīgu viedokli, cita starpā 1918. gada 3. decembrī pat nesaskatot nepieciešamību nosūtīt uz Latviju un Igauniju diplomātiskos pārstāvjus: „Mums pietrūkst cilvēku, lai nosūtītu viņusuz valstīm, kas tikai vakar izveidojušās. Valdība neuzskata to par lietderīgu, jo nekāds labums no tā nav paredzams."278 1919. gada rudenī minēto viedokli Lietuvas ārpolitikā stiprināja arī nenoteiktā, dažkārt liekulīgā un ḷoti savtīgā Antantes

\footnotetext{
273 Plensners A. Pret vētrām un negaisiem. - Grāmatu Draugs, 1982. - 155. lpp.

${ }^{274}$ LCVA, f. 383, ap. 7, b. 36, 1. 35; AAN, Akta L. Wasilewskiego, t. 43, k. 38.

${ }^{275}$ LVVA, 2575. f., 11. apr., 8. 1., 9. 1p.; AAN, Attachaty, A - II/81/1. Minētās A. Voldemara vēstules kopiju Z. Meierovics uzbrukuma priekšvakarā Latgalē piesūtīja armijas virspavēlniekam J. Balodim, un viņš ar sarūgtinājumu tās saturu atcerējās vēl pēc 40 gadiem. - Balodis J. Ģenerāḷa Jāṇa Baloža atmiņu burtnīcas//Neatkarīgā Rīta Avīze. - 1997. - 29. marts.

276 Butkus Z. Lietuvos ir Latvijos... - P. 43.

${ }^{277}$ LCVA, f. 929, ap. 1, b. 362, 1. 3-5.
} 
lielvalstu nostāja. Piemēram, vairāki ASV politiḳi lietuviešu pārstāvjiem 1919. gada novembrī lika noprast, ka Lietuvai cerības uz starptautisku atzīšanu "de iure" ir, bet Latvijai un Igaunijai nav (pirmkārt tāpēc, ka Krieviju interesē šo valstu ostas). ${ }^{279}$

Katrā zin̄ā Voldemara sarakste ar Z. Meierovicu noskaṇoja Latvijas ārlietu ministru vēl nelabvēlīgāk pret Lietuvu. Nedaudz vēlāk, 1920. gada februārī, viṇš pat publiski uzsvēra, ka nav saprotamas "leišu tieksmes pēc Daugavpils un vinuu domas, ka latgalieši arī valodas ziṇā stāvot leišiem tuvāk nekā mums". Ministrs šajā laikā atklāti secināja, ka tādēḷ Latvija parakstījusi militāras sadarbības līgumu ar valsti (Poliju), kura nav pretendējusi uz Latgali. $^{280}$ 1919. gada beigās Lietuvas prese par galveno nesaskaṇu cēloni ar Latviju uzskatīja tās labās attiecības ar Poliju. L,oti ticams, ka lietuvieši notiekošo nojauta, vai arī viņiem par kaut kādu vienošanos starp latviešiem un poliiem bija vismaz aizdomas. ${ }^{281}$ Saskaṇā ar Latvijas diplomātiskā pārstāvja Kauṇā vērtējumu, 1920. gada janvāra sākumā Lietuvas valdībā bijusi jūtama "zināma nervozitāte, kas izskaidrojama ar faktisko lietu stāvokḷa nezināšanu un galvenokārt ar nespēju pret mūsu [Latvijas - E. J. J.] kombinācijām ar poliem šādā vai tādā veidā reaǵēt”. ${ }^{282}$

Rīgā no 26. līdz 28. decembrim norisa sarunas starp J. Balodi, P. Radziṇu, K. Ulmani, Z. Meierovicu, no vienas puses, un A. Miškovski, no otras puses. Sarunās tika saskaṇotas topošā līguma detaḷas. 28. decembrī J. Balodis iesniedza A. Miškovskim oficiālu lūgumu Polijas armijas virspavēlniekam palīdzēt atbrīvot Latgali. Par to J. Pilsudskim tika telegrafēts 31. decembrī un vēlreiz 1920. gada 3. janvārī. Dokuments bija tapis pēc A. Miškovska prasības. Poḷu pusei tas bija nepieciešams, lai apliecinātu Antantes lielvalstīm, ka tās karaspēks uz Latvijas teritoriju devies palīgā latviešiem pēc viṇu pašu lūguma un dokumentam bija tīri formāls raksturs. ${ }^{283}$

1919. gada 30. decembrī284 J. Balodis un P. Radziṇš, no vienas puses, un A. Miškovskis, no otras puses, parakstīja abu valstu virspavēlniecību līgumu par kopīgu uzbrukumu Sarkanajai armijai Latgalē un Latgales atbrīvošanu. Operācijas sākums tika noteikts uz 1920. gada 3. janvāri. Mērḳis bija Krāslavas-Dubnas upes līnijas ien,emšana un abu armiju savienošanās. Līgums vēl paredzēja šādus nosacījums: Latvijas puse izdala operācijai 10000 durkḷu, Polijas puse - 30000 durkḷu poḷu ǵenerāḷa E. Ridza-Smiglija vadībā (turklāt P. Radziṇš apsolīja "savā darbībā vadìties pēc poḷu virspavēlniecības

\footnotetext{
278 Skirius J. Prof. Augustinas Voldemaras ir tarptautinis Lietuvos valstybingumo įteisinimo procesas// Lietuvos užsienio reikalų ministrai 1918-1940. - Kaunas, 1999. - 32 p.

${ }^{279}$ Laurinavičius Č. Lietuvos - Sovietu Rusijos taikos sutartis. - Vilnius, 1992. - P. 33, 51. Č. Laurinavičs atzīst, ka 30. decembra A. Voldemara vēstulē bijusi ietverta "aroganta" prasība pēc Daugavpils. Turpat, 53. 1pp.

${ }^{280}$ Latvijas Sargs. - 1920. - 4. febr.

${ }^{281}$ Lietuva. - 1919. - 23 grūodis.

${ }^{282}$ LVVA, 2575. f., 11. apr., 8. 1., 9. 1p. (diplomātiskā pārstāvja V. Bandreviča ziņojums no Kauņas).

283 CAW, II Oddział Naczelnego Dowództwa Wojska Polskiego (turpmāk: II ND WP), t. 24.; WBH, 341. 1. 157.

${ }^{284}$ Daži līguma eksemplāri (CAW, II ND WP, t. 24) parakstīti 28. decembrī, taču patiesībā tas ir tikai dokumenta tapšanas laiks.
} 
norādījumiem"); pie apvienotās grupas štāba būs piekomandēts latviešu virsnieks; Latvijas pusei jāapgādā poḷu karaspēks ar pārtiku (pēc Francijas armijas karavīru apgādē pieṇemtajām normām ${ }^{285}$ ); vietējās administrācijas organizēšanai pie grupas štāba jāpiekomandē pilnvarotais civillietās; poḷi būvē dzelzceḷa tiltu pāri Daugavai, un tas kopā ar posmu līdz Daugavpils stacijai paliek viṇu rīcībā; iegūtie ieroči un munīcija jānodod Latvijas pusei, bet dzelzceḷa ritošais sastāvs jādala uz pusēm (turklāt mutiski vienojās dalīt uz pusēm arī ienaidniekam atñemtos medikamentus $-\bar{E}$. J.); Polijas armija paliek Daugavas labajā krastā (Latgalē) tik ilgi, kamēr Latvijas armija ieņems visu fronti; pēc tam labajā krastā paliek tikai poḷu karaspēka nodaḷa tilta un dzelzcel̦a līnijas apsardzībai līdz Daugavpils stacijai (to neiekḷaujot); vienošanās ir spēkā līdz jauna līguma noslēgšanai. Turklāt puses vienojās nepiel̦aut lietuviešu pārcelšanos uz Daugavas labo krastu, Latvijas armijas daḷām ātri virzoties gar upi uz Daugavpili un nepieciešamības gadījumā izmantojot pat artilērijas sprostuguni. ${ }^{286}$

A. Miškovskis ar panākto vienošanos bija apmierināts. 31. decembrī viṇš ziṇoja uz Varšavu, ka dzelzceḷu etapu vadības jautājumā viņam izdevies panākt vairāk, nekā plānots, bet apgādes jautājumā viṇš darījis visu iespējamo. Turklāt līgumā neesot minēts, ka Latvijas pusei būtu jāatdod zirgi un apgēerbs, kas atñemti Sarkanajai armijai, tātad tos var paturēt Polijas karaspēks. ${ }^{287}$ Tās bija detaḷas, jo, neapšaubāmi, galvenais abām pusēm bija pati militārā sadarbība un Latgales atbrīvošana.

$* * *$

1919. gadā skaidri iezīmējās apstākḷi, kuri gada beigās noveda pie zināmā mērā īpatnēja, militāra līguma starp Latviju un Poliju. Sis līgums bija noslēgts tikai uz Latgales atbrīvošanas operācijas laiku. Abas puses, kuras atradās atšḳirīgā situācijā un kurām bija atšķirīgi ārpolitiskie mērķi, uzskatīja, ka nepieciešams sadarboties vienai ar otru. Sevišk,i aktuāli tas kḷuva Bermonta karaspēka akcijas laikā, jo šī armija reprezentēja abu pušu divu galveno ienaidnieku - Krievijas un Vācijas - politiskos mērķus.

Līdz 1919. gada vasarai Polijas puse pret Latviju izturējās piesardzīgi, un tas bija izskaidrojams, pirmkārt, ar nedrošo Latvijas iekšpolitisko stāvokli lielinieku un vācu okupāciju, kā arī reāli pastāvošo divvaldību (K. Ulmaṇa un provāciskās A. Niedras valdības vienlaicīgo darbību). Šajā laikā arī K. Ulmaṇa Pagaidu valdībai bija aktuālākas problēmas par sakaru nodibināšanu ar Poliju (pirmkārt, šīs problēmas bija saistītas ar valsts izdzīvošanu). Polija pagaidām kopējās robežas trūkuma dēḷ tika vērtēta vienīgi kā potenciāls sabiedrotais nākotnē. Galvenā cerība pagaidām saistījās ar sadarbību politiskā jomā, jo vajadzēja noskaidrot, vai var cerēt uz Polijas atbalstu Latvijas neatkarības starptautiskas atzīšanas panākšanā. Turklāt no paša sākuma Latvijas valdības attieksmē iezīmējās divas skaidri saskatāmas

\footnotetext{
${ }^{285}$ Balodis J. Ģenerāḷa Jāṇa Baloža atmiṇu burtnīcas//Neatkarīgā Rīta Avīze. - 1997. - 22. marts.

286 Документы и материалы... - 444-445, 465-466 стр.

${ }^{287}$ CAW, WBH, 341. 1. 157.
} 
tendences. Pirmkārt, Latvijas puse apzinājās, ka Polijas intereses šajā laika posmā zināmā mērā sakrīt ar Latvijas interesēm un tā var sniegt Latvijai ievērojamu atbalstu, otrkārt - bija skaidri saskatāma piesardzība attiecībā uz Polijas patiesajiem nodomiem pret Latviju (arī attiecībā uz Latgales valstisko piederību).

Tikai pēc Igaunijas un Latvijas armijas panākumiem kaujās ar Baltijas vācu Landesvēru un Dzelzsdivīziju pie Cēsīm 1919. gada jūnijā un Strazdmuižas pamiera jūlija sākumā vara atbrīvotajā Latvijas teritorijā vismaz nomināli pilnībā pārgāja K. Ulmaṇa Pagaidu valdības rokās un sākās savstarpēja Latvijas un Polijas tuvināšanās, ko noteica zināmā mērā kopējās intereses un kopējie ienaidnieki. Šo procesu aktualizēja un paātrināja vācu karaspēka atrašanās Baltijas valstīs. Bermonta vadìtais reakcionārais vācu-krievu karaspēks uzbruka Latvijas galvaspilsētai 1919. gada oktobrī. Uzbrukumu izdevās apturēt latviešu tautas pašaizliedzības, karavīru varonības un skaitliski ievērojami lielāko Bermonta spēku neorganizētības un talantīgas vadības trūkuma dēḷ. Tieši šìs akcijas laikā 1919. gada rudenī notika noteikta Latvijas un Polijas savstarpēja tuvināšanās. To izraisīja, pirmkārt, Latvijas vēlme saṇemt Polijas atbalstu cīnā pret Bermontu un Polijas cerība piesaistīt sev Latviju politiski un militāri un tādējādi iespaidot Lietuvu un tuvināt J. Pilsudska nometnes „federatīvās koncepcijas” īstenošanu reǵionā, vienlaikus neitralizējot arī abu Polijas ienaidnieku - Padomju Krievijas un Vācijas mēǵinājumu rast savstarpēju kontaktu Baltijā. Nozìme bija arī operatīva rakstura apsvērumiem: Bermonta uzvaras gadījumā ievērojami pagarinātos Polijas varbūtējā fronte pret Vāciju un pat rastos iespēja savienoties vācu un padomju (vai krievu monarhistu) spēkiem, kas vērsti pret Poliju. 1919. gada rudenī Latvijas un Polijas attiecības bija vienas no labākajām to vēsturē. Tas lielā mērā izskaidrojams ar simpātijām, ko Polijā izraisīja latviešu tautas varonīgā cīṇa pret Bermonta karaspēku, un Latvijas nopietnām teritoriālajām un citām nesaskaṇām ar Lietuvu. Śo nesaskaṇu dēl, Latvijai un Lietuvai nebija iespējams vienoties. Vēl nebija aktualizējušās arī problēmas (muižnieku zemes īpašumu piederības jautājums Latgalē, nesaskaṇas Latvijas poḷu minoritātes jautājumā, teritoriālās domstarpības), kas vēlāk radīja sarežǵịijumus abu valstu attiecībās. Polija bija ar mieru noslēgt militāru savienību ar Latviju (galvenais priekšnoteikums no latviešu puses bija Polijas izteiktais atzinums, ka Latgale pieder Latvijai, un tas tika izpildīts). Latvija vēlējās atbrīvot Latgali un nepiel̦aut tās nonākšanu Polijas vai pat Lietuvas kontrolē, ko nevarētu ietekmēt. Šādos apstākḷos tika noslēgts slepenais militārās sadarbības līgums. Tas ievadīja Latvijas atbrīvošanās kara pēdējo cēlienu un pavēra jaunu, sarežǵgitu lappusi attiecībās ar kaimiṇvalstīm. 


\section{2. nodallă
LATGALES ATBRİVÓsANAS LAIKS (1920. gada janvāris-marts)}

\section{Militārās operācijas norise}

1919. gada decembra otrajā pusē Polijas valdībai un armijas virspavēlniecībai jau bija skaidrs, ka gaidāma militāra sadarbība ar Latvijas armiju Latgalē. 22. decembrī ǵenerālis E. Ridzs-Smiglijs poḷu karaspēka daḷām, kas viṇam bija pakḷautas, deva pavēli sagatavoties operācijai. Saskaṇā ar pavēli trieciengrupai (komandieris pulkvedis J. Ol̦šina-Viḷčin,skis) - 1. un 5. Leǵionu kājnieku pulkam (kuri kopā veidoja 1. Leǵionu kājnieku brigādi), četrām 1. Leǵionu lauka artilērijas un divām 3. smagās artilērijas pulka baterijām, ${ }^{288}$ kā arī 1. sapieru bataljona rotai - bija jāpāriet Daugava, jāien,em Daugavpils un jāuzbrūk Višķu virzienā; labā spārna grupai (ğenerālis L. Berbeckis) - 3. Leǵionu divīzijas 7., 8., 9. kājnieku pulkam, 3. artilērijas brigādei (3. Leǵionu lauka artilērijas pulkam un 2. smagās artilērijas pulka divizionam ${ }^{289}$ ) un 1. jātnieku strēlnieku pulka eskadronam ${ }^{290}$ - jāuzbrūk Krāslavas rajonā; Turmantas grupai (pulkvedis S. Borovskis) - 23. kājnieku pulka diviem bataljoniem, ${ }^{291}$ trijām 6 . un trijām 1. smagās artilērijas pulka baterijām, prožektoru vadam, 3. Leǵionu divīijas aizmugures iestādēm un grupas komandiera vārdā nosauktajam bruṇuvilcienam "Śmigły" -jānodrošina trieciengrupas kreisais spārns pret varbūtējām Lietuvas armijas akcijām un jāieṇem pozīcijas Daugavas kreisajā krastā (lietuviešu pāriešanu pāri upei uzskatīja par politiski nepiel̦aujamu). ${ }^{292}$ Rezervei (majors B. Popovičs) 6. Leǵionu kājnieku pulkam un 1. lauka artilērijas pulka trijām baterijām jāatrodas Turmantas-Fabianovas-Jānuciema (Janovkas) rajonā. Poḷu kaujas vadības punktam jāizvietojas Dukštā, bet E. Ridza-Smiglija komandpunktam Kalkūnē. Turklāt trieciengrupā vēl ietilpa: 1. aviācijas eskadriḷa Svenčonē, divas tilta, divas inženieru, divas dzelzceḷa rotas, 1. Leǵionu divīzijas telegrāfa

\footnotetext{
${ }^{288}$ Lewicki R. Zarys historji... - S. 29; Zaufał W. Zarys historji... - S. 13.

${ }^{289}$ Myrek K. Zarys historji wojennej 3-go pułku artylerii polowej Legjonów. - Warszawa, 1928. S. 7-8; Gintel J. Zarys historji wojennej 2-go pułku artylerii cięźkiej. - Warszawa, 1929. - S. 13-14.

${ }^{290}$ Reāli divi šī pulka eskadroni atbalstīja Ridza-Smiglija grupu, uzbrūkot Drisas rajonā. - Mularczyk J. Zarys historji wojennej 1-go pułku strzelców konnych. - Warszawa, 1931. - S. 6.

${ }^{291}$ Polijas armijas 23. kājnieku pulks ietilpa 3. Leǵionu divīzijā. Tā 3. bataljons Latvijā ieradās tikai 1920. gada martā. - Witkowski S. Zarys historji... - S. 14.

292 Jau 12. decembrī poḷu daḷām bija dots rīkojums lietuviešu pārcelšanās gadījumā uz Daugavas labo krastu atsviest tos atpakal̦. Vēlāk tika pavēlēts demonstratīvi koncentrēt spēkus, lai lietuvieši justos apdraudēti un tiem nerastos doma pāriet Daugavu, bet 16. decembrī - lietuviešu uzbrukuma gadījumā ar artilēriju apšaudīt upi. - CAW, WBH, 341. 1. 155, 157.
} 
rota, radiostacija, etapu rota, trīs lauka hospitāli, sanitārā priekšgrupa un vilciens, divas autokolonnas, kā arī abu divīziju munīcijas un pārtikas priekšgrupas. Savukārt Latvijas armijas 3. Jelgavas kājnieku pulkam (pulkvedis J. Dombrovskis), kas ietilpa trieciengrupā, uzbrukuma (tā dēvētajā "Y") dienā bija jāpāriet Daugava un ar diviem bataljoniem jāuzbrūk gar Dubnas upi līdz Bramaṇiem, bet ar vienu bataljonu jādodas uz Daugavpili. 9. Rēzeknes pulkam (pulkvedis-leitnants L. Bolšteins) jāieņem Dubnas krasts no Mačinas līdz Lozdāniem. Vācu zemessargiem (britu pulkvedis-leitnants H. Aleksanders) jāieṇem Dubnas krasts Šḳilbēnu-Mutṇiku līnijā. Rezervei (kapteinis K. Zīverts) jāatrodas Jēkabpilī, bet diviem bruṇuvilcieniem Livānos. Turpat jābūt arī latviešu daḷu komandiera pulkveža-leitnanta J. Puriņa komandpunktam. ${ }^{293}$

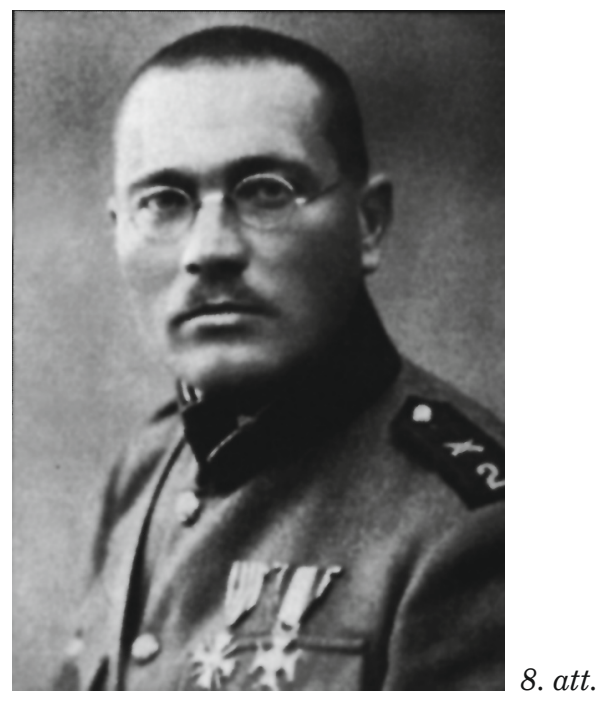

Poḷu štābam pakḷauto Latvijas armijas vienību komandieris Jānis Puriṇš

Gar Daugavu izvietotā poḷu 3. Leǵionu divīzija 1919. gada nogalē pēc Daugavas aizsalšanas regulāri veica nelielas "traucējošas" akcijas austrumos no pilsētas. Akciju mērķis bija nepiel̦aut Sarkanās armijas Daugavpils garnizona palielināšanos un bojāt vienu no diviem dzelzcel̦iem, pa kuriem pilsētai varēja piegādāt rezerves (līnijā Daugavpils-Polocka). Decembra beigās šĩ darbība tika vēl pastiprināta, lai radītu iespaidu, ka varētu sekot uzbrukums Krāslavas iecirknī. 21. decembrī 8. Leǵionu kājnieku pulka bataljons pārgāja Daugavu pie Kaplavas, bet 9. Leǵionu kājnieku pulka bataljons - pie Lupandas. Pēc dažām dienām 8. Leǵionu kājnieku pulka vienības, ciešot zaudējumus, uz laiku ieṇēma vairākas apdzīvotas vietas austrumos no Krāslavas, bet 9. Leǵionu kājnieku pulks - Piedruju un apkārtni. ${ }^{294}$ Kopumā 3. Leǵionu divīzija veica 10 reidus pāri Daugavai, bet Sarkanā armija 22. novembrī

\footnotetext{
${ }^{293}$ Borkiewicz A. Dzieje 1-go pułku... - S. 356-357; Dąb - Biernacki S. Grupy oporowe... - S. 231. ${ }^{294}$ CAW, WBH, 341. 1. 155, 150 (Hupert W.).
} 
mēǵināja uzbrukt Grīvai. ${ }^{295}$ Arī gar Daugavu izvietotās Lietuvas armijas daḷas veica samērā regulārus izlūkgājienus un iebrukumus Daugavas labajā krastā. ${ }^{296}$

Pirms Ziemassvētkiem aktivizējās abu pušu artilērijas darbība. Līdz 24. decembrim no poḷu karaspēka ieņemtā krasta uz Daugavpili bija izšauti apmēram 250 šāviṇi. ${ }^{297}$ 26. decembrī Sarkanās armijas artilērija spēcīgi apšaudīja rajonu pie Krāslavas un Grīvu, vēlāk - poḷu pozīcijas pie Lašiem. Saskaṇā ar liecībām, kuras poḷiem sniedza gūstekṇi, 28. decembra naktī lielinieki pat gatavojušies uzbrukt pie Daugavpils, taču tās izrādījās baumas. ${ }^{298}$ 29. decembrī padomju brunuvilciens, atbildot uz poḷu artilērijas uguni, kas tika raidīts pret cietoksni, izšāva uz Grīvu ap 400 šāviṇu, aizdedzinot vairākas ēkas. $^{299}$

Visu decembri poḷu štābs apstrādāja ziṇas par operācijas rajonu (arī izlūkoja no gaisa), un 22. decembra pavēlē grupai tika īsi raksturota Daugavpils un citas Dienvidlatgales apdzīvotās vietas. Līdz 31. decembrim poḷu daḷas akcijai bija gatavas (1. Leğionu divīzija bija nomainījusi 7. Leǵionu kājnieku pulku Lašu-Geitvinišķu iecirknī). ${ }^{300}$

Savukārt Latvijas armijas virspavēlniecība 27. decembrī deva pavēli Latgales divīzijai izbraukt uz Latgales fronti, bet 28. decembrī - mutiskus norādījumus 9. Rēzeknes pulkam nākamajā dienā no Rīgas cauri Krustpilij doties uz 3. Jelgavas kājnieku pulka rajonu frontē (sadarbībai ar poliem A. Miškovskis bija pieprasījis pastiprināt Latvijas armijas labo spārnu ar vienu kājnieku pulku). 29. decembrī poḷiem pakḷautās Kurzemes divīzijas daḷu komandiera vietas izpildītājs J. Puriņš saṇēma pavēli par kopīgu uzbrukumu Daugavpilij naktī uz 3. janvāri. Savukārt 31. decembrī Latvijas armijas virspavēlnieks J. Balodis izdeva pavēli - sadarbībā ar Polijas armiju sākt Latgales atbrīvošanas operāciju. Karaspēka labā spārna grupai 3. Jelgavas pulkam (trīs bataljoniem, baterijai ar četriem lielgabaliem, jātnieku eskadronam), 9. Rēzeknes pulkam (trīs bataljoniem, desmit lielgabaliem, trīs eskadroniem) - J. Puriṇa vadībā bija jāpāriet Daugava un jāuzbrūk uz ziemel̦austrumiem no Daugavpils, kamēr poḷi uzbruks pilsētai tieši (29. decembra pavēlē Kurzemes divīzijai bija teikts, ka poḷi pāries Daugavu pie Drisas (lai pārrautu dzelzceḷa satiksmi ar Daugavpili), Rozališķu rajonā

${ }^{295}$ Encyklopedja Wojskowa. - T. 2. - Warszawa, 1932. - S. 481; Lukomski G., Polak B. W obronie Wilna, Grodna i Mińska... - S. 180-182; Łukomski G., Polak B., Wrzosek M. Wojna Polsko - Bolszewicka 1919-1920. - T. I. - Koszalin, 1990. - S. 147-150.

${ }^{296}$ Lietuva. - 1919. - 3 lāpkr., 30 grūod.

297 Brīvā Zeme. - 1919. - 25. dec.

${ }^{298}$ CAW, WBH, 341. 1. 153.

${ }^{299}$ Herzog S. Historja wojenna... - S. 16.

${ }^{300}$ CAW, WBH, 341. 1. 155, 156, 150. Neilgi pirms uzbrukuma sākuma 5. Leǵionu pulka izlūku vienībai naktī izdevās nemanītai pāriet Daugavu, ieiet pilsētā un ieņemt cietokšña komandantūru. Apšaude izcēlās tikai, patruḷai kopā ar sagūstīto komandantu atgriežoties Daugavas kreisajā krastā. - Wojskowy Instytut Historyczny (tālāk: WIH), Styliński J. Wspomnienia źołnierza 5 pp Legionów 1915-1929. I/2/37, s. 58. 
(lai dotos uz Višķiem) un pie Daugavpils, apejot to no ziemel̦iem). ${ }^{301}$ Pēc sakaru nodibināšanas ar poḷiem J. Puriṇa grupai jāpāriet Ridza-Smiglija pakḷautībā. Par apvienotās poḷu-latviešu karaspēka grupas otro štāba priekšnieku tika iecelts Latvijas armijas Virspavēlnieka štāba Operatīvās daḷas nodaḷas priekšnieks pulkvedis-leitnants A. Veiss. ${ }^{302}$ Latvijas armijas kreisā spārna grupai (Latgales divīzijai K. Berķa vadībā), kura uzbrukumam vēl nebija gatava, vajadzēja aktivizēt izlūkdarbību. Šì nesagatavotība tika apspriesta ar A. Miškovski Rīgā pirms līguma noslēgšanas, un viṇš piekrita, ka Latvijas armijas kreisais spārns sāks uzbrukumu vēlāk. ${ }^{303}$

P. Radziṇa izstrādātais un ar poḷiem saskaņotais Latvijas armijas uzbrukuma plāns paredzēja atbrīvot visu „latviešu apdzīvoto teritoriju” (operatīvu apsvērumu dēl pat nedaudz vairāk). Dodot pirmo triecienu dienvidos, kopā ar poḷiem bija jāien,em Osvejas ezera-Zilupes līnija. ${ }^{304} 1919$. gada 30. decembra naktī poḷu grupas štābā Svenčonē ieradās A. Veiss kopā ar 1. Leǵionu divīzijas štāba kapteini V. Bortnovski, kurš bija nosūtīts uz Rīgu pie Latvijas armijas virspavēlniecības (V. Bortnovskim radās iespaids, ka A. Veiss ir "uzticams cilvēks ar plašām pilnvarām”). 31. decembrī E. Ridzs-Smiglijs ar viṇu vēlreiz konkretizēja abu armiju sadarbības, apgādes, satiksmes un apgabala civilpārvaldes organizācijas jautājumus. Pēc tam Latvijas armijas virspavēlniecībai un A. Miškovskim Rīgā tika paziņots, ka uzbrukums sāksies 3. janvārī plkst. 6.30. Tajā pašā dienā uz Kurzemes divīzijas un 3. Jelgavas pulka štābu tika nosūtīti poḷu sakaru virsnieki. Vienlaikus decembra beigās uz poḷu štābu (acīmredzot sakaru tehniskai nodibināšanai) tika komandēts operācijā iesaistītās Kurzemes divīzijas štāba sakaru nodaḷas virsseržants A. Ronis, kurš savā vienībā atgriezās 2. janvārī. ${ }^{305}$ Savukārt J. Puriṇa pavēli ar tiešajiem uzdevumiem un akcijas laiku operācijā iesaistītās latviešu daḷas saṇēma tikai 1. janvārī. ${ }^{306}$

Latgalē izvērstajā Padomju Krievijas 15. armijā 1919. gada 25. decembrī skaitījās 26000 durkḷ, 600 zobenu un 180 lielgabalu. Tās komandieris bija bijušais Krievijas armijas apakšpulkvedis igaunis A. Korks, štāba priekšnieks - bijušais štābkapteinis igaunis A. Kuks, bet komisārs - latvietis K. Ozols. Pretī latviešu daḷām 1. janvārī stāvēja 6620 kājnieku un 370 jātnieku ar 60 lielgabaliem, 243 automātiskajiem ieročiem un četriem bruṇuvilcieniem (3. atsevišḳā Petrogradas brigāde, 3. divīzijas 2. brigāde, 4. divīzijas 2. brigāde, jātnieku divizions). Latvijas armijas daḷās Latgales frontē bija 640 virsnieku, 14150 kājnieku, 470 jātnieku ar 330 ložmetējiem, 79 patšautenēm, 32 lielgabaliem un 19 mīnmetējiem. ${ }^{307}$

Pret poḷiem Latgalē stāvēja 7700 kājnieku ar 112 ložmetējiem, 31 lielgabalu un diviem bruṇuvilcieniem (4. divīzijas 1. un 3. brigāde, 53. divīzija

\footnotetext{
${ }^{301}$ LVVA, 6033. f., 1. apr., 68. 1., 2. 1p.

302 Turpat, 5601. f., 1. apr., 6876. 1., 2. 1p. (A. Veisa personīgā lieta.)

${ }^{303}$ Turpat, 3601. f., 1. apr., 471.1., 39. lp. A. Miškovskis 1. janvārī ziṇoja, ka uzbrukuma dienā Dienvidlatgalē latviešiem notiks "liela demonstrācija" arī Pitalovas virzienā. - CAW, WBH,341. 1. 157.

304 Apsītis A. Latgales atbrīvošana. - 259., 262. lpp.

${ }^{305}$ CAW, WBH, 341. 1. 151, 156, 157; LVVA, 1515. f., 1. apr., 26. 1., 1. 1p.

306 Radziņš P. Latvijas atbrīvošanas karš. - 45. lpp.

${ }^{307}$ Bērzinš̌ V., Bambals A. Latvijas armija. - Rīga, 1991. - 32. lpp.
} 
rezervē pie Višķiem un Daugavpils garnizons). Abu poḷu divīziju kaujas ierindā bija 340 virsnieku, 31260 kājnieku, 250 ložmetēju un 72 lielgabalu (no tiem 28 smagie), ${ }^{308}$ bet vispār 1 . Leǵionu divīzijā uzturā skaitījās 650 virsnieku, 18000 karavīru ar 5000 zirgiem, bet 3. Leǵionu divīzijā - 330 virsnieku un 13000 karavīru ar 3200 zirgiem. ${ }^{309}$

1920. gada 1. janvārī Latvijas armijas daḷas Dienvidlatgalē ieṇēma pozīcijas no Kazimires līdz Dubnas ietekai Daugavā pie Dignājas (3. Jelgavas pulka 1800 vīri) un tālāk uz ziemel̦iem līdz Atašienas dzelzceḷa stacijai (2 100 vācu zemessargu). 1. janvārī frontē ieradās arī 9. Rēzeknes pulks (1 800 vīru), kas nomainīja 3. Jelgavas pulka vienības Nīcgales-Dunavas iecirknī, atstājot šim pulkam iecirkni Kazimire-Jadvigova. Pretī šìm daḷām stāvēja 3 kājnieku pulki, 2. jātnieku eskadrons un 30. komunistu rota - bez rezervēm 2000 vīru ar 24 lielgabaliem. ${ }^{310}$ Polijas armija ieņēma fronti gar Daugavu no Polockas līdz Daugavpilij. No Daugavpils-Viḷnas dzelzceḷa līdz Lašiem - Turmantas grupa, no Lašiem līdz Geitvinišķiem - trieciengrupa (tās 1. pulkā 1. janvārī bija 50 virsnieku un 2798 karavīru, bet 5. pulkā - 2518 cilvēku ${ }^{311}$ ), tālāk - labā spārna grupa (7. pulks no Geitvinišķiem līdz Kaplavai, 8. pulks - no Kaplavas līdz Indricas upei, 9. pulks - no Indricas līdz Vjatas ietekai Daugavā). Rezerve (6. pulkā 4. janvārī bija 58 virsnieki un 2612 karavīri) atradās Turmantā un Jāṇuciemā. ${ }^{312}$ Starp latviešu un poḷu spēkiem gar Daugavu (no Kazimires līdz Grīvai) apmēram 20 kilometru garu fronti ieṇēma Lietuvas armija (šajā laikā Ilūkstes aprinḳī atradās: Lietuvas armijas 3. kājnieku pulka devinas rotas Eglainē, 8. kājnieku pulka septiṇas rotas - Turmantas rajonā, 9. kājnieku pulka sešas rotas - pretī Daugavpilij, Baltkrievu bataljona divas rotas - pie Kalkūnes, dzelzceḷu rota un neliela sapieru nodaḷ - pie Lilienfeldes pretī Daugavpilij). ${ }^{313}$

Kaut arī Latvijas pusei uzbrukumā Dienvidlatgalē bija jāiesaista 10000 durkḷu, tomēr reāli operācijas sākumā J. Puriṇa grupā bija 5800 karavīru ar 240 ložmetējiem, 17 lielgabaliem un brunuuvilcienu. Tas izskaidrojams ar faktu, ka Zemgales divīziju Kurzemē vēl tikai formēja, un ar to, ka sarunās ar A. Miškovski, sagatavojot sadarbības līgumu, tika minēts lielāks karaspēka skaitliskais sastāvs par faktisko - P. Radziṇa vārdiem runājot, lai "radītu poḷos cienību pret sevi" un nodrošinātos pret varbūtēju informācijas noplūdi. ${ }^{314}$

1. janvārī E. Ridza-Smiglija štābs no Svenčones ieradās Dūkštā, kur apspriedās ar 3. Leǵionu divīzijas vadību, precizējot tās kaujas uzdevumu. ${ }^{315}$ Naktī uz 2. janvāri Ridza-Smiglija vilciens cauri Turmantai, kur palika telegrāfa rota, ieradās Lisičku ciema rajonā (sešus kilometrus no Daugavas, pie Kalkūnes). 2. janvārī notika vēl viena apspriede ar 3. Leǵionu divīzijas komandieri L. Berbecki (viṇa štābs atradās Červonkā pie Skrudalienas),

\footnotetext{
${ }^{308}$ Encyklopedja Wojskowa. - T. 2. - S. 410.

309 CAW, WBH, 341. 1. 151.

${ }^{310}$ Radziņš P. Latvijas atbrīvošanas karš. - 44. lpp.; Latvijas armija 20 gados. - 221. 1pp.

311 Borkiewicz A. Dzieje 1-go pułku... - S. 360; Dąb - Biernacki S. Grupy oporowe... - S. 243.

312 Encyklopedja Wojskowa. - T. 2. - S. 410, 481; CAW, WBH, 341. 1. 154.

313 LVVA, 6033. f., 1. apr., 25. 1., 7. 1p.

314 Radziņš P. Latvijas atbrīvošanas karš. -23 . lpp.

315 CAW, WBH, 341. 1. 151, 150.
} 
1. Leǵionu brigādes (trieciengrupas) komandieri J. Ol̦šinu-Viḷčiṇski un 1. artilērijas brigādes komandieri J. Rummelu. Trieciengrupas rīcībā tika nodots jātnieku strēlnieku vads. ${ }^{316}$ 3. janvārī plkst. 6.00 Ridzs-Smiglijs, bet dažas stundas vēlāk - visas Lietuvas-Baltkrievijas frontes virspavēlnieks S. Šeptickis ieradās Kalkūnes pilī (uzkalnā trīs kilometrus no Daugavpils), lai no turienes vērotu operācijas gaitu. ${ }^{317}$

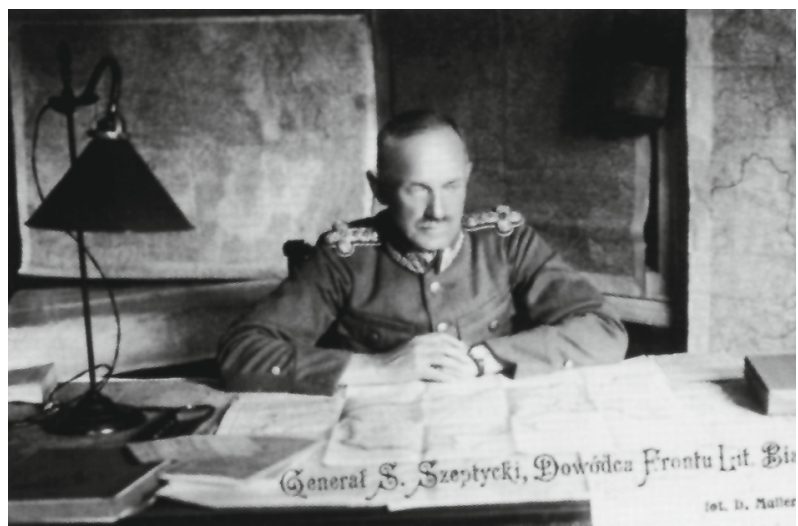

9. att.

\section{Lietuvas-Baltkrievijas frontes virspavēlnieks Staṇislavs Šeptickis}

1920. gada ziemā klimatiskie apstākḷi ofensīvas sākumam bija labvēlīgi, jo sals sasniedza 25-30 grādus un Daugavas biezais ledus l̦āva šḳērsot upi arī smagajai artilērijai. Tomēr vēlāk dziḷais sniegs nopietni apgrūtināja karaspēka pārvietošanos. Sākoties uzbrukumam, sals bija nedaudz mazinājies, taču vēlāk atkal pieṇēmās. ${ }^{318}$

Uzbrukums sākās 3. janvārī. Pēc iepriekšejāa dienā veiktās izlūkošanas latviešu daḷas plkst. 6.30 sāka pāriet Daugavu. 3. Jelgavas pulks upi škēēsoja pie Glaudāniem. ${ }^{319}$ Tā 2. bataljons, kurš bija pastiprināts ar Ilūkstes apriṇķa komandantūras komandu, pēc īsas kaujas gar Daugavu devās uz Daugavpili, lai nepiel̦autu lietuviešu pārcelšanos un savienošanos ar poḷiem. No Kazimires lietuvieši bija atklājuši uguni pret latviešiem, kuri atradās otrajā krastā un kurus lietuvieši acīmredzot nebija atpazinuši. Līksnas dzelzceḷa stacijā dažas bataljona rotas izcīnija kauju ar padomju bruṇuvilcienu (tas gan sastāvēja tikai no lokomotīves un atklātas metāla og̣̣u platformas, kurai sānos bija

316 3. janvārī grupā ieradās 2. jātnieku strēlnieku pulka 3. eskadrons, kas 5. janvārī frontē nomainīja 1. jātnieku strēlnieka pulka ziņnešus, kuri atgriezās Daugavpilī. 1. februārī eskadrons atgriezās Vilınā. - CAW, WBH, 341. 1. 155.

317 CAW, WBH, 341. 1. 341; II ND WP, t. 114. Operācijas sagatavošanas darbu veica Ridza-Smiglija grupas štābs, frontes štābs deva vienīgi vispārīgus norādījumus.

318 Smigły - Rydz E. Teicams karavīrs. - 68. lpp.; Nasz Głos. - 1933. - 1 stycz.; Dzwon. - 1930. 6 stycz.

319 Sīkāk sk.: Jēkabsons Ē. Latvijas un Polijas bruṇoto spēku kaujas ar Sarkano armiju Dienvidlatgalē 1920. gadā//Militārais Apskats. - 1994. - Nr. 1. - 59.-75. lpp.; LVVA, 1515. f., 1. apr., 693. 1., 7.-25. lp. (Kurzemes divīzijas kaujas apraksts par laiku no 1920. gada 1. janvāra līdz 29. februārim). 
šaujamlūkas $\left.{ }^{320}\right)$. Bruṇuvilcienu tās sagūstīja, stacijā dabūjot arī citas trofejas un sañemot 20 gūstekṇus. ${ }^{321}$ Vilcienā sakāpa 8 . rota un piespieda notverto mašīnistu un kurinātāju braukt uz Daugavpili. Apmēram trīs kilometrus no pilsētas 8. rota plkst. 14.00 vilcienā sastapās ar poḷu karavīriem. Pārējās bataljona rotas sasniedza Daugavpils Veco priekšpilsētu plkst. 16.00 un drīz pēc tam Poguḷankā arī sastapās ar poḷiem. No 4. janvāra šis 3. Jelgavas kājnieku pulka bataljons veidoja Daugavpils latviešu garnizonu, reprezentējot Latvijas valsts militāro varu. Tam neapšaubāmi bija arī politiska nozīme. ${ }^{322}$ Nevar piekrist poḷu mūsdienu historiogrāfijā izplatītajam viedoklim: Latvijas puses neuzticēšanās poḷiem bijusi tik liela, ka bataljons steidzīgi nosūtīts uz Daugavpili, kaut arī frontē trūcis karaspēka. ${ }^{323}$ 1920. gada 3. janvārī tas notika pilnīgā saskaṇā ar grupas virspavēlnieka E. Ridza-Smiglija pavēlēm, ${ }^{324}$ tātad bija iepriekš saskaņots, iespējams, pēc Latvijas puses prasības. Uzdevumu līdz vakaram izpildīja arī pārējās latviešu karaspēka daḷas. 9. Rēzeknes kājnieku pulks izcīnīja kauju pie Nīcgales stacijas un padzina no tās bruṇuvilcienu, ko vēlāk Līksnā sagūstīja 3. pulka vienības. ${ }^{325}$

Tomēr pirmās dienas neapšaubāmi svarīgākais uzdevums bija Daugavpils pilsētas un cietokšņa ieņemšana. 19. gadsimta 30. gados būvēto cietoksni ar vaḷniem un četriem samērā vājiem fortiem, kā arī pašu pilsētu aizstāvēja Sarkanās armijas 4. divīzijas 2. brigāde, 30. pulks, 62. dzelzceḷa apsardzības bataljons un 53. divīzijas 474. pulks, kurš 3. janvāra rītā iebrauca no Igaunijas frontes ${ }^{326}$ (šajā dienā tur stājās spēkā pamiers). E. Andersons uzskata, ka Daugavpils garnizona skaitliskais sastāvs bijis 6 000-8 000 vīru un 50 lielgabalu, ${ }^{327} \mathrm{kas}$, šḳiet, ir zināms pārspīlējums. Poḷu avoti liecina, ka 4. divīzijas brigādēs un pilsētas garnizonā pirms 474. pulka ierašanās ierindā nebija vairāk par 2500 durkḷiem un 20 lielgabaliem. Turklāt tikai viena brigāde atradās Daugavpilī un tās apkārtnē, bet otra ienēma iecirkni pie Daugavas no Kaplavas līdz Čurilovai. ${ }^{328}$ Savukārt S. Dombs-Bernackis, pamatojoties uz gūstā kritušo 28., 29., 30., 33., 471., 474. pulka, 52. dzelzceḷa bataljona un sardžu bataljona karavīru liecībām, rēḳināja, ka Daugavpils garnizonā ir ap 4000 kājnieku. ${ }^{329}$

\footnotetext{
${ }^{320}$ Lavenieks J. Bruṇoto vilcienu pulks. - Izd. V. Laveniece, 1971. - 50. 1pp.

${ }^{321}$ LVVA, 6033. f., 1. apr., 188. 1., 19.-20. 1p.; 192. 1., 2. 1p.; Latgales Vēstnesis. - 1939. - 2. janv.

${ }^{322}$ Latvijas armija 20 gados. - 222. lpp. 20. februārī 3. Jelgavas pulka 2. bataljonu Daugavpilī nomainīja 3. bataljons, ko savukārt 19. aprīlī nomainīja 1. bataljons. Turklāt Daugavpilī 12. janvārī ieradās un palika 1. Daugavpils garnizona rota, kas bija saformēta no Kurzemes divīzijas papildu bataljona karavīriem un ko vadīja virsleitnants A. Turks. - LVVA, 6033. f., 1. apr., 192. 1., 6., 16. 1p.; 5601. f., 1. apr., 6622. 1., 2. 1p.

323 Łossowski P. Łotwa... - S. 12.

${ }^{324}$ LVVA, 3601. f., 1. apr., 471. 1., 5. 1p.

${ }^{325}$ Latvijas armija 20 gados. - 221.-222. 1pp.

${ }^{326}$ LVVA, 1515. f., 1. apr., 694. 1., 5. 1p.

327 Andersons E. Sacensība par Daugavpili. - 50. lpp.

${ }^{328}$ CAW, WBH, 341. 1. 151; Encyklopedja Wojskowa. - T. 2. - S. 410

${ }^{329}$ Dąb - Biernacki S. Grupy oporowe... - S. 243.
} 


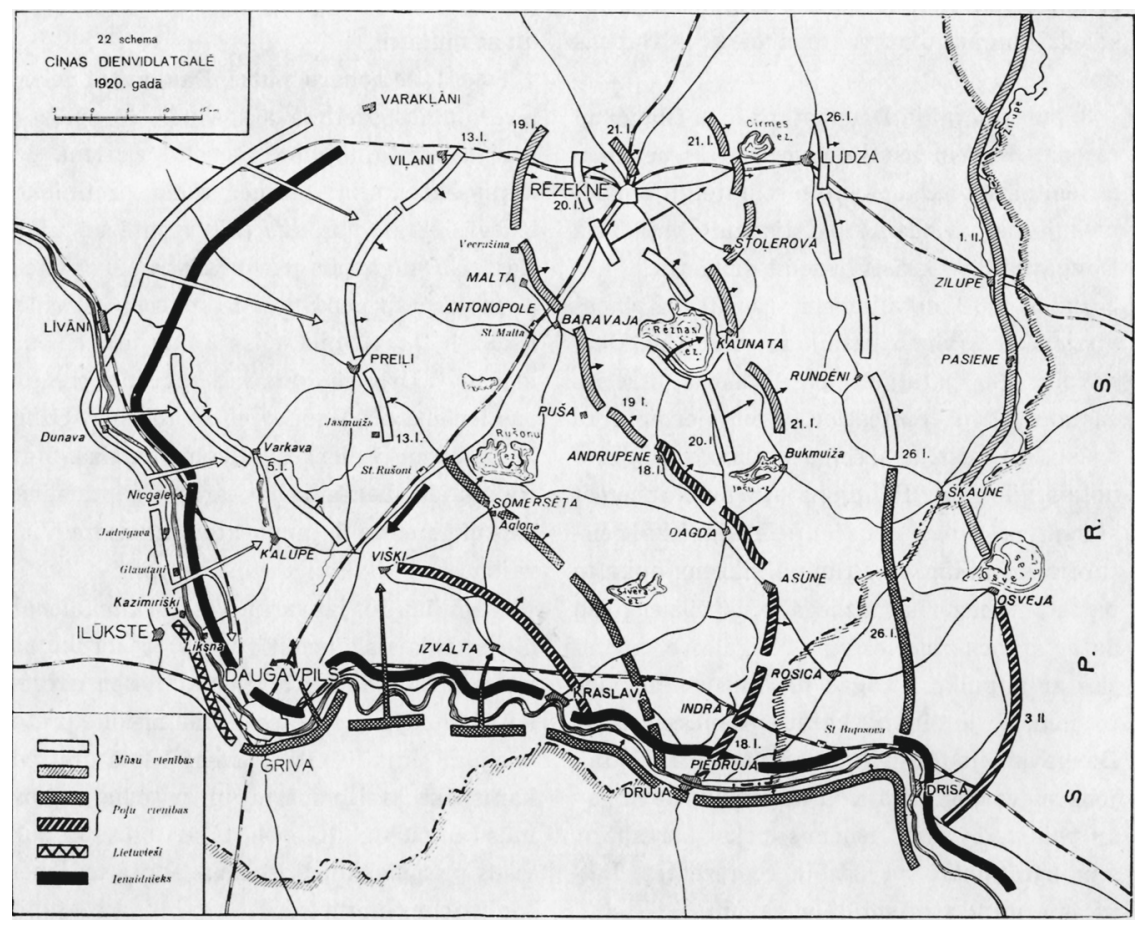

1. karte. Dienvidlatgales atbrīvošanas operācija 1920. gada janvārī

Vairākas dienas pirms uzbrukuma poḷu artilērija no Grīvas sāka intensīvi apšaudìt cietoksni, tilta nocietinājumu, armijas noliktavu un dzelzceḷa staciju, radot iespaidu, ka iespējamais uzbrukums no Grīvas un Kalkūnes būs vērsts pret pilsētas centru un cietoksni. Padomju artilērija atbildēja, šaujot no Stropu ezera rajona. ${ }^{330}$

Taču poḷu trieciengrupas uzdevums bija pāriet Daugavu un pārraut padomju fronti austrumos no Daugavpils, ar kreiso kolonnu apiet pilsētu no austrumiem un ziemeliem, ienemot cietoksni un izveidojot aizsardzību pret lietuviešiem. Ar labo kolonnu vajadzēja sasniegt Dubnas upi pie Višķiem, lai kavētu padomju rezervju kustību no Rēzeknes, kā arī savienotos šajā vietā ar latviešiem. ${ }^{331}$

3. janvārī no rīta 1. Leǵionu kājnieku pulka 2. bataljons un nedaudz vēlāk arī 1. bataljons ziemeḷos no Lašiem pārgāja Daugavu un uzsāka uzbrukumu cauri Vecsētai un uzspridzināja dzelzcel̦u uz Baḷbinovu (Indru). Abi bataljoni pēc kaujas Stropu vasarnīcu rajonā ielauzās Daugavpilī Jaunbūves rajonā un Vecajā priekšpilsētā, kur iesaistījās ielu kaujās. Ap plkst. 12.00 ienaidnieks atkāpās no Vecās priekšpilsētas uz cietoksni. Kad poḷi ar kauju bija ieṇēmuši pilsētas II dzelzceḷa staciju, padomju daḷām radās reāli ielenkšanas draudi,

\footnotetext{
${ }^{330}$ Kampania "Zima"//Polska Zbrojna. - 1938. - 1 stycz.; Jaunākās Ziṇas. - 1920. - 5. janv.; Latvijas Sargs. - 1920. - 8. janv.; Brīvā Zeme. - 1920. - 10. janv.

${ }^{331}$ Dąb - Biernacki S. Grupy oporowe... - S. 231-232.
} 
tāpēc tās pameta cietoksni, kurā plkst. 13.00 iegāja polii. Sarkanās armijas vienību lielākajai daḷai izdevās izlauzties Stropu ezera un tālāk Rēzeknes

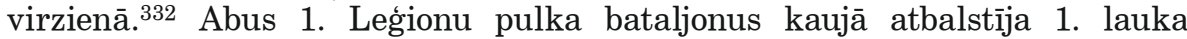
artilērijas pulka 9. baterija, kas plkst. 9.00 ar grūtībām (stāvo krastu dēḷ) pārgāja Daugavu. ${ }^{333}$

\section{Daugavpils ienemšanas operacija.}
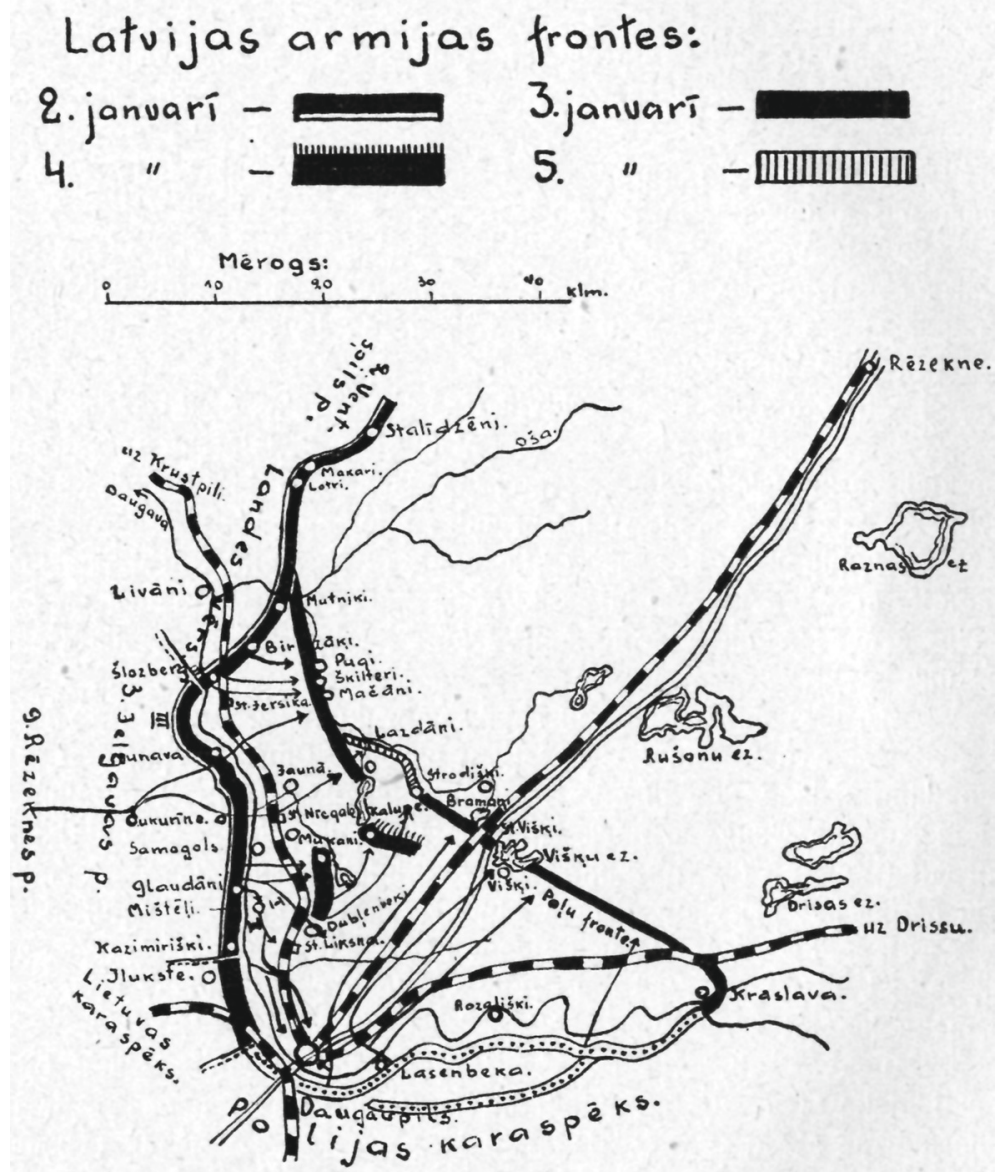

\section{2. karte. Daugavpils atbrivošanas operācija 1920. gada 3. janvārī}

Jau plkst. 11.00 Ridzs-Smiglijs Kalkūnē pavēlēja bruṇuvilcienam "Śmigły" piebraukt pie izpostītā tilta, lai novērtētu stāvokli pilsētā. Vilciena komandieris

\footnotetext{
${ }^{332}$ Borkiewicz A. Dzieje 1-go pułku... - S. 367-378; B. S. Jakeśmy Dźwińsk zafasowali//Źołnierz Polski. - 1921. - 31 lip., 7 sierp.; Merwin B. Wzięcie Dźwińska//Nasz Kraj. - 1920. - 14, 15, 16, 17 stycz. Sīkāk sk.: Bebris R. Daugavpils atbrīvošana... - 219.-226. lpp.

${ }^{333}$ Lewicki R. Zarys historji... - S. 27.
} 
ziṇoja, ka ienaidnieks nav manāms, tādēḷ uz Daugavpili tika nosūtīta virsnieku patruḷa un jātnieku strēlnieku vads. Vienlaikus Kalkūnes stacijā ieradās grupas virspavēlniecības vilciens, munīcijas priekšgrupa, sanitārais vilciens, autokolonna, vezumi un telegrāfa rota (tā sāka dibināt sakarus ar uzbrūkošajām daḷām). Plkst. 14.00 pilnībā bija atbrīvota pilsētas dienvidu daḷa, bet 15.00 - visa pilsēta, taču tikai 18.00 tika nodibināti sakari ar 1 . Leǵionu pulka 1. un 2. bataljonu Daugavpilī; par pārējām trieciengrupas vienībām ziṇu grupas štābam pagaidām nebija. ${ }^{334}$

3. janvārī no rīta Daugavu pie Vilušiem ar kauju bija pārgājis 1. Leǵionu kājnieku pulka 3. bataljons, kura uzdevums bija uzbrukt Višķu virzienā. Sekoja kauja pie Locikiem (Lāčiem) ar padomju 29. un 30. pulku, kuri atkāpās no Daugavpils, un vēlā vakarā bataljons sasniedza Jauno Zaḷo Pušču pie Rēzeknes dzelzcel̦a. ${ }^{335}$

Savukārt trieciengrupas labais spārns - 5. Leǵionu kājnieku pulks un 1. lauka artilērijas pulka divizions - gatavojās Daugavas pāriešanai Rozališḳu rajonā. Aizkavējās 2. bataljona un artilērijas pārcelšanās, tādēḷ Višķu virzienā vispirms devās 1 . un 3 . bataljons, kam nedaudz vēlāk sekoja aizkavējušās apakšvienības (abus bataljonus tās panāca naktī uz 4. janvāri). Ar nelielām sadursmēm tika sasniegti Mozuḷi, kur notika nopietna kauja (mēǵinot triecienā ieņemt ienaidnieka nocietinātās pozīcijas, tikai 3. bataljons vien šajā kaujā zaudēja 80 kritušos un ievainotos, tajā skaitā vairākus virsniekus). So apdzīvoto vietu poḷiem izdevās ien,emt plkst. $16.45 .{ }^{336}$

3. janvārī plkst. 15.00 Daugavu pārgāja arī 7. Leǵionu pulks, 18.30 ieṇemot Meḷnicas dzelzceḷa staciju un Lipišķus. Tādējādi tika nodrošināts Trieciengrupas labais spārns. Tomēr tikai plkst. 21.00 izdevās Lipiškos nodibināt sakarus ar 5. Leǵionu pulku, kā bija paredzēts. Turpmākajās dienās pulks nocietinājās līnijā Pantel̦išḳi-Mel̦nica-Račinas stacija-Daugava pie Kaplavas. Neizdevās 4. janvārī paredzētais 8. pulka uzbrukums. ${ }^{337}$

3. janvārī plkst. 14.00 6. Leǵionu pulks, kas atradās rezervē, tika pārvietots uz Grīvas rajonu, bet tā 1 . bataljons un 1. lauka artilērijas pulka 7. baterija sakarā ar ziṇu trūkumu no 5. Leǵionu pulka plkst. 23.00 maršā no Daugavpils devās Višku virzienā. Naktī pie Maḷinovkas šie spēki izcīnīja kauju ar sarkanarmiešiem un 4. janvārī no rīta Mozuḷos nodibināja sakarus ar 5. Leǵionu pulku. ${ }^{338}$

Operācijas sākums bija veiksmīgs. Tas pārsteidza gan lieliniekus, gan lietuviešus, kaut arī lieliniekiem bija aizdomas par varbūtēju poḷu uzbrukumu 1920. gada 15. janvārī (saskaṇā ar liecībām, kuras decembrī sniedza poḷu gūstā kritušie sarkanarmieši). Padomju avoti liecina, ka 15. armijas štābs

\footnotetext{
${ }^{334}$ CAW, WBH, 341. 1. 151.

335 Dąb - Biernacki S. Grupy oporowe... - S. 237-238.; Encyklopedja Wojskowa. - T. 3. - Warszawa, 1933. - S. 527.

${ }^{336}$ Babiński K. Zarys historji... - S. 44-46; Lewicki R. Zarys historji... - S. 27-28; Pociej S. Walki 1 baonu 5 p. p. za Dźwiną//Źołnierz Polski. - 1920. - 10 marzec; Lipiński W. Wspomnienia pośmiertelne. Liwacz i Wolski//Rząd i Wojsko. - 1920. - 18 styczień.

${ }^{337}$ CAW, WBH, 341. 1. 150, 151, 154; Markiewicz F. Zarys historji... - S. 12.

${ }^{338}$ CAW, WBH, 400. 1. 2784 (Piotrowski K.); 341. 1. 151; Skarbek E. Zarys historji... - S. 19; Lewicki R. Zarys historji... - S. 28.
} 
bijis pat pārliecināts par gaidāmo uzbrukumu. 2. janvāra pavēlē padomju 477. robežsargu pulkam teikts, ka 4. divīzijas iecirknī gaidāms "poḷu, latviešu un lietuviešu" uzbrukums. Nepalika nepamanìta arī latviešu Latgales divīzijas ierašanās frontē pie Pitalovas. ${ }^{339}$ Poḷu pulkvedis A. Borkēvičs atzīst, ka jau decembra vidū uzbrukumā iesaistāmo Polijas armijas daḷu virsnieki par to zinājuši, tikušas dotas attiecīgas pavēles un saimnieciskās iestādes "neievēroja nepieciešamo slepenību"340 (Latvijas armijas vadība attiecīgās pavēles izdeva vēlāk, bet intendantūra tādas vispār nesaṇēma pirms uzbrukuma sākuma. Tas vēlāk radīja apgādes grūtības ${ }^{341}$ ). Tomēr 15 . armijas vadība pienācīgu rezervju trūkuma dēḷ nespēja uzbrukumam atbilstoši sagatavoties, tādē mēǵināja aizstāvēties dziḷumā, gar grūti aizsargājamo Daugavu izvietojot mazākus spēkus. Taču, izvēloties šādu taktiku, skaitliski, materiāli un psiholoğiski pārāki izrādījās poḷu spēki.

Lietuvieši par akciju uzzināja tikai tad, kad kaujas jau norisinājās Daugavpils ielās, kaut arī saskaṇā ar vēlāko Lietuvas armijas G̦enerālštāba ziņojumu jau 2.-3. janvāra naktī pirms uzbrukuma sākuma lietuviešu izlūki bija pārgājuši Daugavu un pēc īsas kaujas uz laiku ieṇēmuši Līksnu. ${ }^{342}$ Tomēr arī 3. janvārī viṇi Daugavu pārgāja (acīmredzot lietuviešu akcija notika pēc vietējo komandieru iniciatīvas, tas arī liecina par apjukumu, ko vin,os izraisīja uzbrukums). Plkst. 17.00 poḷu 1. Leǵionu pulka 8. rota no cietokšna devās nodrošināt pagaidu aizsardzību pret lietuviešiem gar Daugavu. Pogulankā (Mežciemā) poḷi sastapa Lietuvas armijas rotu. Poḷiem šoreiz jebkuriem līdzekḷiem bija jāpanāk lietuviešu atkāpšanās. Tas izdevās, pārliecinot lietuviešu komandieri, ka poḷi veido šurp nākoša bataljona priekšējo sardzi. Līdzīgā kārtā izdevās panākt Lietuvas armijas Baltkrievu bataljona rotas atkāpšanos no Līksnas vasarnīcu ciemata. Līdz plkst. 21.00 poḷi bija izveidojuši aizsardzību gar Daugavu līdz Augšguḷāniem un nodibinājuši sakarus ar latviešu 3. Jelgavas pulka rotu Moslovajā. ${ }^{343}$ Saskaṇā ar Lietuvas armijas virspavēlnieka P. L,atuka ziṇojumu, kas bija tapis dažas dienas vēlāk, lietuviešu vienības 3. janvārī plkst. 16.00 bija ieṇēmušas nelielu iecirkni no Augšguḷāniem gar dzelzceḷu uz ziemel̦iem, taču tās nevēlējās iesaistīties bruṇotā sadursmē ar poḷiem un latviešiem, tāpēc bija izpildījušas prasību atkāpties pāri Daugavai (prasību bija izteikuši gan poḷi, gan latvieši). ${ }^{344} 3$. janvāra vakarā Ridzs-Smiglijs pavēlēja pilsētā ienākušajam 3. Jelgavas kājnieku pulka 2 . bataljonam gar Daugavu izveidot kordonu, ${ }^{345}$ jo pāri Daugavai apmēram divus kilometrus no Daugavpils bija pārcēlušās divas-četras Lietuvas armijas rotas. Tomēr šis bataljons politisku iemeslu dēl vēlējās palikt pilsētā, tāpēc vilcinājās pildīt pavēli (3. janvārī bataljona komandieris kapteinis A. Apsītis-Apse bija saṇēmis mutisku solījumu, ka

\footnotetext{
339 CAW, WBH, 341. 1. 155, 150.

${ }^{340}$ Borkiewica A. Dzieje 1-go pułku... - S. 348.

${ }^{341}$ Radziņš P. Latvijas atbrīvošanas karš. - 49. lpp.

${ }^{342}$ Lietuva. - 1920. - 10 saūsis.

${ }^{343}$ CAW, WBH, 400. 1. 489 (Fedorczyk S.), 341. 1. 150. P. Losovskis raksta, ka lietuvieši pārgājuši Daugavu 5. janvārī. Šis datums nav precīzs. - Łossowski P. Stosunki polsko - litewskie... - S. 187.

${ }^{344}$ LCVA, f. 384, ap. 3, b. 14, 1. 6.

${ }^{345}$ LVVA, 3601. f., 1. apr. 471. 1., 5. 1p.
} 
pavēle tiks izpildīta "vēlāk"). Līdz ar to kordonu izveidoja 6. Leǵionu pulka bataljons, kaut arī poḷi vēl 5. janvārī gaidīja, ka latvieši ien,ems pozīcijas pret lietuviešiem. Tomēr arī pirms E. Ridza-Smiglija pavēles saṇemšanas paši latvieši apzināti kavēja lietuviešu pārcelšanos pāri Daugavai. 3. janvārī 3. Jelgavas pulka 2. bataljona vienības pa ceḷam uz Daugavpili Poguḷankā saṇēma ziṇas, ka lietuvieši gatavojas pāriet Daugavu Līksnas rajonā. Tieši šī iemesla dēḷ Ilūkstes apriṇķa komandantūras komanda naktī palika Līksnā, bet 6. un 8. rota - Poguḷankā (pavēlē bija teikts: "Lai brīdinātu lietuviešus, ka tiem Daugavpilī nekas nav darāms") un tikai nākamajā dienā pievienojās pārējam bataljonam Daugavpilī. ${ }^{346}$

Pirmajā uzbrukuma dienā Latvijas armijai bija 1 kritušais un 25 ievainotie; tā bija sagūstijjusi 121 sarkanarmieti, ieguvusi jau minēto bruṇuvilcienu Līksnā, vagonus ar lādiṇiem, ieročus. Poḷu zaudējumi bija lielāki - 1. Leǵionu kājnieku pulkam 20 kritušie, 71 ievainotais, 14 bezvēsts pazudušie (525 sagūstīti sarkanarmieši, iegūti 3 lielgabali, 14 ložmetēji, ieroči, munīcija, vezumi, 43 zirgi); 5. Leǵionu kājnieku pulkam (3.-4. janvārī) - 33 kritušie (no tiem 3 virsnieki), 115 ievainotie; 6 . Leǵionu pulka 1 . bataljonam (4. janvārī) 4 kritušie, 26 ievainotie; 7. leǵionu pulkam - 3 ievainotie. ${ }^{347}$

Sarkanās armijas zaudējumi Daugavpilī ir grūti nosakāmi. Laikraksta “Jaunākās Ziṇas" korespondents vēstīja, ka kaujas pilsētas centrā bijušas nenozīmīgas, vienīgi pie II (Petrogradas) dzelzceḷa stacijas gulējis ap 50 kaujā kritušu sarkanarmiešu līk,u. ${ }^{348}$ Savukārt 6. Leǵionu pulka karavīri 3. janvāra vakarā kapsētu rajonā pie pilsētas ziemeḷu robežas bija redzējuši “kaujaslauku, pilnu ar lielinieku līķiem”. ${ }^{349}$ Daugavpilī daudzi bija krituši gūstā (437 padomju karavīri). Poḷu štābs vērtēja, ka ienaidnieks 3. janvārī Daugavpilī un pie tās zaudējis ap 800 kritušo, ievainoto un gūstā nonākušo karavīru. ${ }^{350}$ Šis skaitlis ir nedaudz pārspīlēts. Oficiālajā padomju virspavēlniecības ziṇojumā bija teikts, ka Sarkanā armija Daugavpili aizstāvējusi varonīgi, lai gan bija "ārkārtīgi smags stratēǵiskais stāvoklis"." 351

Sarkanā armija pameta pilsētā ieročus, dažas 6,9 collu haubices, piecas lokomotīves, pāri par 200 vagoniem, Rīgas-Orlas dzelzceḷa līnijas darbnīcas utt. Saskaṇā ar vienošanos ieroči un munīcija tika nodoti Latvijas pusei, bet dzelzceḷa ritošo sastāvu sadalīja uz pusēm (latvieši saṇēma trīs nebojātas lokomotīves un vienu bojātu, 122 dažādus vagonus). ${ }^{352}$

4. janvāra rītā Daugavpilī no rezerves ieradās 6. Leǵionu pulka divi bataljoni ar 1. lauka artilērijas pulka trīs baterijām. Savukārt 1. Leǵionu pulka 1 . bataljons ar 1. lauka artilērijas pulka divām citām baterijām devās

\footnotetext{
346 3. Jelgavas kājnieku pulks. 1919. 16. VIII - 1929. 16. VIII. - Rīga, 1929. - 126. lpp.

347 CAW, WBH, 341. 1. 154.

348 Jaunākās Ziṇas. - 1920. - 8. janv.

${ }^{349}$ CAW, WBH, 341. 1. 154 (Piotrowski K.).

350 Borkiewicz A. Dzieje 1-go pułku ... - S. 376, 384.

351 Pruszyński M. Dramat Piłsudskiego. Wojna 1920. - Warszawa, 1995. - S. 22.

${ }^{352}$ LVVA, 5192. f., 1. apr., 1562. 1., 3. 1p.; Jaunākās Ziṇas. - 1920. - 16. janv.; Brīvā Zeme. - 1920. 9. janv. Sociāldemokrāts. - 1920. - 13., 20. janv.; Strādnieku Avīze. - 1920. - 18. janv. A. Veiss 4. janvārī ziņoja, ka Daugavpilī iegūti 105 preču un 5 pasažieru vagoni, 2 lokomotīves, 15-20 ložmetēji, 2 lielgabali, 5 vagoni ar pārtiku. - LVVA, 6033.f., 1. apr., 24. 1., 4. lp.
} 
uz Višķiem, kur nonāca 5. janvārīīs53 (arī 1. Leǵionu pulka 2. bataljons 8. janvārī devās uz Višku rajonu, lai 1. brigāde pārṇemtu to savā rīcībā). 5. janvārī uz Daugavpili no Kalkūnes pārcēlās karaspēka grupas štābs. Pilsētas garnizonā bez minētajām poḷu daḷām šajā dienā vēl bija vairākas 1. un 6. lauka artilērijas pulka baterijas un tehniskās vienības. Jau 4. janvārī poḷ garnizonam tika uzdots organizēt pilsētas aizsardzību. Inženieru rota aukstuma dēl neraka ierakumus, bet ar gūstekṇu un algotu civiliedzīvotāju palīdzību sniegā uzstādīja dēḷu barjeras (tā dēvētos „spāṇu āžus”).354 4. janvārī pilsētu apmeklēja frontes virspavēlnieks S. Šeptickis un tās pašas dienas pēcpusdienā atgriezās Viḷnā. ${ }^{355}$

Latvijas armijas 3. Jelgavas kājnieku pulks 4. janvāra pievakarē ar kaujām sasniedza Kalupi, bet 5. janvāra vakarā - Dubnas upi, nodibinot sakarus ar 9. Rēzeknes kājnieku pulku kreisajā spārnā un ar polu daḷām - labajā spārnā. Šajās dienās 9. Rēzeknes pulks un Vācu zemessargi veica sekmīgu izlūkdarbību, zaudējot divus kritušus karavīrus.

Poḷu 5. Leǵionu pulks pēc nakts aizstāvēšanās kaujas pie Mozuḷiem 4. janvārī no rīta jau pilnā sastāvā (bija pienācis 2 . bataljons) pārgāja pretuzbrukumā. Ienaidnieku atbalstīja brunuvilciens “Смерть или победа” („Nāve vai uzvara”) no Dubnas stacijas (vēlāk to pārdēvēja par Višḳu staciju). Apvidus vairākkārt gāja no rokas rokā. Poḷiem, izjaucot sliedes, gandrīz izdevās sagūstīt bruṇuvilcienu, un to glāba divu citu padomju vilcienu (“Ленин” un “Троцкий”) ierašanās. ${ }^{356}$ Plkst. 15.00 tikai pēc papildspēku - 6. Leǵionu pulka bataljona - pienākšanas no Daugavpils izdevās ieņemt Dubnas staciju. Vēl pēc stundas Višku rajonā tika nodibināti sakari ar latviešu 3. Jelgavas pulku. Sakarā ar lielajiem dzīvā spēka zaudējumiem un ārkārtīgo nogurumu 5. janvārī 5. Leǵionu pulka vadība pieprasīja maiṇu. Turklāt šajā dienā 1. Leğionu brigādes rīcībā nonāca 1. smagās artilērijas pulka 2. baterija (pārējā smagā artilērija pagaidām palika Kalkūnē) un 2. jātnieku strēlnieku pulka eskadrons. Rūpes sagādāja aizmugures sakārtošana, jo vietējie zemnieki uzskatīja, ka briesmas jau garām. Tādēl, 1. brigādes vadība aizliedza civilpersonām "vazāties" pa frontes līniju un tās tuvumā. Karavīriem bija jāpiespiež apkārtstaigātāji "slēpties mājās". ${ }^{357}$

Tādējādi 5. janvārī pirmais operācijas posms bija sekmīgi noslēgts. Apvienotās grupas daḷu fronte atradās: Daugava (pretī Kaplavai)-Bramanišk̦i (7. Leǵionu pulks); Bramanišḳi-Višķi (5. Leǵionu pulks); tālāk no Dubnas stacijas - 1. Leǵionu pulka 3. bataljons; Bramaṇi-Lozdāni (3. Jelgavas pulks); Lozdāni-Mačina (9. Rēzeknes pulks); Mačina-Mutṇiki (Vācu zemessargi). ${ }^{358}$

\footnotetext{
353 CAW, WBH, 341. 1. 154; Lewicki R. Zarys historji... - S. 28.

354 CAW, WBH, 341. 1. 155; LVVA, 3601. f., 1. apr., 471. 1., 5. 1p.

355 CAW, II ND WP, t. 114. Pārspīlēts ir apgalvojums, ka S. Šeptickis akcijas laikā "divkārt atradies nāves briesmās, pirmajās līnijās dodot norādījumus" (Ziemia Wileńska. - 1920. - 11 stycz; Kurjer Lwowski. - 1920. - 9 luty u. c.). İstenībā viņš atradās Kalkūnes pilī.

${ }^{356}$ Latvijas Sargs. - 1920. - 11. janv. J. Lavenieks nepareizi atzīmēe, ka 5. janvārī poḷus pie Višķiem atbalstīja latviešu 3. bruņuvilciens, kas 4. janvārīi ieradies Daugavpilī (īstenībā tas tur iebrauca 9. janvārī). Faktiski Daugavpilī 5. janvārī ieradās 2. bruṇuvilciens, kas laboja ceḷu KrustpilsDaugavpils posmā (Krustpilī tas atgriezās 6. janvārī). - Lavenieks J. Bruṇoto vilcienu pulks. - 1971; LKM, Paulockis A., 127., 206. 1p.

357 CAW, WBH, 341. 1. 151, 154; Babiński K. Zarys historji... - S. 47-48.

${ }^{358}$ Bebris R. Daugavpils atbrīvošana... - 228. 1pp.
} 
Bez 23., 31. un 33. pulka, kas bija cietuši 3. janvārī, šajās dienās cīṇā pret latviešu dạ̄ām iesaistījās arī 30. un 32. padomju pulks, turklāt 30. pulks ar kreiso spārnu darbojās arī pret poḷiem. Poḷu kreisajā spārnā, kur jau atradās 28. un 29. pulks, cīnā iesaistījās padomju 1. divīzijas 3. brigāde (7., 8., 9. pulks) un 6. divīzijas 1. brigāde (46., 47., 48. pulks). Abas 6. janvārī ieradās Rušonas stacijā no Igaunijas frontes (pulkā 6 rotas, rotā - 50 durkḷu un ložmetējs). Rietumos no dzelzceḷa atradās 3. divīzijas 22. pulks (ap 500 durkḷ), Rušonas stacijā - 2 brunuvilcieni. Iecirknī Krāslava-Čurilava darbojās 4. divīzijas 3. brigāde (34., 35., 36. pulks), bet Čurilavas-Drisas iecirknī bija ieradušies divi jauni pulki. ${ }^{359}$

Pēc 5. janvāra Rušonas stacijā tika sakārtotas Daugavpilī sakautās padomju daḷas un izveidots 5000 durkḷ liels grupējums (ar divām artilērijas baterijām un diviem bruṇuvilcieniem). Pēc Latvijas izlūkdienesta ziṇām ap Rēzekni koncentrējās spēki, lai izdarìtu pretuzbrukumu Krustpils virzienā un vienu no otras atšķeltu poḷu un latviešu uzbrucēju operatīvās grupas. Karaspēks koncentrējās arī Sebežas rajonā. ${ }^{360}$

7. janvārī E. Ridzs-Smiglijs pavēlēja 1. brigādei ieņemt līniju BramaṇiKsaverinova-Kaḷki-Meša un sabojāt Rušonas stacijas iekārtas, bet 3. divīzijai - ieṇemt Šķeltovu. 1. brigādes kreisais spārns akcijas laikā bija jānodrošina vismaz divām latviešu rotām. ${ }^{361}$ 9. janvārī 1 . brigādē no Daugavpils ieradās sapieru vads, taču avārijas dēḷ aizkavējās latviešu bruṇuvilciens. Tomēr Sarkanās armijas pretuzbrukums izjauca 10. janvārī paredzēto akciju. ${ }^{362}$ 6.-7. janvārī latviešu-poḷu spēki likvidēja vairākus sīkus ienaidnieka pretuzbrukumu mēǵinājumus, ${ }^{363}$ bet 8 . janvārī pēc artilērijas sagatavošanas tas pārgāja lielā uzbrukumā. No Špoǵiem atkāpās poḷu baterija, tomēr poḷiem izdevās noturēties. 9. janvārī 1. Leǵionu pulks ierakās, spridzinot sasalušo zemi. Četras 1. smagās artilērijas pulka baterijas nespēja apklusināt padomju brunuvilcienu lielgabalus, kas nogalināja 9 un ievainoja 23 poḷu karavīrus. Tādēḷ poḷi ar cerībām sagaidīja latviešu 3. bruṇuvilcienu, kas 10. janvārī ieradās Dubnas stacijā. Tā komandieris A. Paulockis atcerējās, ka 1. Leǵionu brigādes štāba virsnieki izskatījušies vīlušies, jo vilciens sastāvējis no piemērotām platformām ar "Maxim" ložmetējiem, četriem lielgabaliem un mīnmetēja. Tomēr kaujā tas pavadìts ar "sajūsmu un cerībām". Ar trāpīgu uguni latviešu vilciens piespieda ienaidnieka vilcienus atkāpties, poḷu karavīru "urā" kliedzienu pavadìts. Poḷi, pieslēdzoties telefona vadiem, uzzināja, ka brunuvilciens “Смерть или победа" nopietni bojāts (uz tā daudzi krituši) un no Rēzeknes aizvilkts uz Krieviju, bet vilcienam “Ленин” pavēlēts izvairīties no kaujām ar "balto vilcieniem”. 10. janvārī latviešu vilciens Daugavpilī uzṇēma munīciju un atgriezās Višḳu rajonā. Poḷu 1. brigādes komandieris

\footnotetext{
${ }^{359}$ LVVA, 6033. f., 1. apr., 68. 1., 2. 1p.

${ }^{360}$ CAW, WBH, 341. 1. 151; LVVA, 6033. f., 1. apr., 24. 1., 9. 1p.

${ }^{361}$ LVVA, 1515. f., 1. apr., 694. 1., 6.-7. 1p.

362 CAW, WBH, 341. 1. 155.

${ }^{363}$ LVVA, 6033. f., 1. apr., 24. 1., 9. lp. Uz Daugavpils-Rēzeknes dzelzceḷa šajā laikā strādāja divi poḷu sanitārie vagoni, kas uzṇēma arī ievainotos latviešus.
} 
izteica apkalpei savu atzinību un pateicību. Kaujā bija viegli ievainots vilciena komandieris un vēl daži karavīri. ${ }^{364}$

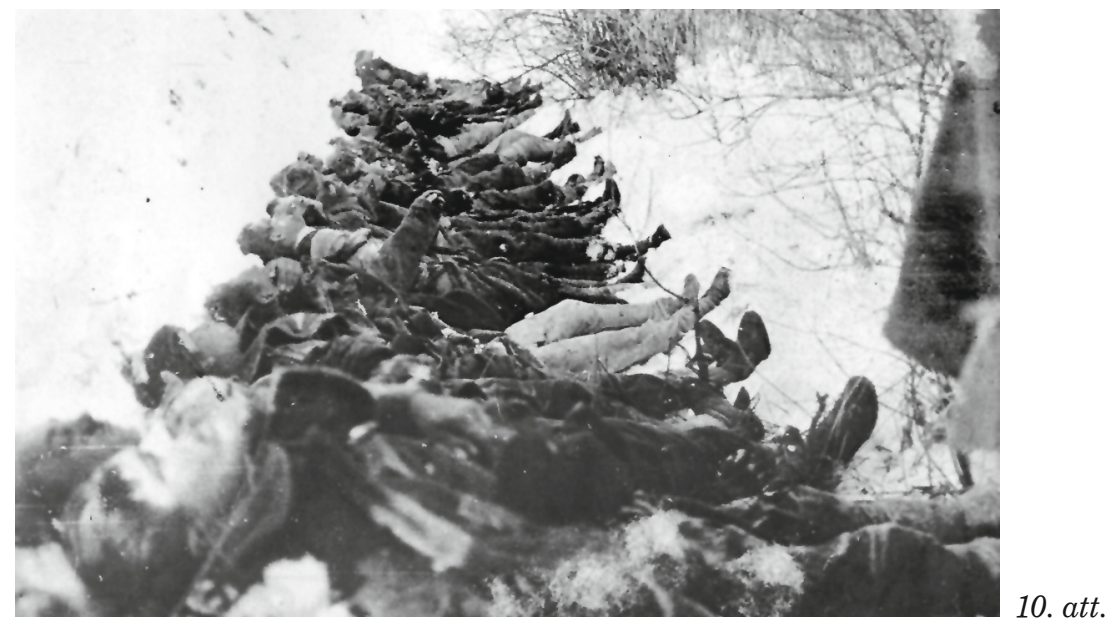

\section{Kritušie poḷu karavīi pie Viškiem 1920. gada janvārī}

Poḷu grupas štābs atcēla paredzēto tālāko uzbrukumu sakarā ar "1. Leǵionu brigādes daḷu ārkārtīgo nogurumu". Lai atvieglotu 1. brigādes stāvokli, 3. Leǵionu divīzijas 8. pulks naktī uz 10. janvāri pārgāja Daugavu un ieṇēma Krāslavu. Tajā palika viens bataljons, bet pārējie divi sasniedza Ludvigovu un Indricu. 10. janvārī 7. pulks devās uzbrukumā Šḳeltovai, bet 8. pulks Kombuḷiem, tomēr 11. janvārī abi bija spiesti atgriezties izejpozīcijās (nebija saskan,ota darbība ar 5. pulku). ${ }^{365}$

9. janvārī sākās arī Latvijas armijas kreisā spārna uzbrukums Ziemeḷlatgalē, lai ieṇemtu Pitalovas dzelzcel̦a mezglu. Šajā dienā tika ieṇemta Viḷaka, bet 10. janvārī - Kārsavas stacija (līdz ar to ienaidniekam Latgalē tika pārtraukta satiksme ar Pleskavu), Dricēni un Varakḷāni, bet 11. janvārī - Kārsava. Tomēr neizdevās sasniegt plānoto, jo arī šajā iecirknī bija pievilkti $9-10$ svaigi padomju pulki. ${ }^{366}$

Savukārt 10. janvārī E. Ridzs-Smiglijs pavēlēja sākt atlikto akciju 12. janvārī, izmantojot Latvijas armijas uzbrukuma izraisīto ienaidnieka dezorganizāciju. Poḷu daḷas uzdevumu izpildīja, un kaujā tās atbalstīja latviešu 3. bruṇuvilciens, kura apkalpe ieņēma arī vairākus ciemus gar DaugavpilsRēzeknes dzelzcelu. Saspridzinātā tilta dēḷ vilcienam neizdevās ieṇemt Rušonas staciju. ${ }^{367}$ 12. janvārī uz Daugavas labo krastu pilnībā pārgāja arī 3. Leǵiionu divīzija (ciešot smagus zaudējumus). Tā ieṇēma Šḳeltovu (ienaid-

\footnotetext{
${ }^{364}$ LKM, Paulockis A., 122.-123. lp. Sīkāk par Latvijas armijas bruņuvilcienu sadarbību ar poḷu karaspēku Latgalē 1920. gadā sk.: Jēkabsons Ē. Współpraca łotewskich pociągów pancernych z Wojskiem Polskim w 1920 roku//Pociągi pancerne 1918-1943. Organizacja-struktura-działania wojenne. - Białystok: Muzeum Wojska w Białymstoku, 1999, s. 28-40.

365 CAW, WBH, 341. 1. 151, 150.

${ }^{366}$ Latvijas armija 20 gados. - 224.-226. 1pp.

${ }^{367}$ LKM, Paulockis A., 122.-123., 130.-131. 1p.
} 
nieka rezervju koncentrācijas vietu), bet 13. janvārī - Kombuḷus, atsitot vairākus spēcīgus pretuzbrukumus. ${ }^{368}$

Pildot E. Ridza-Smiglija pavēli, 13. janvāra rītā uzbrukumu turpināja J. Puriňa komandētās latviešu daḷas, lai sasniegtu Rušonas stacijas-Preiḷu-Velēnu līniju. Šajā dienā Rušonas stacijā, ko ienaidnieks naktī bija pametis, iebrauca latviešu 3. brunuvilciens. Tas devās tālāk un aktīvi piedalījās kaujā, atbalstot 1. Leǵionu pulku. Pulkveža-leitnanta J. Puriṇa (poḷu štāba) pakḷautībā pārgāja arī 2. Ventspils kājnieku pulks, bet 9. Rēzeknes kājnieku pulks ieṇēma Preiḷus. ${ }^{369}$

Padomju 15. armijas daḷas Dienvidlatgalē bija dezorganizētas. Par to liecināja nekoordinēti pretuzbrukumi. Pret poḷiem darbojās padomju 1. divīzijas 7., 8., 9. pulks, 4. divīzijas 28., 29., 30., 35., 36. pulks un 53. divīzijas 471., 473., 474. pulks. Turklāt pēdējais dažu dienu laikā cīnījās gan poḷu 1. Leǵionu brigādes, gan 3. Leǵionu divīzijas, gan latviešu spēku iecirknī. Vēl grupas frontē bija ieradies padomju 5. divīzijas 38., 39. un 40. pulks no Denikina frontes, kā arī 18. divīzijas 157. pulks. Poḷu-latviešu daḷas ieṇēma Krāslavas-Šķeltovas-Rušonas stacijasPreilu-Velēnu līniju. Tālākais uzbrukums bija atkarīgs no Latvijas armijas sekmēm Ziemel̦latgalē un Rēzeknes ien,emšanas. Padomju 15. armijas rīcībā vēl palika Rēzeknes-Veḷikije Luki dzelzceḷa līnija, tādēḷ tā centās Rēzekni noturēt. ${ }^{370}$

Ziemeḷlatgalē 14. janvārī Latvijas armijas Latgales divīzija ieṇēma Pitalovas dzelzceḷa staciju, taču turpmākajās dienās ienaidnieka pretuzbrukumi ofensīvu apturēja. Tomēr šī Latgales divīzijas akcija bija izjaukusi padomju pretuzbrukumu, kas bija paredzēts 14.-15. janvārī Krustpils virzienā. ${ }^{371}$

Jau 12. janvārī Polijas armijas virspavēlniecība piekrita turpināt operāciju “Ziema”. ${ }^{372}$ Kaujas Ziemeḷlatgalē varēja ieilgt, tādēḷ 16. janvārī Rīgā tika noslēgta jauna Latvijas armijas virspavēlniecības vienošanās ar A. Miškovski par tālāku militāro kopdarbību Latgalē. Vienošanās noteica, ka uzbrukums turpināsies līdz linijai Drisa-Osvejas ezers-Zilupe līdz Melnā strauta ietekai-Gamaṇi-Žogovas stacija-Volkova-Berjozki. Pēc paredzētās līnijas sasniegšanas vienai polu divīzijai bija jāatrodas frontē no Drisas līdz Plisūna ezeram, otrai - rezervē ziemel̦austrumos no Daugavpils. Attiecībā uz trofejām, dzelzceḷu, apgādi un poḷu dalı izvešanu no Latgales palika spēkā iepriekšējās vienošanās noteikumi. Lìgumā bija jaunums - poḷu kontrolē tika nodota dzelzceḷa līnija līdz Daugavpils stacijai, to iekḷaujot (pirms tam nebija iekḷauta). Turklāt poḷi ieguva tiesības turēt vienu jātnieku pulku. Janvāra beigās Latvijā ieradās 7. ulānu pulks ${ }^{373}$ Daugavpils-Krustpils dzelzceḷa līnijas apsardzībai (pret lietuviešiem $-\bar{E}$. J.). ${ }^{374}$

\footnotetext{
${ }^{368}$ CAW, WBH, 341. 1. 150, 154; Encyklopedja Wojskowa. - T. 3. - Warszawa, 1933. - S. 527.

${ }^{369}$ LKM, Paulockis A., 123.-124., 131.-133. 1p.; Radziņš P. Latvijas atbrīvošana. - 82. lpp.

${ }^{370}$ LVVA, 3601. f., 1. apr., 471. 1., 44. 1p.; 473. 1. 10. 1p.; Jaunākās Ziṇas. - 1920. - 16. janv.

${ }^{371}$ Latvijas armija 20 gados. - 228. lpp.

372 CAW, WBH, 341. 1. 157.

373 27. janvārī Kalkūnē un 31. janvārī Bukmuižas-Vaboles rajonā ieradās 7. ulānu pulks un uzṇēmās dzelzcel̦a apsardzību. Pulks atstāja Latviju aprīlī. - CAW, WBH, 341. 1. 151, 157; Laudyn W. Zarys historji wojennej 7-go pułku ułanow lubelskich. - Warszawa, 1931. - S. 12; LVVA, 3601. f., 1. apr., 471. 1., 22. 1p.; 2574. f., 3. apr., 17. 1., 111., 113. 295. lp. Februāra vidū šajā pulkā bija 34 virsnieki, 768 ulāni un apakšvirsnieki. - Smoliński A. Jazda Rzeczypospolitej Polskiej w okresie od 12 X 1918 do 25 IV 1920. - Toruń, 2000. - S. 342.

374 Документы и материалы... - 479 стр.
} 
Jau 13. janvārī E. Ridzs-Smiglijs pavēlēja gatavoties tālākam uzbrukumam, kuru iedalìja trīs fāzēs. Pirmajā fāzē 1. Leǵionu brigādei, 3. Leǵionu divīzijai un J. Puriņa latviešu dạ̄ām bija jāien,em līnija Indrica-Sīvers-Rušons-Maltas upe-Velēni. Grupas rezerve bija 6. Leǵionu pulka 1. bataljons Viškiu rajonā. Pārējie divi 6. pulka bataljoni palika rezervē Daugavpilī, bet Turmantas grupai bija jāpaliek Kalkūnē un frontē pret Lietuvas armiju. Otrajā fāzē vajadzēja ieṇemt Vjatas upes grīvas-Baļbinovas-Dagdas ezera-Ežezera-Rāznas ezeraKārsavas stacijas līniju. ${ }^{375}$ Trešajā fāzē - Latvijas etnogrāfisko robežu.

15. janvārī J. Puriṇa daḷas pārgāja uzbrukumā un drīzumā sasniedza paredzēto Lageru-Stupānu-Kulču-Povrevas līniju. Nākamajā dienā uzbrukumā Krāslavas-Rušona līnijā devās poḷu vienības, atspiežot ienaidnieku no ezeru apkārtnes, kas ir izdevīga aizsardzībai. Šajā dienā poḷu 3. Leǵionu divīzijas štābs pārcēlās uz Krāslavu. Latviešu 3. Jelgavas kājnieku pulks pārgāja Rēzeknes-Daugavpils dzelzceḷu, 9. Rēzeknes kājnieku pulks izvirzīja savu labo spārnu, bet Vācu zemessargi - kreiso spārnu un izlīdzinājās ar 2. Ventspils kājnieku pulku savā kreisajā spārnā. 17. janvārī poḷu 9. Leǵionu kājnieku pulks ieņēma Baḷbinovas staciju. Arī pārējie 3. Leǵionu divīzijas kājnieku pulki turpināja virzìties uz priekšu (7. pulks 18. janvārī ien,ēma Asūni). Poḷi 18. janvārī sasniedza līniju, ko vajadzēja ieņemt uzbrukuma otrajā fāzē. Šajā dienā 5. Leǵionu pulka 2. bataljons vietējo apstākḷu pazinēja - zemnieka - pavadībā apgāja Dagdu un ienēema to bez kaujas (drīz uz turieni pārcēlās 1. Leǵionu brigādes štābs). Savukārt latviešu daḷas 19. janvārī sasniedza Pušas-Maltas-Vecružinas līniju. ${ }^{376}$

Šīs ofensīvas dēl padomju 15. armijas vadība vairs nebija pārliecināta, vai galvenais trieciens gaidāms Rēzeknes vai Krāslavas rajonā. Demoralizētās Sarkanās armijas daḷas atkāpās gandrīz bez kaujām (īpaši poḷu iecirknī). Atseviškas vienības palika poḷu aizmugurē, nezinot par galveno spēku atkāpšanos. Pret poḷiem operēja 7., 8., 9., 28., 29., 30., 157. pulks, pret latviešiem 31., 32., 472., 474. pulks. Sarkanās armijas vienību skaitliskais sastāvs bija ievērojami sarucis. Lielākas rezerves no Krievijas vairs nepienāca. ${ }^{377}$

Jaunajā operatīvajā situācijā radās nepieciešamība ieṇemt Rēzekni. Poḷu daḷas bija ievērojami izvirzịjušās uz priekšu, turpretī vājāk brun,otās un apgādātās latviešu vienības atpalika. Poḷu štābs izteica gatavību palīdzēt J. Puriņa daḷām, taču, kā rakstīja P. Radziṇš, Latvijas puse priekšlikumu bija spiesta noraidīt politisku apsvērumu dēl - "vismaz Rēzekni un Ludzu vajadzēja ieṇemt mums". ${ }^{378}$ Poḷu frontes štābs 15. janvārī ziṇoja, ka tālākā grupas kustība būs atkarīga no Rēzeknes ieṇemšanas, "kuru latviešiem, lai tur vai kas, jāieñem pašu spēkiem". ${ }^{379}$

19. janvārī E. Ridzs-Smiglijs pavēlēja J. Puriṇa daḷām no AntonopolesMaltas rajona uzbrukt Rēzeknei un uzbrukuma laiku noteikt pašam

\footnotetext{
375 LVVA, 3601. f., 1. apr., 471. 1., 44. 1p.

376 CAW, WBH, 341. 1. 151, 154; Radzin̦š P. Latvijas atbrīvošanas karš. - 87.-92. lpp.; Latvijas Sargs. 1920. - 20. janv.

377 LVVA, 3601. f., 1. apr., 471. 1., 47. 1p.

${ }^{378}$ Radziņš P. Latvijas atbrīvošanas karš. -87 . lpp.

379 CAW, WBH, 341. 1. 157.
} 
J. Puriṇam. Vienlaikus poḷu spēkiem bija jāsāk Latgales atbrīvošanas operācijas trešā fāze. ${ }^{380}$ 19. janvārī latviešu 3. Jelgavas kājnieku pulks atradās Pušas rajonā, 9. Rēzeknes kājnieku pulks - starp Pušu un Maltas staciju, Vācu zemessargi - šajā stacijā, 2. Ventspils pulks - gar Krustpils-Rēzeknes dzelzceḷu. J. Puriņš pavēlēja 3. un 9. pulkam uzbrukuma laikā uzturēt sakarus ar poḷiem, bet Vācu zemessargiem apiet Rēzekni no dienvidaustrumiem un 2. pulkam uzbrukt pilsētai gar dzelzceḷu. Operācija sākās 20. janvārī un bija sekmīga. Nākamās dienas rītā vispirms Vācu zemessargi, tad 2. Ventspils pulks iegāja Rēzeknē. ${ }^{381} \mathrm{Līdz}$ ar to fronte bija pavirzìta 22 kilometrus uz austrumiem un iztaisnota. Turpmākajās dienās J. Puriṇa daḷas neiesaistījās nopietnās sadursmēs un darbojās saskaṇā ar poḷu štāba norādījumiem. ${ }^{382}$

Savukārt poḷi 21. janvārī ar savu kreiso spārnu sasniedza Bukmuižu (Ezerniekus) Ežezera austrumu krastā, bet līdz 24. janvārim 1. Leǵionu brigādes daḷas ar kaujām nonāca līdz Daugavas labā krasta pietekai Sarjankai. ${ }^{383}$ Savukārt 3. Jelgavas pulks sasniedza Kriņicas-Bḷižn,ajas līniju.

Pēc 20. janvāra gaisa temperatūra noslīdēja līdz 25-30 grādiem zem nulles. 3. Jelgavas pulka 1. rotas komandieris 24. janvārī ziṇoja, ka aukstuma dēl nedarbojas automātiskie ieroči. Poḷi savējos glabāja zemnieku mājās un laukā nesa tikai galējas nepieciešamības gadījumā, bet zem lielgabaliem kurināja ugunskurus. $^{384}$ Tādēl 25. janvārī paredzētais Latvijas armijas Latgales divīzijas uzbrukums frontes ziemel̦u sektorā (Ziemeḷlatgalē) tika atlikts.

Jau 23.-24. janvārī ienaidnieks Ludzas virzienā bija izvirzījis 11. divīzijas 2. (pēc poḷu štāba datiem - 1.) brigādes 94., 95., 96. pulku, taču poḷi 25. janvārī piespieda tos atkāpties. Śie pulki Sebežā bija tikko saformēti no jauniesauktajiem un līdz ar to bija gandrīz kaujas nespējīgi. ${ }^{385}$ 26. janvārī 3. Jelgavas pulks sasniedza Kononovas-Bḷižnejas, bet 9. Rēzeknes pulks Čamatu-Ostrovskajas līniju. Lai gan poḷu sakaru virsnieks prasīja turpināt uzbrukumu, lai izlīdzinātos ar poḷu karaspēka daḷām, tomēr J. Puriṇš sākotnēji atteicās to darīt lielā sala dēḷ. Tomēr vēlāk latviešu daḷas turpināja uzbrukumu $^{386}$ un sīvās kaujās atsvieda padomju labo spārnu. 26. janvārī 2. Ventspils pulks ieṇēma Ludzu. Pēc divām dienām poḷi ar kreiso spārnu atradās Plusona ezera krastā un 3. Jelgavas pulkam bija ar to jāizlīdzinās, pārvarot apmēram 13 kilometrus. Kaujās sadarbojoties ar poliem, tas tika izdarìts, un 28. janvārī 3. Jelgavas pulks nomainīja poḷus Cerņavsku ezeru iecirknī. ${ }^{387}$

Poḷi 23. janvārī bija uzsākuši tā dēvētās (nedēḷu ilgās) Poḷeščinas kaujas. Ienaidnieks bija šeit sakoncentrējis ap 3000 durkḷu (gan bez artilērijas; poḷus atbalstīja 1. lauka artilērijas pulka baterija). Tikai 25. janvārī

\footnotetext{
${ }^{380}$ LVVA, 3601. f., 1. apr., 471. 1., 47.-49. 1pp.; 1515. f., 1. apr., 694. 1., 16.-18. 1p.

${ }^{381}$ Par godu Rēzeknes ien̦emšanai 22. janvārī Daugavpilī notika latviešu garnizona parāde, ko pieṇēma A. Veiss. - LVVA, 1491. f., 1. apr., 1991. 1., 74. lp.

${ }^{382}$ Latvijas armija 20 gados. - 229.-231. lpp.

383 AAN, Attachaty, A - II, 81/1, k. 6-7. Tikai 24. janvārī 1. Leǵionu pulkā bija 6 kritušie, 15 ievainotie un 300 apsaldētie. - Borkiewicz A. Dzieje 1-go pułku... - S. 441.

${ }^{384}$ LVVA, 6033. f., 1. apr., 188. 1., 11. 1p.; Lewicki R. Zarys historji... - S. 31.

${ }^{385}$ LVVA, 3601. f., 1. apr., 471. 1., 55. 1p.

386 AAN, Attachaty, A- II, 81/1, k. 21, 23.

${ }^{387}$ LVVA, 6033. f., 1. apr., 190. 1., 35. 1p.
} 
1. Leǵionu pulka 1. bataljonam izdevās ieṇemt Poḷeščinas ciemu. Šajā dienā tika ieṇemta arī Landskorona, bet 26. janvārī - Čerṇavski. Tādējādi 1. Leǵionu brigāde ieṇēma līniju Annapole-Volkarezi-Zamšoviki-Landskorona-Saveiki. Savukārt 3. Leǵionu divīzija jau 22. janvārī bija sasniegusi Sarjanku, 23. janvārī - Drisas staciju (8. pulks), bet 26. janvārī 7. pulks pārgāja Sarjanku un visa divīzija turpināja virzìties uz austrumiem. ${ }^{388}$ Ārkārtīgi smagos apstākḷıs Poḷeščinas kaujās 1 . brigādē durkḷu skaits bija krities par 50\%. 26. janvārī 1. Leǵionu pulka 1 . bataljonā 128 cilvēki bija guvuši apsaldējumus, turklāt 15 no viṇiem draudēja locekḷu amputācija (ierindā bija palikuši tikai 263 durkḷi). Tādēḷ pulka vadībalūdzašo bataljonu nosūtītuzaizmuguri. ${ }^{389}$ Kopumā 1. Leǵionu pulkā pie Poḷeščinas bija 18 kritušie, 51 ievainotais un pāri par 900 apsaldētajiem (90 cilvēkiem apsaldējumi bija smagi, un, braucot ar ragavām uz Daugavpili, vairāki no viniiem nomira pa ceḷam). Automašīnas nedarbojās, zirgu stāvoklis bija katastrofāls. ${ }^{390}$

Laika apstākḷi ietekmēja arī ienaidnieku. Saskaṇā ar 29. janvāra poḷu štāba informāciju Sarkanās armijas pulkos (poḷiem pakḷauto latviešu daḷu frontē atradās 22., 24., 31. pulks, poḷu frontē - 157., 473., 94., 95., 7., 8., 9. pulks) vidējais durkḷu skaits bija krities līdz 150, karavīri bieži padevās. Tomēr gūstekṇi liecināja, ka gaidāms pretuzbrukums (Sarkanās armijas virspavēlnieks patiešām 25. janvārī bija devis pavēli Rietumu frontes pavēlniekam „stingri turēt frontes līniju", aktīvi aizsargājoties un dodoties ìsos pretuzbrukumos, turklāt nevis tajos iecirknos, kur bija gaidāms pretinieka uzbrukums, bet no blakus esošajiem iecirkṇiem. 15. armijai tika pavēlēts dot triecienu „visizdevīgākajā virzienā, nerēkinoties ar uzbrucēja [pretinieka $-\bar{E}$. J.] nacionalitāti”, lai novērstu paredzēto pretinieka uzbrukumu, tomēr tas netika īstenots). ${ }^{391}$ Poḷi šajā laikā ienēma fronti no Sarjankas līdz Plusonam, latvieši - no tā uz ziemeliem gar Nirzas ezeru. 29. janvārī E. Ridzs-Smiglijs pavēlēja turpināt uzbrukumu. Poḷu daḷas sekmīgi traucēja padomju spēku koncentrāciju karaspēka grupas frontē, kamēr 9. Rēzeknes pulks un Vācu zemessargi sasniedza Zilupes upi. 31. janvārī latvieši ieņēma Šķauni un Gubinu, arī 3. Jelgavas pulkam nonākot līdz Zilupei. 1. februārī 9. pulks ieṇēma Pasienu, bet 2. februārī Ziemeḷlatgalē tika ieņemta Augšpils. 3. februārī 3. Jelgavas pulks jau bez kaujas ieṇēma Zilupes austrumu krastu un nostiprinājās uz tā. 4. februārī Latvijas armijas uzbrukums Latgalē pilnībā bija pabeigts. ${ }^{392}$ Atkāpjoties uz Zilupes līniju, ienaidnieks bija izrādījis lielāku pretestību nekā līdz šim (îpaši poḷu 1. Leǵionu brigādes un latviešu labā spārna sektorā). Tomēr, neraugoties uz laika apstākḷiem (atkusnis iestājās tikai 3. februārī), februāra sākumā apvienotā grupa sasniedza paredzēto līniju.

1. februārī stājās spēkā slepenais Latvijas-Padomju Krievijas pamiers, taču Latvijas armijas daļas frontē par to nezināja un bez īpašas pavēles turpināja ierobežotu karadarbību, kuras dēḷ sīkas un nelielas sadursmes

\footnotetext{
388 CAW, WBH, 341. 1. 150, 151, 154; Źołnierz Polski. - 1921. - 22 czerw.

389 AAN, Attachaty, A- II, 81/1; CAW, WBH, 341. 1. 151, 154; Nasz Głos. - 1933. - 1 stycz.

${ }^{390}$ Borkiewicz A. Dzieje 1-go pułku... - S. 459.

391 Какурин Н., Меликов В. Гражданская война в России: война с белополяками. - Москва, 2002. - 26 стр.

${ }^{392}$ Latvijas armija 20 gados. - 232.-233. 1pp.; LVVA, 6033. f., 1. apr., 190. 1., 37. lp.
} 
ar savstarpējiem izlūkgājieniem turpinājās līdz pat miera noslēgšanai 11. augustā (dažkārt izlūkgājieni pārauga nopietnākās kaujās, kurās daudzi krita un nonāca gūstā).

1. februārī grupas fronte dienvidos sniedzās līdz Vjatas (Daugavas pietekas) pagriezienam uz ziemel̦iem, bet ziemel̦os līdz Dekteriem Eversmuižā Ciblas pagastā. Kamēr ūdeṇi bija aizsaluši, šai līnijai nebija dabīgu aizsardzības spēju, tomēr tās priekšā nebija arī ceḷu, kas atvieglotu ienaidniekam kustību. Tas varēja uzbrukt gar Polockas-Drisas dzelzcelu, gar Velikije Luki-Rēzeknes dzelzcelıu vai gar Sebežas-Bukmuižas ceḷu, vienlaikus demonstrējot pie minētajiem dzelzceḷiem. Pēdējā iespēja bija reālāka, tādēl nedrīkstēja piel̦aut ienaidnieka spēku koncentrāciju ziemeḷos no Osvejas ezera. Grupas vadība domāja to novērst ar regulāriem "triecieniem" frontē. Tādēḷ poḷu dalas vietām turpināja virzību (4. februārī 7. pulks ieṇēma Osveju), bija artilērijas apšaude un sadursmes (īpaši 3. divīzijas iecirknī). E. Ridzs-Smiglijs 1. februārī pavēlēja 1. brigādei nodot savu frontes sektoru 3. divīzijai (Prošku-Osvejas-Drisas līnijā) un J. Puriṇa daḷām (Zilupe-Proški ziemeḷos no Osvejas ezera). 1. Leǵionu brigādei vajadzēja doties uz Daugavpili, bet 6. Leǵionu pulkam nomainìt 23. kājnieku pulku Turmantas grupā un doties uz Krāslavu 3. Leǵionu divīzijas pakḷautībā (nomainot 1. brigādes sakaru virsnieku pie 3. Jelgavas pulka ar 3. divīzijas virsnieku). ${ }^{393}$ 7. februārī uz Daugavpili no Dagdas devās 1. un 5. Leǵionu pulka tehniskās rotas, bet no 1. brigādes frontes - 1. lauka artilērijas pulka baterija. 8. februārī latvieši nomainīja 1. Leǵionu pulka 1. un 3. bataljonu un devās uz Dagdu, bet 9. februārī 3. Jelgavas pulks nomainīja arī 2. bataljonu. ${ }^{394} 1$. Leǵionu pulks pārgājienā ieradās Daugavpilī 18. februārī. Savukārt 23. pulks ieradās frontē 15. februārī, nomainot 7. pulku, kas atgāja rezervē, un 16.-18. februārī arī 5. Leǵionu pulku (ieradās Daugavpilī 23. februārī). Tādējādi poḷu 1. brigādi frontē bija nomainījušas poḷu 3. divīzijas un latviešu daḷas, starp kurām sakarus uzturēja poḷu 7. ulānu pulka eskadrons (nomainot 2. un 3. strēlnieku jātnieku pulka karavīrus, kuri atgriezās Polijā). ${ }^{395}$

Februārī-martā notika vienīgi vietēja rakstura sadursmes, Latvijas armija frontē gatavojās pilnībā nomainīt poḷus. Apvienotās grupas frontē ienaidnieks turēja 48. divīzijas 141., 142., 143. pulku ziemeḷos no Osvejas ezera un devinuus (91.-99.) 11. divīzijas pulkus no Osvejas ezera līdz Volinciem. Sākoties šḳīdonim, 3. Leǵionu divīzija atkāpās līdz Poḷeščinas-Saveiku līnijai, jo apvidus ūdeņu dēḷ bija necaurejams. ${ }^{396}$

Apvienotā grupa kaujās Latgalē bija ieguvusi šādas trofejas: brunuvilcienu, 8 lokomotīves, 300 segtus vagonus, 300 dzelzceḷa platformas, 5 lielgabalus,

\footnotetext{
${ }^{393}$ LVVA, 3601. f., 1. apr., 471. 1., 67.- 70. 1p.; 1515. f., 1. apr., 694. 1., 22.-35. 1p.; CAW, WBH, 341.1. 150; Latvijas Kareivis. - 1920. - 8., 11. febr.

394 1. Leǵionu pulka 7. rotas komandieris A. Borkēvičs vēlāk atcerējās, ka "laipnais" latviešu 3. Jelgavas pulka 1. bataljona komandieris paātrinājis maiṇu, pēc kuras latviešu un poḷu virsnieki apmainījušies ar kokardēm, apliecinot "ieroču brālību”. - Borkiewicz A. Dzieje 1-go pułku... - S. 464.

395 CAW, WBH, 341. 1. 151, 155; Broniewski W. Pamiętnik... - S. 162.

${ }^{396}$ LVVA, 3601. f., 1. apr., 471. 1., 2. 1p.; 9. Rēzeknes k. p. gaitas. - 143. 1pp.
} 
ieročus un munīciju. ${ }^{397}$ Bruṇojums tika nodots Latvijas armijai. Jau 5. janvārī latviešu 2. bruṇuvilciens Daugavpilī no poḷiem saṇēma 200 lādiṇus, čaulas, 55 šautenes un patronas, savukārt A. Veiss 13. februārī ziṇoja uz Rīgu, ka poḷi sagatavojuši nodošanai 1047 šautenes un lūdz atsūtìt pieṇēmēju. ${ }^{398}$

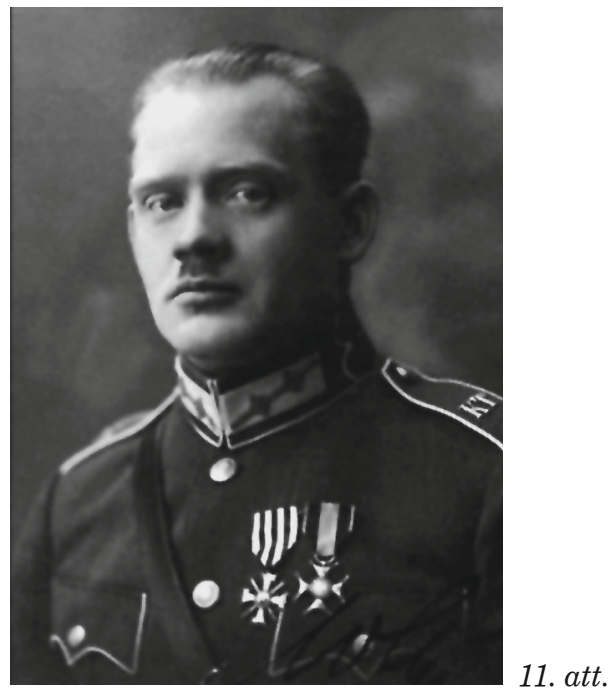

\section{Latvijas armijas sakaru virsnieks poḷu štābā Aleksandrs Veiss}

Latvijas armija Latgalē bija zaudējusi ap 400 karavīru. ${ }^{399}$ Polu 1. Leǵionu brigādē, uz kuras gūlās galvenais cīṇu smagums, bija 106 kritušie, 392 ievainotie un 30 bezvēsts pazudušie (1. Leǵtionu pulkā attiecīgi 59, 232 un 24, bet 5. Leǵionu pulkā - 47, 160 un 6). Daudz bija apsaldēto. Tikai 1. Leǵionu pulkā vien 368 smagi apsaldēti, 252 viegli apsaldēti karavīri. Daudzi ievainotie vēlāk nomira. Hospitāḷos Daugavpilī mira 12, bet Polijā - vēl 4 karavīri no 1. pulka vien. ${ }^{400}$ Zaudējumi bija arī 6. Leǵionu pulkā un 3. divīzijā. Krāslavā poḷu karavīru kapos guldīti 45 zināmi un 42 nezināmi šīs divīzijas karavīri. Poḷu karavīru kapi ir Daugavpilī, Višķos, pie Juzefovas, Varnavičos, Laucesē (kur apglabāti jau 1919. gadā kritušie) un citur Latvijā. ${ }^{401}$

Par varonību Latgales kaujās pavisam tika apbalvoti 63 Polijas armijas karavīri. Viṇi saṇēma Lāčplēša kara ordeni (maršals J. Pilsudskis - pirmās

397 1. Leǵionu pulks ieguva trīs lielgabalus, 31 ložmetēju, 635 šautenes, 11 telefona aparātus, 195 rokasgranātas un 64 munīcijas kastes, 4 lokomotīves, 47 vagonus, vezumus, bet 5. Legínu pulks: lielgabalu, 24 ložmetējus utt. - Borkiewicz A. Dzieje 1-go pułku... - S. 471; Babiński K. Zarys historji... - S. 49.

398 LVVA, 3601. f., 9. apr., 353. 1., 117. 1p.

399 Andersons E. Latvijas vēsture 1914-1920. - 575. 1pp.

400 Borkiewicz A. Dzieje 1 - go pułku... - S. 471, 985-1029; Babiński K. Zarys historji... - S. 49.

${ }^{401}$ Likerts V. Brīvības un kritušo pieminekḷi. - Rīga, 1938. - 132.-133. lpp. Sīkāk sk.: Groby źołnierzy polskich na Łotwie. Poḷu karavīru kapi Latvijā//Groby źołnierzy polskich (1919-1920) na Łotwie/ Red. J. Sozański. - Ryga, 1995. - S. 38-43. 
šḳiras ordeni, ǵenerāḷi E. Ridzs-Smiglijs, S. Šeptickis un J. Rummels - otrās šķiras, pārējie ${ }^{402}$ - trešās šķiras Lāčplēša kara ordeni), ${ }^{403}$ bet astoṇi Latvijas armijas virsnieki (ǵgenerāḷi J. Balodis, P. Radziņš, E. Kalniņš, pulkveži J. Puriņš, E. Laimiņš, A. Tone, K. Ramats, A. Veiss) saṇēma dažādu šḳiru Polijas "Virtuti Militari" ordeni.

\section{Armiju sadarbība un apgāde operācijas laikā}

Latvijas un Polijas armiju sadarbība Latgales atbrīvošanas laikā bija veiksmīga. Lielā mērā par to jāpateicas pulkvedim-leitnantam A. Veisam, kurš, kā teica P. Radziņš, sekmīgi pildīja sakaru virsnieka pienākumus poḷu štābā. Pats viṇš no tiem bija noguris, jo „vajadzējis vairāk politisku nekā militāru iemanu". No komandējuma poḷu štābā, kur vinam palīdzēja Latvijas armijas Virspavēlnieka štāba Operatīvās daḷas virsleitnants H. Pētersons, ${ }^{404}$ A. Veiss atgriezās 12. aprīlī. ${ }^{405}$

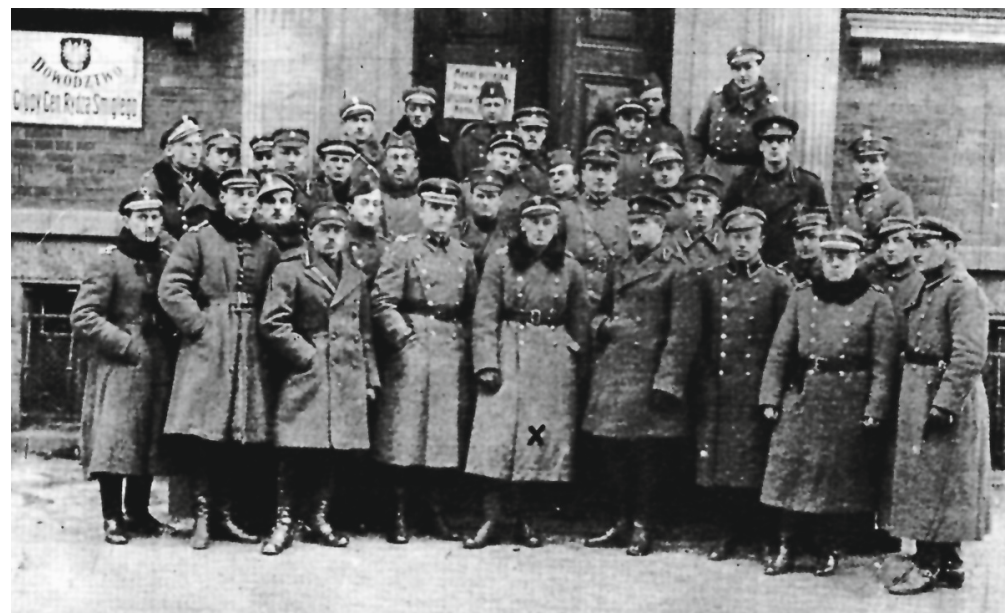

12. att.

Poḷu-latviešu karaspēka grupas štābs Daugavpilī 1920. gada janvārī (centrā - E. Ridzs-Smiglijs un A. Veiss)

402 Starp trešās šḳiras kavalieriem 12 bija no 5., 11 no 1., seši no 6. Leǵionu pulka, pieci no 1. lauka artilērijas pulka, pa vienam no 7. ulānu pulka, 23. kājnieku pulka, 1. brigādes štāba, tehniskās grupas, 3. artilērijas brigādes; pa diviem no 1. un 3. divīzijas štāba; 14 no 3. divīzijas kājnieku pulka. Apbalvojamo sarakstu pēc Latvijas kara aǵenta (militārā atašeja ) lūguma 1925. gadā sastādīja E. Ridzs-Smiglijs (izṇēmums bija maršals J. Pilsudskis, ǵenerālis S. Šeptickis, L. Berbeckis, E. Ridzs-Smiglijs, pulkvedis T. Kučeba un bijušais militārais pārstāvis Latvijā majors A. Miškovskis. Viņus personīgi apbalvoja Latvijas armijas Galvenā štāba priekšnieks M. Peniķis 1922. gadā Varšavā. - Źołnierz Polski. - 1922. - 19, 26 marzec). - LVVA, 3602. f., 1. apr., 1.-9. 1.

${ }^{403}$ LVVA, 1304. f., 1. apr., 1843. 1.; 1474. f., 1. apr., 634. 1., 2.-4. 1p.; 5601. f., 1. apr., 1828., 4865. 1. Par poḷu karavīriem - Lāčplēša orden̦a kavalieriem sk.: Lāčplēša Kara ordeṇa kavalieri. Biogrāfiska vārdnīca. - Rīga, 1995.

${ }^{404}$ H. Pētersons 1922. gadā kopā ar vēl četriem Latvijas armijas virsniekiem - kopīgo cīṇu dalībniekiem (H. Rozenšteinu, J. Dombrovski, M. Hartmani, Ž. Bahu) - tika apbalvots ar Polijas Drošsirdīgo krustu. - Apsardzības ministra 1922. gada 30. nov. pavēle.

${ }^{405}$ LVVA, 5601. f., 1. apr., 6876. 1., 2. 1p.; 3601. f., 9. apr., 354. 1., 145. 1. 
Saskaṇā ar P. Radziṇa atzinumu poḷu štābs un personīgi E. Ridzs-Smiglijs pilnībā neizmantoja savas komandiera tiesības pret padotajām Latvijas armijas daḷām un vairāk izturējās pret tām kā pret sabiedroto. Nemot vērā, ka sarunās pirms līguma noslēgšanas latviešu daḷu pakḷaušana poḷiem bija viena no galvenajām viṇu prasībām, jāsecina, ka tai bija vairāk politiska nekā militāra nozīme. ${ }^{406}$

Uzbrukuma pirmajā dienā 1. Leǵionu pulks saṇēma pavēli - ar patruḷu strapniecību uzturēt sakarus ar 3. Jelgavas pulku un latviešus par situāciju informēt vienīgi vispārīgi, nesniegt sīkākas ziṇas, taču izturēties pret tiem uzsvērti draudzīgi. Tā labi raksturo abu armiju savstarpējo nostāju, kurai operācijas sākumā bija raksturīgs demonstratīvs draudzīgums un zināma piesardzība. Operatīvās pavēles grupas štābs latviešu daḷām nosūtīja ar A. Veisa starpniecību, retāk - tieši J. Puriṇam. No 16. janvāra Rušonas stacijā darbojās poḷu ziṇu nodošanas punkts (28 poḷu jātnieki nogādāja stafeti uz Daugavpili un J. Puriņa štābu). Pie 3. Jelgavas pulka atradās poḷu sakaru virsnieks no 1. Leǵionu brigādes štāba ( $\operatorname{līdz} 6$. martam kapteinis Z. Kučin,skis, vēlāk - podporučņiks V. Kšižanovskis). ${ }^{407}$

Dažkārt ziṇas par latviešu daḷu stāvokli poḷi saṇēma novēloti. 17. janvārī E. Ridzs-Smiglijs uz to norādīja J. Puriṇam. Šajā laikā starp poḷu štābu un A. Veisu bija radies zināms saspīlējums. 18. janvārī viṇš ziṇojumā E. Ridzam-Smiglijam secināja, ka nav uzaicināts uz pēdējām operatīvā stāvokḷa apspriedēm un nav parakstījis pavēles kā otrais štāba priekšnieks. 20. janvārī E. Ridzs-Smiglijs paskaidroja, ka poḷu štābos tā priekšnieks nav komandiera vietnieks un ar savu parakstu vienīgi apstiprina pavēles autentiskumu; operatīvos jautājumus izlemj grupas komandieris, bet apspriedēs štāba priekšnieks vienīgi informē par izdotajām pavēlēm. Grupas komandieris apsolìja, ka, neraugoties uz šo apspriežu "iekšējo raksturu”, turpmāk A. Veiss uz tām tiks aicināts un viñam būs tiesības uzstāties. Komandieris arī solīja, ka turpmāk pavēles latviešu daḷām parakstīs personīgi un pēc tam tās nodos A. Veisam tulkošanai un parakstīšanai. Lai pilnībā novērstu pārpratuma sekas, Veiss 22. janvārī tika uzaicināts uz pusdienām poḷu virsnieku klubā. ${ }^{408}$

Armiju sadarbībai svarīgi bija telegrāfiskie sakari starp Rīgu, Daugavpili, Viḷnu, Varšavu, karaspēka daḷām Latgalē. Ridzs-Smiglijs 20. janvārī lūdza A. Veisu veicināt sakaru nodibināšanu starp Rīgu un Poliju, jo pašreizējie radiotelegrāfa sakari sadarbību sarežğìja. Arī Latvijas puse bija ieinteresēta nodibināt stabilus sakarus. Līdz šim Lietuvas noraidošās nostājas dēl telegrāfa sakari ar Poliju tika uzturēti caur Dāniju un Vāciju. 1920. gada 9. janvārī Latvijas satiksmes un darba ministrs T. Hermanovskis lūdza Ārlietu ministriju panākt, lai poḷi uzbūvētu sakaru līnijas posmu līdz Daugavpilij. ${ }^{409}$ 20. februārī poḷi pabeidza Varšavas-Viḷnnas-Daugavpils līnijas būvi, un 24. februārī viṇi piedāvāja divu vadu līnijas atklāšanai "palīdzību ar cilvēkiem,

\footnotetext{
406 Radziņš P. Latvijas atbrīvošanas karš. -29 . lpp.

${ }^{407}$ CAW, WBH, 341. 1. 154, 155, 156. Janvāra beigās poḷu sakaru virsnieks 3. Jelgavas pulkā podporučņiks Višn,evskis ar divu jātnieku starpniecību sūtīja ziņojumus uz 1. brigādes štābu divas reizes dienā.

${ }^{408}$ LVVA, 2601. f., 1. apr., 471. 1., 7., 13.-14., 27. 1p.

409 Turpat, 16. 1p.; 2574. f., 3. apr., 13. 1., 157. lp.
} 
materiāliem un instrumentiem" Daugavpils-Rīgas līnijā. ${ }^{410}$ Pēc tam Latvijas iestādes ar poḷu 1. Leǵionu divīzijas telegrāfa rotas speciālistu palīdzību saremontēja līniju, un februāra beigās tika nodibināti telegrāfa sakari starp Rīgu un Varšavu. ${ }^{411}$ Tomēr nebūtu pareizi uzskatīt, ka Latvijas puse necentās neko darìt šajā lietā. Jau 4. janvārī uz Daugavpili nodibināt sakarus ar Rīgu devās Atsevišķās telegrāfa un telefona rotas centrāles karavīri, kas 7. janvārī sāka apkalpot latviešu iestādes pilsētā. Taču sakarus ar Rīgu nodibināt neizdevās, jo gar dzelzceḷu bijušās līnijas bija izpostītas un telefonogrammas pa lauka kabeli tika nodotas uz Nīcgali, tad - uz Stukmaņiem un no turienes uz Rīgu. Izmantot līnijas, kas atrodas Daugavas kreisajā krastā, nepiel̦āva tur esošie lietuvieši, bet līnijas, kas stiepās gar dzelzceḷu, remontēja, un remonts sala dēl ieilga. Tomēr rotas karavīri 31. janvārī iedarbināja RīgasKrustpils-Rēzeknes līniju. ${ }^{412}$ Savukārt poḷu 1. Leǵionu divīzijas telegrāfa rota bija ieradusies Daugavpilī 3. janvārī un kā trofeju ieguvusi telefona centrāli. Telefona sakarus ar štābu, kas atradās Kalkūnē, rota nodibināja 5. janvārī, bet 6. janvārī darbu Daugavpilī sāka poḷu telefona centrāle. Vēlāk rota izremontēja līniju uz Viškiiem, no turienes uz Rušonu un Rēzekni, kur atradās J. Puriṇa štābs, kā arī Daugavpils-Krāslavas līniju. Turklāt poḷu sakarnieki uzbūvēja jaunu līniju (Daugavpils-Līksna-Glaudāni), lai kontrolētu ledus kustību Daugavā. ${ }^{413}$ Tas viss ievērojami atviegloja armiju sadarbību (A. Veiss jau 2. februārī lūdza nodibināt tiešus sakarus starp Daugavpili un Rēzekni, jo bez tiem viņš esot "kā bez rokām"114).

Operācijas sākumā un dažkārt arī vēlāk poḷu puse Latvijas armijas kaujasspējas nevērtēja visai augstu. Poḷu 4. pretizlūkošanas posteņa vadītājs Daugavpilī februāra sākumā ziṇoja: "Līdz šim kontakts ar latviešiem samērā vājš. Pie viniem valda liela nekārtība un kukuḷnemšana. Par naudu visu var izdarìt."“115 Arī P. Radziṇš uzsvēra, ka poḷi nepazina "mūsu improvizēto, uz ātru roku saformēto karaspēku”, ${ }^{416}$ kurš atšķīrās no Polijas armijas, kas jau bija pilnībā noformējusies kā labi apgādāta un saskaņota militāra struktūra. Latvijas armijā tiešām bija disciplīnas pārkāpumi, taču tie bija raksturīgi arī Polijas armijai, kuras izveidošanās un apgādes apstākḷi bija daudz labvēlīgāki. Operācijas gaitā poḷi pārliecinājās, ka viedoklis par Latvijas armijas zemajām kaujasspējām un lieliniecisma iespaidu uz armiju bijis lielā mērā maldīgs. To atzina arī A. Miškovskis, kurš pēc Kurzemes divīzijas apmeklējuma Rēzeknē janvārī ziṇoja uz Varšavu, ka "tendenciozās baumas" par lieliniecismu Latvijas armijā ir l,oti pārspīlētas. ${ }^{417}$

Saskaṇā ar vienošanos Latvijas pusei uzbrukuma sākumā bija jāapgādā poḷu puses zirgi ar lopbarību, bet no 7. dienas pēc operācijas sākuma karavīri

\footnotetext{
410 Turpat, 3601. f., 9. apr., 353. 1., 137. 1.; 354. 1., 95. 1.

411 Staniewicz W. Zarys historji... - S. 5; Jaunākās Ziṇas. - 1920. - 2. marts.

${ }^{412}$ LKM, Antens P., 303.-304. 1p.

413 Staniewicz W. Zarys historji... - S. 5; CAW, WBH, 341. 1. 154.

${ }^{414}$ LVVA, 3601. f., 9. apr., 353. 1., 12. 1p.

415 AAN, Instytucje wojskowe, t. 296/1 - 62, k. 80.

416 Radziņš P. Latvijas atbrīvošanas karš. -28 . lpp.

417 AAN, Attachaty, A - II, 81/1.
} 
jānodrošina ar pārtiku. ${ }^{418}$ Poḷiem bija jābūt līdzi pārtikas rezervei trīs dienām (vēlāk puses vienojās par lopbarības piegādi no 3. dienas, bet par pārtikas piegādi - no 10. dienas ${ }^{419}$ ). Tādēl poḷi akciju sāka ar zināmām pārtikas rezervēm, ${ }^{420}$ taču solītajā laikā viṇi pārtiku no latviešu intendantūras iestādēm nebija saṇēmuši. P. Radziņš rakstīja: "Nemot vērā mūsu trūcīgos apstākḷus, mums, zināms, nebija viegli piegādāt uzturu poḷiem, bet, ja mēs to bijām apnēēmušies, tad mums vajadzēja to pildìt." 6. janvārī A. Miškovskis viṇam minēja, ka vēl nekas nav nosūtīts. Sakarā ar slepenību iepriekšèji norādījumi saimniecības iestādēm par gaidāmo poḷu apgādi netika doti un tās nevarēja pienācīgi sagatavoties. P. Radziṇam bija "jālieto visasākie draudi, lai kaut kas tiktu sūtīts““. ${ }^{421}$

7. janvārī Daugavpilī iebraukušais Armijas saimniecības pārvaldes nodaḷas priekšnieka vietas izpildītājs leitnants $H$. Dzelzîtis ziṇoja, ka poḷi nekavējoties pieprasa 10000 pudus rudzu miltu, 15000 pudus auzu un 2000 pudus gaḷas un turpmāk lūdz ik dienu piegādāt 500 pudus gaḷas, norādot, ka ar pārējiem produktiem viṇi ir apgādāti līdz 20. janvārim. Ap 12. janvāri H. Dzelzītis organizēja Daugavpilī pārtikas noliktavu poḷu karavīru un tur esošā latviešu karaspēka apgādei, bet pārtika no Rīgas sāka pienākt tikai 14. janvārī. ${ }^{422}$

Tādējādi poḷi bija spiesti organizēt frontes un aizmugures daḷu apgādi no saviem krājumiem. 5. janvārī grupas intendantūra ierīkoja apgādes punktu Maḷinovkā, 6. janvārī - uz dzelzcel̦a aiz tās, vēl pēc dažām dienām - Rušonā (caur to pārtiku saṇēma arī 3. Jelgavas kājnieku pulks). No Polijas cauri Kalkūnei un poḷu noliktavai Daugavpilī (Varšavas ielā) pienāca arī munīcija 1. Leǵionu brigādei frontē. No 11. janvāra katru dienu no Daugavpils uz Dubnas staciju kursēja poḷu apgādes vilciens. Janvāra beigās 1. Leǵionu brigādes etapu punkts tika pārvietots no Rušonas stacijas uz Baltinas (tag. Skaistas) staciju Krāslavas-Baḷbinovas līnijā). ${ }^{423}$

Vienlaikus Latvijas armijas saimnieciskās iestādes panāca, ka poḷu štābs piekrīt par ceturtdaḷu samazināt karavīram gaḷas devu (Polijas armijas devas bija lielākas). Latvieši apsolīja iespēju robežās piegādāt zivju vietā gaḷu, lūdza poḷus sagādāt cukuru, taukvielas, marmelādi un speḳi no Polijas (vēlāk pieprasot par to rēḳinu Latvijas pusei) un apṇēmās vest uz Daugavpili tikai auzas, jo salmus un sienu bija paredzèts rekvizēt un nodot poḷiem ar Apgādības ministrijas pārstāvjiem uz vietas. Poḷu prasība pēc cigaretēm un konjaka tika noraidìta, jo "Latvijā diez vai to būšot iespējams iegādāties". ${ }^{424}$

\footnotetext{
418 A. Miškovskis jau 1919. gada 27. decembrī ziņoja, ka latvieši pārtiku varēs piegādāt tikai ar 15. janvāri. Par to viņu bija brīdinājis P. Radziņš. - CAW, WBH, 341. 1. 150.

${ }^{419}$ LVVA, 3601. f. 1. apr., 248. 1., 317. 1p.

${ }^{420}$ Uzbrukumā tieši iesaistītajiem karavīriem izsniedza spēcinātas brokastis, katram līdzi dodot gaļas konservu kārbu un divas paciṇas sausiṇu. - CAW, WBH, 341. 1. 150.

${ }^{421}$ Radziņš P. Latvijas atbrīvošanas karš. - 79.- 80. lpp.

${ }^{422}$ LVVA, 3605. f., 1. apr., 197.1., 2., 4. 1p.; 6033. f., 1. apr., 24. 1., 9. lp. Latviešu piegādāto pārtiku izmantoja karaspēka apgādei tikai Daugavas labajā krastā. Turmantas grupa saṇēma no Polijas atvesto pārtiku Kalkūnes stacijā. - CAW, WBH, 341. 1. 155.

423 CAW, WBH, 341. 1. 152, 155, 157.

${ }^{424}$ LVVA, 3605. f., 1. apr., 197. 1., 102. 1p.
} 
16. janvārī E. Ridzs-Smiglijs lūdza katras desmit dienas piegādāt poḷu noliktavā Daugavpils Preču stacijā pārtiku un lopbarību 1200 virsniekiem, 35000 karavīru un 15000 zirgu; 500 litru petrolejas un 20 tonnu oglu, kā arī 1000 steru malkas. ${ }^{425}$ Minētais karavīru skaits pārsniedza līgumā paredzētos 30 000, tādēl E. Ridzs-Smiglijs 20. janvārī A. Veisam skaidroja, ka reāli poḷu daḷās ir 35000 vīru. ${ }^{426}$ Izsakot savu izpratni par Latvijas puses saimnieciskajām grūtībām, ğenerālis lūdza iesniegt priekšlikumus, kā noregulēt un atvieglot apgādi. ${ }^{427}$

Saskaṇā ar 16. janvāra vienošanos palielināja poḷu karavīru skaitu un Latvijā l̦āva ievest vienu ulānu pulku. A. Miškovskis 18. janvārī atzina, ka latvieši uztvēruši to kā smagu noteikumu tieši apgādes dēḷ un lūguši, lai kopējais poḷu grupas zirgu skaits nepārsniegtu 10000 (A. Miškovskis atzīmēja, ka visā Latvijas armijā pagaidām ir tikai 7000 zirgu). ${ }^{428}$

A. Veiss 23. janvārī uzskaitīja produktus, kuri poḷiem bija piegādāti no 14. līdz 22. janvārim, un paskaidroja, ka viṇam nav turpmākās apgādes plāna. ${ }^{429}$ Tas poḷu intendantūrai netika iesniegts, piegādes notika neregulāri, produkti ne vienmēr bija kvalitatīvi. Sevišķi lielas pretenzijas bija pret kaltētajām zivīm, ko pirms lietošanas vajadzēja vairākas dienas sala apstākḷos mērcēt, un skābajiem kāpostiem, kuri bieži bija bojāti. ${ }^{430}$ Karaspēkam frontē trūka medikamentu, ieroču el̦las, taukvielu un gal,as produktu. ${ }^{431}$

26. janvārī Daugavpilī abu pušu virspavēlnieki vienojās, ka latvieši piegādās pārtiku līdz 10. februārim, bet vēlāk - tikai maizi un lopbarību, kamēr pārējo poḷu intendantūra iepirks no zemniekiem par Latvijas saimniecības iestāžu apstiprinātām cenām. Tomēr arī līdz 10. februārim netika piegādāta pat puse no paredzētā. Trūkstošie produkti tika piegādāti pēc šī datuma, tomēr 18. februārī E. Ridzs-Smiglijs uzsvēra, ka grupa ir spējīga darboties, vienīgi pateicoties "Centrālo Polijas iestāžu" atbalstam. ${ }^{432}$

Tikai 10. martā tika dota pavēle nogādāt uz Daugavpili trūkstošos miltus, daḷu gal̦as, zivis, putraimus, saknes, kafiju, sīpolus, piparus, auzas, sienu. Turpretī marmelādes krājumi nebija pietiekami. Martā piegāžu lietas nokārtošanai Armijas saimniecības pārvalde komandēja uz Daugavpili sevišḳu uzdevumu kara laika vecāko ierēdni R. Brencēnu. ${ }^{433}$

\footnotetext{
${ }^{425}$ CAW, II ND WP, t. 24.

426 1920. gada janvāra sākumā poḷu intendantūra iesniedza prasību jau par 28000 apgādāmajiem karavīriem un 7500 zirgiem. Pēc dažām dienām A. Miškovskis minēja 35000 vīrus un 10000 zirgus. Galīgais skaits Latvijas pusei tā arī palika neskaidrs. Aprīlī puses vienojās par šo skaitli, kaut arī poḷi centās panākt vēl lielāka skaiț̣a akceptēšanu. - LVVA, 3601. f., 1. apr., 248. 1., 317. 1p.; 3605. f., 1. apr., 105. 1., 38. 1p.

${ }^{427}$ LVVA, 3601. f., 1. apr., 471. 1., 11., 16., 26.-27. 1p.

${ }^{428}$ CAW, II ND WP, t. 24. Latvijā izvietotajā Polijas armijas 7. ulānu pulkā 1920. gada februāra vidū kopumā bija 786 zirgi. - Smoliński A. Jazda Rzeczypospolitej Polskiej... - S. 342.

${ }^{429}$ LVVA, 3601. f., 1. apr., 471. 1., 26. 1p.

${ }^{430}$ Borkiewicz A. Dzieje 1 - go puku ... - S. 471.

431 AAN, Attachaty, A - II, 81/1; CAW, WBH, 341.1. 154.

432 Turpat, 3601. f., 9. apr., 353. 1., 72. 1p.; 3605. f., 1. apr., 197. 1., 60. 1p.

433 Turpat, 3605. f., 1. apr., 197. 1., 38., 72. 1p.
} 
Janvārī par Apgādības ministrijas pārstāvi pie Polijas armijas tika iecelts K. Līkums, kurš ieradās Daugavpilī. Viṇam bija padoti trīs ierēdṇi (aǵenti), un katrs no tiem bija atbildīgs par savu (Višķu-Pužānu, Krāslavas un DagdasBukmuižas) iecirkni. Viṇu uzdevums bija rekvizèt lopbarību no vietējiem zemniekiem un nodot to poḷu karaspēkam. Darba apstākḷi bija sarežǵiti. Zemniekiem, kuri devās nodot auzas vai sienu, dažkārt jau pa ceḷam visu atṇēma poḷi, samaksājot 6-10 Polijas markas par pudu. Višk,os strādājošais ierēdnis A. Klucis 3. februārī ziṇoja, ka turpina pienākt jaunas poḷu vienības ar zirgiem, kuriem trūkst lopbarības, bet vietējais poḷu komandieris apgalvo, ka viņam jāpabaro 400 zirgu (dienā nepieciešams vismaz 150 pudu siena). A. Klucis lūdza panākt, lai poḷiem aizliegtu "brīvu iepirkšanu", kas faktiski izvērtās vienkāršā lopbarības atṇemšanā, draudot ar "nagaiku". ${ }^{434}$ Latvijas armijas saimnieciskās iestādes vairākkārt centās panākt, lai poḷu vienību zirgi saņemtu lopbarību vienīgi no minētajiem ierēdṇiem, taču mēǵinājumi bija nesekmīgi gan vinuu nevarības dēḷ (kopumā tie nodeva poḷiem 1697 pudus auzu, 11233 pudus siena, 2287 pudus salmu un 45 pudus kartupeḷu), gan arī poḷu patvarību dēl,.435

Lai atvieglotu stāvokli ar poḷu apgādi, Latvijas Armijas apgādības pārvalde 3. februārī piekrita iepirkt pārtikas preces par poḷu piedāvātajām cenām (Polijas markās), kuras nebija mākslīgi pazeminātas. Savukārt Apgādības ministrija centās reǵistrēt poḷu rekvizētos, pirktos un nolaupìtos krājumus. K. Līkums rēkināja, ka līdz 20. februārim rekvizēti vismaz 10000 pudi siena, 620 pudi gaḷas un 2000 pudi auzu. ${ }^{436}$ Spriežot pēc rekvizīciju un laupīšanu skaita, reālie skaitḷi bija lielāki.

Martā A. Miškovskis trūkstošo piegāžu segšanai lūdza izsniegt 2000000 Latvijas rubḷu lielu avansu produktu iepirkšanai Latgalē. ${ }^{437}$ Summa pieškirta netika, un galīgā norēḳināšanās notika tikai Latviešu-poḷu likvidācijas komisijā maijā.

\section{Poḷ karaspēks Latgalē un tã attiecības ar Latvijas iestādēm}

Tūlìt pēc Daugavpils ieṇemšanas pilsēta kḷuva par poḷu karaspēka grupas bāzi. Bez garnizona šeit atradās grupas štābs, saimnieciskās iestādes (trīs pirtis, veḷas mazgātava, divas maizes ceptuves, lopkautuve, virsnieku èdnīca - „kazino”, pasts, karavīru nakts patversme un barošanas punkts, bēgḷu stacija), daḷa no Tehniskās grupas (4. un 16. dzelzceḷa kolonna, 1. un 2. tiltu un tehnisko ierīču kolonna, celtniecības rota, prožektoru vads), 13., 14., 15. vezumnieku kolonna, 22. un 27. autokolonna ar darbnīcām, 523. gūstekṇu savākšanas stacija, viena pārtikas un divas munīcijas

\footnotetext{
434 Turpat, 2574. f., 3. apr., 17. 1., 115. lp. Jau 1919. gadā Latvijas teritorija bija sadalīta 40 iecirkņos ar Apgādības ministrijas pilnvarotajiem, kuri savāca rekvizēto pārtiku, lai nodotu to tālāk armijai. - Bērziņš P. Karaspēka īsa saimniecības vēsture. - Rīga, 1924. - 151. 1pp.

${ }^{435}$ LVVA, 3601. f., 1. apr., 248. 1., 327. 1p.; 2574. f., 3. apr., 17. 1., 457.-466. 1p.

436 Turpat, 3605. f., 1. apr., 197. 1., 15. 1p.; 3601. f., 9.apr., 354. 1., 154. 1p.

437 Turpat, 3601. f., 1. apr., 248. 1., 317. 1p.
} 
noliktavas, 9. radiostacija, 101. un 102. lauka hospitālis, vairākas mazākas medicīnas iestādes, 1. zirgu hospitālis, 3. Krakovas etapu bataljons, no 16. janvāra - arī 1. aviācijas eskadriḷa un trīs 8. eskadriḷas lidmašīnas. Turklāt Kalkūnē bija vēl viena karavīru naktsmītne, bet Kalkūnes-Turmantas dzelzcela līnijā bez brunuvilciena "Śmigły" - arī sanitārais vilciens. Citur atradās: 30. zirgu hospitālis (Červonkā), 17. vezumnieku kolonna (Varnavičos), sanitārās priekšgrupas (Baḷbinovā un pretī Krāslavai Daugavas kreisajā krastā; turpat arī tiltu rota), 1. un 3. sanitārais vilciens (starp Krāslavu un Baḷbinovu), pārtikas priekšgrupa, apǵērbu noliktava, 3. divīzijas štābs, 21., 22. vezumnieku kolonna, četras sapieru rotas, 113. un 602. lauka hospitālis (Krāslavā), slimnieku savākšanas punkts, 1. brigādes štābs un 13. vezumnieku kolonna (Dagdā). 27. janvārī no Rušonas uz Baltiṇu pārvietojās 1. brigādes aizmugures daḷas ar 12 . vezumnieku kolonnu. ${ }^{438}$

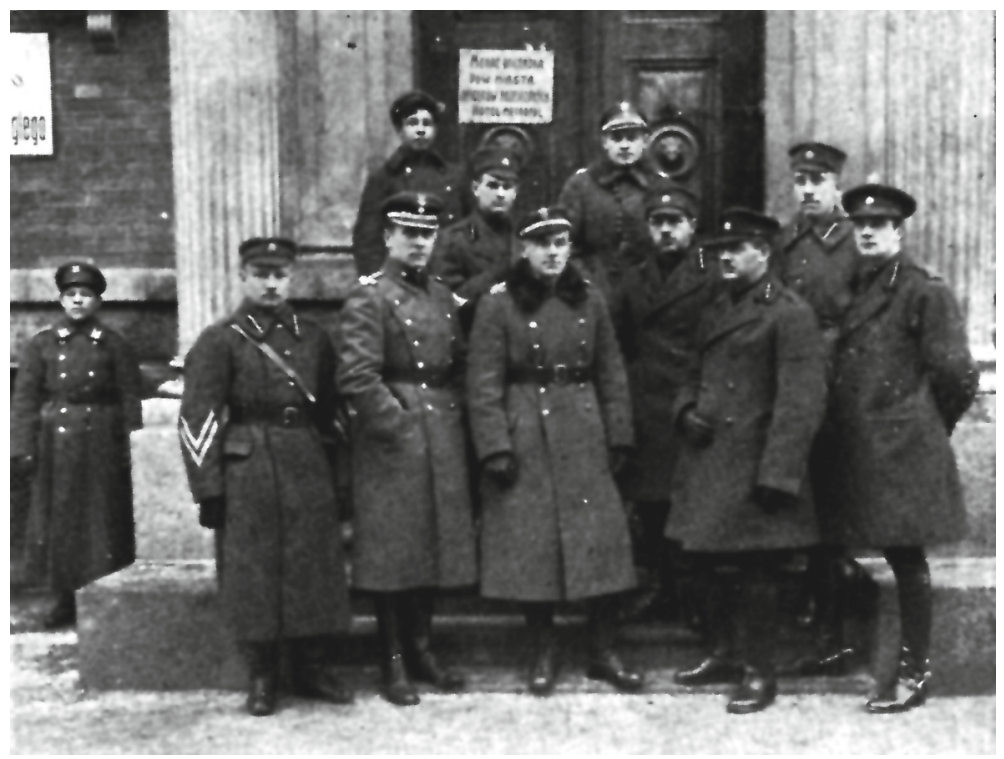

13. att.

\section{Poḷu un latviešu virsnieku grupa Daugavpili 1920. gada janvārī}

Karaspēka apgādei un darbībai svarīga bija satiksme pāri Daugavai. Tilti bija izpostīti, tādēḷ, sākot pastāvīgo tiltu remontu, Tehniskā grupa (1. sapieru bataljona rota, 1 . un 2. tiltu rota, 3. sapieru bataljona rota un vads, 7., 8., 9. Leǵionu kājnieku un 23. kājnieku pulka tehniskā rota, 2. sapieru bataljona rota, 1. divīzijas prožektoru vads un celtniecības rota, tehniskās kolonnas ${ }^{439}$ kapteiṇa L. Hickēviča vadībā 10 dienās uzcēla pagaidu tiltus Daugavpilī un Krāslavā. Jau 4. janvārī L. Hickēviča rīcībā tika nodoti 180 karagūstekṇi, bet

${ }^{438}$ CAW, WBH, 341. 1. 155, 157; AAN, Attachaty, A - II, 64/1, k. 16, 52.

439 Tehniskajā grupā ietilpa 1. sapieru bataljona rota, 1. un 2. tiltu rota, 3. sapieru bataljona rota un vads, 7., 8., 9. un 23. pulka tehniskās rotas, 2. sapieru bataljona rota, 1. divīzijas prožektoru vads un celtniecības rota, tehniskās kolonnas. 
18. janvārī sāktajā dzelzceḷa tilta ${ }^{440}$ atjaunošanā piedalījās 300 gūstekṇu un tikpat daudz algotu vietējo civiliedzīvotāju. ${ }^{441}$ Janvāra beigās J. Balodis solīja J. Pilsudskim palīdzēt būvēt tiltu Daugavpilī, tomēr vēl 12. februārī poḷu štāba priekšnieks T. Kučeba lūdza A. Veisu novērst kvalificētu strādnieku vervēšanu Daugavpilī darbiem Rīgā. ${ }^{442}$ Arī Krāslavā poli pastāvīgā tilta būvē iesaistīja civiliedzīvotājus. Spriežot pēc miesta valdes priekšsēdētāja poḷa F. Miltoviča sūdzībām, civiliedzīvotāji ne vienmēr tam piekrita. ${ }^{443}$ Turklāt poḷi janvārī uzbūvēja pagaidu tiltu pie Rozališḳiem, Maḷinovkas pagastā pāri Līksnas upei un vēl vairākās vietās, kā arī atjaunoja uzspridzināto dzelzceḷa tiltu pāri Sarjankai Daugavpils-Polockas līnijā.444 Daugavpilī, būvējot dzelzceḷa tiltu, poḷi iedarbināja kokzāǵētavas, nelielu elektrostaciju, atvēra vairākas darbnīcas. Starp būvē nodarbinātajiem gūstekṇiem bija izcēlusies izsituma tīfa epidēmija, tāpēc tika uzcelts neliels hospitālis. Kokmateriālus piegādāja no apkārtnes mežiem. ${ }^{445}$

Marta sākumā ledus Daugavā sāka kustēties un pagaidu tiltus vajadzēja nojaukt. Poḷu štābs organizēja ierobežotu pārcelšanu ar laivām pāri Daugavai par samaksu. Biḷetes varēja iegādāties Tehniskās grupas štābā pie tilta (vēlāk pēc poḷu karaspēka lielākās daḷas aiziešanas pārvadāšanu organizēt uzṇēmās Daugavpils pilsētas valde). ${ }^{446}$

Tūlìt pēc operācijas sākuma vajadzēja atrisināt dzelzceḷa izmantošanas jautājumus. 10. janvārī Daugavpilī Latvijas armijas Kara satiksmes pārvaldes priekšnieks P. Ozols un poḷu grupas štāba priekšnieks T. Kučeba vienojās, ka dzelzceḷa kalpotāji Daugavpilī ir administratīvi paḳ̦auti Latvijas Dzelzceḷu valdei (izṇemot poliem nodoto posmu līdz stacijai). Viṇi nolēma, ka stacijās uz Daugavpils-Baḷbinovas līnijas pie poḷu komandantiem jānorīko latviešu komandanti (tas gan ilgi netika ievērots un izpildīts, jo poḷi to nevēlējās piel̦aut), savukārt Daugavpils stacijā - poḷu pārstāvis pie latviešu komandanta. Formāli Latvijas dzelzceḷi pārnēma minētās līnijas 13. janvārī (līdz tam strādāja poḷu štāba ieceltais dzelzcel̦u direktors). Vienošanās paredzēja poḷu karavīru pārvadāšanu par puscenu. ${ }^{447}$

Poḷu ietekme Daugavpilī un apkārtnē bija pilnīga. Jau 1919. gada 28. decembrī par nākamo pilsētas komandantu tika iecelts 5. Leǵionu pulka majors J. Dobrodzickis, kurš ar 1. Leğionu divīzijas lauka žandarmērijas

\footnotetext{
${ }^{440}$ Poḷu karavīru un Daugavpils dzelzcel̦a tilta foto sk.: Lāčplēša Kara ordeņa kavalieri. Biogrāfiska vārdnīca. - 15. lpp.; Tilta remontdarbu foto sk.: O niepodległość i granice 1914-1921. - S. 153 (šajā izdevumā ievietoti arī citi uzṇēmumi, kas izdarīti Latgalē operācijas "Ziema” laikā, - poḷu kritušie karavīri pie Višḳiem, poḷu karaspēka atgriešanās Daugavpilī no frontes utt. - S. 161, 164, 165).

${ }^{441}$ CAW, WBH, 341. 1. 155 (Raport Rydza - Śmigłego o działalnośći wojsk technicznych w akcji Dźwińskiej); Michalczyk W. Zarys historji wojennej 1-go pułku saperów kolejowych. - Warszawa, 1931. - S. 48.

442 AAN, Attachaty, A - II, 81/1; LVVA, 3601. f., 9. apr., 353. 1., 125. 1p.

${ }^{443}$ LVVA, 2574. f., 3. apr., 17. 1., 251. 1p. F. Miltoviču pašu piespieda piedalīties tilta būvē.

${ }^{444}$ CAW, WBH, 341. 1. 155; Latvijas Sargs. - 1920. - 3. febr.; Baltijas Vēstnesis. - 1920 - - 26. febr.

445 K. L. Historja pułków i bataljonów saperskich w latach 1918 - 1928//Przegląd Wojskowo - Techniczny. Saper. - 1928. - T. IV. - Zesz. 6. - S. 407, 818; LVVA, 3601. f., 1. apr., 309. 1., 30. 1p.; 496. 1., 70. 1p. 446 CAW, WBH, 341. 1. 154; AAN, Attachaty, A - II, 81/1; Наша жизнь. - 1920 - 19 марта, 22 апр. ${ }^{447}$ LVVA, 5192. f., 1. apr., 1562. 1., 6. 1p.
} 
vadu 3. janvārī plkst. 13.30 stājās pie kārtības uzturēšanas, lai "tūlīt novērstu dažādas laupī̌sanas". Kopumā apstākḷi bija samērā mierīgi, kaut arī Turmantas grupā ietilpstošā 23. kājnieku pulka 6. un 7. rotas karavīri bija patvaḷịi pārgājuši Daugavu un "uzvedušies neatbilstoši reglamentam", jo bija aplaupījuši iedzīvotājus. Grupas vadība 3. janvāra vakarā pavēlēja šīm rotām nekavējoties atstāt pilsētu un komandantam gādāt par privātā un sabiedriskā īpašuma drošību, uzsverot, ka "poḷu karavīra uzvedībai šajā zemē jābūt nevainojamai”. Arī vietējie iedzīvotāji, kuri mēǵinātu pāriet uz upes kreiso krastu, bija jānosūta atpakal, „l, loti pieklājīgi”. ${ }^{448}$

Tomēr izplatījās baumas par poḷu veiktajām varmācībām Daugavpilī. Latvijas prese centās tās atspēkot, rakstot, ka neviens iedzīvotājs nav nošauts un par katru "varbūtēju stingrāku izturēšanos poḷu pavēlniecība uzsākusi nopietnu izmeklēšanu". ${ }^{449}$ 3.-4. janvārī tika aplaupīti veikali. Vēlāk Daugavpils pilsētas II policijas iecirknī tika sastādīts šo veikalu saraksts. Lielākā daḷa no 31 izlaupìtā veikala īpašniekiem bija ebreji, ${ }^{450}$ tomēr nevar nepārprotami apgalvot, ka viṇi cietuši savas tautības dēl, jo starp pilsētas iedzīvotājiem ebrejiem bija l,oti augsts īpatsvars (starp tirgotājiem tas bija vēl augstāks un tuvojās 100\% no viṇu kopskaita). Turklāt daḷa veikalu varēja būt aplaupiti vēl padomju varas laikā un īpašnieki liecināja pret poḷiem, lai tādā veidā atgūtu vismaz dalu kara laikā zaudēto. No otras puses, nav noliedzams, ka poḷu karavīri Latgalē bija iesaistīti atseviškās antisemìtiskās akcijās. ${ }^{451}$ Arī poḷu 1. Leǵionu divīzijas virsnieks V. Broṇevskis 4. janvārī bija redzējis Daugavpilī "varonīgo armiju pa stūriem laupām ebreju veikalus", kā arī secinājis, ka daži karavīri atklājuši savus "zemākos instinktus". ${ }^{452}$

Neskaidrs Rīgā bija arī jautājums par Daugavpilī notverto komunistu likteni. Tika ziņots, ka apcietināti vietējā revolucionārā tribunāla locekḷi un "šī slepkavu banda saṇēmusi pelnīto sodu"; ka poḷi apcietinātos komunistus nosūtījuši uz koncentrācijas nometnēm; pilsētā aizturēti daži bijušie Rīgas padomju darbinieki; “arestētos čekistus" tiesāšot poḷu karatiesa, bet daḷa padomju iestāžu darbinieku atbrīvota uz iedzīvotāju galvojuma pamata. ${ }^{453}$ Latvijas armijas Virspavēlnieka štāba Iekšējās izlūkošanas daḷas Daugavpils nodaḷas vadītājs virsleitnants J. Sausais 9. janvārī ziṇoja, ka poḷi apcietinājuši 30 „lielinieku”, bet 3. Jelgavas pulka karavīri, kas veido pilsētas latviešu garnizonu, - ap 60 "lielinieku". ${ }^{454}$ Tomēr patiesu priekšstatu par notiekošo pilsētā iespējams gūt vienīgi Polijas puses avotos.

\footnotetext{
448 CAW, WBH, 341. 1. 155.

449 Brīvā Zeme. - 1920. - 17. janv.; Latvijas Sargs. - 1920. - 8. janv.; Сегодня. - 1920. - 16 янв.

${ }^{450}$ LVVA, 1368. f., 1. apr., 1385. 1., 52.-54. 1p.

${ }^{451}$ Martā pirms J. Pilsudska plašajām vārdadienas svinībām poḷu karavīri Daugavpils ielās, kas veda no pilsētas centra uz kapsētu, bija notvēruši ebrejus un lika tiem kopā ar ieslodzītajiem cietumniekiem piedalīties padomju karavīru pārapbedīšanā. Starp notvertajiem bija pilsētas rabīns (akcijā esot piedalījušies arī atsevišķi Daugavpils latviešu garnizona karavīri). Savukārt Virspavēlnieka štāba Operatīvās daḷas Izlūkošanas nodal̦as priekšnieks V. Bekers 14. aprīlī ziṇoja, ka Latgalē "poḷu karavīri vietvietām čamda vietējos žīdus“. - LVVA, 2574. f., 3. apr., 15. 1., 26. 1.; 3601. f., 1. apr., 248. 1., 480. 1.; Воля. - 1920. - 1 апр.

452 Broniewski W. Pamiętnik... - S. 156-157.

453 Brīvā Zeme. - 1920. - 9., 17. janv.; Baltijas Vēstnesis. - 1920. - 8. janv.; Sociāldemokrāts. - 1920. 22. janv.

${ }^{454}$ LVVA, 3235. f., 1/14. apr., 16. 1., 6. 1p.
} 
Jau 3. janvārī poḷu Trieciengrupas 1. Leǵionu kājnieku pulkam bija pavēle, pirmkārt, censties ieṇemt padomju administrācijas iestādes un nepiel̦aut dokumentu iznīcināšanu. 4. janvārī Daugavpilī ieradās astoṇi poḷu pretizlūkošanas aǵenti, lai pārṇemtu šos materiālus, un Lietuvas-Baltkrievijas frontes štāba pretizlūkošanas sekcijas vadītājs kapteinis I. Berners ar ǵenerāli S. Šepticki un diviem virsniekiem, no kuriem podporučniks K. Višin,skis palika Daugavpilī kā 4. pretizlūkošanas posteṇa priekšnieks. ${ }^{455}$ Līdz 26. janvārim poḷi (4. postenis, lauka žandarmērija un Leǵionu kājnieku pulku vienības) Daugavpilī aizturēja 170 cilvēkus. 4. postenis līdz 15. janvārim bija arestējis 87 personas, no kurām 21 tika atbrīvota, divas nosūtītas uz Viḷnu, četras - uz „internēto nometnēm”, bet 60 joprojām atradās arestā pilsētā. Bija izmeklēta 632 cilvēku darbība un sarīkotas trīs „vispārējas revīzijas” (kratīšanas), kā arī no karatiesas, žandarmērijas, pretizlūkošanas posteņa un vietējiem iedzīvotājiem (acīmredzot - vietējiem poḷiem) izveidota ìpaša komisija. Ar komisijas lēmumu izbeigtās lietas 7. janvārī tika nodotas pilsētā iebraukušajai Latvijas armijas Virspavēlnieka štāba Iekšējās izlūkošanas daḷas Daugavpils nodalıia (tomēr personas, kuru darbība bija saistīta ar "Polijas valsti un armiju", netika nodotas latviešu pusei). ${ }^{456}$ Jau 10. janvārī poḷi nodaḷai nodeva daḷu gūstekṇu, bet 11. janvārī - daḷu arestēto komunistu. J. Sausais vienojās ar 4. posteṇa vadību, ka poli turpmāk izmeklēs aizturēto lietas sazināa ar viṇa nodaḷu, nododot tai latviešu tautības un Latvijas pilsonības apcietinātos. ${ }^{457}$ 21. janvārī Daugavpils latviešu komandants ziņoja Tieslietu ministrijai Rīgā, ka viṇa rīcībā atrodas jau 108 apcietinātie un to skaits ar katru dienu pieaug. Tā kā nebija iespējams apcietināto lietas izskatīt, viņš lūdza atsūtīt uz Daugavpili izmeklēšanas tiesnesi, un mēneša beigās tas tika izdarīts. ${ }^{458}$

1. februārī par Iekšējās izlūkošanas daḷas Daugavpils nodaḷas priekšnieku J. Sausā vietā tika iecelts līdzšinējais Daugavpils apriṇķa apsardzības priekšnieks - poḷu tautības Latvijas armijas kapteinis S. Girdo. Sadarbība ar 4. poḷu posteni ievērojami aktivizējās. Puses apmainījās ar informāciju par meklējamām personām u. c. Februārī abas iestādes sadarbojoties atklāja, ka bijušais padomju milicis E. Elksniņš kopīgi ar poḷu karavīriem veicis laupīšanu (pēc tam minēto noziedznieku poḷi nodeva latviešu rīcībā). ${ }^{459}$ Tomēr nodaḷa bija spiesta ievērot E. Ridza-Smiglija 12. janvāra pavēli, kurā noteikts, ka revīzijas (kratīšanas) pilsētā drīkst veikt vienīgi ar poḷu pretizlūkošanas posten,a atḷauju vai arī pats postenis, ar kuru latvieši varēja tikai sadarboties. ${ }^{460}$

\footnotetext{
${ }^{455}$ CAW, II ND WP, t. 114.

${ }^{456}$ CAW, WBH, II ND WP, t. 114. Jau februārī aizturēto likteni izlēma komisija, kurā bija poḷu grupas štāba tieslietu referents, viṇa vietnieks, pretizlūkošanas un žandarmērijas pārstāvis, kā arī vietējais iedzīvotājs ar padomdevēja tiesībām. Ja komisija nolēma, ka persona "jāinternē", tā tika nodota latviešu iestāžu rīcībā. - LVVA, 3601. f., 1. apr., 471. 1., 1. lp.

${ }^{457}$ LVVA, 3235. f., 1/14. apr., 16. 1., 2.-3., 5.-7. 1p.

458 Tieslietu ministrijas un tiesu vēsture 1918-1938. - Rīga, 1939. - 375. lpp.

${ }^{459}$ LVVA, 3235. f., 1/14. apr., 18. 1., 11., 22., 23. 1p.; 17. 1p., 18. 1p.; 3601. f., 9. apr., 377. 1., 8. 1p. S. Girdo martā tika atvaļināts no armijas, bet 12. aprīlī iecelts par izmeklēšanas tiesnesi Daugavpilī Tieslietu ministrijas dienestā. - Tieslietu ministrijas un tiesu vēsture 1918-1938. - Rīga, 1939. - 375. lpp.

${ }^{460}$ CAW, II ND WP, t. 24.
} 
Arī poḷu komandantūra pārvaldīja pilsētu nedalīti. Kapteinis J. Everts, kas tika iecelts par Daugavpils latviešu komandantu, pilsētā ieradās 6. janvārī, bet amatā stājās 10. janvārīí1 (5. februārī viṇu nomainīja pulkvedis-leitnants E. Graudiṇš), kaut arī Ridzs-Smiglijs jau 3. janvārī bija lūdzis, lai A. Veiss panāk, ka tiek iecelts latviešu komandants, kurš sadarbotos "ar poḷu komandantu". Savukārt jau minētā 12. janvāra pavēle noteica, ka latviešu komandantūrai tiks ierādìta noteikta pilsētas daḷa, taču, risinot garnizona, dzīvokḷu un policijas jautājumus, tā būs pakḷauta poḷu komandantūrai; ar pēdējo jāsaskaņo visi rīkojumi. Jāsāk policijas organizēšana (tai gan nebūtu nekādas aizturēšanas un citas tiesības attiecībā pret poḷu karavīriem), paredzot, ka pie katras poḷu patruḷas jāpiekomandē latviešu karavīrs, un otrādi - pie attiecīgā karavīra griežas viṇa tautietis (tas netika īstenots $-\bar{E}$. J.). Civiliedzīvotāju kustība piefrontes joslā tika ierobežota, nosakot, ka caurlaides uz teritorijām, kas atrodas austrumos no cietokšña - no Bramanu līnijas - izdos poḷu komandantūra, bet uz rietumiem no tās - latviešu komandantūra. ${ }^{462}$ 18. janvārī A. Veiss lūdza, lai katra karspēka darbība notiek tikai tā atrašanās rajonā, un noteica, ka abām komandantūrām ir vienādas tiesības (vienīgi vispārīgos jautājumos jāpakḷaujas garnizona priekšniekam). Ridzs-Smiglijs atbildēja, ka atbilstoši kara apstākḷu prasībām pilsētā jābūt vienam komandierim un tas "pagaidām" ir poḷu komandants. Tomēr 22. janvārī viṇš deva rīkojumu par abpusēju informācijas apmaiṇu starp komandantūrām (līdz šim vienīgi latviešiem bija jāinformē otra puse). A. Veiss bija spiests atbildēt, ka domājis abu komandantu pakḷaušanos kopīgam komandierim - poḷu garnizona priekšniekam, un, ja poḷu komandants vienlaikus ir arī garnizona priekšnieks, tad jautājums ir atrisināts. ${ }^{463}$

Ārēji abu armiju attiecības sākotnēji bija samērā labas. Arī laikraksta "Jaunākās Ziṇas" korespondentam Daugavpilī janvārī radās "siltas jūtas", vērojot draudzīgās poḷu un latviešu karavīru attiecības. Latviešu virsnieki vairākkārt bija ielūgti viesībās poḷu virsnieku klubā (piemēram, 16. janvārī).464 Tomēr zināma nesaprašanās pastāvēja no paša sākuma. Daudzējādā ziṇā Kurzemes divīzijas daḷas bija atkarīgas no poḷiem. Līdz aprīlim, kad izveidoja Daugavpils garnizona lazareti, latviešu karavīri ārstējās poḷu 101. Lauka un infekcijas slimību hospitālī. ${ }^{465}$ Poḷi bija pilnīgi stāvokḷa noteicēji teritorijā starp Daugavpili, Krāslavu un Dagdu (Kapiṇu, Višķu, Maḷinovkas, Krāslavas, Dagdas, Izabelinas, Asūnes pagastā, daḷēji Līksnas, Kalupes un Izvaltas pagastā Daugavpils apriṇkịi, dalēeji Landskoronas pagastā Ludzas apriṇkī un dalēji Silajāṇu pagastā Rēzeknes apriṇkī). Latvijas puse bija spiesta ievērot šo kārtību, piemēram, 5. februārī Daugavpils latviešu komandants lūdza poḷiem pagarināt civilpersonu - Latvijas iestāžu ierēdṇu - brīvas pārvietošanās laiku ielās līdz plkst. 23.00 (līdz šim tas civiliedzīvotājiem bija noteikts līdz plkst. 20.00).466

\footnotetext{
${ }^{461}$ LVVA, 3235. f., 1/14. apr., 16. 1., 3. 1p.

${ }^{462}$ CAW, II ND WP, t. 24; LVVA, 6033. f., 1. apr., 68. 1., 4. 1p. No 18. februāra caurlaides uz piefrontes rajoniem un Poliju izdeva 3. kontroles stacija, kas bija pakḷauta 4. postenim. Latviešu iestādes šajā laikā izdeva caurlaides uz rajoniem, kas atrodas rietumos no Daugavpils-Rēzeknes dzelzceḷa un ziemel̦os no Rušonas-Bukmuižas-Porošku līnijas. - AAN, Attachaty, A - II, 81/2.

${ }^{463}$ LVVA, 3601. f., 1. apr., 471. 1., 14.-16., 22., 26.-27. 1p.

464 Jaunākās Ziṇas. - 1920. - 15. janv.; Brīvā Zeme. - 1920. - 16. janv.

${ }^{465}$ LVVA, 3601. f., 9. apr., 356. 1., 10. 1p.; 1. apr., 309. 1., 66. 1p.

466 Turpat, 2574. f., 3. apr., 15. 1., 102. 1p.; CAW, WBH, 341. 1. 155.
} 
2. februārī poḷu grupas štābs atḷāva veidot latviešu komandantūras līdz Dagdas-Baḷbinovas līnijai. Tikai tad varēja sākt darbu kapteinis P. Maksimovs, kas 22. janvārī bija iecelts par Krāslavas iecirkṇa komandantu. Ierīkot telpas Krāslavā vinamam izdevās tikai 7. februārī pēc incidenta ar "poḷu priekšniecību", bet 8. februārī Maksimovs pavēlē noteica, ka iebraukšanas atlaujas jāuzrāda poḷu 3. Leǵionu divīzijas lauka žandarmērijā vai komandantūrā. 1. martā poḷu komandants viṇam lūdza neiejaukties dzīvokḷu sadales lietās, kas atrodoties pilnīgā poḷu pārziṇā. Maksimovs pakḷāvās un turpmākajās dienās lūdza atḷauju saviem darbiniekiem ieṇemt poḷu virsnieku atstātās telpas, kā arī piešķirt viņam vienu trofeju - telefona automātu. ${ }^{467}$

Līdzīgā sarežğìtā stāvoklī Dienvidlatgalē atradās valsts administrācija. Jau 1919. gada decembrī Rīgā A. Miškovskis piekrita, ka tūlìt pēc atbrīvošanas Latgalē tiks organizēta civilpārvalde. Savukārt A. Veiss decembra beigās informēja E. Ridzu-Smigliju, ka Daugavpils "administratīvais aparāts" jau sagatavots un tūlìt ieradīsies Dūkštā (poḷu štābā). ${ }^{468}$ Tas nenotika. Kaut arī pastāvēja noruna ar Iekšlietu ministriju, ka Latgales apgabala priekšnieks ieradīsies Daugavpilī atbrīvošanas dienā, tomēr arī tas nenotika. ${ }^{469}$ Šajā amatā ieceltais Kara tiesu pārvaldes nodaḷas priekšnieks kara laika ierēdnis O. Muižnieks ieradās Daugavpilī 6. janvārī. ${ }^{470}$ Oficiāli amatā viņš stājās 10. janvārī, kaut gan jau 8. janvārī izdeva uzsaukumu iedzìvotājiem, kurā par savu galveno uzdevumu izvirzỉja normālu dzīves apstākḷu atjaunošanu. ${ }^{471}$ Daugavpilī bija ārkārtīgi smagi apstākḷi visās dzīves jomās. Šajā pilsētā bija daudz bēgḷu, trūka pārtikas, medikamentu, kurināmā, nestrādāja veikali, divas trešdaḷas namu nebija apdzīvojami (artilērijas un citu postījumu dēḷ). ${ }^{472}$

Drīz pēc atbrīvošanas un apgabala priekšnieka lūguma poḷi izdalīja vietējām slimnīcām, patversmēm un skolām zināmu daudzumu pārtikas, par ko vēlāk norēḳinājās Latvijas puse. ${ }^{473}$ Stāvoklis pilsētā iedvesa šausmas. Aculiecinieku liecības pilnībā apgāž Latgales muižnieku apgalvojumus par Daugavpils "poliskumu” un svinīgo Polijas armijas sagaidī̌̌anu. J. Pilsudska līdzgaitnieks I. Berners 4. janvārī bija redzējis Daugavpilī neticamu netīrību un postījumus, retie garāmgājēji lūkojušies uz poḷiem ar "pilnīgu apātiju”, bet retie apsveicēji (kas saukuši “Sveicināti, tautieši!") bijuši ebreji. ${ }^{474}$ Kādam poḷu

${ }^{467}$ LVVA, 3479. f., 1. apr., 27. 1., 1.-3., 14. 1p.; 2. 1., 1. 1p.; 5601. f., 1. apr., 4009. 1., 2. lp. Sīkāk sk.: Jēkabsons Ē. Poḷu karaspēks Krāslavā 1920. gadā//Acta Latgalica. Zinōtniski roksti. Dokumenti. Apceris - 13. sēj. - Daugavpiḷs-Rēzekne, 2004, 234.-240. lpp.

468 CAW, WBH, 341. 1. 151, 157.

469 Radziņš P. Latvijas atbrīvošanas karš. -80 . lpp.

${ }^{470}$ Brīvā Zeme. - 1920. - 9. janv.; Jaunākās Ziņas. - 1920. - 10. janv. Vēl 5. janvārī A. Veiss izmisīgi jautāja virspavēlniecībai: "Kāpēc neierodas civilpārvalde?" - LVVA, 6033. f., 1. apr., 24. 1., 4. 1p.

${ }^{471}$ Сегодня.. - 1920. - 17 янв. Poḷu štābs jau 3. janvārī uzsaukumā iedzīvotājiem informēja, ka Polijas armija kopā ar Latvijas karaspēku atbrīvos valsti no "lielinieku anarhijas", un solīja nodrošināt sabiedrisko drošību, īpašuma neaizskaramību, vārda un preses brīvību.

${ }^{472}$ Sīkāk sk.: Jēkabsons Ē. Dienvidlatgales administratīvās pārvaldes veidošanās 20. gs. 20. gados// Acta Latgalica. - 9. sēj. - Daugavpiḷs, 1997. - 101.-113. lpp.; Jēkabsons Ē. Latvijas varas iestāžu darbs Daugavpilī, Daugavpils apriņķ̄i un Grīvā 1920. gadā//Acta Latgalica. - 10. sēj. - Daugavpiḷ,s, 1999. - 83.-103. 1pp.

${ }^{473}$ LVVA, 3605. f., 1. apr., 197. 1., 65. 1p.; 6033. f., 1. apr., 24. 1., 13. 1p.

${ }^{474}$ CAW, II ND WP, t. 114. 
karavīram Daugavpils atstājusi izmirušas pilsētas iespaidu, retajiem gājējiem bijušas "iebiedētas, badīgas" sejas. ${ }^{475}$ Virsnieks V. Broṇevskis 4. janvārī bija redzējis "tipiski krievisku pilsētu" ar "platām ielām, mazām, netīrām koka mājiṇām", viss bijis "nospiests, bailīgs un naidīgs". ${ }^{476}$ Savukārt poḷu preses korespondentam P. Mončevskim februārī bija radies iespaids, ka Minska, kurā viṇš bija nākamajā dienā pēc atbrīvošanas, "salīdzinot ar Daugavpili, bijusi kā Parīze". 477 Tādos apstākḷos bija jāstrādā Latgales apgabala priekšniekam un viṇa veidotajam pārvaldes aparātam. Viṇš vienojās ar poḷu štābu par sadarbību un savā pirmajā rīkojumā noteica, ka Latgalē maksāšanas līdzeklis vienlaikus ir Latvijas rublis, Polijas marka, Krievijas cara rublis, Vācijas “ostrublis" un Vācijas marka (attiecībā 1:2:2:1:2), un aizliedza norēḳināties ar padomju naudu, bet pagaidām aț̣āva lietot Krievijas Pagaidu valdības maiṇas sīknaudu. ${ }^{478}$ Loti auksta laika apstākḷos O. Muižnieks nespēja apgādāt ar kurināmo (ar malku) ne iedzīvotājus, ne garnizonu, tādēl 15. janvārī viṇš l̦āva poḷiem malkas iegūšanai nojaukt atseviškas koka ēkas, kā arī apsolīja ar tiem norēkināties par kazarmās un citās iestādēs veiktajiem remonta vai pārbūves darbiem. ${ }^{479}$ Savas darbības sākumā Latgales apgabala priekšnieks darbojās pat bez pienācīgiem sakariem ar valdību un Iekšlietu ministriju Rīgā.

Poḷi tūlìt pēc Daugavpils atbrīvošanas bija organizējuši pilsētas pagaidu valdi, kurā bija pieci iedzīvotāju pārstāvji, ${ }^{480}$ bet 10. janvārī, vienojoties latviešu, pol,u, ebreju un krievu sabiedriskajiem darbiniekiem, tika izveidota pilsētas dome. Tājā bija 35 cilvēki (10 latvieši, 10 poḷi, 8 krievi, 7 ebreji). Savukārt dome ievēlēja valdi ar pārvācotu igauni E. Zinkelu priekšgalā, un tā uzsāka smago pilsētas dzīves normalizēšanas darbu. ${ }^{481}$ Ievērojamu palīdzību sniedza Latvijas valdība un ASV Palīdzības misijas Eiropas bērniem Latvijas nodaḷa, kā arī ASV Sarkanais Krusts. Janvārī l,oti smagos apstākḷos pilsētā darbu sāka Latvijas policija prefekta K. Berķa vadībā, Daugavpils apriņķa policija, kā arī Latvijas Dzelzceḷu policijas Daugavpils nodaḷa. ${ }^{482}$ 18. janvārī Daugavpilī ieradās Daugavpils apriņ̧̧a apsardzības priekšnieka pārvaldes darbinieki. 10. martā apriṇķ̄i strādāja jau astoṇas latviešu iecirkṇu komandantūras, taču to karavīri bija trūcīgi apgādāti un atstāja sliktu iespaidu uz "sabiedrotajiem" (poliem). ${ }^{483}$

Apgabala priekšnieks O. Muižnieks bija spiests daudzkārt piekāpties poḷu militārajai administrācijai. P. Radziṇš secināja, ka viṇš nav bijis spējīgs pienācīgi pārstāvēt valsts varu. ${ }^{484}$ Šì iemesla dēl 18. janvārī Muižnieks tika

\footnotetext{
475 List z Dyneburga//Źołnierz Polski. - 1920. - 13 marzec.

476 Broniewski W. Pamiętnik... - S. 156.

477 Mączewski P. Z podróźy na Łotwę//Gazeta Warszawska. - 1920. - 13 marzec.

${ }^{478}$ LVVA, 2574. f., 3. apr., 15. 1., 83.-86., 94.-97. 1p.

479 Turpat, 6033. f., 1. apr., 24. 1., 13. 1p.; 3601. f., 9. apr., 353. 1., 114. 1p.; 1368. f., 1. apr., 1044. 1., 4., 26. 1p.

${ }^{480}$ Baltijas Vēstnesis. - 1920. - 13. janv.

${ }^{481}$ Brīvā Zeme. - 1920. - 17. janv.; Latvijas Sargs. - 1920. - 14. febr. u. c.

${ }^{482}$ Latvijas iekšējās drošības nostiprināšanas vēsture. - Rīga, 1925. - 78.-79. lpp.; LVVA, 5604. f., 1. apr., 957. 1.

${ }^{483}$ LVVA, 6033. f., 1. apr., 296. 1., 1. 1p.; 309. 1., 25.-26. 1p.

484 Radziņš P. Latvijas atbrīvošanas karš. - 80. lpp.
} 
izsaukts uz Rīgu un nākamajā dienā atcelts no amata. ${ }^{485}$ Daugavpilī viṇš atgriezās, lai nodotu amatu, taču vēl 12. februārī komandants E. Graudiṇš pieprasīja nekavējoties izsaukt $O$. Muižnieku uz Rīgu un neierašanās gadījumā draudēja to apcietināt. ${ }^{486}$ Acīmredzot poḷi izmantoja bijušā apgabala priekšnieka klātbūtni savos strīdos ar jauno apgabala priekšnieku A. Bērzinuu par Muižnieka kādreiz dotajiem solījumiem (saistībā ar kurināmo, naudas kursu u. c. ). Tomēr jāpiezīmē, ka savās vēlāk publicētajās atmiṇās O. Muižnieks bija îpaši uzsvēris: poḷu grupas vadības izturēšanās pret "mūsu valsti un valsts interesēm bija viscaur tādā mērā lojāla, ka par kādu nebūt negatīvu faktisku iedarbību šai ziṇā nemaz nevarēja būt runas”. Šādu izturēšanos O. Muižnieks izskaidroja ar to, ka E. Ridzs-Smiglijs, T. Kučeba un citi poḷu štāba augstākie virsnieki bija "augsti inteliğenti un vārda vislabākajā nozīmē džentlmeniski vīri", un no vinu puses nav bijusi "ne mazākā iejaukšanās" O. Muižnieka kompetencē. Šie 1935. gadā izteiktie pirmā apgabala priekšnieka apgalvojumi skaidri norāda uz situācijas sarežğìtību 1920. gada sākumā un uz to, ka arī Latvijas puse attiecībās ar poliem nebija pilnībā bez vainas. ${ }^{487}$

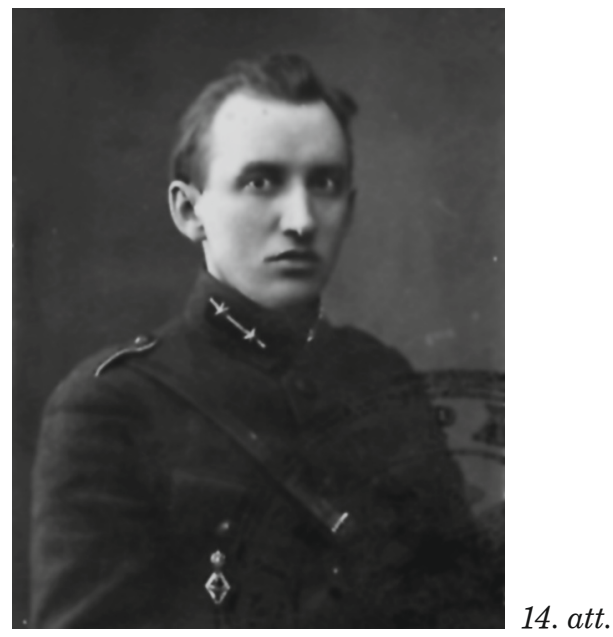

\section{Latgales apgabala priekšnieks Oskars Muižnieks}

Jaunais apgabala priekšnieks A. Bērziṇš ieradās Daugavpilī februāra sākumā un saskārās ar minētajām vietējo apstākḷu radītajām problēmām. Jau 26. janvārī Finanšu ministrija anulēja O. Muižnieka izsludināto naudas kursu Latgalē un pielīdzināja Polijas marku Latvijas rublim (viena Polijas marka līdzinājās 40 kapeikām). Poḷu štābs atbildēja, pielīdzinot 100 Latvijas rubḷiem 120 Polijas markas (reālais tirgus kurss bija 1,90 Latvijas rublis - 2 Polijas markas $\left.{ }^{488}\right)$. A. Bērzin̄š pasludināja kursu 1 marka - 40 kapeikas. Vienlaikus ziṇojumā Finanšu ministrijai viņš atzina, ka poḷu markas pielīdzināšana

\footnotetext{
485 Brīvā Zeme. - 1920. - 20. janv.

${ }^{486}$ LVVA, 3601. f., 9. apr., 353. 1., 115. 1.; 1368. f., 1. apr., 1044. 1., 8.-9. 1p. O. Muižnieks no Daugavpils aizbrauca 13. februārī.

${ }^{487}$ Muižnieks O. Pirms piecpadsmit gadiem//Latgales Vēstnesis. - 1935. - 18. janv., 1. febr.

488 AAN, Attachaty, A - II, 64/1, k. 97.
} 
40 kapeikām bijusi politiska kḷūda, jo poḷi ar varu piespieduši rēḳināties ar reālo kursu. Tādējādi markas nenonāca Valsts kasē, bet pie privāttirgotājiem. ${ }^{489}$ Akcijas mērkiis bija Latvijas rubḷa vērtības palielināšana uz Polijas markas rēḳina. Poḷi tam nevarēja piekrist. 24. februārī E. Ridzs-Smiglijs rakstīja A. Miškovskim, ka vina grupas vadībai nav iebildumu pret Latgales administrācijas mainuu pēc Latvijas valdības ieskatiem, taču nav pielaujama iepriekš noslēgto vienošanos anulēšana (A. Bērziṇš pasludināja par spēkā neesošām arī citas O. Muižnieka vienošanās ar poliem). ${ }^{490}$ Latgales apgabala priekšniekam bija nepieciešamas četras nedēḷas, lai iegūtu pastāvīgas telpas savai pārvaldei. Februāra beigās šì iemesla dēḷ pat nopietni tika apsvērta iespēja pārcelt apgabala pārvaldi uz Rēzekni. Tikai 8. martā virs apgabala pārvaldes (bijušās poḷu biržas) ēkas tika uzvilkts Latvijas karogs. ${ }^{491}$

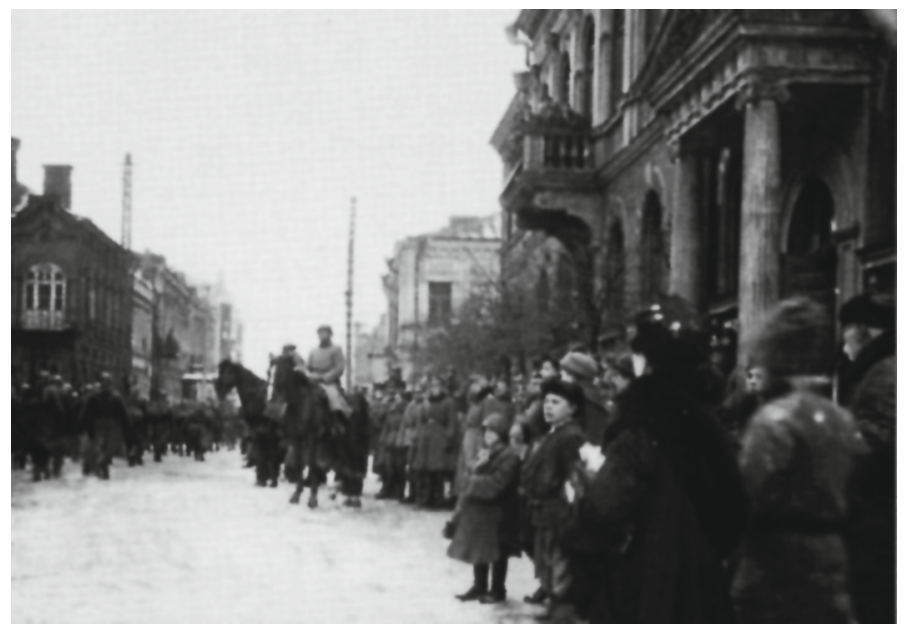

15. att.

\section{Poḷu karaspēka daḷu parāde Daugavpilì 1920. gadā}

Poḷu karspēks Daugavpilī izvietojās ne tikai bijušajās Krievijas armijas kazarmās, bet arī citās labākajās pamestajās ēkās. Tieši poḷu garnizonā atdzima pilsētas kultūras dzīve. Jau janvārīizrādes sniedza 1. Leǵionu divīzijas teātris (pilsētā trūka kultūras pasākumu, tādēḷ teātri esot apmeklējuši arī latviešu karavīri). 29. janvārī tika atklāts Poḷu karavīru klubs, kurā bija bufete, bibliotēka, lasītava un koncertzāle. ${ }^{492}$ Turklāt laikrakstus saṇēma grupas štābs, amerikāṇu YMCA („Young Men's Christian Association” - Jaunu vīriešu kristīgā savienība pie poḷu karaspēka, 1937. gadā organizācija iegūst nosaukumu "Jaunatnes kristīgā savienība") kantīnē bija pieejami šaha komplekti un laikraksti. Poḷu virsnieku klubs (kazino) bija labi iekārtots, tajā notika koncerti, lekcijas un pārrunas. ${ }^{493}$ Turpretī latviešu virsnieku klubā

\footnotetext{
${ }^{489}$ LVVA, 2574. f., 3. apr., 15. 1., 83., 94.-97., 105. 1p.; 1368. f., 1. apr., 1392. 1., 1.-17. 1p.

490 AAN, Attachaty, A - II, 64/1, k. 97.

491 LVVA, 1368. f., 1. apr., 1404. 1., 1. 1p.

492 Źołnierz Polski. - 1920. - 3 kwiec.

493 Mączewski P. Z podróźy na Łotwę//Gazeta Warszawska. - 1920. - 19 marzec.
} 
šaurības un tumsas dēḷ laiks pavadīts vienīgi sarunās un dziesmās. ${ }^{494}$ Tikai 21. martā tika atklāts Latviešu karavīru klubs. ${ }^{495}$

Galvenais Polijas armijas daḷu nesaskaṇu cēlonis ar Latvijas iestādēm bija saistīts ar to, ka tās atradās svešā zemē un tāpēc viṇu darbība tika novērota īpaši uzmanīgi. Turklāt divvaldība, kāda bija Daugavpilī, nevarēja pastāvēt bez savstarpējām domstarpībām (poḷi bija stāvokḷa noteicēji, bet latvieši centās palielināt savu iespaidu, ko uzskatīja arī par politiski svarīgu). Nelabvēlīgu iespaidu atstāja arī zemāka ranga Polijas armijas komandieru un karavīru patvaḷa - daudzi uzskatīja Latgali par iekarotu teritoriju un izturējās kā iekarotāji. Sliktās disciplīnas dēḷ nereti notika pārkāpumi. Tos veicināja arī tas, ka Latvijas puse nespēja pildìt savas saistības Polijas karaspēka apgādes jautājumā (17. martā Latvija armijas Virspavēlnieka štāba Iekšējās izlūkošanas nodaḷa ziṇoja, ka, pateicoties pārtikas piegādes apstākḷu uzlabošanai, Polijas karavīru garastāvoklis kḷuvis apmierinošs un attiecības starp abām armijām nedaudz „labākas nekā agrāk"496).

23. februārī poḷu grupas štābs vēlreiz noteica, ka Daugavpils policijai nav tiesību aizturēt poḷ karavīrus, bet gadījumā, ja tie traucētu sabiedrisko kārtību, policijai jāgriežas pēc palīdzības pie poḷu militāriestādēm. Vienīgi tad, ja rastos dzīvības apdraudējums, policija drīkstēja to novērst un nodot aizturēto poḷu karavīru (vai karavīrus) tām pašām poḷu militāriestādēm. A. Bērziņš ziṇojumā uzsvēra, ka nevar prefektam atḷaut pildīt šādu rīkojumu. Tas ir pretrunā ar likumu par iekšējo apsardzību, jo poḷu karavīru patvarības "pieņemtos bez sava gala - viṇi mazāk vēršas pret dzīiību, bet vairāk pret ārējo kārtību un īpaši pret privātīpašumu". ${ }^{497}$

Poḷu karavīri pret Latvijas policiju pilsētā tiešām izturējās nevērīgi. Neapšaubāmi, viens no iemesliem bija arī tās krieviskums. ${ }^{498} 16$. februārī Daugavpilī poḷu žandarmi piekāva un apcietināja policistu, kurš negribēja piel̦aut, ka viṇi nozog kādam cilvēkam sienas pulksteni; 17. februārī Daugavpils kārtībnieki Morozovs un Zinčenko tika turēti cietumā kopā ar "sarkanarmiešiem, sievietēm, žīdiem”, un šiem apcietinātajiem poḷu karavīri lika sagatavot malku; 28. februārī piedzēries poḷu karavīrs piekāva jaunāko kārtībnieku A. Špakovski, bet, kad piesteidzās citi policisti, patvērās karavīru pulciṇā, lamājot Latvijas policiju; 1. martā maizes ceptuves karavīri mēǵināja padzìt policistu no posten,a, jo viņš traucēja spekulatîvos darījumus (policists bija spiests brīdinot šaut gaisā). Stāvoklis nebija labāks arī ārpus Daugavpils. Martā un aprīlī poḷi ar virsnieku Butkēviču priekšgalā n̦irgājās par Višku policistiem, bet policistu N. Grigorjevu piekāva. Pazemotie policisti pēc šì negadījuma lūdza atbrīvot viṇus no darba. Civilo iestāžu amatpersonas arī izjuta neciencu; bija pagasta vecāko, valžu locekḷu, citu iestāžu darbinieku îslaicīgas aizturēšanas gadījumi. 499

\footnotetext{
${ }^{494}$ LVVA, 2574. f., 3. apr., 18. 1., 1. 1p.

495 Baltijas Vēstnesis. - 1920. - 7. febr.; Republikas Sargs. - 1920. - 27. marts.

${ }^{496}$ LVVA, 3601. f., 1. apr., 465. 1., 31. 1p.

497 Turpat, 2574. f, 3. apr., 17. 1., 213.-214. 1p.

498 Gazeta Warszawska. - 1920. - 14 marzec.

${ }^{499}$ LVVA, 3444. f., 1. apr., 109. 1., 12. 1p.; 3605. f., 1. apr., 197. 1., 60. 1p.; 2574. f., 3. apr., 17. 1., 88., 241. 1p.
} 


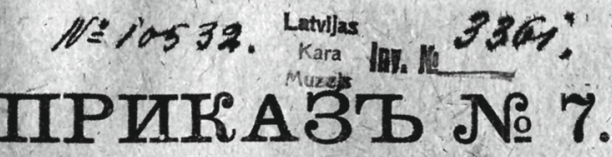

$\$ 1$.

До моего свтдљнія допло, что нЖкоторыя лица, нестотра на \$ $\$$ приваза по тореду с. $r$. № 4, все еще продөлжаюты Утапвать присвоенное ини посль ухода бодьневиковт имушество, отобранное носльдними у частныхъ лицъ и государственныхъ учрежденій и даже пропвводятъ раскіродажу такового.

Строғо воспрещаю всъмъ гракданамь города производить перемещеліе, продажу In покуику мебели и пр. имущестьа безь особаго на то разржшенія Префекта города. Префекту же выдавать эти разрж;шенія лишь, посль тщательной поверки, дъйствительно-ли лицо, изъявившее желаніе перельстить или гродать имунество, яв.ляетея его законнымы собетвеннииомъ.

Тородской полиціи сльддить за исполненіемъ сего приказа, провъряя при каждомъ замъченномб слууаљ перемьшенія, продажи и покупки имушества имъется ли на, то соотвытствующее разрышеніе Префекта города.

$$
\$ 2 .
$$

Увъдомлаю, что по соглашенію съ Польскими военными властями, сльдованіе по төроду безъ ночныхъ иропусковт разръшено до 11. часовъ ночи.

Датв. Комендантв гор. Деинека,

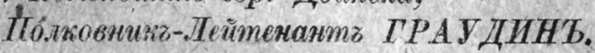

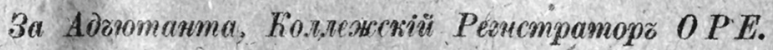

Г. ДВинСКЂ,

9-го Февраля 1920 r.

Городская тинографія, Зеленая 8

\section{Dokuments}

\section{Pilsētas komandanta E. Graudiṇa rīkojums 1920. gada februārī̄500}

Arī dažādi afēristi bija ievērojuši, kam pieder reālā vara Daugavpilī. Kāds Ā. Zeiferts, kam prefekts nebija l̦āvis atvērt deju klasi ar "spirtoto dzērienu bufeti”, to atvēra, kad bija saṇēmis poḷu žandarmērijas atḷauju, un iekārtoja publisko namu. Marta beigās Ā. Zeifertam par to tika piespriests mēnesi ilgs cietumsods, bet viṇa māte skaidroja, ka dēls iestādi atvēris, jo rīkojumu izdevis poḷu komandants, "kurš pats katru vakaru nācis un sūtījis savus

500 Turpat, 5434. f., 1. apr., 980. 1., 1. 1p. 
žandarmus". ${ }^{501}$ Viss minētais apliecina, ka poḷu karavīri Dienvidlatgalē bija pilnīgi stāvokḷa noteicēji un ar nepatiku uztvēra Latvijas iestāžu centienus viṇu ietekmi mazināt. Sevišķi uzskatāmi tas izpaudās Daugavpilī.

Par poḷu iespaidu liecina arī J. Pilsudska un Ridza-Smiglija vārdadienas svinību pompozitāte 18. martā Daugavpilī. 13.-15. martā pilsētas valdei, apgabala priekšniekam, latviešu garnizona priekšniekam un komandantam E. Graudiṇam tika nosūtīti ielūgumi uz svinībām (poḷu virsnieku korpusa vārdā tos parakstīja grupas štāba priekšnieks T. Kučeba). ${ }^{502}$ Tomēr 18. martā (svinību pirmajā dienā) A. Veiss un E. Graudiņš Ridzu-Smigliju gan apsveica, taču rautā neieradās neviens Latvijas pārstāvis (apgabala priekšnieks A. Bērziňš savu neierašanos skaidroja ar to, ka Ridzs-Smiglijs vēl nebija viṇam atmaksājis vizìti poḷu štābā, stājoties amatā februārī). A. Bērziṇš ziṇoja, ka rautā plaši pārstāvēta bijusi "pilsētas valde, garīdzniecība un atsevišķi polonofili”. Baznīcas laukumā notika ugunošana, ko pavadījusi nekārtīga šaudīšanās gaisā. Vienlaikus no cietokšņa tika raidìti 17 lielgabala šāvieni uz Lietuvas armijas pozīciju pusi Daugavas otrā krastā. 18. martā notika karaspēka skate, dievkalpojums, kura laikā lidmašīnas kaisīja virs pilsētas krāsainus papīrīšus, un parāde. Pēc tam E. Ridzs-Smiglijs pieṇēma apsveikumus štābā, kur ieradās arī Latvijas armijas garnizona rota ar orḳestri un nospēlēja abu valstu himnas. Uz svinīgajām pusdienām atkal neieradās apgabala priekšnieks. Svinības noslēdza svinīgs sarīkojums teātrī. ${ }^{503}$ Arī 3. Leǵionu divīzija 19. martā Krāslavā organizēja dievkalpojumu, karaspēka skati, parādi, banketu, koncertu un atpūtas vakaru, un uz šiem pasākumiem tika uzaicināts latviešu komandants P. Maksimovs. ${ }^{504}$

Īpatnēja bija Daugavpils pilsētas valdes un domes nostāja, ievērojot saspīlētās poḷu militāriestāžu un apgabala priekšnieka attiecības. Pirms svinībām valde griezās pie pēdējā ar jautājumu, kā Latvijas valdība uztvers domes pārstāvju piedalī̌sanos tajās, piezīmējot, ka pati dome to uzskata par nepieciešamu. A. Bērziñš atbildēja, ka Latvijas iestādēs arī atzīmēs draudzīgās valsts galvas "goda dienu". Savukārt pilsētas domes apsveikums J. Pilsudskim konkrētajā situācijā (kurai bija raksturīga attiecību saasināšanās ar Poliju) izraisīja asu reakciju. Kopumā teksts bija diezgan nevainīgs, ${ }^{505}$ taču vārdos "nedalāmā Republika" tika saskatīta vēlme pievienot "nedalāmajai" Polijai arī Daugavpili. ${ }^{506}$ A. Bērziņš uzskatīja, ka pilsētas valde "grib sēdēt uz diviem krēsliem". ${ }^{507}$ Tādējādi pagaidām vēl daḷēji slēptajā konfliktā starp poḷu štābu un apgabala priekšnieku iesaistījās arī pilsētas administrācija.

\footnotetext{
${ }^{501}$ Наша жизнь. - 1920. - 23, 30 марта; LVVA, 2574. f., 3. apr., 17. 1., 217. 1p.

${ }^{502}$ LVVA, 1368. f., 1. apr., 1404. 1., 8.-10. 1p.

${ }^{503}$ LVVA, 2574. f., 3. apr., 17. 1., 22., 25., 26., 30. 1p.; Latgolas Words. - 1920. - 24. marts; Latgalīts. 1920. - 22. marts; Borkiewicz A. Dzieje 1-go pułku... - S. 467. 1. Leǵionu divīzijas karavīri Latgalē bija saziedojuši dāvanā J. Pilsudskim 200000 Polijas marku. - Źołnierz Polski. - 1920. - 3 kwiec.

${ }^{504}$ LVVA, 3479. f., 1. apr., 27. 1., 41. 1p.

505 Tas skanēja: "Pilsētas dome (...) apsveic lielās un nedalāmās Republikas pilsoni Juzefu Pilsudski. Lai dzīvo Polija, lai dz̄ivo tās slavenais vadonis!"

${ }^{506}$ Latvijas Kareivis. - 1920. - 30. marts.

${ }^{507}$ LVVA, 2574. f., 3. apr., 17. 1., 24. 1p.
} 
Minētās svinības norisinājās poḷu-lietuviešu bruṇotā konflikta laikā Ilūkstes apriṇkīi, tāpēc arī bija 17 lielgabala šāvieni uz lietuviešu pozīcijām 18. martā. Pēc poḷu-lietuviešu uzbrukuma janvāra sākumā lietuvieši sāka izrādīt atklātu naidīgumu (arī pret latviešiem), tomēr tas vēl nepārauga konfliktā (pretēji poḷu bažām, lietuvieši pat palīdzēja pacelties poḷu lidmašīnai, kas 16. janvārī bija spiesta nolaisties pie Turmantas). ${ }^{508}$ Demarkācijas līnija starp Lietuvas un Polijas armiju bijušajā Kurzemes guberṇā atradās 10 kilometrus uz rietumiem no Daugavpils-Viḷnas dzelzceḷa. Pusēm radās domstarpības par tās vietu dabā, un lietuvieši sāka traucēt dzelzceḷa satiksmi, bet poḷiem trūka līdzekḷu, lai to pienācīgi apsargātu (vienīgā grupas rīcībā esošā motordrezīna patrulēja Dienvidlatgalē). Februāra sākumā E. RidzsSmiglijs atgādināja Turmantas grupai tās uzdevumu - nepieḷaut pat ìslaicīgu lietuviešu ienākšanu poḷu darbības rajonā. ${ }^{509}$

Poḷu-lietuviešu attiecību saasināšanās dēḷ pirmo reizi poḷu daḷās Daugavpilī 10.-11. februārī tika izsludināta kaujas gatavība. Grupas štābam pakḷautajai ložmetēju nodaḷai tika pavēlēts būt gataviem doties uz fronti. Tomēr sadursmes vēl nenotika, kaut arī Lietuvas prese ziņoja, ka 12. februārī poḷi apšaudījuši lietuviešu posteni pāri Daugavai. ${ }^{510}$ İstas sadursmes sākās 12. martā, kad poḷu 6. Leǵionu kājnieku pulka izlūki padzina no Antonoles (ziemel̦os no Turmantas) tur tikko novietoto lietuviešu posteni. Šĩs pašas dienas rītā lietuvieši ar karabīnēm un ložmetējiem apšaudīja poḷu lidmašīnu, kas pacēlās no Ruǵelu lidlauka pie Daugavpils, lai noskaidrotu stāvokli dzelzceḷa līnijā līdz Rokišķiem un Eglaines-Ilūkstes apkārtnē (pilots tika viegli ievainots). 511 Turpmākajās dienās notika daudz sīku sadursmju, abās pusēs bija ievainotie un gūstā kritušie (drīz pēc sagūstīšanas tos atlaida ${ }^{512}$ ). 15. martā lietuvieši starp Turmantu un Kalkūni aizbarikadēja dzelzcel̦u, pārgrieza telegrāfa vadus, ar granātām apmētāja poḷu vilcienu un pieprasīja 6. Leǵionu kājnieku pulka atkāpšanos uz rietumiem no dzelzceḷa. Pēc tam 6. pulks atspieda lietuviešus aiz demarkācijas līnijas, vietām to pārejot. 18. martā Kalkūnē ieradās Antantes valstu militāro misiju pārstāvjiangḷu kapteinis un franču virsleitnants kopā ar diviem Lietuvas armijas virsniekiem - un pieprasīja atvilkt poḷu karaspēku uz 13. martā ieņemto līniju. 6. Leǵionu pulka bataljona komandieris kapteinis V. Rīkemans atteicās to darīt, aizbildinoties ar dzelzcel̦a drošības nodrošināšanu. Antantes valstu pārstāvji apsolīja atrisināt šo jautājumu. 19. martā Ridza-Smiglija štābs deva

${ }^{508}$ CAW, WBH, 341. 1. 155. 1920. gada 16. februārī Latvijā atradās Lietuvas armijas 3. kājnieku pulks (1 100 vīru gar Daugavu, Iūkstē un Dvietē), 6. kājnieku pulks (840 vīru Eglainē un Subatē), 9. kājnieku pulks (gar dzelzcel̦u no Daugavpils līdz Turmantai), Baltkrievu bataljons (250 vīri Šederes muižā pie Eglaines). Eglainē atradās arī 3. brigādes štābs, noliktavas, neliela gūstekṇu nometne, komandantūra. Marta sākumā 9. pulkam piedalīja 1. huzāru pulka eskadronu un artilērijas bateriju. Pēc poḷu ziṇām, šajos lietuviešu spēkos bija 4000 karavīru. - AAN, Attachaty, A - II, 64/ 1, k. 35, 203; 81/2; CAW, WBH, 341. 1. 155.

${ }^{509}$ LVVA, 3601. f., 1. apr., 471. 1., 70. 1p.; CAW, WBH, 341. 1. 152, 154.

${ }^{510}$ Lietuva. - 1920. - 20 vas.

511 CAW, II ND WP, I. 301. 14. 67.

512 Saskaņā ar Lietuvas armijas Ģenerālštāba ziņojumiem kopumā lietuvieši šajās sadursmēs bija sagūstījuši vienu poḷu virsnieku, 24 karavīrus un ieguvuši divus ložmetējus. - Lietuva - 1920. - 17, $18,19 \mathrm{kōv}$. 
rīkojumu 6. un 1. Leğionu kājnieku pulkam naktī uz 21. martu ieṇemt jaunu demarkācijas līniju, kas atradās krietni tālāk par noteikto, bet aizliedza ieiet Zarasos. Abus pulkus atbalstītu divas baterijas, jātnieku vads, aviācijas eskadriḷa un brunuvilciens. Tomēr pārcelšanās prāmjos pār pārplūdušo Daugavu aiznēma pusotru dienu, un tikmēr pienāca virspavēlniecības pavēle akciju apturēt - 21. martā tā bija vienojusies ar Anglijas militāro misiju Polijā, ka poḷi atkāpsies uz 13. martā ieṇemto līniju, atkārtota lietuviešu uzbrukuma gadījumā iegūstot sev pilnīgu rīcības brīvību (angḷi vairs neiejauksies tālākā strīda risinājumā). Poḷu dạ̄ām tika pavēlēts atkāpties un pie mazākās lietuviešu "provokatīvās darbības" atklāt pret viņiem uguni. Atgriešanās iepriekšejās pozīcijās 26. martā norisa mierīgi. ${ }^{513}$

Latvijas armijas virspavēlniecība uzmanīgi sekoja notikumiem. Pamats bažām bija. To apliecina arī 18.-19. aprīḷa naktī notikusī apšaude starp poḷiem un lietuviešiem pāri Daugavai Līksnas-Kazimires līnijāan, kurā tika smagi ievainots poḷu karavīrs. ${ }^{514}$ Šādi un līdzīgi gadījumi sagādāja rūpes Latgales administrācijai un Latvijas valsts iestādēm. Raizes darīja arī daudzie poḷu karavīru pārkāpumi un pat noziegumi un darbības, kuras notika atšḳirīgo valstisko interešu dēḷ. Polijas armijas uzturēšanās Latgalē kḷuva Latvijas valstij arvien neizdevīgāka gan no politiskā, gan saimnieciskā, gan arī no militārā viedokḷa. Pastiprinājās poḷu konflikti ar Latvijas valsts un pašvaldības iestādēm Dienvidlatgalē, pirmkārt, Daugavpilī.

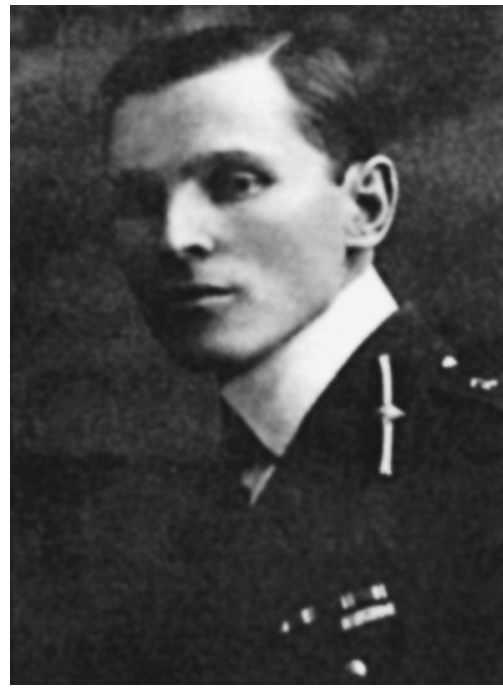

16. att.

\section{Daugavpils komandants Eduards Graudiṇš}

${ }^{513}$ AAN, Sztab Główny, t. 616/5, k. 81; Attachaty, A - II, 64/1, k. 203, 228; CAW, WBH, 341. 151, 155, 157; Borkiewicz A. Dzieje 1-go pułku... - S. 468.

${ }^{514}$ LVVA, 2574. f., 3. apr., 15. 1., 28. 1p. Konfliktā cieta pat ASV humanitāro organizāciju pārstāvji. 1920. gada 17. aprīlī lietuvieši no kreisā krasta sešas verstis no Daugavpils atklāja uguni pa ASV Sarkanā Krusta motorlaivu, kas atradās ceḷā uz Rīgu, bet 18. aprīlī viṇi apšaudīja šīs organizācijas automobili, kas brauca no Rīgas uz Daugavpili. - LVVA, 6033. f., 1. apr., 25. 1., 82. lp. 
26. februārī E. Graudiṇš no Daugavpils ziṇoja, ka stāvoklis poḷu karavīru patvarību dēḷ arvien pasliktinās, kaut arī iedzìvotāji bailēs no represijām Latvijas varas iestādēm gandrīz ne par ko nesūdzas. Poḷu izturēšanās pret latviešiem bija kḷuvusi izaicinoša, kaut arī latviešu karavīru attieksme joprojām bija "lojāla". Tomēr par "tālāku pacietību nevar galvot". Rezultātus nedeva arī A. Veisa starpniecības mēǵinājumi poḷu štābā. Tajā pašā dienā A. Bērziņš ziņoja, ka Latvijas iestādes nevar normāli strādāt, jo ierēdṇu pārvietošanās ir ierobežota, "komandantūru dzen no telpām laukā, man nedod iespēju pārvaldi pienācīgi novietot". Par stāvokḷa nopietnību liecina arī viṇa pavisam pesimistiskais paredzējums: “... ja poḷi drīzumā neatstās Daugavpili, viṇi mūs noteikti padzīs, un velti kareivji būs lējuši asinis par Latgali”. ${ }^{515}$

Ārpus Daugavpils stāvoklis bija zināmā mērā labāks. 11. martā Daugavpils apriṇķa komandants ziṇoja, ka iecirkṇu komandantūru attiecības ar "poḷu karaspēka priekšniekiem un iestādēm ir labas un viṇu izturēšanās korekta". Dažos gadījumos latviešu komandantūrām pat izdevās atgūt īpašumu, ko poḷi bija rekvizējuši no zemniekiem. Latviešu komandantu rīkojumi pirms to stāšanās spēkā gan bija jāapstiprina vietējai poḷu militārajai vadībai. ${ }^{516}$

Ievērojami cieta valsts, pašvaldību un privātais īpašums. Martā poḷu 1. smagās artilērijas pulka baterijas komandieris pieprasīja Višḳu pagasta valdei ierīkot pagastnama šḳūnī grīdu zirgu novietošanai. Materiālu trūkuma dēḷ tas netika izdarīts, tāpēc zirgus izvietoja skolas telpās, un līdz ar to mācības tika pārtrauktas. Krāslavā pils zirgu staḷlos izvietojās poḷu 3. zirgu hospitālis. Tā kā telpu stāvoklis bija slikts, poḷi tās februārī izremontēja. Krāslavas latviešu komandants atteicās apgādāt ar iztiku zirgu hospitāli, aizbildinoties, ka tādas iestādes atrašanās pilsētā iepriekš nav bijusi paredzēta. Marta beigās poḷi izjauca un malkā sadedzināja bijušās Krievijas armijas kazarmas Krāslavā. Latvijas iestāžu bezspēcību raksturo komandanta rezolūcija uz policijas priekšnieka ziṇojuma par notiekošo: "Par vēlu. Kazarmas jau nojauktas". Daugavpilī tādā pašā veidā tika iznīcinātas bijušās Krievijas armijas 99. Ivangorodas kājnieku pulka kazarmas (februārī uz latviešu komandanta protestiem poḷi atbildēja, ka to darìt atḷāvis bijušais apgabala priekšnieks O. Muižnieks), vairākas mājas tika pārvērstas par staḷ̣iem un tualetēm, ēkām noplēsti skārda jumti. ${ }^{517}$ Daugavpilī un citur neuzmanības dēḷ poḷu karavīri nodedzināja vairākas ēkas un apzināti (lai iegūtu malku) - lauku privātīpašumu. Janvārī poḷu karavīru nolaidības dēḷ izdega Višḳu pils, kas piederēja Latgales poḷu muižniekam H. Molam. Tās īpašnieks bija 1. Leǵionu divīzijas virsnieks, un paradoksāli, bet likumsakarīgi, ka apmēram šajā pašā laikā pēc viṇa pavēles tika aplaupìta poḷu grāfam Borham piederošā Astašovas muiža Dagdas pagastā (minētais skaidri apliecina, ka Polijas karaspēka daḷās bija disciplīnas problēmas). ${ }^{518}$

\footnotetext{
515 Turpat, 2575. f., 15. apr., 1. 1., 77. 1p.; 3601. f., 1. apr., 308. 1., 7. 1p.

516 Turpat, 6033. f., 1. apr., 309. 1., 27. 1p.

517 Turpat, 2574. f., 3. apr., 17. 1., 120. 1p.; 3479. f., 1. apr., 27. 1., 9., 30., 58., 91. 1p.; 3601. f., 1. apr., 9. apr., 353. 1., 114. 1.; 1. apr., 248. 1., 582. 1p.

${ }^{518}$ Latgolas Words. - 1920. - 27. marts; LVVA, 3601. f., 1. apr., 309. 1., 51. 1p.; 2574. f., 3. apr., 17. 1., 82., 111., 497. lp. Būdams Polijā, H. Mols sūdzējās par Ridza-Smiglija grupas kara ieguvumu referentu, kurš pavēlējis aizvest visu, kas palicis Višķu muižā. H. Mols nav spējis aizkavēt karavīru nodaļu,
} 
Visvairāk šādos apstākḷos cieta vietējie zemnieki. Poḷu izdarīto rekvizīciju dēl kara izpostīto un izputināto lauku saimniecību stāvoklis vēl vairāk pasliktinājās. Par atsavināto īpašumu karavīri bieži atstāja kvītis bez karaspēka daḷu nosaukumiem un parakstiem, dažkārt pievienojot vērtībai neatbilstošu samaksu par atsavinātajiem krājumiem poḷu markās. Pagastu valdēm bija jāpiegādā graudi un lopbarība centralizēti (piemēram, Jasmuižas pagasts veda auzas un sienu uz Rušonas staciju, kur par atvesto tika samaksāts). Landskoronas pagasta vecākais un rakstvedis par atteikšanos piegādāt labību “izsukāti ar pletnēm”. Notika arī pagastu pašvaldību amatpersonu īslaicīga apcietināšana, viņiem draudēja ar nošaušanu, bija piekaušanas gadijjumi. "Pieprasījumos" bieži bija minēts, ka "nepiegādāšanas gadījumā sādža tiks sodīta“. Nereti tika atṇemta pat sēklas labība. Visas vardarbības nevar izskaidrot ar novēlotajām Latvijas puses piegādēm, jo dažkārt poḷu karavīri atsavinājumu vienkārši uzreiz pārdeva blakuspagastā un par iegūtajiem līdzekḷiem iegādājās alkoholu. Poḷi rekvizēja arī lopus. Zemnieku īpašums tika reǵistrēts, un viṇi to pamatoti uzskatīja par gatavošanos tālākām poḷu rekvizīcijām. ${ }^{519}$

Visvairāk zemnieki cieta pie Viškiem, Izabelinas, Užvaldes (Izvaltas), Krāslavas un Dagdas. Februāra beigās Krāslavas miesta valde, kura galvenokārt sastāvēja no poḷiem un tikai nesen bija izlēmusi nosūtìt pateicību par atbrīvošanu arī Latvijas valdībai, ${ }^{520}$ lūdza Latgales apgabala priekšnieku novērst poḷu karavīru patvarības. Zemniekiem tika atṇemts viss, ko tie veda uz Krāslavu, un miestam draudēja bads. Latviešu komandants stāvokli mainìt nespēja. Martā uz Višḳu-Daugavpils ceḷa poḷi ierīkoja pat posteņus, kas braucējiem rekvizēja pārtiku. ${ }^{521}$

Tiesa, ar laiku nedaudz mainījās metodes, ar kurām poḷu karaspēks ieguva pārtiku. Februāra beigās Latvijas Apgādības ministrijas pārstāvis pie Polijas armijas K. Līkums konstatēja, ka rekvizīcijas gandrīz mitējušās un notiek tā dēvētā brīvā iepirkšana - nepieciešamais tiek pieprasīts no pagastu valdēm un pret nederīgām kvītīm tiek ievākta pārtika no zemniekiem. Tomēr februārī poḷi bija sākuši rekvizēt arī Daugavas kreisajā pusē - Ilūkstes aprinka pagastos, kuri bija mazāk izpostīti. Uz Dvietes pagastu pāri Daugavai pat tika nosūtīti seši Daugavpils apriņķa komandantūras karavīri, lai kopā ar vietējiem aizsargiem aizstāvētu zemniekus pret poḷiem, kuru atrašanās Daugavas kreisajā krastā bija pilnīgi nelikumīga (pēc Latvijas puses protestiem 8. martā E. Ridzs-Smiglijs ar oficiālu pavēli aizliedza padotajiem rekvizēt šajā teritorijā). ${ }^{522}$

Poḷu karaspēka daḷas Daugavpils apriṇķa priekšniekam pastāvīgi pieprasīja šḳūtniekus. Parasti par tiem tika norīkoti tuvāko pagastu

kas esot aizvedusi pat ğimenes relikviju - viṇa vectēva kāzu karieti. - APAN, Djarjusz M. S. Kossakowskiego, t. V, cz. 1, s. 48.

${ }^{519}$ LVVA, 3035. f., 1/ 14. apr., 17. 1., 52. 1p.; 2574. f., 3. apr., 17. 1., 159., 166., 175. lp.; 3601. f., 1. apr., 308. 1., 14., 8.-9. 1p.

${ }^{520}$ Brīvā Zeme. - 1920. - 19. febr.

${ }^{521}$ LVVA, 3601. f., 1. apr., 271. 1., 222. 1p.; 1368. f., 1. apr., 1385. 1., 1.-136. lp.

522 Turpat, 3605. f., 1. apr., 197. 1., 70. 1p.; 3601. f., 1. apr., 248. 1., 327. 1p.; AAN, Attachaty, A - II, 64/1, k. 299. 
zemnieki. 15. februārī apgabala priekšnieks ziṇoja, ka rekvizīcijas un šķūtis draud izraisīt zemnieku sacelšanos. Viņš pārrunāja šo jautājumu ar E. Ridzu-Smigliju, kas izrādīja sapratni, tomēr lūdza informēt, "uz ko viṇš var cerēt, jo citādi armijas apgādība draudot sabrukt". Konkrētajos apstākḷos jautājumu atrisināt nevarēja, un patvarīgā šķūtnieku mobilizācija turpinājās. Daudzkārt zemnieku zirgi tika nodzīti līdz nāvei. Martā Kalupes pagasta zemnieki bija spiesti braukt šķūtīs (vest baḷķus) katru otro vai pat katru dienu. Martā Daugavpils apriņķa priekšnieks škūtniekus darbam organizēt nevarēja, jo ceḷā tos apturēja poḷu karavīri un iesaistīja citos darbos (tādēḷ nebija iespējama Polijas armijas munīcijas pārvešana no Kalkūnes, telegrāfa remonts, poḷu 3. Leǵionu divīzijas apakšvienību transports u. c.). ${ }^{523}$ Turklāt poḷi janvārī satiksmes ceḷu attīrīšanai no sniega kopā ar gūstekṇiem piespiedu kārtā nodarbināja arī vietējos iedzīvotājus. ${ }^{524}$

Daži poḷu karavīri izdarīja kriminālpārkāpumus, galvenokārt laupīšanas. Gadījās pat atklātas bruṇotu grupu laupī̌sanas (piemēram, 20. aprīlī Maḷinovkas pagasta vējdzirnavās, kur iebruka sešu poḷu karavīru banda). No uzbrukumiem sekmīgi izvairīties izdevās vienīgi Andrupenes pagastam, kura valde panāca piecu Kaunatas komandantūras latviešu karavīru piekomandēšanu. Pie laupīšanām jāpieskaita arī īpašuma atṇemšana, ko veica poḷu karavīi un žandarmi savu pienākumu pildīšanas laikā. Piemēram, februārī Daugavpilī kādam iedzīvotājam tika atṇemts pulkstenis. Kad aplaupītais pieprasīja izdot kvīti, vinu apcietināja uz 10 dienām, par to pilsētas latviešu komandants sūdzējās pat Latvijas ārlietu ministram. Marta sākumā Latvijas tieslietu ministrs ziṇoja, ka Latgalē par laupīšanām apcietināti vairāki polu karavīri un tas noticis pat vietās, kur poḷu karaspēka nav bijis (dažos Rēzeknes apriṇka pagastos). Dažkārt aizturētie bija izrādījuši bruṇotu pretošanos, ${ }^{525}$ taču uz Tieslietu ministrijas pieprasijumu 8. martā Apsardzības ministrija atbildēja, ka "ar poḷu kara spēka virspavēlnieku nav noslēgts līgums, kurš noteiktu poḷu karavīru tiesāšanas kārtību par vispārīgiem noziegumiem". ${ }^{526}$ Vairāki gadījumi beidzās ar civiliedzīvotāju nāvi: 10. martā Daugavpilī poḷu karavīrs nošāva Š. Golbraihu; 21. martā Daugavpilī 101. lauka hospitāla šoferis, šaujot vārnas, nejauši nošāva bijušā Zarasu (tobrīd Braslavas) apriņ̧,a Opsas pagasta zemnieku K. Bejnaru (vainīgais aizbēga, taču tika notverts); 15. aprīlī divi poḷu karavīri Daugavpils pilsētas mežā aplaupīja un noslepkavoja vietējo zemnieku M. Anañjevu, bet 27. aprīlī vairāki poḷu karavīri Daugavpilī aplaupīšanas laikā nošāva K. Gordonu, kas bija izrādījis pretošanos. ${ }^{527}$ Tas viss norisinājās, lai gan janvāra beigā 1. Leǵionu divīzija un 1. Leǵionu brigāde bija izdevušas pavēli, kas noteica, ka karavīri, kas izdarījuši laupīšanu un slepkavību, tiks nodoti lauka karatiesai un sodīti ar nāvessodu nošaujot. ${ }^{528}$

\footnotetext{
${ }^{523}$ LVVA, 3601. f., 1. apr., 271. 1., 200. 1p.; 309. 1., 51. 1p.; 6033. f., 1. apr., 309. 1., 28. 1p.; 2574. f., 3. apr., 17. 1., 200. 1p.; 1368. f., 1. apr., 1385. 1., 12. 1p.

${ }^{524}$ CAW, WBH, 341. 1. 154. (1. Leǵionu brigādes štāba 15. janvāra ziṇojums.)

${ }^{525}$ LVVA, 2574. f., 3. apr., 17. 1., 109., 179. 1p.; 15. 1., 63., 65. 1p.

526 Turpat, 5192. f., 1. apr., 57. 1., 104. 1p.

527 Turpat, 13. 1., 115. 1p.; 17. 1., 257., 260., 263. lp.; 1368. f., 1. apr., 1385. 1., 69., 77. 1p.

${ }^{528} \mathrm{CAW}, \mathrm{WBH}, 341.154$.
} 
Par poḷu karavīru pārkāpumiem Latvijas varas iestādes informēja A. Miškovski, kas sazinājās ar E. Ridza-Smiglija štābu Daugavpilī. Štāba priekšnieks T. Kučeba 1. aprīlī atbildēja, ka daži konflikti starp iedzīvotājiem un poḷu karavīriem ir bijuši Latvijas puses novēloto pārtikas un lopbarības piegāžu dēḷ. Konfliktus izraisījuši "latviešu amatpersonu uzkūdìti” zemnieki, kas atteikušies pārdot pārtiku, tādēḷ vajadzējis viṇus piespiest pārdot, un lielāki konflikti neesot notikuši, vienīgi pateicoties "poḷu karavīru taktam un disciplinētībai". ${ }^{529}$ Šādu nostāju neapšaubāmi ietekmēja aprīḷa sākumā vērojamā Latvijas-Polijas starpvalstu attiecību saasināšanās. Polijas pārstāvis Latvijā B. Boufals bija objektīvāks, 26. aprīlī ziṇojot, ka novēlotās piegādes izraisījušas pārkāpumus, kuru dēḷ pat vietējie poḷi tikuši naidīgi noskaṇoti pret Polijas armiju. Viṇš rakstīja: "Bieži mūsu karavīri darbojās pēc principa - ja tam visam [Latgalei - $\bar{E}$. J.] jāpieder Latvijai, tad nav iemesla svešā valstī kaut ko saudzēt.” Arī A. Miškovskis 13. aprīlī ziṇoja, ka viṇam par poḷu karavīru uzvedību Latgalē sūdzoties pat vietējie poḷi. Labais iespaids, kāds sākotnēji bija radies par Polijas armiju, pasliktinājies "ne vienmēr lojālās vietējo varas iestāžu izturēšanās dēḷ" un "arvien pieaugošā mūsu karavīru pārkāpumu un izlēcienu skaita dēẹ" (viṇš minēja uzbrukumus veikaliem, rekvizīcijas, kam ar pārtikas trūkumu nav nekā kopēja u. c.). Pat polu nacionāldemokrātu prese atzina, ka poḷi Latgalē nav uzvedušies pienācīgi, kā citās austrumu zemēs, jo esot zinājuši, ka jāatdod Latvijai šī "poliskā" zeme. ${ }^{530}$

Martā, kad Polijas markas vērtība tirgū svārstījās no 60 līdz 62 Latvijas kapeikām, apgabala priekšnieks joprojām bija spiests ievērot janvārī pieṇemto kḷūdaino lēmumu par markas pielīdzināšanu 40 kapeikām. Viṇš ziṇoja, ka visās poḷu karaspēka atrašanās vietās "notiek nepanesama spekulācija ar naudas kursa vērtību". Latvijas iestāžu oficiālos pazinojumus par naudas kursiem poḷi noplēsa, bet iebiedētie iedzīvotāji nezināja, kā rīkoties un kuram rīkojumam pakḷauties. Februārī poḷu štābs sūdzējās, ka zemnieki nepieṇem poḷu markas, jo latviešu komandanti brīdina tos no iespējamiem zaudējumiem. Savukārt aprīlī Drisas apriṇķa zemnieki nepieņēma Latvijas naudu un nepārdeva linus, gaidot poḷu "drīzu atgriešanos" un samaksu "vērtīgajā" poḷu naudā. ${ }^{531}$

Kopēja robeža pavēra iespēju arī spekulatīviem darījumiem, kuros bija iejaukti poḷu karavīri, kas atradās Latgalē. 12. martā Latvijas iestādes Daugavpilī aizturēja un konfiscēja 10 vezumus linu, kurus vietējie ebreju tirgotāji veda uz Poliju, taču poḷu žandarmērija pieprasīja nekavējoties atbrīvot tirgotājus. To varēja izskaidrot vienīgi ar zināmu ieinteresētību. Daugavpils muitas pārzinis 6. martā ziņoja, ka poḷi paši regulāri izved pāri Daugavai linus un „lupatas”, bet Latvijas muita ir pilnīgi bezspēcīga un lūdz palīdzību Ārlietu ministrijā. Tai izdevās panākt, ka Polijas armijas G̦enerālštābs 23. aprīlī aizliedza jēlvielu izvešanu bez Latvijas iestāžu atḷaujas, ${ }^{532}$ tomēr šis

\footnotetext{
529 AAN, Attachaty, A- II, 64/1, k. 256.

530 Turpat, Kod, t. 4, s. 201-202; t. 2, s. 152; Gazeta Warszawska. - 1920. - 22 marzec.

${ }^{531}$ LVVA, 3601. f., 1. apr., 277. 1., 14. 1p.; 309. 1., 9. 1p; 2574. f., 3. apr., 15. 1., 90. 1p.; 3235. f., 1/14. apr., 16. 1., 135. $1 \mathrm{p}$.

532 Turpat, 3601. f., 1. apr., 277. 1., 14. 1p.; 2574. f., 3. apr., 15. 1., 71. lp.; Latgalīts. - 1920. - 12. marts; Воля. - 1920. - апр.
} 
ziṇojums nespēja pilnībā aizkavēt nelikumīgo darbību uz Latvijas robežsargu vāji apsargātās Daugavas (Robežsargu divīzijas 3. rajons, kas apsargāja demarkācijas līniju ar lietuviešu karaspēka ieṇemto teritoriju Ilūkstes apriṇkīi, tika izveidots 1920. gada janvārī, bet uz Daugavas līnijas pretī poḷu ienemtajai Ilūkstes aprinkka daḷai ar l̦oti vājiem spēkiem novietojās tikai martā beigās-aprīlī ${ }^{533}$ ). Turklāt spekulatīvo preču plūsma ienāca Latvijā šajā robežas sektorā. Krāslavas komandants P. Maksimovs jau 16. aprīlī ziņoja, ka polu karaspēks ved pāri Daugavai „visu, kas vien viņiem patīk”. Pārbaudot vietējās tirgotavas Krāslavā, tika atrastas dažādas Polijas preces lielā daudzumā - papirosi, tēja u. c. Turklāt poḷi uz Krāslavu un no turienes uz Daugavas otru pusi „veseliem vagoniem” veduši trūkstošo sāli. ${ }^{534}$

Šādos apstākḷos Dienvidlatgalē sākās Latvijas Satversmes sapulces vēlēšanu organizēšana (vēlēšanas bija paredzētas aprīlī). ${ }^{535}$ 8. martā apgabala priekšnieks A. Bērziṇš ziṇoja uz Rīgu, ka Daugavpilī un Krāslavā poḷu varas iestādes „stipri ağitē” pret vēlēšanām un ilgstošā atvalinājumā uz mājām esot atlaisti Latgales muižnieki, kas dienē Polijas armijā par virsniekiem. ${ }^{536}$ Vēlētāju reǵistrācija bija apgrūtināta, jo pārvietoties drīkstēja vienīgi, ja bija poḷu komandantūru atḷaujas. Tās Daugavpilī bijajāgaida vairākas dienas. Tādēḷ dažos Daugavpils aprinkka pagastos vēlētāji tika reǵistrēti tikai 12. martā. ${ }^{537}$ Apriņka komandants Ž̉. Grundmanis šajā dienā ziṇoja, ka iedzīvotāju ticību nākotnei nevairo dažu poḷu muižnieku rīcība - viņi pieprasa no rentniekiem samaksu par pagājušo gadu un pat par pasaules kara gadiem (arī B. Boufals poḷu saraksta neveiksmi Satversmes sapulces vēlēšanās skaidroja ar Janopoles muižas īpašnieka A. Romera, Krāslavas muižas īpašnieka M. Plātera-Broela un citu zemes nomnieku uzlikto 20-kārtīgu samaksu par zemes lietošanu ${ }^{538}$ ). Iedzīvotājiem interese par vēlēšanām nav bijusi liela. ${ }^{539}$ Tomēr 18.-19. aprīlī pilnvērtīgas vēlēšanas notika arī Dienvidlatgalē, iedzīvotājiem piedaloties neatkarīgās un demokrātiskās Latvijas pirmā parlamenta veidošanā. Tajās piedalījās arī apvienotais Poḷu un mazgruntnieku savienības (latviešu organizācijas) koalīcijas saraksts, un šī savienība ieguva vienu deputāta vietu, taču to ieṇēma daḷēji pārpoḷotais mazgruntnieku savienības pārstāvis, latvietis N. Skangelis. ${ }^{540}$

\footnotetext{
533 Jau 23. martā Robežsargu divīzijas 3. rajona priekšnieks ziņoja, ka pagaidām ieņemti tikai četri posteṇi no Vaikul̦āniem līdz Poguḷankai (katrā pa trijiem-pieciem karavīriem), iecerētie posteṇi pie Daugavpils dzelzceḷa tilta un koka tilta tiek „,apvaktēti” ar patruḷām, bet tālāk gar Daugavu plānotos piecus posteņus bija iecerēts ieņemt tikai ,pēc pieprasīto kareivju pienākšanas”. - LVVA, 4967. f., 1. apr., 246. 1., 117. 1p.

${ }^{534}$ LVVA, 4967. f., 1. apr., 246. 1., 113. 1p.

${ }^{535}$ Marta sākumā E. Ridzs-Smiglijs norādīja P. Radziņam, ka ienaidnieks var vēlēšanu laiku izmantot pretuzbrukumam frontē. Atbildē P. Radziņš pamatoja nepieciešamību iesaistīt vēlēšanās arī frontes daḷas ar "vērtīgajiem nacionālajiem elementiem" (atzīstot, ka sākotnēji bijis pret to) un garantēja, ka fronte vēlēšanu laikā netiks novājināta. - AAN, Attachaty, A - II, 64/1, k. 119. Acīmredzot šajā Latvijas armijas vadības nostāju ietekmēja arī 1. februārī noslēgtais slepenais pamiers ar Padomju Krieviju.

${ }^{536}$ LVVA, 2574. f., 3. apr., 9. 1., 114. 1p.

537 Latgalits. - 1920. - 5. marts; Republikas Sargs. - 1920. - 30. marts.

538 AAN, Kod, t. 4, k. 199.

${ }^{539}$ LVVA, 6033. f., 1. apr., 309. 1., 27. 1p.

540 Valdības Vēstnesis. - 1920. - 28. apr.
} 
Par poḷu karaspēka nodarìtajiem zaudējumiem pagastu un apriṇku valdēm bija jāsastāda akti līdz 10. maijam, un tie kopā veidoja 16025 569,35 Latvijas rubḷu lielu summu. Netika izskatīti akti vēl par 16022 502,55 rubļiem. No pieprasītās summas poḷi piekrita atmaksāt tikai 3 066,80 rubḷus. Šo summu veidoja formāli pareizi aizpildìtas rekvizīcijas kvītis. Turklāt aprēḳinā netika iekḷauta arī Daugavpils, kas bija cietusi apmēram 140000000 Latvijas rubḷu lielus zaudējumus (rēḳinot tikai nopostīto un bojāto ēku vērtību). ${ }^{541}$

\section{Starptautiskā reakcija un Latvijas-Polijas starpvalstu attiecības}

Sakarā ar Daugavpils atbrīvošanu Rīgā 1920. gada 5. janvārī notika plaša karaspēka un iedzīvotāju manifestācija. Garnizona daḷas orḳestra pavadībā devās uz valdības namu, kur tās uzrunāja Ministru prezidents K. Ulmanis, pieminot arī sabiedroto - poḷu karavīru - nopelnus. Pēc tam tās devās uz armijas Virspavēlnieka štābu un Polijas diplomātisko pārstāvniecību. Pie tās garnizona priekšnieks O. Asmans un Polijas militārais pārstāvis A. Miškovskis uzrunāja karavīrus, kuri uzsauca trīskārtīgu "urrā" par godu Polijas valsts vadītājam un armijas virspavēlniekam J. Pilsudskim. Vēl tika apmeklēta arī Francijas, Anglijas, ASV un Lietuvas misija. ${ }^{542}$ Tomēr šo valstu attieksme pret Latgales notikumiem bija l,oti atškirīga.

Plānojot uzbrukuma operāciju kopīgi ar Poliju, Latvijas puse rēķinājās, pirmkārt, ar Lietuvas reakciju. Tādēl jau 1919. gada decembra beigās uz Rīgu tika izsaukts militārais pārstāvis Kauṇā A. Kraulis, lai "noregulētu speciālus jautājumus" (saṇemtu instrukcijas). ${ }^{543}$

Par Daugavpils ieņemšanu Lietuvas armijas štābā Kauñā uzzināja 4. janvārī no rīta. Virspavēlnieks P. L,atuks un Ministru prezidents E. Galvanausks apspriedās ar Anglijas militārās misijas vadītāju H. Rouenu-Robinsonu, kas ieteica aprobežoties ar protestu. Attiecīga telegramma tika nosūtīta uz Rīgu. Latvijas pārstāvis Lietuvā V. Bandrevičs 6. janvārī ziṇoja, ka Lietuvas armijas štābā valda uztraukums. Īpaši nepatīkams Lietuvas valdībai bija pretlielinieciskās frontes zaudējums Ilūkstes apriṇķī: "Tas, ko lietuvieši pat domās negribēja pieḷaut un no kā visvairāk baidījās - no latviešu kontakta ar poliiem -, ir piepildījies, pateicoties Dvinskas [Daugavpils nosaukums cariskajā Krievijā $-\bar{E}$. J.] ieṇemšanai." Lietuvas armijas G̦enerālštābs īsu paziṇojumu par Daugavpils ieṇemšanu un Lietuvas karaspēka nepiedalīšanos uzbrukumā sniedza tikai 6. janvārī un pēc tam vēlreiz 10. janvārī. ${ }^{544}$ Dažas dienas pēc uzbrukuma sākuma A. Miškovskis izteica atzinību P. Radziṇam par to, ka lietuviešiem netika izpausta uzbrukuma sagatavošanas gaita (vēl decembrī viṇš bija šaubījies, vai Latvijas apstākḷ los tas būs iespējams). ${ }^{545}$

\footnotetext{
${ }^{541}$ LVVA, 3601. f., 1. apr., 248. 1., 582. 1.; 9. apr., 356. 1., 4., 6. 1p.; 2574. f., 3. apr., 17. 1., 91.-92. 1p.

${ }^{542}$ Сегодня. - 1920. - 6 янв.; CAW, WBH, 341. 1. 157; Kurjer Poranny. - 1920. - 9 stycz.

543 Сегодня. - 1919. - 30 дек.

544 Lietuva. - 1920. - 6, 10 saūs.

${ }^{545}$ LVVA, 3601. f., 1. apr., 248. 1., 65. 1p.
} 
Notikumi Latvijā veicināja Lietuvas valdības krīzi, un 8. janvārī tā atkāpās (amatu atstāja arī armijas virspavēlnieks P. L,atuks ${ }^{546}$ ). Pēc frontes sektora zaudēšanas ievērojami sarežǵījās Lietuvas starptautiskais stāvoklis. Polijas G̣enerālštābs 15. janvārī ziṇoja, ka "Kauṇas valdība atrodas milzīgā atkarībā no Polijas un ir nevarīga". ${ }^{447}$ Tomēr arī tas bija pārspīlējums. Lietuvas valdības rīcības dēḷ pat draudēja bruṇots konflikts, kurā būtu iesaistīta arī Latvija. 6. janvārī Valkā pēc angḷu iniciatīvas notika Igaunijas, Latvijas un Lietuvas armiju virspavēlniecību pārstāvju apspriede, ${ }^{548}$ lai saskaṇotu ārpolitisko darbību. Ang̣̣u virsnieks, kas pavadīja Lietuvas delegācijas vadītāju A. Merki, piedāvāja nekavējoties noslēgt Baltijas valstu militāro konvenciju. ${ }^{549}$ Turklāt Lietuvas pārstāvji centās panākt, lai tiktu parakstīts kopīgs aicinājums Antantei. Tas piespiestu poḷus atstāt Viḷnu (tā kā šo pilsētu un apgabalu okupējuši poḷi un pret tiem ir apvienoti ievērojami lietuviešu spēki, tos nevar izmantot cīṇā pret kopīgiem ienaidniekiem - Padomju Krieviju un Vāciju). Tam nepiekrita Igaunijas un Latvijas armiju virspavēlnieki J. Laidoners un J. Balodis, aizbildinoties ar pilnvaru trūkumu. J. Balodis nepiekrita lietuviešu piedāvājumam un izteica bažas, ka, pieņemot aicinājumu, Baltijā var izveidoties tāds stāvoklis, kāds ir Balkānos. Viṇš uzskatīja, ka pat Lietuvas, Latvijas un Igaunijas apvienotie spēki nespētu tikt galā ar Polijas armiju. Tādējādi apspriede beidzās neveiksmīgi. ${ }^{550}$ Vienlaikus Lietuvas pārstāvji Rīgā centās atgūt frontes iecirkni pret Sarkano armiju, lūdzot Latvijas armijas vadību novietot frontē vismaz vienu lietuviešu bataljonu tās operatīvā pakḷautībā. Lūgumu atbalstīja Anglijas militārā misija, taču armijas virspavēlnieks J. Balodis un štāba priekšnieks P. Radziṇš izvirzịja nepien,emamus noteikumus un pieprasīja atzīt par Latvijas sastāvdaḷu Palangu, visu Ilūkstes apriṇķi un Mažeiķus. Lai nepiel̦autu Latvijas un Lietuvas attiecību uzlabošanos, A. Miškovskis J. Balodim un P. Radziņam solīja Polijas atbalstu visās teritoriālajās prasībās un grasījās atbalstīt viṇu pretenzijas, cerot, ka gaidāmajās sarunās par robežu Latvijai un Lietuvai neizdosies vienoties ${ }^{551}$ (pirmais sarunu posms norisinājās Jelgavā 18.-23. janvārī un beidzās bez rezultātiem; lietuvieši bija pretendējuši uz Ilūksti, bet latvieši - uz Mažeikiiem un Palangu ${ }^{552}$ ).

Polijas armija nopietni gatavojās atvairìt lietuviešu uzbrukumu Viḷṇai. Jau 1919. gada 28. decembrī Francijas misijas pulkvedis K. Rebūls informēja poḷu Lietuvas-Baltkrievijas frontes štābu, ka franču izlūkdienests uzzinājis par uzbrukumu, kurš gaidāms it kā 8. janvārī. ${ }^{553}$ Savukārt janvāra sākumā B. Boufals saṇēma līdzīgu informāciju Francijas militārajā misijā Rīgā (par šḳietami gaidāmo lietuviešu akciju zināja arī Anglijas misija). Poḷu pārliecību

\footnotetext{
546 Laisve. - 1920. - 26 saūs.

547 AAN, Sztab Główny, t. 616/5, k. 58.

548 Jau 1919. gada 19. decembrī angḷu militārā misija Rīgā panāca latviešu un igauņu piekrišanu sākt šādu apspriedi 1920. gada 1. janvārī Rīgā. Tomēr 29. decembrī par tikšanās vietu tika izvēlēts abu pušu galvenais strīda objekts - Valka, kur sarunas sākās 6. janvārī. - LCVA, f. 384, ap. 3, 1. 14.

549 Počs K. Sanitārā kordona valgos. - Rīga, 1971. - 62. lpp.

${ }^{550}$ LCVA, f. 384, ap. 3, b. 14, 1. 11-15; AAN, Stab Główny, t. 616/5, k. 58.

551 CAW, II ND WP, t. 24.

${ }^{552}$ LVVA, 2574. f., 3. apr., 7. 1.

${ }^{553}$ CAW, II ND WP, t. 114.
} 
apstiprināja Lietuvas armijas pārgrupēšanās, baumas Lietuvas armijas daḷās un 8. janvārī pamanītā lietuviešu dal̦u kustība Kaišadores virzienā. Poḷu puse uztvēra šīs darbības kā lietuviešu gatavošanos pārraut sakarus starp E. Ridza-Smiglija karaspēka grupu Daugavpilī un Viḷnu. ${ }^{554}$ Līdz ar to 9. janvārī A. Miškovskis sanēma pavēli panākt Latvijas armijas atbalstu poḷiem, ja notiek lietuviešu uzbrukums. Poḷi plānoja reağèt, uzbrūkot Kaunai, un tādā gadījumā "latviešu ieiešanai Šauḷu rajonā būtu izšķiroša nozīme”. 16. janvārī Miškovskis ziṇoja, ka izdarīts daudz, taču latviešu sociāldemokrātu naidīgā nostāja pret Poliju neḷauj cerēt uz aktīvu atbalstu. Tomēr Latvijas armijas Virspavēlnieka štābs regulāri sniedza poḷiem ziṇas par Lietuvas spēku virzību un pat par "tuvākā laikā gaidāmo lietuviešu uzbrukumu Suvalku rajonā", bet vēl janvāra beigās apgādāja ar "bēgḷa" dokumentiem poḷu izlūku A. Vojtoviču, kas devās no Rīgas uz Lietuvu. ${ }^{555}$ Šajā laikā bruṇota konflikta draudi starp Latviju un Lietuvu bija mazinājušies, taču slikto attiecību dēl Latvijas armijas vadība gandrīz pilnībā atbalstīja Poliju. Par to, cik tuvu bija konflikts, liecina notikumi Ilūkstes apriṇkīi. Kad 3. janvārī 3. Jelgavas kājnieku pulks pārgāja Daugavu, lietuvieši pasludināja, ka demarkācijas līnija atrodas piecus kilometrus no Subates-Lašu-Ilūkstes ceḷa un iet cauri Pilskalnes pagastam līdz Daugavai. Lietuvas armijas kontrolētajā teritorijā tika vardarbīgi likvidētas Latvijas pašvaldības iestādes. Ilūkstes apriṇķa komandants atzina, ka viṇa spēki ir par vājiem, lai spētu to aizkavēt (vēl jo vairāk tāpēc, ka apriņķa komandantūras komanda uzbrukuma sākuma posmā Latgalē bija piedalīta 3. Jelgavas kājnieku pulkam - $\bar{E}$. J.). ${ }^{556}$ 9. janvārī Z. Meierovics vēstulē Lietuvas ārlietu ministram A. Voldemaram sakarā "ar Latvijas armijas uzvaru pār lieliniekiem" pateicās Lietuvas tautai un valdībai par līdzšinējo atbalstu cīnā pret Sarkano armiju. Sekoja vārdi: "Pēc Daugavpils ieņemšanas radies stāvoklis, ka Latvijas armijas uzbrukums plašā frontē un citi iemesli spiež to bez kavēšanās ieņemt lietuviešu karaspēka uz laiku okupēto Kurzemes teritoriju." Galvenais arguments - vairs nepastāv Lietuvas fronte pret Padomju Krieviju. Lìdz ar to nav iemesla Lietuvas armijai oficiāli atrasties Latvijā. 21. janvārī Lietuvas ārlietu ministrs atbildēja, ka karaspēks netiks izvests, jo Latvijas puses argumentācija nav pamatota un turpmāk Lietuvas valdība vispār neatbildēs uz prasībām, kas izteiktas nepiel̦aujamā "pavēles formā". A. Voldemars bija acīmredzami sašutis par Z. Meierovica vēstuli un uzsvēra, ka Lietuvas valdība nevar pieṇemt tajā izteikto pateicību, jo nav piedalījusies Latgales atbrīvošanas operācijā "tā vienkāršā iemesla dēḷ,

\footnotetext{
554 Paluszyński T. Walka o niepodległość Łotwy 1916-1921. - S. 310.

${ }^{555}$ LVVA, 2574. f., 3. apr., 7. 1. P. Losovskis atzīst, ka patiesībā šajā laikā Lietuvas armijai nebija nodoma uzbrukt un tās uzdevumi saistījās vienīgi ar aizsardzību. - Łossowski P. Konflikt polsko - litewski... - S. 97.; CAW, II ND WP, t. 114.; WBH, 341. 1. 157; AAN, Attachaty, A-II/ 81/1.

${ }^{556}$ LVVA, 6033. f., 1. apr., 25.1., 34. 1p.
} 
ka operācija tika izplānota un izpildīta bez Lietuvas ziṇas". ${ }^{557}$ Kampaṇu pret Latviju sāka arī Lietuvas prese, pārmetot savienības noslēgšanu ar Poliju (pirmkārt, oficiozs "Lietuva", kas pārmeta latviešiem nepateicību, nepamatotu pretendēšanu uz Lietuvas zemēm, draudzēšanos ar poliem, no kuriem galu galā paši latvieši neko labu nesagaidīs utt.; otrkārt, "Laisve", kas 25. februārī pat prasīja dot Latgales iedzīvotājiem tiesības brīvi izvēlēties, pie kuras valsts tie grib palikt - pie Latvijas vai Lietuvas, kas kultūras un valodas ziṇā viṇiem ir tuvāka, u. c. $\left.{ }^{558}\right)$. Poḷu valodā iznākošā Viḷṇas lietuviešu avīze "Echo Litwy" brīdināja poḷus pārāk nepaḷauties uz jauno sabiedroto - Latviju. ${ }^{559}$ Kopumā diplomātiskais pārstāvis Kauṇā V. Bandrevičs pamatoti saskatīja "apzinātu, sistemātisku kūdīšanu un aǵitāciju pret latviešiem presē”. Latvijas Ārlietu ministrija slikto attiecību galveno iemeslu nepārprotami redzēja Lietuvas valdības un, pirmkārt, ārlietu ministra A. Voldemara nostājā. Tieši viṇš, pēc Latvijas pārstāvniecības domām, bija izjaucis līguma noslēgšanu starp Lietuvu un Latviju decembrī. Janvāra vidū A. Voldemars vaḷsirdīgi izklāstīja V. Bandrevičam savu nemainīgo ārpolitisko koncepciju. Saskaṇā ar to Padomju Krievija Lietuvu neapdraudēja un vienīgais Lietuvas ienaidnieks bija Polija. Savukārt Latviju un Poliju Krievija agri vai vēlu iznīcināšot (pirmo - ostu dēḷ, otro - "vecā naida" dēl). Latvijas pastāvēšanai Lietuvas valdība neticot, tādēl karaspēku no Ilūkstes aprinka neatvilkšot. Latvijas valdībai pēc šiem ciniskajiem apsvērumiem radās pārliecība, ka ar "pašreizējiem Lietuvas ārpolitikas vadītājiem būs grūti sasniedzama Baltijas valstu vienotība". ${ }^{560}$ Līdzīgs noskan,ojums dominēja Ārlietu ministrijas departamenta direktora L. Sējas pārskatos. Tajos bija runa gan par Lietuvas "šaubīgajiem veikaliem ar lieliniekiem", gan tās valdības tuvredzību un lietuviešu preses un valdības notu "provokatīvo toni". 4. februārī viņš rakstīja: "Grūti pateikt, vai ir darīšana ar muḷkību vai nodevību pret pašu leišu tautu," izsakot pārliecību, ka Lietuvas valdībai ir slepena, tieši vai netieši pret Latviju vērsta vienošanās ar Vāciju. Turklāt Latvijas diplomāts zināja arī par A. Voldemara organizēto interpelāciju Lietuvas parlamentā. Lietuvas ārlietu ministrs bija piẹ̦āvis, ka Lietuvas sadalī̌̌anas nolūkos ir iespējama slepena Latvijas un Polijas sadarbība. 28. februārī, jau pēc Kauñā notikušajiem lielinieciski noskaṇoto karaspēka daḷu nemieriem, kuru norisei vērīgi sekoja Latvijas pārstāvniecība,

\footnotetext{
557 Turpat, 3601. f., 1. apr., 273. 1., 79. 1p.; 247. 1., 197. 1p.; LCVA, f. 929, ap. 1, b. 35, 1. 1, 4. Savā atbildē uz šo vēstuli Z. Meierovics samērā strikti norādīja: „Kas zīmējas uz tiem iemesliem, aiz kuriem Lietuvas valdība joprojām neatsauc savas karaspēka daḷas no Ilūkstes apriṇķa un bijušās administratīvās robežas, tad, tiešām, līdz šim nav man bijis iespējams to saprast, un, jāatzīstas, šie iemesli sāk pat palikt arvien nesaprotamāki, ievērojot to, ka Lietuva nav spiesta karot ar lieliniekiem.” Tālāk viņš noraidīja pārmetumus par pārlieku kategorisko toni korespondencē un atzīmēja: „Vienīgi no Lietuvas valdības atkarājas izbēgt pārāk kategoriskus termiṇus, kurus, par lielu nožēlošanu, es biju spiests lietot. Tas būtu panākams, piegriežot lielāku vērību mūsu piln̄̄gi likumīgām prasībām, kuras saskan ar tiem lojalitātes un pilnīgas sirsnības principiem, kurus Jūs mums tik karsti rekomendējat. Pagaidām es jūtos spiests Jums pašiem ieteikt pārdomāt šos cildenos principus un izsaku cerību, ka Jūs izlietosat visu iespējamo, lai izbēgtu no visa tā, kas varētu ienest kādas pārmaiṇas tanīs īstajās draudzības jūtās, kādas mūsu zeme arvien ir izjutusi pret lietuviešu tautu." - LVVA, 2574. f., 3. apr., 6. 1., 99. 1p.

${ }^{558}$ Lietuva. - 1920. - 9, 16, 31 saūs., 1 vas.; Laisve. - 1920. - 27 saūs., 4, 25 vas.

559 Echo Litwy. - 1919. - 14 stycz.

${ }^{560}$ LVVA, 2575. f., 11. apr., 8. 1., 27.-31. 1p.
} 
L. Sēja uzsvēra: "Arī neatkarīga Lietuva Latvijai vajadzīga, protams, bez ǵermanofilās orientācijas, kāda uzskatāma par pārejošu parādību, jo leišu tauta šim virzienam nebūt nepiekrīt." ${ }^{561}$ Abu valstu attiecības neuzlaboja arī Z. Meierovica mēǵinājums 4. februārī panākt lietuviešu karaspēka atvilkšanu no Ilūkstes apriṇka ar Antantes militārās misijas locekḷa - brita A. Ternera starpniecību, jo pēdējais 10. februārī Latvijas ārlietu ministra vēstules kopiju pārsūtīja uz Kauṇu un prasīja sniegt attiecīgus paskaidrojumu (vēstulē bija informācija par lietuviešu vardarbībām pret vietējiem latviešu iedzīvotājiem un lūgums panākt, lai tie izvestu savu karaspēku). Šì rīcība kārtējo reizi radīja jūtīgajos lietuviešos aizvainojumu pret latviešiem. ${ }^{562}$

Francija uzbrukumu Latgalē uztvēra ar apmierinājumu, jo Polijai bija liela nozīme šīs valsts ārpolitiskajā koncepcijā un Francija cerēja izveidot pretpadomju savienību sev īpaši draudzīgās, izteikti frankofilās Polijas vadībā (Francija arī cerēja, ka Baltijas reǵionā pieaugs tās politiskā un saimnieciskā ietekme).563 Informācija par franču gandarījumu pienāca no vairākiem avotiem. ${ }^{564}$ Francijas nostājas mainuu ietekmēja arī Krievijas pretlieliniecisko spēku nespēja atjaunot Antantei draudzīgu Krieviju, turklāt tās vecajās robežās (tieši 1919. gada 31. decembrī Latvijas diplomātiskais pārstāvis O. Grosvalds ziņoja no Parīzes, ka „franči uz Kolčaku un Deņikinu pilnīgi zaudējuši cerību"565). Līdz ar to pakāpeniski mainījās arī Francijas attieksme pret Baltijas valstu neatkarību. 1920. gada janvārī Francijas pārstāvji pret Latvijas neatkarības atzīšanu izturējās "ḷoti labvēlīgi" (patiesībā tikai nedaudz labvēlīgāk nekā iepriekš - É. J.), tomēr vēl neuzṇēmās nekādas konkrētas saistības. 1919. gada beigās uzsāktā Latvijas armijas Zemgales divīzijas formēšana Kurzemē turpinājās, izmantojot Francijas piegādāto bruṇojumu un ievērojot franču instruktoru norādijumus. ${ }^{566}$

Savukārt Anglijas nostājā izpaudās tās nesaskaṇas ar Franciju un politiskā un saimnieciskā konkurence ar šo valsti. Latvijas pārstāvis Londonā G. Bisenieks 1920. gada janvārī ziṇoja, ka vairāki Anglijas valdības locekḷi brīdinājuši no "pārliecīgas draudzības" ar Poliju, uzsverot, ka nav piel̦aujama Lietuvas patstāvības ierobežošana un nepieciešams "stingri uzstāties pret Francijas nodomiem" un vienoties ar Lietuvu un Igauniju. ${ }^{567}$ 8. februārī britu pārstāvis Sabiedroto komisijā Baltijas valstīs S. Talentss Latvijas militārajam pārstāvim Londonā J. Kī̄selim izklāstīja savu sarunu ar premjerministru D. Loidu-Džordžu, kas ieteicis viṇam Latvijā un Lietuvā neoficiāli „uzstāties par mieru”. Atklāti briti to darīt nevarot, jo Francija vēl arvien „grib redzēt apvienotu Krieviju" un šìs idejas vārdā karot kopā ar jaunajām valstīm.

\footnotetext{
${ }^{561}$ Turpat, 2574. f., 4. apr., 7. 1., 50., 95., 107., 111., 139. 1p.; Stranga A. Latvijas-Padomju Krievijas miera līgums 1920. gada 11. augustā. -32 . lpp.

${ }^{562}$ LCVA, f. 929, ap. 1, b. 35, 1. 11.

${ }^{563}$ Sīkāk sk.: Schramm T. Działalność francuskich misji wojskowych w krajach Bałltyckich po I wojnie światowej//Studia i materiały do historii wojskowości. - T. XXVI. - 1983. - S. 263-291.

564 Počs K. Sanitārā kordona... - 60. lpp.

${ }^{565}$ LVVA, 2575. f., 7. apr., 6. 1., 364. 1p.

566 CAW, II ND WP, t. 24.

${ }^{567}$ LVVA, 3601. f., 1. apr., 248. 1., 52. 1p.
} 
S. Talentss l̦oti negatīvi novērtēja Latvijas „stipro saistīšanos” ar Poliju tas ir ,[..] tas pats, kā piesiet bērnu pie mirona", 568 jo tās stāvoklis ir finansiāli kritisks. Anglija nevēlējās, ka Baltijā pieaug Polijas ietekme, jo Polija savukārt atradās Francijas iespaidā. Sakarā ar Polijas iekšējo nestabilitāti Anglija uzskatīja Poliju par potenciālu militāro konfliktu izraisītāju visā reǵionā, jo Polija bija iekšēji nestabila, tai bija milzīga armija, kuras uzturēšanai nepieciešami ḷoti lieli finansiālie līdzekḷi, un ambiciozi ārpolitiskie mērk̦i. Savukārt Francijas un Polijas valdošās aprindas nelabvēlīgi izturējās pret Anglijas centieniem aktivizēt darbību Baltijā, jo saskatīja vēlmi izveidot tajā reǵionu, kas ir saimnieciski un politiski atkarīgs no Anglijas (tālredzīgi bija arī britu nākotnes tirdzniecības plāni ar Krieviju - Baltijas valstis neapšaubāmi būtu izdevīgs tranzītkoridors).

A. Miškovskis 20. janvārī ziṇoja, ka uzbrukums Latgalē angḷus pilnīgi pārsteidzis un vērojama viṇu ietekmes mazināšanās Latvijā. Saasinājās attiecības starp Latvijas armijas virspavēlniecību un angḷu militāro misiju, kas pat draudēja atsaukt abus savus aviācijas instruktorus no Latvijas armijas un pārtraukt bruṇojuma piegādes. Tomēr pēc dažām dienām attiecības normalizējās. A. Miškovskim šḳita, ka ang̣̣i un franči vienojušies par turpmāko līdzāspastāvēšanu Baltijā un abu misiju darbībā manāma vēlme Antantes vadībā koordinēt Baltijas valstu spēkus pret Padomju Krieviju. ${ }^{569}$ Tas dalēji atbilda patiesībai, kaut gan pretrunas starp abām valstīm pilnībā neizzuda arī Baltijas jautājumā, turklāt abām lielvalstīm šajā laikā jau bija atšḳirīgi plāni attiecībā uz Padomju Krieviju (angḷi pēc Judeṇiča karaspēka sakāves pie Petrogradas bija sākuši nopietni rēķināties ar padomju valsts pastāvēšanas iespēju un, kā jau minēts, bija nepieciešams domāt par sev izdevīgiem tirdznieciskiem sakariem ar šo valsti).

Vienlaikus vairāk ārēji pagaidām saglabājās arī Antantes lielvalstu kopējā nostāja. Anglijas militārās misijas vadītājs ǵenerālis A. Bērts 6. janvārī ieradās Daugavpilī, lai iepazìtos ar stāvokli tikko atbrīvotajā pilsētā. 8. janvārī viṇš pieṇēma poḷu un latviešu karaspēka parādi un pēc atgriešanās Rīgā 9. janvārī pauda publisku atzinību par abu armiju sadarbību Latgalē. ${ }^{570}$ Vēlāk fronti Ziemeḷlatgalē apmeklēja arī Francijas un ASV militārās misijas pārstāvji. ${ }^{571}$ Kauju laikā Dagdas apkārtnē poḷu vienību frontē ieradās kāds Anglijas militārās misijas pulkvedis un pat piedalījās 5. Leǵionu pulka 1. rotas sarīkotā iebrukumā ienaidnieka ieṇemtā sādžā. ${ }^{572}$

Padomju Krievijas reakcija uz uzbrukumu Latgalē bija paredzama. Kopīgajā uzbrukumā tā saskatīja tiešu savu tālejošo interešu apdraudējumu -

\footnotetext{
${ }^{568}$ Turpat, 6033. f., 1. apr., 26. 1., 2. 1p.; Stranga A. Latvijas-Padomju Krievijas miera līgums 1920. gada 11. augustā. -45 . lpp.

${ }^{569}$ CAW, II ND WP, t. 24.

${ }^{570}$ Jaunākās Ziṇas. - 1920. - 10. janv.; Počs K. Sanitārā kordona... - 60. lpp. Acīmredzot saistībā ar angḷu vizīti Daugavpilī komandējumā šajā pilsētā 7.-18. janvārī atradās Latvijas armijas Virspavēlnieka štāba tulks kapteinis H. Brašñevics - LVVA, 3601. f., 1. apr., 922. 1., 61. 1p.

${ }^{571}$ Diparkē E. Latvju tautas augšāmcelšanās//Latvju varoṇu gaitas. - Rīga, 1938. - 253. lpp. Sīkāk sk.: Jēkabsons Ē. ASV attieksme pret Latviju 1918.-1922. gadā//Vēsturnieks profesors Dr. phil. LZA ārzemju loceklis Andrievs Ezergailis. Bibliogrāfija. Darbabiedru veltījumi 70 gadu jubilejā/Sast. J. Bērzin̦š. - Rīga: LU Latvijas vēstures institūts, 2000, 198.-263. lpp.

572 WIH, Styliński J. Wspomnienia źołnierza 5 pp. Legionów 1915 - 1920, k. 62 - 65.
} 
politisku Latvijas vienošanos ar Poliju. Šĩ vienošanās radītu pamatus Baltijas valstu savienībai, kuras izveidi Padomju Krievija nedrīkstēja pieḷaut - tas bija viens no galvenajiem Padomju Krievijas ārpolitiskajiem mērḳiem. Mēneša sākumā uz Maskavu izbraukusī Latvijas Sarkanā Krusta delegācija (kurai bija arī jānoskaidro pamiera noslēgšanas iespējas) 6. janvārī ziņoja, ka Krievijas ārlietu tautas komisārs G. Čičerins saskata uzbrukumā saskan,otu Latvijas un Polijas militāru kopdarbību "ar tālejošiem mērḳiem”. Viṇš pieprasīja paskaidrojumus un garantiju, ka Polijas karaspēks izies no Latgales tūlìt pēc pamiera noslēgšanas. Līdz atbildes saṇemšanai jebkuras sarunas ar Latvijas delegāciju Maskavā tika pārtrauktas. 8. janvārī Z. Meierovics pilnvaroja delegāciju paziņot padomju pusei, ka Latvijai "kopīga uzbrukuma plāna ar Poliju pret Padomju Krieviju nav" un poḷu karaspēks atstās Latgali tūlìt pēc pamiera noslēgšanas. 11. janvārī sarunas ar Sarkanā Krusta delegāciju Maskavā atsākās un pēc Latvijas puses prasības bija slepenas. Tās notika ar īsiem pārtraukumiem un turpinājās Latvijas delegācijai l̦oti smagos apstākḷos. ${ }^{573}$ Padomju puses sākotnējās prasības bija nepieņemamas, īpaši prasība par Latgales neitralizāciju jeb Latvijas armijas izvešanu no tās līdz politiskai jautājuma noskaidrošanai starp Latviju un Padomju Krieviju.

Latvijas attiecības ar Poliju 1920. gada sākumā bija labas. 3. janvārī A. Ķeniņš uzsvēra, ka pēc Bermonta sakāves "poḷi pārliecinājušies, ka mazā, bet enerǵiskā Latvija būs ḷoti vērtīgs cīṇu biedrs pret kopīgajiem ienaidniekiem", kaut arī nav zudušas bažas par "Latvijas draudzīgajām attiecībām ar Lietuvu un labā spārna tendenciozi uzsvērto latviešu radikālismu”. Viṇš konstatēja, ka Latvijai nelabvēlīgās aprindas pašlaik nespēj ietekmēt valdības politiku. ${ }^{574}$ Polija bija apmierināta ar poḷu-latviešu militāro sadarbību un uzsvēra arī tās politisko nozīmi. Lietuvas-Baltkrievijas frontes virspavēlnieks S. Šeptickis presē atzina, ka pēc Daugavpils dzelzceḷa tilta remonta Polijas armija varēs saṇemt no Rietumiem bruṇojumu cauri Rīgai. ${ }^{575}$ Gandrīz visa prese uzsvēra abu valstu armiju savstarpējo draudzību un tās pozitīvas sekas - "starp Maskavu un Berlīni” radīs nopietns šḳērslis. ${ }^{576}$ Tika publicēts pat Polijas sabiedrībā valdošais un pārspīlētais viedoklis, ka Polija ir „mazo tautu glābēja un aizbildnis" un ka E. Ridzs-Smiglijs pēc latviešu lūguma sāks "Latvijas armijas organizēšanu". Tas gan pēc dažām dienām tika atsaukts, atzīmējot, ka šì armija jau sen organizēta un varonīgi cīnījusies pret Bermontu un lieliniekiem, ${ }^{577}$ taču šì preses pīle lielā mērā atspogul,oja poḷu sabiedrībā valdošo priekšstatu par savu zemi kā „prometejisku lielvalsti”. Tomēr par iespējamo stāvokḷa maiṇu liecināja baumas par Daugavpils gaidāmo iekḷaušanu Polijā. Tāpēc Latvijas Preses biroja vadītājs Varšavā R. Lazdiṇš paziṇojumā poḷu laikrakstiem paskaidroja, ka Latgale ir Latvijas sastāvdala un to atzinusi arī Polijas valdība. ${ }^{578}$ Tas izraisīja poḷu nacionāldemokrātu sašutumu pret

\footnotetext{
${ }^{573}$ Stranga A. O niektórych problemach polsko - łotewskich stosunków ... - S. 147; Stranga A. Latvijas-Padomju Krievijas miera līgums 1920. gada 11. augustā. - 30.-31. 1pp.

${ }^{574}$ LVVA, 2575. f., 15. apr., 11. 1., 75. 1p.

575 Nasz Kraj. - 1920. - 25 stycz.

576 Źołnierz Polski. - 1920. - 10 stycz, 7 luty; Kurjer Polski. - 1920. - 14, 15 stycz.; Rząd i Wojsko. $-1920 .-18$ stycz.

577 Nasz Kraj. - 1920. - 8 stycz.; Kurjer Polski. - 1920. - 10 stycz.

578 Kurjer Poranny. - 1920. - 9 stycz.; Kurjer Polski. - 1920. - 10 stycz.; Czas. - 11 stycz.
} 
savu valdību un J. Pilsudska politiskajām aprindām. Ārlietu ministrs S. Pateks nevarēja dot paskaidrojumus, jo neatradās Varšavā, bet prese uzsvēra, ka vēl nebūt nav izškirta Daugavpils valstiskā piederība. ${ }^{579} \mathrm{Uz}$ Latvijas Preses biroja paziṇojumu Polijas valdība oficiāli nereaǵēja, un nacionāldemokrātu prese pārmeta valdībai un J. Pilsudskim, ka ir notikusi uzurpācija un Latvijai bez Seima ziṇas atdota Latgale, kurā ir ievērojams poḷu iedzīvotāju skaits. Tiesa, daḷa nacionāldemokrātu uzskatīja, ka Polija varētu arī atteikties no Latgales, ja panāktu savienības izveidi un Polija saṇemtu plašas garantijas sev un vietējai poḷu minoritātei. ${ }^{580}$ Valdībai tuvu stāvošais laikraksts "Rząd i Wojsko" rakstīja, ka klaigāšana par Daugavpili kā poḷu pilsētu bojā attiecības ar Latviju un rada iespaidu, ka Polijai ir agresīvi nodomi. Latgale nav "poḷu zeme", kā apgalvo nacionāldemokrāti, un, "kamēr Pilsudskis strādā, lai piesaistītu latviešus, baltkrievus un ukraiṇus, nacionāldemokrāti dara visu, lai tos atbaiditu". 581

Šie notikumi piesaistīja Latvijas sabiedrības, politiķu un valdības uzmanību. ${ }^{582}$ To vēl vairāk pastiprināja brīdinoši signāli no citiem avotiem. Armijas izlūkdienests 19. janvārī ziṇoja, ka poḷu virsnieki Viḷnā runā par poḷu karaspēka palikšanu Latgalē. ${ }^{583}$ Kaut arī Latvijas valdība bija informēta par divu politisko virzienu (J. Pilsudska un R. Dmovska) cīnuu Polijā, tomēr izlūkdienesta ziṇas darīja to piesardzīgāku (Latvijas attieksmē pret Poliju piesardzība nekad neizzuda). Oficiālā Polijas puses nostāja palika Latvijai visumā labvēlīga un izpaudās visās jomās. Arī pats ārlietu ministrs S. Pateks 26. janvārī Parīzē sarunā ar Latvijas pārstāvi O. Grosvaldu uzsvēra, ka viṇš Latvijas „stāvokli visur aizstāvot” un pat esot piedāvājis Antantes Augstākajai Padomei izveidot atsevišḳu militāru komisiju, kas kontrolētu cīnu pret Padomju Krieviju, iespējams, ar latviešu pārstāvja piedalīšanos. Pēc S. Pateka domām, „kādu laiku vilksies vēl defensīva cīṇa ar padomju republiku, Polija būs centrā, Latvija kreisajā spārnā un Rumānija labajā spārnā". Turklāt O. Grosvalds uzskatīja, ka Latvijas militārpolitiskā situācija šobrīd ir pietiekami laba (lielā mērā - pateicoties militārajai sadarbībai ar poḷiem pret Padomju Krieviju - $\bar{E}$. J.), lai kārtējo reizi pieprasītu no Antantes lielvalstīm atzī̌̌anu „de iure”. ${ }^{584}$

Arī Latvijas oficiālā nostāja pret Poliju ārēji pagaidām nemainījās. A. Ķeniņš 11. janvārī Polijas presē uzsvēra, ka Polija vienīgā no koalīcijas valstīm izpratusi "spēcīgas Latvijas" nozìmi un attiecības ar to ir l̦oti labas. Viṇš par valdības galveno mērḳi deklarēja triju Baltijas valstu, Somijas un Polijas savienības izveidi, atzīstot, ka Lietuva pagaidām "tiek apieta" sakarā ar tās "nenoteikto pozīciju” un simpātijām pret Vāciju. A. Keniṇš arī solīja Polijai, ka tā varēs izmantot Latvijas ostas (pretēji valdības vēlākajai

\footnotetext{
579 Czas. - 1920. - 9, 11 stycz.; Kurjer Powszechny. - 1920. - 15 stycz.

${ }^{580}$ Gazeta Warszawska. - 1920. - 21 stycz.; Hłasko J. Polityka wewnętrzna//Przegląd Narodowy. 1920. - T. XVII; Hłasko J. Wątpliwosci na Wschodzie//Gazeta Warszawska. - 1920. - 21 stycz.

${ }^{581}$ Rząd i Wojsko. - 1920. - 10, 25 stycz.; 1 luty.

582 Sociāldemokrāts. - 1920. - 18. janv.

${ }^{583}$ LVVA, 3235. f., 1/14. apr., 27. 1., 3. lp.

${ }^{584}$ Turpat, 2575. f., 7. apr., 6. 1., 358. 1p.
} 
nostājai - E. . J.). Turklāt Polijas prese atreferēja Latvijas diplomātiskā pārstāvja O. Grosvalda Parīzē teikto par Latvijas-Polijas militāro aliansi kā pirmo soli pretī Baltijas valstu un Polijas savienībai. ${ }^{585}$

Tieši šādas savienības izveide bija kārtējās Baltijas valstu konferences galvenais mērḳis. Sākotnēji konferenci bija paredzēts sasaukt Helsinkos 4. janvārī, taču pēc Polijas lūguma konference sākās 15. janvārī un turpinājās līdz 23. janvārim, kad aizsalušā Somu jūras līča dēl visas delegācijas somu ledlauzī atstāja Helsinkus. ${ }^{586}$

Jau 1919. gada beigās J. Pilsudskis deva norādījumu L. Vasiḷevskim mēǵināt panākt darbības saskaṇošanu ar pārējām valstīm pie Baltijas jūras pret Padomju Krieviju, lai noslēgtu ar to kopīgu miera līgumu. Viṇaprāt, vienīgi Baltijas valstu, Polijas un Somijas savienība var nodrošināt visu šo valstu neatkarību un Lietuvas piekrišanu iegūt būs grūti. ${ }^{587} 1919$. gada novembrī J. Pilsudskis piedāvāja Somijas diplomātiskajam pārstāvim Varšavā vispirms savstarpēji vienoties, bet pēc tam runāt ar pārējām Baltijas valstīm. Saskaṇā ar viṇa priekšlikumu Polija atzītu par Somijas ietekmes sfēru Igauniju, bet Somija par Polijas ietekmes sfēru - Latviju un Lietuvu. Pēc mēneša viṇš Somijas armijas virspavēlniekam K. G. Mannerheimam piedāvāja attiecīgi sadalìt atbildību par minēto valstu drošību. Kaut arī Somijas valdība konkrētu piekrišanu nedeva, tomēr tās darbība liecināja, ka tā priekšlikumu neoficiāli pieṇēmusi vai vismaz akceptējusi. ${ }^{588}$ Minētie notikumi apliecina plānotās savienības dalībvalstu savstarpējās pretrunas, kas skaidri izpaudās, pirmkārt, Polijas un zināmā mērā arī Somijas atšķirīgajā skatījumā uz savu lomu plānotajā savienībā. Vēl lielākā mērā šīs atšḳirības bija saskatāmas Lietuvas gadijumā.

Helsinku konferencē darbs noritēja ārlietu, tautību, saimnieciskajā un militārajā komisijā. Pēdējā strādāja pie konvencijas projekta. Saskaṇā ar Polijas militāro un politisko aprindu priekšstatu tika atzīts, ka situācija (pirmkārt, sakarā ar kopējo Polijas un Latvijas militāro operāciju) „Baltijas valstīs ir nobriedusi līdz tam, lai Polija uzsāktu šajā rajonā realizēt noteiktu un skaidru politiku, jo Baltijas valstu savstarpējās saprašanās koncepcija sāk zust. Baltijas valstīm nepieciešama roka, kura vadìtu to kopējo politiku uz vienotu mērki. Konferences sasaukšana Helsinkos un Polijas valdībai izteiktais piedāvājums piedalìties tajā skaidri liecina, ka Somija un Polija izjūt nepieciešamību savstarpēji

585 Kurjer Polski. - 1920. - 11, 21 stycz.; Kurjer Lwowski. - 1920. - 23 stycz.

${ }^{586}$ Robotnik. - 1920. - 3 luty. Somiju konferencē pārstāvēja J. Vennola, R. Holsti u. c.; Igauniju J. Tenisons, A. Birks; Lietuvu - Ārlietu ministrijas departamenta direktors D. Zauņus, Ģenerālštāba pārstāvis P. Vaicuška, pārstāvis Helsinkos V. Gilis; Poliju - L. Vasiḷevskis (9. janvārī viṇš izbrauca no Viḷnas un cauri Daugavpilij ieradās Rīgā, no kurienes tālāk devās jau kopā ar Z. Meierovicu), S. Pruss-Boguslavskis, konsuls Helsinkos M. Samsons-Himmelstjerna, diplomāts M. Sokoḷnickis un militārais atašejs M. Požerskis; Latviju - Z. Meierovics, Senāta loceklis V. Zāmuels, vairāki militārie eksperti.

587 Pobóg - Malinowski W. Najnowsza historia... - S. 234.

${ }^{588}$ Hovi K. Polish - Finnish cooperation in Border - state Policy, 1919-1922//Journal of Baltic Studies. - 1983. - XIV. - Nr. 2. - 124-125. Poḷu puse uzsvēra, ka Polijas diplomātiskais pārstāvis strādā Rīgā, nevis Tallinā, lai parādītu somiem, ka poḷi nevēlas atṇemt viṇu ietekmes tiesības Igaunijā. Savukārt somi vairākkārt lika noprast, ka vēlas darboties Latvijā, Igaunijā, Lietuvā, Baltkrievijā un Ukrainā vien̄̄gi ar poḷu puses piekrišanu. 
saprasties un ka tām ir svarīgi, lai tieši Polija būtu šis galvenais faktors". ${ }^{589}$ Tas bija acīmredzams pārspīlējums. Atmosfēra konferencē bija svinīga, taču vēlamā rezultāta nebija. Igaunija šajā laikā jau bija noslēgusi pamieru un turpināja sarunas par mieru ar Padomju Krieviju. Kaut arī Polija pirmo reizi atklāti izteica vēlmi piedalīties savienībā, tomēr pret Vāciju to nevarēja noslēgt Somijas noraidošās nostājas dēḷ. ${ }^{590}$ Bet galvenais sarunu neveiksmes iemesls bija Lietuvas nesaskaṇas ar Poliju. Lietuviešu delegācija ierosināja veidot tikai Lietuvas, Latvijas un Igaunijas savienību, kura nepieciešamības gadījumā varētu vērsties arī pret Poliju. Latvijas pārstāvji noraidīja šo priekšlikumu, bet igauņi aizbildinājās ar pilnvaru trūkumu. ${ }^{591}$ Savukārt lietuvieši aizbildinājās ar to pašu, kad bija runa par visu valstu kopīgu komisiju, kas mēǵinātu noregulēt Lietuvas un Polijas attiecības (20. janvārī Lietuvas delegācija pazin̄oja, ka nevar strādāt kopā ar Polijas delegāciju, jo poḷi turpina okupēt Lietuvas zemes, un turpmāk palika Helsinkos vienīgi kā novērotāja ${ }^{592}$ ). Atsaucību neguva arī Igaunijas priekšlikums par visu piecu valstu savienību, kas neierobežotu pašu igaunu rīcības brīvību miera sarunās. Dalībnieki vienojās, ka sarunas viṇi turpinās pavasarī Rīgā, un pienēma rezolūciju par gatavību veidot attiecības ar Padomju Krieviju saskaṇā ar Antantes lielvalstu politiku, kā arī vienojās attīstīt saimnieciskos sakarus un apmainìties ar preses pārstāvjiem. ${ }^{593}$ Latvijas delegācijas priekšlikums dalībvalstīm neparakstīt miera līgumu ar Padomju Krieviju, kamēr nebūs noslēgta savstarpēja militāra konvencija, guva vienīgi Polijas un Somijas atbalstu. Igauņi balsoja pret, bet lietuvieši vispār nepiedalījās balsošanā. L,oti trāpīgi dalībvalstu nostāju 1920. gada 19. janvāra ziṇojumā uz Tallinu raksturoja Igaunijas delegācijas vadītājs J. Tenisons. Viņš rakstīja, ka Igaunija ieṇēmusi pret Padomju Krieviju stingru nostāju, Somija izraudzijusies aizstāvēšanās taktiku, savukārt Polija - agresīvu taktiku, Latvija izrādijjusi nenoteiktību, bet Lietuva - vienaldzību. ${ }^{594}$

Ārēji Latvijas un Polijas attiecības pēc konferences nemainījās (Polijas valdība un J. Pilsudskis arī pēc tās saglabāja cerību, ka pretrunas izdosies pārvarēt un nākotnē izveidot kopēju fronti pret Padomju Krieviju). 25. janvārī Daugavpilī uz tikšanos ar J. Pilsudski pēc viṇa uzaicinājuma ieradās Latvijas armijas virspavēlnieks J. Balodis (kopā ar P. Radziṇu un citiem virsniekiem, Anglijas

\footnotetext{
589 Okulewicz P. Koncepcja „międzymorza”. - S. 117.

${ }^{590}$ Počs K. Sanitārā kordona... - 65., 67. lpp.; Skrzypek A. Związek... - S. 54.

591 Łossowski P. Stosunki polsko - litewskie... - S. 190.

592 Čepenas P. Naujuju laiu Lietuvos istorija. - II t. - Chikago, 1986. - P. 515; Laurinavičius Č. Lietuvos-Sovietu Rusijos taikos sutartis. - P. 56.

593 Pobóg - Malinowski W. Najnowsza historia polityczna... - S. 234; Počs K. Sanitārā kordona... 68.-69. lpp.; Andersons E. Latvijas vēsture... - 563. lpp.; Sąsiedzi wobec wojny 1920 roku. - S. 239240. Igaunijas attiecības ar Poliju bija ļoti labas. Sīkāk sk.: Łossowski P. Stosunki polsko - estońskie 1918-1939. - Gdańsk, 1992. Tomēr P. Losovskis maldās, rakstot, ka 1920. gada janvārī poḷu jātnieku izlūku grupa sastapusies Ziemeḷlatvijā ar igauṇu karavīriem (s. 15). Tas nebija iespējams milzīgā attāluma dēl (no Daugavpils līdz Balviem ir 175 kilometri). Poḷu štāba pavēlēs nebija paredzēti šādi nevajadzīgi reidi tehnisku iemeslu un klimatisku apstākḷu dēḷ (poḷi operācijas laikā nesasniedza pat Rēzekni), turklāt Igaunijas karaspēks (izņemot no tā izslēgto S. Bulaka-Balahoviča vienību) vairs neatradās Latvijā.

${ }^{594}$ Pullat R. Od Wersalu do Westerplatte. - S. 86.
} 
militārās misijas vadītāju A. Bertu un Polijas militāro pārstāvi A. Miškovski). ${ }^{595}$ J. Pilsudskis ar pavadoniem (un frontes virspavēlnieku S. Šepticki) pilsētā iebrauca 26. janvārī. Sajā dienā notika abu virspavēlnieku tikšanās Poḷu virsnieku klubā. Viṇi kopīgi apskatīja pilsētu un apmeklēja poḷu 1. Leǵionu divīzijas teātra izrādi. ${ }^{596}$ J. Pilsudskis un vina pavadoṇi atstāja uz latviešiem labu iespaidu, un tikšanās noritēja ḷoti draudzīgā atmosfērā, ko apliecināja abas puses. Runājot par abu valstu sadarbību, Pilsudskis lietoja līdzīgu argumentāciju kā sarunā ar Z. Meierovicu rudenī Varšavā un atstāja uz sarunu biedriem tikpat labu iespaidu kā iepriekš uz Latvijas ārlietu ministru. J. Balodis vēlāk rakstīja: „Kopiespaids no pirmās sagaidīšanas un satikšanās ar maršalu l,oti labs." ${ }^{597}$ Virspavēlnieki pārrunāja turpmāko politisko un militāro sadarbību. J. Pilsudskis piekrita piegādāt Latvijai vairākus lielgabalus (februārī Latvija no Polijas saṇēma 10000 artilērijas lādiṇu). ${ }^{598}$ J. Baloža individuālajā sarunā ar J. Pilsudski (P. Radziṇš vienlaikus runāja ar S. Šepticki un E. Ridzu-Smigliju) Polijas armijas virspavēlnieks novērtēja Latgales operāciju kā gandrīz veiksmīgi nobeigtu. J. Balodis atzīmēja, ka Latgale vēl „nav atbrīvota no nevēlamiem elementiem”, kā piemēru minot poḷu muižnieku aǵitāciju par Latgales palikšanu Polijas sastāvā. J. Pilsudskis atbildējis: „Tā ir atsevišku bezatbildīgu cilvēku politika, protams, muižnieku, turklāt personiskā politika, tai nav lielas nozīmes." Sarunā tomēr iezīmējās arī viens no problēmjautājumiem, kas tuvākajā nākotnē aktualizēsies abu valstu attiecībās un radīs nopietnus sarežǵịjumus. J. Balodis gribēja zināt sarunas biedra viedokli par Polijas presē pausto atziṇu, ka Braslavas apriṇkīi jau iekḷautie seši Ilūkstes apriṇk,a pagasti un Grīva, ko poḷu karaspēks bija ieñēmis 1919. gada augustā-septembrī, ir Polijas teritorija. J. Pilsudskis šoreiz bija izvairīgāks un atbildēja, ka Daugavpils un „daḷa kreisā krasta” Polijas armijai „pagaidām” nepieciešama, lai nostiprinātu savu kreiso spārnu, kas „kontaktējas ar Latvijas armiju”. J. Balodis tomēr bija uzstājīgs un sarunas turpinājumā klāstīja Latvijas puses viedokli par zemnieku pārpoḷošanu šajā teritorijā, kur Polijas statistikas iestādes konstatē polu vairākumu. Pilsudskis atbildējis: „Pašreizējais stāvoklis jāuzskata par pagaidu soliem Daugavpilī un daḷā Ilūkstes apriņ̧̧a. Man nav nekādu pretenziju uz šiem Ilūkstes apriņķa pagastiem, tāpat arī uz Daugavpili.” Atbilde bija izvairīga, jo poḷu maršals strikti noraidīja Baloža priekšlikumu pārcelt uz šo apvidu kādu no latviešu divīzijām, lai neizraisītu „nevēlamus incidentus kaujas apstākḷıs”. Kopumā J. Balodis atzina sarunas ar J. Pilsudski par „val̦sirdīgām, draudzīgām un arī l,oti noteiktām”. No tām viņš kā virspavēlnieks „bija l,oti daudz ieguvis, runājot ar cilvēku, kas izturējās vienkārši, draudzīgi, turklāt atklāti un noteikti”. „Latvijas Pagaidu

595 Brīvā Zeme. - 1920. - 25. janv.; Jaunākās Ziṇas. - 1920. - 31. janv.; Sīkāk sk. Jēkabsons Ē. Ģenerālis Jānis Balodis Polijas diplomātijas skatījumā//Latvijas Arhīvi. - 1995. - Nr. 3. - 24.-25. lpp.

596 AAN, Attachaty, A - II, 81/1, k. 1-2; Latvijas Kareivis. - 1920. - 1. febr.; Polska w pierścieniu prób i ognia. Rok 1918-1926. - Warszawa, 1933, S. 147-148. (J. Pilsudska un J. Baloža tikšanās, Polijas karaspēka fotouzṇēmumi Daugavpilī un citur Latgalē).

597 Jaunākās Ziṇas. - 1920. - 31. janv.; Smigły - Rydz E. Teicams karavīrs. - 68.-69. 1pp.; Piłsudski J. Pisma zbiorowe. - S. 142; Balodis J. Ģenerāḷa Jāṇa Baloža atmiṇu burtnīcas//Neatkarīgā Rīta Avīze. - 1997. - 29. marts.

598 AAN, Attachaty, A- II, 81/1; LVVA, 3601. f., 1. apr., 248. 1., 309.-310. lpp. Februārī Latvijas militārais pārstāvis Varšavā atteicās no 12 poḷu piedāvātajiem lielgabaliem, jo tie bija sliktā tehniskā stāvoklī. Viņam tika uzdots turpmāk vest sarunas par patronu un lielgabalu lādiṇu piegādi, tomēr pagaidām nebija izdevies atrast informāciju par sarunu rezultātiem (jādomā, ka tās beidzās neveiksmīgi). 
valdība no maniem [J. Baloža - $\bar{E}$. J.] ziņojumiem, pamatodamās uz maršala Pilsudska vaḷsirdīgām, skaidrām domām, runām un paskaidrojumiem, varēja secināt: Latgales jautājums un līdz ar to poḷu tautības jautājums jau no Latvijas neatkarības pirmajām dienām pareizi sākts risināt, atliek iet vienu draudzības un saprašanās celu: viena valsts, viena tauta!" Sarunu beidzot, J. Balodis izteica Pilsudskim pateicību par Polijas palīdzību gan Latgales atbrīvošanā, gan ieroču piegādē bermontiādes laikā: „Latvijas armijas virspavēlniecība un visi apzinīgie latvieši ir Jūsu un Polijas parādnieki. Vēlreiz paldies par visu!” Pilsudskis esot atbildējis: „Man žēl, ka maz varēju Jums palīdzēt, mans nolūks bija - stiprināt draudzību starp Latviju un Poliju."599

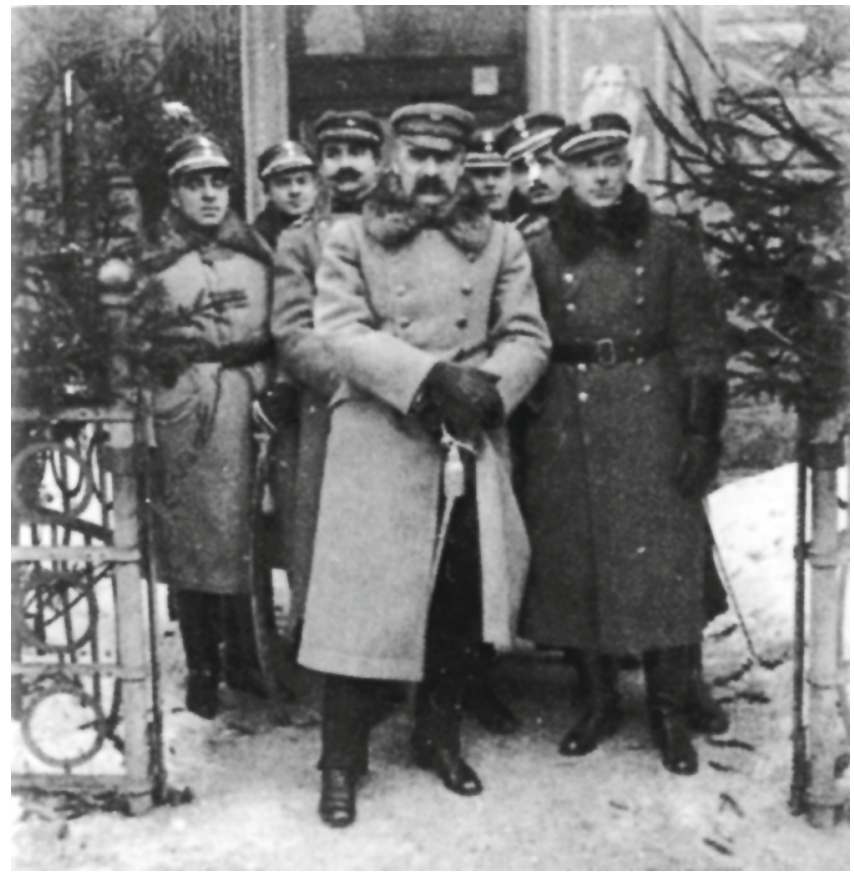

17. att.

\section{J. Pilsudskis un poḷu virsnieku grupa Daugavpilī}

Sakarā ar abu virspavēlnieku ierašanos Daugavpilī, 27. janvārī bija paredzēta karaspēka parāde un frontes apmeklējums, bet lielā aukstuma dē šie pasākimi nenotika. J. Pilsudskis apmeklēja vienīgi 101. lauka hospitāli un 6. Leǵionu kājnieku pulka bataljonu pilsētā, kā arī pasniedza grupas komandierim E. Ridzam-Smiglijam nesen atjaunoto "Virtuti Militari" ordeni. Viṇš arī pieṇēma vietējo poḷu pārstāvju delegāciju ar aptiekas īpašnieku V. Zaḷeski priekšgalā. Delegācija prasīja panākt, lai Latvijas valdība garantētu poḷu kultūras attīstību Latgalē. J. Pilsudskis atbildējis, ka nekādām bažām šajā ziṇā nav pamata. ${ }^{600}$ Tas skaidri apliecina, pirmkārt, šī vadošā poḷu

599 Balodis J. Ģenerāḷa Jāṇa Baloža atmiṇu burtnīcas//Neatkarīgā Rīta Avīze. - 1997. - 29. marts.

${ }^{600}$ CAW, WBH, 341. 1. 154; Kurjer Lwowski. - 1920. - 1 luty; Nasz Kraj. - 1920. - 30 stycz.; Dzwon. - 1928. - 20 maj; Jędrzejewicz W. Kronika źycia Józefa Piłsudskiego. - S. 475; Marszałek Edward Smigły - Rydz. 1886-1986. - Londyn, 1986. - S. 15. 
politikia spēju novērtēt savas valsts ārpolitikas prioritātes, otrkārt, apstiprina viņa gatavību panākt kompromisu ar Latviju, kuras draudzība Polijai tobrīd bija ārkārtīgi nepieciešama ārpolitisko apstākḷu dēḷ. 28. janvārī J. Pilsudskis no Daugavpils devās uz Viḷnu, bet J. Balodis ar pavadoṇiem - uz Rēzekni, kur notika dažu Kurzemes divīzijas vienību skate. Ierindas priekšā J. Balodis izteica pateicību Polijas armijai. A. Miškovskis pēc brauciena īpaši uzsvēra, ka Latgales iedzīvotāji uzṇem atbrīvošanu ar prieku. ${ }^{601}$ Savukārt 7. februārī Daugavpili sava Latgales brauciena laikā apmeklēja Ministru prezidents K. Ulmanis, un viṇa sagaidīšanā piedalījās arī Polijas armijas pārstāvji. ${ }^{602}$ Uz tikšanos ar K. Ulmani Daugavpilī no lietuviešu karaspēka okupētās Jeruzalemes (Ilūkstes apriṇķī) ieradās arī Latgales un Ilūkstes apriṇķa latviešu sabiedriskais darbinieks E. Bržezinskis. Viņš vēlāk aprakstīja Ilūkstes apriṇķa toreizējo kārtību un savstarpējo lietuviešu-poḷu demarkācijas līniju no Daugavas, gar Daugavpils-Kauņas šoseju līdz Grīvas-Eglaines dzelzcel̦a pārbrauktuvei, tad - virzienā uz Birḳeneles muižu. Pēdējais lietuviešu postenis atradās pie minētās pārbrauktuves, bet tālāko posmu līdz Daugavai apsargāja poḷi (satiksme bija likvidēta; tas arī saprotams, zinot poḷu-lietuviešu savstarpējās attiecības - $\bar{E}$. J.). Poḷi jebkuru gājēju uzlūkoja „kā spiegu, kas mēǵina pāriet fronti; arestēja un stiepa uz štābu Grīvā, tad - uz galveno štābu Polijas iekšienē, no kurienes varēja atgriezties pēc ilgāka laika". Ar latviešu tautības lietuviešu rotas komandiera Jeruzalemē izdoto caurlaidi E. Bržezinskim izdevās veiksmīgi nokḷūt līdz Daugavai un nepamanìtam to pāriet pie izpostītā dzelzceḷa tilta. Kopīgu pusdienu laikā viņš izklāstīja K. Ulmanim par situāciju lietuviešu un poļu okupētajā Ilūkstes apriṇķa daḷā. Pēdējais to „laipni uzklausīja” un solīja „darìt visu iespējamo”, piezīmējot, ka jārīkojas diplomātiski, un norādot, ka iedzīvotājiem vēl „vajadzēs paciesties”. ${ }^{603}$ Faktiski šajā laikā Latvijas valdība nebija spējīga risināt šo jautājumu.

Pēc Latvijas delegācijas atgriešanās no Helsinku konferences Latvijas ārpolitikā notika zināms pavērsiens, ko veicināja arī neveiksmīgas sarunas ar citām Baltijas valstīm. Sarkanā Krusta delegācija Maskavā bija saṇēmusi atḷauju pamiera līguma noslēgšanai ar Padomju Krieviju. Tas tika parakstīts 30. janvārī un stājās spēkā 1. februārī plkst. 12.00. Pēc Latvijas puses lūguma pagaidām tas bija slepens ${ }^{604}$ - galvenokārt tādēḷ, lai saglabātu Antantes atbalstu. P. Radziņš atzina, ka armijas vadība atradās nepatīkamā stāvoklī. Slepena pamiera apstākḷos bija "jārāda" Polijai, ka Latvija joprojām karo. Viņš izteica pārliecību, ka Polija, pateicoties tās izlūkdienestam, par pamieru bija uzzinājusi, taču A. Miškovskis bija korekts un "nekad nelika just, ka kaut ko zinātu par mūsu slepenām sarunām ar Padomju Krieviju”. ${ }^{605}$ Pagaidām nav skaidrs, kad poḷi bija uzzinājuši par pamieru. 19. februārī A. Miškovskis ziṇoja, ka 14. februārī Anglijas Telegrāfa ağentūras izplatītā ziṇa par pamieru esot nepatiesa, kaut arī Latvijas prese atzīmē, ka karadarbība faktiski pārtraukta. Acīmredzot saskaṇā ar J. Baloža un P. Radziṇa apliecinājumiem

\footnotetext{
${ }^{601}$ CAW, WBH, 341. 1. 157; AAN, Attachaty, A -II, 81/1.

${ }^{602}$ Latvijas Sargs. - 1920. - 11. febr.; Наша жизнь. - 1920. - 18 марта.

${ }^{603}$ Brzežinskis E. Cel̦ojums uz Daugavpili pirms 15 gadiem//Latgales Vēstnesis. - 1935. - 4. janv.

${ }^{604}$ LVVA, 1313. f., 2. apr., 34. 1., 213.-215. 1p.

${ }^{605}$ Radziņš P. Latvijas atbrīvošanas karš. -122 . lpp.
} 
A. Miškovskis bija uzsvēris, ka pirms miera sarunām Latvijas valdība noteikti apspriedīsies ar Polijas valdību. ${ }^{606}$

Pamiera slepenības dēḷ sarežǵìtā situācijā bija arī Latvijas valdība. Jau 30. janvārī Z. Meierovics delegācijai Maskavā bija spiests dot rīkojumu uz pastāvīgajiem padomju puses pārmetumiem par sadarbību ar poḷiem pret Sarkano armiju atbildēt, ka Latvijas armijas labajā spārnā poḷu karaspēks jau atrodas Krievijas teritorijā un Latvijas valdība nevar atbildēt par poḷu darbību ārpus Latgales. Savukārt G. Čičerins pieprasīja norādīt, kur vispār atrodas Latvijas un Polijas robeža, bet atbildi pagaidām nesaṇēma un nevarēja saṇemt. Tomēr 16. februārī Z. Meierovics ar delegāciju Maskavā solīja panākt Polijas karaspēka izvešanu no Latgales. ${ }^{607}$

Francijas valdība par pamieru zināja jau 6. februārī, tomēr neinformēja par to poḷus ${ }^{608}$ un tādējādi rādīja savu nepārprotamo attieksmi pret Poliju, kura frančus uztvēra kā savus galvenos draugus. Zināma informācija arī poḷiem bija (lielā mērā padomju puses rīcības dēl - tā nebija ieinteresēta slepenībā). 1. februārī frontē J. Puriņa vienību iecirknī ienaidnieks izšāva baltas raķetes un izkāra baltu karogu. Sarkanarmiešu pārstāvji paskaidroja, ka viṇi plkst. 12.00 pārtrauks karadarbību, atkāpsies aiz Zilupes, un aicināja, lai arī latvieši nešauj. Turklāt tika izplatīts uzsaukums, kurā bija runa par pamieru. Poḷi par to uzzināja. ${ }^{609}$ Tajā pašā dienā blakusesošo poḷu vienību rokās nonāca rakstisks padomju puses aicinājums latviešiem pārtraukt uguni. Poḷi zināja arī par 2. februārī rakstīto aicinājumu Latvijas armijas pavēlniecībai. Aicinājumā tika pārmests, ka tā neievēro vienošanos, un jautāts, vai latvieši vispār zina par "miera noslēgšanu". ${ }^{610}$ Kaut arī latviešu daḷu vadība frontē skaidroja, ka tā ir provokācija (šim apgalvojumam viṇa pati ticēja), tomēr poḷu štābs Daugavpilī jau 23. februārī ziṇoja, ka "grupas vadība vēro lielinieku kustību sakarā ar iespējamo pamieru latviešu frontē". ${ }^{611}$

Latvijas oficiālie pārstāvji arvien biežāk sāka pieminēt gaidāmās miera sarunas ar Padomju Krieviju un uzmanīgi centās sagatavot tām Polijas pusi. Februārī A. Keniṇš Polijas presē uzsvēra, ka Krievijas militārais stāvoklis ir slikts, tāpēc var ticēt tās priekšlikumiem un aicinājumiem uz miera sarunām. Tomēr viṇš atzīmēja, ka Latvija kopā ar Poliju un Somiju arī turpmāk būs gatava stāties pretī agresijai. Labākais nodrošinājums būtu militāra savienība Polijas vadībā un ar Ukrainas Tautas Republikas piedalī̌̌anos. Latvijas mērḳi karā ir sasniegti, tādēl sabiedriskā doma tiecas pēc miera. Turklāt A. Keniṇš asi vērsās pret Lietuvu, ${ }^{612}$ kas izturējās pret kaimin,valstīm nenoteikti (jo bijusi "apziṇa, ka nav pamata neatkarīgas politikas ìstenošanai”). Lietuviešu neuzticība Polijai ietekmējot arī Lietuvas valdības attieksmi pret Latviju, kas

\footnotetext{
${ }^{606}$ AAN, Attachaty, A - II, 64/1, k. 15.

607 Stranga A. O niektórych problemach polsko - łotewskich stosunków... - S. 150.

${ }^{608}$ Hovi K. Alliance de Revers. - Turku, 1984. - P. 35.

${ }^{609}$ CAW, WBH, 341. 1. 157.; AAN, Attachaty, A - II, 81/1. Sīkāk sk.: Jēkabsons Ē. Pamiers Latgales frontē 1920. gadā//Latviešu Strēlnieks. - 1996. - Nr. 6.

${ }^{610}$ CAW, WBH, 341. 1. 157.

611 AAN, Attachaty, A - II, 64/1, k. 57.

${ }^{612}$ Kaut arī A. Ķeniņš pauda valdības attieksmi, tomēr izteikumos jaušama arī personiskā negatīvā attieksme pret Lietuvas valdības ieņemto nostāju. Tas vēlreiz apliecina, cik nepamatota ir versija par viṇa pārliecīgajām simpātijām pret šo valsti.
} 
nepiel̦aus, ka Lietuvā taps "jauns Krievijas un Vācijas saprašanās tilts". ${ }^{613}$ Savukārt Z. Meierovics 18. februārī Rīgā intervijā poḷu nacionāldemokrātu presei atklāti paskaidroja, ka Latvijai nākotnē jārēḳinās ar saimnieciskajiem sakariem austrumos, tādēḷ valdība izškīirusies sākt miera sarunas un tālāku aktīvu karadarbību uzskata par neiespējamu. ${ }^{614}$

Kopumā Latvijas attieksmē saglabājās līdzšinējās tendences. No vienas puses - cenšanās neuzṇemties saistības, kas cieši piesaistītu Latviju Polijai cīṇā pret Padomju Krieviju, no otras puses - vēlme saglabāt labas attiecības ar Poliju, kuras atbalsts bija l̦oti vēlams gaidāmajās miera sarunās. Latvija centās neienemt noteiktu nostāju Polijas konfliktā ar Lietuvu (Z. Meierovics 18. februāra intervijā kārtējo reizi uzsvēra Latvijas neitralitāti Viḷnas piederības problēmas risināšanā).

Savukārt Polija, kuras interesēs joprojām bija panākt vismaz divpusēju savienību ar Latviju, arī turpināja līdzšinējo politiku. Janvāra beigās, atgriežoties no Helsinkiem, Latvijas Tautas Padomes sēdi apmeklēja L. Vasiḷevskis, kurš priekšparlamenta locekliem tika stādìts priekšā kā "sabiedrotais no dienvidiem". ${ }^{615}$ Intervijā Latvijas presei viňš vēlreiz uzsvēra, ka Latgale pieder Latvijai un Polija nekad nav uz to pretendējusi, kā arī to, ka draudzīgo attieksmi pret Latviju nosaka Polijas ǵeogrāfiskais un politiskais stāvoklis. ${ }^{616}$ L. Vasilevskis Varšavā atgriezās 7. februārī un tūlīt ziṇoja ārlietu ministram S. Patekam par Helsinku konferences rezultātiem. ${ }^{617}$

Polijas ārlietu resora vadība turpināja uzsvērti labvēlīgu politiku pret Latviju. Ārlietu ministrijas departamenta direktors un ministra vietnieks Z. Okenckis 3. februārī informēja A. Keniṇu par Polijas nostāju pret 28. janvārī izteikto kārtējo padomju miera piedāvājumu, uzsverot vēlmi šajā jautājumā būt pastāvīgā saskarē ar Latviju un solot nenostādīt to notikuša fakta (noslēgta poḷu-padomju miera līguma) priekšā. Līdzīgu viedokli pēc dažām dienām pauda arī Polijas Seima Ārlietu komisija un Kara lietu komisija. ${ }^{618}$

Tajā pašā laikā sāka izpausties arī poḷu šovinistisko aprindu ietekmes pieaugums un biežāki kḷuva dažādi pārmetumi Latvijai. 14. februārī arī S. Pateks izteica neapmierinātību ar 50 poḷu tautības dzelzcelnieku atlaišanu no darba Latgalē latviešu valodas nezināšanas dēḷ. Ministrs lūdza dot viniiem laiku tās apgūšanai. Īstenībā Latgalē atradās ap 4000 bijušo Krievijas dzelzceḷnieku, kurus visus nodarbināt uz Latvijas dzelzcel̦iem nebija iespējams. Tāpēc tika atlaisti 3000 cilvēki, starp kuriem tikai 57 bija poḷi. Tādējādi atlaišanu noteica vienīgi saimnieciskie apstākḷi un valodas nezināšana nebūt nebija galvenais iemesls. ${ }^{619}$

\footnotetext{
${ }^{613}$ Kurjer Polski. - 1920. - 14 luty.

${ }^{614}$ Gazeta Warszawska. - 1920. - 4 marzec; Kurjer Lwowski. - 1920. - 6 marzec.

615 Gazeta Warszawska. - 1920. - 31 stycz.

${ }^{616}$ Latvijas Sargs. - 1920. - 1. febr.

${ }^{617}$ Kurjer Polski. - 1920. -8 luty.

${ }^{618}$ LVVA, 2575. f., 15. apr., 11. 1., 65. 1p.; Latvijas Sargs. - 1920. - 13. febr.

${ }^{619}$ LVVA, 2575. f., 15. apr., 1. 1., 73. 1p.; 11. 1., 40. 1p.
} 
21. februārī A. Keniṇš un pārstāvniecības sekretārs P. Oliṇš Varšavā tikās ar J. Pilsudski, ${ }^{620}$ pārrunājot Latvijas iespējamo starptautisko atzī̌sanu „de iure" un miera jautājumus. A. Keniņš uzsvēra, ka "kopīgi veiktie kara darbi dod tagad iespēju kopīgi uzsākt miera sarunas", bet J. Pilsudskis apsolīja, ka sarunās ar Krieviju Polija prasīs padomju valdībai atzìt visas valdības, kas pastāv bijušajā impērijā. Savukārt Parīzē poḷi mēǵinās panākt Antantes piekrišanu šādai prasībai (līdz ar to arī Antante atzìtu Baltijas valstis). Polija nevarot pirmā atzìt Latviju, jo Antante uzskatot Baltijas valstu jautājumu par vienu no Krievijas problēmām. Pilsudskis lika noprast, ka neatzīst nacionāldemokrātu pretenzijas uz Latgali, taču atturējās no atklāta to nosodījuma. Tas apliecina, ka Polijas valsts vadītāja attieksme bija mainījusies. A. Keniņšs secināja, ka Ziemel̦latgalē poḷus interesē vienīgi muižnieku īpašumi, turpretī Dienvidlatgalē Polijai ir "valstiskas intereses", un brīdināja, ka "separāta rīcība miera jautājumā varētu izraisīt nevēlamus sarežǵịjumus Latgales lietā”. Arī premjers L. Skuḷskis 23. februārī solīja, ka Polija "darīs visu, lai [Latviju] atzìtu Krievija un sabiedrotie", kā arī izteica pārliecību, ka valdība Latgales jautājumu neapspriedīs "atbilstoši poḷu muižnieku interesēm”. Tomēr A. Keniṇš atzīmēja, ka nav vēlami tādi raksti Latvijas presē, kuros tiek atzìts nelatviešu augstais îpatsvars atsevišḳās Dienvidlatgales vietās, jo nacionāldemokrāti "rūpīgi krāj visus argumentus, sevišķi etnogrāfiskus". ${ }^{621}$ Šajā laikā daḷa nacionāldemokrātu vairs neprasīja atjaunot Polijas 1772. gada robežas, taču viṇu uzskati kopumā nebija mazāk bīstami Latvijai un citām jaunajām valstīm. Tādējādi šajā laikā, pretēji poḷu puses deklarētajam, abu valstu attiecībās atklājās iepriekš paredzama problēma, kas skaidri norādīja uz iemesliem, kāpēc Latvijas pusei attiecībās ar Poliju bija jābūt piesardzīgai.

21. februārī Polijas Kara lietu ministrija secināja, ka poḷu preses lielākā daḷa arvien simpatizē Latvijai. Tomēr trūka vienprātības Latgales jautājumā. Tika uzsvērta poḷu faktora īpašā nozīme Latgalē un viṇu škiietamā vēlme pievienoties Polijai (poḷi to bija izteikuši Viḷnā Pilsudskim). Turklāt poḷi bija neapmierināti ar Daugavpils atdošanu Latvijai, lai gan politisku apsvērumu dēḷ tomēr piel̦āva nelielu piekāpšanās politiku nākotnē attiecībā pret Latviju. ${ }^{622}$ Raksturīgs ir komentārs laikrakstā "Kurjer Lwowski", kas pauž valdības uzskatus. Komentārā uzsvērts, ka Latvija ir vienīgā valsts, kas kopā ar Poliju cīnās ar lieliniekiem, tādēl kā zināma atmaksa tai esot atdota Daugavpils un Latgale. ${ }^{623}$ Tāpat raksturīgs ir A. Keniṇa 1. martā rakstìtais lūgums Latgales apgabala priekšniekam. A. K,eniņš rakstīja, ka viens no Latvijas diplomātiskās misijas galvenajiem uzdevumiem šajā laikā ir atspēkot "kādas poḷu sabiedrības daḷas un šovinistiski noskaṇoto Seima partiju" uzturētās Polijas pretenzijas uz Daugavpili un Daugavpils apriṇkịi. Tādēl A. Keniņš piedāvāja apgabala priekšniekam savstarpēju sadarbību, lūdzot sniegt viṇam informāciju par poḷu karaspēka un poḷu muižnieku darbību, vienkāršo poḷu tautības iedzīvotāju noskan,ojumu Latgalē u. c. ${ }^{624}$

\footnotetext{
${ }^{620}$ Jaunākās Ziņas. - 1920. - 4. marts.

${ }^{621}$ LVVA, 2575. f., 15. apr., 11. 1., 44.-46., 38. 1p.

622 Документы и материалы... - 538 стр.

${ }^{623}$ Kurjer Lwowski. - 1920. - 13 luty.

${ }^{624}$ LVVA, 1368. f., 1. apr., 1404. 1., 2.-3. lp.
} 
Labvēlīgākais posms abu valstu attiecībās bija beidzies. Ārlietu ministrija pārskatā uzsvēra, ka "poḷu virsvadība gan ir korekta, bet poḷu karaspēka izturēšanās izraisa vispārēju ìgnumu un bažas par nākotni" (tika saskatîts arī, ka "visi Latgales polonofili būs pamatīgi izārstēti"). ${ }^{625}$ Pēc B. Boufala iniciatīvas turpinājās sarakste par 1919. gada decembrī Liepājā notikušo nepatīkamo incidentu ar Polijas karogu. 28. februārī Ārlietu ministrija oficiāli izteica nožēlu par šo gadījumu. ${ }^{626}$ Stāvokli sarežǵịja Latvijas iestāžu un B. Boufala savstarpējo attiecību pasliktināšanās. Latvijas Ārlietu ministrija vērtēja viṇu kā "pretenciozu un histērisku kungu, kurš ik dienas sūta uz Varšavu attiecīgus ziņojumus". ${ }^{627}$ Tas bija l,oti tuvu patiesībai. B. Boufala īpatnējo nostāju apliecina fragments no viṇa 22. aprīḷa ziṇojuma: "Latvijā vienīgā sekmīgā mūsu politika var būt tikai latviešu piespiešanas politika rēķināties ar mums, prasmīgi lietojot ekonomiskās represijas." Polijas pārstāvis ieteica pārṇemt savā kontrolē Rīgas-Orlas dzelzcel̦u pie Daugavpils. Līdz ar to Latvija nonāktu pilnīgā atkarībā no Polijas. Vēlāk viṇa aizvainojums pret latviešiem vēl vairāk pieauga, un, atstājot Liepāju angḷu karakuği 11. augustā, uz cita poḷu ierēdṇa jautājumu par pārstāvja apǵērbu, Boufals atbildēja, ka tā ir "diplomātu forma mežonīgās valstīs". ${ }^{628}$

Latvijas attiecības ar Lietuvu arī palika sarežǵìtas. Panākumus nedevajau minētā vēršanās pie Antantes komisijas locekḷa-angḷu ǵenerāla A. Ternera ar lūgumu panākt Lietuvas karaspēka izvešanu no Ilūkstes apriṇķa. Tāpēc nopietni tika apsvērta iespēja jautājuma atrisināšanā izmantot brunotu spēku. Ārlietu ministrijas departamenta direktors L. Sēja rakstīja, ka pret lietuviešiem vajadzēs "izšaut stiprāku pulveri", ${ }^{629}$ bet P. Radziṇš 17 . februārī informēja A. Miškovski, ka pēc Zemgales divīzijas apmācību nobeiguma tā frontē nomainīs Latgales divīziju, ko savukārt izvietos Ilūkstes apriṇḳī (Miškovskis pareizi secināja, ka armijas vadība atbalsta "asāku rīcību pret lietuviešiem"). ${ }^{630}$ Šajā pašā laikā arī Lietuvā atskanēja publiski aicinājumi rīkot "karagājienu" uz Daugavpili un Latgali. ${ }^{631}$ Sarunas par robežu turpinājās no 26. februāra līdz 11. martam Kauñā un atkal bija neveiksmīgas, jo puses nevarēja vienoties ne par Palangas, ne Ilūkstes apriņķa piederību. Turklāt stāvoklis bija saspringts ne tikai lietuviešu karaspēka dạ̄eji ieņemtajā Ilūkstes apriṇkīi, bet uz visas abu valstu robežas, piemēram, 12. februārī Latvijas Iekšlietu ministrija ziṇoja armijas Virspavēlnieka štābam, ka Bauskas rajonā pierobežas joslā

${ }^{625}$ Starp augstākajām militārajām iestādēm attiecības palika labas. Latvijas militārais izlūkdienests regulāri piegādāja A. Miškovskim informāciju par padomju izlūku kustību poḷu aizmugurē, bet no 25. februāra Virspavēlnieka štābā par sakarnieku strādāja E. Ridza-Smiglija grupas štāba pretizlūkošanas daļas podhorunžijs O. Bušs. Tomēr Polijas izlūkdienesta vēsturnieks A. Peploṇskis atzīst, ka 1920. gada sākumā, galvenokārt sakarā ar poḷu pagrīdes sagrāvi Lietuvā, uz laiku apturēta arī izlūku tīkla izbūve Latvijā un Igaunijā. - Pepłoński A. Wywiad polski na ZSSR 1921-1939. - S. 25.

${ }^{626}$ Ārpolitisku iemeslu dēḷ nekādas varas iestāžu represijas apzināti netika vērstas pret poḷu skolniekiem Rīgā, kas bija demonstratīvi noṇēmuši savā skolā Latvijas karogu.

${ }^{627}$ LVVA, 2575. f., 15. apr., 1. 1., 73., 78.-81. 1p.

${ }^{628}$ AAN, Kod, t. 2, k. 156; APAN, Djarjusz M. S. Kossakowskiego, T. IV, cz. 2, s. 86.

${ }^{629}$ LVVA, 2574. f., 4. apr., 7. 1., 107. 1p.

${ }^{630}$ AAN, Instytucje Wojskowe, t. 296/1-62, k. 2.

${ }^{631}$ LVVA, 2575. f., 11. apr., 8. 1., 51. 1p. 
tiek koncentrēts Lietuvas karaspēks, kas uzsāk „šaušanu”, tiklīdz latviešu aizsargposteņi mēǵina tuvoties robežai. ${ }^{632}$

Polijas valdība lieliski apzinājās, ka nesaskan,as par robežu ir LatvijasLietuvas labo attiecību galvenais traucēklis un varētu nopietni kavēt Polijas ārpolitisko plānu īstenošanu attiecībā uz Latviju. A. Miškovskis 20. februārī secināja, ka nav pamata Latvijas sabiedrības pastāvīgai nepatikai pret Lietuvu un agri vai vēlu būs tuvināšanās mēǵinājumi, kā arī atstāstīja laikraksta "Latvijas Sargs" ievērojama redakcijas darbinieka teikto par politiḳu aprindās izplatīto ideju - saskaṇā ar to jācenšas izveidot Latvijas-Lietuvas federāciju, kurā Latvijai būtu galvenā nozīme, jo iedzīvotāju izglītības līmenis un rūpniecības attīstības līmenis tajā ir ievērojami augstāks. Tas glābtu Lietuvu no Vācijas ietekmes. Miškovskis saprata, ka reāli tā varēja būt vienīgi atsevišķu Lietuvai labvēlīgu politiķu ideja. Tomēr viṇš rakstīja: "Neatkarīgi no tā, vai valdība par šo projektu interesējas vai ne, un vai tas vispār iespējams, tas ir vienīgais aktīvais projekts, kas palīdz atrisināt stāvokli, tādēḷ liek mums laikus spert pretsolus." 633

Pagaidām poḷu politiķiem īpašas pūles nebija jāpieliek, jo LatvijasLietuvas attiecības bija sliktas. Pašas Polijas nostāju raksturo viṇas prasības, kuras bija saskan,otas savā valdībā un izteiktas pirms Varšavas konferences, kas notika martā. Šîs prasības paredzēja, ka Latvijai jāpatur viss Ilūkstes apriṇķis (tiesa, bez Polijā jau iekḷautajiem sešiem pagastiem un Grīvas pilsētas apriṇķa austrumu daḷā) un Mažeik̦i. ${ }^{634}$ Turpinājās Latvijas un Lietuvas "preses karš", jo Lietuvā nebija pārliecības, vai Latvijas-Polijas militārās sadarbības līgums nav vērsts arī pret Lietuvu. 4. februārī L. Sēja izteica neizpratni par to, ka virspavēlniecība vēl arvien uzskata 1919. gada 29. decembra līgumu par slepenu, jo tas nodarot vairāk l̦aunuma nekā iespējamā "indiskrēcija". ${ }^{635} \mathrm{Z}$. Meierovics pēc tam paziṇoja: Lietuvas valdība ir informēta, ka ar Poliju noslēgta tikai vienošanās par Latgales atbrīvošanu, Latvija arī turpmāk vēlas uzturēt ar Lietuvu labas attiecības un vienmēr tiekusies "iet ar Lietuvu roku rokā"636 (savukārt Polijas prese rakstīja, ka Lietuva ir "melns traips pie atdzimušās Polijas politiskā horizontā", un tas traucē visu Baltijas valstu savstarpējās attiecības $\left.{ }^{637}\right)$. Martā Latvijas iestādes izraidīja no valsts vairākus Lietuvas pilsoṇus. Lietuvas valdība uz to reaǵēja, dodot rīkojumu Latvijas pilsoṇiem - zemes rentniekiem Lietuvā - atstāt valsti un neḷaut izvest pat personiskās mantas. Sūtnim V. Bandrevičam ārlietu ministrs A. Voldemars šādu attieksmi pamatoja ar minēto Lietuvas pilsoṇu izraidīšanu no Latvijas. Marta beigās Lietuvas preses naidīgā nostāja pret Latviju nebija mainījusies, kaut arī Z. Meierovics intervijā Kauņas oficiozam "Lietuva" îpaši uzsvēra, ka Latvijas mērķis attiecībās ar Poliju ir spēcīgas nelielo valstu savienības izveidošana no Baltijas līdz Melnajai jūrai, taču bez Polijas virsvaldības tajā. Viṇš uzsvēra arī, ka militārajam līgumam ar Poliju

\footnotetext{
632 Turpat, 3601. f., 1. apr., 275. 1., 80. 1p.

${ }^{633}$ AAN, Instytucje Wojskowe, t. 296/1 - 62, k. 3.

${ }^{634}$ Turpat, Kod, t. 2, k. 167.

${ }^{635}$ LVVA, 2575. f., 15. apr., 1. 1., 89. 1p.

${ }^{636}$ Latvijas Sargs. - 1920. - 4. febr.

637 Przegląd Wieczorny. - 1920.- 15 luty.;
} 
ir vienīgi stratēǵisks, nevis politisks raksturs un tas nekādi nav bijis un nav vērsts pret Lietuvu. ${ }^{638}$

Sarežǵìtās attiecības ar Lietuvu lielā mērā joprojām bija saistītas ar Latvijas un Polijas ārēji labajām attiecībām (faktiski šajā laikā dažādu apstākḷu dēḷ tās gan bija ievērojami pasliktinājušās). Lietuvas-Polijas attiecības palika loti sliktas un laiku pa laikam izpaudās pat bruṇotās sadursmēs. Tā kā gan Polijas, gan Lietuvas armija atradās arī Latvijā, tas sagādāja nopietnas rūpes Latvijas valdībai. Visi izklāstītie procesi norisinājās laikā, kad Latgalē formāli turpinājās latviešu-poḷu militārā sadarbība un noritēja sagatavošanās darbi S. Bulaka-Balahoviča karaspēka nodaḷas pārvešanai no Alūksnes uz Daugavpili Polijas armijas pakḷautībā. ${ }^{639}$ Latvijā šī Judeṇiča armijas, vēlāk Igaunijas armijas sastāvā karojušā „Baltkrievu” nodaḷa atradās no 1920. gada sākuma un nepakḷāvās igauṇu virspavēlniecības rīkojumam atgriezties Igaunijā. Nodaḷas vadība veda sarunas par tās tālāko likteni ar Latvijas, Baltkrievijas Tautas Republikas un Polijas pārstāvjiem Rīgā. Poḷi, plānojot savas turpmākās militārās operācijas pret Padomju Krieviju, piekrita nodaḷas pāriešanai viṇu pakḷautībā, un A. Miškovskis panāca Latvijas puses akceptu tās tranzìtam. 1920. gada 5.-6. martā apmēram 900 S. BulakaBalahoviča karavīru pa dzelzcel̦u ieradās Daugavpilī, no kurienes drīzumā tika pārcelti uz Baltkrieviju un turpmāk iesaistīti karadarbībā pret Sarkano armiju. ${ }^{640}$

\section{Varšavas konference un tās sekas}

Izdevīgas attiecības ar Latviju Polijas valdība cerēja panākt t. s. Baltijas valstu konferencē Varšavā. Tā kā Polija, Somija un Lietuva bija izteikušas zināmu gatavību piedalīties kopīgās miera sarunās un Latvijas valdība 16. februārī nolēmusi mēǵināt uzsākt miera sarunas kopā ar kaimiṇvalstīm, tā aicināja šo valstu pārstāvjus uz konferenci Rīgā, taču Polijas puse uzstāja rīkot konferenci Varšavā. ${ }^{641}$ 28. februārī L. Sēja atzīmēja, ka Latvijai būtu izdevīgāk, ja konference notiktu Rīgā (kā tika nolemts Helsinkos), taču tajā jāpiedalās jebkurā gadījumā. Tomēr "no konferences ḷoti maz ir gaidāms, jo Polijā miera jautājums vēl nav tā nobriedis kā Latvijā un uz miera slēgšanu kopā ar Poliju jāskatās skeptiski. Nav ko baidīties, ka paliksim vieni, jo Somija

${ }^{638}$ LVVA, 11. apr., 8.1., 71., 73., 76. 1p.; AAN, Kod, t. 2, k. 167.; LVVA, 2575. f., 15. apr., 1.1., 89. 1p.; Latvijas Sargs. - 1920. - 4. febr.; Lietuva. - 1920. - 28 kōv.; Przegląd Wieczorny. - 1920.- 15 luty.

${ }^{639}$ Sīkāk sk.: Jēkabsons Ē. Ģenerālis Stanislavs Bulaks-Balahovičs un Latvija//Latvijas Arhīvi. 1995. - Nr. 1. - 16 -21. lpp.; Jēkabsons Ē. Latvijas un Baltkrievijas Tautas Republikas attiecības (1919-1920)//Latvijas Arhīvi. - 1996. - Nr. 1/2, 35.-41. lpp.

${ }^{640}$ Paluszyński T. Przejście oddziału generała Stanisława Bułak - Bałachowica z Estonii do Polski (marzec 1920 roku)//Polska i Europa w XIX - XX wieku. - Poznań, 1992. - S. 113-118; Karpus Z. Wschodni sojusznicy Polski w wojnie 1920 roku. Oddziały wojskowe ukraińskie, rosyjskie, kozackie i białoruskie w Polsce w latach 1919-1920. - Toruń, 1999. - S. 66-70; Karpus Z. Działalność gen. Stanisława Bułak - Bałachowicza i jego oddziału w Polsce podczas wojny 1920 r. Zeszyt Naukowy Muzeum Wojska w Białymstoku, 1990. - S. 89-101; Cabanowski M. Generał Stanisław Bułak - Bałachowicz. - Warszawa, 1993. - S. 21-24; Łatyszonek O. Białoruskie formacje wojskowe 1917-1923. - Białystok, 1995. - S. 149-152.

${ }^{641}$ Sīpols V. Slepenā diplomātija. - 51. lpp.; Valdības Vēstnesis. - 1920. - 18. febr. 
un Lietuva arī domā slēgt mieru. Varšavas konferencē jāpiedalās. Ja nebūs sekmīga, Rīgā varēs atseviškịi apspriesties ar somiem un lietuviešiem”. ${ }^{642}$

Polijas mērḳi gaidāmajās sarunās ar latviešiem tika formulēti 22. februārī Ārlietu ministrijā. L. Vasiḷevskis, A. Luce-Birks, kas nesen bija iecelts par konsulu Rīgā, ${ }^{643}$ Ârlietu ministrijas un G̦enerālštāba pārstāvji nolēma, ka galvenais uzdevums ir noslēgt militāru konvenciju ar Latviju un panākt, ka tā atzīst Ilūkstes apriṇka austrumu daḷu (Grīvas pilsētu un sešus pagastus) par Polijas sastāvdaḷu. Poḷi garantēja savu atbalstu Mažeiḳu dzelzceḷa mezgla iekḷaušanai Latvijā, prasīja atvieglojumus Polijai uz Latvijas dzelzceḷiem (arī Eiropas standartiem atbilstoša platuma dzelzcela izbūvi vairākās līnijās u. c.) Viṇi vēlējās, lai Liepājas, Rīgas un Ventspils ostā poḷiem tiktu iedalìta teritorija un dzelzcel̦a priekštilts Daugavpilī atstāts poḷu kontrolē "līdz politisko apstākḷu noskaidrošanai austrumos". Ja tiktu īstenota zemes reforma, poḷu puse prasīja garantēt, lai Latgales poḷu muižnieki saṇemtu kompensāciju. Poḷu puse gatavojās pieprasīt, lai poḷu karaspēka vienības pavaditu tranzitkravas uz Latvijas dzelzceḷiem, un nebija ar mieru šādas tiesības dot Latvijas pusei uz Polijas dzelzcel,iem. Savukārt Latvijai Polijas puse garantētu tās neatkarību un robežu neaizskaramību, saimnieciskas koncesijas noslēgšanu un iespēju izmantot Polijas izejvielas. Tāpat Polija atbalstītu Latvijas prasības sarunās ar Krieviju, kā arī Latvijas atzīšanu „de iure”. Pati Polija atteiktos no savām škietami vēsturiskajām ties̄ibām uz Latgali, ja vietējiem poḷiem tiktu nodrošināta kultūras autonomija. ${ }^{644}$

Poḷu puses projekts bija latviešiem nepieṇemams no visiem viedokḷiem, jo projekta autori paredzēja Latvijai Polijas satelītvalstiṇas lomu. Smagākā bija prasība par sešiem Augškurzemes pagastiem un Grīvu. Kaut arī apgabals jau 1919. gada septembrī bija faktiski iekḷauts Polijas Braslavas apriṇḳī, tomēr Latvijas puse par to kā par bijušās Kurzemes guberņas sastāvdaḷu izrādīja pieaugošu interesi. ${ }^{645} \mathrm{Ka}$ jau minēts, pirmo reizi jautājums Latvijas un Polijas pārstāvju sarunās tika skarts 1920. gada 26. janvārī, Latvijas armijas virspavēlniekam J. Balodim tiekoties ar J. Pilsudski Daugavpilī, kad pēdējais deva samērā izvairīgu atbildi. Burtiski pēc dažām nedēḷām - 11. februārī E. Ridzs-Smiglijs protestēja pret latviešu ierēdṇu ierašanos Grīvā, lai organizētu vietējo administrāciju. A. Veiss atbildēja, ka noticis pārpratums. ${ }^{646}$ Tomēr viṇš nezināja, ka jau 17. janvārī Latvijas Iekšlietu ministrija bija iecēlusi amatā Grīvas policijas priekšnieku. Viṇš ieradās pilsētā, kur tika informēts, ka tagad tā pieder Polijai. Savukārt 4. martā Latvijas robežsargu 3. rajona karavīri mēǵināja novietot savus posteņus Salienas, Kaplavas un Varnaviču

${ }^{642}$ LVVA, 2575. f., 15. apr., 1. 1., 73. 1p.

${ }^{643}$ A. Luce-Birks pirmo lūgumu savai valdībai iecelt viņu par konsulu Rīga iesniedza 1919. gada 2. septembrī, otro - 12. decembrī. - AAN, Akta L. Wasilewskiego, t. 41, k. 16, 51.

${ }^{644}$ AAN, Kod, t. 2, k. 167.

${ }^{645}$ Sīkāk sk.: Jēkabsons Ē. Sešu pagastu un Grīvas pilsētas problēma Latvijas un Polijas attiecībās 20. un 30. gados//Latvijas Vēstures Institūta Žurnāls. - 1995. - Nr. 1. - 80.-101. 1pp.; Jēkabsons Ē. Latvijas un Polijas robeža 1919.-1939. gadā//Daugavpils universitāte. Humanitārās fakultātes XII Zinātnisko lasījumu materiāli. Vēsture/History. Proceedings of the XIIth Scientific Readings of the Faculty of Humanities. - VI (I). - Daugavpils, 2003, 69.-79. lpp. Publicēts arī: http://www.historia. lv/publikacijas/konf/daugp/012/1dala/jekabson.htm

${ }^{646}$ LVVA, 3601. f., 1. apr., 471. 1., 32. 1p. 
apkaimē Daugavas kreisajā pusē, aizbraucot līdz Krāslavai un tur pārejot pāri Daugavai, taču poḷu žandarmi viņus Daugavas otrā pusē aizturēja, pieprasot atl̦auju „iebraukšanai Polijā”, un pēc tam izraidīja pāri Daugavai uz Krāslavu. Šeit 3. Leǵionu divīzijas štābā tās komandieris L. Berbeckis latviešiem „aizrādīja”, ka „politiskā un faktiskā robeža ar Latviju esot Daugava - no Daugavpils līdz Kreslavkai [Krāslavai] - tālāk aiz Kreslavkas, taisnā līnijā uz Dagdu, esot Operācijas rajons un robežsargus izstādīt tur nevarot pielaist, jo poḷi skaitot par Latgales politisko robežu dzelzceḷa līniju DaugavpilsRēzekne". Latvijas varas iestādēs ienāca ziṇas, ka Daugavas kreisā krasta pagastos it kā notiek Polijas pasu izsniegšana, parakstu vākšana par apgabala iekḷaušanu Polijā (kā otra alternatīva tiek izvirzìta tikai apgabala nonākšana Lietuvas sastāvā), citādi domājošajiem draud izraidīšana un nesamērīgi lielas šḳūtis. ${ }^{647}$

26. februārī apgabala priekšnieks ziṇoja, ka poḷu ieṇemtā teritorija kreisajā krastā būs "atdabūjama tikai ar ieročiem", tomēr 1. martā Ārlietu ministrijā tika nolemts, ka delegācijai Varšavā jācenšas panākt bijušās Kurzemes guberṇas robežas atjaunošanu. ${ }^{648}$ Savukārt Polijas valdība 8. martā secināja, ka Latvija saṇems Latgali un Daugavpili, bet Ilūkstes apriṇķis paliks Polijā. Šie bija galvenie jautājumi, kas jārisina poḷu delegācijai Varšavā sarunās ar latviešiem. ${ }^{649}$

Konferencē bija jāpiedalās visām valstīm, kas karoja ar Padomju Krieviju, taču Polijas valdība politisku un citu saprotamu motīvu dēl neuzaicināja Lietuvas delegāciju. Uzaicinājumus saṇēma Somija, Latvija, Rumānija un Ukrainas Tautas Republika. Oficiālais mērḳis bija saskaṇot kopējo nostāju sarunās ar Krieviju, kā arī noslēgt militāru un saimniecisku līgumu (par plānotajiem līgumiem gan vienprātības trūka pat Polijas politiskajās un militārajās aprindās). ${ }^{650}$ Turklāt Polija šajā laikā, nebrīdinot Latviju par saviem nodomiem, nopietni apsvēra iespēju uzsākt miera sarunas ar Padomju Krieviju. Polijas nodomi atklājās jau konferences gaitā un pārsteidza latviešus.

Jau februāra beigās tika plānots, ka Latvijas delegāciju vadīs ārlietu ministrs Z. Meierovics, ${ }^{651}$ taču viṇa noslogotības dēḷ par vadītāju tika iecelts iekšlietu ministra biedrs J. Kēemanis. Delegācijā tika ieklauts arī Ārlietu ministrijas departamenta direktors L. Sēja, Galvenās artilērijas pārvaldes

\footnotetext{
${ }^{647}$ Turpat, 2574. f., 3. apr., 17. 1., 9., 211., 220. 1pp.; 4967. f., 1. apr., 246. 1., 90. 1p. Armijas Virspavēlnieka štāba priekšnieka P. Radzin̦a rezolūcija uz ziņojuma par robežsargu izraidīšanu liecina, ka viņš poḷu puses rīcību uzskata par pareizu: „Kādēḷ visi šie vīri negrib ievērot kara teātra frontes joslu? Ja es būtu tur ar savu karaspēku, tad arī nelaistu bez savas atḷaujas nevienu iekšā."

${ }^{648}$ LVVA, 3601. f., 1. apr., 308. 1.; 496. 1., 5. 1p.

649 Документы и материалы... - 569 стр. Jau pēc konferences Varšavas krievu prese uzsvēra, ka Polija atteikusies no tiesībām uz Latgali apmaiṇā pret Ilūkstes apriṇķa dalı. To noliedza gan Latvijas pārstāvniecība, gan poḷu nacionāldemokrāti (pirmā nevēlējās atzīt sešu pagastu iekḷaušanu Polijā, otrā puse nevēlējās, lai Latgales jautājums atrisinātos par labu Latvijai. - Варшавское слово. 1920. - 8 апр.; Gazeta Warszawska. - 1920. - 8 kwiec.

${ }^{650}$ Skrzypek A. Związek... - S. 59.

${ }^{651}$ LVVA, 2575. f., 15. apr., 1. 1., 73. 1p.
} 
priekšnieks pulkvedis E. Kalniņš ${ }^{652}$ ar adjutantu leitnantu A. Oši (Varšavā delegācijai pievienojās arī Latvijas pārstāvji, kas tur strādāja). Kopā ar delegāciju 3. martā uz Varšavu izbrauca arī A. Miškovskis. Nākamajā dienā tā ieradās Daugavpilī. Pēc pilsētas apskates L. Sēja ziṇoja, ka dzirdētas "briesmu lietas par polu varmācībām", uz kurām delegācijas locekḷi Varšavā mēǵinās "neuzkrītoši vērst poḷu kungu vērību". Poḷu puses rīkotajās vakarināàs E. Ridzs-Smiglijs nepiedalījās. Tas tika izskaidrots ar viṇa slikto pašsajūtu un nogurumu, kaut gan patiesībā liecināja par poḷu karaspēka grupas štāba un Latvijas varas iestāžu saspīlētām attiecībām Daugavpilī. Viḷnāa delegācija tika sagaidìta svinīgi, un 6. martā tā iebrauca Varšavā. Tajā pašā dienā E. Kalniṇš apmeklēja Polijas kara lietu ministru un G̦enerālštāba priekšnieku. Polijas Ārlietu ministrijas Preses nodaḷas vadītājs S. Gutovskis informēja delegāciju, ka Lietuvas pārstāvji uz Varšavu nav uzaicināti un paredzētas tikai atsevišḳas sarunas ar Latvijas un Somijas delegāciju, kā arī ar pilnvaroto Rumānijas sūtni. Pēc apspriešanās ar citiem delegācijas locekliem J. Kēmanis piekrita šādai darba kārtībai ar noteikumu, ka organizatori pamatos tās maiṇu. Par to pašu tika runāts arī vizìtē pie ārlietu ministra S. Pateka. Viņš atzina, ka A. Keniṇam tiešām solījis - konferencē piedalīsies vairākas valstis, taču nodoms mainīts un noticis "zināmā mērā pārpratums". Vēsturnieks A. Skšipeks skaidroja: pēc rūpīgas jautājuma izskatīšanas nolemts, ka piecpusējās sarunās saskaṇa nav iespējama, tādēḷ bija jāmaina norises kārtība. ${ }^{653}$ Faktiski Polijas puse cerēja, ka divpusējās sarunās ar katru delegāciju tai būs vieglāk ìstenot savas intereses. 6. martā notikušajā Latvijas pārstāvniecības rīkotajā banketā piedalìjās tirdzniecības un rūpniecības ministrs A. Oḷševskis, L. Vasilevskis un citi. Polijas prese atreferēja tā gaitu rakstā, kam bija zīmīgs un cerīgs nosaukums - "No Baltijas līdz Melnajai jūrai". ${ }^{654}$

Nākamajā dienā tika organizēta ekskursija, baleta apmeklējums un svinīgi mielasti, kuru dēl iecerētā apspriede ar Somijas delegāciju nebija iespējama. 8. martā no rīta Latvijas delegācija vēlreiz konkretizēja savus svarīgākos uzdevumus - panākt Lietuvas piedalīšanos kopīgajās miera sarunās ar Padomju Krieviju un Polijas armijas izvešanu no Latvijas, bet vakarā S. Pateka vadībā notika pirmā konferences poḷu-latviešu sēde, kurā tika izlemti organizatoriskie jautājumi. Tās sākumā Latvijas delegācija izteica savu neapmierinātību ar to, ka konferencē nepiedalās visas Baltijas valstis, un gatavību apspriest ar Polijas pārstāvjiem divpusējo attiecību jautājumus. Tika izveidota konferences Politiskā, Militārā un Saimnieciskā komisija. Šajā sēdē poḷi, kā jau minēts, paziņoja, ka viṇi tuvākā nākotnē gatavojas uzsākt miera sarunas ar Krieviju Oršā, Smoḷenskā vai citā pierobežas pilsētā un ir pat iecelts Polijas delegācijas vadītājs - S. Pateks. ${ }^{655}$

9. martā notika pirmā, bet 12. martā - otrā Politiskās komisijas sēde. Pirms miera sarunu sākšanas ar Padomju Krieviju poḷu puse iepazīstināja,

\footnotetext{
${ }^{652}$ 28. februārī A. Miškovskim tika pavēlēts, lai viņš panāk, ka delegācijā tiek iekḷauts pēc iespējas atbildīgāks virsnieks, vēlams - poḷiem visumā labvēlīgais Latvijas armijas Virspavēlnieka štāba priekšnieks P. Radziņš. - AAN, Attachaty, A - II, 64/1, k. 95.

${ }^{653}$ LVVA, 2574. f., 3. apr., 15. 1., 49. 1p.; 18. 1., 1.-2. lp.; Skrzypek A. Związek... - S. 59.

${ }^{654}$ Kurjer Poranny. - 1920. - 7 marzec (rakstu 14. martā kḷūdaini atstāstīja “Latvijas Sargs”).

${ }^{655}$ LVVA, 2575. f., 8. apr., 85. 1., 30., 33. 1p.
} 
kādi ir tās noteikumi Krievijai - tai būtu jāatzīst Latvijas un Igaunijas neatkarība, jāatdod Polijai 1772. gadā anektētās teritorijas, tātad arī Latgale, kuru poḷi savukārt atdotu Latvijai (tādējādi Latvija saṇemtu to nevis no Krievijas, bet no Polijas). Latgale tiktu Latvijai ar noteikumu, ka tā neuzturēs draudzīgas attiecības ar Krieviju un Vāciju, kā arī garantēs polu minoritātes kultūras autonomijas tiesības Latgalē. Poḷi uzsvēra, ka vēlas noslēgt ar Latviju militāru konvenciju, kas vērsta pret Krieviju, Vāciju un arī Lietuvu, un izveidot robežu gar Daugavu. Tad nepieciešamības gadījumā Latvijai varētu sniegt ātru militāru palīdzību, kā arī vienoties par sadarbību saimnieciskā jomā un garantēt Polijai pieeju Latvijas ostām un attiecīgajiem dzelzceliem. Poḷi no savas puses piedāvāja ogles, naftu un citas izejvielas. Savukārt Latvijas delegācija izklāstīja savas valsts prasības Krievijai un noraidīja iespēju noslēgt konvenciju arī pret Lietuvu. ${ }^{656}$ Poḷi pieprasīja sešus pagastus un Grīvu. Robeža tādējādi atrastos apmēram 12 kilometrus rietumos no Viḷnas-Daugavpils dzelzceḷa un tālāk ietu gar Daugavas līniju. L. Vasilevskis un S. Pateks atzina strīdus teritoriju par Latvijas īpašumu, taču izteica pārliecību, ka izdosies latviešus pārliecināt par tās atdošanas lietderīgumu. Vini lūdza Latvijas delegāciju iegūt no savas valdības pilnvaras šā jautājuma risināšanā. Vienošanās panākta netika, un jautājums palika atklāts. Turklāt S. Gutovska vadītie Polijas pārstāvji prasīja atstāt Polijas karaspēka kontrolē Daugavpils cietoksni līdz poḷu-padomju miera līguma noslēgšanai, kā arī solīja atbalstīt Latvijas pretenzijas uz Mažeiķiem un prasību par Lietuvas karaspēka izvešanu no Ilūkstes apriņķa. ${ }^{657}$ Vienošanos neizdevās panākt arī J. Ķēmaṇa un S. Pateka privātā sarunā 15. martā. ${ }^{658} \mathrm{~S}$. Pateks presē uzsvēra, ka ar latviešiem sarunas noris smagāk nekā ar somiem, jo Latvijas delegācijā ir par maz "speciālistu”, tādēḷ nepārtraukti jāsazinās ar savu valdību, un tas kavē darbu. ${ }^{659}$

Militārās komisijas sēdēs 9., 11., 12. un 13. martā poḷi piedāvāja savu militārās konvencijas projektu. Tas paredzēja abu armiju kopdarbību, ja Polijai vai Latvijai uzbruktu, un tam bija aizsardzības raksturs. Daudzos jautājumos abu pušu viedokḷi bija līdzīgi, taču latvieši uzskatīja, ka konvencijai jādarbojas vienīgi līdz miera noslēgšanai ar Padomju Krieviju. Latvijas puse izteica vēlmi līdz 1. aprīlim pārṇemt no poḷiem visu fronti Latgalē un piekrita, ka Daugavpilī paliek ierobežots un noteikts poḷu karavīru skaits dzelzceḷa tilta apsardzībai, kā arī informēja poḷu pusi par Latgalē notiekošajām poḷu karaspēka patvarībām. E. Kalniṇš atzina, ka poḷu "augstākā virsniecība", neraugoties uz tās labajiem nodomiem, nav spējīga stāvokli labot. Militārās komisijas sēdēs poḷi par strīdīgajiem Augškurzemes pagastiem izteicās tiešāk. Latvieši piedāvāja konvencijas projektā fiksēt, ka Latvijas-Krievijas miera noslēgšanas gadījumā Polijas karaspēks atstātu Latgali un bijušo Kurzemes guberṇu un Latvijas armija savas robežas apsargātu pati. Poḷu pārstāvis

\footnotetext{
${ }^{656}$ L. Vasiḷevskis uzsvēra, ka priekšlikums izvirzīts, zinot par Lietuvas pretenzijām uz Daugavpili. Vairākkārt tika atzīmēts, ka Polija piekrīt Latgales un Daugavpils iekḷaušanai Latvijā, nevis Lietuvā vai Krievijā.

657 Документы и материалы... - 575-577, 580-581 стр.; AAN, Akta L.Wasilewskiego, t. 45, k. 97; Kurjer Polski. - 1920. - 10 marzec.

${ }^{658}$ Počs K. Sanitārā kordona... - 87. lpp.

${ }^{659}$ Czas. - 1920. - 11 marzec.
} 
majors M. Staževskis norādīja, ka "valstisku un stratēǵisku" iemeslu dēl Polija paturēs sešus pagastus un no šīs prasības neatkāpsies. Nelīdzēja E. Kalniṇa arguments: parakstot militāras sadarbības līgumu 1919. gada decembrī, nav bijis zināms, ka Polija uzskata Latgali par savu īpašumu, ko var apmainìt pret Augškurzemes dal̦u, kura tāpat kā Latgale pieder Latvijai. Tādēḷ "apmaiṇai" Latvijas puse nevarēja piekrist un arī militārās komisijas darbs beidzās faktiski bez rezultātiem, kaut gan poḷu puse bija sagatavojusi arī militārās konvencijas projektu gadījumā, ja Latvija noslēgtu ar Padomju Krieviju miera līgumu viena. Projekts paredzēja, ka abu valstu attiecības nemainās, lai gan ir noslēgts latviešu-padomju miers; poḷu rīcībā paliek Daugavpils cietoksnis un dzelzceḷa tilts; Latvijas puse apṇemas nodrošināt poḷu kreiso spārnu, izveidojot spēcīgu kordonu starp Daugavu un Osvejas ezeru, un dot Polijai tiesības militāro un citu kravu pārvadāšanai no Latvijas ostām pa dzelzceliem. Ja Polijai reizē uzbruktu Padomju Krievija un Lietuva, Latvijas karaspēks ieņemtu lietuviešu karaspēka okupēto Ilūkstes apriṇka daḷu un Lietuvas Zarasu apriņ̧̦i, bet, ja Latvijai uzbruktu Lietuva, poḷu karaspēks dotos uzbrukumā Kauņai. Abas puses apṇemtos apmainīties ar informāciju par Padomju Krievijas un Lietuvas armiju. ${ }^{660}$ Konvencija šādā redakcijā Latvijas pusei bija pilnīgi nepien,emama.

Saimnieciskā komisija izskatīja abu valstu ekonomiskās sadarbības jautājumus un poḷu piedāvāto saimnieciskās konvencijas projektu. Tas paredzēja Polijai tiesības nomāt sektorus Liepājas, Rīgas un Ventspils ostā (tos apsargātu poḷu karavīri), izmantot Latvijas dzelzceḷus un pretī dot ogles, naftu un cukuru (apjomu noteiktu Polijas saimnieciskās vajadzības).

Visās komisijās bija jautājumi, kuru izskatīšanai Latvijas delegācijai trūka pilnvaru. Tādēḷ J. Ķēmanis 13. martā secināja, ka ir saskaṇota nostāja gaidāmajās miera sarunās, noskaidroti savstarpējo attiecību jautājumi, tomēr radušās neskaidrības, kuru dēl būtu lietderīgi konsultēties ar valdību Rīgā, uz laiku pārtraucot sarunas. ${ }^{661}$ Faktiski, kā atzīst arī T. Palušiṇskis, Latvijas puses atturību izraisīja Polijas pazemojošās prasības Latvijai. ${ }^{662}$

15. martā abu valstu pārstāvji parakstīja paziṇojumu, kurā konstatēja interešu sakritību un nepieciešamību nākotnē vienoties. Tika paziṇots, ka Latvijas delegācija izbrauc uz Rīgu, lai “iepazīstinātu savu valdību ar paredzētās vienošanās noteikumiem un saṇemtu attiecīgas pilnvaras". ${ }^{663}$ Ārpus sarunām Latvijas delegācija 10. martā Varšavā bija pieṇemšanā pie J. Pilsudska. Viṇš uz latviešiem atstāja "nosvērta, mierīga cilvēka iespaidu, kurš drošu skatu raugās nākotnē", un atzinīgi izteicās par Latvijas armiju. 14. martā J. Kēmanis apspriedās ar Ukrainas Tautas Republikas diplomātiskās misijas vadītāju Polijā A. Luivickiju. 15. martā delegācija atstāja Varšavu. Pēc aizkavēšanās

${ }^{660}$ Paluszyński T. Walka o niepodległość Łotwy 1916-1921. - S. 327.

661 Документы и материалы... - 578-584 стр.

662 Paluszyński T. Walka o niepodległość Łotwy 1916-1921. - S. 326.

${ }^{663}$ LVVA, 2575. f., 15. apr., 1. 1., 52. lp. Tādējādi delegācija nepalika Varšavā līdz 16. martam, kad bija paredzēts koncerts, kuru organizēja Polijas Sanitārā komiteja un kura ienākumus bija plānots ziedot “varonīgajiem sabiedrotās Latvijas armijas karavīriem" - Gazeta Warszawska. - 1920. - 3 marzec. 
Viḷnā poḷu-lietuviešu konflikta dēḷ tā 17. martā ieradās Kalkūnē, poḷu armijas motorlaivā pārcēlās pāri Daugavai un 18. martā atgriezās Rīgā. ${ }^{664}$

Sarunu laikā Varšavā Polijas puse ievērojami palielināja neuzticību pret sevi, jo mēǵināja panākt Latvijas puses piekāpību arī ar nediplomātiskām metodēm. Jau 8. martā E. Ridzs-Smiglijs bija izdevis pavēli par "Poḷu frontes likvidācijas komisijas" izveidi. Tūlìt pēc tam Latvijas armija frontē uzsāka pakāpenisku poḷu dalu maiṇu. Tomēr 12. martā frontē tika apturēta poḷu 3. Leǵionu divīzijas maiña ar latviešiem, bet 13. martā E. Ridzs-Smiglijs paziṇoja, ka J. Pilsudskis pavēlējis atturēties no aktìvas darbības līdz turpmākam rīkojumam, kurš tikšot izdots "pēc konvencijas noslēgšanas Varšavā ar Latviju tuvākās dienās”. Viṇš izteica pārliecību, ka arī Polijas armijas virspavēlniecība ir ieinteresēta, lai ātrāk nomainītu karaspēku, tomēr šeit skaidri izpaudās politiskas šantāžas mēǵinājums no Polijas puses, turklāt zināmā mērā tika izmantots militārais faktors. Maiṇa frontē atsākās tikai 16. martā. ${ }^{665}$

Polijas cerības panākt tuvināšanos ar Latviju nepiepildījās. L. Sēja 24. martā atzina, ka Latvijai nav pienemamas arī Polijas saimnieciskās prasības un ar piedāvāto projektu tā "brīdinājusi par savu apetīti", kas valdībā radījusi (pastiprinājusi - É . J.) zināmu neuzticību pret Poliju. Tomēr "nākotnē zināma šaurāka vienošanās nav izslēgta, jo poḷu imperiālisti drīz būs spiesti savu apetīti ierobežot. Loti iespējams, ka kopējais ienaidnieks mūs atkal piespiedīs iet kādu gabalu kopā, kā šoziem Latgalē”. ${ }^{666}$ Neveiksmi atzina Polijas Ārlietu ministrija, konstatējot, ka "Latvija stāv krustcelēs un laikam ne tik drīz piesliesies kādai politiskajai kombinācijai", ${ }^{6} 67$ bet savu vainu šajā situācijā tā nesaskatīja. Arī attiecībās ar Somiju poḷiem neizdevās gūt īpašas sekmes. Varšavas konferencē viņi centās noslēgt ar somiem militāru un politisku vienošanos, taču Somijas delegācijas taktika liecināja, ka somi traktē sarunas vienīgi kā informācijas iegūšanas veidu. Tomēr viṇi principiāli piekrita varbūtējas militāras konvencijas noslēgšanai ar Poliju, bet tas nekad nenotika, jo Somijas valdībai tas nebija izdevīgi. Somijas delegācija nevairījās no diskusijām un apṇēmās ziṇot par poḷu priekšlikumiem savai valdībai. ${ }^{668}$ Savukārt tā, atbildot uz padomju puses 27. marta priekšlikumu, 12. aprīlī uzsāka miera sarunas ar Padomju Krieviju (pagaidām gan tās nebija sekmīgas un 24. aprīlī uz laiku tika pārtrauktas).

Latvijas delegācija diplomātisku apsvērumu dēḷ bija solījusi, ka Varšavā atgriezīsies, bet, protams, neatgriezās - galvenokārt politisku iemeslu dēl,

${ }^{664}$ LVVA, 2574. f., 3. apr., 18. 1., 3. lp.; Brīvā Zeme. - 1920. - 19. marts. Kopā ar delegāciju uz Rīgu izbrauca arī Romas pāvesta nuncijs Polijā A. Rati (Ratti), lai nokārtotu baznīcas lietas Latvijā. Aizbildinoties ar nevēlēšanos pārcelties pāri Daugavai laivā, vinšs devās uz Rīgu cauri Kauņai, taču atpakal atgriezās cauri Daugavpilij. Tas liek domāt, ka tilta trūkums bija tikai iegansts, lai A. Rati varētu apmeklēt arī katolisko Lietuvu. Viņš viesojās Rīgā 20.-24. martā, un pēc tam par Rīgas arhidiecēzes bīskapu tika iecelts latvietis A. Springovičs (pārpoḷotā bīskapa E. O’Rurka darbs neapmierināja Latvijas mācītāju lielāko daḷu, jo viņš nezināja latviešu valodu). - AAN, Akta L. Wasilewskiego, t. 41, k. 8; Gazeta Warszawska. - 1920. 23 marzec; Latgalīts. - 1920. - 20., 29. marts.

665 AAN, Attachaty, A - II, 64/1, k. 298-299; LVVA, 6033. f., 1. apr., 68. 1., 6. 1p.

${ }^{666}$ LVVA, 2575. f., 15. apr., 1. 1., 48.-49. 1p.

${ }^{667}$ Łossowski P. Stosunki polsko - litewskie... - S. 191.

${ }^{668}$ Hovi K. Polish - Finnish cooperation... - P. 125; Sąsiedzi wobec wojny. - S. 255. 
kaut arī 19. martā J. Balodis un P. Radziṇš sarunā ar A. Miškovski atzina, ka pilnīgu abu valstu sapratni militārajās problēmās traucē vienīgi jautājums par Ilūkstes apriṇka austrumu daḷas piederību. A. Miškovskis kārtējo reizi centās pārliecināt sarunu biedrus par Polijas prasību pamatotību. 23. martā P. Radziṇš piel̦āva, ka iespējams noslēgt vismaz Latvijas-Polijas militāru konvenciju, lai gan ir politiskas domstarpības. ${ }^{669}$ Tomēr 24. martā Latvijas valdība nolēma sākt miera sarunas ar Padomju Krieviju. 26. martā Z. Meierovics par to paziņoja padomju valdībai. 10. aprīlī Latvijas delegācija izbrauca uz Maskavu, kur 16. aprīlī sākās sarunas. ${ }^{670}$ Polijas valdība gan nevarēja Latvijas pusei pārmest nelojalitāti, jo Varšavas konferences laikā sarunās tika piel̦auta iespēja slēgt mieru ar Padomju Krieviju atsevišķi (vienīgi iepriekš par to informējot draudzīgās valstis), bet pirmās sēdes sākumā Polijas pārstāvji, kā jau minēts, bija paziņojuši, ka tuvākajā nākotnē gatavojas uzsākt miera sarunas Oršā, Smoḷenskā vai citā pierobežas pilsētā un par poḷu miera sarunu delegācijas vadītāju jau izraudzīts S. Pateks. Turklāt paši poḷi nebija par to latviešus informējuši iepriekš (šīs sarunas gan nekad netika uzsāktas). ${ }^{671}$

Līdz šim laikam Polijas valdība tomēr cerēja, ka Latvijas delegācija atgriezīsies Varšavā. A. Keniņš 29. martā pārrunāja ar S. Gutovski vienošanās iespējas. Pēdējais uzsvēra, ka visu sarežǵgijumu atrisināšana atkarīga no Latvijas piekāpšanās sešu pagastu jautājumā un no gatavības noslēgt militāru konvenciju. Bez tās S. Gutovskis atteicās pārrunāt citus jautājumus un juridiski formulēt arī Polijas attieksmi pret Latgali. A. K̦eniņš iebilda, ka Polijas vēlmes liek domāt par tieksmi kontrolēt Latgali, jo palīdzēt Latvijai agresijas gadījumā efektīvi var arī no tālākas robežas (aiz Daugavas upes līnijas). S. Gutovskis atbildēja, ka Polijai jāatrodas pozīcijās, no kurām varētu aizstāvēt Latviju brīdī, kad uzskatīs to par apdraudētu (pati Latvija nespēšot nosargāt Latgali un Polijai jādomājot par Viḷnas aizsargāšanu). A. Ķeniņš šajos izteicienos pamatoti saskatīja pat zināmus draudus vai kārtējo šantāžu un ieteica valdībai neatteikties no sešiem pagastiem (vismaz tiesiski $-\bar{E}$. J.). 31. martā S. Gutovskis paziņoja, ka vairs nav Polijas delegācijas vadītājs, jo Latvijas "miera uzaicinājums faktiski likvidējot konferences darbību". 672 Jāpiezīmē, ka A. Miškovskis 29. martā Rīgā bija saṇēmis uzdevumu un instrukciju noskaidrot Latvijas valdības nostāju Varšavas konferencē apspriesto jautājumu sakarā. İpašu vērību viṇam vajadzēja pievērst jebkurai darbībai, kas bija vērsta uz miera sarunu sākšanu. Turklāt viṇam vajadzēja sekot Latvijas attiecībām ar Lietuvu un Igauniju, Latvijas nostājai pret

${ }^{669}$ AAN, Attachaty, A - II, 64/1, k. 217-219.

${ }^{670}$ Sīpols V. Slepenā diplomātija. - 51.-52. lpp.; Przegląd Wieczorny. - 1920. - 3 kwiec.

${ }^{671}$ LVVA, 2575. f., 8. apr., 30. 1p.

${ }^{672}$ LVVA, 2575. f., 15. apr., 11. 1., 27., 29. 1p. Šajā laikā Varšavā uzturējās dzejnieks Rainis, kas bija devies no Šveices uz Latviju un kam 31. martā Polijas Seima Sociālistiskā frakcija sarīkoja mielastu. Tajā tika mēǵināts viṇu pārliecināt, ka Polijas pretenzijas uz sešiem pagastiem ir pamatotas. Dzejnieks esot iesaucies: "Tad jau jūs gribat atn̦emt manu dzimteni un tās vietas, kur esmu pavadījis savu bērnību!” - Donass F. Politiskos krustcel̦os. - 17. lpp.; Kurjer Polski. - 1920. - 26 marzec; Latvijas Kareivis. - 1920. - 30. marts. Rainis un Aspazija no Polijas Latvijā atgriezās 9. aprīlī. - Baltijas Vēstnesis. - 1920. - 8. apr.; Latvijas Kareivis. - 1920. - 11. apr. Abi dzejnieki iebrauca ar vilcienu Kalkūnē, kur tos sagaidīja Latgales apgabala priekšnieka auto, kas bija atsūtīts ar poḷu 
gaidāmajām sarunām nākamajā konferencē ar Poliju, kā arī Latvijas armijas „organizācijai, dislokācijai un morālajam stāvoklim”. ${ }^{673}$

Sešu pagastu un Grīvas problēma nebija atrisināta, un Latvijas valdībai bija nopietni jārēḳinās ar iespēju, ka tos atgūt neizdosies.

\section{Latvijas un Polijas saimniecisko sakaru un satiksmes nodibināšana. Bēglu un gūstekṇu atgriešanās no Polijas}

Saimnieciskie sakari starp Latviju un Poliju bija atkarīgi, pirmkārt, no abu valstu politiskajām attiecībām un ārējiem apstākḷiem (arī no kopējas robežas izveidošanās). Šie sakari neapšaubāmi veicinātu abu valstu sadarbību. Perspektīvu tirdzniecībā ar Poliju saskatīja arī Latvijas valdība. Polijā varēja iegādāties naftas produktus, akmeņogles, sāli, cukuru, stiklu, pārtikas un rūpniecības preces. Tādēḷ diplomātiskajā pārstāvniecībā Varšavā jau no 1919. gada novembra strādāja tirdzniecības atašejs H. Steinmanis. Janvārī Polijas varas iestādes atḷāva izvest uz Latviju 50 cisternas naftas produktu, bet 10. februārī A. Keniņš ziņoja, ka trūkst vagonu un lokomotīvju, lai nogādātu tos Viḷnāā, kur sākās platsliežu dzelzceḷš. Polijas valdība piekrita Latvijas vilcienu satiksmei uz Poliju. Turklāt vairāki latviešu tirgotāji ar konsula A. Luces-Birka starpniecību bija saṇēmuši atḷauju izvest uz Latviju 75 vagonus naftas produktu, ogḷ u un cukura. Pēc līguma noslēgšanas ar valdību viṇi bija ar mieru pastāvīgi būt par starpniekiem. ${ }^{674}$ Janvārī Latvijas individuālie uzṇēmumi Polijā uzsāka iepirkt vairumā arī tabaku. ${ }^{675}$ Tūlìt pēc Daugavpils atbrīvošanas šajā pilsētā parādījās Polijas un Lietuvas preces, kuras tika realizētas par spekulatīvām cenām. Pēc kopējās robežas nodibināšanas aktivizējās abu pušu privātuzṇēmēji. Latvijas prese ziṇoja, ka poḷu uzṇēmēji gatavo preču sūtījumus uz Latviju, bet uz Polijas rūpniecības centriem devušies vairāki Latvijas tirgotāji. ${ }^{676}$

Tā kā bija gaidāma tirdzniecisko sakaru attīstība, februāra sākumā Daugavpilī darbu sāka Latvijas muitas nodaḷa ${ }^{677}$. Tomēr tās darbība, kā jau minēts, bija ievērojami apgrūtināta poḷu karaspēka klātbūtnes dēḷ. Savukārt Polijas presē janvāra beigās parādījās informācija, ka drīzumā uz Rīgu dosies

iestāžu atḷauju un kas tos pārveda pāri tiltam uz Daugavpili. Sekoja svinīga sagaidīšana un apgabala priekšnieka apmeklējums. Pēc tam Rainis aplūkoja cietoksni un pilsētu. Viņš arī izteica vēlmi apmeklēt Daugavas otrā krastā redzamo Randeni, ar ko saistījās dzejnieka bērnības atmiņas. Uz paskaidrojumu, ka tas neesot iespējams, jo apgabalu ieņēmis lietuviešu karaspēks, Rainis iesaucies: „Mūsu zemi? Mēs viṇu atbrīvosim, jo viṇa ir mūsu! Atbrīvosim bez asins izliešanas!” - Latvijas Kareivis. $-1920 .-12$. apr.

${ }^{673}$ Pepłoński A. Wywiad w wojnie polsko- bolszewickiej 1919-1920. - Warszawa, 1999. - S. 61; Pepłoński A. Wywiad a dyplomacja II Rzeczypospolitej. - Toruń, 2004. - S. 75.

${ }^{674}$ LVVA, 2575. f., 15. apr., 11. 1., 52.-54., 61. 1p.; Latgolas Words. - 1920. - 1. febr. Februārī A. Ķeniņš ieteica H. Steimaņa vietā par tirdzniecības atašeju Polijā iecelt Lodzas fabrikantu K. Biggi, bet tas netika izdarīts. - AAN, Attachaty, A - II, 81/1.

675 Сегодня. - 1920. - 6 февр.

676 Jaunākās Ziņas. - 1920. - 12., 20. janv.

${ }^{677}$ Brīvā Zeme. - 1920. - 12. febr. 
tirdzniecības pārstāvji, kas runās par linu piegādi no Latvijas. ${ }^{678}$ Marta sākumā Varšavā tika nodibināta Polijas-Latvijas saimnieciskā sabiedrība ("Latpol"), lai panāktu sadarbību un tranzìta atvieglojumus, bet marta otrā pusē Rīgā - "Latvju-poḷu tirdzniecības sabiedrība". Abas organizācijas nodibināja savstarpējus sakarus. Pēc tam A. Keniņš paziṇoja, ka Polija gatava eksportēt no Latvijas papi, kartonu, ietinamo papīru un linsēklas. Stāvokli atviegloja tas, ka Lietuvas valdība aț̣āva kravu tranzìtu cauri Kauñai, jo Daugavpils dzelzceḷa tilts vēl nebija salabots. Tomēr dažādu apstākḷu dẹ̄̂ pirmais vilciens uz Poliju izbrauca tikai aprīḷa beigās un Galīciju sasniedza pēc vairākām nedēḷām. Sekojošo poḷu-padomju kara notikumu dēḷ tas Rīgā ar naftas produktiem atgriezās tikai augusta beigās. ${ }^{679}$ Visi tālākie Latvijas puses centieni panākt Lietuvas puses piekrišanu kravu tranzìtam cauri Lietuvas teritorijai uz Poliju un no tās beidzās nesekmīgi. 1920. gada 8. maijā diplomātiskais pārstāvis no Kauṇas ziṇoja, ka par regulāra tranzīta sakariem ar Poliju "nav ko domāt leišu-pol,u attiecību dēl,". ${ }^{680}$

1920. gada pavasarī dažādu iemeslu dēḷ abu pušu cerības uz aktīvu tirdzniecisko sakaru attīstību nepiepildījās. Latvijā nelielos daudzumos pa dzelzceḷu un jūras ceḷu ieveda tekstilpreces, sakṇaugu sēklas, rakstāmpiederumus, naglas u. c. Tomēr, tā kā nebija nenoslēgta saimnieciskā konvencija, visai ierobežoti tirdznieciskie sakari pagaidām notika tikai starp privātajiem uzṇēmējiem. ${ }^{681}$ Turklāt oficiālajos Latvijas ārējās tirdzniecības statistiskajos rādītājos starp kaiminvvalstīm (Igauniju, Lietuvu, Somiju) 1920. gada pirmajos četros mēnešos Polija ieṇēma pēdējo vietu. Saskaṇā ar tiem janvārī un februārī uz Poliju no Latvijas bija izvestas preces 3500 Latvijas rubḷu vērtībā, bet martā un aprīlī - par 485610 Latvijas rubliem. Ievests nebija nekas. Apsardzības ministrijas laikraksta „Latvijas Kareivis” apskatnieks izteica pārsteigumu par šo faktu, jo pastāv „ l,oti tuvas politiskās attiecības”, turklāt no Polijas varētu ievest Latvijā tik nepieciešamās akmeņogles un manufaktūras preces. ${ }^{682}$ Tikai 1920. gada 21. jūnijā Latvijas valdība nolēma izveidot sevišķu komisiju tirdznieciskām sarunām ar Poliju, ${ }^{683}$ taču praktiski tā darbu nevarēja uzsākt, jo reǵionā notika straujas militārpolitiskas pārmaiṇas.

Saimnieciskos sakarus neapšaubāmi apgrūtināja arī sarežğìtā satiksme starp abām valstīm. Tūlìt pēc Latgales atbrīvošanas, saṇēmuši vīzas Polijas pārstāvniecībā Rīgā, cilvēki devās uz Daugavpili, kur dažādās poḷu iestādēs pārbaudīja vinu personību. Kopumā Daugavpilī, kurā trūka pienācīgi ierīkotu apmešanās vietu, bija jāpavada vairākas dienas. Vilcieni no Kalkūnes, kas atrodas Daugavas kreisajā krastā, uz Viḷnu devās ik dienas, taču tie sastāvēja vienīgi no stipri bojātiem preču vagoniem un brauciens tajos bija mokošs. Ceḷā braucējus vairākkārt pārmeklēja poḷu karavīri. Arī Viḷnā un

\footnotetext{
${ }^{678}$ Kurjer Polski. - 1920. - 28 stycz.

${ }^{679}$ Brīvā Zeme. - 1920. - 6. marts, 27. maijs; Latvijas Sargs. - 1920. - 25. marts; Republikas Sargs. 1920. - 27. marts, 9., 27. apr.; Baltijas Vēstnesis. - 1920. - 3. jūl.

${ }^{680}$ LVVA, 6823. f., 2. apr., 69. 1., 285. lp.

${ }^{681}$ Republikas Sargs. - 1920. - 25. marts.

${ }^{682}$ Latvijas ārējā tirdzniecība//Latvijas Kareivis. - 1920. - 21. jūl.

${ }^{683}$ LVVA, 5192. f., 1. apr., 2. 1., 39. 1p.; Sīkāk sk.: Jēkabsons Ē. Latviešu tautības karagūstekṇi Polijā// Latvijas Arhīvi. - 2006. - Nr. 2. - 119.-139. lpp.
} 
Varšavā bija grūtības iegādāties biḷetes. ${ }^{684}$ Ar laiku dzelzceḷa satiksme gan uzlabojās. 1. martā tika atklāta tieša satiksme Varšavas-Turmantas līnijā, tāpēc Latvijas dzelzceḷa vadība lūdza poḷu pusi saskaṇot vilcienu pienākšanas laikus Kalkūnes-Turmantas posmā. Tomēr līdz pat vasarai bija jāizdara pārsēšanās Krustpilī. Latvijas pilsoni sūdzējās par poḷu karavīru patvarībām Kalkūnes stacijā, par atṇemtajām personīgajām lietām un pasažieru aizturēšanu. Lai atvieglotu latviešu bēgḷu atgriešanos dzimtenē, Latvijas armijas Virspavēlnieka štābs 3. jūnijā lūdza atḷauju Kalkūnē strādāt latviešu virsniekam un rakstvedim, kuri reǵistrētu bēglus. A. Miškovskis savai virspavēlniecībai lūgumu nodeva tikai jūlija sākumā pirms Sarkanās armijas uzbrukuma poḷu frontē. Uzbrukuma dēḷ atbildes nebija. ${ }^{685}$

Sarežğìtā satiksme bija jāpiedzīvo arī latviešu tautības karagūstekṇiem, kuri 1919. gada beigās un 1920. gada sākumā lielās grupās atgriezās no Polijas. 1920. gada 5. janvārī pilnvarotais bēgḷu un gūstekṇu lietās Polijā P. Strods lūdza Ārlietu ministriju parūpēties, lai Latvijā pret poḷu bēg̣̣iem izturas labi, jo no tā ir atkarīgs, kā izturēsies pret latviešiem Polijā. ${ }^{686}$

Karagūstekṇu un bēgḷu atbrīvošanas komisija, kas pastāvēja pie Iekšlietu ministrijas, savu iespēju robežās noskaidroja, kuri bijušie gūstekṇi ir atgriezušies no Polijas, un nosūtīja tos uz iepriekšējām dzīvesvietām. Turpmāk viṇu skaits samazinājās. Pilnvarotais bēgḷu un gūstekṇu lietās Polijā marta beigās ziṇoja, ka gandrīz visi 1300 Latvijas pilsonības gūstekṇi atgriezušies dzimtenē, taču no Dienvidkrievijas bija sākusies latviešu bēg̣̣u plūsma. Turklāt pārstāvniecībā Varšavā bija reğistrēti arī apmēram 200 Latvijas pilsoṇi, kuri pagaidām gribēja palikt Polijā. Luṇiṇecas apkārtnē dzīvoja 10 latviešu zemnieku ǵimenes, kas grasījās pārdot zemi un atgriezties Latvijā. Tika rēķināts, ka Polijā martā dažādu iemeslu dēḷ atrodas apmēram 1000 latviešu. ${ }^{687}$ Visumā poḷu varas iestāžu attieksme pret latviešu bēg̣̣iem bija labvēlīga, kaut arī bija sūdzības par ierēdṇu korumpētību. ${ }^{688}$

Pēc Daugavpils ieṇemšanas beidzot pavērās iespējas nodibināt tiešus pasta un telegrāfa sakarus ar Poliju un caur to - arī ar citām Eiropas valstīm. Jau 1920. gada janvārī Latvijas Satiksmes un darba ministrijas Pasta un telegrāfa departaments nosūtīja uz Daugavpili savu ierēdni, lai atjaunotu Latgales pasta un telegrāfa darbu. Tajā pašā mēnesī tika organizēta vienkāršu un ierakstītu vēstuḷu pasta satiksme ar Poliju, Baltkrieviju un Ukrainu. Telegrāfa sakari gan šajā laikā vēl atradās vienīgi militārā resora pārzin̄ā, un Latvijas Valsts telegrāfs uz Poliju telegrammas nosūtīja cauri Liepājai, Dānijai un Vācijai pa zemūdens kabeli. Tā kā Polija bija kḷuvusi par vienīgo Latvijas Pasta un telegrāfa izeju uz Eiropu (neskaitot gadījuma rakstura kuğu sakarus ar Skandināviju), Pasta un telegrāfa departaments februāra sākumā oficiāli griezās pie Polijas Pasta administrācijas ar priekšlikumu noslēgt vienošanos

\footnotetext{
${ }^{684}$ Jaunākās Ziṇas. - 1920. - 17. febr.

${ }^{685}$ LVVA, 3601. f., 1. apr., 9. apr., 350. 1., 31. lp.; CAW, II ND WP, t. 192; Jaunākās Ziṇas. - 1920. 21. jūn. 
par savstarpējiem sakariem un sakariem, kuri caur Poliju notiktu ar citām valstīm. ${ }^{689}$

Kopumā jāatzīst, ka Latvijas un Polijas militārā sadarbība Latgalē bija sekmīga. Ienaidnieka - Sarkanās armijas - operatīvā situācija Daugavpils zaudējuma dēḷ ievērojami pasliktinājās. To atzīst arī padomju militārie vēsturnieki, ${ }^{690}$ turpretim Polijas situācija ievērojami uzlabojās, bet Latvija bija atguvusi vēl līdz tam neatbrīvoto savas valsts daḷu. Latviešiem un poḷiem saskaṇoti darbojoties, tika pilnībā sasniegti apvienotās karaspēka grupas operatīvie mērḳi. Trūkumi - nepilnīgie sakari, dažkārt novēlotā pavēḷu izpilde un citi - nebija tik nozīmīgi, lai ietekmētu galīgā uzdevuma izpildi, un bija izskaidrojami ar objektīviem apstākḷiem, galvenokārt ar divu atšķirīgu armiju sadarbības grūtībām (kaut arī tās bija formāli apvienotas un tām bija kopēja pavēlniecība). Turklāt šīm armijām bija jāsadarbojas sevišḳi ekstremālos klimatiskos apstākḷos (stiprs sals un sniegs). Vienīgi Latvijas puses pārtikas piegādes dažādu apstākḷu dēḷ nebija pietiekošas un nenotika laikus. Tomēr Polijas armijas kaujas spējas tas ietekmēja maz vai neietekmēja nemaz (poḷu puse bija rēḳinājusies ar novēlotu piegāžu varbūtību). Sliktā pārtikas piegāde vairāk iespaidoja aizmugurē dzīvojošos zemniekus, kuru pārtikas krājumus parasti pirka par neatbilstoši zemu maksu, turklāt bieži vien tos vienkārši rekvizēja vai pat nolaupijja. Līdz ar to Latvijas nelabvēḷiem Polijā bija iegansts pārmest tai līguma nepildīšanu, un šiem pārmetumiem jau bija politiski mērḳi. Sīs pašas aprindas mēǵināja attiecināt intendantūras dienestu trūkumus arī uz operatīvo sadarbību. Poḷu muižniecībai dažkārt labvēlīgais E. Maḷiševskis, piemēram, pilnīgi nepamatoti apgalvoja, ka Latvijas armija īsteno "speciālu taktiku", kuras dēḷ poḷi bijuši spiesti iet kaujā pa priekšu. Tādēḷ latviešiem gandrīz neesot bijis kritušo. ${ }^{691}$ Arī Latvijai nelabvēlīgais Latgales muižnieks M. Svežbiṇskis rakstīja, ka poḷu karavīri latviešus nicinājuši slikto pārtikas piegāžu dēl. ${ }^{692}$ Šādi izteicieni liecina, ka to autori nostājas pret Latviju politisku motīvu dēḷ. Tomēr šādu pilnīgi neobjektīvu attieksmi noteica, pirmkārt, aizvainojums par Latvijas "uzdrošināšanos” apdraudēt Latgales poḷu muižnieku milzīgos zemes ìpašumus. Gandrīz neviens Polijas armijas karavīrs neapgalvo, ka kopīgā operācija Latgalē nebija sekmīga. ${ }^{693}$ Turpretī gandrīz visi atzīst, ka operācija bija sekmīga, jo abām pusēm tas bija gan operatīvi, gan politiski izdevīgi. No mūsdienu vēsturniekiem vienīgi anglis

${ }^{689}$ LVVA, 1532. f., 1. apr., 2236. 1., 41.-42. 1p., 86. lp.

${ }^{690}$ Какурин Н., Меликов В. Гражданская война в России: война с белополяками. - Москва, 2002. - 25-26 стр.

${ }^{691}$ Maliszewski E. Polacy na Łotwie. - S. 20.

692 APAN, Świerzbiński M. Martyrologia Inflant Polskich. - S. 68.

${ }^{693}$ Izņēmums ir brigādes ǵenerālis T. Mahaḷskis, kas operācijas laikā bija Lietuvas-Baltkrievijas frontes štāba kapteinis. Viņš vēlāk izteica neizpratni par Latgales operācijas nozīmi un apgabala "atdošanu" Latvijai. Tomēr to, šķiet, noteica, pirmkārt, viņa domstarpības ar grupas štāba priekšnieku T. Kučebu. - Machalski T. Generał Tadeusz Kutrzeba. Studyum krytyczne. - Londyn, 1983. - S. 31. Jāpiezīmē, ka pats T. Mahaļskis (vēl kā apakšpulkvedis) 30. gados veica samērā detalizētu pētījumu par Baltijas valstu atbrīvošanās cīṇām. - Machalski T. Wyzwolenie państw bałtyckich: Finlandii, Estonii i Łotwy//Bellona. - 1937. - T. XX. - Zesz. 3. - S. 473-514. 
N. Deiviss pilnīgi nepamatoti, nenorādot nekādus avotus, raksta, ka operācija bijusi "neprasmības kalngals", sākusies ar novēlošanos (sakarā ar Latvijas puses bažām, ka "Latvijas poḷu minoritāte pieprasīšot ūniju ar Poliju"), poḷi 3. janvārī, sākot uzbrukumu, nav varējuši "daudz sagaidīt no saviem latviešu sabiedrotajiem". Angḷu vēsturnieka uzskatu nepamatotību skaidri apliecina arī viṇa pielaistās nopietnās faktoloğiskās kḷūdas: N. Deiviss apgalvo, ka Daugavpils cietoksnim uzbrukusi 3., nevis 1. Leǵionu divīzija; pārceḷoties pāri Daugavai, zem artilērijas ielūzis ledus (tas neatbilst patiesībai); 5. janvārī, kad pabeigta Daugavpils ieņemšanas operācija, uz laiku pārtraukta karadarbība visā poḷu-padomju frontē. ${ }^{694}$

Sadarbība frontē un attiecības starp latviešu-poḷu frontes daḷu karavīriem patiesībā bija ievērojami labākas nekā starp Latvijas iestādēm (tās organizēja ar grūtībām) un Polijas armiju Daugavpilī un citur frontes aizmugurē. To noteica gan politiskas, gan sadzīviskas problēmas, kas gan bija savstarpēji cieši saistītas. Tomēr arī aizmugurē nepieciešamā sadarbība starp abu valstu institūcijām (piemēram, starp pretizlūkošanas struktūrām Daugavpilī) notika. Polijas karaspēks tiešām nodarīja milzīgus saimnieciskus zaudējumus Latgalē, tomēr kara apstākḷ os vairāk vai mazāk cieta visi, arī sava karaspēka ieṇemti apgabali. Piekrītot sadarbībai ar poḷiem savā teritorijā, Latvijas valdībai bija nopietni un laikus jārēḳinās ar sekām, kādas izraisīs sveša karaspēka atrašanās Latgalē, jo pieredze šajā ziṇā jau bija (1919. gadā Igaunijas armijas ieṇemtajā Ziemel̦vidzemē zemnieki cieta, iespējams, vēl smagāk). Acīmredzot politiskais un militārais izdevīgums, ko radīja minētā sadarbība, atsvēra visus sarežǵịjumus (vismaz līguma noslēgšanas brīdī 1919. gada beigās tas nebija apšaubāms). Vēl jo vairāk, tilti un sakaru līnijas, kuras Latgalē savu taktisko interešu dēḷ bija uzbūvējušas Polijas armijas inženierdaḷas, pēc poḷu aiziešanas pārgāja Latvijas īpašumā.

Polijas armijas izturēšanās Latgalē bija cieši saistīta ar Latvijas un Polijas starpvalstu attiecībām un atstāja uz tām noteiktu iespaidu. Tomēr noteicošie šajās attiecībās bija ārējie faktori (attieksme pret Padomju Krieviju, Lietuvu u. c.). Kopumā ar Varšavas konferences neveiksmi 1920. gada martā noslēdzās tas posms Latvijas un Polijas attiecībās, kurš bija aizsācies 1919. gada rudenī ar Polijas atbalstu Latvijai Bermonta karaspēka uzbrukuma izraisītās krīzes laikā. Abu valstu vēsturē šim posmam bija raksturīga lielākā savstarpējā tuvināšanās, ko noteica īpašā politiskā un militārā situācija reǵionā. Galvenais notikums minētajā laika posmā bija kopīgā militārā operācija Latgalē, taču uz tās politiskā fona izpaudās tendences, kuras veidoja Latvijas-Lietuvas-Polijas savstarpējās attiecības, šo valstu attieksme pret Padomju Krieviju un saistība ar Antantes lielvalstīm.

1920. gada pirmajos mēnešos skaidri iezīmējās politiskās attiecības un pretrunas starp plānotās Baltijas savienības valstu savienības loceklēm - Somiju, Igauniju, Latviju, Lietuvu un Poliju. Starp abām pēdējām tās bija īpaši asas, turpretī abas pirmās īstenoja izolētu ārpolitiku. Savukārt Latvija atradās ne tikai tīri ǵeogrāfiskajā, bet arī ǵeopolitiskajā centrā, un tai bija

${ }^{694}$ Davies N. Orzeł biały, czerwona gwiazda. Wojna polsko - bolszewicka 1919-1920. - S. 73-74. Diemžēl N. Deivisa nepamatoto militārās operācijas zemo novērtējumu nekritiski citē A. Stranga: Latvijas-Padomju Krievijas miera līgums 1920. gada 11. augustā. - 30. 1pp. 
īpatnēja loma Polijas un Lietuvas konfliktā. Latvijas domstarpības ar Lietuvu šajā laikā no tīri teritoriālām domstarpībām bija pārvērtušās jau politiskās domstarpībās, turklāt tās ievērojami padziḷināja Latvijas tuvināšanās Polijai.

Latvijas attiecībās ar Poliju turpināja pastāvēt zināmas tuvināšanās tendences. Galvenokārt tās izpaudās abu pušu centienos gūt sev politisku izdevīgumu ar otras puses atbalstu vai starpniecību. Tiesa, atšḳīās mērḳi un līdzekḷi. Polija uzstājīgi centās panākt Latvijas piekrišanu vismaz divpusējai militārpolitiskai savienībai, kura būtu izdevīga Polijas konfliktā ar Lietuvu, kā arī plānotajā lieluzbrukumā Padomju Krievijai. Pēdējo reizi tā mēǵināja panākt „federatīvās koncepcijas” ìstenošanu vai vismaz Polijai draudzīgas un ar to cieši saistītas Ukrainas un Baltkrievijas izveidi. Turpretī Latvijas interesēs nebija cieša saistīšanās ar Poliju, kuras intereses ievērojami atšķīās no nelielo Baltijas valstu interesēm. Tāpēc Latvijas valdība izturējās l,oti piesardzīgi. Drīz pēc Helsinku konferences, kura kārtējo reizi apliecināja, ka Baltijas valstu starpā valda sarežğìtas pretrunas, tika noslēgts slepens Latvijas un Padomju Krievijas pamiera līgums. Sākās ilgstoša diplomātiska spēle, kas ilga vairākus mēnešus un parādijja, ka Latvija vēl karo ar Krieviju un mēǵina ierobežot karadarbību līdz izlūkošanai, kas pārauga atsevišḳās vietēja rakstura sadursmēs un ko pilnībā novērst šādos apstākḷos nebija iespējams.

Polijas attieksmē aplūkojamajā periodā skaidri parādījās iezīme, kas bija raksturīga zināmai poḷu sabiedrības daḷai visu laiku starp diviem pasaules kariem un kura līdz šim nebija izpaudusies, jo nebija aktuāla Latvijai tās cīṇā pret sevišķi reakcionārajiem un arī Polijas intereses apdraudošajiem Bermonta vācu-krievu spēkiem. Turpretī pēc Latgales atbrīvošanas poḷu nacionāldemokrāti un citas šovinistiski noskaṇotās aprindas (ar Latgales muižniecību priekšgalā) izvirzīja ideju, ka šo novadu varētu paturēt sev. Kaut arī tā pilnīgi nesaskanēja ar Polijas valdības deklarēto politiku pret Latviju, tomēr atstāja zināmu iespaidu arī uz poḷu oficiālajām aprindām. Raksturīgs piemērs ir Polijas pirmā diplomātiskā pārstāvja Latvijā B. Boufala negatīvā nostāja pret Latviju un latviešiem. Pārmaiṇas attieksmē pret Latgali sāka iezīmēties arī oficiālajā politikā un spilgti izpaudās Varšavas konferences laikā, kad Polijas delegācija pēkšṇi ignorēja iepriekš deklarētās nostādnes un centās panākt, ka Latvija saṇem Latgali no Polijas, kas brīvprātīgi atsakās no šìs savas bijušās provinces ar izdevīgiem politiskiem nosacijumiem.

Šajā laikā aktualizējās arī teritoriālais strīds starp Latviju un Poliju par sešiem bijušās Kurzemes guberņas pagastiem un Grīvu Ilūkstes apriṇķa austrumos. To faktiskai iekḷaušanai Braslavas apriṇkī 1919. gadā Latvijas valdība līdz šim nebija pievērsusi pienācīgu uzmanību aktuālāku problēmu dēḷ. Turpretī 1920. gada martā Polijas nostāja bija kategoriska, un šĩ pretruna kḷuva par vienu no galvenajiem Varšavas konferences neveiksmes cēloṇiem.

1920. gada martā, kad aktuāla kḷuva Polijas karaspēka izvešana no Latvijas, abu valstu attiecības bija citādākas nekā gada sākumā. Tomēr ārējie apstākḷi turpmākai sadarbībai joprojām saglabājās. 


\section{3. nodallă
ATTIECİBU SAREŽ Š ŠANĀS (1920. gada marts-jūnijs)}

\section{Polijas karaspēka lielākās daḷas izvešana no Latgales}

Martā fronti pret Sarkano armiju līdz Osvejas ezera ziemeḷu krastam joprojām bija ieṇēmusi poḷu 3. Leǵionu divīzija. Tā kontrolēja arī aizmugures teritoriju līdz Dubnas stacijas-Dagdas ezera ziemel̦u krasta-Osvejas ezera līnijai. ${ }^{695} \mathrm{Lìdz}$ 1920. gada marta beigām Latvijas prese regulāri publicēja poḷu karaspēka grupas štāba priekšnieka T. Kučebas sagatavotos frontes stāvokḷa apskatus, kuri parasti vēstīja par biežām izlūkvienību sadursmēm. ${ }^{696}$ 8. martā frontē bija sākusies poḷu karaspēka daḷu nomaiṇa ar Latvijas armijas vienībām (kā jau minēts, pēc dažām dienām uz laiku politisku iemeslu dēl tā tika apturēta), ienaidnieks vairākās vietās mēǵināja uzbrukt. Piemēram, 19. martā 150 sarkanarmieši uzbruka 3. Jelgavas pulka pozīcijām pie Poḷeščinas, taču šis uzbrukums tika atsists (latviešu gūstā krita 56 sarkanarmieši).

Šajā laikā tapa lıti pieklājīgs Latvijas armijas virspavēlnieka J. Baloža lūgums J. Pilsudskim pilnībā izvest Polijas karaspēku no Latvijas. 22. martā J. Pilsudskim tika nosūtīts arī līdzīgs Latvijas Ārlietu ministrijas memorands. Šajā dienā Latgales apgabala priekšnieks A. Bērziṇš ziṇoja, ka "poḷu pārgrupēšanās turpinās, taču viṇu galīgie nodomi vēl nav noteikti zināmi". ${ }^{697}$ Interesanti, ka no 17. martā sastādītā Latvijas armijas Virspavēlnieka štāba Iekšējās izlūkošanas nodaḷas pārskatā skaidri redzams, ka Latvijas puse šajā laikā zināja arī par gaidāmo poḷu gatavošanos lieluzbrukumam padomju frontē. Sakarā ar to jau tuvākajā laikā 1. Leǵionu divīzija gatavojās doties Kamen,ecas-Podoḷskas virzienā, bet pārējās karaspēka daḷas Latgalē palikt ne ilgāk par 8. aprīli. ${ }^{698}$

Polijas armijas G̦enerālštābs 21. martā pavēlēja 3. Leǵionu divīzijai nekavējoties nodot frontes iecirkni ziemel̦os no Daugavas Latvijas armijas vienībām un E. Ridzam-Smiglijam par to noslēgt īpašu vienošanos. 24. martā A. Miškovskis ziṇoja, ka panācis Latvijas armijas virspavēlniecības piekrišanu nomainìtā poḷu karaspēka pagaidu izvietošanai BaḷbinovasKrāslavas-Baltiṇu rajonā un ir izdota pavēle atsākt galīgu poḷu vienību

\footnotetext{
695 AAN, Attachaty, A - II, 64/1, k. 154.

${ }^{696}$ Наша жизнь. - 1920. - 17, 19, 20, 21, 25 марта.

${ }^{697}$ LVVA, 2574. f., 3. apr., 15. 1., 51., 52.-53., 57. lp.

698 Turpat, 3601. f., 1. apr., 465. 1., 31. 1p.
} 
nomaiṇu frontē 27. martā. 699 Lielā mērā poḷu puses zināmo piekāpību izraisīja gatavošanās lieluzbrukumam, kurš bija paredzēts Ukrainā, Kijevas virzienā, un kura īstenošanai bija nepieciešamas arī Latvijā esošās karaspēka daḷas, kas pamatoti tika uzskatītas par vienām no kaujasspējīgākajām Polijas karaspēkā.

Z. Meierovics paredzēja, ka līdz 1. aprīlim poḷu karaspēka izvešana būs pabeigta. ${ }^{700}$ 28. martā poḷu komandantūras galvenās funkcijas Daugavpilī bija jāpārṇem Latvijas militāriestādēm. ${ }^{701} 29$. martā tika paziṇots, ka Latvijas armijas virspavēlniecība "pārṇem savā atbildībā visu fronti lìdz Daugavai un līdz ar to visas karaspēka daḷas un iestādes, kas agrāk bija padotas apvienotās Latvijas-Polijas karaspēka grupas pavēlniekam ğenerālim Ridzam-Smiglijam, pāriet viṇas zināšanā un rīcībā padotības kārtībā". Tajā pašā dienā E. Ridzs-Smiglijs paziņoja, ka 30. martā nodod Latvijas armijas virspavēlnieka padotībā latviešu daḷas, kas līdz šim bija pakḷautas viṇam, un uz Rīgu izbrauc kapteinis V. Bortnovskis, ${ }^{702}$ kurš ir pilnvarots noslēgt vienošanos par "polu frontes likvidāciju” (30. martā V. Bortnovskis Rīgā pārrunāja stāvokli ar J. Balodi, bet nākamajā dienā turpināja sarunas jau ar A. Veisu ${ }^{703}$ ). Poḷu sakaru virsniekam pie Kurzemes divīzijas štāba gan vēl kādu laiku bija jāpaliek savā vietā. ${ }^{704}$ Savukārt 31. martā poḷu 1. armijas vadība pārṇēma Latvijā esošos spēkus, pildot virspavēlniecības pavēli par fronšu (arī Lietuvas-Baltkrievijas frontes) likvidāciju. ${ }^{705}$ Stāvokli Latvijā tas gan nekādi neietekmēja. Attiecības starp poḷu un latviešu karavīriem, kuri atradās Drisas rajonā un kurus škīira Daugava, bija samērā labas. 2. Ventspils kājnieku pulka karavīri atcerējās, ka poḷi no otra Daugavas krasta mēdzuši pārcelties pāri upei un viesojušies pie latviešiem. ${ }^{706}$

1. aprīlī Latvijas armijas Galvenās apgādības pārvaldes priekšnieks K. Švīders un V. Bortnovskis apmainījās ar abu pušu priekšlikumiem par poḷu karaspēka izvešanas kārtību. Poḷu projekts balstījās uz 16. janvāra Rīgā parakstītās vienošanās noteikumiem un paredzēja, ka Daugavpils cietoksnis, dzelzcel̦a stacija, kā arī Drisas tilts un Drujas prāmis paliek poḷu kontrolē līdz karadarbības beigām. Saskaṇā ar to Daugavpilī pagaidām paliktu

\footnotetext{
${ }^{699}$ AAN, Attachaty, A - II, 64/1, k. 176, 215, 229. Nomaiņas norise redzama no 2. Ventspils kājnieku pulka piemēra: šī pulka bataljoni nomainīja poḷu 23. kājnieku pulka vienības 27.-29. martā 25 kilometru iecirkn̄̄ aiz Zarjankas upes. 30. martā ienaidnieks šajā iecirknī pārgāja pretuzbrukumā, taču tika atsists (savukārt poḷu 23. pulks līdz 3. aprīlim ieradās Daugavpilī). - 2. Ventspils pulks. 325.-327. lpp. (Šajā grāmatā sniegto informāciju 1934. gadā bija būtiski papildinājis bijušais poḷu 7. Leǵionu pulka virsnieks B. Oḷševskis, būdams šajā laikā piekomandēts Latvijas armijai. - AAN, Sztab Główny, t. 616/ 261, k. 157, 161); CAW, WBH, 341. 1. 154, 151, 155).

${ }^{700}$ Latvijas Sargs. - 1920. - 26. marts; Republikas Sargs. - 1920. - 4. apr.; Latgalīts. - 1920. 25. marts.

701 LVVA, 2574. f., 3. apr., 15. 1., 54. 1p.

702 Sākotnēji vest sarunas tika uzdots arī A. Miškovskim, taču viņš 28. martā lūdza sevi atbrīvot no šī pienākuma, jo militārā atašeja piedalīšanās tajās "neizskatīsies dabīgi”. - AAN, Attachaty, A - II, 64/1, k. 233.

703 Paluszyński T. Walka o niepodległość Łotwy 1916 - 1921. - S. 330.

${ }^{704}$ LVVA, 6033. f., 1. apr., 24. 1., 54.-55. 1p.

705 CAW, WBH, 341. 1. 156; Piłsudski J. Pisma zbiorowe. - S. 153-154.

${ }^{706}$ Ezergailis J. Pirms 50 gadiem//Daugavas Vanagu Mēnešraksts. - 1971. - Nr. 3.-32. lpp.
} 
poḷu komandants, likvidācijas komisija, hospitāḷi, munīcijas noliktavas (līdz satiksmes atklāšanai Viḷnas-Daugavpils dzelzceḷa līnijā) un Latgales civilpārvaldei jānorēḳinās ar poḷiem par izdarītajiem remontdarbiem u. c. ${ }^{707}$ Latvijas puses projektā tika noraidītas svarīgākās poḷu prasības un uzstāts, lai tiktu izvests karaspēks no Daugavpils un vara pilsētā nekavējoties pārietu latviešu komandantūras rokās. ${ }^{708}$ E. Ridzs-Smiglijs reaǵēja, 1. aprīlī apturot karaspēka izvešanu līdz laikam, kad Latvijas puse piekritīs 16. janvāra vienošanās noteikumiem. Vienlaikus gan tika dots rīkojums turpināt evakuēt atlikušo 1. Leğionu divīzijas daḷu un 7. ulānu pulku, kā arī nodot ēkas Latvijas armijas Kara ēku un būvju pārvaldei (1. leǵionu kājnieku pulks no Grīvas-Kalkūnes rajona aizbrauca 29.-30. martā, 5. Leǵionu kājnieku pulks -1.-3. aprīlī, bet 6. Leǵionu kājnieku pulks no Kalkūnes un Turmantas 1. aprīlīing). Vienīgi 1. lauka artilērijas pulkam tika pavēlēts līdz vienošanās parakstīšanai ar Latviju palikt Daugavpilī 3. Leǵionu divīzijas štāba rīcībā. Polijas G̦enerālštābs 3. aprīlī līguma nenoslēgšanas gadījumā paredzēja 3. divīzijas koncentrēšanos Daugavpils rajonā tā, lai "vajadzības gadījumā varētu izveidot pietiekoši plašu priekšlauku uzbrukumam". ${ }^{710}$ Ģenerālštāba priekšnieks pavēlē 1. armijai uzsvēra, ka Latgalē jāuztur tāds stāvoklis, lai uz latviešiem varētu izdarìt spiedienu. Viṇš pat piel̦āva, ka Daugavpilī iespējama 1. Leǵionu divīzijas daḷu atgriešanās. ${ }^{711}$

Pašā pilsētā stāvoklis pakāpeniski kḷuva kritisks. Saskaṇā ar A. Veisa 29. marta pavēli par varas pāriešanu latviešu komandantūras rokās, aprīḷa sākumā latviešu virsnieks mēǵināja pārṇemt savā kontrolē stacijas komandantūru, taču saņēma poḷu komandanta atbildi, ka saskaņā ar E. Ridza-Smiglija pavēli "viss paliek pa vecam”. Poḷu karaspēku pagaidām vairs neizveda, taču 7. aprīlì poḷu sapieri pabeidza pontonu tilta būvi augšpus dzelzceḷa tilta Daugavpilī. Pilsētas latviešu komandantūras un Latgales apgabala priekšnieka rīkojumi vairs vispār netika ņemti vērā. 3. aprīlī pie komandanta un garnizona priekšnieka E. Graudiṇa ieradās poḷu majors un paziṇoja par karaspēka izvešanas apturēšanu. Pastiprinājās poḷu karavīru patrulēšana ielās. Tajā pašā dienā E. Graudiņš sūdzējās E. RidzamSmiglijam, ka "poḷu karavīru patvarības pārsniedz jebkādas robežas". Poḷi aizturot uz ielām latviešu karavīrus un pat virsniekus, lai pārbaudītu dokumentus. Viņš paziņoja, ka, turpinoties šādai darbībai, polu karavīri tiks apcietināti un nodoti poḷu komandantūrā. Ridzs-Smiglijs atbildēja, ka jebkura "uzstāšanās" pret poḷu patruḷām vai žandarmēriju tiks sodīta saskanāa ar Polijas Kara sodu likumu. 3. aprīḷa vakarā (plkst. 22.00) poḷu žandarmi aizturēja piecus 3. Jelgavas kājnieku pulka karavīrus, kas bija dienesta norīkojumā. Viṇi nedrīkstēja atrasties ielās pēc plkst. 21.00. Klātesošais E. Graudiṇš mēǵināja panākt viṇu atbrīvošanu. Kad viņš deva pavēli latviešu karavīriem doties uz kazarmām, bet poḷu žandarmi mēǵināja E. Graudiṇu pašu tādēḷ apcietināt, gandrīz izraisījās kautiņš. Pēc tam latviešu komandants

\footnotetext{
${ }^{707}$ LVVA, 6033. f., 1. apr., 24. 1., 12.-14. 1p.; AAN, Kod, t. 2, k. 180.

708 Skrzypek A. Związek... - S. 63-64.

709 CAW, WBH, 341. 1. 151.

${ }^{710}$ AAN, Kod, t. 2, k. 185-186.

${ }^{711}$ CAW, WBH, 341. 1. 157.
} 
un karavīri bija spiesti sekot žandarmiem, jo pretējā gadījumā viṇi draudēja lietot ieročus. Tomēr notiekošo pamanīja latviešu garnizona 1. rotas karavīri, kas izskrēja no savas novietnes un apturēja gājienu. Šajā brīdī ieradās poḷu virsnieks, pavēlot saviem kareivjiem izklīst. Nākamajā dienā poḷu karavīri padzina latviešu sargposteni no Daugavas dambja pie poḷu būvētā pontonu tilta. Majors T. Kučeba izskaidroja notikušo kā "lielu pārpratumu" un solīja dot rīkojumu netraucēt latviešiem ieņemt posteni. Tomēr poḷu karavīri atkal to nel̦āva. Analoǵiska rīcība pret latviešu posteni bija 5. aprīlī pie prāmja piestātnes. E. Graudiṇš uzskatīja, ka latviešu postenis tur traucē izvest no Latvijas preces, un ziņoja, ka poḷu izturēšanās pēdējās dienās ir izaicinoša un pastāvīgi aizskar latviešu karavīrus. Uz ielām bez iemesla notiek šaudīšanās (nejauši pat ievainojot vairākus iedzīvotājus), bet naktīs - "atklātas laupīšanas". Latviešu karavīri ir uztraukti par "varmācīgajiem kaimiṇiem", un "kuru katru brīdi var izcelties lielas nepatikšanas". Tādēl E. Graudinš aizliedza saviem karavīriem bez īpašas vajadzības iziet ielās, bet uzbrukuma gadījumā pavēlēja rīkoties saskaṇā ar sardžu dienesta nolikumu un atklāt uguni pret uzbrucējiem (par šo pavēli tika informēts arī poḷu štābs). 6. aprīḷa naktī poḷi sarīkoja ielās tādu šaudīšanos, ka apgabala priekšniekam A. Bērziñam "mums draudzīgā armija likās traka palikusi". 8. aprīlī E. Graudiṇš Virspavēlnieka štābā Rīgā kārtējo reizi lūdza norādījumus tālākai rīcībai, jo nevarēja uzskatīt par saistošu Ridza-Smiglija pavēli, kura "dod patvarību darītājiem tik pamatīgas garantijas par vinuu neaizskaramību pat tad, ja patvarības vērstas pret Latvijas karavīriem". ${ }^{712}$ No Rīgas nekādu norādījumu joprojām nebija, un vajadzēja rīkoties atkarībā no apstākḷiem uz paša atbildību. Latvijas Dzelzceḷu policijas Daugavpils nodaḷas policisti Krāslavā apcietināja vairākus vietējos poḷu tautības iedzīvotājus, kuri Krāslavas dzelzceḷa stacijas apkārtnē "veduši aǵitāciju” par labu apgabala iekḷaušanai Polijā..$^{13}$

Poḷu štāba pārstāvis Rīgā kapteinis V. Bortnovskis, kuram bija nopelni konflikta noregulēšanā, jo viṇa nostāja bija latviešiem labvēlīga, ${ }^{714} 3$. aprīlī diplomātiski informēja Latvijas armijas Virspavēlnieka štāba pārstāvjus, ka poḷu karaspēka izvešana apturēta "no grupas virspavēlnieka neatkarīgu iemeslu dēḷ" un sarunas par to var tikt turpinātas (Bortnovskis informēja latviešus par izvešanas apturēšanu tikai 2. aprīlī pēc atkārtotas pavēles no grupas štāba, jo 1. aprīlī A. Miškovskis viṇu bija pārliecinājis, ka šāds solis ir pāragrs un nevajadzīgi sabojās attiecības). Pildot štāba pavēli, Bortnovskis arī uzsvēra, ka sarunām jābalstās uz 16. janvāra vienošanos, pretējā gadījumā tās nevarēs turpināties, jo pārrunājamie jautājumi pārsniegs viṇa pilnvaras. Šajā pašā dienā J. Balodis lūdza A. Miškovskim panākt karaspēka izvešanu un skaidroja sarežğìto valsts iekšpolitisko stāvokli, ko vēl vairāk sarežǵī poḷu karaspēka atrašanās Latgalē. A. Miškovskis apsolīja darīt visu iespējamo,

\footnotetext{
712 LVVA, 3601. f., 1. apr., 309. 1., 15.-22.; 248. 1., 465.-468. 1p.; 2574. f., 3. apr., 17. 1., 224. 1p.

713 Turpat, 5604. f., 1. apr., 957. 1.

714 V. Bortnovskis 4. aprīlī telegrammā Ridzam-Smiglijam izteica neizpratni par poḷu vienošanās projektā ietvertajām prasībām, kas "nerēķinās ar to, ko mēs jau mutiski esam norunājuši, un kas nerēķinās arī ar reālo lietu stāvokli Latvijā”. - AAN, Kod, t. 2, k. 198.
} 
izsakot cerību, ka “ar [karaspēka] evakuāciju saistītās tehniskās grūtības drīz izdosies pārvarēt". ${ }^{715}$

Neskaidrs bija stāvoklis poḷu kontrolētajos Latgales rajonos. 7. aprīlī Krāslavas komandants P. Maksimovs lūdza viņu informēt, kura rokās atrodas militārā vara austrumos no Indricas upes un vai Krāslavas un Izabelinas pagasts vēl ir poḷu operatīvais rajons. Viṇam arī nebija skaidrs, vai tāpat kā līdz šim ar visiem jautājumiem jāgriežas poḷu 3. Leǵionu divīzijas štābā.716 Katrā ziṇā par stāvokli nelielajā miestā liecina arī Tieslietu ministrijas jaunieceltā Krāslavas iecirkṇa miertiesneša ziṇojums. 12. aprīlī viņš ziṇoja, ka miestā nav izdevies atrast telpas šai iestādei, jo visās ēkās izvietots poḷu karaspēks un jāgaida tā aiziešana. ${ }^{717}$

Ar abpusēju piekāpšanos sarunas Rīgā atjaunojās un kopīgi tika izstrādāts līguma projekts. Polijas armijas virspavēlniecība deva norādijumus: ja latvieši piekrìt, ka cietoksnis un dzelzceḷa tilts paliek poḷu kontrolē Daugavpilī, tad drīkst piekāpties finansiālās norēḳināšanās jautājumā718 (tāpēc V. Bortnovskis atteicās no samaksas par nepiegādāto pārtiku un lopbarību apmēram 20 miljonu Polijas marku vērtībā $\left.{ }^{719}\right)$. 11. aprīlī pulkveži-leitnanti A. Veiss un K. Švīders, no Latvijas puses, un kapteinis V. Bortnovskis, poručniks S. Vojevudzkis, no Polijas puses, parakstijja līgumu par Polijas karaspēka evakuāciju uz Daugavas kreiso krastu. Līgums noteica, ka Daugavpilī paliek poḷu karaspēka nodaḷa dzelzcel̦a apsardzībai posmā no tilta līdz stacijai, to neiekḷaujot (poḷi palika arī cietoksnī), 400 vīru liela tehniskā vienība pie tiltu būves un 350 vīru liels etapu bataljons noliktavu un iestāžu apsardzībai, kamēr tās evakuēs; Daugavpils poḷu komandantūrai pēc septiṇām dienām vara pilsētā jānodod latviešiem, un turpmāk poḷu vienībām jāpakḷaujas latviešu komandantūrai (tas notika 18. aprīlī plkst. 18.00); pilsētā paliek Poḷu likvidācijas komisija, kura poḷu daḷām pildīs arī komandantūras funkcijas; pie stacijas komandanta darbojas piekomandēts poḷ sakaru virsnieks, kurš ir atbildīgs par savu karaspēka daḷu transportu un ar to saistītajiem jautājumiem; Daugavpilī pagaidām paliek vairāki hospitāḷi un noliktavas; galīgiem norēkininiem tiek sastādīta kopīga komisija. Turklāt Poḷu likvidācijas komisijas rīcībā pagaidām palika arī lauka žandarmērijas postenis pilsētā.720

11. aprīlī E. Ridzs-Smiglijs atcēla savu 2. aprīḷa pavēli par karaspēka izvešanas apturēšanu un apstiprināja aiziešanas kārtību. Tūlìt pēc tam pāri Daugavai pārgāja artilērija un 7. ulānu pulks, bet 18. aprīlì uz Baranovičiem pie aizbraukušajām 1. Leǵionu divīzijas daḷām devās E. Ridzs-Smiglijs ar štābu. ${ }^{721}$ Arī 3. Leğionu divīzija gatavojās aiziešanai. 15. aprīlī sakarā ar

\footnotetext{
715 AAN, Kod, t. 2, k. 190; Attachaty, A - II, 64/1, k. 245-246.

716 LVVA, 3479. f., 1. apr., 27. 1., 71. 1p.

717 Tieslietu ministrijas un tiesu vēsture 1918-1938. - Rīga, 1939. - 378. lpp.

718 CAW, Teki Laudańskiego, 440. 12/4 - 5, k. 126. 10. aprīlī Polijas armijas Ģenerālštābs uzskatīja, ka Polijai nepieciešams spēcīgs garnizons Daugavpilī un vienošanās neparakstīšanas gadījumā par spēkā esošu tiks atzīts 16. janvāra līgums, kurš tādas tiesības jau dod. - AAN, Attachaty, A - II, 64/1, k. 392.

719 AAN, Kod, t. 2, k. 153.

${ }^{720}$ Dokumenty z dziejów polskiej polityki zagranicznej 1918-1939. - Warszawa, 1989. - T. 1. - 90-93; LVVA, 3605. f., 1. apr., 105. 1., 31.-32. 1p.

${ }^{721}$ AAN, Attachaty, A - II, 64/1, k. 297; CAW, WBH, 341. 1. 151.
} 
poḷu jātnieku ziṇnešu posteṇu noṇemšanu divīzijas štābs Krāslavas policijai pieprasīja ik dienas atsūtìt tā rīcībā piecus šḳūtniekus. ${ }^{722}$ 9.-14. aprīlī Piedrujā tika uzcelts pagaidu tilts. 20. aprīlī pāri tam pārgāja sapieru dal̦as, 7., 8., 9. Leǵionu kājnieku pulks, 3. lauka artilērijas un 3. smagās artilērijas pulka divizions (divīzijas transports un 602. lauka hospitālis 18.-19. aprīlī pa dzelzceḷu devās uz Daugavpili). ${ }^{723}$ 21. aprīlī Krāslavu atstāja pēdējās poḷu vienības un 3. Leǵionu divīzijas štābs. Pagaidām palika sapieru rota, lai nodotu Latvijas puses komisijai tilta būvi un neizmantotos celtniecības materiālus (vēl 24. aprīlī poḷi ar nepacietību gaidīja šo iespēju). Runājot latviešu komandanta vārdiem, miests bija atstāts "pilnā kārtībā”. Arī pati aiziešana no Krāslavas bija noritējusi samērā kārtīgi, ja neskaita dažas izdemolētas ēkas. Līdz 23. aprīlim Krāslavas stacijā palika poḷu komandants, vēl dažas dienas turpinot "radīt nekārtības - aizturēt vilcienus, izdarìt kratīšanas un rekvizìcijas". ${ }^{24}$ 20. aprīlī ārlietu ministrs Z. Meierovics paziṇoja, ka poḷi Latgali atstājuši, bet 22. aprīlī šo ziṇu apstiprināja Latvijas Preses birojs. ${ }^{725}$

Poḷu karaspēka izvešanas laikā Latvijas iestādes saskārās ar vēl vienu nepatīkamu problēmu - dažādu vērtību izvešanu no valsts, tas gan bija aktuāli jau agrāk. Uz Latgales apgabala priekšnieka 16. aprīḷa aicinājumu pārtraukt mēbeḷu izvešanu no pilsētas poḷu grupas štāba priekšnieks T. Kučeba 21. aprīlī atbildēja, ka tikai grupas štābs vien janvāra sākumā esot ievedis no Polijas Daugavpilī 12 vagonus ar mēbelēm no pamestām muižām. Tās tikšot vestas atpakal, bet ir dots rīkojums neizvest Latvijas pilsoṇiem piederošas "mēbeles un iekārtas". ${ }^{726}$ Saprotamu iemeslu dēḷ šādos apstākḷos pilnvērtīgi kontrolēt izvešanas procesus nebija iespējams. 29. martā no Daugavpils teātra izveda mēbeles, 2. aprīlī kastēs tika iesaiṇotas skatuves dekorācijas, telpās neielaižot pat pilsētas latviešu komandanta atsūtītos virsniekus. Par to un tikko notikušo poḷu-latviešu karavīru konfliktu Daugavpilī Latvijas diplomātiskās pārstāvniecības Varšavā sekretārs P. Oliṇš 10. aprīlī izklāstīja Polijas ārlietu ministram S. Patekam. Ministrs nosūtīja ierēdni uz armijas Ģenerālštābu un pieprasīja nekārtības nekavējoties izbeigt un pēc izmeklēšanas vainīgos sodīt. S. Pateks apsolīja personīgi telegrafēt E. Ridzam-Smiglijam teātra piederumu izlaupīšanas jautājumā, bet 13. aprīlī informēja P. Oliṇu, ka aizvestās mēbeles un dekorācijas "tikšot visā drīzumā atsūtītas atpakal,”.727 Tomēr jāšaubās, vai tas notika.

\footnotetext{
${ }^{722}$ LVVA, 3479. f., 1. apr., 27. 1., 82. 1p.

723 CAW, WBH, 341. 1. 151, 154.

${ }^{724}$ LVVA, 2574. f., 3. apr., 17. 1., 195. 1p.; 3479. f., 1. apr., 27. 1., 72., 74., 84. 1p.

${ }^{725}$ Republikas Sargs. - 1920. - 21. apr.; Strādnieku Avīze. - 1920. - 22. apr.

${ }^{726}$ LVVA, 1368. f., 1. apr., 1390. 1., 3. 1p.

${ }^{727}$ LVVA, 3601. f., 1. apr., 309. 1., 23. 1p.; 2574. f., 3. apr., 17. 1., 454. 1p.
} 


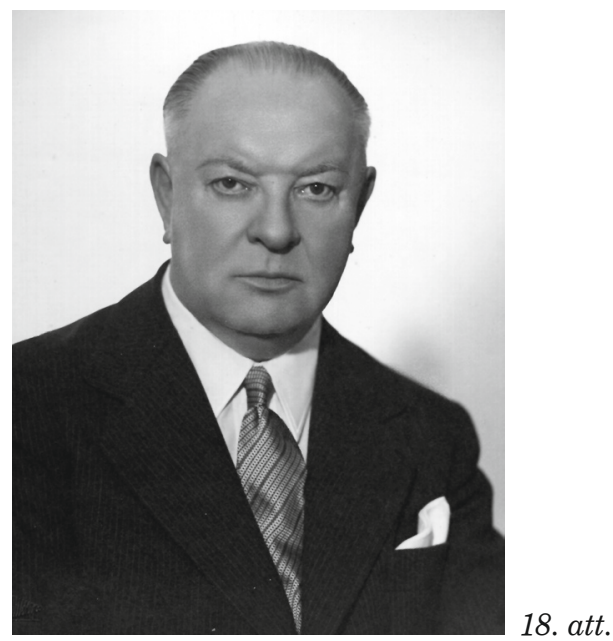

Latvijas diplomātiskās pārstāvniecības Varšavā sekretārs Pēteris Oliṇš

Neizdevās atgūt pilsētas centrālās bibliotēkas krājumu daḷu, kas drīz pēc Daugavpils atbrīvošanas tika aizvesta uz Viḷnu. Aprīlī Izglìtības ministrijas pilnvarotā persona, kas bija atbildīga par kultūras vērtībām V. Melderis - konstatēja, ka aizvesti apmēram 4500 sējumi. Spriežot pēc polu karavīru teiktā, tie tika izmantoti Viḷnas poḷu universitātes bibliotēkas veidošanā. ${ }^{728}$ Turklāt grāmatas un dokumenti tika izvesti arī no vairākām Dienvidlatgales poḷu muižnieku bibliotēkām (jādomā, ka daudzos gadījumos tas notika ar īpašnieku piekrišanu) ${ }^{729}$ No Daugavpils poḷi izveda arī dzelzcel̦a stacijas iekārtas, Dzelzceḷa slimnīcas inventāru un meiteṇu ǵimnāzijas iekārtu. ${ }^{730}$

Neraugoties uz E. Graudina protestiem, Polu likvidācijas komisijas vadītājs un poḷu garnizona priekšnieks majors A. Kersnovskis ${ }^{731}$ aprīla beigās pavēlēja izvest uz Molodečno cietokšna ugunsdzēšamās mašīnas un iekārtas. Tikai laimīgas nejaušības dēḷ 8. maijā izdevās apdzēst ugunsgrēku Daugavpils cietoksnī. Jautājuma risināšanā tika iesaistīts pat A. Miškovskis, kurš 2. jūnijā ziṇoja, ka, n,emot vērā "nepieciešamību uzturēt ar latviešiem iespējami labas attiecības”, mēǵinājis pie A. Kersnovska panākt iekārtu atdošanu, taču tas atsaucies uz pavēli par iekārtu izvešanu - marta beigās šo pavēli viṇam bija devis E. Ridzs-Smiglijs. ${ }^{732}$ Šḳiet, ka A. Miškovska darbībai

${ }^{728}$ LVVA, 2574. f., 3. apr., 13. 1., 110. 111. lp.; Izglītības Ministrijas Mēnešraksts. - 1920. - Nr. 7. 59. lpp.; Latvijas Sargs. - 1920. - 29. marts.

${ }^{729}$ Latvijas Sargs. - 1920. - 18. jūn. Daḷa muižnieku bibliotēku tika izvazātas. Par to liecina gan kāds vietējais muižnieks, kas jūnijā Rēzeknes apkārtnē redzējis izpostītas un aplaupītas „Polijas pilsoṇu” bibliotēkas, gan Polijas armijas virsnieks V. Broṇevskis, kas atzinās, ka pamestajās bibliotekās "šo to nočiepis”. - Naród. - 1920. - 26 czerw.; Broniewski W. Pamiętnik... - S. 160.

${ }^{730}$ CAW, IV oddział Naczelnego Dowództwa WP, 301. 10. 37, k. 78.

${ }^{731}$ Latvijas puses dokumentos majora Kersnovska uzvārds rakstīts kḷūdaini - "Kerkovskis".

${ }^{732}$ LVVA, 2574. f., 3. apr., 15. 1., 58. 1p.; 3601. f., 1. apr., 309. 1., 34., 36., 56. 1p.; AAN, Attachaty, A - II, t. $64 / 1$, k. 370 . 
nebija rezultātu, tāpat kā to nebija Latvijas puses centieniem vēl 1928. gadā atgūt 1920. gadā pazudušo Daugavpils Svētā Vladimira Pareizticīgo baznīcas ikonu. ${ }^{733}$

\section{Politiskās attiecības pēc Varšavas konferences neveiksmes}

Ziṇa par Latvijas iesaistīšanos miera sarunās ar Padomju Krieviju Polijā izraisīja samērā asu reakciju. Attieksme pret Latviju kḷuva ievērojami vēsāka. 10. aprīlī ārlietu ministrs S. Pateks izteica savu sarūgtinājumu P. Oliṇam par Latvijas delegācijas "atturīgo un vēso toni konferencē", kas "gandrīz radījis iespaidu, ka sarunājas divas naidīgas puses”. S. Pateku sevišḳi apbēdinājusi neuzticība pret viṇu, kurš esot "latviešu-poḷu apvienošanās karsts piekritējs un tagadējā kabineta visradikālākais loceklis, kam jau tā nācies lauzt daudz šḳēpu Latvijas labā”. Ministrs esot noticējis delegācijas solījumam atgriezties Varšavā, taču tā "devusies taisnā ceḷā uz Maskavu”. Uz P. Oliṇa piezīmi, ka arī dažu Polijas pārstāvju (S. Gutovska) "tonis bijis l̦oti augstprātīgs un pat draudīgs", ministrs atbildējis, burtiski nolamājot S. Gutovski, un uzsvēris, ka vajadzēja tikai dot mājienu, un pēdējais būtu nomainìts ar Latvijas pusei pienemamāku politiki. P. Oliṇš kā attaisnojumu Latvijas valdības rīcībai minēja lēmumu, kurš bija pieṇemts vienā no konferences Militārās komisijas sēdēm un ar kuru separāta miera noslēgšana ar Krieviju uz kopīgi pārrunāto principu pamata neietekmēs Latvijas un Polijas attiecības. ${ }^{734}$ Tomēr Polijas puse bija cerējusi, ka Latvija miera sarunas uzsāks saskaṇā ar Poliju vai vismaz saziṇā ar to. Tādēḷ jaunajā situācijā pārmests tika arī Polijas Ârrlietu ministrijas vadībai. Pat salīdzinoši liberālā prese rakstīja par pilnīgu Pateka “taktisko plānu sabrukumu” un Polijas diplomātijas sakāvi. ${ }^{735}$ Savukārt kāds Seima sociālistu frakcijas deputāts sarunā ar A. Keniṇu atzina, ka ministrs S. Pateks netiek uzskatīts par labu diplomātu tieši dēḷ neveiksmīgās politikas pret Latviju. ${ }^{736}$ Nacionāldemokrātu prese apgalvoja, ka valdība ,atdevusi” Latgali un Daugavpili Latvijai, nenodrošinot "kopdarbību" nākotnē (pat ne Polijas "taisnīgo robežprasību" atzīšanu). Līdz ar to Varšavā vairs nav bijis, ko latviešiem piedāvāt, jo viss jau atdots (pat vairāk, nekā „pienāktos”). ${ }^{737}$ Raksturīga bija Polijas valdībai tuvu stāvošā laikraksta "Kurjer Lwowski" nostāja. Tas rakstīja, ka "Latvija, ar kuru attiecības sāka veidoties labi, pašlaik sāk traucēt un kaitēt Polijai". Latvija gan esot saṇēmusi Latgali no Polijas armijas, taču politiski jautājums vēl neesot atrisināts, jo Polija ir spiesta savu līdzšinējo nostāju revidēt.738

\footnotetext{
733 AAN, MSZ, t. 6210. Polijas varas iestāžu veiktā izmeklēšana šajā lietā bija bez rezultātiem.

734 LVVA, 2575. f., 15. apr., 11. 1., 11. 1p.

735 Przegląd Wieczorny. - 1920. - 3 kwiec.

${ }^{736}$ LVVA, 2575. f., 15. apr., 11. 1., 11. 1p.

737 Gazeta Warszawska. - 1920. - 11, 12 kwiec. Nacionāldemokrāti šajā laikā gan atzina, ka Polija darījusi pareizi, atbalstot Latviju militāri, taču tas noticis bez "kopīgo interešu noteikšanas".

${ }^{738}$ Kurjer Lwowski. - 1920. - 11 kw.; Gazeta Warszawska. - 1920. - 13 kwiec. Rakstu 20. aprīli atreferēja "Jaunākās Ziṇas".
} 
Daži Seima deputāti pat iesniedza projektu par robežas slēgšanu un preču eksporta pārtraukšanu uz Latviju, kas "acīmredzami atsvešinājusies no Polijas" (šajā laikā šis eksports gan bija visai nenozīmīgs). P. Oliṇš sarunā ar S. Pateku 15. aprīlī izteica cerību, ka projekts netiks pieņemts, jo "Latvija nebūt nedomā un negrib atsvešināties no Polijas". Ministrs "draudzīgā un siltā tonī" izteicis cerību, ka "nervozie bērni" (S. Gutovskis un citi) turpmāk vairs netraucēs abu valstu tuvināšanos. Tomēr kopumā diplomātiskajās un militārajās aprindās saskaņā ar M. Hartmaṇa ziṇojumu no Varšavas bija vērojams zināms sarūgtinājums un neapmierinātība ar Latvijas nostāju. ${ }^{739}$

Polijā bija politiḳi, kas centās piemēroties reālajai situācijai, ievērojot nepieciešamību par katru cenu vienoties ar Latviju. 16. aprīlī laikraksts "Kurjer Poranny" rakstīja, ka abu pušu vēlme un veiktie sagatavošanās darbi vēl atḷauj uzlabot attiecības, bet Polijas prasību pēc "maza Ilūkstes apriṇķa stūrīša" nosaka vienīgi Baltkrievijas zemju drošības apsvērumi. Nav arī pamata apgalvot, ka Latvijas sarunas ar Krieviju nelabvēlīgi ietekmē abu pušu labo gribu vienoties. ${ }^{740}$

Kaut arī Polijas valdošās aprindas pamazām pieslējās minētajam politiskajam virzienam, tomēr saspīlējums attiecībās izpaudās arī sūtṇa B. Boufala ${ }^{741}$ intervijā Latvijas dienas laikrakstam "Republikas Sargs" 14. aprīlī. Tā izvērtās politiskā skandālā. Pēc 24. marta-4. aprīḷa komandējuma Varšavā B. Boufals paziṇoja, ka Polijas un Latvijas attiecības kḷuvušas daudz vēsākas. Iemeslus viṇš nenorādīja, bet minēja otršķirīgus incidentus un vietējo poḷu "interešu neievērošanu" (valsts valodas nepratēju atlaišanu no darba u. c.). Gadījumā, ja Latvija noslēgs ar Krieviju mieru, bet Polija turpinās karot, Latvijai būšot jārisina Latgales juridiskās piederības jautājums tieši ar Poliju. Turklāt Polija nevarēšot atzìt šāda miera līguma likumību un savu karaspēku no Latgales neizvedīs, jo Daugavpils tai nepieciešama kā "stratēǵisks atbalsta punkts". ${ }^{742}$ Nākamajā dienā militārajā oficiozā "Latvijas Kareivis" publicists J. Simsons asi vērsās pret B. Boufalu, kas esot paudis Polijas ārpolitikas patiesos nolūkus, kuri jāṇem vērā Latvijas valdībai (angḷu pārstāvji jau agrāk "nopietni brīdinājuši poḷus Latgalē nelaist, nedz ciest, ka viṇi ieņemtu Daugavpili”). Viňš uzsvēra, ka Latgale ir Latvijas sastāvdaḷa, un gadījumā, ja Boufals pārteicies (sakot, ka par Latgali slēgtos līgumus starp Latviju un Padomju Krieviju Polija nevarēs atzît), Polijas valdībai vienalga jāsaprot, ka šāds diplomātiskais pārstāvis "diez vai spēs veicināt labu saprašanos", un viṇš jānomaina ar cilvēku, kurš "prot cienīt Latvijas nacionālo apziṇu”. Laikraksts "Sociāldemokrāts" atreferēja interviju, uzsverot dažu Latvijas Sociāldemokrātiskās strādnieku partijas vadošu darbinieku jau 1919. gadā aizstāvēto tēzi par iespējamu Latgales atgūšanu no Padomju Krievijas mierīgā ceḷā un apgalvojumu, ka visi sarežǵijumi cēlušies valdības neapdomības dēḷ,

\footnotetext{
739 LVVA, 2575. f., 15. apr., 11. 1., 11. 1p.; 6033. f., 1. apr., 16. 1p.

${ }^{740}$ Kurjer Poranny. - 1920. - 16 kw.

${ }^{741}$ Neilgi pirms tam B. Boufals bija kḷuvis par pārstāvi vien̄̄gi Latvijā, jo par pārstāvi Igaunijā tika iecelts L. Vasiḷevskis (stājās amatā 24. aprīlī). - Łossowski P. Ustanowienie stosunków Polski z Estonią w latach 1918 - 1921//Z dziejów polityki i dyplomacji polskiej. - Warszawa, 1994. - S. 201.

742 Republikas Sargs. - 1920. - 14. apr.
} 
iesaistot Latgales atbrīvošanā Polijas karaspēku (savukārt militārais oficiozs "Latvijas Kareivis" par pēdējo apgalvojumu nosodīja "Sociāldemokrātu"). ${ }^{743}$

Pēc šīs vētrainās reakcijas Poḷu Preses birojs Rīgā skaidroja, ka B. Boufala sniegtā intervija atstāstīta neprecīzi ("Republikas Sarga" redakcija gan apgalvoja pretējo ${ }^{744}$ ). Sagrozits esot teiktais par iespējamo mieru ar Krieviju. Boufals norādījis, ka "ciktāl Latvijas un Padomju Krievijas nodomātā miera līguma noteikumi šādā vai tādā virzienā tieši aizskartu Polijas intereses, Polijas Republika būs spiesta paturēt sev rīcības brīvību”. Attiecībā uz Latgali Polija vienīgi prasa nodrošināt Latgalē dzīvojošo poḷu intereses un nepadarìt Latgali par "tirgošanās objektu". Pats B. Boufals neveikli centās mazināt savas intervijas radito iespaidu, skaidrojot, ka Latgale nepārprotami pieder Latvijai, taču, ja tā tiktu atdota lieliniekiem (vai Latvija un Padomju Krievija noslēgtu savienību pret Poliju), viṇa valsts būtu spiesta ieņemt Latgali savu militāro interešu dēl. B. Boufals uzsvēra, ka Polijas labvēlība pret Latviju izpaužas sava karaspēka izvešanā no Latgales. Atbildē J. Simsons atgādināja, ka Latgale nevis pieder Latvijai, bet ir tās sastāvdaḷa, un šādi izteicieni ir apvainojoši. Poḷu nācija, kura "tik lepna uz savu nacionālo godu", sapratīs, ko tās pārstāvis aț̄āvies, piel̦aujot, ka Latgale tiek atdota Krievijai (tika piel̦auta arī savienība ar to). Sekoja vēl vairāki Polijai naidīgi J. Simsona raksti, un vienu no tiem viňš noslēdza ar secinājumu: "Boufala kunga tiesiska saprašana un izturēšanās pret Latvijas suverenitāti ir tādas, ka tās l,oti kavē vin,a lietderīgu darbu Latvijā."745

Pats B. Boufals 18. aprīlī ziṇoja uz Varšavu, ka intervijā balstījies uz baumām par Latvijas valdības gatavību apspriest iespēju atdot daḷu Latgales Krievijai apmaiṇā "pret ekonomiskām priekšrocībām”. Sagrozìto interviju viņš izskaidroja ar "Republikas Sarga" naidīgo nostāju pret ārlietu ministru Z. Meierovicu, kā arī kārtējo reizi atklāja savu patieso nostāju pret Latviju, rakstot: "Latviešu sabiedriskā doma beidzot parādījusi savu īsto nostāju pret Poliju” un “.. vienīgi ar konsekventu noteiktību varam atgūt mums šeit pienākošos ietekmi, kuru neguvām, pārāk ātri sniedzot Latvijai bruṇotu palīdzību bez garantijām". ${ }^{746}$

Pēc dažām nedēlāàm B. Boufals intervijā presei uzsvēra, ka par palīdzību Latgales atbrīvošanā Polijai pret Latviju nav nekādu pretenziju, un LatvijasPolijas attiecību pamatprincipi nav mainījušies. Polija neliks šķēršļus Latvijas sarunām ar Krieviju. Runājot par iespējamo pārstāvja maiṇu Latvijā, B. Boufals atzìmēja, ka tās ir tikai baumas un Latvijas-Polijas attiecības "pašlaik ir vislabākās, kādas vien var būt divu valstu starpā". Acīmredzot šādi viṇš bija izteicies pēc sarunas (Varšavā) ar J. Pilsudski , kurš kārtējo reizi lika darīt visu, lai Latvija nenoslēgtu "pāragru" mieru un nepanāktu saprašanos ar Lietuvu, kā arī cīnīties ar angḷu iespaida pieaugumu Latvijā. To varēja veikt, vienīgi normalizējot attiecības ar Latvijas varas iestādēm un sabiedrību. ${ }^{74}$ Oficiāli arī Z. Meierovics 20. aprīlī paziṇoja, ka attiecības ar

\footnotetext{
${ }^{743}$ Latvijas Kareivis. - 1920. - 15., 16. apr.; Sociāldemokrāts. - 1920. - 15. apr.

${ }^{744}$ Republikas Sargs. - 1920. - 17. apr.

745 Turpat, 20. apr.; Latvijas Sargs. - 1920. - 16. apr.; Latvijas Kareivis. - 1920. - 17., 18. apr.

746 AAN, Kod, t. 2, k. 203-205.

747 Turpat, k. 215; Jaunākās Ziṇas. - 1920. - 6. maijs.
} 
Poliju "joprojām ir korektas un draudzīgas". ${ }^{448}$ Jāpieṇem, ka šis subjektīvu, bet l̦ti loǵisku apsvērumu izraisītais incidents laikā, kad Polijas valsts vadītājs J. Pilsudskis gatavojās sākt savas armijas uzbrukumu Ukrainā, bija viṇam seviški nepatīkams. To, kādu nozīmi viṇš šajā laikā piešḳīra Latvijas labvēlīgai pozìcijai un kādas cerības ar to saistīja, apliecina telegramma, kura 18. aprīlī tika izsūtīta A. Miškovskim uz Rīgu un kurā bija rīkojums nākamajā dienā ierasties Viḷṇā, lai tur personiski tiktos ar J. Pilsudski. Militārais pārstāvis saṇēma telegrammu ar novēlošanos, taču 19. aprīlī pats telegrafēja uz Varšavu, lūdzot atḷauju ierasties savā galvaspilsētā sniegt ziṇojumu un saṇemt jaunas instrukcijas. Tas viss - sakarā ar „lielajām pārmaiṇām poḷulatviešu attiecībās”.

B. Boufala izteikumi par valstu attiecībām bija seviški pārspīlēti. Tie bija īpaši uzkrītoši pēc nesen presē izvērstās diskusijas (par notiekošo l̦oti apmierināta bija Lietuvas prese, nosaucot to par latviešu neapdomīgās politikas likumsakarīgu rezultātu ${ }^{749}$ ). Pamatotas bija arī runas par gaidāmo Polijas pārstāvja maiṇu. P. Oliṇš Varšavā 20. aprīlī Polijas Ārlietu ministrijā pauda savu neizpratni par interviju: "Ja Boufals Latvijas Satversmes sapulces priekšvakarā izteic tādā formā patiesības, kuras poḷi paši lūdza uzskatīt par Varšavas konferences noslēpumu, tad var iedomāties, cik nelabvēlīgi tas atsauksies uz attiecībām." Teiktais izraisīja satraukumu, un P. Oliṇš tika lūgts piesūtīt intervijas tulkojumu. Sociālistu prese dēvēja B. Boufalu par "konservatīvi un inerti domājošu cilvēku", izteikdama izbrīnu par viṇa nosūtīšanu darbā uz Latviju. Arī Ārlietu ministrijas Baltijas valstu nodaḷas darbinieki privātā sarunā P. Oliṇam izteica pārliecību par drīzu B. Boufala atsaukšanu. ${ }^{750}$ Patiesībā intervija bija vienīgi iegansts pārstāvja atsaukšanai, jo ar viņa darbu bija neapmierināti gandrīz visi Polijas politiskie grupējumi, ieskaitot Latgales muižniecību, kura pārmeta viṇam pārliecīgu "piekāpību" Latvijas valdībai un "Latgales poliskuma pazudināšanu”. Savukārt Viḷnas laikraksts "Nasz Kraj”, kas pārstāvēja valdības aprindu politiskās intereses, Boufalu dēvēja par „pilnīgi nepiemērotu jebkuriem diplomātiskiem amatiem savas neaprēḳinātības dēl’’. ${ }^{751}$ Arī Vācijas prese saskaṇā ar Lietuvas laikrakstu atreferējumu ziṇoja par gaidāmo Polijas diplomātiskā pārstāvja atsaukšanu no Rīgas. ${ }^{752}$ Polijas vēsturnieki šodien atzīst, ka "jaunās un ambiciozās valsts [Latvijas] politiki l̦oti spēcīgi izjuta dažkārt brutālo, bet dažreiz pat gandrīz aizvainojoši tēvišķ̧o pieeju no B. Boufala puses". ${ }^{753}$

Arī Latvijas pārstāvis Varšavā A. Keniṇš nonāca zināmā konfliktā ar Polijas Ārlietu ministriju, pirmkārt, uzturot sakarus ar Baltkrievijas Tautas Republikas un Ukrainas Tautas Republikas pārstāvjiem - ar abām šīm valstīm Polijai bija nopietnas politiskas un teritoriālas nesaskaṇas. 26. martā A. Keniņš iesniedza Ukrainas pārstāvim šīs valsts atzīšanas aktu no Latvijas puses un pārrunāja turpmākās sadarbības iespējas. Pirms atgriešanās

\footnotetext{
748 Republikas Sargs. - 1920. - 21. apr.

${ }^{749}$ Lietuva. - 1920. 22, 24 bal.

${ }^{750}$ LVVA, 2575. f., 15. apr., 11. 1., 6. 1p.; Robotnik. - 1920. - 20 kwiec.

${ }^{751}$ Kurjer Polski. - 1920. - 3 kwiec.; Gazeta Warszawska. - 1920. - 22 marzec; Nasz Kraj. - 1920. - 7 lip.

${ }^{752}$ Lietuva. - 1920. - 1 geg.

753 Okulewicz P. Koncepcja „międzymorza”. - S. 178.
} 
Varšavā aprīḷa beigās viṇš Rīgā tikās ar B. Boufalu, kurš vēlāk ziṇoja par Latvijas pārstāvja apṇēmību pieprasīt sešu Ilūkstes apriṇk,a pagastu atdošanu (atzīmējot, ka Z. Meierovics bijis "pielaidīgāks un pieḷāvis š̄̄s teritorijas palikšanu Polijā vai plebiscìtu tajā"). Boufals informēja arī, ka Keniṇš pārmetis Polijai agresivitāti austrumos un izteicis pārliecību, ka Latgalē etnisku poḷu vispār nav, vienīgi ir latviešu tautai naidīgie poḷu muižnieki. B. Boufals secināja, ka A. Keniņš pieder inteliğences daḷai, kas "gatava pilnīgi nerēḳināties ar mums". Beigās P. Oliṇam Polijas Ārlietu ministrijā tika atklāti norādits, ka Latvijas diplomātisko pārstāvi vēlams nomainīt. Vēlāk A. Ķeniṇš ilgākus periodus uzturējās Rīgā un viṇa pienākumus Varšavā pildīja P. Oliṇš (tam promesot - darbvedis F. Donass), taču arī A. Keniņš līdz pat oficiālajai atcelšanai no amata 1921. gadā laiku pa laikam strādāja Varšavā. ${ }^{254}$

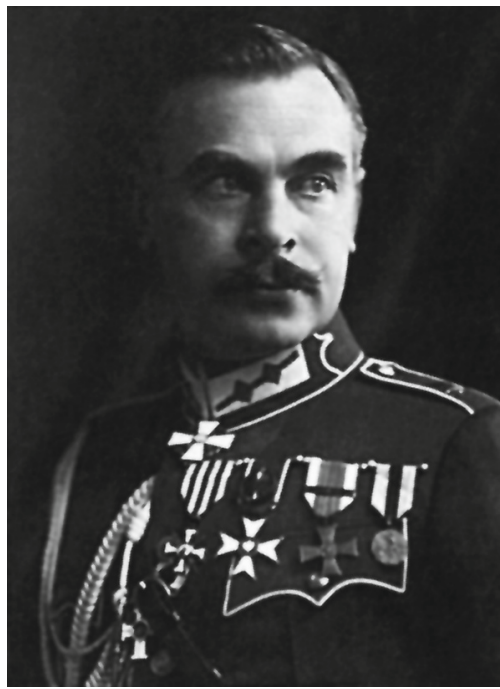

19. att.

\section{Latvijas militārais pārstāvis Varšavā Mārtiṇš Hartmanis}

Lai gan pastāvēja domstarpības, 15. aprīlī P. Oliņš iesniedza Polijas ārlietu ministram oficiālu uzaicinājumu piedalīties Baltijas valstu konferencē Rīgā. Tās sākums bija paredzēts 15. maijā, un tajā apspriestu turpmāko sadarbību. ${ }^{755}$ Savukārt militārais pārstāvis M. Hartmanis 19. aprīlī ziṇoja par gaidāmo poḷu uzbrukumu padomju frontē, lai ieṇemtu Gomeḷas-KijevasCerkasu līniju (viṇš bija sīki informēts par uzbrukuma detaḷām). Poḷu militārās aprindas izteica nožēlu, ka ar Latviju nav panākta vienošanās "miera slēgšanas jautājumā". M. Hartmanis izteica pārliecību, ka "nogaidot poḷu uzbrukumu vai pat sākot to kopā, mēs būtu izkaulējuši izdevīgākus noteikumus". Viṇš uzskatīja, ka miera sarunu dalībniekiem Maskavā

754 AAN, Kod, t. 2, k. 208-210; Donass F. Politiskos krustceļos. - 23. lpp.; Gazeta Warszawska.1920. - 1 maj.

${ }^{755}$ LVVA, 2575. f., 15. apr., 11. 1., 11. 1p.; Łossowski P. Łotwa... - S. 14. Latvijas ārlietu ministrs Z. Meierovics rīkojumu par konferences termiņu bija diplomātiskajiem pārstāvjiem izsūtījis 12. aprīīî, lūgdams paziņot paredzamo savu delegāciju locekḷu skaitu. - LVVA, 1313. f., 2. apr., 66. 1., 2. 1p. 
nevajadzētu steigties - "Polijas panākumi frontē var būt stipri sajūtami pie Maskavas konferences galdiem". ${ }^{756}$

25. aprīlī Ukrainā sākās l,oti plaša Kijevas operācija, kurā poḷi sākotnēji guva ievērojamus militārus panākumus. Daḷēji tieši ši iemesla dēḷ viṇi diezgan vienaldzīgi izturējās pret Latvijas 15. aprīḷa piedāvājumu, kaut arī P. Oliņš tagad bija par politisku pretimnākšanu Polijai, lai "nostādītu mūs daudz labvēlīgākā un izdevīgākā laikā, ja poliem patiešām izdodas satriekt lieliniekus". ${ }^{757}$ Patiesi, saskaṇā ar vēsturnieka A. Strangas secinājumiem, Latvijas valdība vērojusi poḷu ofensīvas sākumu ar neslēptām bažām, taču maija sākumā Ārlietu ministrijā radās cerība, ka poḷu-padomju karš var labvēlīgi iespaidot Latvijas un Padomju Krievijas miera sarunas, kas bija nonākušas zināmā strupceḷā, jo padomju pusei bija svarīgi noslēgt mieru ar Latviju, lai iegūtu rīcības brīvību pret Poliju. Oficiālā padomju puses nostāja izpaudās 30. aprīlì kara un jūras lietu tautas komisāra L. Trocka tēzēs par fronti pret Poliju. Tajās Latvija tika nosaukta par Polijas marioneti. Savukārt ārlietu tautas komisārs G. Čičerins 4. maijā runāja par jaunu Antantes valstu intervenci, kurā Latvija nav neitrāla, bet „nosliecas uz Poliju”. 758

Poḷu militārie panākumi Ukrainā tiešām zināmā mērā iespaidoja Latvijas valdības nostāju (26. aprīlī Z. Meierovics deva rīkojumu diplomātiskajiem pārstāvjiem paziṇot attiecīgajām valdībām, ka plānotās Baltijas valstu konferences termiṇš tiek pārcelts no 15 . maija uz jūliju ${ }^{759}$ ). Tie iespaidoja arī Latvijas delegācijas izturēšanos Maskavā: tā turpināja prasīt, lai par Latvijas teritoriju atzīst arī vairākus Drisas apriṇķa pagastus līdz Zarjankas upei (šo teritoriju bija atbrīvojuši poḷi un pēc tam nodevuši šeit fronti Latvijas armijas vienībām, un Polija bija ieinteresēta, lai šī teritorija piederētu Latvijai, nevis Padomju Krievijai, bet pēdējā baidījās, ka latvieši šajā operatīvi svarīgajā teritorijā varētu ielaist poḷu spēkus vai l,aut to viṇiem izmantot). Turklāt militārā situācija Ukrainā un Padomju Krievijas vēlme pēc iespējas ātrāk vienoties ar Latviju, lai ar visiem spēkiem varētu vērsties pret Poliju, lika aprīḷa sākumā padomju pusei piekāpties Pitalovas dzelzceḷa mezgla piederības jautājumā - tas tika atdots Latvijai. Maijā sarunās Maskavā puses vienojās, ka strīdīgajā Drisas apriņķa teritorijā tiks sarīkots referendums (dažādu apstākḷu dēḷ - galvenokārt sakarā ar straujajām pārmaiṇām poḷu-padomju frontē jūlija sākumā - tas nenotika). ${ }^{760}$ Sarunās Maskavā Latvijas delegācijai pastāvīgi tika pārmesta militārā sadarbība ar Polijas armiju frontē. Maija beigās padomju pārstāvji paziņoja, ka pārtverta pavēle, kas paredz poḷu daḷu pārvietošanu uz Daugavas labo krastu pie Drujas. Latvijas puse šādu varbūtību noliedza, atzīstot, ka operatīvi sakari ar poliem tiek uzturēti un tas vēl nenozīmē kopdarbību. ${ }^{761}$ Patiesībā ierobežota militāra sadarbība notika,

\footnotetext{
756 LVVA, 6033. f., 1. apr., 24. 1., 22. 1p.

757 Počs K. Sanitārā kordona... - 92. lpp.

758 Stranga A. Latvijas-Padomju Krievijas miera līgums 1920. gada 11. augustā. - 54. lpp.

${ }^{759}$ LVVA, 1313. f., 2. apr., 66. 1., 7., 9. 1p.

${ }^{760}$ Stranga A. Latvijas-Padomju Krievijas miera līgums 1920. gada 11. augustā. - 55. lpp.; Mieriņa A. No Latvijas Republikas robežu vēstures//Latvijas Zinātṇu Akadēmijas Vēstis. - 1990. - Nr. 8. 49.-50. lpp.

${ }^{761}$ LVVA, 3601. f., 1. apr., 496. 1., 112. 1p.
} 
kaut arī poḷi Daugavas labajā krastā neatradās. 10. maijā Latvijas armijas Aviācijas parka lidmašīnā (pilots - virsleitnants V. Korobovskis) no Rēzeknes uz Glubokoje un 12. maijā atpakal tika nogādāts poḷ sakaru virsnieks. ${ }^{762} \mathrm{Kad}$ 14. maijā sākās Sarkanās armijas pretuzbrukums un tā dēḷ Baltkrievijā poḷi nedaudz atkāpās (ienaidnieks aiz Dzisnas pārgāja Daugavu), viena Latvijas armijas 2. Ventspils kājnieku pulka rota prāmī pārcēlās pāri Daugavai un ieradās Trudos, kur atradās poḷu bataljona rezerve. Turpmākajās dienās rota uzturēja sakarus ar poḷu 21. kājnieku un 7. ulānu pulka vienību. 28. maijā, poḷiem pārejot uzbrukumā, tos ar kauju atbalstīja 2. Ventspils pulka 3. bataljons, ien,emot Usmaņas muižu. Pēc poḷu lūguma latvieši nosūtīja tiem vairākas kastes ar ložmetēju lentēm. Kopīgās kaujas turpinājās līdz 13. jūnijam, kad 3. bataljons atgriezās Drisā un poḷi atkal pārṇēma savā kontrolē visu Daugavas kreisā krasta teritoriju, ${ }^{763}$ likvidējot arī Latvijas armijai lıti nepatīkamo stāvokli. Tas bija izveidojies, kad labajā spārnā negaidìti un ievērojami pagarinājās fronte, kas bija vērsta pret Sarkano armiju. Pastāvēja arī kaujas sakari starp Zemgales divīzijas atsevišķo eskadronu un poḷu 18. ulānu pulku. 19. jūnijā no L,avonpoles rajona (Daugavas kreisajā krastā) atgriezās puseskadrons, kurš kauju laikā nodrošināja poḷu kreiso spārnu. ${ }^{764}$ Maijā un jūnijā Latvijas armijas Kurzemes divīzijas štābā par poḷu sakaru virsnieku darbojās poruçniks L. Švejcers, bet 12. jūnijā par sakaru virsnieku uz Polijas 1. armiju tika komandēts Latvijas armijas Virspavēlnieka štāba Operatīvās daḷas virsleitnants E. Klūge (20. jūnijā viņš ieradās frontes štābā Minskā, kur to laipni uzṇēma virspavēlnieks S. Šeptickis, bet no turienes - 1. armijas štābā Daṇilovičos; kopā ar Šepticki Klūge frontē palika gandrīz mēnesi). Turpinājās regulāra izlūkdienesta datu piegāde Polijas militārajam pārstāvim Rīgā (par padomju spēku kustību, padomju spiegiemu.c.). A. Miškovskis saṇēma pat tiešu informāciju no pulkveža-leitnanta K. Ramata, kurš maijā atgriezās no miera sarunām Maskavā, kā arī par notiekumiem Maskavā regulāri apspriedās ar Latvijas armijas vadību (J. Balodis un P. Radziņš viņam apgalvoja, ka ir pret miera noslēgšanu). ${ }^{765}$

Tas viss nepalika pilnībā apslēpts padomju pusei, kura jau kopš pavasara sevišḳu vērību pievērsa jautājumam, vai Latvija varētu sniegt aktīvu militāru atbalstu Polijai (tā noskaidrošana bija viens no galvenajiem daudzo padomju spiegu uzdevumiem Latvijā). ${ }^{766}$ 21. jūnijā delegācijai Maskavā atkal

\footnotetext{
${ }^{762}$ Bukhman M. Baltic Civil War Calendar 1918-1920/Manuskripts autora rīcībā. - P. 47.

763 2. Ventspils pulks. - 337.-342. lpp. Daugavas pāriešana notika saskaṇā ar Polijas armijas vadību, kas 26. un 30. maijā pieprasīja, lai Latvijas armijas daḷas turpinātu atbalstīt poḷu kreiso spārnu. - AAN, Attachaty, A - II, 64/1, k. 510, 521.

764 Jātnieku pulks 10 gados. - Rīga, 1929. - 22.-24. 1pp.; LKM, Artum-Hartmanis A., 24. 1p. Bijušais eskadrona seržants V. Siliņš 1930. gadā griezās pie Polijas militārā atašeja Rīgā ar lūgumu pieškirirt viņam Polijas Neatkarības krustu, jo 1920. gadā viņš piedalījies kaujās "kopā ar poḷu kavalēristiem”. Łossowski P. Nic nie dzieli - wszystko łączy// Polska Zbrojna. - 1992. - 21-23 luty.

${ }^{765}$ LVVA, 3601. f., 9. apr., 366. 1., 21. 1p.; 5601. f., 1. apr., 3017. 1., 2. 1p.; 6033. f., 1. apr., 24. 1., 40. lp.; AAN, Attachaty, A - II, 64/1, k. 379, 446. Polijas armijas Ģenerālštābs aț̣auju piekomandēt latviešu sakaru virsnieku pie 1. armijas deva 1. jūnijā. Sīkāk par Latvijas-Polijas militāro sadarbību 1920. gada maijā-augustā sk.: Jēkabsons Ē. Łotewsko - polska współpraca wojskowa w maju-sierpniu $1920 \mathrm{roku} / /$ Księga jubileuszowa Muzeum Wojska 1968-1998. - Białystok: Muzeum Wojska w Białymstoku, 1999, s. 139-148.

${ }^{766}$ Stranga A. Latvijas-Padomju Krievijas miera līgums 1920. gada 11. augustā. - 75. lpp.
} 
tika pārmesta pamiera neievērošana. No krituša poḷu 21. pulka virsnieka dokumentiem sarkanarmieši bija noskaidrojuši, ka viņš bijis sakaru virsnieks pie 3. Jelgavas, 2. Ventspils un 12. Bauskas pulka, bet latviešu kara lidmašīna esot nometusi vairākas bumbas uz Ostrovu.767 Jau 4. jūnijā Z. Meierovics pieprasīja armijas virspavēlniecībai paskaidrojumus par padomju puses regulāri izteikto pārmetumu pamatotību. P. Radziňš 10. jūnijā skaidroja, ka līdz miera noslēgšanai ar Padomju Krieviju armija ir spiesta darīt visu, lai nodrošinātu savu labo spārnu, bet tas iespējams, vienīgi uzturot sakarus ar "mums draudzīgo" Polijas armiju. Turklāt jārīkojas atkarībā no stāvokḷa frontē, tādēḷ poḷi var atrasties Daugavas labajā krastā, bet latvieši - kreisajā krastā. Viṇš secināja, ka līdz miera noslēgšanai atteikšanās no kopdarbības ar Polijas armiju nav iespējama, jo tā atbilst abu pušu interesēm. ${ }^{768}$

Arī Polijas prese apmierināta atzīmēja, ka Latvija vēlas Polijas uzvaru iespaidā saskaṇot ar to savu austrumu politiku un Latvijas delegācija Maskavā uzņem padomju priekšlikumus ar „milzīgu rezervētību”. 769

Maija sākumā Rīgā ieradās Polijas Seima Ārlietu komisijas loceklis V. Kameñeckis un Ārlietu ministrijas Baltijas valstu nodaḷas priekšnieks A. Tarnovskis, lai apsveiktu tikko ievēlēto Satversmes sapulci, kas bija uzsākusi darbu, kā arī nodibinātu ciešākus saimnieciskos sakarus un sagatavotu augsni plašākai politiskai sadarbībai. 9. maijā Polijas konsuls A. Luce-Birks organizēja viṇu apspriedi ar Latvijas valdības, preses un saimniecisko struktūru pārstāvjiem. Tika pārrunātas arī kopīgu tirdzniecisku sabiedrību izveides iespējas. Tajā pašā dienā Z. Meierovics informēja delegāciju miera sarunās Maskavā, ka Polijas pārstāvji izteikuši neapmierinātību ar Latvijas sarunām ar Padomju Krieviju (viņi bija pārliecināti par savas armijas gaidāmajiem panākumiem), taču Latvijas puse uzsvērusi apṇemšanos iesāktās sarunas turpināt. ${ }^{770}$ Pavadīdams Latvijā nedēlu, V. Kameṇeckis presē sniedza vairākus pārskatus par abu valstu attiecībām, īpaši uzsverot, ka Polija nekādā gadījumā nepretendē ne uz vienu Latvijas daḷu. ${ }^{771}$

A. Miškovskis stāvokli šajā laikā vērtēja šādi: “No vienas puses, bruṇota palīdzība un Latgales atzīšana latviešiem, no otras - ǵgenerāḷa Smiglija draudi neizvest karaspēku no Latgales un, kas bija nesalīdzināmi sliktāk - Polijas sūtniecības preses karš ar Latvijas valdību. Bet tad, kad beidzot viss bija noregulēts un latvieši poḷu uzvaru iespaidā Ukrainā piedāvāja 9. maijā Rīgā konferenci, kurā būtu jānoslēdz militāra, politiska un saimnieciska konvencija, ar atbildi līdz pēdējam vilcinājāmies." [Patiesībā priekšlikums tika izteikts vēl pirms poḷu uzbrukuma un sākotnējais termiṇš bija 15. maijs $\bar{E}$. J.] Arī A. Keniṇš Varšavā izteicies: "Sakarā ar lielajiem panākumiem Ukrainā Jūs, kungi, vairs neesat ieinteresēti uzturēt sakarus ar Latviju, kuras

\footnotetext{
${ }^{767}$ LVVA, 6033. f., 1. apr., 406. 1., 16. 1p.

${ }^{768}$ Dokumenti stāsta. Latvijas buržuāzijas nākšana pie varas/Sastādītājs V. Bērziṇš. - Rīga, 1988. 253.-254. 1pp.

${ }^{769}$ Kurjer Polski. - 1920. - 16 maj.

${ }^{770}$ Stranga A. O niektórych problemach polsko - łotewskich stosunków... - S. 152.

${ }^{771}$ LVVA, 2575. f., 15. apr., 11. 1., 6. 1p.; Latvijas Sargs. - 1920. - 5., 7., 11., 12. maijs.
} 
priekšlikumi paliek bez atbildes!"772 Tikai 4. jūnijā Polijas pārstāvniecība Rīgā paziņoja, ka Polijas valdība piekrìt atjaunot sarunas konferencē un ap 15. jūniju delegācija ieradīsies Rīgā. Latvijas puse tajās bija iecerējusi galveno vērību pievērst saimnieciskiem jautājumiem un vēlreiz mēǵināt noskaidrot Augškurzemes (sešu Ilūkstes apriṇka pagastu un Grīvas pilsētas) piederības jautājumu. ${ }^{773}$ Polijas armijas virspavēlniecības 13. jūnija pārskatā teikts, ka konferencei Rīgā jāsākas 16. jūnijā, bet šās dienas pārskatā - ka sarunas ar latviešiem nav sākušās Polijas valdības krīzes dēḷ, kaut arī Latvijas puses attieksme nav mainījusies. Jūnija beigās Polijas prese uzsvēra, ka "Baltijas valstu konference Rīgā tiek aktīvi gatavota un notiks jūlija sākumā", bet 5. jūlijā Polijas Telegrāfa aǵentūra no Helsinkiem ziṇoja, ka ar Latvijas Ārlietu ministriju panākta vienošanās par konferences sākšanu 20. jūlijā774 (Lietuvas diplomāti Somijā šo baumu zināja jau 27. jūnijā un pat apsvēra iespēju konferences organizēšanu izjaukt, panākot, ka Igaunijas atsakās tajā piedalīties ${ }^{775}$ ). Taču bija jau par vēlu. Atliktās sarunas poḷu-padomju kara norišu dēḷ pagaidām kḷuva neiespējamas.

Lai gan B. Boufals bija optimistiski paziņojis par savu palikšanu amatā Rīgā, tomēr jūnija pirmajā dekādē Latvijā izplatījās vēsts, ka viṇš izsaukts uz Varšavu sakarā ar norīkošanu citā darbā. Tika minēti iespējamie kandidāti Polijas diplomātiskā pārstāvja amatam Rīgā, starp tiem bija arī profesors V. Kameṇeckis. ${ }^{776}$ Šì kandidatūra Latvijas politiskajās aprindās tika uzṇemta ar atsaucību, jo, viesojoties Latvijā maijā, viṇš bija radījis Latvijai labvēlīga un līdz ar to pieņemama politiķa iespaidu. Jūnija vidū tiešām tika paziņots, ka Polijas pārstāvja pienākumus pagaidām pildīs konsuls A. Luce-Birks, un B. Boufals atstāja Latviju. ${ }^{777}$

772 Łossowski P. Łotwa... - S. 14. Attiecības neveicināja arī 24. maija incidents Sarnu stacijā Polijā, kur poḷu virsnieks piekāva un uz četrām dienām apcietināja Latvijas Ārlietu ministrijas diplomātisko kurjeru, kad tas atteicās atvērt diplomātisko pastu. - LVVA, 2574. f., 3. apr., 13. 1., 44.-75., 80.-81. lp. Jāpiezīmē, ka līdzīgs gadījums 4. martā bija noticis arī Pjotrovices robežstacijā, kur Latvijas diplomātiskajam kurjeram, kas brauca no Varšavas uz Parīzi, tika atṇemtas vairākas vēstules. - 2575. f., 7. apr., 6. 1., 345. 1p.

${ }^{773}$ LVVA, 2575. f., 15. apr., 2. 1., 133. 1.; 3601. f., 1. apr., 309. 1., 63. 1p. Polijas prese ziņoja, ka Rīgā tiks izskatīta Somijas, Latvijas, Lietuvas, Igaunijas, Polijas, Ukrainas un Rumānijas tirdzniecības palātas izveidošanas iespēja. - Kurjer Poranny. - 1920. - 27 maj.

774 CAW, II ND WP, t. 194; Kurjer Poranny. - 1920. - 30 maj, 6 lip., Gazeta Warszawska. - 1920. 29 lip.

775 LCVA, f. 383, ap. 7, b. 72, 1. 34

776 Latvijas Sargs. - 1920. - 9. jūn.

777 Jaunākās Ziņas. - 1920. - 18. jūn.; Latvijas Kareivis. - 1920. - 19. jūn. Jūlijā B. Boufals atgriezās, oficiāli atvadījās no valdības un 10. augustā aizbrauca pavisam, pirms tam kategoriski atsakoties sniegt interviju laikrakstam "Latvijas Kareivis". - Latvijas Kareivis. - 1920. - 25. jūl.; Brīvā Zeme. - 1920. - 25. jūl.; APAN, Djarjusz M. S. Kossakowskiego, T. V, cz. 1, s. 71. 


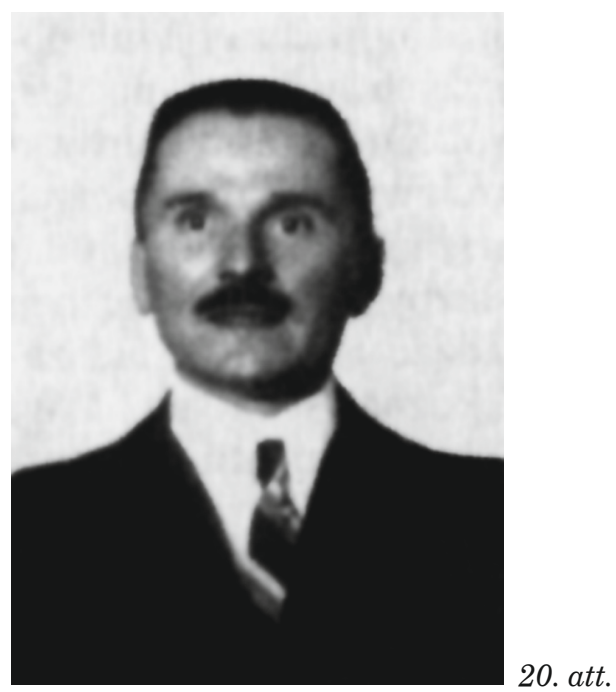

\section{Polijas diplomātiskais pārstāvis Latvijā Vitolds Kameṇeckis}

Latvijas pārstāvniecības sekretārs P. Oliṇš jūnijā presē uzsvēra, ka Latvijas un Polijas attiecības, neraugoties uz aizejošo poḷu karaspēka daḷu radītajām "nekārtībām un sarūgtinājumu" Latgalē, ir samērā labas. Viṇš atzīmēja, ka daudzas nesaprašanās rodas tāpēc, ka poḷu sabiedrība ir vāji informēta par Latviju un nosaukuma līdzības dēl Latvija pat tiek jaukta ar Lietuvu. Tādēḷ "bieži naids pret Lietuvu aiz pārpratuma tiek pārnests uz Latviju". 778

Patiesībā Polijā zināmas aprindas centās veidot naidīgu attieksmi arī pret Latviju, un viens no galvenajiem līdzekḷiem bija runas par vietējo poḷu tiesību ierobežošanu Latvijā. Lielā mērā šāda satura informāciju izplatīja Latgales muižniecības aktīvākā un konservatīvāk noskaņotā daḷa. Jau janvārī pirms J. Pilsudska brauciena uz Daugavpili Austrumzemju civilās pārvaldes ierēdnis M. Kosakovskis atzīmēja dienasgrāmatā, ka Latvijas draudzība nopirkta par dārgu maksu - atdodot Latgali. Taču "Latgales poḷu pārstāvji”, kaut arī "sirdij asiṇojot", izpratuši Polijas valstiskās politikas prioritāti pār "apgabala problemātisko izdevīgumu". Tādēḷ savu memorandu ar prasību, lai Latgali administrētu vietējais latvietis katolis, vini piekrituši iesniegt Pilsudskim nevis Daugavpilī, bet Viḷnā. ${ }^{779}$ İstenībā Latgales muižnieku prasības nebija tik pieticīgas. 9. martā Polijas, Baltkrievijas un Latgales zemju Poḷu nacionālā padome Polijas Ārlietu ministrijā piedāvāja Latvijas valdībai izvirzìt šādas prasības: Latgalei jābūt autonomai, ar savu Seimu; poḷiem ir tiesības ieņemt valsts amatus, poḷu ievēlēta komiteja rīkojas ar proporcionālu budžeta daḷu, poḷu valodai otras valsts valodas statuss Latgalē, poḷu zemes īpašums neaizskarams, poḷu skolas uztur valsts, valdībā poḷu lietu ministra amats (tajā - Latgales polis), poḷiem brīvas pilsonības

\footnotetext{
${ }^{778}$ Latvijas Kareivis. - 1920. - 11. jūn.

779 APAN, Djarjusz M. S. Kossakowskiego, T. V, cz. 1, s. 48.
} 
izvēles tiesības u. c. ${ }^{780}$ Šīs pārspīlētās prasības Polijas valdība nopietni neizskatīja, taču šādas darbības nevarēja palikt nezināmas Latvijas pusei, jo daudzi Latgales muižnieki atradās augstos amatos Polijas armijā un civiliestādēs. ${ }^{781} \mathrm{M}$. Hartmanis marta beigās ziņoja, ka Varšavā tiek izteikti iebildumi pret to, kā izturas pret poḷu muižniekiem Latgalē - tos "nepelnìti” jauc ar vāciešiem. Viṇš uzskatīja, ka līdzība gan ir l,oti liela un tas nav poḷu muižnieku nopelns, ka Latvija ir labākās attiecībās ar Poliju nekā ar Vāciju: "Visi ḷoti mīl savu mazo dzimtenīti - Latgali, jeb pareizāk sakot - savus neizsmel̦amos bagātību avotus. Viṇi grib paturēt savas lielās muižas un nevienam nenāk ne prātā pāriet mūsu pavalstniecībā [..]. Viṇi cer, ka priekš viņiem, poḷiem, būs sevišķas privilẹgijas, un, ka viṇu privātais îpašums netiks ne aizskarts, ne dalìts - ka par to rūpēsies poḷu valdība [..]. Latgales muižniecība tiek Polijā oficiāli uzskatīta kā avangards priekš Latgales iegūšanas Polijas pilnam un nedalītam iespaidam." ${ }^{82}$

Jāpiezīmē, ka bija izdots Latvijas valdības rīkojums, ar kuru zemes īpašniekiem vajadzēja atgriezties savos īpašumos līdz 10., bet Latgalē - līdz 15. martam. Pēc tam pamestos īpašumus pārṇēma valsts (daži Polijas preses izdevumi sākotnēji novērtēja to pozitīvi ${ }^{783}$ ). Martā Polijas pārstāvniecība Rīgā lūdza atlikt “muižu sekvestrēšanu” Latgalē līdz 15. aprīlim, bet saṇēma atbildi, ka sekvestrēšana nenotiek, muižas tiek pārṇemtas valsts īpašumā tikai tad, ja tām nav īpašnieku vai pārvaldnieku, un tas notiek stingrā saskaṇā ar pastāvošo likumdošanu. Patiesībā iestādes (līdz pat 1920. gada rudenim) bija lıti pielaidīgas pret poḷiem, un, ja muižnieks uzrādīja Polijas pārstāvniecības apliecību par savu nacionālo piederību, zemes īpašums netika aizskarts. ${ }^{784}$

Reālais Latvijas poḷu minoritātes stāvoklis bija labs. Jau 1919./1920. mācību gadā valstī darbojās 17 poḷu pamatskolas ar 3600 skolēniem un 120 skolotājiem (nākamajā mācību gadā - vidusskola un 19 pamatskolas, vēlāk šie skaitḷi vēl vairāk pieauga). ${ }^{785}$ 1920. gadā Rīgā, Liepājā un Daugavpilī atjaunoja vai uzsāka darbību vairākas poḷu organizācijas un skauti (harceri). 1920. gada 3. maijā Rīgā vietējie poḷi svinīgi atzīmēja Polijas nacionālos svētkus, kuros piedalījās B. Boufals un Polijas pārstāvis Igaunijā L. Vasiḷevskis. ${ }^{786}$ Poḷu publicists J. Cinarskis atzina poḷu stāvokli par apmierinošu un atzìmēja, ka vietējiem poḷiem nepieciešams ciešāk sadarboties ar Latvijas valdību un varas iestādēm, n,emot vērā, ka Polijai šeit vienmēr būs "savas intereses".787 Jūnijā Latvijā veiktā tautas skaitīšana uzrādīja 52244 poḷus (starp viṇiem

\footnotetext{
780 AAN, Kod, t. 2, k. 211-212.

781 Jaunākās Zin̦as. - 1920. - 9. marts. Piemēram, V. Studṇickis bija Austrumzemju civilās pārvaldes statistiskās nodaḷas priekšnieks, B. Šahno - Braslavas apriņķa priekšnieks (viṇu šajā amatā nomain̄̄ja V. Šadurskis, kas arī bija Latgales muižnieks). Visas minētās personas lielākā vai mazākā mērā bija noskaņotas pret Latvijas valsti nelabvēlīgi.

782 LVVA, 3601. f., 1. apr., 248. 1., 477. 1p.

783 Tygodnik Wileński. - 1920. - 12 marzec.

${ }^{784}$ LVVA, 2574. f., 3. apr., 13. 1., 9.-10. 1p.; Gazeta Warszawska. - 1920. - 22 marzec.

${ }^{785}$ LVVA, 2574. f., 3. apr., 2733. 1., 110. 1p. Sīkāk sk.: Jēkabsons Ē. Poḷi Latvijā. - 27.- 41. lpp.

786 Latvijas Sargs. - 1920. - 5. maijs.

${ }^{787}$ Krzesławski [Cynarski] J. Polacy na Łotwie//Rząd i Wojsko. - 1920. - 7 marzec.
} 
40872 bija Latvijas, bet 4254 - Polijas pilsoṇi). ${ }^{788}$ Šo skaitli visumā jāatzīst par reālu, kaut arī gan Latvijā, gan Polijā bija aprindas, kas dažādu apstākḷu dēḷ to apšaubīja.

Jūnijā Daugavpils pašvaldību vēlēšanās starp Latgales apgabala priekšnieku un „Poḷu saraksta” pilsētas domes deputātu kandidātiem izraisījās konflikts. „Poḷu saraksts” vēlēšanās ieguva 20 vietas pilsētas domē, taču apgabala priekšnieks apturēja kopumā 16 domnieku - ārvalstu pilsoṇu pilnvaras. Starp viṇiem bija arī astoṇi „Poḷu saraksta” deputāti un vēl viens polis no cita saraksta. Kaut arī viṇu vietā varēja izvirzìt citus deputātus Latvijas pilsoṇus no tiem pašiem sarakstiem, tomēr "Poḷu saraksta" dalībnieki, galvenokārt nevarēdami vienoties par amatu sadali starp jaunievēlētās domes poḷu, ebreju, latviešu un krievu deputātiem, 1. jūlijā savu darbību domē apturēja. ${ }^{789}$

Pašvaldību vēlēšanu notikumi un citi apstākḷi izraisīja jaunu, Latvijai naidīgu, l,oti tendenciozu publikāciju vilni Polijas presē jūnijā un jūlija sākumā. Latvieši tika vainoti poḷu vajāšanā. Polijas Telegrāfa aǵentūra pat paziņoja, ka Latvijas valdība gatavojas pārvietot Latgales administrācijas iestādes no Daugavpils uz Rēzekni tikai tādēḷ, ka Daugavpilī starp iedzīvotājiem ir ievērojams poḷu skaits (lai mazinātu viṇu iespaidu). ${ }^{790}$ Laikraksts "Naród”, kas līdz šim bija paudis J. Pilsudska politiskās nostādnes, ievietoja anonīma "Polijas pilsoṇa" vērojumus Latgalē. Tajos bija plaši aprakstīta valdošā postaža un secināts, ka lielākā iedzīvotāju daḷa (arī latviešu katoḷi un krievu vecticībnieki) šķietami "labprāt sagaidìtu poḷu okupāciju". 791 Nacionāldemokrātu prese turpināja žēloties par Daugavpils atdošanu latviešiem un aicināja valdību beidzot aizstāvēt Latgales poḷu tiesības.792 Preses rakstu nosaukumi liecināja par to saturu: "Latvija pret Poliju", "Poḷu vajāšana Inflantijā" u. c. ${ }^{793}$ 28. jūnijā tika atreferēta A. Keniṇa intervija skandināvu laikrakstam "National Tridente", kurā viṇš izteicies, ka nepieciešamības gadijjumā Latvija ir gatava bruņoti atbalstīt Lietuvu cīn,ā pret Poliju. Pats A. Keniņš kategoriski noliedza, ka būtu šādi teicis, uzsverot, ka vienmēr nosodījis Lietuvas "rusofilisko un germanofilisko politiku" ${ }^{794}$ Laikraksts "Rzeczpospolita” jau 5. jūlijā ievietoja plašu aprakstu par Latgali.

${ }^{788}$ Latvijas statistiskā gada grāmata. 1920. - Rīga, 1921. - 10. lpp. Lietuvas un Polijas karaspēka ieņemtajā Ilūkstes apriņķa daḷā skaitīšana tika izdarīta tikai 1921. gada februārī, taču tur dzīvojošie poḷi iekḷauti minētajā kop̄̄gajā skaitā. - Latvijas Kareivis. - 1921. - 11. febr.

789 LVVA, 3723. f., 2. apr., 146. 1., 106. 1p. Sīkāk sk.: Jēkabsons Ē. Poḷu organizācijas Daugavpilī 20.-30. gados//Latgale un Daugavpils: vēsture un kultūra. Rakstu krājums. - Daugavpils, 1996. - 138.-139. lpp. Tiesa, vēl pirms darbības apturēšanas poḷu deputāti paspēja izvirzīt par pilsētas galvas amata kandidātu advokāta S. Sireviča kandidatūru. Vienlaikus viņš bija (no 1920. gada februāra) Polijas goda konsuls Daugavpilī. Tas izraisīja latviešu sabiedrības sašutumu, jo viņš vācu okupācijas laikā 1918. gadā bija Daugavpils apgabala prokurors un uz viņa apsūdzības pamata tika apcietināts sabiedriskais darbinieks, vēlākais Satversmes sapulces deputāts J. Pabērzs. - Latvijas Kareivis. - 1920. 7. jūl.

${ }^{790}$ Brīvā Zeme. - 1920. - 9. jūl.

791 A. List z Łotwy// Naród. - 1920. - 25, 26 czerw.

792 Hł. J. Zaprzepaszczenie Inflant//Gazeta Warszawska. - 1920. - 29 czerw.

${ }^{793}$ Latvijas Kareivis. - 1920. - 9. jūl.

794 Przegląd Wieczorny. - 1920. - 30 czerw. 
Tajā bija apgalvots, ka iedzīvotāju vairākums sveicis Polijas karaspēku cerībā, ka tas te arī paliks. Tomēr noticis citādi un poḷi Latgalē tiekot vajāti: "arvien biežāk redzami mantu vezumi, kas dodas uz Daugavas kreiso krastu". ${ }^{795}$ Sie apgalvojumi bija sevišķi absurdi. Nekāda poḷu bēgšana no Latvijas nenotika. M. Svežbiṇskis vēlāk atzina, ka Latgali kopumā atstāja apmēram 120 poḷu muižnieku ǵimeṇu (turklāt lielākā daḷa - 1918. gada beigās, atkāpjoties vācu un ienākot padomju karaspēkam). ${ }^{796}$ Turklāt Polijā atgriezās pasaules kara bēgḷi, kas Latgalē bija raduši patvērumu vai cauri Latgalei bēga no Krievijas (februārī poḷu štābs Daugavpilī aț̣āva atgriezties Polijā tikai bēg̣̣iem un tiem dzelzcel,niekiem, kas bija atbrīvoti no darba, citiem tas bija l̦auts vienīgi "ārkārtējos gadījumos", ${ }^{797}$ tātad viṇu nebija daudz). Varēja būt runa vienīgi par poḷu tautības bēgḷiem, kuri cauri Igaunijai un Latvijai atgriezās dzimtenē no Ziemeḷkrievijas. Sādu bēgḷu grupas ieradās regulāri. Ar Latvijas armijas Virspavēlnieka štāba dzelzceḷa transportu tās nogādāja Rīgā, no kurienes cauri Daugavpilij devās uz Poliju. ${ }^{798}$ Rīgā poḷu bēg̣̣i tika izvietoti Iekšlietu ministrijas Gūstekṇu un bēgḷu nodaḷas patversmē..${ }^{79}$

Polijas valdība un atsevišķas valsts amatpersonas Polijā izrādīja īpašu pretimnākšanu Latvijas bēgḷiem, kuri atgriezās Latvijā no Dienvidkrievijas. Pavasarī A. Keniņš izteica pateicību Polijas konsulam Odesā Sorokovskim, vicekonsulam Harkovā Bociņskim un militārajam pārstāvim Rumānijā majoram O. Gurkam par palīdzību, ko viṇi sniedza Latvijas bēgḷiem, kas atgriezās dzimtenē. Vairākos gadījumos tie tika uzṇemti poḷu bēgḷu kuğu transportos. ${ }^{800}$

Tomēr varbūtējais kārtējās Baltijas valstu konferences sasaukšanas laiks nebija izdevīgs, jo Latvijas-Polijas attiecībās bija vērojams saspringums (12. aprīlī Z. Meierovics lūdza diplomātiskos pārstāvjus paziṇot Polijas, Lietuvas un citu valstu valdībām, ka konference Rīgā sāksies 15. maijā, taču jau 26. aprīlī konferences sākums tika atlikts uz jūliju ${ }^{801}$ ). Labas attiecības nebija arī ar Lietuvu - to joprojām noteica teritoriālās domstarpības, kaut arī 23. aprīlī Lietuvas militārais pārstāvis Rīgā V. Natkēvičs ar apmierinājumu konstatēja, ka Latvijas attiecības ar Poliju kḷūst arvien sliktākas un tas pamanāms visās jomās. ${ }^{802}$ Lietuvieši ieṇemtajā Ilūkstes apriṇķa daḷā arvien noteiktāk rīkojās kā savas valsts teritorijā, pastāvīgi radās sīkas konfliktsituācijas. Marta beigās lietuvieši Eglainē bija aizturējuši latviešu

\footnotetext{
795 N. N. Z Inflant Polskich//Rzeczpospolita. - 1920. - 5 lip.

${ }^{796}$ APAN, Świerzbiński M. Martyrologia Inflant Polskich, s. 74.

797 AAN, Attachaty, A - II, 81/2.

${ }^{798}$ LVVA, 2574. f., 3. apr., 17. 1., 245. 1p.; 90. 1., 123. 1p.; 3593. f., 1. apr., 196. 1., 75., 91. 1p.; Baltijas Vēstnesis. - 1920. - 6. apr., 3., 18. maijs, 2., 10. jūn., 5. jūl.; Kurjer Polski. - 1920. - 20 maj. Pēc Latgales atbrīvošanas bēg̣̣i atgriezās Polijā arī cauri Rēzeknei (29. janvārī A. Miškovskis lūdza E. Ridza-Smiglija štābu nogādāt Daugavpilī 280 bēgḷus no Rēzeknes). - AAN, Attachaty, A - II, 81/1; 64/1, k. 330.

${ }^{799}$ LVVA, 2570. f., 10. apr., 5. 1., 54. lp.

800 Turpat, 51. 1., 79.-88., 116. 1p.

${ }^{801}$ Turpat, 1313. f., 2. apr., 66. 1., 2., 7. 1p.

${ }^{802}$ LCVA, f. 384, ap. 3, b. 73, 1. 146.
} 
vilcienu un divas dienas apkalpi turējuši apcietinājumā bez pārtikas, ${ }^{803}$ aprīḷa beigās no Mažeiķu stacijas bija padzìts latviešu komandants, ${ }^{804} 2$. maijā Rīgas stacijā kāds bija šāvis uz Lietuvas miera delegācijas vilciena vagonu ceḷā uz Maskavu, par ko lietuvieši iesniedza protesta notu Latvijas valdībai ${ }^{805}$ utt. 18. aprīlī Lietuvas Ārlietu ministrija pat lūdza savu pārstāvi noskaidrot, vai nav pamata baumām, ka latvieši apgādājot ar Latvijas armijas formastērpiem poḷu karavīrus un nogādājot tos Palangā. Lietuvas diplomātiskais pārstāvis izteica pamatotas šaubas par šo baumu ticamību, jo "latviešu-poḷu attiecības tagad vairs nav tādas". ${ }^{806}$ Jūnijā Latvijas armijas vadība izsludināja par dezertieriem vairākus Lietuvas armijas latviešu tautības virsniekus, kuri “šajā Latvijai tik grūtajā laikā, kad tās jaunuzbūves darbā nepieciešams ikviens pilsonis, patīgu nolūku vadīti atgriezuši [aizgriezuši $-\bar{E}$. J.] savai dzimtenei muguru un kḷūst par savas tautas un valsts noliedzējiem". ${ }^{807}$ Tomēr Polijas G̣enerālštābs 1. jūnijā secināja: "Kaut arī latviešus spēcīgi ietekmē lietuviešu šovinistiskie uzskati un teritoriālās prasības, kā arī biežie uzbrukumi latviešu posteņiem uz robežas, nevar būt ne runas par Latvijas palīdzību Polijai gadījumā, ja lietuvieši uzbruktu Viḷ,nai."808

Lai gan Latvijas valdība šajā laikā nopietni rēḳinājās ar iespēju, ka seši Ilūkstes apriṇka pagasti paliks Polijas sastāvā, tomēr Latgales iestādes turpināja izrādìt interesi par šo apgabalu. 13. jūnijā Daugavpils komandants E. Graudiṇš saṇēma no poḷiem atḷauju Kurzemes divīzijas luterāṇu mācītāja E. Stanges braucienam uz Daugavpili, lai noturētu dievkalpojumus. Mācītājs E. Graudiṇa un Latgales apgabala priekšnieka A. Bērziṇa pavadībā tajā pašā dienā ieradās Bornes (E. Graudiṇa dzimtajā) pagastā. 14. jūnijā izpostītajā Bornes luterāṇu dievnamā notika dievkalpojums. Pirms tā sākuma A. Bērziṇš atnākušajiem vietējiem latviešu zemniekiem dievnama priekšā skaidroja Latvijas valsts uzbūvi, bet dievkalpojumā mācītājs aicināja lūgt Dievu par "brīvu, neatkarīgu Latviju, mūsu dzimtenes visiem novadiem - arī tiem, kas vēl nav atbrīvoti”. Pēc tam tas pats notika Siķeles luterāṇu baznīcā. Pēc atgriešanās Daugavpilī A. Bērziņš lūdza Zemgales divīzijas štābu organizēt latviešu preses izdevumu nosūtīšanu poḷu ien,emto pagastu latviešu tautības iedzīvotājiem. ${ }^{809}$

\footnotetext{
${ }^{803}$ Сегодня. - 1920. - 2 апр.

${ }^{804}$ Sīkāk sk.: Petruitis J. Mūsu žygiai. - 186-195 p.

${ }^{805}$ LCVA, f. 383, ap. 7, b. 72, 1. 180; Lietuva. - 1920. - 4 geg.; Gazeta Warszawska. - 1920. - 2 maj; Przegląd Wieczorny. - 1920. - 22 maj.

${ }^{806}$ LCVA, f. 383, ap. 7, b. 72, 1. 4.

${ }^{807}$ Armijas virspavēlnieka pavēles. 1920. - Nr. 90.

808 AAN, Sztab Główny, t. 616/ 5, k. 101.

${ }^{809}$ LVVA, 2574. f., 3. apr., 15. 1., 32. 1p.
} 


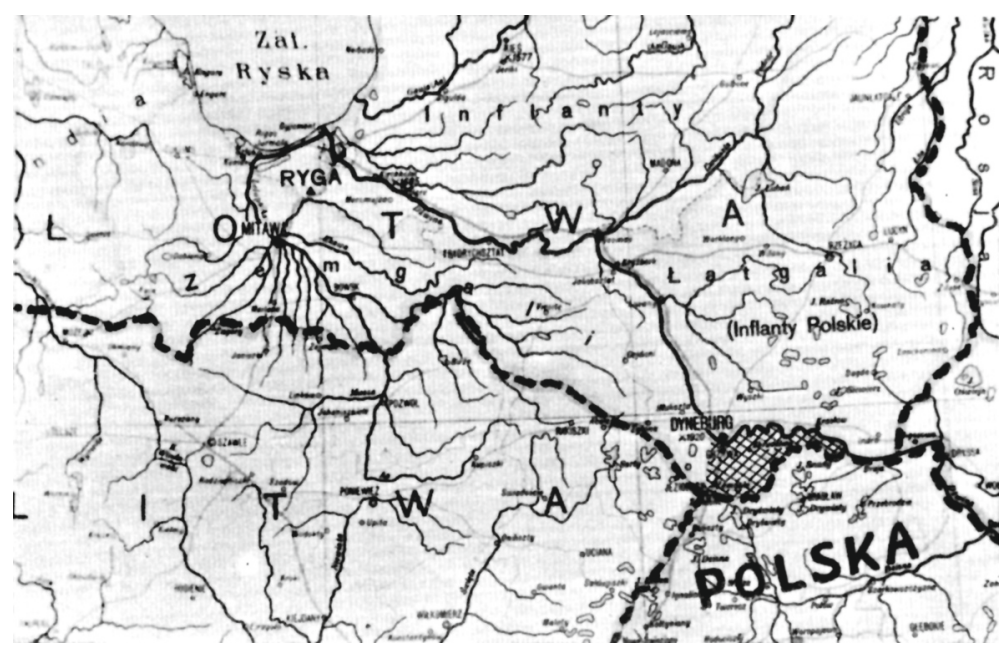

3. karte. Poḷu karte: robeža ar Latviju (iekrāsots apgabals, uz kuru Polija izteica teritoriālas pretenzijas lïdz 1929. gadam

Saskaṇā ar Latvijas tautas skaitīšanas datiem (tā gan šajā apgabalā tika veikta 1921. gada sākumā) apmēram 1500 kvadrātkilometru lielajā strīdīgajā teritorijā, kas aptvēra Bornes, Demenes, Kalkūnes, Skrudalienas, Salienas un Borovkas (no 1925. gada Silenes) pagastu, kā arī Grīvas pilsētu, (pagastos) bija 18571 iedzīvotājs (1 702 latvieši, 6116 poḷi, 758 lietuvieši, 3015 baltkrievi, 6612 krievi, 323 ebreji un 45 vācieši). 1919. gada decembrī poḷi veica skaitīšanu un pagastos konstatēja 9207 poḷus, 1396 latviešus, 1273 baltkrievus, 5068 krievus, 251 lietuvieti, 134 ebrejus un 131 citu tautību pārstāvi. ${ }^{810}$ Grīvā latviešu dati uzrādīja 1458 (332 krievus, 855 poḷus, 161 ebreju, 49 latviešus, 42 lietuviešus, 19 vāciešus), bet poḷu dati - 1673 iedzīvotājus (38,7\% poḷi, $52,4 \%$ krievi, 5,3\% ebreji, 1,1\% baltkrievi, $2,5 \%$ latvieši un pārējie). ${ }^{811}$

Kaut arī abu pušu rīcībā esošie skaitḷi atšḳ̄inās, tie skaidri liecināja, ka šajā teritorijā latviešu bija maz. Galvenais iemesls - ippatnējais novada vēsturiskās attīstības cel̦š. Vēl salīdzinoši nesenā pagātnē šis Kurzemes guberņas nostūris bija pārsvarā latvisks novads, par ko liecināja gan iedzīvotāju konfesionālais sastāvs, gan atsevišķi vietvārdi. ${ }^{812}$ Tomēr šeit ieplūda daudz poḷu (īpaši 19. gadsimta 2. pusē, kad Vitebskas un citās apkārtējās guberṇās ieviestais aizliegums poḷiem iegādāties īpašumā zemi neattiecās uz Kurzemes guberṇu) un krievu iedzīvotāju (pirmkārt, vecticībnieku). Zeme atradās galvenokārt poḷu muižnieku rokās, bet latviešu iedzīvotāji pakāpeniski zaudēja nacionālo identitāti. Katrā ziṇā 1920. gada jūnijā Latvijas valdībai nebija pamata rēķināties ar vienkāršu apgabala atgūšanu no Polijas.

${ }^{810}$ Skrzypek A. Związek... - S. 84; Maliszewski E. Polacy na Łotwie. - S. 32.

${ }^{811}$ Latvijas statistiskā gada grāmata. 1920. - 13. lpp.; Krzesławski J. Stosunki polsko - łotewskie. - S. 11.

812 Raksturīgs piemērs ir apdzīvotā vieta Peski. Tā atrodas starp Laucesi un Grīvu un poḷu 1919.-1920. gada militārajās kartēs nosaukta par Smilšinuvku. Šis nosaukums šodien ir izzudis. - Borkiewicz A. Dzieje 1 -go pułku... - S. 268. 


\section{Stāvoklis Daugavpilī}

Pēc lielākās poḷu karaspēka daḷas aiziešanas no Latvijas Daugavpils cietoksnī pagaidām izvietojās Polijas armijas 23. kājnieku pulks (16. maijā tas atstāja pilsētu ${ }^{813}$ ), tehniskās vienības (viena sapieru, divas tiltu rotas, pontonu kolonna, 8. Leğionu kājnieku pulka un 23. kājnieku pulka tehniskā rota) kapteina L. Hickēviča vadībā (Daugavpils dzelzceḷa tilta būvi poḷi pamatā pabeidza 16. maijā un 22. maijā aizbrauca uz Kijevu, pēc tam cietoksnī palika tikai viena poḷu karaspēka rota). ${ }^{814}$ Pilsētas centrā izvietojās majora Mikul,ska komandētais 3. Krakovas etapu bataljons (300 vīru) un dažādas sīkākas vienības (vēl 300 vīru). ${ }^{815}$ Tomēr poḷu karavīru skaits un bruṇojums Daugavpilī nebija pastāvīgs, piemēram, 11. maijā no Grīvas cietoksnī ieveda piecus lielgabalus, bet 12. maijā - ievērojamu karavīru skaitu. ${ }^{816}$

Saskañā ar vienošanos bija jāizveido jaukta komisija galīgiem norēkiiniem. Par Latvijas puses pārstāvju vecāko un komisijas līdzpriekšsēdētāju tika iecelts Galvenās armijas apgādības pārvaldes pulkvedis-leitnants P. Skrapce (bez viṇa šo iestādi pārstāvēja arī pulkvedis-leitnants F. Jēkabsons), no Apgādības ministrijas komisijā iegāja bijušais pārstāvis pie Polijas armijas K. Līkums, 23. aprīlī tika dots rīkojums iecelt komisijā Kara ēku un būvju pārvaldes pārstāvi. Poḷu puses līdzpriekšsēdētājs bija majors A. Kersnovskis, ar kuru 25. aprīlī Daugavpilī F. Jēkabsons nodibināja sakarus. ${ }^{817}$ Turklāt poḷu pusi komisijā vēl pārstāvēja Krāslavas muižnieks poručniks L. Plāters-Broels un citi virsnieki. ${ }^{818}$

Darba apjoms bija milzīgs. Tika aprēkināts Latvijas puses parāds apgādes lietās, vēlreiz analizējot poḷu daḷu skaitlisko sastāvu un pārtikas uzturdevas, pieṇemtas ēkas un iesniegti rēḳini par nodarītajiem materiālajiem zaudējumiem. Vajadzēja izskatīt iedzīvotāju sūdzības par poḷu nodarījumiem (18. maijā bija ienācis 7000 tādu sūdzību). P. Skrapce 13. maijā secināja: "Tā kā darbība jābeidz 1. jūnijā un šajā laikā īsā laika dēl nav iespējams ievākt un pārbaudīt sūdzību materiālus caur liecinieku nopratināšanu uz vietām u. t. t., komisijai nākas grūti par vienu otru lietu dot galīgu spriedumu.” Viṇš ieteica šo lietu izskatīšanu nodot civiliestādēm, bet tas nekad netika izdarīts. 2. jūnijā Latvijas puses komisijas locekḷi pēc darba pabeigšanas atgriezās

\footnotetext{
813 Witkowski S. Zarys historji... - S. 14.

${ }^{814}$ Wejtko T. Zarys historji... - S. 6; CAW, WBH, 341. 1. 155; Latvijas Sargs. - 1920. - 18. lp.; LVVA, 6033. f., 1. apr., 496. 1., 70. 1p. Jau 26. aprīlī Latvijas armijas Virspavēlnieka štābs pauda bažas, ka poḷu sapieru vienības varētu aiziet pirms tilta būves pabeigšanas. A. Miškovskis 3. maijā atbildēja, ka tas nenotiks. - AAN, Attachaty, A - II, 64/1, k. 365.

815 Počs K. Sanitārā kordona... - 91. 1pp.; LVVA, 3601. f., 9. apr., 365. 1., 51. 1p.

816 LVVA, 2574. f., 3. apr., 17. 1., 11. 1p.

817 Turpat, 3601. f., 1. apr., 309. 1., 26. 1p.; 3605. f., 1. apr., 197. 1., 100. 1p.; 105. 1., 43. 1p.

${ }^{818}$ CAW, IV oddział Naczelnego Dowództwa WP, I. 301. 10. 37, k. 72.
} 
Rīgā. 819 Darbu nobeidzot, kopīgās komisijas locekḷi parakstīja vienošanās protokolu. Pamatojoties uz to, Latvijas puse apṇēmās samaksāt poḷiem par laikā nepiegādātajiem pārtikas produktiem un cigaretēm, ziepēm, salmiem, lopbarību; atmaksāt par poḷu izsniegto pārtiku Daugavpils pašvaldībai, par latviešu karavīru ārstēšanos poḷu hospitāḷos, kazarmu un maizes ceptuves remontu, ko Daugavpilī bija veikuši poḷi, par būvmateriāliem, kas bija nepieciešami tiltu remontam, kā arī par pārtiku, ko poḷi bija iepirkuši Latgalē. Savukārt poḷi piekrita atmaksāt daḷu no Latgalē rekvizīciju ceḷā iegūtās pārtikas un lopbarības vērtības un 258008 Latvijas rubḷus par izvestajām Daugavpils dzelzceḷa stacijas iekārtām. Turpretī netika panākta vienošanās izvestā inventāra lietā. Dzelzceḷa slimnīcai sagādātos zaudējumus latvieši vērtēja par 796 614, bet meitenuu ǵimnāzijai - par 100900 Latvijas rubḷiem un nepiekrita polu piedāvātajai kompensācijai (attiecīgi 300000 un 25000 Latvijas rubḷu). ${ }^{820}$ 1. maijā Daugavpilī ieradās Poḷu dzelzceḷu komisija, lai norēkinātos ar Latvijas pusi par dzelzceḷu iekārtām. 11. maijā tā iebrauca Rīgā un nākamajā dienā noslēdza attiecīgu līgumu ar Latvijas Dzelzceļu valdi. ${ }^{821}$ Latvijas puse ieguva pagaidu nomas tiesības uz 20 vagoniem, kas piederēja Polijas dzelzcel̦iem. ${ }^{822}$

Attiecības ar palikušo poḷu karaspēku Daugavpilī bija sliktas. Aprīḷa beigās un maija sākumā vairāki poḷu kareivji par izdarītajiem krimināliem pārkāpumiem tika apcietināti. Kaut arī pilsētu (izṇemot cietoksni) kontrolēja latviešu militāriestādes, poḷu klātbūtne bija jūtama. Komandantūra nespēja panākt vairāku latviešu tautības poḷu karagūstekṇu palikšanu Latvijā. Vinus aizveda uz Viḷnu, bet uz pieprasījumiem poḷi atbildēja, ka viṇu rīcībā šādu gūstekṇu nav. Maija sākumā latviešu un poḷu komandantūra diskutēja par turpmāk savstarpējā sarakstē lietojamo valodu. E. Graudiṇš vairākkārt nosūtīja atpakal poḷu valodā piesūtītos dokumentus, bet poḷu komandants 6. maijā paziņoja, ka saskaṇā ar E. Ridza-Smiglija pavēli pilsētā vēl arvien iestādēs galvenā ir poḷu valoda un uz rakstiem citā valodā netiks atbildēts. E. Graudiṇš uz šì paziņojuma uzlika rezolūciju: "Nesaprotu, nosūtīt atpakal’”. Tā liecina par nesaskaṇu dziḷumu. E. Graudiņš labi pārvaldīja poḷu valodu, jo bija dzimis strīdīgajā Ilūkstes apriṇķa daḷā. ${ }^{823}$

No marta visu Daugavas krastu apsargāja Latvijas robežsargi, kuriem bieži notika konflikti ar poḷu posteņiem. Pēc sarakstes Daugavpils poḷu garnizona komandants 5. maijā informēja, ka devis instrukcijas, lai novērstu

819 Turpat, 3605. f., 1. apr., 105. 1., 50.-55. lp. Viens no poḷu puses pārstāvjiem komisijāa - podporučņiks A. Ružickis - piedāvāja komisijas sekretāram kara ierēdnim P. Ābolam 5000 rubḷus par palīdzību, ja uz Drisu tiks nogādāti 62 kilogrami saharīna. Saziṇā ar priekšniecību Ābols kopā ar Daugavpils tirgotāju Golmanu (kurš izmantoja poḷu 1. Leǵionu divīzijas sagādnieka apliecību) un poḷu kareivi devās uz Drisu, kur vain̄̄gie tika apcietināti. Lietā bija iejaukti ar̄̄ vairāki 2. Ventspils pulka kareivji, kuri palīdzēja nogādāt preces pāri frontei. - LVVA, 3601. f., 9. apr., 371. 1., 6. lp.

${ }^{820}$ CAW, IV oddział Naczelnego Dowództwa WP, I. 301. 10. 37, k. 77-78.

${ }^{821}$ Strādnieku Avīze. - 1920. - 5. maijs; LVVA, 3601. f., 9. apr., 360. 1., 3. lp.

822 CAW, II ND WP, t. 192. Jūlijā Latvijas puse gatavojās atdot vagonus Polijai, taču sakarā ar notikumiem frontē tas vēl nenotika. 15. jūlijā A. Miškovskis deva rīkojumu savam palīgam Daugavpilī nodrošināt to uzglabāšanu.

${ }^{823}$ LVVA, 3235. f., 1/14. apr., 18. 1., 26.-30. 1p.; 3601. f., 1. apr., 309. 1., 47., 58. 1p.; 2574. f., 3. apr., 15. 1., 32. $1 \mathrm{p}$. 
turpmākas nesaprašanās starp posteniiem. Tomēr 12. maijā latvieši pie pontonu tilta aizturēja poḷu bēĝ̣us no Igaunijas, kuriem bija vienīgi Polijas diplomātiskā pārstāvja atḷauja izbraukšanai, bet trūka Latvijas vīzas. ${ }^{824}$ Taču poḷu karavīri iejaucās, un viṇu apsardzībā bēg̣̣i mierīgi šḳērsoja upi. ${ }^{825}$

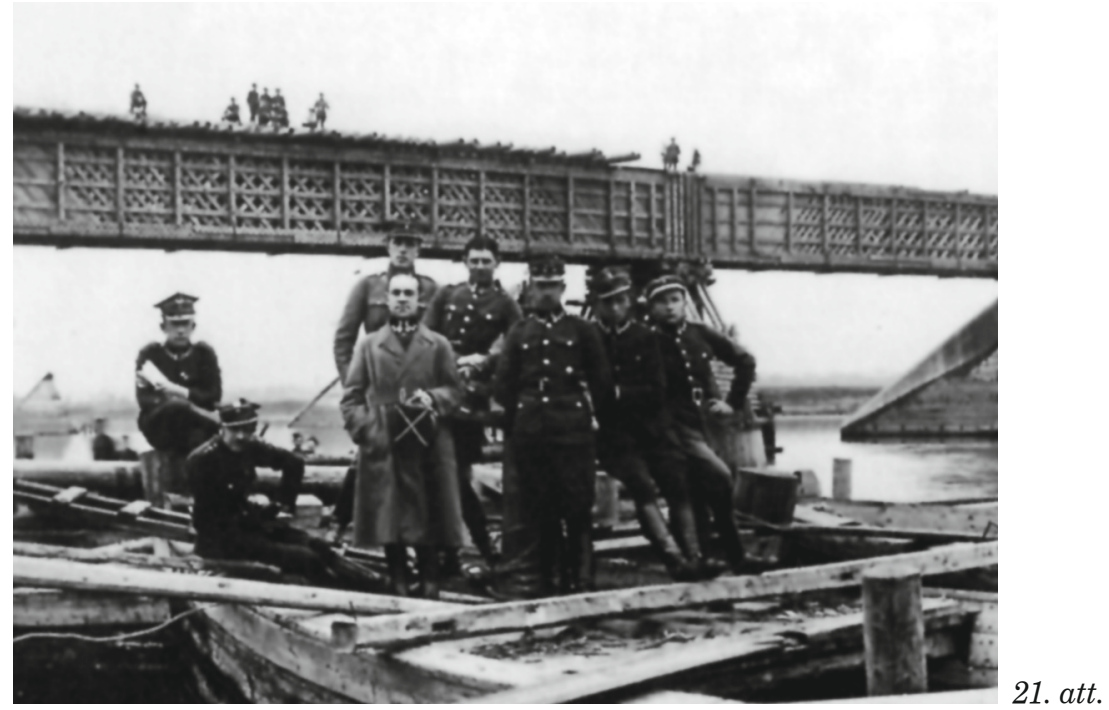

\section{Poḷu karaspēka inženieru vienības karavīri pie Daugavpils dzelzceḷa tilta 1920. gadā}

Turpinājās gadījumi, kad personas Polijas vai Latvijas armijas formā izdarīja laupīšanas un pat slepkavības (pirms tam iekḷūstot dzīvokḷos ar ieganstu veikt pārmeklēšanu vai rekvizīiju). Šajā sakarā E. Graudiṇš 6. maijā pavēlē uzsvēra, ka nevienam nav tiesību izdarīt rekvizīcijas bez Latvijas Apsardzības ministrijas atl̦aujas. ${ }^{826}$ Maija beigās Daugavpilī poḷu karavīri atḷāvās aizturēt uz ielām iedzīvotājus un nodarbināt tos vilcienu izkraušanas darbos Kalkūnes dzelzcel̦a stacijā otrā Daugavas krastā. ${ }^{827}$

Stāvoklis saasinājās vēl vairāk, kad 7. maijā pilsētā ieradās kāds poḷu poručniks un ierīkoja "Frontes kontroles staciju" (šādu staciju mērḳis bija "cīṇa pret spiegošanu un nevēlamu personu nokḷūšanu valstī un frontē" ${ }^{828}$ ). Tam bija pilnvaras izdot atḷaujas iebraukšanai Polijā, un viņš lūdza E. Graudiṇu nelikt šḳēršlus tiem, kas dodas uz kontroles staciju. Tādā veidā

\footnotetext{
${ }^{824}$ Par 20. aprīlī aizturētajiem trīs bijušajiem Judeņiča armijas poḷu tautības virsniekiem, kam bija vien̄̄gi Polijas pārstāvja aţ̦aujas izbraukšanai no Latvijas, apgabala priekšnieks ziņoja Ārlietu ministrijai.

${ }^{825}$ LVVA, 2574. f., 3. apr., 17. 1., 11., 245. 1p.

${ }^{826}$ Наша жизнь. - 1920. - 11 мая.

${ }^{827}$ LVVA, 3601. f., 1. apr., 309. 1., 59. 1p.

${ }^{828}$ CAW, II VD WP, t. 176. Šādā stacijā parasti bija priekšnieks, divi rakstveži, 10 kareivji, četri žandarmi, Austrumzemju civilās pārvaldes ierēdnis un viens revidents. 1920. gada ziemā un agrā pavasarī šādas stacijas darbojās arī Krāslavā un Drujā.
} 
robežas pāriešana lielā mērā kḷuva grūti kontrolējama, taču stacija darbojās, lai gan Latvijas iestādes bija neapmierinātas. Stacijas priekšnieks skaitījās arī Polijas pārstāvis Daugavpilī poḷu lietās. Tāpēc 2. jūnijā viňš lūdza aizturētos Polijas pilsonus nosūtìt vina rīcībā, solot aizturētos Latvijas pilsoṇus nodot Latvijas iestādēm. 4. jūnijā E. Graudiṇš ziņoja, ka kontroles stacija atṇem latviešu bēg̣̣iem naudu (piemēram, 3. jūnijā vairākiem virsniekiem no Dienvidkrievijas). Uz iebildumu, ka Daugavas labajā krastā šāda rīcība nav piel̦aujama, un prasību ievākt noteiktu naudas summu no bēg̣,iem "poḷu krastā" stacijas pārstāvji atbildēja, ka arī Latgales apgabala priekšnieka ierēdṇi ievāc naudu no poḷu bēgḷiem (īstenībā katrs bēglis drīkstēja izvest 3000 Latvijas rubḷu, pārējo konfiscēja latviešu robežsargi). 30. jūnijā apgabala priekšnieks uzsvēra, ka no stacijas darbības "stipri cieš valsts prestižs". ${ }^{829}$ Savukārt latviešu bēgḷiem Kalkūnē poḷi aț̣āva izvest uz Latviju tikai 300 poḷu markas un 250 cara Krievijas rubḷus, pārējo atṇēma. ${ }^{830}$

Polijas armijas Tiesu korpusa apakšpulkvedis Latgales muižnieks M. Svežbiņskis 3. maijā (Polijas valsts nacionālajos svētkos) guva "nepatīkamu, šausmīgu" iespaidu, jo poḷu garnizona parādē Daugavpils centrā bijusi vienīgi "neliela poḷu nodaḷa, nedaudzi virsnieki un daži vietējie poḷi, bet nav bijis neviena Latvijas iestāžu pārstāvja un apkārtne bijusi pilnīgi izmirusi". ${ }^{831}$ Šādos saspīlētos apstākḷos pat škietami nevainīga rīcība izraisīja neadekvātu otras puses reakciju, īpaši neiedziļinoties lietas būtībā. Piemēram, 18. maijā pilsētā izlīmētie poḷu virspavēlniecības "atgādinājumi karavīriem", kas saturēja vienīgi humāna rakstura pamācības poḷu-padomju karā iesaistìtajām militārpersonām, pēc apgabala priekšnieka rīkojuma tika noplēsti, lūdzot poḷu komandantu turpmāk atturēties no līdzīgu "sludinājumu” izplatīšanas pilsētā. ${ }^{832}$

Sakarā ar poḷu-padomju frontē uzsākto Sarkanās armijas pretuzbrukumu 17. maijā pie E. Graudiṇa ieradās cietokšṇa komandants poručniks Boguslavskis. Viṇš paziņoja, ka padomju karaspēks pārrāvis Latvijas armijas fronti, ieṇemot Krāslavu, bet latvieši panikā atkāpjoties, tāpēc Daugavpilī esošās poḷu karaspēka daḷas ir gatavas iziet pretī ienaidniekam, un to vajadzētu darìt arī latviešu garnizonam. E. Graudiṇš noskaidroja, ka informācija ir pilnīgi nepamatota, un ziņoja uz Rīgu, ka "šādas panikas poḷi ceturto reizi atkārto, kas atstāj sliktu iespaidu uz iedzīvotājiem" (Boguslavskim viṇš ironiski ieteicis Daugavpili atstāt, ja poḷi tajā jūtas apdraudēti). ${ }^{833}$

Izplatījās arī baumas par Latvijas un Polijas armijas sadursmēm Daugavpilī. P. Radziṇš uzskatīja, ka tās lielā mērā notika padomju puses darbības dēḷ, jo tā bija ieinteresēta abu valstu sanaidošanā. Armijas Virspavēlnieka štābā ieradās arī Francijas militārās misijas vadītājs

\footnotetext{
${ }^{829}$ LVVA, 2574. f., 3. apr., 13. 1., 125.-138. lp.; 15. 1., 15. lp. Ar kontroles stacijas darbību nebija apmierināts arī A. Miškovskis, 3. jūnijā ziṇojot, ka tā veic bēgḷu nosūtīšanu "uz savu roku", bez Polijas militārā pārstāvja aț̣aujas (runa bija par $31 \mathrm{~S}$. Bulaka-Balahoviča vienības karavīru). - AAN, Attachaty, A - II, 64/1.

${ }^{830}$ LVVA, 3601. f., 1. apr., 469. 1., 341, lp.

831 APAN, Świerzbiński M. Martyrologia Inflant Polskich, s. 68.

${ }^{832}$ LVVA, 2574. f., 3. apr., 15. 1., 78. 1p. Aicinājuma teksts publicēts: Rząd i Wojsko. - 1920. - 2 maj.

833 Turpat, 3601. f., 9. apr., 364. 1., 9. 1p.
} 
E. Diparkē un lūdza informāciju par it kā notiekošām latviešu-poḷu bruṇotām sadursmēm Daugavpilī. Anglijas pārstāvja A. Kīnena aǵents pat esot redzējis un saskaitījis 28 artilērijas lādiṇu sprādzienu bedres. ${ }^{834}$ Lādiṇus uz pilsētu esot izšāvuši poḷi. Reaǵējot uz angḷu darbību, 25. maijā Virspavēlnieka štāba Operatīvā daḷa pieprasīja no E. Graudiṇa apstiprinājumu tam, ka "nedēḷu atpakal poḷi esot apšaudijuši ar artilēriju Daugavpili". ${ }^{835}$ Nekas tāds nebija noticis, par to drīz pārliecinājās pats D. Kīnens, kopā ar Latvijas armijas pārstāvjiem cauri Daugavpilij dodoties uz Lietuvas armijas ieṇemto Ilūkstes apriṇķa daḷu. Pilsētā viṇš apmeklēja arī poḷu garnizona priekšnieku un bija l,oti saniknots, ka vairākas stundas nācās gaidīt poḷu kontrolētās teritorijas caurbraukšanas atḷauju. ${ }^{836}$ Tādējādi izpaudās poḷu neapmierinātība ar Anglijas īstenoto politiku Baltijas reǵionā. Tās galvenais nolūks bija mazināt šeit savas tradicionālās konkurentes - Francijas - iespaidu, savukārt starp Antantes lielvalstīm tieši Francija bija galvenā Polijas sabiedrotā un aizbildne (ar Polijas starpniecību tā centās savu iespaidu reǵionā stiprināt).

$$
* * *
$$

Laika posmā no 1920. gada marta, kad bija sākusies Polijas armijas izvešana no Latvijas, līdz jūlijam Latvijas un Polijas attiecībās bija vērojamas vairākas zināmā mērā lēcienveidīgas pārmaiṇas, kuras kopumā tām bija raksturīgas visus 20.-30. gadus (vienīgi vēlāk - miera laika apstākḷos - tās nenoritēja tik strauji un parasti norisinājās ilgāku laika posmu).

Polijas karaspēka maiṇas brīdī frontē Polijas valdība spēra kḷūmīgu soli, mēǵinot ar tā palīdzību piespiest Latvijas pusi izpildīt Polijas politiskās prasības. Uz laiku tika apturēta armijas izvešana no Latvijas. Tas Daugavpilī gandrīz izraisìja bruṇotu sadursmi starp poḷu un latviešu karavīriem. Dziḷākie konflikta cēloni bija meklējami starpvalstu politiskajās attiecībās, taču nozīme bija arī iepriekšējos mēnešos pakāpeniski pieaugošajam sasprindzinājumam starp Polijas un Latvijas militāriestādēm. Pirmās nevēlējās zaudēt līdzšinējo iespaidu, bet otrās pamazām nostiprinājās un prasīja lielākas pilnvaras zemē, kura pamatoti tika uzskatīta par savas valsts teritoriju. Minēto apliecina arī nesaskaṇas ar palikušajām poḷu karaspēka vienībām un iestādēm. Šīs nesaskaṇas bija spiesta izskatīt gan kopīgā likvidācijas komisija, gan abu valstu ārlietu ministriju ierēdṇi.

Politiskajās attiecībās starp abām valstīm dominēja noskaṇas, kuras bija izraisījusi Varšavas konferences neveiksme un Latvijas uzsāktās miera sarunas ar Padomju Krieviju. Polijas oficiālās aprindas jutās sarūgtinātas, bet nacionālšovinistiski noskaṇoto organizāciju aktivitāte ievērojami pieauga, tās centās kārtējo reizi aktualizēt Latgales piederības jautājumu un apšaubīja Latvijas vēsturiskās tiesības uz to (cita starpā, apvainoja Latviju poḷu minoritātes vajāšanā, kaut arī patiesībā tās stāvoklis bija apmierinošs). Ja pie Latgales muižniecības rīcības Latvijas valdība bija jau pieradusi, tad atsevišķu nacionāldemokrātu ideju paušana no oficiālu amatpersonu (piemēram,

\footnotetext{
${ }^{834}$ Radziṇš P. Latvijas atbrīvošanas karš. - 134. lpp.

${ }^{835}$ LVVA, 6033. f., 1. apr., 406. 1., 14. 1p.

836 Turpat, 3601. f., 1. apr., 248. 1., 582. 1p.
} 
B. Boufala) puses ievērojami palielināja Latvijas valdības piesardzību, kā arī mazināja sabiedriskās domas un pat armijas uzticību Polijai, kaut gan armijas augstākā virsniecība līdz šim bija viens no galvenajiem piekritējiem sadarbībai un pat militārai savienībai ar Poliju. Šādos apstākḷos Polijā nepopulārs kḷuva Latvijas diplomātiskais pārstāvis A. Keniṇš, kurš, raugoties no Polijas ārlietu resora viedokḷa, pārlieku stingri aizstāvēja savas valsts intereses un izrādīja nepiekāpību jautājumos, kuros pat ārlietu ministrs Z. Meierovics, acīmredzot diplomātisku apsvērumu vadìts, bija piekāpīgāks.

Tomēr abu valstu intereses sarežgìitajā starptautiskajā situācijā kārtējo reizi mudināja valdības meklēt tuvināšanās ceḷus. Šoreiz tas nenotika vienlaikus, un arī noteicošie motīvi joprojām bija atšḳirīgi. Polijas sekmīgā uzbrukuma iespaidu padomju frontē Latvija centās izmantot savās sarunās ar Padomju Krieviju, kā arī izrādīja zināmu vēlmi tuvināties Polijai. Savukārt Polija šajā laikā uz to gandrīz nereaǵēja, jo cerēja uz ātriem panākumiem cīṇā ar Sarkano armiju Ukrainā (līdz ar to - uz J. Pilsudska federālistisko principu īstenošanu un Polijas starptautiskās nozīmes ievērojamu pieaugumu). Tas notika vēlāk, kad stāvoklis frontē mainījās un vajadzēja meklēt sabiedrotos varbūtējam ilgstošam karam. Šajā laika posmā Latvijas valdība turpināja, no vienas puses, nesekmīgi organizēt Rīgā kārtējo Baltijas valstu konferenci un pat bruṇoti atbalstīja poḷu karaspēka daḷas Drisas apriṇkī padomju pretuzbrukuma laikā, no otras puses, - Maskavas sarunās oficiāli noliedza minētā atbalsta sniegšanu un nevēlējās bez ierunām noslēgt ar Poliju militārpolitisku savienību apstākḷos, kad tās armijas uzbrukums bija apturēts un militārpolitiskais stāvoklis - ievērojami sarežğìtāks, nekā pirms diviem mēnešiem. 


\section{4. nodalla SAREŽG̣ITIIE NOTIKUMI 1920. GADA OTRAJĀ PUSË UN LATVIJAS ATZİŠANA "DE IURE" (1920. gada jūlijs-1921. gada janvāris)}

\section{Situācija Ilūkstes apriņ̧̣ī}

1920. gada jūlijā Latvijai pilnīgi negaidot izšḳīrās līdz šim neskaidrais, bet tagad faktiski jau Polijas sastāvā (Braslavas apriṇḳī) iekḷauto sešu Ilūkstes apriņka pagastu un Grīvas pilsētas valstiskās piederības jautājums. 25. aprīlī Ukrainā sāktais Polijas armijas un Ukrainas Tautas Republikas karaspēka uzbrukums tika apturēts, 26. maijā Sarkanā armija pārgāja pretuzbrukumā pie Kijevas, bet 4. jūlijā no rīta (pēc stundu ilgas artilērijas apšaudes) - arī Baltkrievijā. Lai gan ienaidniekam bija pieckārtīgs pārsvars artilērijā, Polijas karaspēka apakšgrupa "Dźwina” (33. kājnieku pulks, 155. kājnieku pulka bataljons un 18. ulānu pulka divizions, kā arī nelieli artilērijas spēki), kuras uzdevums bija segt frontes spārnu un uzturēt sakarus ar Latvijas armiju, noturējās līdz plkst. 15.00 un tad nekārtībā atkāpās. ${ }^{837}$ Tas pats notika arī citos frontes sektoros.

Daugavpilī un Ilūkstes apriṇķi izvietotajām poḷu daḷām līdz ar to draudēja atšḳelšana no saviem galvenajiem spēkiem. Savukārt Sarkanās armijas 3. kavalērijas korpuss G. Gaja vadībā devās rietumu virzienā gar Dzisnas upi, un tā komandieris, nebūdams drošs par Latvijas armijas reakciju, pavēlēja palēnināt marša tempu un vienai jātnieku divīzijai nodrošināt labo spārnu pret varbūtēju uzbrukumu no ziemel̦iem. ${ }^{838}$

Fronti no Osvejas ezera līdz Daugavai ienēma Latvijas armijas Zemgales divīzijas daḷas (divīzijas štābs atradās Krāslavā). Jau maija beigās tās bija nomainījušas Kurzemes divīziju. 4. jūlijā divīzijas komandieris O. Dankers pavēlējā rezervē esošā 11 . Dobeles pulka 3. bataljona rotai pāriet Daugavu, ieṇemt pozīcijas no Marinkiem līdz L,avonpolei un aizsargāt tās "visiem spēkiem". 5. jūlijā sekoja pavēle Daugavpils garnizona priekšniekam E. Graudiṇam: gadījumā, ja poḷi atstātu pilsētu, ar viṇa rīcībā esošajiem

${ }^{837}$ Krzyźanowski B. Oddział wydzielony w działaniach obronnych na szerokim froncie// Bellona. 1935. - Lipiec - grudzień. - S. 171-180.

838 Łossowski P. Wydarzenia militarne i polityczne wojny 1920 roku na ziemiach północno - wschodnich//Wojna Polsko - Sowiecka 1920 roku. - Warszawa, 1991. - S. 41. 
spēkiem organizēt aizsardzību, izvietojot nelielus spēkus (pusotru rotu un vadu) arī Daugavas kreisajā krastā. ${ }^{839}$

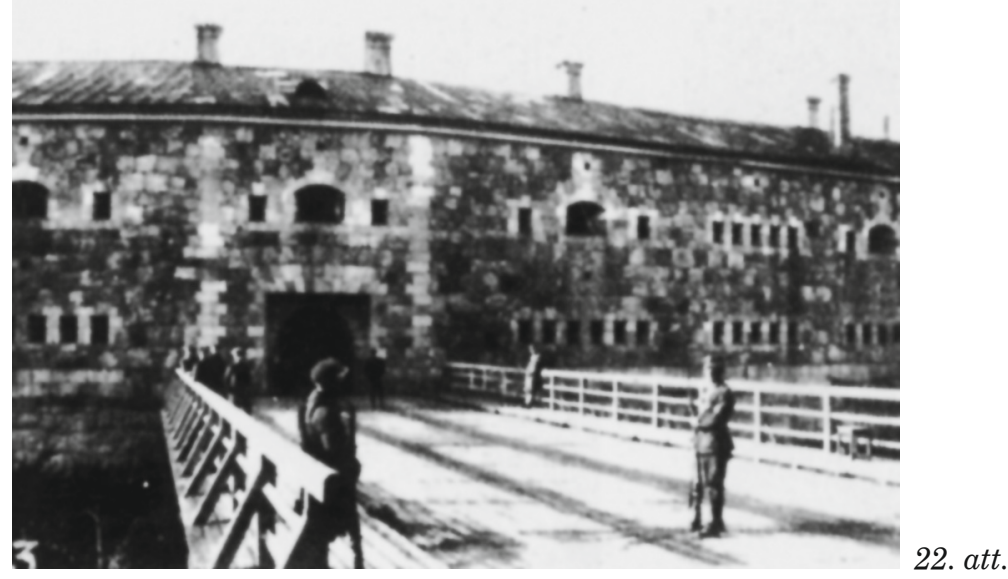

\section{Poḷu sargkareivis pie Daugavpils priekštilta nocietinājuma Grīvā 1920. gadā}

Daugavpils garnizona priekšnieks 5. jūlijā atradās izbraukumā apriṇkī. Viņu aizvietoja virsleitnants J. Budovskis, kurš kopīgi ar apgabala priekšnieka pārvaldei piekomandēto virsleitnantu J. Preisbergu organizēja komandantūras rotas un pilsētas apsardzības rotas 27 karavīru (leitnanta J. Misiṇa vadībā) nosūtīšanu pāri Daugavai uz Elernes muižu, lai tur ieņemtu aizsardzības pozīcijas. Pārējie 80 apsardzības rotas karavīri tika nosūtīti uz cietoksni, ko šajā laikā atstāja poḷu karaspēks. Ceḷā uz cietoksni J. Budovskis un J. Preisbergs no sastaptās poḷu rotas komandiera uzzināja, ka poḷi atstāj visu "Daugavas fronti” un arī Ilūkstes apriṇķi. J. Preisbergs automašīnā šķērsoja tiltu, uz kura vairs nebija poḷu sargposteṇa, un poḷu štābā Grīvā guva tam oficiālu apstiprinājumu. Viṇš atgriezās cietoksnī un deva rīkojumu 70 no tur esošajiem 80 karavīriem skriešus sekot viṇa automašīnai pāri tiltam un pirms lietuviešiem ienemt Kalkūnes dzelzceḷa staciju. 15 minūtes pēc tam, kad viṇi to bija izdarījuši, parādījās lietuviešu karavīri. Redzot, ka ir apsteigti, viṇi aizgāja. Lietuvieši, zinādami, ka latviešu spēki Daugavpilī ir l,oti niecīgi, ar jātnieku priekšposteṇiem mēǵināja izvirzìties arī Skrudalienas virzienā, ap Grīvas pilsētu ieņemot pakavveidīgas pozīcijas. Kāda lietuviešu jātnieku patruḷa uzdūrās latviešu karavīru nodaḷai un pēc īsas apšaudes atkāpās. Arī tad, kad jau pieminētie 70 apsardzības rotas karavīri (galvenokārt "Daugavpils kurpnieki un skroderi”) ieṇēma fronti pret Lietuvas karaspēku, tos dažās vietās sagaidīja ar šauteņu uguni. Tomēr pēc tam, kad viṇi uz to atbildēja ar uguni, nesaprašanās bija beigušās. ${ }^{840}$

5. jūlija vakarā 3. Jelgavas pulka komandieris J. Dombrovskis saṇēma pavēli pārṇemt Daugavpils kaujas rajonu, vienu rotu novietot Kalkūnes stacijā, visas laivas no kreisā Daugavas krasta pārvest uz labo, kreisajā

${ }^{839}$ LVVA, 1527. f., 1. apr., 616. 1., 17. 1p.; 617. 1., 2.-8. 1p.; 618. 1., 1. 1p.; 6033. f., 1. apr., 406. 1., 28. 1p. 840 Turpat, 2574. f., 3. apr., 15. 1., 36., 39. 1p. 
krastā veikt izlūkdarbību un nepieciešamības gadījumā aizstāvēt Daugavpili "lìdz pēdējam, kamēr pienāks papildspēki". Turklāt bija jānodibina sakari ar poliem Turmantas stacijā ${ }^{841}$ (tas vairs nebija iespējams).

5. jūlijā Latvijas armijas virspavēlniecība konstatēja, ka poḷi atkāpjas Viḷnas virzienā caur Slobodku un Jodi. Zemgales divīzija tika pastiprināta ar dažām rezerves vienībām, tomēr Latvijas armijas vadībai nebija gandrīz nekāda priekšstata par Sarkanās armijas kustību un nodomiem, tādēl Daugavpilī esošajām kara lidmašīnām tika plānots piegādāt degvielu, lai ar to palīdzību noskaidrotu "ienaidnieka grupēšanos”. Pagaidām P. Radziṇš pavēlēja "pēc iespējas ātrāk ieņemt mūsu etnogrāfiskās robežas" un "uzṇemt uz uztura" pāri Daugavai pārnākušos poḷu karavīrus. ${ }^{842}$

Pirmkārt, tas attiecās uz 18. ulānu pulka uz 18. ulānu pulka 1. divizionu, ko komandēja poručņiks B. Tščin,skis. 4. jūlija vakarā tas ar kaujām atkāpās līdz Vjatas upei, 5. jūlijā nokḷuva aplenkumā un pēc nesekmīgiem izlaušanās mēǵinājumiem peldus šķērsoja Daugavu pie Piedrujas. Upē noslīka vismaz viens ulāns ${ }^{843}$ un Latvijas armijas Zemgales divīzijas atsevišḳā eskadrona kaprāli K. Eṇgelis un E. Blumbergs, kuri septiṇu cilvēku patrulas sastāvā tieši pirms Sarkanās armijas uzbrukuma sākuma bija nosūtīti nodibināt sakarus ar poḷu jātniekiem pie L̦avonpoles (to patruḷa izdarīja, taču vēlāk bija spiesta steigšus atkāpties kopā ar jātniekiem). ${ }^{844}$ 7. jūlijā divizions ieradās Daugavpilī un tur savienojās ar savu saimniecības komandu, kura 6. jūlijā nokḷva līdz Kalkūnei, bet no turienes - Daugavpilī. Divizions kādu laiku palika pilsētā Latvijas armijas apgādībā, un uz to tika nosūtīti arī citu Polijas armijas daḷu karavīri, kas bija patvērušies Latvijā. Tādējādi pie diviziona (ap 100 vīru un 76 zirgu) pakāpeniski izveidojās kājnieku vienība (64 vīri un 29 zirgi). ${ }^{845}$ Jau 6. jūlijā Zemgales divīzijas vadība piedāvāja nosūtīt karavīrus uz Rīgu un vēlāk pa jūras ceḷu uz Gdaṇsku, bet zirgus atstāt divīzijas rīcībā. Tomēr Polijas militārais pārstāvis Latvijā A. Miškovskis nepiekrita, ka zirgi paliek Latvijā. Viṇš 15. jūlijā nosūtīja uz Daugavpili poručniku L. Plāteru-Broelu pārbaudìt divizionu, bet bijušo sakaru virsnieku pie Kurzemes divīzijas poručniku L. Švejceru iecēla par sakaru virsnieku Daugavpilī un uzdeva organizēt karavīru transportu uz Rīgu. Savukārt B. Tščinsskim tika pavēlēts ierobežot karavīru došanos uz pilsētu un "stingri uzmanīt zirgus". 20. jūlijā Daugavpilī ieradās Latvijas armijas Virspavēlnieka štāba komisija, lai pieṇemtu zirgus, taču poḷi pamanījās tos neatdot. Šajā laikā Zemgales divīzijas komandieris uzsvēra, ka poḷu karavīriem politisku apsvērumu dēl palikt pilsētā nav vēlams. 22. jūlijā tos kopā ar zirgiem pa dzelzceḷu nogādāja Rīgā,

\footnotetext{
${ }^{841}$ Turpat, 1527. f., 1. apr., 617. 1., 18. 1p.; 616. 1., 16. 1p.; 6033. f., 1. apr., 406. 1., 20. 1p.

842 Turpat, 6033. f., 1. apr., 406. 1., 16., 29.-30. 1p.

${ }^{843}$ Kłopotowski M., Dobiecki J. Zarys historji wojennej 18-go pułku ułanow pomorskich. - Warszawa, 1929. - S. 9-11.

${ }^{844}$ LKM, Artum-Hartmanis A., 24. 1p.; Jātnieku pulks 10 gados. - 22.-24. 1p.; Strautnieks Ž. Kāda jātnieka atmiņas//Kara Invalīds. - 1985. - Nr. 30. - 55.-60. lpp. (Ž. Strautnieks atkāpšanās neorganizētībā un cilvēku noslīkšanā vaino poḷu diviziona komandieri).

${ }^{845}$ LVVA, 2574. f., 3. apr., 15. 1., 36. 1p.; CAW, II ND WP, t. 192. Ulānu rīcībā bija 130 karabīnes, 3 ložmetēji, bet kājnieku rīcībā - 21 karabīne. Starp kājniekiem galvenokārt bija karavīri no 33., 22. , 36., 39., 155., 159. pulka, 15. brigādes telegrāfa vada, 13. ulānu, 1. strēlnieku-jātnieku pulka, Drujas, Slobodkas, Pristaņas, Plusu žandarmērijas, kā arī Bulaka-Balahoviča grupas 5. Ostrovas pulka.
} 
bet 26. jūlijā Liepājā. 30. jūlijā ar Polijas tvaikoni "Pomorzanin" aizbrauca pirmie 60 kājnieki. Lai izvairìtos no atbruņošanas, pēc Latvijas-Padomju Krievijas miera noslēgšanas 11. augustā ${ }^{846}$ divizions devās uz Palangas apkārtni, kur tam vajadzēja izlauzties līdz Klaipēdai, kurā atradās Francijas karaspēks. Kad 12. augustā kḷuva redzams, ka lietuviešu stingri apsargātās robežas dēl tas nebūs iespējams, B. Tščin,skis ar vienu karavīru daḷu nodeva ieročus, atgriezās Liepājā un no turienes A. Miškovska iznomātajā Latvijas tvaikonī "Saratovs" devās uz dzimteni. Pārējos karavīrus kopā ar zirgiem 15. augustā slepus uzṇēma tvaikonis "Pomorzanin" pie Palangas, kas tolaik piederēja Latvijai, un abi kuği 18. augustā sasniedza Gdiṇu (no 22. septembra divizions frontē piedalījās kaujās ar Sarkano armiju). ${ }^{847}$

Jūlijā patvērumu Latvijā rada arī citi Polijas pilsoṇi. Daḷa no viṇiem pārgāja Daugavu Krāslavas rajonā un stāstīja par laupīšanām un vardarbībām, ko otrajā krastā izdarījuši sarkanarmieši. Tas Latgales iedzīvotājos izraisīja nemieru. ${ }^{848}$ Septembrī un oktobra sākumā Skrudalienas pagasta Tabores muižā uzturējās septiņi Polijas policijas ierēdṇi ar ǵimenēm (galvenokārt no Drujas, ieskaitot šì miesta policijas priekšnieku) un 10 lauksaimniekibēgḷi (Polijas konsulārais aǵents Daugavpilī jau 31. augustā lūdza Latgales apgabala priekšnieku aț̣aut viṇiem uzturēties Latvijā, jo atgriešanās Polijā nebija iespējama ${ }^{849}$ ). Latvijas Iekšlietu ministrija atḷāva bēgliem palikt valstī līdz laikam, "kad būs iespējams atgriezties dzimtenē". ${ }^{850}$ Turklāt pēc LatvijasPadomju Krievijas miera līguma noslēgšanas 11. augustā atseviški iedzìvotāji, kas atradās teritorijās, kuras līdz šim bija ieṇēmusi Latvijas armija un atdevusi padomju pusei, centās iegūt atḷauju pārcelties uz Latviju. Piemēram, 14. augustā to lūdza Drisas apriṇka Tobolkovas pagasta Poguḷankas muižas īpašnieks M. Lisovskis (vin,š pats sevi dēvēja par katoḷticīgu baltkrievu). L,isovskis apgalvoja, ka padomju represīvās iestādes likvidē visus, kurus tur aizdomās par saistību ar Poliju. ${ }^{851}$

Latvijas armijas Zemgales divīzijas komandieris 8. jūlijā norādīja, ka "lielinieki no Pārdaugavas [Daugavas kreisā krasta $-\bar{E}$. J.] sūta pāri pie mums privātus un pārǵērbtus poḷu formās spiegus” un pavēl pārbēdzējus

\footnotetext{
846 9. augustā A. Miškovskis pavēlēja uzvest zirgus uz tvaikoņa "Saratov", lai tos it kā nogādātu Rīgā, bet cilvēkiem uz kuğa kāpt naktī. Miera līguma noslēgšana starp Latviju un Padomju Krieviju plānu izjauca. - CAW, II ND WP, t. 192.

${ }^{847}$ LVVA, 6033. f., 1. apr., 406. 1., 18.-28. 1p.; CAW, II ND WP, t. 192; Kłopotowski M., Dobiecki J. Zarys historji... - S. 11 - 15. Pēdējais 18. ulānu pulka karavīrs Latviju atstāja septembrī, jo līdz tam ārstējās Liepājas garnizona lazaretē. - AAN, Attachaty, A - II, 81/1. Kopumā līdz septembra beigām Polijas militārā pārstāvniecība pa jūras ceḷu uz Poliju nosūtīja 440 karavīrus un 137 zirgus (nosūtīšana turpinājās arī vēlāk). Liepājā tika izveidots Poḷu bēgḷu punkts, kura komandants bija Polijas armijas virsnieks, bet Rīgā varas iestādes poḷu bēgl̦us par velti izmitināja kazarmu telpās. Sīkāk sk.: Kurzemes Vārds. - 1920. - 27., 29., 31. jūl., 3., 6. aug., 24. sept., 2. okt. Sīkāk par poḷu karavīriem Latvijā 1920. gada jūlijā-augustā sk.: Jēkabsons Ē. Żołnierze polscy na Łotwie w lipcu - jesieni 1920 roku //Bitwa Niemeńska. - Białystok: Muzeum Wojska w Białymstoku, 2000, s. 121-127.

${ }^{848}$ LVVA, 1368. f., 1. apr., 261. 1., 21. 1p.

849 Turpat, 814. 1., 142.-143. 1p.

${ }^{850}$ Turpat, 2574. f., 3. apr., 90. 1., 19. 1p.

851 Turpat, 1368. f., 1. apr., 814. 1., 28. 1p.
} 
nopratināt. Protams, spiegu nebija daudz, to netieši apliecina arī dotā pavēle poḷu karavīrus, kas ievainoti kaujās, ievietot Latvijas armijas Daugavpils lazaretē. ${ }^{852}$

Katrā ziṇā jūlijā Latvijas armijas virspavēlniecība savu iespēju robežās darīja visu, lai nodrošinātos pret varbūtējām Sarkanās armijas akcijām Latvijas teritorijā. Jau 5. jūlijā izlūki dienvidos no Krāslavas uzdūrās sarkanarmiešu jātniekiem, kuri vienu izlūku sagūstīja. Nākamajā dienā šis karavīrs atgriezās savā daḷā ar padomju pulka komandiera vēstuli, kurā tas informēja, ka saṇemta pavēle nešaut uz Latvijas armiju, un lūdza latviešus darīt to pašu. Arī Demenes pagastā pie Briğenes muižas bija sagūstīti seši bruṇoti sarkanarmiešu jātnieki. Viṇi liecināja, ka 88. un 90. kavalērijas pulkam, kura izlūknodaḷas darbojās Latvijā, pavēlēts latviešiem neuzbrukt (pie Skrudalienas latvieši pret tām bija atklājuši uguni). Turklāt 9. jūlijā 3. Jelgavas kājnieku pulka vienību novietojumā pie Briğenes muižas nejauši iejāja vēl 14, bet nākamajā dienā - vēl 10 sarkanarmieši, kuri tika sagūstīti. ${ }^{853}$ Arī ar lietuviešiem Sarkanajai armijai sadursmju nebija - kāds padomju eskadrons pārlaida nakti Turmantas stacijā, kur atradās arī lietuviešu karavīri. Zemgales divīzijas komandieris O. Dankers atzina, ka viṇam pagaidām pietrūkst spēku, lai ieņemtu visu Polijas armijas atstāto Ilūkstes apriņ̧̧a daḷu, un ka līdz šim neviena šāviena no Sarkanās armijas puses pret latviešiem nav bijis. ${ }^{854}$ Tomēr bija ziṇas, ka 8. jūlijā Sarkanās armijas vienības, kas dodas cauri apgabalam, rekvizē zemniekiem zirgus, labību un pārtiku. ${ }^{855}$

Acīmredzot padomju puse uzskatīja pavēli nešaut par saistošu vienīgi Ilūkstes apriṇķī. Turpretī Drisas apriṇḳī, par kura galīgo piederību LatvijasPadomju Krievijas miera sarunās vēl nebija panākta vienošanās, sadursmes notika. 6. jūlijā Sarkanās armijas daḷas uzbruka Latvijas armijas 11. Dobeles pulka 7. rotai un piespieda to atkāpties pāri Daugavai. Nākamajā naktī ienaidnieka kēdes uzbruka 12. Bauskas pulka pozīcijām pie Šmulkovas, taču tika atsistas. Uz kreiso krastu devās arī Zemgales divīzijas atsevišḳā eskadrona vads, lai atbalstītu tur esošās vienības. ${ }^{856}$

Pārspīlēts šķiet poḷu pārtvertais Sarkanās armijas 3. kavalērijas korpusa štāba ziņojums par 7. jūlija notikumiem, kas izraisīja zināmas nesaskaņas Polijas un Latvijas attiecībās. Tajā bija teikts: "Sarunās ar latviešu karavīriem noskaidrots, ka viņiem ir pavēle nešaut uz Sarkano armiju. Tikšanās bija sirsnīga, latvieši novēlējuši sarkanarmiešiem veiksmi. Lai noskaidrotu stāvokli Daugavpils rajonā un segtu korpusa labo spārnu, bija pavēlēts ieṇemt Skrudalienu, ko jau bija ieṇēmuši latviešu kājnieki. Eskadrons pie Skrudalienas sastapās ar latviešiem, kas uzṇēma to draudzīgi." ${ }^{857}$ Iespējams,

\footnotetext{
${ }^{852}$ Turpat, 1527. f., 1. apr., 617. 1., 17. lp. Vēl 19. jūlijā tika aizturēti Z. Vangins un G. Skurkevičs, kurus atbrīvoja tikai pēc tam, kad A. Miškovskis bija apliecinājis, ka abi ir bijušie Polijas 36. pulka maksas aǵenti. - LVVA, 3601. f., 6. apr., 100. 1., 2. lp.; CAW, II ND WP, t. 192.

853 3. Jelgavas kājnieku pulks. 1919. 16. VIII-1929. 16. VIII. - 165. lpp.

${ }^{854}$ LVVA, 6033. f., 1. apr., 406. 1., 24.-28. lp. Šis avots vēsta, ka ienaidnieka izlūki pienākuši pie Skrudalienas, ievākuši no iedzīvotājiem ziṇas par Latvijas armijas daḷu novietojumu un aizgājuši.

${ }^{855}$ LVVA, 1640. f., 1. apr., 830. 1., 3. 1p.

${ }^{856}$ LKM, 12. Bauskas kājnieku pulka vēsture. - 600. lp;; Artum-Hartmanis A., 24. lp.

857 AAN, Kod, t. 2, k. 237. Pat šādu ziṇu Polijas armijas Ģenerālštāba vadība (S. Hallers) novērtēja ar piezīmi: "Jāṇem vērā, ka latvieši ir spiesti tā rīkoties."
} 
ka tā bija provokācija, lai panāktu Latvijas un Polijas attiecību saasināšanos, kaut arī nevar noliegt, ka nesen frontē novietotās Zemgales divīzijas atsevišksi karavīri labvēlīgi izturējās pret sarkanarmiešiem. ${ }^{858}$ Skaidrs, ka bija norādījums izvairīties no nevajadzīgām sadursmēm. 7. jūlijā Z. Meierovics deva rīkojumu paziņot padomju valdībai, ka Latvijas armija ieņems Polijas armijas atstāto teritoriju līdz bijušās Kurzemes guberṇas administratīvajai robežai, un lūdza neuzskatīt to par militāru akciju pret Padomju Krieviju. ${ }^{859}$

Savukārt Lietuvas armijas 1. divīzijas divi pulki pēc poḷu aiziešanas ievērojami izvirzìjās uz austrumiem, pārṇemot savā kontrolē dzelzceḷu no Kalkūnes līdz Turmantai, un atradās gar Grīvas-Drisvjatu cel̦u, vietām tie ieṇēma arī atseviškas vietas Demenes un pat Borovkas (tag. Silenes) pagastā. 3. Jelgavas kājnieku pulka vadība piedāvāja lietuviešiem atkāpties uz dienvidiem, jo tagad viņu priekšā atrodas Latvijas armija, taču viṇi atteicās to darīt un pieprasīja atdot tiem Kalkūnes staciju. ${ }^{860}$ 7. jūlijā P. Radziņš informēja Lietuvas militāro pārstāvi Latvijā E. Talatu-Kelpšu, ka Latvijas armija ieṇems bijušo Kurzemes guberņas robežu, un pieprasīja, lai lietuvieši nepārietu bijušo poḷu-lietuviešu demarkācijas līniju. ${ }^{861}$ Pagaidām strīdu atrisināja Anglijas militārā misija, panākot, ka dzelzceḷš līdz Kalkūnei tiek nodots Latvijas armijas kontrolē, taču lietuviešiem ir brīva tranzìta tiesības. ${ }^{862} \mathrm{Uz}$ Daugavpili izbrauca Latvijas armijas Virspavēlnieka štāba komisija, kura 11. jūlijā parakstīja vienošanos ar Lietuvas armijas pārstāvjiem par turpmāko sadarbību. Saskaṇā ar to Lietuvas karaspēks pagaidām palika Ilūkstes apriṇḳī. ${ }^{863}$ Nākamajā dienā Maskavā Lietuva noslēdza miera līgumu ar Padomju Krieviju (saskaṇā ar šo līgumu abu valstu robeža ziemeḷos sākās Drujā pie Daugavas ${ }^{864}$ ), bet Lietuvas attiecībās ar Latviju turpināja dominēt teritoriālas un politiskas domstarpības.

Pirmā informācija Latvijas presē par notikumiem Augškurzemē parādījās tikai 10.-11. jūlijā. Tika ziṇots vienīgi par Latvijas armijas ieiešanu šajā teritorijā, kā arī sniegts īss Lietuvas un Polijas militārā pārstāvja stāvokḷa vērtējums. $^{865}$ Tomēr apgabala ieņemšana noritēja tikai pakāpeniski. 9.-10. jūlijā lielā apgabala daḷā, kur nebija Latvijas vai Polijas karaspēka, saimniekoja laupìtāju bandas un zemnieki daudzviet bija spiesti organizēti aizstāvēties ar ieročiem rokās. 10. jūlijā Latvijas armijas karavīri nonāca līdz Skrudalienai, bet nākajā dienā - līdz Lauceses pagasta centram. ${ }^{866}$

\footnotetext{
${ }^{858}$ Daugavpils apriņķa komandantūras apsardzības rotas kareivis K. Briņķis, kurš tolaik atradās Skrudalienā, atceras, ka izlūkgājiena laikā apsvēris iespēju pie pirmās izdevības padoties un šo nodomu izjauca vienīgi otra kareivja apņemšanās cīnīties. - Briṇksis K. Autobiogrāfija (manuskripts). - Kultūras fonda arhīvs, 45.-46. lpp.

${ }^{859}$ LVVA, 6033. f., 1. apr., 406. 1., 29. 1p.

${ }^{860}$ Turpat, 24. 1p.; 2. Ventspils pulks. - 344. lpp.; LKM, Caunītis O., 88. 1p.

${ }^{861}$ LCVA, f. 384, ap. 3, b. 73, 1. 178.

${ }^{862}$ CAW, II ND WP, t. 193; LVVA, 3601. f., 1. 1. apr., 496. 1., 33. lp. (P. Radziņa 8. jūlija pavēle militārajam pārstāvim Lietuvā).

863 Počs K. Sanitārā kordona... - 104. lpp.

${ }^{864}$ Lithuania 700 Years/Edited by A. Gerutis. - New York, 1969. - P. 164.

865 Brīvā Zeme. - 1920. - 10., 11. jūl.

${ }^{866}$ LVVA, 1640. f., 1. apr., 830. 1., 3. 1p.
} 
15. jūlijā Latvijas armija pilnībā bija ieṇēmusi vienīgi Grīvas pilsētu, Kalkūnes un Skrudalienas pagastu. Pārējo pagastu iedzīvotājiem pagaidām nebija skaidrības par savu likteni. Salienas pagasta iedzìvotāji pat atsūtīja pie karaspēka savus pārstāvjus, kuri lūdza paātrināt vinuu pagasta ieṇemšanu, un solīja attiecīgo armijas vienību apgādāt ar pārtiku un lopbarību. Pieci šì pagasta zemnieki pat sagūstīja 11 bruṇotus sarkanarmiešu jātniekus un nodeva Latvijas armijai. ${ }^{867}$ Saskaṇā ar Polijas armijas virspavēlniecības 15. jūlija stāvokḷa pārskatu Latvijas armija šajā laikā bija ieṇēmusi KalkūnesSkrudalienas līniju (lai nodrošinātu savu spārnu un uzsvērtu savas valsts tiesības uz Ilūkstes apriṇķi), bet "lielinieki izvairās no sadursmēm ar to".868 Tikai ilgāku laiku pēc poḷu aiziešanas Zemgales divīzija saṇēma pavēli ieņemt "Latvijas etnogrāfiskās robežas". 16. jūlijā pavēle daḷēji tika izpildìta, nākamā valsts robeža tomēr pilnībā vēl netika sasniegta. ${ }^{869}$ Tas notika tikai augusta sākumā, kad Latvijas armijas dalas sasniedza arī Piedruju un citas apdzīvotās vietas. ${ }^{870}$ Turklāt arī kādu laiku pēc tam pat Latvijas valdībai nebija pārliecības, ka šīs teritorijas paliks Latvijā. Atbildot uz Tirdzniecības un rūpniecības ministrijas pieprasījumu par Salienas pagasta valstisko piederību, Ârlietu ministrijas departamenta direktors L. Sēja 10. augustā rakstīja: „... attiecībā uz Salanajas [Salienas $-\bar{E}$. J.] pagasta piederību šimbrīžam nevarēdami noteikt, kurai valstij minētais pagasts turpmāk tiks galīgi pievienots, pagodināmies Jums ziņot, ka pēc Iekšlietu ministrijā ievāktām ziṇām, pagaidām Salanajas pagastā tiek organizētas mūsu administrācijas iestādes." 871

Atgūtajā apgabalā stāvoklis bija sarežǵìts. Nedarbojās skolas, nebija nekādu sociālo iestāžu, iedzīvotāji pārtika gandrīz vienīgi no pārtikas, kas iegūta naturālās saimniekošanas ceḷā. Jaunieceltajam Grīvas un apkārtnes komandantam bija jārūpējas arī par poḷu atstāto akmeņog̣̣u, malkas, dzelzceḷa inventāra u. c. resursu nodrošināšanu pret izlaupīšanu. ${ }^{872}$ Tomēr pakāpeniski Latvijas varas iestādes pārṇēma atgūto apgabalu pilnīgā kontrolē un nodibināja tajā kārtību.

\section{Starpvalstu attiecības reǵionā poḷ-padomju kara notikumu iespaidā}

Jūlijā, sākoties Sarkanās armijas uzbrukumam Baltkrievijā, Polijas ārlietu resors kārtējo reizi pievērsa îpašu vērību Latvijai, jo cerēja noslēgt ar to militāru savienību un tādējādi iegūt sabiedroto karā ar Padomju Krieviju. Jau 5. jūlijā A. Miškovskis Rīgā centās noskaidrot Latvijas armijas vadības nostāju šajā jautājumā, taču P. Radziṇš sarunā bija atturīgs un apliecināja Latvijas puses gatavību militāri sadarboties ar poḷiem vienīgi Ilūkstes apriṇķa

\footnotetext{
867 Turpat, 2574. f., 3. apr., 15. 1., 36. 1p.

868 CAW, II ND WP, t. 194.

${ }^{869}$ LVVA, 6033. f., 1. apr., 406. 1., 24. 1p.; 1527. f., 1. apr., 617. 1., 19. 1p.

870 Paluszyński T. Konflikty graniczne... - S. 38.

${ }^{871}$ LVVA, 2574. f., 3. apr., 6. 1., 26. 1p.

872 Turpat, 3461. f., 1. apr., 20. 1., 2. 1p.; 1. 1., 1. 1p.; 3485. f., 1. apr., 1. 1., 12., 57. 1p.
} 
robežās ${ }^{873}$ (sešos pagastos, ko Latvijas valdība uzskatīja par saviem). Jūlija sākumā par Polijas diplomātisko pārstāvi Latvijā tika iecelts V. Kameṇeckis, un 8. jūlijā viņš tika pilnvarots darīt visu, lai panāktu militāras savienības noslēgšanu. Ja Latvijas puse "stūrgalvīgi" būtu uzstājusi, lai Ilūkstes aprinka austrumu daḷs tiktu tai atdotas, vinam tika atlauts piekāpties. "Visizdevīgākajā brīdī" bija jāiesniedz Latvijas "de iure" atzīšanas raksts, kurš tika sagatavots. ${ }^{874}$ Polijas G̦enerālštāba priekšnieka vietas izpildītājs S. Hallers 10. jūlijā nosūtīja A. Miškovskim uz Rīgu Polijas-Latvijas slepenas militārās konvencijas projektu, kas paredzēja savstarpēju tūlìtēju militāru atbalstu, ja vienai pusei uzbruks. ${ }^{875}$ Polijas armijas virspavēlniecība 12. jūlijā konstatēja, ka tiek vestas sarunas ar latviešiem par Latvijas karaspēka uzbrukumu Sarkanās armijas labajam spārnam un Polija atzīst visa Ilūkstes apriṇķa piederību Latvijai (līdz kara beigām gan paturot tiesības savam karaspēkam to škēēsot, kā arī turēt garnizonu Daugavpils cietoksnī). Šādā situācijā rezultāts varēja būt tikai negatīvs, un 22. jūlija virspavēlniecības pārskats vēstīja, ka "Latvijas puse neizrāda vēlmi sniegt Polijai palīdzību" (arī uz M. Hartmana ziṇojumiem no Varšavas par poḷ centieniem iegūt palīdzību Latvijas armijas Virspavēlnieka štābs neatbildēja). ${ }^{876}$ Polijas pārstāvja vietas izpildītājs Rīgā J. Baḷin,skis 13. jūlijā ziṇoja, ka Latvijas attieksme pret Poliju, kura "nekad nav bijusi draudzīga, pašlaik kḷvusi smaga. Dažas aprindas ieņem nogaidošu pozīciju, tomēr lielākā daḷa pilnīgi no mums novērsusies, zaudējusi ticību mūsu spēkiem". 877

23. jūlija Latvijas Ārlietu ministrijas pārskatā tika konstatēts, ka Polijas stāvoklis ir katastrofāls, tās armija vairs neatkāpjas, bet bēg. Pārskata autors L. Sēja uzsvēra, ka Latvijā ar zināmām bažām uztverts poḷu uzbrukums, kas bija sācies pavasarī, taču to, ka "notikumi dabūs tik strauju tempu", neviens nav iedomājies. Poḷu karavīri un viṇu bruṇojums atstājis labu iespaidu, tāpēc sakāves cēloṇi meklējami virsnieku nesagatavotībā un Sarkanās armijas skaitliskajā pārsvarā. Viṇš secināja, ka "Latvijā Polijas imperiālistiskās tieksmes tika vienmēr nosodītas, bet tagad, kad stāvoklis ir tik grūts, viṇai sāk just līdz. Galīga satriekšana mūs apdraud, un diezgan spēcīga Polija etnogrāfiskās robežās mums ir no paša lielākā svara, sevišķi tagad, kur jautājums par vēsturiskajām poḷu tiesībām uz Latgali un Daugavpili atkrīt pats no sevis, kur Augškurzemes lielo dal̦u ien̄ēmis latviešu karaspēks. Jācer tomēr, ka Poliju pilnīgi sagraut lieliniekiem neizdosies, poḷu tautas masās mostas nacionālā pašapziṇa[..]". 878 Savukārt Z. Meierovics sarunā ar V. Kamen,ecki tieši atzinis, ka gadījumā, ja "Polija kritīs", būs apdraudēta arī Latvijas neatkarība. ${ }^{879}$

\footnotetext{
873 Paluszyński T. Walka o niepodległość Łotwy 1916-1921. - S. 339.

874 AAN, Kod, t. 2, k. 242-243.

875 AAN, Attachaty, A - II/ 115, k. 62-66.

876 CAW, II ND WP, t. 194; LVVA, 6033. f., 1. apr., 24. 1., 51. lp.

877 Łossowski P. Łotwa... - S. 16.

${ }^{878}$ LVVA, 2575. f., 15. apr., 2. 1., 99. 1p. Citāts atstāts nemainīts, kaut arī nav šaubu, ka ar vārdiem "nacionālā pašapziņa" domāts milzīgais nacionālo jūtu pacēlums, kurš iedvesmoja visu tautu ķerties pie ieročiem, lai cīnìtos pret iebrucējiem.

${ }^{879}$ APAN, Djarjusz M. S. Kossakowskiego, T. IV, cz. 2, s. 77.
} 
Notikumi frontē kavēja V. Kameṇecka ierašanos Liepājā. Viṇš tika gaidīts jau jūlija vidū, bet ieradās tikai 29. jūlijā. Viṇam par godu vietējais Polijas konsulārais ağents sarīkoja šeit banketu, un 31. jūlijā V. Kameneckis iebrauca Rīgā, bet 2. augustā apmeklēja Ârlietu ministriju. Jau 31. jūlijā viṇš sniedza interviju Latvijas Telegrāfa aǵentūrai un uzsvēra, ka ir cerības uz militārā stāvokḷa uzlabošanos un „pacilāto noskan,ojumu” visā tautā, kā arī jaunās valdības galveno uzdevumu - ,aizsargāt zemi un slēgt mieru”. V. Kameņeckis arī izteica atzinību Latvijas valstij par Baltijas valstu konferences organizāciju un „Baltijas valstu savienības idejas propagandēšanu”, ka arī cerību, ka tieši konferencē ir iespēja „nodibināt mieru mūsu teritorijā”. 880

Attieksme pret Latviju Polijā šajā laikā bija dažāda. Kamēr daḷa preses rakstīja par Latvijas armijas izdarītajām "laupīšanām” Braslavas apriṇkī (ar to domājot Ilūkstes apriṇķi - $\bar{E}$. J.), izmantojot "īslaicīgu Polijas karaspēka atkāpšanos", 881 vairākums laikrakstu noliedza baumas par škietamu Latvijas un Padomju Krievijas armiju kopīgu ieiešanu Daugavpilī, kā arī nosodīja "lielinieku sākto kampaņu", lai sanaidotu Latviju un Poliju. ${ }^{882}$ Laikraksts "Naród” pauda izpratni par apstākḷiem, kas piespieduši Baltijas valstis (ar to bija domāta faktiski tikai Latvija $-\bar{E}$. J.) iesaistīties miera sarunās ar Padomju Krieviju (sociāldemokrātu spiediens), tomēr pārmeta latviešiem, ka tie, "poḷu-latviešu tuvināšanās pretinieku propagandas apdullināti, neredz Latvijas neatkarības vienīgo garantu - Poliju", jo pat apvienotas Baltijas valstu armijas nespēšot ilgāk par pāris nedēlām pretoties Sarkanajai armijai. Turpretī Polija vēlāk vairs negribēšot palīdzēt saviem "dabīgajiem, taču šodien tik nedabīgā veidā neitrālajiem sabiedrotajiem". ${ }^{883}$

Jaunā militārpolitiskā situācija iespaidoja arī Latvijas un Polijas militāro sadarbību. Sākotnēji poḷu attieksme pret latviešu sakaru virsnieku E. Klūgi, kas bija komandēts uz Polijas 1. armiju, bija īpaši labvēlīga. Taču pēc sagrāves frontē un atkāpšanās haosa (ko E. Klūge sīki aprakstīja ziṇojumā pēc atgriešanās), kā arī pēc Latvijas miera sarunām ar Krieviju tā mainījās. 15. jūlijā poḷu 1. armijas štāba izlūkošanas daḷas priekšnieks E. Klūgem pavēstīja, ka Latvijas karaspēks pārgājis Daugavu un pie Skrudalienas "ḷti mīli saticies ar lieliniekiem”. E. Klūge uzzināja, ka ziṇas nāk no pārtvertās padomju 3. kavalērijas korpusa štāba telegrammas. 18. jūlijā Operatīvās daḷas priekšnieks viṇam ārēji laipni aizrādīja, ka nav nozīmes turpmākai sadarbībai, jo sakaru ar Rīgu nav un galu galā poḷi nezina, kā uz latviešiem skatīties - kā “uz lieliniekiem vai kā citādi”. Tajā pašā dienā E. Klūge atstāja štābu Belostokā, 19. jūlijā ieradās Varšavā un cauri Austrumprūsijai atgriezās Latvijā. Neskaidrās Latvijas nostājas dēḷ arī pret pārstāvi bēgḷu un gūstekṇu lietās Viḷnā - kapteini A. Krūmu - poḷi izturējušies "ḷoti naidīgi”. Nākamajā dienā pēc Viḷnas krišanas Sarkanās armijas rokās - 14. jūlijā - viṇš cauri Varšavai arī devās uz dzimteni. ${ }^{884}$

\footnotetext{
${ }^{880}$ Latvijas Kareivis. - 1920. - 13. jūl., 1. aug.; Brīvā Zeme. - 1920. - 31. jūl

${ }^{881}$ Ziemia Wileńska. - 1920. - 11 lip.

882 Przegląd Wieczorny. - 1920. - 12 lip.; Kurjer Poranny. - 1920. - 15 lip.

${ }^{883}$ Naród. - 1920. - 11 lip.

${ }^{884}$ LVVA, 3601. f., 1. apr., 469. 1., 358., 371. lpp.
} 
Šajā laikā Polijā pastiprinājās runas par gaidāmo Latvijas-Krievijas mieru. 26. jūlijā M. Hartmanis ziņoja no Varšavas, ka frontes virspavēlnieks S. Šeptickis Anglijas militārās misijas pārstāvjiem pat apgalvojis, ka tas jau noslēgts. ${ }^{885}$ Apgalvojums bija sasteigts, taču pamatoti. Zināmā mērā sakarā ar notikumiem poḷu-padomju frontē miera sarunas virzījās uz priekšu, kaut arī padomju puse sāka izvirzīt stingrākus noteikumus. ${ }^{886}$ 15. jūlijā tās tika pārceltas uz Rīgu, bet 11. augustā beidzās ar miera līguma parakstīšanu. Šajā laikā notika kaujas Varšavas pievārtē, un padomju delegācijas vadītājs A. Jofe pēdējā latviešu-padomju miera sarunu sēdē 10. augustā aṭ̣āvās nediplomātiski un pat ar apslēptiem draudiem norādīt, ka ar "Krievijas ienaidnieku" (Poliju) uz Latvijai ir pārāk labas attiecības, kuru dēl miers noslēgts tik vēlu. ${ }^{887}$ Savukārt Polijas armijas G̦enerālštābs 15. augustā secināja, ka Latvijas-Padomju Krievijas miera līgums ir "Polijas militārās sagrāves (Baltkrievijā) dabiskas sekas" un tāpēc Polija atrodas šķietami bezcerīgā militārā situācijā un Latvijas valdība gribējusi "glābt to, kas vēl glābjams". 888

Arī Latvijas attiecības ar Lietuvu palika sarežǵìtas. 1919. gada martā ar Lietuvu bija parakstīts līgums, bet jūnija beigās Latvijas valdība nolēma izbeigt tā darbību, jo saskaṇā ar šo līgumu sniegtais aizdevums apmaiṇā pret tiesībām izmantot Liepājas ostu bija atmaksāts (no paredzētajiem pieciem miljoniem marku Latvijai tika aizdoti trīs miljoni). Liedzot lietuviešiem brīvu pieeju Liepājas ostai, Latvijas valdība cerēja padarìt viņus piekāpīgākus robežas jautājumā. 11. jūlijā tas tika paziņots Lietuvas valdībai, kura vēl 6. jūlijā bija lūgusi atḷauju nosūtīt uz Liepāju 12 karavīrus savu kravu apsardzībai. ${ }^{889}$ Tomēr 26. jūlijā saskaṇā ar Daugavpilī 11. jūlijā parakstīto vienošanos Lietuvas armijai tika piekomandēti militārie speciālisti pulkvežileitnanti J. Vìtols, A. Apsìtis un pulkveži V. Kaminskis (visi līdz 1921. gadam), J. Ruškēvics (līdz 1920. gada novembrim). ${ }^{890}$ Turklāt jau 1920. gada 22. jūlijā Kauṇā ieradās un Lietuvas armijas G̦enerālštāba rīcībā stājās pulkvedisleitnants V. Ozols, kurš līdz 1921. gadam štābā ieṇēma vadošus amatus ${ }^{891}$ un daudzkārt (kā vienīgais no minētajiem virsniekiem) tieši piedalījās Lietuvas-

\footnotetext{
885 Turpat, 6033. f., 1. apr., 24. 1., 34., 42. 1p.

886 Stranga A. O niektórych problemach polsko - łotewskich stosunków... - S. 152.

887 Turpat, 153. lpp.; Stranga A. Cel̦ā uz mieru. Krievijas-Latvijas 1920. gada 11. augusta miera līgums// Pretstatu cīṇa. - Rīga, 1990. - 121. lpp. Augusta sākumā R̄̄gā ieradās Polijas Austrumzemju civilās pārvaldes ǵenerālkomisāra vietnieks M. Kosakovskis, kurš ar padomju delegācijas vadītāja vietnieku J. Haṇecki pārrunāja apcietināto apmaiņas jautājumu starp Poliju un Krieviju. - APAN, Djarjusz M. S. Kossakowskiego, T. IV, cz. 2, s. 70-86.

${ }^{888}$ Sąsiedzi wobec wojny 1920 roku. - S. 252; Międzynarodowe aspekty wojny polsko - bolszewickiej 1919-1920. Antologia tekstow historycznych/Oprac. M. M. Drozdowski. - Warszawa, 1996. S. 53.

${ }^{889}$ LVVA, 2575. f., 11. apr., 61. 1., 34. 1p.; 2574. f., 4. apr., 71. 1., 206. lp.

${ }^{890}$ LCVA, 384 f., 3 ap., 358 b., 244 p. 1920. gada jūlijā neilgu laiku Lietuvas armijai bija piekomandēts arī intendantūras virsnieks kapteinis E. Lajas-Sauss un Lietuvas militārā pārstāvja sarunās ar J. Balodi bija runa arī par iespēju nosūtīt uz Lietuvu arī pulkvedi M. Peniķi.

${ }^{891}$ LVVA, 5601. f., 1. apr., 221., 2762., 4697., 5637., 7103. 1.; LCVA, f. 384, ap. 3, b. 73, 1. 177, 192; b. 16, 1. 75 .
} 
Polijas bruṇotajā konfliktā. Augustā Rīgā notika sarunas par vairāku Latvijas armijas bruṇuvilcienu pārdošanu Lietuvai. ${ }^{892}$

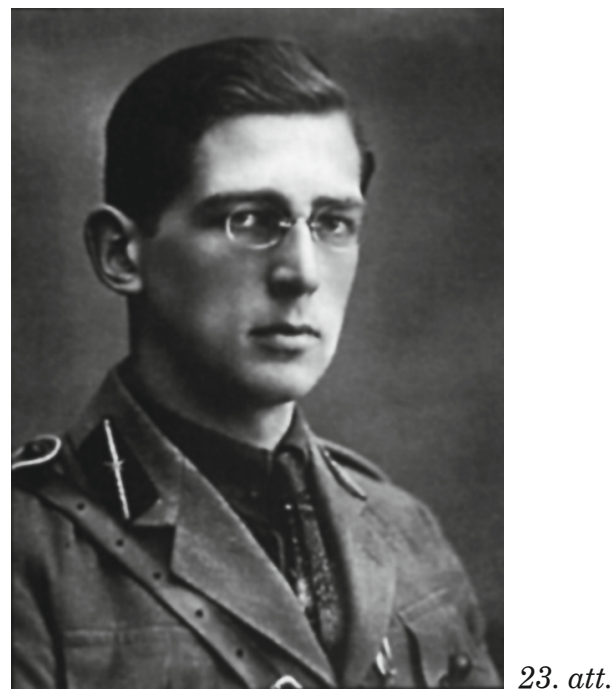

\section{Militārā pārstāvja palīgs Varšavā Gustavs Celmiṇš}

Pasliktinoties Polijas armijas stāvoklim frontē, sarežğìjās arī Latvijas diplomātiskās un militārās pārstāvniecības darbs Varšavā. ${ }^{893}$ M. Hartmanis 13. jūlijā ziṇoja, ka nelielais ziṇojumu skaits saistīts ar pastāvīgu kurjeru trūkumu un to nosūtīšanas dārdzību. Viṇš ziņoja, ka pagaidām nevar ierasties Rīgā, jo "lietas tik drudžainas, ka nepieciešams turēt roku uz pulsa". ${ }^{894}$ Poḷu stāvoklim frontē vēl vairāk pasliktinoties, pārstāvniecības darbinieki Varšavā kḷuva par lieciniekiem poḷu tautas patriotisma vilnim, kas pieauga, Sarkanajai armijai tuvojoties Polijas galvaspilsētai. Sekretāru P. Oliṇu poḷu sievietes kādā kafejnīcā kauninājušas, ka viṇš nav armijā un frontē, kur jābūt katram poḷu vīrietim (pēc pārpratuma noskaidrošanas sievietes atvainojušās). ${ }^{895}$ 7. augustā P. Oliṇš ziṇoja, ka ārvalstu pārstāvniecības izbrauc uz Poznaṇu. Viṇš pats un militārā pārstāvja palīgs leitnants G. Celmiṇš gatavojās palikt galvaspilsētā un "atstāt to pēdējā brīdī reizē ar poḷu valdību". Saskaṇā ar P. Oliṇa vērtējumu stāvoklis bija draudošs, ielās tika rakti ierakumi un uzstādīti dzeloṇdrāšu aizžogojumi, tomēr nekārtīgā atkāpšanās bija beigusies

${ }^{892}$ LCVA, f. 929, ap. 1, b. 364, 1. 22. Interesanti, ka Lietuvas armijā šajā laikā dienēja samērā daudzi latvieši vai latviešu izcelsmes virsnieki. Piemēram, 1920. gada septembrī lietuviešu-poḷu kauju laikā Lietuvas armijas frontes virspavēlnieks bija latviešu izcelsmes ǵenerālleitnants M. Kathe, frontes štāba priekšnieks bija minētais V. Ozols. Lietuvas armijas artilērijas daļās dienēja pulkvedisleitnants A. Jansons utt., taču tam nebija nekāda sakara ar Latvijas valdību un varas iestādēm. - Jankauskas V. Kario kelias. - 269-270, 293 p.

${ }^{893}$ Sīkāk sk.: Jēkabsons Ē. Varšavas kauja - brīnums pie Vislas 1920. g.//Militārais Apskats. - 1995. Nr. 2. - 49.-55. lpp.

${ }^{894}$ LVVA, 6033. f., 1. apr., 24. 1., 48., 51. 1p.

895 Donass F. Politiskos krustceḷos. - 13. lpp. 
un pieauga Polijas armijas pretestība.896 8. augustā uz Poznaṇu aizbrauca daḷa Latvijas pārstāvniecības darbinieku, bet G. Celmiṇš apnēēās palikt "līdz pēdējam", izbraucot "dažas stundas pirms eventuālās lielinieku ienākšanas". Pilsēta gatavojās izškirošajai kaujai. P. Oliṇš un G. Celmiņš uz Poznaṇu devās tikai 15. augusta vakarā un Polijas militārās izredzes vērtēja kā "ne tik tumšas". Nākamajā dienā Polijas armija panāca izškirošo lūzumu karadarbībā un ar kaujām devās uz austrumiem. Tāpēc Latvijas un citas diplomātiskās pārstāvniecības drīz atgriezās Varšavā. ${ }^{897}$

Kara norišu dēl tikai augustā sākās Baltijas valstu konference, kas sākotnēji bija plānota maijā. Rīgā ieradās Polijas, Somijas, Lietuvas, Igaunijas un nedaudz vēlāk - arī Ukrainas Tautas Republikas pārstāvji. Galvenais mērḳis bija militāras aizsardzības savienības izveidošana, kā arī saimniecisku, tiesisku, kultūras, medicīnas un citu jautājumu apspriešana. ${ }^{898}$ Konferenci 6. augustā Rīgas pilī atklāja Latvijas Ministru prezidents K. Ulmanis, bet turpmākās sēdes notika Bulduru viesnīcā. ${ }^{899}$ Darbs noritēja Politiskajā, Juridiskajā, Saimnieciskajā un Kultūras komisijā. Latvijas delegāciju vadīja Z. Meierovics, darbā piedalījās K. Ulmanis, A. Ķeniṇš (30. jūlijā viṇš no Gdan,skas devās uz Latviju, 31. jūlijā iebrauca Liepājā, bet Varšavā atgriezās tikai 1. oktobrī), Rainis, V. Zamuels, K. Kasparsons, P. Radzin̄š un K. Ramats. Polijas delegāciju vadīja L. Vasil̨evskis, tajā ietilpa V. Kamen,eckis, A. Tarnovskis, A. Miškovskis, sūtnis Somijā J. Sokoḷnickis, no 20. augusta arī ǵenerālkonsuls A. Luce-Birks un citi. ${ }^{900}$

Tika izstrādāti vairāki līgumprojekti: par pilsonību, ārzemnieku vienlīdzību civiltiesībās, pilsoṇu optāciju, tirdzniecību un rūpniecību, arbitrāžu, kriminālnoziegumiem, autortiesībām, medicīnas pētījumiem. Nolēma izveidot kopēju propagandas biroju ārzemēs un pastāvīgu dalībvalstu padomi, kā arī sasaukt pasta un dzelzceḷa pārstāvju kongresu. Kopumā pieṇēma 21 saimniecisku rezolūciju, septiṇus vienošanās projektus un 11 konvenciju projektus (arī militārās un politiskās konvencijas). ${ }^{901}$

Tomēr pretrunas dalībvalstu starpā bija nepārvaramas. 16. augustā, kad kaujās pie Varšavas izšķīrās Polijas liktenis, Lietuvas delegācija pieprasīja Jēkabpils un Ilūkstes apriņķa daḷas iekḷaušanu savā valstī līdz Susējas-Dvietes-Daugavas upes līnijai. Z. Meierovics konstatēja, ka "Bulduru apspriede beidzās tāpat kā visas iepriekšējās konferences - ar konstatējumu, ka savstarpēja vienošanās Lietuvas-Latvijas robežas lietā nav diemžēl panākama". ${ }^{902}$ Vēl vairāk sarunas traucēja jau tradicionālās Lietuvas nesaskaņas ar Poliju. Poḷu delegācijas vadītājs L. Vasiḷevskis paziṇoja, ka

\footnotetext{
${ }^{896}$ LVVA, 2574. f., 3. apr., 16. 1., 117. 1p.

897 Turpat, 2574. f., 3. apr., 16. 1., 116. 1p.; 13. 1., 176. 1p.; Donass F. Politiskos krustceḷos. - 13. lpp.

898 Počs K. Sanitārā kordona... - 101. lpp.; Сегодня. - 1920. - 11 авг.

${ }^{899}$ Brīvā Zeme. - 1920. - 8. aug.; Vīlands R. Kā būtu, ja būtu//Jūrmala. - 1990. - 19. apr.

900 Brīvā Zeme. - 1920. - 3., 20. aug.; Kurzemes Vārds. - 1920. - 1. aug.; APAN, Djarjusz M. S. Kossakowskiego, T. IV, cz, 2, s. 69; Gazeta Warszawska. - 1920. - 2 paźdz. Sk. arī: Klīve Ā. Latvijas neatkarības gadi. Latvijas politiskā veidošanās un augšana. - B. v., 1976. - 93.-102. lpp.

901 Skrzypek A. Związek... - S. 68.

902 Počs K. Sanitārā kordona valgos. - 104., 106. 1pp.
} 
lietuviešu nostāja kavē konvencijas noslēgšanu, ${ }^{903}$ bet delegācijas loceklis V. Kameneckis uzskatīja, ka tā bijusi konferences neveiksmes galvenais iemesls. Lietuvas valdības instrukcijā delegācijai bija īpaši norādīts piekopt mierīgu kompromisa politiku, neizrādīt îpašu iniciatīvu, bet atstāt to "rīkotājiem", un uzturēt pastāvīgus sakarus ar Antantes valstu pārstāvjiem, ippaši angḷiem. Ja angḷu un franču uzskati kādā jautājumā atšķirsies, jāpieṇem angḷ nostāja, necenšoties radìt iespaidu, ka lietuvieši ir spēcīgā vinuu ietekmēe. ${ }^{904}$ Pārējās delegācijas pat bija apsvērušas iespēju noslēgt konvenciju bez Lietuvas piedalīšanās, taču atturējušas bažas, ka tādējādi Lietuva nonāktu vēl spēcīgākā Vācijas un Padomju Krievijas ietekmē.905 Polijas armijas G̦enerālštābs 15. augustā konstatēja, ka, neraugoties uz Rīgā parakstīto Latvijas un Padomju Krievijas miera līgumu, tieši Latvija un Igaunija izrāda lielāku vēlmi noslēgt militāru konvenciju, kamēr Lietuva oficiāli prasa neiekḷaut šo jautājumu darba kārtībā (lai gan piekrīt par to vest slepenas sarunas) un Somija neizrāda nekādu aktivitāti. Līdz ar to sarunām Bulduros lielā mērā bija "apolitisks" raksturs. ${ }^{906}$

Notikumi frontē ietekmēja arī konferences norisi. Vēsturnieks A. Skšipeks bija secinājis, ka "izstrādātajā Baltijas savienības projektā neapšaubāmi dominē Polijas intereses kā tās militāro panākumu sekas".907 26. augustā V. Kameņecka rīkotajā rautā piedalījās arī Satversmes sapulces priekšsēdētājs J. Čakste, K. Ulmanis, Z. Meierovics un citi ievērojami Latvijas politiki un militārpersonas, kā arī Francijas un Itālijas diplomāti, konferences dalībnieki, vietējo poḷu pārstāvji, korespondenti, angḷu laikraksta "Times" fotokorespondents u. c. Sarunas galvenokārt skāra notikumus poḷu-padomju frontē, un poḷu diplomātu un politiḳu noskaṇojums bija l̦oti pacilāts. ${ }^{908}$

Lietuvieši sākotnēji vispār noraidīja domu par militāras savienības izveidi, jo Lietuvas miera līgums ar Padomju Krieviju paredzēja, ka tai tiek nodotas teritorijas, par kurām norisa strīds ar Poliju. Vēlāk lietuvieši piedāvāja izveidot savienību no valstīm, kas jau noslēgušas mieru ar Krieviju. Polijas delegāti paziṇoja, ka gadījumā, ja Lietuvas nostājas dēḷ netiks noslēgta konvencija ar visu dalībvalstu piedalīšanos, Polija paturēs sev brīvas rīcības tiesības attiecībā pret šo valsti. ${ }^{909}$ Antantes lielvalstu spiediena dēḷ Lietuvas delegācija galu galā piedalījās militārās konvencijas projekta izstrādāšanā. Tas paredzēja izveidot vienotu virspavēlniecību jau miera laikā, bet kara gadījumā - īpašu militārpolitisku padomi. ${ }^{910} 30$. augustā tika parakstīts politiskās savienības līguma projekts (Lietuvas pārstāvji to parakstīja ar vairākiem nosacījumiem), kas bija jāratificē līdz 15. decembrim un kas stātos spēkā arī tad, ja kāda no valstīm to neratificētu (tika piel̦auts, ka Lietuva varētu palikt ārpus

\footnotetext{
903 Jaunākās Ziṇas. - 1920. - 23. aug.

904 LCVA, f. 383, ap. 7, b. 72, 1. 53.

905 Kamieniecki W. Polityka Bałtycka//Przegląd Współczesny. - 1922. - T. XVI. - S. 271.

906 Sąsiedzi wobec wojny. - S. 253.

907 Skrzypek A. Związek... - S. 69.

${ }^{908}$ Brīvā Zeme. -1920. - 28. aug.

909 Lietuva. - 1920. -3 rugs.

${ }^{910}$ Počs K. Sanitārā kordona valgos. - 108. lpp.
} 
savienības). 4. septembrī konference beidza darbu, bet 7. septembrī uz pirmo sēdi sanāca Baltijas valstu pilnvaroto pārstāvju dome. Tā darbojās divus gadus, tai nebija lielas nozīmes, un Lietuva darbā nepiedalījās. Neviena valsts līgumu neratificēja, kaut arī visas oficiāli izteica apmierinājumu ar sarunu rezultātiem Bulduros. ${ }^{911}$

Tieši konferences laikā atkal saasinājās Latvijas un Lietuvas attiecības. 30. augustā Lietuvas valdība, atbildot uz 2. jūlija Latvijas Satversmes sapulces lēmumu par noteiktu ārzemnieku kategoriju izraidīšanu no valsts, deva rīkojumu: 24 stundu laikā Latvijas pilsoniem (pārsvarā turīgiem zemniekiem) atstāt Lietuvu. Īpašumu izvest viniem bija aizliegts (kā bija teikts Ārlietu ministrijas pārskatā, netika izraidīti lietuviešu zemnieki, bet galvenokārt citu tautību Lietuvas pilsoṇi no pilsētām). Kad Latvijas valdības prasība apturēt izraidīšanu palika bez atbildes, K. Ulmanis un iekšlietu ministrs A. Bergs 10. septembrī parakstīja paziņojumu par visu lietuviešu izraidīšanu 24 stundu laikā (līdz 12. septembra beigām) no Rīgas un Liepājas ${ }^{912}$ (šādi rīkoties tā nedomāja, kaut arī Liepājā vietējās varas iestādes pēc savas iniciatīvas pat uzsāka izraidīt Lietuvas konsulāta darbiniekus ${ }^{913}$ ). Nākamajā dienā - pēc tam, kad Lietuvas valdība bija paziņojusi par Latvijas pilsoṇu izraidīšanas apturēšanu un apsolījusi noslēgt ar Latviju īpašu konvenciju par pilsoṇu tiesībām, bet Lietuvas diplomātiskā pārstāvniecība Latvijā bija apsolījusi, ka visi izraidìtie drīkst atgriezties Lietuvā - A. Bergs atcēla 10. septembra rīkojumu un savstarpējā izraidīšana beidzās. ${ }^{914}$ Tiesa gan, lietuviešu robežsargi turpināja izraidìt no valsts atsevišķus Igaunijas pilsoṇus, vienkārši bez brīdinājuma pārlaižot viṇus pāri Latvijas robežai. Tādējādi par vinu nogādāšanu dzimtenē tālāk bija jārūpējas Latvijas iestādēm. Arī tas izraisīja šo iestāžu neapmierinātību. ${ }^{915}$

Latvijas armijas Zemgales divīzijas komandieris 21. augustā pavēlē konstatēja, ka Ilūkstes apriņķī Lietuvas armija padara iedzīvotāju dzīvi "smagu un nepanesamu", ignorē Subates latviešu komandantu, tiek "dzìta propaganda" un lietuviešu nodalas virzās "arvien dziḷāk Kurzemes iekšienē"916. Skaidrs, ka tas notika ar valdības ziṇu. Sekoja asi vārdi, piemēram, "leišu jūgs arvien smagāk gulstas uz vietējiem latviešiem", "Kurzemes ražai draud liktenis pāriet mūsu nekaunīgo kaimiṇu klētīs" un "tāpēc mūsu valdība nolēmusi, ka mums pašiem jāapsargā savi brāḷi Kurzemē pret visu, ko viṇi tagad cieš. Mūsu varonīgajiem karavīriem jāieved miers un kārtība visā Kưzemē [..]. Mēs negribam karot, bet tikai darīt galu

\footnotetext{
911 Skrzypek A. Związek Bałtycki. - S. 66-68.

912 Valdības Vēstnesis. - 1920. - 10. sept.

913 LCVA, f. 384, ap. 3, b. 73, 1. 201.

${ }^{914}$ LVVA, 3601. f., 1. apr., 291. 1., 35. 1.; 2574. f., 4. apr., 71. 1., 337. 1p. CAW, II ND WP, t. 188; Valdības Vēstnesis. - 1920. - 13. sept. 1920.-1921. gadā no Latvijas uz Lietuvu pārcēlās ievērojams skaits lietuviešu un lielākā daḷa to darīja brīvprātīgi (sk.: Kurzemes Vārds. - 1920. - 27. marts, 19. maijs, 11. aug., 28. nov.; 1921. - 7. apr.).

915 LVVA, 2574. f., 3. apr., 77. 1., 5. lp. (iekšlietu ministra biedra 1920. g. 21. sept. ziṇojums Ārlietu ministrijai).

916 Domāta bijušās Kurzemes guberṇas teritorija.
} 
mūsu kaimiṇu - leišu bezkaunīgajai uzbāzībai”. 12. Bauskas kājnieku pulks, Zemgales divīzijas atsevišķais eskadrons un artilērijas baterija saṇēma pavēli 22. augustā pie Nīcgales pārcelties pāri Daugavai un atspiest lietuviešus līdz Asares-Bebrenes (pa lielcel̦)-ezeru (starp Bebreni un Daugavu)-Daugavas līnijai. Tika pavēlēts neuzsākt "kara darbību", vienīgi nepakḷaušanās gadijumā lietuviešus atbruṇot un nosūtīt "uz Lietuvu". ${ }^{917} 24$. augustā tomēr notika nelielas sadursmes, bet 26.-27. augustā 12. pulks pavēli izpildīja, atspiežot lietuviešus, kas bija ievērojami pārgājuši demarkācijas līniju. 27. augustā apvidū dzīvojošajiem zemniekiem tika paziņots, ka no šīs dienas viṇi dzīvo Latvijā. ${ }^{918}$ 25. augustā uz Kauṇu izbrauca armijas Virspavēlnieka štāba pārstāvis J. Ceplītis un Zemgales divīzijas komandieris O. Dankers, lai vienotos par demarkācijas līniju, tādēḷ 12. pulks saṇēma pavēli "nekādu agresīvu darbību pret Lietuvu nesākt". ${ }^{19}$ Par stāvokḷa nopietnību, kā arī Latvijas - Lietuvas saspīlētajām attiecībām šajā laikā liecina Zemgales atseviškā eskadrona kareivja Z̆. Strautnieka atminas. Viṇš apgalvo, ka pirms akcijas uzsākšanas tās vadītājs - 12 . Bauskas pulka komandieris pulkvedis K. Kūḳis - ierindā nostādītajiem karavīriem teicis „l,oti kareivīgu runu”, no kuras atmin,ā Ž. Strautniekam palicis rīkojums „šaut tieši vēderā”. ${ }^{920}$

Saskaṇā ar J. Ceplīša un O. Dankera 27. augustā Kauṇā noslēgto vienošanos ar Lietuvas apsardzības ministru K. Žuku robežlīnija bỉja lielcel̦š no Subates uz Lašiem un Ilūksti, bet Kalkūnes dzelzcel̦a staciju varēja izmantot arī lietuvieši. ${ }^{921}$ Lietuvas virspavēlniecība solīja nekavējoties dot attiecīgus rīkojumus. 2. septembrī Lietuvas militārais pārstāvis Rīgā K. Talats-Kelpša, kas jūnijā bija šajā amatā nomainījis V. Natkeviču, tika informēts, ka nākamajā dienā Latvijas armija ieṇems Subates ziemeḷu daḷu, kā arī Lašu un Pilskalnes pagastu. Tas tika paziņots arī Subatē izvietotās lietuviešu rotas komandierim, kurš atbildēja, ka uzskatīs šādu akciju par kara sākumu. 3. septembrī no rìta lietuvieši ieñēma pozīcijas pie Subates, bet, tuvojoties latviešu bataljonam kiēēès, atkāpās no pilsētas. Subatē tika sagūstīts 21 lietuviešu karavīrs, bet citur - vēl divi karavīri (nākamajā dienā viṇus atlaida un atdeva ieročus). Vairākas stundas pēc tam sākās apšaude, kurā viens Lietuvas armijas karavīrs krita un divi tika ievainoti. Pēcpusdienā pēc 12. pulka komandiera sarunām ar lietuviešu komandieri lietuvieši izvietojās pilsētas dienvidu daḷā. 3. septembrī latvieši ieṇēma vēl Pilskalni, bet pretestības dēl nevarēja ieiet Lašos. Tikai vakarā Lietuvas militārais pārstāvis Rīgā informēja, ka štābs Kaunā pavēlējis atkāpties, taču vietējie komandieri joprojām noliedza, ka pavēle saṇemta. 4. septembra naktī lietuvieši no Lašiem apšaudīja latviešu rotas novietni un 12. pulka komandieris K. Ķūķis paziņoja, ka, šādiem gadijumiem atkārtojoties, viṇš Lašus "ar zemi sajauks" (divīzijas štābs gan pavēlēja censties neiesaistīties sadursmēs). Tika atbrunoti vairāki lietuviešu sargposteṇi. Tikai 4. septembra vakarā pēc ilgākām sarunām lietuvieši

\footnotetext{
917 LVVA, 1527. f., 1. apr., 617. 1., 34. 1p.

${ }^{918}$ LCVA, f. 384, ap. 2, b. 139, 1. 8; Andersons E. Latvijas vēsture 1914-1920. - 604. 1pp.

919 LVVA, 1490. f., 1. apr., 404. 1., 153. 1p.

920 Strautnieks Ž. Kāda jātnieka atmiṇas//Kara Invalīds. - 1985. - Nr. 30. - 60. lpp.

${ }^{921}$ LCVA, f. 384, ap. 3, b. 15, 1. 47.
} 
evakuēja savu komandantūru, bet 5. septembrī atkāpās pilnībā. ${ }^{922}$ Savukārt 2. Ventspils pulks 6. septembrī ar viltu panāca lietuviešu aiziešanu no Demenes pagasta daḷas un Borovkas pagasta. ${ }^{923}$ Eglaines stacijā joprojām turpinājās darbība, kas izraisīja Latvijas puses nepatiku. Piemēram, gūstekṇi demontēja un izveda dzelzceḷa iekārtas utt. ${ }^{924}$ Starp gūstekniem bija arī apmēram 200 latviešu - bijušo sarkanarmiešu, kurus 11. septembrī lietuvieši atteicās nodot Latvijas varas iestādēm (lai aizvestu latviešu gūstekṇus, 6. septembrī Eglainē ieradās īpašs Latvijas ešelons, kura komandierim lietuvieši apzināti meloja, ka latviešu gūstekṇu Eglainē vairs nav). ${ }^{925}$ Eglaines lietuviešu komandanta izveidota komisija rūpīgi uzskaitīja Lietuvas armijas piederumus (vienu uniformu, durkli, šauteni, nedaudz auzu u. c.), ko 27.-29. augustā un 3.-5. septembrī bija paṇēmuši latviešu karavīiri. ${ }^{926}$ Savukārt Latvijas armijas daḷu vadība pierobežā turpināja izrādīt aktīvu interesi par "Kurzemes okupētajām daḷām”. 9. oktobrī lietuviešu pārvaldītajā teritorijā kā izlūks dziḷi tika iesūtīts civilās drēbēs pārǵērbts 3. Jelgavas kājnieku pulka virsleitnants, kurš, uzdodamies par bēgli, noskaidroja apstākḷus, iedzīvotāju noskaṇojumu un atgriezās pulkā tikai 13. oktobrī. ${ }^{927}$

1920. gada septembrī Latvijas diplomātiskie un militārie pārstāvji no Kauṇas pārcēlās uz Viḷnu, ko saskaṇā ar miera līgumu Sarkanās armija bija atdevusi Lietuvai (tas notika vienīgi tad, kad bija pasliktinājies Sarkanās armijas stāvoklis frontē un izzudusi cerība par Polijas armijas sakaušanu). Pilsētas nonākšanu lietuviešu rokās Ārlietu ministrija nevērtēja kā lielu ieguvumu (mazā lietuviešu skaita dēḷ - "apakšzemes klints, no kuras Lietuvas kuǵim l,oti jāsargās"). ${ }^{928}$ Septembra beigās Latvijas un Lietuvas pārstāvji Rīgā, tiekoties ar Anglijas misijas vadītāju Baltijā S. Talentsu, vienojās par škīrējtiesas izveidošanu Lielbritānijas pārstāvja vadībā (šajā postenī tika iecelts skotu profesors Dž. Simpsons) ${ }^{929}$ un 28. septembrī parakstīja līgumu starp Latvijas un Lietuvas valdību par galīgu robežu noteikšanu. ${ }^{930}$ Jāpiezīmē, ka briti savā ārpolitikā attiecībā pret visu Austrumeiropas reǵionu, arī Baltiju, 1920. gada vasarā bija piedzīvojuši kārtējo attīstību. Jūlijā bija sācies Sarkanās armijas uzbrukums Polijai. Tas apstiprināja angḷu bažas par Polijas nestabilitāti un draudiem visai Eiropai, kā arī par britu politiskajām un saimnieciskajām interesēm. Britu valdība centās panākt situācijas atrisinājumu un, uzsverot savu nozīmi reǵionā, pēc eventuālās pamiera noslēgšanas padomju-poḷu frontē Londonā sasauca plašu konferenci, kurā piedalījās Padomju Krievija, Polija, Baltijas un Kaukāza valstis. Konferencei bija jānoskaidro un jānoregulē attiecības starp Maskavu un pārējām

\footnotetext{
${ }^{922}$ LVVA, 3601. f., 1. apr., 291. 1., 66. 1p.; 6033. f., 1. apr., 25. 1., 34.-43., 54.-55., 59. 1p.; 1490. f., 1. apr., 404. 1., 19. 1p.; LCVA, f. 384, ap. 2, b. 139, 1. 8.

923 2. Ventspils pulks. - Liepāja, 1936. - 347. lpp.

${ }^{924}$ LVVA, 6033. f., 1. apr., 61. 1., 15. 1p.

925 Turpat, 3601. f., 1. apr., 469. 1., 431., 433. 1p.; 2574. f., 3. apr., 78. 1., 169.-170. 1p.

${ }^{926}$ LCVA, f. 384, ap. 2, b. 139, 1. 3.

${ }^{927}$ LVVA, 2574. f., 3. apr., 77. 1., 6. 1p.

928 Turpat. 4. apr., 71. 1., 233. 1p.

929 Butkus Z. Great Britain's ... - P. 362-363.

${ }^{930}$ Likumu un valdības rīkojumu krājums. - 1920. - 8. dec.
} 
minētajām valstīm. ${ }^{931}$ Militārpolitisku apstākḷu dēḷ nodoms neīstenojās, taču tas iezīmēja kārtējo britu gājienu, kas atškīrās no frančiem, - briti diezgan haotiski meklēja arī savu (pirmkārt, saimniecisko) attiecību noregulēšanas iespējas ar Padomju Krieviju un vēlējās, lai šajās attiecībās Baltijas valstīm un Polijai būtu katrai sava, nedaudz atšķirīga, taču būtiska nozīme. Militārie notikumi pie Varšavas ietekmēja britu politiku pret Poliju un Austrumeiropu kopumā - tie skaidri liecināja, ka atbalsts, ko viṇi bija snieguši poḷiem, baltiešiem un citiem, var kḷūt bīstams pašiem britiem. Tādēḷ kopš šī laika briti vēl vairāk nekā iepriekš nevēlējās uzṇemties reǵionā nekādas saistības. ${ }^{932}$

Katrā ziṇā 1920. gada rudens sākumā stāvoklis reǵionā bija daudzmaz nostabilizējies un konference Bulduros veicināja tuvināšanos LatvijasPolijas attiecībās. 18. septembrī P. Oliṇš no Varšavas ziṇoja, ka Rīgā lieliski organizētā konference un latviešu inteliğence atstājusi uz poḷu un ukraiṇu pārstāvjiem labu iespaidu. Polijas Ārlietu ministrijā viṇam pat solīta drīza Latvijas atzǐšana "de iure" (ne vēlāk par 15. decembri - dienu, kad bija jābūt ratificētam politiskās konvencijas projektam). 25. septembrī P. Oliṇš ziṇoja, ka "tagadejjais moments attiecībās ir viens no vislabākajiem, lai panāktu atzīšanu „de iure”, jo ar kopīgās robežas pazaudēšanu netiek vairs cilāts Augškurzemes jautājums", bet Latgales muižnieku pastāvīgā žēlošanās nacionāldemokrātu presē neiespaido Polijas valdību. ${ }^{933}$

Savukārt A. Miškovskis 1920. gada jūlijā un augustā Rīgā bija aktivizējis izlūkdarbību pret Padomju Krieviju (tas notika saskaṇā ar pavēli no Varšavas; viṇa izveidotais ağentūras tīkls "Dor" viṇam bija piegādājis ziṇas, un Polijas armijas vadība tika informēta par vairākiem Sarkanās armijas uzbrukuma virzieniem augusta sākumā). ${ }^{934}$ 29. septembrī Miškovskis ziṇoja, ka, pateicoties "arvien labākajām attiecībām", panācis Latvijas armijas Virspavēlnieka štāba Ārējās izlūkošanas nodaḷas piekrišanu nosūtīt uz Maskavu poḷu izlūkdienesta aǵentu kā Latvijas diplomātiskās pārstāvniecības darbinieku ar Latvijas diplomātisko pasi, lai viṇš varētu stāties sakaros ar turienes Polijas aǵentiem un pat "saṇemtu savā rīcībā speciālu izlūku grupu", ko slepeni vadītu (šādā ceḷā iegūtie dati tiktu nosūtīti kā Latvijas diplomātiskais pasts, un Latvijas puse tādēl bija gatava palielināt kurjeru skaitu ar noteikumu, ka Polija pati maksātu šādiem "saviem" kurjeriem algu). ${ }^{935}$ Nav izdevies rast apstiprinājumu šì nodoma îstenošanai. Šķiet, ka tas īstenots netika. Tomēr abu valstu izlūkdienestu sadarbība turpinājās (1921. gada 26. janvārī ziṇojumā no Rīgas A. Miškovskis uzsvēra, ka izlūku nosūtīšana caur Latviju uz Krieviju bez Latvijas izlūkdienesta ziṇas ir sarežğìta un vēlams to veikt saziṇā ar latviešiem). ${ }^{936}$ 1920. gada oktobra sākumā Latvijas valdība, pamatojoties uz konferencē nospraustajiem darbības virzieniem, deva pagaidām gan

\footnotetext{
${ }^{931}$ Latvijas Kareivis. - 1920. - 18. jūl.

932 Sīkāk sk.: Sundbäck E. Finland in British Baltic Policy. British political and economic interests regarding Finland in the aftermath of the First World War. 1918-1925. - Saarijärvi, 2001. - P. 193.

933 LVVA, 2575. f. 15. apr., 12. 1., 38., 41. 1p.

934 Pepłoński A. Wywiad polski na ZSSR 1921-1939. - S. 26; Pepłoński A. Wywiad w wojnie polsko bolszewickiej 1919-1920. - S. 254-255.

935 AAN, Attachaty, A - II, 165/1, k. 144-145.

936 Pepłoński A. Wywiad polski na ZSSR 1921-1939. - S. 138.
} 
vienīgi formālu atḷauju poḷu karakuǵiem izmantot Latvijas ostas atpūtai un remontam, bet teritoriālos ūdeṇus - mācībām (ar noteikumu, ka Polija piešķirs tādas pašas tiesības Latvijas kuǵiem savās ostās; novembrī Polijas puse deva savu piekrišanu $)^{937}$ un A. Miškovskis noslēdza attiecīgu vienošanos ar P. Radzinu. ${ }^{938}$

Saskaṇā ar Bulduru konferences lēmumiem 18.-30. oktobrī Rīgā notika Latvijas, Polijas, Igaunijas, Somijas un Ukrainas Tautas Republikas armijas virspavēlniecības pārstāvju apspriede, lai izstrādātu militārās konvencijas projektu, ${ }^{939}$ kas vēlāk būtu jāapstiprina šo valstu valdībai. Latviju apspriedē pārstāvēja P. Radziṇš un pulkvedis-leitnants K. Ramats, Poliju A. Miškovskis un kapteinis J. Stankēvičs. Izstrādātais projekts paredzēja kopdarbību Padomju Krievijas uzbrukuma gadījumā kādai no dalībvalstīm, kopīgu virspavēlniecību kara gadījumā, vienotas militārās izglītības sistēmas ieviešanu utt. Apspriedei tuvojoties nobeigumam, Rīgā ieradās Polijas G̦enerālštāba 2. (Izlūkošanas) daḷas priekšnieks pulkvedis I. Matuševskis, lai ar Baltijas valstu armiju štābiem saskaņotu izlūkošanas darbu pret Padomju Krieviju un inspicētu A. Miškovska neoficiāli vadīto poḷu izlūkdienesta tīkla veidošanu Latvijā. ${ }^{940}$ Viṇš uzṇēmās arī poḷu ekspertu darba vadību militāro pārstāvju padomē, kurā notika sarunas starp Rīgā iebraukušajiem ārvalstu virsniekiem un Latvijas armijas vadību. Nav pilnībā skaidrs, vai I. Matuševskim bija J. Pilsudska pilnvaras, taču viṇa darbība nebija saskaṇota ar ārlietu ministru E. Sapehu, kurš uzskatīja, ka militāra konvencija var tikt noslēgta vienīgi pēc politiskās konvencijas ratificēšanas. Savukārt I. Matuševskis paziņoja, ka militāro līgumu var noslēgt neatkarīgi no politiskās konvencijas ratificēšanas. Šis paziṇojums izraisīja konfliktu pašā Polijā. ${ }^{941}$ Arī Latvijas valdība nebija gatava slēgt militāro konvenciju ar Poliju bez politisko attiecību noregulēšanas. Kārtējo reizi izpaudās tendence, kas pastāvēja jau no 1919. gada - abu pušu militārās aprindas izrādīja ievērojami lielāku vēlmi savstarpēji tuvināties nekā valdības un politiķi. To noteica militārpersonu īpatnējās intereses.

Rudenī, lielā mērā pateicoties starptautiskajam stāvoklim, turpināja pieaugt Latvijas nozīme reǵionālo nesaskaṇu risināšanā. 17. augustā Minskā sāktās Polijas un Padomju Krievijas miera sarunas nedeva rezultātus padomju delegācijas vadìtāja - poḷu izcelsmes ${ }^{942}$ latviešu komunista

937 AAN, Kod, t. 2, k. 300-302.

938 Turpat, Sztab Główny, t. 616/131, k. 437-438. Faktiski vienošanās netika izmantota, jo abu valstu kara flotes tikai veidojās. Poḷu puse līgumu atcerējās tikai 1933. gadā, kad militārais atašejs Latvijā mēǵināja noskaidrot, vai tas nevar būt par pamatu plānotajai Polijas Kara flotes Zemūdeṇu diviziona vizītei Latvijas ūdeņos.

939 Sąsiedzi wobec wojny 1920 roku. - S. 245-247.

940 Pepłoński A. Wywiad polski na ZSSR 1921 - 1939. - S. 178.

${ }^{941}$ Skrzypek A. Związek... - S. 70-72.

942 J. Daniševska vecaistēvs - poḷu muižnieks Ādams Daniševskis - par piedalīšanos 1830.-1831. gada poḷu sacelšanās norisē tika izraidīts no Polijas uz Kurzemes guberņu. - Šteins V. Mēs vērām vārtus. - Rīga, 1987. - 64. lpp. 
J. Daniševska - augsto prasību dēl. Polijas puse nebija apmierināta ar pastāvīgo sakaru traucēšanu, kā arī drošības trūkumu un citiem darba apstākḷiem Minskā. Tādēl 26. augustā Polija izteica oficiālu protestu, ${ }^{943}$ bet nākamajā dienā Polijas Valsts aizsardzības padome nolēma pieprasīt pārcelt sarunas uz Rīgu un pienēma attiecīgu Latvijas valdības piedāvājumu. Padomju Krievija būtībā piekrita sarunu vietas maiṇai uz neitrālu valsti, taču sākotnēji ieteica Igaunijas pilsētu Tērbatu vai Tallinu, jo vēl nebija ratificēts Latvijas-Padomju Krievijas miera līgums. Tomēr Polijas Ārlietu ministrija tam nepiekrita un 2. septembrī saṇēma oficiālu Maskavas piekrišanu pārcelt sarunas uz Rīgu, taču vienīgi ar plašām Latvijas valdības garantijām par padomju delegācijas locekḷu un sūtījumu neaizskaramību, pārvietošanās brīvību, sakaru nodrošināšanu utt. Tajā pašā dienā Polijas ārlietu ministrs uzdeva savam pārstāvim Rīgā lūgt šādas garantijas Latvijas valdībai, ${ }^{944}$ kas 3. septembrī piekrita, kaut arī "garantijas bija diezgan smagas". ${ }^{445}$

13. septembrī Rīgā ieradās Padomju Krievijas un Padomju Ukrainas delegācija 44 cilvēku sastāvā ar A. Jofi priekšgalā, bet 16. septembrī - Polijas delegācija (80 cilvēki) ar ārlietu viceministru J. Dombski priekšgalā (Liepājā tā bija iebraukusi ar ang̣̣u torpēdkuğiem no Gdaṇskas). ${ }^{946}$ Ieradās arī dažādu valstu preses korespondenti. Poliju vien pārstāvēja deviṇi dažādu laikrakstu korespondenti, kas informēja Polijas sabiedrību arī par Latvijas vēsturi, sabiedrisko iekārtu, saviem iespaidiem, kas gūti Liepājā un Rīgā, kā arī sniedza Polijas un Latvijas attiecību analīzi. ${ }^{947}$ Visi poḷu korespondenti īpaši uzsvēra, ka viṇus laipni uzṇēmušas Latvijas varas iestādes, sākot ar ierašanos Liepājā, kur kug̣us sagaidīja vietējais Polijas konsuls V. Lopato, ${ }^{948}$ Liepājas prefekts un Ārlietu ministrijas pārstāvis. Liepājā tika ierīkots lidlauks ("aeroplānu stacija"), kurā turpmāk nolaidās poḷu lidmašinas ceḷā uz Rīgu un no tās. ${ }^{949}$

Latvijas puse pilnībā apzinājās, ka rīkot poḷu-padomju sarunas Rīgā ir izdevīgi. L. Sēja rakstīja, ka "pēdējā izvēršas par pašu svarīgāko politisko centru Austrumeiropā, caur šo mēs izdarām svarīgu pakalpojumu abām valstīm, kas nostiprina attiecības un uzliek viṇām pret mums zināmus pienākumus".

\footnotetext{
943 Dokumenty z dziejów polskiej polityki zagranicznej... - S. 107.

944 Kurjer Poranny. - 1920. - 28, 30 sierp., 3 wrz.

${ }^{945}$ LVVA, 2575. f., 15. apr., 2. 1., 35. lp.; Brīvā Zeme. - 1920. - 5. sept.

${ }^{946}$ Brīvā Zeme. - 1920. - 14., 17. sept. Polijas delegācijā ietilpa lielāko Seima frakciju pārstāvji: S. Grabskis, N. Barḷickis, V. Kerņiks, A. Mečkovskis, L. Vaškēvičs, M. Vihḷiṇskis, diplomātiskie pārstāvji V. Kameņeckis un L. Vasiḷevskis, Ģenerālštāba priekšnieka vietnieks ğenerālis M. Kuḷiņskis, nesen par majoru paaugstinātais kara atašejs A. Miškovskis, vēl vairākas militārpersonas (arī Krāslavas muižas īpašnieka dēls poručņiks L. Plāters-Broels, kurš oktobrī Rīgas komandantūrā lūdza ațlauju apraudzīt sava tēva īpašumu) u. c. - AAN, Attachaty, A - II, 81/2, k. 1; CAW, II ND WP, t. 194.

${ }^{947}$ Kurjer Polski. - 1920. - 4 paźdz.; Robotnik. - 1920. - 28 wrz., 30 paźdz., 3, 6 list.; Kurjer Lwowski. 1920. - 2 paźdz.

948 1919. gada ruden̄̄ Liepājā iekārtotā Polijas konsulārā aǵentūra 1920. gada septembrī tika pārveidota par konsulātu. No 1919. gada rudens Polijas goda konsulārā aǵentūra darbojās Rīgā ar Tautas Padomes locekli J. Salcēviču goda konsula amatā, bet 1920. gada februārī Polijas goda konsulāts strādāja arī Daugavpilī (advokāts S. Sirevičs). - Kurzemes Vārds. - 1920. - 18. sept.; Gazeta Warszawska. - 1920. - 22 marzec. Savukārt Latvijas konsuls Varšavā A. Jākobsons darbu uzsāka 1920. gada oktobra beigās. - Kurzemes Vārds. - 1920. - 23. okt.

${ }^{949}$ Kurzemes Vārds. - 1920. - 22. sept.
} 
Viṇš atzina, ka daudzie ārzemju žurnālisti popularizē Latviju pasaulē. ${ }^{950}$ Tas atbilda patiesībai. Vēl pirms sarunu sākuma Z. Meierovics pieñēma ārzemju žurnālistus un informēja tos par Latvijas ārpolitisko stāvokli, kā arī norādīja uz Baltijas valstu savienības veidošanas nepieciešamību, ṇemot vērā Krievijas un Vācijas imperiālisma radītos draudus reǵiona drošībai. ${ }^{951}$

21. septembra pēcpusdienā Melngalvju nama zālē Z. Meierovics svinīgi atklāja pirmo poḷ-padomju miera sarunu sēdi ar runu, kurā uzsvēra miera nepieciešamību Eiropai. Pēc J. Dombska un A. Jofes atbildes runas Latvijas pārstāvji atstāja zāli. ${ }^{952}$ Turpmākās sarunu sēdes notika Bulduros, bija garas un sarežğìtas, kā to jau 20. septembrī bija paredzējis L. Sēja. ${ }^{953}$ 12. oktobrī tika parakstīts pamiers, kurš stājās spēkā 18. oktobrī, bet sarunas ar pārtraukumiem turpinājās vēl vairākus mēnešus. Polijas-Padomju Krievijas un Padomju Ukrainas vai t. s. Rīgas miera līgums tika parakstīts Melngalvju namā 1921. gada 18. martā. ${ }^{954}$ Beidzot arī visā Austrumeiropā tika pārtraukta karadarbība, kas faktiski bez pārtraukuma šeit bija ilgusi no 1914. gada. Līdz ar to tieši Latvijas galvaspilsētā pilnībā beidza veidoties Versaḷas sistēma, kas bija pastāvējusi visu starpkaru posmu un ko pamatoti var dēvēt par Versaḷas-Rīgas sistēmu (šo terminu ieviesis latviešu vēsturnieks A. Stranga).

\section{Latvija un Viḷnas jautājums}

Jau 1920. gada 9. un 10. septembrī Latvijas valdība mēǵināja panākt Polijas un Lietuvas attiecību noregulējumu, jo abas no 2. septembra faktiski atradās karastāvoklī. Tas tika darīts, piedāvājot starpniecību un sarunu vietu Rīgā. Polijas ārlietu ministrs E. Sapeha pateicās un informēja, ka Polijas un Lietuvas valdība jau vienojušās sākt sarunas Kalvarijā. Arī Lietuvas puse Latvijas priekšlikumu novērtēja atzinīgi, ${ }^{955}$ kaut arī kopumā jāatzīst, ka tas šajā situācijā bija diezgan nesekmīgs Latvijas starpniecības mēǵinājums (cita starpā tā mērḳis bija celt Latvijas starptautisko prestižu). Kalvarijā poḷu-lietuviešu sarunas bija bez panākumiem, taču Tautu savienības un Rietumu lielvalstu spiediena dēḷ tās atsākās 29. septembrī Suvalkos, kur 7. oktobrī tika parakstīta vienošanās. ${ }^{956}$ Līgums fiksēja pagaidu demarkācijas līniju starp Polijas un Lietuvas armiju, netieši atstājot lietuviešu kontrolētajā teritorijā arī galveno nesaskaṇu cēloni - Viḷnu. Likās, ka konflikts tuvojas

\footnotetext{
${ }^{950}$ LVVA, 2575. f., 15. apr., 2. 1., 35. 1p.

951 Gazeta Poranna. - 1920. - 21 wrz.

952 Brīvā Zeme. - 1920. - 22. sept.; Przegląd Wieczorny. - 1920. - 23 wrz.; Robotnik. - 1920. 1 pazdz.

953 LVVA, 2575. f., 15. apr., 2. 1., 35. lp.

954 Pobóg - Malinowski W. Najnowsza hisotoria polityczna... - S. 372; Robotnik. - 1920. - 18 list., 31 grudz.; Kurjer Poranny. - 1920. - 16 pazdz. Paralēli oficiālajām miera sarunām Rīgā notika arī dažādas konsultācijas starp Poliju un Padomju Krieviju (piemēram, starp abu pušu Sarkanā Krusta pārstāvjiem u. c.). - Robotnik. - 1920. - 24 grudz.

955 Brīvā Zeme. - 1920. - 18., 19. sept.; Kurjer Lwowski. - 1920. - 16 wrz.

${ }^{956}$ Lietuvas presē parādījās informācija, ka Polijas puse Suvalkos piekritusi turpmāk visus strīdīgos jautājumus apspriest Rīgā. - Lietuva. - 1920. - 12 spālis.
} 
atrisinājumam. Tas pavērtu jaunas iespējas izveidot Baltijas valstu savienības un Rietumu lielvalstu redzējumā panākt mieru starp jaunizveidotajām valstīm tām tik svarīgajā Padomju Krievijas robežvalstu reǵionā.

Tomēr Viḷnas problēma izrādījās pārāk sarežǵīta, lai to varētu tik vienkārši atrisināt. ${ }^{957}$ Polijas valsts vadītāji (pirmkārt, J. Pilsudskis), kaut arī bija spiesti pakḷauties Rietumu prasībām, tomēr nebija gatavi lietuviešiem atdot Viḷnu. 9. oktobrī poḷu karaspēka vienības ǵenerāḷ L. Żeligovska vadībā, šķietami "sadumpojoties", bet faktiski pilnīgā saskaṇā ar Polijas armijas virspavēlniecību (atkal, pirmkārt, ar pašu virspavēlnieku J. Pilsudski), ieņēma Viḷnu, padzenot no tās lietuviešus un izveidojot tā dēvēto Viduslietuvas valsti (ko faktiski pilnībā kontrolēja Polija). 12.-13. oktobrī no Viḷnas atpakaḷ uz Kauṇu pārcēlās ārvalstu un arī Latvijas diplomātiskie pārstāvji u. c. (sūtnis V. Bandrevičs sniedza sīku ziṇojumu par pieredzējumiem Viḷnāā). ${ }^{958}$

Kaut arī Želigovska neoficiālā saikne ar Varšavu bija noprotama uzreiz, Latvijas stāvokli sarežǵīja Lietuvas karaspēka atrašanās Ilūkstes apriņkīi. Tādējādi teorētiski Viduslietuvas spēki varēja tieši apdraudēt arī Latvijas teritoriju. Turklāt neatkarīgi no tālākās notikumu gaitas tā bija lieliska iespēja un iegansts beidzot atrisināt jautājumu par Lietuvas armijas vienību atrašanos Ilūkstes apriņķa daḷā, ko Latvijas puse uzskatīja par savu. Tādēl 12. oktobrī Latvijas armijas virspavēlnieks J. Balodis paziṇoja Lietuvas armijas vadībai, ka Latvijas karaspēks spiests nodrošināt savas zemes drošību, ieņemot bijušo guberņas robežu, taču akcija nav vērsta pret Lietuvu, „kura arī ir ieinteresēta, lai Eglainē būtu latviešu, nevis Želigovska spēki”. ${ }^{959}$

Lietuviešu vienības Ilūkstes apriņkīi nebija lielas, turklāt jau 11. oktobrī šeit esošie 9. kājnieku pulka 450 vīri un Baltkrievu rotas ${ }^{960}$ paši bija sākuši haotisku evakuāciju uz Panevēžu, ${ }^{961}$ tādēḷ karaspēka pārgrupēšanās, kura Eglainē sākās naktī uz 12. oktobri (Subati lietuvieši bija atstājuši jau 11. oktobra vakarā ${ }^{962}$ ), norisa mierīgi. Eglaines lietuviešu komandantam tika izvirzìta prasība nekavējoties evakuēt karaspēku uz bijušo guberņas robežu un atlaut palikt 15 kareivjiem trīs dienas īpašuma izvešanai. Tā kā apkārtnē dzīvojošie latviešu zemnieki atteicās dot viṇiem šḳūtniekus, tos vajadzēja meklēt Lietuvā. Redzot, ka izvešanas darbs šì iemesla dēḷ nesokas, latvieši mainīja izvešanas termiṇu uz 13. oktobri. ${ }^{963}$ Kādās lauku mājās pie Eglaines bija izveidota Lietuvas armijas 5. gūstekṇu nometne. Latviešu 12. Bauskas kājnieku pulka karavīri atbrīvoja šajā nometnē ieslodzìtos 22 poḷu karagūstekņus, bet lietuviešu sargus nosūtīja uz Lietuvu (bijušie gūstekṇi tika nodoti A. Miškovska rīcībā un devās uz Rīgu, vēlāk viṇi vienprātīgi bija

\footnotetext{
957 Sīkāk sk.: Jēkabsons Ē. Viḷnas jautājums un Latvija 1920. gada ruden̄̄//Latvija-Polija. Starptautiskas zinātniskas konferences materiāli/Red. J. Sozaņskis. - Rīga, 1995. - 63.-88. lpp.

958 LVVA, 2575. f., 11. apr., 8. 1., 131.-133. 1p.

959 Turpat, 15. apr., 2. 1., 27. 1p.

${ }^{960}$ Lietuvas armijas Baltkrievu bataljons par rotu bija pārformēts 1920. gada 1. aprīlī.

961 AAN, Attachaty, A - II, 67/2, k. 184.

962 LVVA, 2574. f., 3, apr., 77. 1., 36. 1p.

${ }^{963}$ LCVA, f. 384, ap. 2, b. 139, 1. 9.
} 
uzsvēruši latviešu laipno izturēšanos pret viṇiem). ${ }^{964}$ Šī akcijas laikā notika arī nepatīkami starpgadījumi - latviešu karavīri atbruņotos lietuviešu sargus pirms atlaišanas uz neilgu laiku ieslodzīja gūstekṇu telpās un pat mēǵināja tos piespiest apmainīties drēbēm ar bijušajiem poḷu gūstekṇiem (tas nav noticis, jo poḷi atteikušies to darīt). ${ }^{965}$ Lietuvas puse protestēja pret divu lokomotīvju un 22 vagonu aizturēšanu Eglainē. ${ }^{966}$ Pamestais inventārs tika atdots, un karaspēka daḷas saṇēma pavēli īpaši rūpēties par tiem. Lai noskaidrotu strīdīgos jautājumus, 14. oktobrī Šauḷos tikās abu valstu armiju virspavēlnieki (Lietuvas pusi pārstāvēja arī latvietis pulkvedis-leitnants V. Ozols, bet Latvijas pusi - P. Radziṇš un V. Bandrevičs). Lietuvas apsardzības ministrs un armijas virspavēlnieks K. Žuks runāja par Želigovska draudiem Latvijai, "Latgales muižnieku leǵionu" viṇa karaspēkā, pārmeta latviešiem Eglaines ieṇemšanu, ko J. Balodis skaidroja ar nepieciešamību aizsargāt Daugavpili pret varbūtēju Želigovska spēku uzbrukumu. Cenšoties nomierināt lietuviešus, viṇš uzsvēra, ka latviešu militārā akcija galīgi vēl neizšķir Eglaines valstiskās piederības jautājumu, kuru izlems starptautiskā Robežu komisija. ${ }^{967}$

Savukārt P. Radziņš Rīgā 14. oktobrī informēja A. Miškovski, ka Latvijas armija ieṇēmusi visu bijušo Kurzemes guberṇas robežu, pārkāpjot to vienīgi pie Subates, kur esot "gluži latviska teritorija" (faktiski minētā līnija pilnībā tika ieṇemta dažas dienas vēlāk - $\bar{E}$. J.), un lūdza paziņot Polijas armijas virspavēlniecībai, ka Latvijā vairs nav neviena lietuviešu karavīra. Tas viss - "lai izvairītos no pārpratumiem starp mūsu karaspēku un varonīgo poḷu armiju". ${ }^{968}$ Tajā pašā dienā A. Miškovskis nodeva šo ziṇu Polijas G̦enerālštābam. ${ }^{969}$ Latvijas varas iestādes un cenzūra Rīgā neatḷāva publicēt presē Lietuvas diplomātiskā pārstāvja D. Zauṇa aicinājumu Latvijas lietuviešiem piedalīties Lietuvas valsts atdzimšanas procesā, jo tajā sliktā nozīmē bija minēta Polija un polii. ${ }^{970}$

Patiesībā Žel̦igovska spēku labajā spārnā virzījās Polijas armijas 3. Leǵionu divīzija, formāli ievērojot neitralitāti, bet patiesībā uzturot aktīvus sakarus ar Viduslietuvas spēkiem. 14. oktobrī Latvijas armijas Zemgales divīzijas štāba aǵenti ziṇoja, ka poḷu izlūki ienākuši Slobodkā un Braslavā, taču "lielinieki viṇus no turienes padzinuši". 15. oktobrī Zemgales divīzija saņēma pavēli veikt pastiprinātu izlūkdarbību un, tiklīdz poḷi "tuvotos mūsu administratīvai robežai [..], ieṇemt to ātrāk". Rezervē tika sagatavotas Vidzemes divīzijas daḷas. ${ }^{971}$ Savukārt 16. oktobrī 2. Ventspils kājnieku pulkam

\footnotetext{
964 AAN, Attachaty, A - II, 65/1, k. 265; CAW, II ND WP, t. 194. Poḷu avoti vienprātīgi uzsver Latvijas karavīru un varas iestāžu laipno izturēšanos pret šiem gūstekṇiem.

${ }^{965}$ LCVA, f. 384, ap. 2, b. 139, 1. 9.

${ }^{966}$ Lietuva. - 1920. - 14, 17 spālis; LCVA, f. 384, ap. 3, b. 73, 1. 204; F. 929, ap., 362, 1. 19.

${ }^{967}$ LCVA, f. 384, ap. 3, b. 15, 1. 52; LVVA, 6033. f., 1. apr., 406. 1., 22.-23. lp. Sīkāk sk.: Jēkabsons Ē. Lietuvas karaspēks Ilūkstes apriņ̦īi 1919.-1920. gadā//Latvijas Zinātņu Akadēmijas Vēstis. A daḷa. Sociālās un humanitārās zinātnes. - 2005. - 59. sēj. - Nr. 2, 49.-64. lpp.

968 Počs K. Samitārā kordona... - 116. lpp.

969 AAN, Attachaty, A - II, 65/1, k. 232.

${ }^{970}$ LCVA, f. 384, ap. 3, b. 73, 1. 207 (K. Talata-Kelpšas 1920. gada 19. oktobra ziṇojums).

${ }^{971}$ LVVA, 6033. f., 1. apr., 61. 1., 18. 1p.; 406. 1., 17. 1p.
} 
(dienvidos no Daugavpils) piedalīja vairākas artilērijas baterijas. ${ }^{972}$ 18. oktobrī J. Balodis ziṇoja, ka pilnībā ieṇemta visa bijušās guberṇas robeža no Subates līdz Šafranovai. ${ }^{973}$

15. oktobrī P. Radziṇš pavēlēja “caur izlūkošanu un virsnieku patruḷām” paziṇot par to poḷu karaspēkam un lūgt poḷus nemēǵināt pāriet bijušo guberņas robežu. 25. oktobrī Jakubovas muižā (starp Riču un Sitas ezeru) ieradās poḷu 3. Leǵionu divīzijas 3. artilērijas pulka virsnieks ar vairākiem kareivjiem un informēja 2. Ventspils pulka bataljona komandieri J. Grosvaldu, ka poḷi ien,em līniju apmēram 15-17 kilometrus no „Kurzemes” robežas un pagaidām tiem dots rīkojums to nepāriet. Viṇš uzsvēra, ka poḷu nolūki pret latviešiem ir draudzīgi. Tikšanās bijusi l̦oti „sirsnīga”. 974

Aǵenti šajā laikā ziņoja, ka Vidzos un Svenčonē ienācis poḷu 23. kājnieku pulks, bet 27. oktobrī 2. Ventspils pulka izlūki Drisvjatos (ievērojami aiz robežas) draudzīgi sastapās ar poḷu izlūkiem un vēlāk noskaidroja, ka Turmantā vēl atrodas nelieli lietuviešu spēki, kuri gan l̦oti baidoties no poliem. Tomēr 1. novembrī, kad Turmantā ieradās poḷu izlūki, lietuvieši pret tiem atklāja uguni un uz neilgu laiku piespieda atkāpties. Lietuvieši paši pilnībā no Viḷnas-Daugavpils dzelzceḷa līnijas atkāpās tikai 2.-3. novembrī. Atnākušie poḷi pret latviešiem izturējās korekti un nemēǵināja pāriet robežu. ${ }^{975}$ Polijas armijas G̣enerālštāba priekšnieks T. Rozvadovskis 17. novembra ziṇojumā rakstīja: "Pien,emot, ka attiecībās ar Latviju mums jāizvairās no jebkuriem pārpratumiem, kas varētu pasliktināt pašreizējās attiecības, poḷu daḷas saṇēma pavēli nepāriet bijušās Kurzemes guberņas robežu posmā no Turmantas stacijas līdz Indricai un šo robežu uzskatìt par Polijas-Latvijas demarkācijas līniju līdz laikam, kad abu valstu valdības pieṇems lēmumu par valsts robežu." 976

2. Ventspils kājnieku pulka virsnieks O. Caunītis vēlāk atcerējās, ka attiecības ar poliem jaunajā robežlīnijā bijušas "diezgan saspīlētas, bet ārēji pieklājīgas un miermīlīgas". Tomēr Latvijas karaspēka daḷu skaits uz robežas kādu laiku netika samazināts, un karaspēks bijis gatavs visām varbūtībām. ${ }^{977}$ Savukārt Polijas armijas virspavēlniecības ziṇojumā teikts: "Polijas armija līdz šim [..] stingri ievēro notikumu gaitā izveidojušos demarkācijas līniju. Poḷu un latviešu pulku kaimiņattiecības uzreiz kḷuva draudzīgas [..]."978

Viḷṇas notikumi izraisīja Latvijā nemieru. 14. oktobrī A. Miškovskis ziṇoja, ka Latvijas sabiedriskā doma ir nemierīga un vajadzētu, lai pats Želiigovskis un Polijas prese uzsvērtu viṇa draudzīgo attieksmi pret Latviju. ${ }^{979}$

\footnotetext{
972 2. Ventspils pulks. - 348. 1pp.

973 LVVA, 3601. f., 1. apr., 496. 1., 126. 1p.

974 Turpat, 308. 1., 16. 1p.; 6033. f., 1. apr., 61. 1., 20. 1p.

975 Turpat, 6033. f., 1. apr., 61. 1., 19., 22., 24., 26. 1p.

976 Łossowski P. Łotwa... - S. 16.

${ }^{977}$ LKM, Caunītis O., 89. 1p.

978 CAW, II ND WP, t. 193. Attiecības starp armijām uz robežas tiešām bija samērā labas. 24. novembrī 3. Leǵionu divīzijas vadība izteica pateicību 10. Aizputes kājnieku pulkam, kas bija palīdzējis atklāt slepkavību, kura 13. oktobrī bija izdarīta Plusos (Polijā). - LVVA, 6033. f., 1. apr., 61. 1., 19.-28. lp.; 62. 1., 7. 1p.

979 AAN, Attachaty, A - II, 65/1, k. 232.
} 
Nākamajā dienā viņš ziṇoja, ka Latvijas prese pauž nemieru par Ilūkstes apriṇķa likteni, un piebilda, ka ir "galēji nepieciešams, lai ğenerāḷa Žeḷigovska daḷas, kuras var drīz nonākt saskarē ar latviešiem, izvairītos no jebkādas nesaprašanās ar tiem". ${ }^{980}$ A. Miškovskis un V. Kameñeckis centās pārliecināt Latvijas politikus un sabiedrisko domu par jebkuru bažu nepamatotību. 23. oktobrī Kameṇeckis presē paziṇoja, ka Polijas valdībai nav nekā kopīga ar Želigovska akciju, taču tā "vērīgi seko notikumiem Viḷnā un uzskata tos par dedzīga patriotisma izpausmi". ${ }^{981}$ Arī Polijas miera delegācijas loceklis miera sarunās ar Padomju Krieviju L. Vasiḷevskis apgalvoja, ka Žel̦igovskim nav agresīvu plānu pret Latviju. ${ }^{982}$

Pašai Latvijas valdībai bija puslīdz skaidra Polijas patiesā nozīme notikumos. 25. oktobra Ārlietu ministrijas pārskatā pilnīgi pareizi teikts, ka “Želiigovska uzstāšanās notikusi ar paša Pilsudska personīgu piekrišanu un atbalstu”, un, kamēr "šo lietu pārzina pats Pilsudskis, tā nevar mūsu drošību apdraudēt. Bet, ja Pilsudska iespaids zustu, tad lieta būtu citāda". ${ }^{983}$

Ārēji Latvijas attiecības ar Poliju oktobrī palika labas. To atzina arī Polijas ārlietu ministrs E. Sapeha 20. oktobrī. ${ }^{984}$ Savukārt A. Keniñš 29. oktobrī secināja, ka Polijas prese, valdība un Seims visumā ir noskaṇoti labvēlīgi pret Latviju. E. Sapeha bija solījis, ka Polija drīzumā atzīs Latviju "de iure", un pagaidām tas nenotiekot vienīgi Francijas noraidošās nostājas dēḷ.985 Polijas armijas G̣enerālštābs 3. novembrī secināja, ka "Latvijas valdība pašlaik cenšas labot slikto iespaidu, kādu atstāja tās vēsā izturēšanās pret Poliju tai kritiskā situācijā" (augustā kauju laikā pie Varšavas - ÉE. J.). ${ }^{986}$ Tomēr Latvijas attieksme kārtējo reizi mainījās, attīstoties notikumiem Viḷnas reǵionā. Runājot vēsturnieka P. Losovska vārdiem, pēc Žel̦igovska akcijas sākuma tā sagādājusi Polijai "lielāko pārsteigumu". ${ }^{987}$

Tam bija objektīvi iemesli. Armijas Virspavēlnieka štāba Ārējās izlūkošanas nodaḷa ziṇoja, ka Žel,igovskis plāno gāzt Lietuvas valdību un panākt Lietuvas ūniju ar Poliju, izveidot poḷu kontrolētu koridoru caur Viḷnu, Mažeiķiem un Liepāju "sakaru uzturēšanai ar Franciju”. Viṇa armijā dienē daudzi Latgales poḷi, kas vēlētos arī Latgali pievienot Polijai. Viduslietuvas armijas skaitliskais sastāvs - 75 000-90 000 vīru - tika pārspīlēts. ${ }^{988}$ Savukārt štāba Iekšejāas izlūkošanas daḷa 7. novembrī ziņoja, ka Daugavpils un Ilūkstes apriņk̄i pastiprināti tiek izplatītas baumas par gaidāmo Želigovska spēku ierašanos. Baumas izplatījis pat Polijas goda konsuls Daugavpilī S. Sirevičs, ${ }^{989}$

\footnotetext{
980 Turpat, Kod, t. 2, k. 308.

981 Latvijas Kareivis. - 1920. - 23. okt.

982 Latvijas Sargs. - 1920. - 31. okt.

${ }^{983}$ LVVA, 2575. f., 15. apr., 2. 1., 26. 1p.

984 Łossowski P. Stosunki polsko - litewskie... - S. 329.

${ }^{985}$ LVVA, 2575. f., 15. apr., 12. 1., 21. 1p.

986 CAW, II ND WP, t. 194.

987 Łossowski P. Stosunki polsko - litewskie... - S. 329.

988 LVVA, 6033. f., 1. apr., 24. 1., 28. 1p.

989 S. Sirevičs dzīvoja Daugavpilī, bija zvērinātais advokāts un guva ievērību jau Satversmes sapulces vēlēšanu priekšvakarā 1920. gada aprīlī kā "poḷu saraksta" vēlētāju sapulču galvenais runātājs. LVVA, 1378. f., 2. apr., 3. 1., 28. 1p.
} 
kurš, cita starpā, apgādāja ar Polijas pasēm vietējos poḷu brīvprātīgos un nosūtīja tos uz Poliju, kur tie piedalījās pašvaldību un policijas organizēšanā, kā arī iestājās Viduslietuvas armijā. Ilūkstes apriṇkī bija redzēti vairāki vietējie poḷi, par kuriem bija zināms, ka viṇi dienē Polijas armijas izlūkošanas un pretizlūkošanas struktūrās. Divi no viņiem tika Grīvā aizturēti, jo pie viniem atrada Polijas, Latvijas, Krievijas, Lietuvas pasi un citus dokumentus un priekšmetus, kas liecināja par izlūkošanas uzdevumiem. ${ }^{990}$ Stāvokli vēl vairāk sarežğìja Latgales dziḷais saimnieciskais sabrukums, masveida spekulācija un kontrabanda pierobežas rajonos, nožēlojamie sanitārie apstākḷi (1920. gada rudenī iedzīvotāji Latgalē drīkstēja pārvietoties vienīgi ar ikreizēju komandantūras atḷauju, bet, dodoties uz Rīgu, bija jāuzrāda karantīnas ārsta apliecība, ka veikta atutošana). ${ }^{991}$

Arī Polijas G̣enerālštābs 1. decembrī ziṇoja, ka Latvijā klīst baumas par Polijas 2. armijas (septiṇu divīziju) nodošanu Želigovska rīcībā, par Latgales un Kurzemes ieņemšanas plāniem, pat par varbūtēju Želigovska akcijas saistību ar jaunu Bermonta avantūru Baltijā un Bulaka-Balahoviča darbību. ${ }^{992}$ A. Miškovskis 7. novembrī darīja zināmu, ka sakarā ar baumām Latvijā apturēta armijas demobilizācija un sākta sakaru līdzekḷu reǵistrācija. Viṇš kārtējo reizi Latvijas armijas virspavēlniecībai lika saprast, ka Viduslietuvas spēku akcija pret Latviju nav iespējama, un nākamajā dienā pats personīgi devās uz jauno Latvijas un Polijas robežlīniju Ilūkstes apriṇkīi ${ }^{993}$

Tomēr sabiedriskās domas nemiers Latvijā turpināja pieaugt. 2. novembrī dzejnieks E. Virza presē rakstīja, ka nedrīkst samazināt izdevumus armijai, kamēr "Želigovskis posta leišu brīvību un viṇa divīzijas vērstas arī pret Daugavpili”. ${ }^{994}$ İpaši asi reaǵēja Latgales latviešu inteliğence. J. Pabērzs rakstīja par Viduslietuvas armijas Latgales muižnieku pulku, kurš gatavs uzbrukt Daugavpilij un aicina būt modriem, jo muižnieki grib "glābt savas muižas, sēdēt atkal uz kakla zemniekiem, iztaisìt poḷu zemi ar polu skolām, baznīcām, ar mums nesaprotamu valodu visās iestādēs". ${ }^{995}$ Arī Ārlietu ministrija 7. novembrī ziṇoja par tā saucamo "Latgales pulku", kurš atrodas Svenčones rajonā un kurā ir daudz poḷu un krievu muižnieku. Pulka "izturēšanās ir aizdomīga". ${ }^{996}$ Kaut arī patiesībā ìpaša "latgaliešu" pulka Viduslietuvas armijā nebija, tajā dienēja un civilajā administrācijā darbojās daudzi Latgales muižnieki, kuru attieksme pret Latviju bija naidīga vai vismaz nelabvēlīga. Viens no viṇu spilgtākajiem pārstāvjiem - Daugavpilī dzimušais V. Studṇickis-Gizberts ${ }^{997}$ - arī vēlākajos gados izcēlās ar īpašu

\footnotetext{
990 Turpat, 2574. f., 3. apr., 92. 1., 3. 1p.

991 Turpat, 6823. f., 2. apr., 116. 1., 8. 1p.

992 CAW, II ND WP, t. 194.

993 AAN, Kod, t. 2, k. 312.

994 Latvijas Kareivis. - 1920. - 2. nov.

995 Latgalīts. - 1920. - 11. nov.

${ }^{996}$ LVVA, 2575. f., 17. apr., 63. 1., 18. 1p.; Par Latgales muižnieku pulku izveidošanu Viduslietuvas armijā rakstīja arī Lietuvas prese. - Lietuva. - 1920. - 13 lāpkr.

997 1920. gada novembrī Latvijas krievu prese izklāstīja V. Studṇicka atziṇu, ko viṇš bija paudis savā tikko publicētajā darbā: Kurzemei jāatrodas Polijā kā autonomai vienībai. To vēlēsies arī latvieši un vācieši, jo no Krievijas viņiem neesot cerību saņemt ,autonomiju” - Сегодня. - 1920. - 26 ноября (ievadraksts ar daiḷrun̄̄gu nosaukumu - „Poḷu apetītes uz Latviju”).
} 
nelabvēlību pret Latvijas valsti. ${ }^{998}$ Nav šaubu, ka gan daži Latgales muižnieki, gan citi šovinistiski noskaṇotie Želigovska karavīri patiešām varēja ticēt "Latgales karagājienam", n,emot vērā l,oti îpatnējos Viḷnas un Viḷnas apgabala ieṇemšanas apstākḷus, kā arī Viduslietuvas armijas raksturu.

10. novembrī M. Hartmanis no Varšavas arī ziṇoja par Latgales muižniekiem Želigovska armijā, kā arī par ieročiem un pārtiku, kas uz Viḷnuu bija nosūtīti no Polijas. ${ }^{999}$ Latvijas armijas virspavēlniecība centās nomierināt sabiedrību, uzsverot, ka sperti visi nepieciešamie piesardzības soḷi un baumas par sadursmēm starp Źeliigovska spēkiem un latviešiem pie Daugavpils ir pilnīgi nepamatotas. Turklāt starp Latvijas armiju un poḷu 3. Leǵionu divīziju, kura ietilpa Viduslietuvas armijā un kurā "mūsu kareivji sastop dažu labu vecu paziņu" no Latgales atbrīvošanas kauju laika, atrodas neitrālā josla. ${ }^{1000}$

Lai iegūtu informāciju, uz Viḷnu tika nosūtīts Latvijas militārā pārstāvja palīgs Polijā - kapteinis (rotmistrs) A. Lēvings, kurš ieradās poḷu ieṇemtajā pilsētā 7. novembrī. Sarunā ar viṇu L. Želigovskis uzsvēra, ka vēlas iespējami ātrāk nodibināt draudzīgas attiecības ar Latviju. ${ }^{1001}$ Polijas armijas G̦enerālštābs 15. novembrī secināja, ka "paskaidrojumi, kādus Viḷṇā rotmistram Lēvingam bija devis Žel̦igovskis [..], atstāja Rīgā l,oti labu iespaidu". ${ }^{1002}$ Turklāt Viḷnāā no 15. līdz 21. novembrim komandējumā ar oficiālu diplomātiskā pārstāvja A. Keniṇa udevumu - noskaidrot Latvijas pilsoṇu un bēgḷu stāvokli šajā pilsētā (ceḷā no Polijas) - uzturējās arī Latvijas diplomātiskās pārstāvniecības Varšavā sekretārs P. Oliṇš. Protams, ka viṇam bija arī neoficiāls uzdevums noskaidrot situāciju Viḷṇā kopumā un Želiigovska attieksmi pret Latviju. Uz vinuu Želigovskis bija atstājis "vienkārša, sirsnīga un godīga kareivja” iespaidu. Sarunas par politiku viṇu apgrūtinājušas, tāpēc viṇš labprāt uzticējis tās vest padomniekiem (pirmkārt, A. Pristoram, kas bija sakaru virsnieks un uzturēja sakarus ar J. Pilsudski). G̦enerālis ar sirsnību atcerējies latviešu žēlsirdīgo māsu E. Kundziṇu no Cēsīm, kas pasaules kara laikā kopusi vinuu un citus ievainotos poḷu virsniekus kādā kara hospitālī Podolijā. P. Oliṇam radās droša pārliecība, ka Želigovskis "pakḷauts Varšavai, kas Latvijai labvēlīga". Arī M. Hartmanis no Varšavas ziṇoja, ka "Želigovskis sola vislabākās attiecībās ar mums”. J. Pilsudska adjutants B. Veņava-Dlugoševskis sarunās ar Latvijas pārstāvjiem uzsvēra, ka Želigovskis esot demokrāts un neaizstāvēs Latgales muižnieku intereses, bet pats J. Pilsudskis svinībās, kur viṇam pieškīira maršala pakāpi, vēlreiz A. Keniņam akcentēja savu labvēlību pret Latviju. ${ }^{1003}$ Līdz ar to P. Radziṇam bija pamats skaidrot presei, ka Žeḷigovskis, būdams polis, tieši vai netieši pārstāv Polijas intereses, bet Polija nav ieinteresēta

\footnotetext{
998 Savā 1924. gadā izdotajā grāmatā V. Studņickis aizvainoti rakstīja, ka 1920. gadā latviešu prese melīgi ziṇojusi par „Pulku, ko vin̦š organizējis Lietuvā, lai Latvijai atn̦emtu Daugavpili” - Studnicki W. Zarys państw bałtyckich... - S. 123.

${ }^{999}$ LVVA, 2574. f., 3. apr., 90. 1., 243. 1p.

1000 Latvijas Kareivis. - 1920. - 9. nov.

1001 Kurjer Poranny. - 1920. - 9 list.

1002 CAW, II ND WP, t. 194.

1003 Turpat, 2575. f., 15. apr., 12. 1., 11.-16. 1p.; 2574. f., 3. apr., 90. 1., 244. 1p.; 2570. f., 10. apr., 66. 1., 298. 1p.
} 
apdraudēt Latviju un “dažu poḷu muižnieku vēlēšanās nav poḷu valdības un tautas vairākuma domas". ${ }^{1004}$

Lietuvas valdība šajā laikā centās iegūt Latvijas atbalstu cīṇā pret Viduslietuvu un Poliju, jo apstākḷi šksita labvēlīgi, lai beidzot panāktu Latvijas nostāšanos Lietuvas pusē tās konfliktā ar Poliju. Jau 11. oktobrī Lietuvas Seima Ārlietu komisija nolēma "meklēt saprašanās cel̦us ar latviešiem", lai kopīgi "aizstāvētu neatkarību". ${ }^{1005} 11$. novembrī Rīgā ieradās Lietuvas militārā delegācija (latviešu izcelsmes generālleitnants, Ģenerālštāba sevišḳu uzdevumu ǵenerālis M. Kathe, kas 7. oktobrī Suvalkos bija parakstījis Lietuvas-Polijas ligumu, latvietis pulkvedis-leitnants V. Ozols un vēl viens virsnieks). 17. novembrī Rīgā iebrauca vairāki Seima deputāti (ar M. Slezēviču priekšgalā). Viṇi mēǵināja pārliecināt Latvijas armijas vadību, ka nepieciešams noslēgt abu valstu militāru savienību pret Visuslietuvu. Seima pārstāvju oficiālais uzdevums bija piedalīties Latvijas neatkarības pasludināšanas gadadienas svinībās, bet M. Kathe Kauṇā saṇēma konkrētus uzdevumus - panākt, ka pret Viduslietuvu tiek noslēgta militāra konvencija, kas paredzētu aktīvu Latvijas armijas akciju, ja Žeḷigovska armija virzìtos Kaišadores un Ukmerğes virzienā. Lietuvieši rīkotos līdzīgi, ja Viduslietuvas poḷu spēki virzìtos Daugavpils virzienā. Turklāt bija jāizstrādā kopīgs operatīvais plāns. ${ }^{1006}$ Tomēr Latvijas puse lieliski apzinājās, ka šāda savienība būtu vērsta ne tikai pret Viduslietuvu, bet arī pret Poliju, un, lai gan Satversmes sapulces lielākā frakcija - sociāldemokrāti - bija nelabvēlīgi pret Poliju, ${ }^{1007}$ tomēr lietuviešiem aktīvu palīdzību atteica. 15. novembrī M. Kathe ziņojumā uz Kauņu uzsvēra, ka trīs dienu sarunās latvieši piekrituši sniegt Lietuvai vispusīgu palīdzību cīṇā pret Želigovski, taču atzinuši, ka sabiedriskā doma vēl nav gatava aktīvai Latvijas armijas darbībai pret Viduslietuvu. Tomēr savā 19. novembra ziņojumā M. Kathe jau atzina, ka militāru konvenciju ar Latviju noslēgt neizdosies, kaut arī ievērojama latviešu tautas dạ̣a jūt Lietuvai līdzi. Pirmkārt, tas izskaidrojams ar Latvijas valdības uzskatu, ka cīṇa pret Viduslietuvu būs vēršanās arī pret Poliju. Arī uz piedāvājumu pārrunāt militāras konvencijas projektu "privāti” M. Kathe atbildi nesaṇēma. Tomēr turpmākajās sarunās Latvijas puse lietuviešiem apsolīja iespēju robežās dot militāros speciālistus, kara materiālus, ḷaut izmantot ostas kara materiālu ievešanai, lietot Latvijas kara darbnīcas utt. ${ }^{1008}$ Latvijas armijas štāba priekšnieks K. Ramats liecināja, ka sarunā ar viṇu un J. Balodi ǵenerālis M. Kathe piedāvājis izveidot ciešu abu valstu savienību, bet latvieši atbildējuši, ka jau sen domā par plašāku visu Baltijas valstu savienību. M. Kathe uzsvēra, ka nav pilnvarots runāt par tādu savienību un vajadzētu n,emt vērā "acumirkḷa briesmas”. K. Ramats vēlāk atcerējās: "Tam savukārt

\footnotetext{
${ }^{1004}$ Latvijas Kareivis. - 1920. - 23. nov. Šo rakstu atreferēja arī Polijas prese. - Gazeta Warszawska. $-1920 .-2$ grudz.

1005 Łossowski P. Konflikt polsko - litewski...- S. 199.

${ }^{1006}$ LCVA, f. 384, ap. 3, b. 15, 1. 37, 40; Lietuva. - 1920. - 19 lāpkr.; Laisve. - 23, 30 lāpkr.

1007 1920. gada 18. novembra svin̄̄gajā Satversmes sapulces svētku sēdē Lietuvas valdības apsveikums tika uzṇemts ar vienprātīgiem aplausiem, bet Polijas apsveikumu kreisais spārns uzṇēma klusējot AAN, Kod, t. 2, k. 321; Lietuva. - 1920. - 23 lāpkr.

${ }^{1008}$ LCVA, f. 384, ap. 3, b. 15, 1. 42, 45, 46.
} 
mēs nevarējām piekrist, jo skaidrs neprāts būtu sanaidoties ar mūsu lielāko un stiprāko kaimiṇu, kur mūsu reālās politiskās intereses prasīja vistuvāko draudzību ar viṇu."1009

18. novembrī Satversmes sapulces priekšsēdētājs J. Čakste paziṇoja Lietuvas diplomātiskajam pārstāvim D. Zauṇum, ka Kauṇas ieṇemšanas gadījumā Latvijas valdība apspriedīs iespēju sniegt Lietuvai militāru palīdzību. ${ }^{1010}$ Lietuvas delegācija šo pašu solījumu un morāla atbalsta apliecinājumu saṇēma 20. novembrī. Oficiāli tika izsludināta Latvijas neitralitāte Viḷnas strīdā. Tomēr jau iepriekšèjā dienā (19. novembrī) A. Miškovskis bija ziṇojis savai valdībai, ka lietuvieši saṇems noraidošu atbildi (vinu par to 18. novembra svinīgajā rautā, kurā piedalījās arī oficiālā Lietuvas delegācija, informēja Apsardzības padomes priekšsēdētājs K. Gopers, kā arī politiķi Ā. Klìve un J. Feldmanis). ${ }^{1011}$

Latvijas valdības stāvokli sarežğìja tas, ka Rīgā atradās arī Viduslietuvas delegācija: Pagaidu valdošās komisijas Ārlietu departamenta pārstāvis B. Kšižanovskis, Rūpniecības un tirdzniecības departamenta vicedirektors F. Veḷoglovskis, kā arī armijas pārstāvis poručniks Vasiḷevskis. Viṇi 10. novembrī brunuvilcienā "Paderewski" ieradās Turmantā kopā ar Latvijas militārā pārstāvja palīgu Polijā A. Lēvingu, ${ }^{1012}$ bet 11 . novembrī iebrauca Rīgā. ${ }^{1013}$ Pirms tam A. Lēvings bija telegrāfiski lūdzis Latvijas armijas virspavēlniecībai atlauju iebraukt valstī "Želigovska deleǵētiem virsniekiem”, kuri vēlas runāt ar Latvijas armijas vadību. Tādējādi iebraukšanas atḷauju deva Virspavēlnieka štābs bez Ārlietu ministrijas ziņas, kaut arī B. Kšižanovska galvenais uzdevums bija tieši sarunas ar Ārlietu ministriju. Delegācijai bija jāpārliecina Latvijas puse par Viduslietuvas draudzīgumu un jācenšas vienoties par dzelzceḷa satiksmi, pasta un telegrāfa sakariem. Par savu ierašanos Viḷnas pārstāvji informēja Ārlietu ministriju un Virspavēlnieka štābu. Šĩ ierašanās izraisīja zināmu apjukumu. Z. Meierovics bija prombūtnē, un ministru prezidents K. Ulmanis un J. Čakste izlēma, ka delegāciju oficiāli nepieṇems. Pagaidām tika paziṇots, ka arī K. Ulmaṇa nav Rīgā, un lūgts, lai dažas dienas tā uzkavējas, jo Latvijas puse bija gatava pienemt B. Kšižanovski Ārlietu ministrijā neoficiāli. 15. novembrī notika apmēram stundu gara saruna starp vinu, departamentu direktoriem L. Sēju un V. Šūmani. Tajā B. Kšižanovskis izklāstīja poḷu puses viedokli par Viḷnas notikumiem, kā arī noliedza baumas, ka par Želigovskim attiecībā uz Latviju ir naidīgi nolūki. Saruna norisa draudzīgā tonī. Uz jautājumu par Latvijas nostāju konfliktā L. Sēja atbildēja, ka tā būs nogaidoša, taču Latvija nevar atzīt "etnogrāfiskās Lietuvas iekarošanu". Savukārt F. Veloglovskis 16. novembrī ar Dzelzceḷu valdes pārstāvjiem pārrunāja satiksmes atjaunošanas iespējas. Turklāt šajā dienā delegācijai bija vēl viena neoficiāla tikšanās Ārlietu

\footnotetext{
1009 Ramats K. Virspavēlnieks//Ģenerālis Jānis Balodis. Atmiṇu krājums no Latvijas brīvības cīṇu laika. - Rīga, 1931. - 146. lpp.

1010 Andersons E. Latvijas vēsture 1914-1920. - 614. lpp.; Kurjer Poranny. - 1920. 16 list.; Robotnik. 1920. - 19 list.

1011 AAN, Kod, t. 2, k. 318; Kurjer Poranny. - 1920. - 23 list.; Lietuva. - 1920. - 23 lāpkr.

1012 Lietuvas Telegrāfa aǵentūra 17. novembrī no Rīgas kḷūdaini ziṇoja, ka Viduslietuvas pārstāvjus Latvijā ievedis Polijas militārais pārstāvis Latvijā. - Lietuva. - 1920. - 18 lāpkr.

1013 LVVA, 6033. f., 1. apr., 61. 1., 21. 1p.; AAN, Kod, t. 2, k. 314; Przegląd Wieczorny. - 1920. - 15 list.; Robotnik. - 1920. - 14 list.
} 
ministrijā. Šajā laikā K. Ulmanis izškīinās par savu turpmāko rīcību (lielā mērā- Lietuvas delegācijas un sabiedriskās domas iespaidā). 16. novembrī K. Ulmanis personiskā sarunā informēja Lietuvas puses pārstāvjus, ka Viduslietuvas delegācija tiks izraidìta no valsts. ${ }^{1014} 16$. novembra pēcpusdienā tika atsaukts delegācijai piekomandētais A. Lēvings, bet cits virsnieks informēja Viduslietuvas pārstāvjus, ka tiem nākošajā dienā jāatstāj valsts, un "pilnīgi korekti, bet noteikti” piedāvāja pavadìt viṇus līdz Turmantas robežstacijai. Tomēr delegācija pieprasīja rakstisku rīkojumu par izraidīšanu un 17. novembrī neizbrauca, bet Ârlietu ministrijā iesniedza notu, kurā protestēja pret attieksmi, kas neatbilst "starptautiskajām tradīcijām" (norakstus iesniedza ārvalstu pārstāvniecībās). Rīgu poḷi atstāja tikai 18. novembra rītā. ${ }^{1015}$

Abu delegāciju atrašanās laikā Rīgā norisa asa politiska cīṇa, kurā aktīvi iesaistījās arī Lietuvas un Polijas diplomātiskie un neoficiālie pārstāvji. Sevišḳi noteikti izturējās Lietuvas pārstāvji - īpaši pēc tam, kad 14. novembrī bija saṇēmuši no savas valdības instrukciju, ka Kauṇā latviešu sarunas ar Želígovska pārstāvjiem tiks uzskatītas par Lietuvai naidīgu aktu no kaimiņvalsts (Latvijas) puses. ${ }^{1016}$ Latvietis V. Ozols, kas dienēja Lietuvas armijā un bija iekḷauts iebraukušās Lietuvas delegācijas sastāvā, presē izklāstīja Lietuvas puses viedokli, paužot prieku par Latvijas un Lietuvas tuvināšanos brīdī, kad Želigovskis apdraud abas valstis. ${ }^{1017}$ Polijas pārstāvji loti centās nomierināt sabiedrisko domu, kuru saviḷṇoja gan abu delegāciju atrašanās Rīgā, gan zinas par Želigovska spēku tuvošanos Latvijas robežai. Viḷnas delegācijas ierašanās laikā Polijas pārstāvis V. Kameṇeckis atradās Varšavā. Tūlìt pēc atgriešanās (vēl pirms delegācijas izraidīšanas) viṇš apmeklēja J. Čaksti, iekšlietu ministru A. Bergu un ārlietu ministra biedru H. Albatu un skaidroja Želigovska nolūkus. Pēc sarunām V. Kameneckis informēja savu valdību, ka Latvija paliks neitrāla, ja bruṇota akcija nepārsniegs Viḷnas apgabala robežas. Savukārt A. Miškovskis 17. novembrī runāja ar apsardzības ministra vietas izpildītāju E. Laimiṇu. Šìs sarunas atstāstījums liecina, ka Želigovska oficiāli nenoteikto statusu Latvijas puse izmantoja kā ieganstu, lai īstenotu sev izdevīgu politiku, apzinoties, ka Polijai būs grūti pārmest Latvijai neitrālu nostāju konfliktā, jo pati bija oficiāli noliegusi savu saistību ar Želigovski. ${ }^{1018}$ E. Laimiņš uzsvēris, ka sakarā ar minēto Polijas valdības nostāju Latvijas puse uzskata Želigovski par "bīstamu, neaprēkināmu reakcionāru". Turpretī tagad, kad no Polijas pārstāvjiem „uzzināts”, ka tā “var ietekmēt Žeḷigovski”, vairs nav iemesla iejaukties konfliktā un "Latvija darīs visu, lai saglabātu ar Poliju vislabākās attiecības". Tāpat J. Balodis nākamajā dienā un arī 20. novembrī informēja A. Miškovski, ka Latvija ievēros neitralitāti, bet militāriem pasākumiem ir

\footnotetext{
${ }^{1014}$ LCVA, f. 383, ap. b. 7, 1. 72; b. 72, 1. 113.

1015 LVVA, 2575. f., 15. apr., 2. 1., 6.-7. 1p.; AAN, Kod, t. 314; LCVA, f. 929, ap. 1, b. 364, 1. 23.

1016 LCVA, f. 383, ap. 7, b. 72, 1. 111-112.

${ }^{1017}$ Latvijas Kareivis. - 1920. - 16. nov. Polijas prese atreferēja interviju ar V. Ozolu, dēvējot viņa teikto par "murgiem” un secinot, ka Latvijas iestāžu attieksmi pret Viduslietuvas delegāciju ir iespaidojis arī "nekaunīgais Ozols". - Kurjer Poranny. - 1920. - 21 list.

1018 Polijas prese konstatēja, ka Polijas valdībai nav nekāda formāla pamatojuma "nodarboties" ar Želiigovski, un tas stipri sarežğì poḷu diplomātu darbu Rīgā. - Kurjer Poranny. - 1920. - 18 list.
} 
vienīgi aizsardzības raksturs. Tomēr Latvija ir ieinteresēta Lietuvas valsts pastāvēšanā. Miškovskis korekti lika noprast, ka Polija necietīs jebkuras valsts mēǵinājumus pārlieku kaitēt Želigovskim. ${ }^{1019}$ Raksturīga ir piesardzīgā J. Čakstes intervija Polijas presei 18. novembrī. Tajā viṇš paziṇoja, ka neko nezina ne par ǵenerāli Želigovski, ne Viduslietuvu, tā esot "kabinetu lieta", kuru Satversmes sapulce izskatīs tad, kad valdība to iesniegs izskatīšanai. ${ }^{1020}$ Turpretī Z. Meierovics Ženēvā, bija atklātāks un presē paziṇoja, ka Latvijas valdībai nav pamata uzskatīt, ka Želigovskis apdraud arī Latgali, tādēl, Latvija paliek neitrāla ${ }^{1021}$ (zināmā mērā tas bija teikts poḷu diplomātu ietekmē - tie kārtējo reizi bija pilnvaroti solīt Latvijas atzīšanu "de iure").

Šajā laikā Rīgā esošais poḷu diplomāts L. Vasiḷevskis norādīja, ka Polijas attiecības ar Latviju zināmā mērā ir mainījušās. ${ }^{1022}$ Poḷu puses neapmierinātību izraisīja arī Viduslietuvas delegācijas izraidīšana, un Polijas diplomātiskā pārstāvniecība iesniedza Latvijas Ārlietu ministrijā notu, kurā pauda šo neapmierinātību. Atbildē ministrija "noteikti fiksēja savu stāvokli visā šajā lietā". ${ }^{1023}$

To izdarìt nebija grūti, jo šajā laikā ministrijai bija pilnīgi skaidra turpmākā taktika attiecībā uz Poliju un Lietuvu. Noformulēt to palīdzēja arī A. Lēvinga un P. Oliṇa ziṇojumi par redzēto Viḷnāā. Zinot apstākḷus, jāpieṇem, ka Viduslietuvas delegācija ieradās Rīgā nedaudz par vēlu. Ja tas būtu noticis ātrāk, iespējams, puses būtu vismaz neoficiāli vienojušās par turpmākajām attiecībām (pagaidām vismaz neoficiālā līmenī). Taču stāvokli sarežğìja notikumi Lietuvas un Viduslietuvas frontē, tie Latvijā pamatoti izraisīja bažas par Lietuvas neatkarības likteni.

Drīz pēc tam, kad 10. novembrī Turmantā no Viḷnas bija iebraucis jau minētais bruṇuvilciens, tur ieradās arī Viduslietuvas karaspēka kājnieku vienības, kas devās Zarasu virzienā gar Latvijas robežu. ${ }^{1024} 11$. novembrī rotmistrs A. Lēvings neapzināti izplatīja nepatiesu ziṇu, ka poḷi ieṇemuši Zarasus, kuri atradās jau tā dēvētajā "etnogrāfiskajā Lietuvā". Pēc 10. novembra kaujām septiṇi lietuviešu karavīri patvērās Latvijā (viens no viṇiem bija ievainots). ${ }^{1025} 10$. novembrī K. Talats-Kelpša ziṇojumā uz Kaunuu gan īpaši uzsvēra, ka šajās dienās pierobežā latviešu karavīri sastapušies ar Z̉eligovska armijas jātniekiem un izškīirušies pēc draudzīgas aprunāšanās. ${ }^{1026}$

Tomēr Latvijas pierobežā karadarbība bija nenozīmīga. Turpretī Širvintu rajonā 16. novembrī Viduslietuvas armijas pavēlniecība deva pavēli veikt ierobežotu uzbrukumu, lai novērstu varbūtējās Lietuvas armijas akcijas pret Viḷnu. Viḷṇas kavalērijas brigāde, kas bija zaudējusi sakarus ar savu virspavēlniecību, 17.-21. novembrī veica 250 kilometru garu maršu Kauṇas

\footnotetext{
1019 AAN, Kod, t. 2, k. 315; Łossowski P. Stosunki polsko - litewskie... - S. 333.

1020 Kurjer Poranny. - 1920. - 21 list.

1021 Łossowski P. Stosunki polsko - litewskie... - S. 333.

1022 Kurjer Poranny. - 1920. - 20 list.

1023 LVVA, 2575. f., 15. apr., 2. 1., 7. 1p.

1024 Turpat, 2574. f., 3. apr., 90. 1., 245. 1p.

1025 Turpat, 6033. f., 1. apr., 61. 1., 21. lp.; Latvijas Kareivis. - 1920. - 13. nov.

${ }^{1026}$ LCVA, f. 384, ap. 3, b. 73, 1. 217.
} 
virzienā un sasniedza Ķēdaiṇus. 21. novembrī Tautu Savienībai ar grūtībām izdevās apturēt aktīvu karadarbību Lietuvā. ${ }^{1027}$

Kaut arī politisku apsvērumu dēḷ Viduslietuvas (Polijas) politiķiem tiešām nebija izdevīgi ieṇemt Kauṇu, atsevišk k̦as karaspēka daḷas (Viḷnas kavalērijas brigādes) uz savu roku sāktais uzbrukums varēja būt arī sekmīgs, un nav zināms, kā tādā gadījumā attīstītos tālākie notikumi. Katrā ziṇā būtu grūti prasīt atbildību no vienības, kas nepakḷāvās Viduslietuvas armijas vadībai, kura pati formāli bija "sadumpojusies" (tā atteicās pakḷauties Polijas armijas virspavēlniecības rīkojumiem). Ko vajadzētu nosodīt - L. Želigovski vai Poliju? Polija oficiāli bija atteikusies atbildēt par vina rīcību, un Zeligovskis šādos apstāklos savukārt varētu atteikties atbildēt par vainīgo karaspēka daḷu, bet politiskās sekas Polija neapšaubāmi censtos izmantot savā labā.

Arī Latvijas valdība poḷu akciju novērtēja kā uzbrukumu Lietuvas „pagaidu” galvaspilsētai Kauṇai. Jautājums tika izskatīts apspriedē, kuru Z. Meierovics sasauca 19. novembrī plkst. 23.00 Satversmes sapulces namā un kurā bez vina piedalījās J. Čakste, K. Ulmanis, J. Balodis, P. Radziṇš, K. Ramats, Ā. Klīve, kā arī sociāldemokrātu pārstāvji F. Menders un F. Cielēns. Pēc Z. Meierovica ziṇojuma F. Cielēns uzsvēra, ka nepieciešama tūlìtēja reakcija, lai glābtu Lietuvu - tās pastāvēšana bija viena no Latvijas drošības garantijām. ${ }^{1028} \mathrm{~J}$. Balodis un K. Ramats uzsvēra armijas materiālo un morālo nesagatavotību jaunam bruṇotam konfliktam - virspavēlnieks savu uzrunu beidza ar retorisku jautājumu: "Kā lai pārliecinu kareivi, ka Viḷna mums vajadzīga?" Lielā mērā pateicoties militārpersonu attieksmei, sapulce nolēma aktīvi konfliktā neiesaistīties, taču darìt visu, lai saglabātu Lietuvas neatkarību. ${ }^{1029}$ 20. novembrī Z. Meierovics iesniedza V. Kameņeckim konfidenciālu notu. Latvijas un arī Lietuvas vēsturiskajā literatūrā izplatījies pārspīlēts viedoklis par notas nozīmi Želiigovska uzbrukuma apturēšanā, kā arī pieḷautas neprecizitātes notas satura atstāstīšanā (patiesībā karadarbības pārtraukšanu noteica Tautu Savienības iespaids un pat spiediens uz Poliju un Lietuvu). ${ }^{1030}$ Abu valstsvīru saruna bija draudzīga, un notā bija uzsvērts, ka Želigovska akcija izraisijjusi nemieru, jo viṇu neuzskata par atbildīgu kāda priekšā. Tālāk bija teikts: "Kas attiecas uz Viḷnas valstisko piederību, Latvija paziņo savu neieinteresētību šajā lietā un novēl Polijai vēlamu iznākumu.

${ }^{1027}$ Michniewicz - Hetman M. Zagon wileńskiej brygady kawalerji pod Kiejdany//Bellona. - 1925. T. XIX. - Zesz. 1. - S. 67-71.

1028 Cielēns F. Laikmetu maiṇā. - 2. sēj. - Lidingo, 1963. - 159. lpp.

1029 Ramats K. Virspavēlnieks. - 148. lpp.

${ }^{1030}$ E. Andersons, pamatojoties uz F. Cielēna atmin̄ām, raksta, ka nota brīdināja Poliju: Latvija uzskata, ka Lietuvas valsts pastāvēšana ir nepieciešama, lai nodrošinātu Latvijas neatkarību, un izlietos visus līdzekḷus Lietuvas neatkarības aizstāvēšanai. Sapratuši, ka Latvija gatava ar ieročiem nostāties Lietuvas pusē, poḷi "pārtrauca tālāku invāziju". - Latvijas vēsture 1914-1920. - 161. 1pp. Tas ir acīmredzams pārspīlējums. Pats F. Cielēns nebija tik kategorisks, viṇš vienīgi apgalvoja, ka drīz pēc notas iesniegšanas militārās akcijas Lietuvā beidzās. - Laikmetu maiṇā. - 159. lpp. Arī Lietuvas historiogrāfijā pastāv līdzīgs pārspīlēts viedoklis - Latvijas nostāja izjaukusi Žeḷigovska plānus, jo "bailes kaujas laukā sastapties ar Latvijas armiju, kuru tajā laikā uzskatīja par labi organizētu un kuras karavīi bija paz̄istami ar savu drosmi un kaujas prasmi, bija viens no iemesliem, kāpēc Polija atteicās no visas Lietuvas sagrābšanas". - Surgailis G. Lietuvas un Latvijas armiju sadarbība...35. lpp.; Butkus Z. Hīmansa projekts Polijas un Lietuvas attiecību risinājumā 1921. gadā: Latvijas nostāja//Latvijas Vēsture. - 1995. - Nr. 1.-15. lpp. 
Tomēr gadījumā, ja Želigovska karaspēks dotos uz Kauṇu, Latvija būs spiesta nostāties Lietuvas pusē." V. Kameṇeckis pēc šīs atturīgās notas saṇemšanas sniedzis Z. Meierovicam paskaidrojumus, kuri "pilnībā normalizējuši pēdējā laikā nedaudz saspringtās Polijas un Latvijas attiecības", bet nākamajā dienā intervijā poḷu presei paziņoja, ka nevar iedomāties Latvijas valdību, kas ieṇemtu nelabvēlīgu nostāju pret Poliju. ${ }^{1031}$

Tas arī bija pārspīlējums, jo Žel̦igovska akcijas laikā un īpaši novembra vidū Latvijas attieksme pret Poliju kḷva ievērojami vēsāka un vēl piesardzīgāka. To vēlāk atzina arī pats V. Kameṇeckis. ${ }^{1032} \mathrm{Līdz}$ pat 1921. gada sākumam Latvijas armijas Zemgales divīzijas štābs no saviem ağentiem pierobežā turpināja ievākt informāciju par poḷu karavīru pārvietošanos un noskaņojumu. Sarunās ar latviešiem uz robežas vienkāršie poḷu karavīri vairākkārt jautāja, kad tie "aizies uz savu īsto robežu”, jo tikai 1921. gada martā Simpsona komisija izlēma, ka Ilūkstes apriṇķis pilnībā pieder Latvijai. ${ }^{1033}$ Tomēr pakāpeniski tika atjaunoti pārtrauktie sakari starp Latviju un Viḷnu. 1920. gada decembra beigās Latvijas un Polijas armiju attiecīgās vienības atjaunoja telegrāfa sakarus starp Rīgu un Varšavu (cauri Viḷnai), bet regulāra satiksme Daugavpils-Viḷnas dzelzceḷa līnijā atsākās 1921. gada 15. janvārī. ${ }^{1034}$ Kopējās robežas atjaunošana palīdzēja abām pusēm nodibināt nepieciešamos sakarus visās jomās. Piemēram, 1920. gada 11. decembrī armijas Virspavēlnieka štābs deva atḷauju Zemgales divīzijas komandierim „pārlaist pār fronti” (pār robežu $-\bar{E}$. J.) kārtējos trīs poḷu karavīrus, kurus no Rīgas bija atsūtījis Polijas militārais atašejs un kuri bija bēguši no padomju gūsta cauri Igaunijai. 11. decembrī Rozenavas (tag. Zilupes) stacijā tika aizturēts Polijas pirmās valdības ārlietu viceministrs Tituss Fiḷipovičs, kurš brauca bez tranzìtvīzas un atgriezās no padomju apcietinājuma (kur bija nonācis kā Polijas diplomātiskās misijas vadītājs Dienvidkaukāzā). Pēc attiecīga pieprasījuma Latvijas Ārlietu ministrija caur armijas Virspavēlnieka štābu deva rīkojumu nekavējoties šo personu izlaist cauri Latvijas teritorijai uz Poliju. ${ }^{1035}$

\section{Latvijas starptautiskā atzišana "de iure"}

1920. gada nogalē Latvijas ārpolitikas galvenais mērḳis bija panākt starptautisko atzīšanu “de iure”. Jau vasarā bija zināms pamats cerībām, ka tieši Polija būs pirmā, kas to izdarīs attiecībā uz Latviju un Igauniju. Tajā pašā

\footnotetext{
1031 Kurjer Poranny. - 1920. - 21, 22 list.

1032 Kamieniecki W. Polityka Bałtycka//Przegląd Współczesny. - 1922. - T. XVI. - S. 273.

${ }^{1033}$ LVVA, 6033. f., 1. apr., 61. 1., 19. 1p.; 62. 1., 7.-11. 1p. Turpmākajos gados Polija neatzina Ilūkstes apriṇķa sešu pagastu un Grīvas pilsētas iekḷaušanu Latvijā un laiku pa laikam izteica pretenzijas uz tiem. Tikai 1929. gadā, abām valstīm noslēdzot konfidenciālu vienošanos par kompensācijām Polijas pilsoṇiem - bijušajiem zemes īpašniekiem Latvijā (vienošanās tika attiecināta arī uz strīdīgo Ilūkstes apriņķa daḷu) -, jautājums tika atrisināts. - Sīkāk sk.: Jēkabsons Ē. Sešu pagastu un Grīvas pilsētas problēma Latvijas un Polijas attiecībās 20. un 30. gados. - 80. - 101. 1pp.

${ }^{1034}$ LVVA, 6033. f., 1. apr., 329. 1., 1. 1p.; AAN, Sztab Główny, 616/10, k. 38; Latvijas Kareivis. - 1921. 11. janv.

${ }^{1035}$ LVVA, 3601. f., 1. apr., 469. 1., 735., 736. lp.
} 
laikā Latvijas valdība bija spiesta rēḳināties ar varbūtību, ka Polija nedarīs to bez Rietumu (Antantes) lielvalstu akcepta. Mainoties militārpolitiskajam stāvoklim reǵionā, solījumi par gaidāmo atzīšanu no Polijas puses bija, taču netika pildìti vai arī nebija pieņemami Latvijas pusei. ${ }^{1036}$ Piemēram, oktobra beigās tika doti mājieni par iespējamu Latvijas atzīšanu, ja tā apṇemtos ievērot piln̄̄gu neitralitāti Polijas-Lietuvas konflikta risināšanā, dot Polijai ostu nomas tiesības uz 99 gadiem, neīstenot Latgalē zemes reformu un noslēgt ar Poliju militāru konvenciju. ${ }^{1037}$

Šāda piesardzīga, atturīga un dažkārt pašpārliecināta Polijas attieksme bija, pirmkārt, Francijas ārpolitisko nostādṇu dēḷ. Francija, kuras iespaidā atradās Polija, vēl nebija galīgi izlēmusi, vai atbalstīt valstis, kas bija izveidojušās bijušās Krievijas impērijas teritorijā, kā arī nebija līdz galam atmetusi cerību par impērijas vai demokrātiskākas Krievijas atjaunošanu. Savukārt Polijas ārlietu ministrs E. Sapeha par vienu no savas valsts galvenajiem uzdevumiem uzskatīja militāras konvencijas noslēgšanu ar Franciju (viņa uzskati un politiskā darbība bija cieši saistīta ar poḷu nacionāldemokrātiem). Novembra vidū Somijas iespaidā Polijas valdība izšḳīrās par Latvijas atzīšanu, taču E. Sapeha joprojām saglabāja noraidošu nostāju un uzskatīja, ka Polija var atzìt Baltijas valstis tikai pēc tam, kad to būs izdarījusi Francija. ${ }^{1038}$ Visu šo laiku noteikta Polijas politiķu daḷa centās iespaidot valdību, lai tā atzītu Latviju. Jau 14. oktobrī Galvenās statistikas pārvaldes direktors J. Buzeks, ārlietu viceministrs J. Dombskis ${ }^{1039}$ un vēl 30 Seima deputāti aicināja atzīt Latviju pastāvošajās robežās, jo tā ir Polijas dabiskais sabiedrotais, ar kuru nav un nebūs nopietnu nesaskanu, bet kuram ir ostas, kas tik nepieciešamas Polijai. ${ }^{1040}$ Decembra sākumā Seima sociālistu deputātu klubs arī aicināja savu valdību atzìt Latviju "de iure", jo Polijas ārpolitikai "jātiecas atvieglot stāvokli kaimiṇu tautām, kas atbrīvojušās no carisma”.1041 Sakarā ar Latvijā izplatītajām baumām, ka Polija atzīs Latviju "de iure", decembra beigās Polijas Preses birojs Rīgā paskaidroja, ka pirms Ziemassvētkiem Seima sociālistu deputāts M. N̦edzjalkovskis tiešām iesniedzis priekšlikumu pieņemt valdībai attiecīgu aicinājumu, kurš nodots Ārlietu komisijai. ${ }^{1042}$ Tomēr arī šoreiz nekādu seku nebija.

26. novembrī Latvijas Ārlietu ministrija konstatēja, ka "Latvijas draudzībai ar Poliju Želigovska akcija jau ir devusi lielu belzienu. Arī gaidītais de jure

${ }^{1036}$ Polijas presē pastāvīgi parādījās informācija par "Baltijas valstu atz̄īšanas jautājuma labvēlīgu izlemšanu" Antantes valstu galvaspilsētās un secinājumi, ka nav šḳēršlu arī atzīšanai no Polijas puses. Tomēr esot jāgaida "atbilstošs moments", lai tā nebūtu "izolēts akts". - Kurjer Poranny. 1920. - 22, 26 list.

${ }^{1037}$ LCVA, f. 383, ap. 7, b. 72, 1. 103 (D. Zauņa 1920. gada 27. oktobra ziņojums).

1038 Skrzypek A. Związek... - S. 72.

1039 J. Dombskis šajā laikā izrādīja ievērojamu labvēlību pret Latviju. Cita starpā, viņš kopā ar jau minēto J. Buzeku, premjeru V. Vitosu un vicepremjeru I. Dašiņski 22. oktobrī piedalījās Latvijas pārstāvniecības rīkotajās svinīgajās brokastīs par godu pirmajai gadadienai, kopš Latvijas valdība bija ieradusies Varšavā. - Latvijas Kareivis. - 1920. - 27. okt.

${ }^{1040}$ LVVA, 2575. f., 15. apr., 12. 1., 37. 1p.

${ }^{1041}$ Kurjer Poranny. - 1920. - 10 grudz.

${ }^{1042}$ Latvijas Kareivis. - 1920. - 29. dec. 
nenāk". V. Kameṇeckis turpināja aizbildināties ar zināmiem nosacījumiem, kuri vispirms jāizpilda Latvijai (cita starpā - jāgarantē Polijai tiesības izmantot savas ostas un jānodrošina Latgales poḷu kultūras autonomijas tiesības). Ministrija secināja, ka Antantes lielvalstu iebildumi pret Latvijas atzīšanu, ar kuriem turpina aizbildināties Polijas pārstāvis, "nav vienīgais kavēklis" un "atzīšanu no Polijas pirkt par dārgu naudu Latvijai nav vērts". 1. decembrī A. Keniṇš no Varšavas ziṇoja, ka "atzīšanas jautājums faktiski nevirzās nepavisam”. E. Sapeha gan centies viṇu pārliecināt, ka šajā jautājumā darījis visu iespējamo, taču bez panākumiem. A. Keniņš mēǵinājis noskaidrot daudzās pretrunas, un līdz ar to pieņemšana pie ministra beigusies "stipri vēsi”, E. Sapeham atzīmējot, ka viṇš vispār vairs nevar un nevēlas noteikt, kad "atzīšana notiks". 1043

Polijas ārlietu ministra patieso nostāju pret atzīšanas jautājumu šajā laikā apliecina 18. decembra instrukcija V. Kamen,eckim. Tajā viṇš uzdeva informēt Z. Meierovicu, ka Polijas valdība gan izlēmusi atzit Latviju un Igauniju "de iure", taču to traucē izdarīt "Latvijas neskaidrā nostāja pret Poliju". Ja divu nedēḷu laikā Latvija nesniegs "labvēlīgu" atbildi uz Polijas priekšlikumiem (kura "iznīcinās mūsu šaubas"), tiks atzīta tikai Igaunija un "vainojama pie notikušā būs vienīgi Latvijas valdība". ${ }^{1044}$

Neraugoties uz to, 20. decembrī L. Sēja konstatēja, ka attiecības ar Poliju kḷuvušas vēsākas, "lai gan tās nav nekādā ziṇā sliktas. Polijai ḷoti ḳērusies pie sirds mūsu izturēšanās pret Žel,igovska pasākumu, sevišḳi pret viṇa delegātiem Rīgā”. Tomēr, spriežot pēc poḷu diplomātu attieksmes, īpašu seku tam nebūšot. ${ }^{1045}$ Attiecībā uz atzīšanas jautājumu Polija tomēr turpināja ievērot līdzšinējās nostādnes un izteica vēlmi vispirms noslēgt ar Latviju saimniecisku vienošanos, kas l̦autu Polijai izmantot Latvijas ostas. Neievērots palika Latvijas puses iebildums, ka būtu dabīgi, ja pirms šāda līguma noslēgšanas Polija vispirms atzìtu Latviju "de iure". ${ }^{1046}$

Latvijas un Igaunijas neuzticību Polijai vēl vairāk palielināja I. Paderevska rīcība Ženēvā 15. decembra balsojumā par Baltijas valstu un Gruzijas Republikas uzṇemšanu Tautu Savienībā (I. Paderevskis bija Polijas

${ }^{1043}$ LVVA, 2575. f., 15. apr., 2. 1., 9. 1p.; 12. 1., 2. lp. Sarunas vēl vairāk sarežğīja A. Ķeniṇa un Polijas varas iestāžu attiecības, un Polijas puse uzsāka aktīvu darbību, lai panāktu Latvijas diplomātiskā pārstāvja maiņu. Decembra vidū pēc V. Kameņecka protesta Latvijas Ārlietu ministrijā A. Ķeniņš tika izsaukts uz Rīgu. Turklāt ar V. Kameņecki tika saskaņota arī nākamā pārstāvja kandidatūra. Polijas puse šajā amatā vēēejā̄s redzēt M. Valteru, taču tai nebija iebildumu arī pret L. Sēju. Tomēr formāli A. Ķeniņš joprojām palika amatā, un 1921. gada 9. aprīlī E. Sapeha deva rīkojumu "loti delikātā veidā" mēǵināt panākt pārstāvja maiṇu (A. Ķeniṇš Varšavā oficiālās pien̦emšanās, banketos un citur joprojām “uzvedies provokatīvi”, kritizējot Polijas ārpolitiku u. c.). Tūlīt pēc tam A. Ķeniņš tika atsaukts no amata pavisam. - AAN, Kod, t. 2, k. 296; t. 3, k. 115.

1044 AAN, Kod, t. 2, k. 347.

1045 Šajā laikā nebija mainījusies labvēlīgā Polijas attieksme pret Latvijas bēgḷiem. Polija palīdzēja bēg̣̦iem, kas atgriezās dzimtenē cauri Polijai no Dienvidkrievijas. Novembrī Polija uzņēmās saistības pagaidām pārstāvēt Latvijas pilsoṇu intereses Turcijā. - Latvijas Kareivis. - 1920. 24. nov. Savukārt 25. novembrī, pateicoties par Latvijas varas iestāžu labvēlīgo attieksmi pret poḷu bēgḷiem, Polijas Kara lietu ministrija deva rīkojumu gūstā kritušos latviešu tautības sarkanarmiešus nekavējoties cauri Varšavai nosūtît uz dzimteni. - AAN, Attachaty, A - II, 65/1, k. 18; 81/1; 81/2.

1046 LVVA, 2575. f., 15. apr., 2. 1., 3. lp. 
pārstāvis šajā starptautiskajā organizācijā). Vainīgs bija nevis I. Paderevskis, kam uzbruka Polijas prese, bet gan Ārlietu ministrijas vadība, kura deva vinam attiecīgus norādījumus, būdama pārliecināta, ka Rietumu lielvalstu "pozitīva un solidāra" rīcība Baltijas valstu atzīšanas lietā nav iespējama. ${ }^{1047}$ Tādēḷ I. Paderevskis, paziṇoja, ka nevar balsot “par” (ir spiests atturēties ${ }^{1048}$ ), jo to nevēloties Polijas "labvēḷi" (savā runā viṇš vispirms labvēlīgi izteicās par jaunajām valstīm, kuras bija izveidotas Krievijas impērijas teritorijā un kuru cīṇa par savu brīvību rada dziḷas simpātijas; šis izteikums izraisīja aplausus, jo šķita dabīgi, ka sekos paziņojums: Baltijas valstu uzṇemšana Tautu Savienībā tiek atbalstīta). I. Paderevskis norādīja, ka Polija saprot, kam pašai jāsaka paldies par savas neatkarības atgūšanu, tāpēc "Polijas sirds grib teikt jā un tās balss nevar teikt nē”. Secinājums - balsošanā ir jāatturas. Sekoja gan piebilde, ka viṇa "sirsnīgākā vēlēšanās” esot, lai Polijas "labvēḷii" atrastu ceḷu visu mazo tautu brīvības galīgai pasludināšanai. ${ }^{1049}$ Polijas prese atzīmēja, ka līdz ar to Francijas un Anglijas pārstāvjiem bija jājūtas neērti, jo, pat pieņemot, ka tāda tiešām bija viṇu nostāja, tie nekādā ziṇā nevēlējās, lai kāds to paziņo atklāti. Motīvi, ar kādiem aizbildinājās I. Paderevskis, "izraisot šausmas". ${ }^{1050}$ E. Sapeha Polijas pārstāvja atturēšanos balsojumā par Baltijas valstu uzņemšanu Tautu Savienībā skaidroja vēl primitīvāk: "[... par Lietuvu balsot nebija iemesla, Latvija šajā laikā neizturējās draudzīgi Žeḷigovska lietā, par Igauniju vienu pašu balsot nevarēja. Turklāt I. Paderevskis rēḳinājās ar Antantes nostāju."1051

Skaidrs, ka šāda rīcība bija ievērojams trieciens Polijas un Baltijas valstu attiecībām, un tā jāuzskata par nopietnu Polijas ārpolitikas kḷūdu. Kopumā 1920. gada beigās un 1921. gada sākumā bija vērojams Latgales poḷu muižniecības iespaida pieaugums Polijas ārpolitikā. To izraisīja radikālais agrārās reformas likums, ko 16. septembrī bija pieṇēmusi Latvijas Satversmes sapulce.

Latgalē pirms Pirmā pasaules kara poḷu muižnieku rokās atradās 272323 hektāri zemes 326 îpašumos (no tiem 58 bija lielāki par 1000 hektāriem). ${ }^{1052}$

1047 Łossowski P. Ustanowienie stosunków Polski z Estonią w latach 1918 - 1921//Z dziejów polityki i dyplomacji Polskiej. - Warszawa, 1994. - S. 202.

1048 Par uzṇemšanu nobalsoja Itālija, Kolumbija, Paragvaja, Persija un Portugāle, pret - 24, bet atturējās 13 valstis. - Ārpolitika//Latvju Enciklopēdija/Red. A. Švābe. - 1. sēj. - Stokholma, 1950. 107. lpp.

1049 Vīgrabs J. Latvijas atzīšana “de jure” un uzṇemšana Tautu Savienībā//Latvijas Vēstures Institūta Žurnāls. - 1938. - Nr. 4.-591. lpp.

${ }^{1050}$ Kurjer Poranny. - 1921. - 4 stycz. I. Paderevskis privātā sarunā ar Z. Meierovicu ieteica samierināties ar iespējamu Latvijas neatkarības jautājuma pārskatīšanu brī̄ī, kad tiks atjaunota "vecā Krievija”. - AAN, Kod, t. 2, k. 386.

1051 AAN, Kod, t. 2, k. 336. Polijas Seima Tautas kustības frakcijas vadītājs J. Dombskis 1921. gada janvārī pieprasīja valdībai sniegt paskaidrojumu I. Paderevska rīcības lietā. - Latvijas Kareivis. - 1921. - 25. janv. Tautu Savienības 6. komisija 1921. gada augustā uzsāka apspriest Latvijas un Igaunijas uzņemšanu. Polija nepārprotami atbalstīja uzņemšanu, un 22. septembrī Latvija tika uzṇemta Tautu Savien̄̄bā. Polijas delegācija balsojumā gan nepiedalījās savas prombūtnes dēḷ, taču tās vadītājs paskaidroja latviešiem, ka poḷi nav varējuši piedalīties balsojumā, jo bijuši pret Lietuvas uzņemšanu, un lūdza saprast to pareizi. - Vīgrabs J. Latvijas atzīšana “de jure” un uzņemšana Tautu Savienībā. - 601.-602. lpp.

1052 Maliszewski E. Polacy na Łotwie. - S. 18. 
Kopumā Latgalē poḷu īpašumā bija 45,8\% zemes (Daugavpils apriṇḳī - 68,4\%, Rēzeknes - 57\%, Ludzas - 39,3\%), krievu īpašumā - 22,9\%, vāciešu - 11,5\% un latviešu - tikai $19,8 \%$ zemes. Vidējais zemnieku saimniecības lielums Latgalē bija 8 hektāri (Vidzemē - 47, Kurzemē un Zemgalē - 41,5 hektāri). ${ }^{1053}$ 1920. gada rudenī V. Kameņeckis atzina, ka Latgalē un Ilūkstes apriṇkīi poḷu rokās atrodas apmēram $50 \%$ zemes. ${ }^{1054} \mathrm{P}$. Losovskis raksta, ka poḷu rokās bija pāri par 130 īpašumiem apmēram 350000 hektāru platībā, bet 1929. gada abu valstu līgumā par kompensāciju izmaksām Polijas pilsoṇiem bija minēti 230000 hektāri, kas viṇiem tika atṇemti, atstājot kopumā 89 "pārpalikumus" (katru aptuveni 50 hektāru platībā). ${ }^{1055}$

Kaut arī Polijas pārstāvji bija vairākkārt oficiāli paziṇojuši, ka zemes reforma Latvijā ir Latvijas iekšējā lieta, tomēr, reformu uzsākot (kad kḷuva skaidrs, ka tā skars visus zemes īpašniekus neatkarīgi no tautības un pilsonības), ievērojami aktivizējās muižnieku organizācijas Polijā un mainījās arī Polijas ārlietu resora nostāja. ${ }^{1056}$ Septembra beigās laikrakstā "Rzeczpospolita" par Latgali tika publicēts raksts, kurā izskanēja apgalvojums, ka Latvijā var kaut ko panākt, vienīgi piekukul,ojot ierēdṇus. Tas izraisīja sašutumu pat Latgales poḷos, un vairāki cilvēki, kas apvienojās un parakstījās zem nosaukuma "Latgales poḷu padome", poḷu laikraksta redakcijai iesniedza savu protestu. Tomēr protests netika pieñemts un minētā padome iesniedza to publicēšanai latviešu presē..$^{1057}$

A. Keniņš 1920. gada novembrī ziṇoja, ka "sevišk,i par Polijas atsvešināšanos pret mums interesējas latgaliešu muižnieki un viṇu draugi" un uzsāk aǵitāciju par iejaukšanos Latvijas iekšējās lietās. Arī pie paša A. Keniņa bija ieradušies vairāki Inflantijas Poḷu padomes pārstāvji V. Dovgjalo vadībā un izteica neapmierinātību ar agrāro likumu, kurš "nerunājot nemaz par atlīdzības nenoteiktību, uz ko viṇi cerē, atstāj viṇiem tik maz zemes". Tie apsolīja, ka darīs visu iespējamo, lai panāktu "likuma modifikāciju attiecībā uz Latgales poḷiem”. Arī Seima maršals V. Trompčin,skis pārmeta A. Keniṇam Latvijas varas iestāžu slikto attieksmi pret Latgales muižniekiem. Latvijas pārstāvi pārsteidza maršala "uzbudinājums un karstums, ar kādu viṇš aizstāvēja poḷu prasības labā spārna garā". V. Trompčiṇskis pat draudēja, ka Latgales notikumi var novest pie starptautiska konflikta. A. Keninš bija pārsteigts par šādiem oficiālas personas izteikumiem un atgādināja premjera L. Skuḷska apṇemšanos neizskatīt Latgales jautājumu no muižnieku interešu viedokḷa. Sarunu ar V. Trompčiņski A. Ķeniņš atstāstīja Polijas Ārlietu ministrijā un saṇēma no E. Sapehas, J. Pilsudska un prezidenta V. Vitosa apliecinājumu, ka tāds V. Trompčinsska tonis un apgalvojumi nav bijuši piel̦aujami un ir subjektīvi. ${ }^{1058}$ Tomēr arī Polijas nacionāldemokrātu

\footnotetext{
1053 Albin J. Polski ruch ... - S. 37.

1054 AAN, Kod, t. 4, k. 7.

1055 Łossowski P. Łotwa... - S. 20; AAN, MSZ, t. 6211, k. 33.

1056 Sīkāk sk.: Jēkabsons Ē. Latvijas poḷi un Latgales poḷu muižniecība valsts neatkarības sākuma posmā 1918.-1920. g. - 90.-105. lpp.; Jēkabsons Ē. Latgales poḷu muižniecība un Latvijas valsts 1918.-1940. gados//Acta Latgalica. - 11. sēj. - Daugavpils, 2001, 82.-90. 1pp.

1057 Valdības Vēstnesis. - 1920. - 11. okt.

1058 LVVA, 2575. f., 15. apr., 12. 1., 15.-16. 1p.
} 
presē bija atsākusies kampaṇa, kas vērsta pret Latviju. ${ }^{1059}$ Presē nokḷuva informācija par Seima maršala nepārdomātajiem izteicieniem, kas izraisīja asu reakciju. Demokrātiskais "Kurjer Poranny" pat uzvēla viṇam vainu par Viduslietuvas delegācijas izraidīšanu no Latvijas ${ }^{1060}$ (tas, protams, bija pārspīlējums). Savukārt sociālistiskais "Robotnik" pārmeta V. Trompčinsskim galēju reakcionārismu, jo viṇš "baidījis" Latvijas pārstāvjus ar iespējamo neatzīšanu „de iure” tikai zemes reformas dēl. Laikraksta ievadraksta autors pat izteica aizdomas, ka kāds Seima maršala "brālēns" esot Latgales zemes ipašnieks, kuram grūti šķirties no saviem īpašumiem. Raksts asi nosodīja Polijas ārpolitisko kursu, kura īstenotāji neapzinās nepieciešamību mainīt ukraiṇu, baltkrievu, lietuviešu un latviešu priekšstatu par poḷiem (vēl nesenā pagātnē šīs tautas bija apspieduši poḷu muižnieki), aizstāvēja J. Pilsudski, kas atdodot "neparasti augsti izglìtotajai tautai" (latviešiem) Latgali, kura tai neapšaubāmi pieder. ${ }^{1061}$ Decembrī anonīmu Latgales muižnieku grupa presē nepublicētā atbildē centās pierādìt, ka "jaunradušās tautas", arī latvieši, nevar līdzināties poḷiem un nespēj bez Polijas atbalsta pretoties varbūtējam agresīvo kaimiṇu spiedienam. Viṇi kārtējo reizi klāstīja par poḷu "vajāšanu" Latgalē. ${ }^{1062}$

Savukārt Polijas ǵenerālkonsuls Latvijā A. Luce-Birks tūlīt pēc agrārās reformas likuma pieṇemšanas uzṇēmās iniciatīvu jautājuma risināt starptautiskā līmenī. 28. oktobrī viñš un Somijas, kā arī Vācijas konsuls Rīgā nolēma sarīkot plašāku apspriedi ar ieinteresēto valstu pārstāvju piedalīšanos. 30. oktobrī Dānijas pārstāvniecībā notika Polijas, Somijas, Dānijas, Francijas, Anglijas, Šveices, Beḷǵijas, Norvēǵijas un Zviedrijas konsula apspriede, kurā tika nolemts iesniegt Latvijas valdībai kopīgu protestu pret "zemes konfiskāciju bez atlīdzības". ${ }^{1063}$ Pēc tā iesniegšanas Latvijas puse paskaidroja, ka reforma pauž Latvijas tautas gribu un iekšējās juridisdikcijas jautājumā ārzemniekiem ir vienādas tiesības ar Latvijas pilsoṇiem. ${ }^{1064}$ Tādējādi ārvalstu pārstāvju mēǵinājums iejaukties jautājuma risinājumā tūlītējus rezultātus nedeva un nevarēja dot, taču zināmu papildu spriedzi Latvijas un Polijas attiecībās radīja. V. Kamen,eckis to novērtēja kā visai lielu. ${ }^{1065}$ Jāpiezīmē, ka oficiālais Polijas ārpolitikas mērķis šajā jautājumā redzams instrukcijā, ko Ārlietu ministrija 1921. gada 16. janvārī devusi V. Kameņeckim. Tajā teikts, ka Polija atzīst Latvijā veiktās zemes reformas likumību un to nekavēs, taču vēlas, lai reforma pēc iespējas mazāk kaitētu poḷu zemes īpašumiem Latgalē. Patiesībā zemes reforma ietekmēja gandrīz vienīgi lielos poḷu tautības zemes

\footnotetext{
1059 Gazeta Warszawska. - 1920. - 1920. - 19 list.

1060 Kurjer Poranny. - 1920. - 18 list.

1061 Robotnik. - 1920. - 30 list.

1062 AAN, Towarzystwo Straźy Kresowej, t. 105, k. 5.

1063 AAN, Kod, t. 4, k. 10-11.

1064 Kurjer Polski. - 1920. - 14 list.

${ }^{1065}$ Kamieniecki W. Polityka Bałtycka. - S. 275. Jautājums tika atrisināts 1929. gadā, Latvijai un Polijai Rīgā parakstot konfidenciālu vienošanos, ar kuru Latvija līdz 1937. gadam atmaksāja Polijai par tās pilsoņu īpašumiem piecus miljonus zelta latu, bet Polija apsolīja turpmāk neatbalstīt bijušo zemes īpašnieku pretenzijas. - LVVA, 2570. f., 1. apr., 354. 1., 30.-36. 1p.; AAN, MSZ, t. 6208, k. $27,33$.
} 
īpašniekus. To apliecina arī jaunsaimniecības, kas reformas dēḷ izveidojās Latgalē un piederēja 1516 poḷu tautības zemniekiem. ${ }^{1066}$

1921. gada sākumā Latvijas-Polijas turpmākās attiecības joprojām palika neskaidras. Pirms gada uzsāktā sadarbība, kas viesa cerības, bija beigusies, valdīja zināms saspīlējums un aizdomīgums, pat savstarpējs aizvainojums. No vienas puses, V. Kameneckis bija spiests deklarēt, ka Polija Latviju nevar atzìt pirms konvenciju noslēgšanas, no otras puses, viňš apgalvoja, ka to darīt pagaidām neatlauj Rietumu lielvalstu noraidošā nostāja. ${ }^{1067}$ Viṇš uzstājīgi pieprasīja savai Ârlietu ministrijai dot atḷauju atzīšanai, motivēdams, ka tas ir Polijas ārpolitikas Baltijas virziena sekmīgas attīstības galvenais priekšnoteikums. Tomēr ministrijas un E. Sapehas nostāja pagaidām palika nemainīga ${ }^{1068}$ - viņam bija svarīgi, kā situāciju vērtē Polijas diplomātiskā pārstāvniecība Parīzē. Tā uzskatīja, ka Antantes lielvalstis pirms attiecīgā lēmuma pieņemšanas informēs par to Poliju. Tāpēc šie "Antantei vistuvāk esošie" poḷu diplomāti ieteica turpināt izvirzìt Latvijai dažādus noteikumus, kas ir izdevīgi Polijai. Saņemot šādu informāciju no Parīzes, E. Sapeha neuzskatīja par pamatotiem pārstāvju ziņojumus un prasības no Rīgas un Tallinas. ${ }^{1069}$ Tā bija kārtējā Polijas diplomātijas kḷūda.

Tomēr šajā laikā Latvijas un Igaunijas ārlietu ministram Londonā un Parīzē izdevās panākt Antantes lielvalstu attieksmes maiṇu. Galvenais attieksmes maiṇas iemesls bija meklējams, pirmkārt, Francijas un Anglijas nostājas maiṇā pret Krieviju (pirmā bija pilnībā zaudējusi cerības uz nekomunistiskas Krievijas ātru atjaunošanu, bet otrā - izšķīrusies par nostāšanos uz tirdzniecisku sakaru ceḷa ar Padomju Krieviju, kuras milzīgo tirgu varēja iekarot arī caur Baltijas valstīm).

1921. gada 24. janvārī Parīzē darbu sāka Antantes Augstākās padomes sēde, kura 26. janvārī izlēma atzìt Latviju, Igauniju un Gruzijas Demokrātisko Republiku 1070 "de iure”. ${ }^{1071}$ Raksturīgas bija diskusijas šajā jautājumā. Anglijas ārlietu ministrs vispirms bija pret jauno valstu atzīšanu, taču tad, kad Itālijas ārlietu ministra K. Sforsas priekšlikumu par atzīšanu atbalstīja arī Francijas premjerministrs A. Briāns, tam piekrita arī britu premjers D. Loids Džordžs. Tādējādi notika izškiršanās par Baltijas valstu atzīšanu "de iure"1072 (Lietuvas jautājums tika izskatīts vēlāk, jo pagaidām nebija noteiktas robežas ar Poliju). Tūlìt pēc tam šajā dienā sekoja Somijas, ${ }^{1073}$ Itālijas, Anglijas, Francijas, Japānas un Beḷǵijas valdības paziņojums par Latvijas atzīšanu "de iure”. ${ }^{1074}$

\footnotetext{
1066 Albin J. Polski ruch... - S. 37, 54.

1067 Latvijas Kareivis. - 1920. - 18. janv.

1068 Łossowski P. Łotwa... - S. 18.

1069 Skrzypek A. Związek... - S. 82.

1070 Pēc nepilna mēneša - 1921. gada februārī - Padomju Krievija uzsāka militāru agresiju pret Gruziju un iznīcināja tās neatkarību.

${ }^{1071}$ Feldmanis I. Latvijas valsts: rašanās, starptautiskā atzīšana un ārpolitiskās darbības galvenie virzieni (1918-1940)//Dokumenti par Latvijas valsts starptautisko atžšanu, neatkarības atjaunošanu un diplomātiskajiem sakariem 1918-1998. - Rīga, 1999. - 35.-39. 1pp.; Lauga J. Un Eiropa kḷūtu jaunāka...//Atmoda Atpūtai. - 1993. - 30. janv.

1072 Skrzypek A. Związek... - S. 81.

${ }^{1073}$ Igauniju Somija “de iure” bija atzinusi jau 1920. gada 7. jūnijā. - Hovi K. Polish - Finnish cooperation... $-125 \mathrm{p}$.

1074 LVVA, 2570. f., 3. apr., 1149. 1., 1.-3. 1p.
} 
Polijas pārstāvis Rīgā V. Kameṇeckis uzzināja par notikušo 27. janvārī plkst. 11.00, kad Antantes valstu pārstāvji ieradās Latvijas Ārlietu ministrijā un darīja visu, "lai izvairītos no katastrofas, par kādu izvērstos Latvijas neatzīšana vienīgi no Polijas puses”. Pēc apspriešanās ar pārstāvniecības padomnieku R. Knollu viṇš sazinājās ar Polijas pārstāvi Igaunijā L. Vasilevski un pretēji ministrijas instrukcijām vienojās datēt atzīšanas aktus ar pagājušā gada 31. decembri ${ }^{1075}$ un iesniegt tos (vēl 25.-26. janvāra naktī E. Sapeha bija devis rīkojumu pagaidām neizmantot pārstāvniecībās esošos un paša ministra parakstītos atzīšanas rakstus). V. Kameņeckis un pārstāvniecības sekretārs J. Baḷiņskis aktu iesniedza Latvijas ārlietu ministra biedram H. Albatam 27. janvārī plkst. 13.00 (atzīšanas aktā ietvertā frāze par cerību, ka „Polijas piemēram nekavēsies sekot arī citu valstu valdības", liecina, ka poḷi tiešām nešaubījās - viṇi būs vieni no pirmajiem, kas atzīs Latviju). ${ }^{1076}$ Pēc stundas H. Albats atbildēja uz vizìti, ieradās pie V. Kameṇecka pārstāvniecībā un izteica oficiālu Latvijas valdības pateicību, bet plkst. 15.00 pārstāvniecībā ieradās A. Keniṇš un arī izteica pateicību (viṇš atradās Rīgā un oficiāli pagaidām vēl bija Latvijas pārstāvis Polijā). 28. janvārī Latvijas un Igaunijas galvaspilsētā sakarā ar abu valstu starptautisko atzīšanu notika tautas manifestācija. Îpaši tika manifestēts pie Itālijas un citu lielvalstu pārstāvniecībām, taču demonstranti ieradās arī pie Polijas pārstāvniecības Rīgā un pie konsulāta Liepājā. ${ }^{1077}$ Savukārt Varšavā 30. janvārī Polijas Ārlietu ministrija sarīkoja pusdienas Latvijas, Igaunijas un Gruzijas pārstāvjiem. Latviju pārstāvēja P. Oliņš, bet Poliju - Ārlietu ministrijas Austrumu nodaḷas priekšnieks J. Lukasēvičs, viceministrs J. Dombskis un Ģenerālštāba priekšnieks T. Rozvadovskis, pusdienās piedalījās arī Somijas diplomātiskais pārstāvis Polijā. ${ }^{1078}$

V. Kameṇeckis, kurš 27. janvārī bija uzṇēmies lielu atbildību (E. Sapeha rīkojumu iesniegt atzīšanas aktu deva krietni vēlāk), savu rīcību pamatoja šādi: "Manis iesniegtais atzīšanas akts radīja iespēju arī turpmāk saglabāt ilūziju par draudzīgajām attiecībām. Tomēr tas tika iesniegts par vēlu un to nevar uzskatīt par iemeslu, kādēl tika izteikta pateicība no Latvijas puses, ne arī par [nopietnu] politisku aktu no mūsu puses. Tā gluži vienkārši bija l̦oti smagas un nepatīkamas situācijas glābšana."1079

Tomēr attiecībās ar Latviju Polijas pusei nepatīkamākais vēl bija priekšā. Laikraksta "Kurjer Poranny" korespondents Z. Sahnovskis noskaidroja neveiksmīgās atzīšanas detaḷas, un 31. janvārī avīze sīki tās aprakstīja, minot "sensacionālus sīkumus, kuri atklāj mūsu diplomātu nevarību, turklāt tā tie vēl gribēja visu noslēpt”. Žurnālists uzsvēra, ka vienīgi V. Kamen,ecka "ātrais lēmums" glābis Polijas prestižu Latvijas valdības acīs. ${ }^{1080}$ Polijas Ārlietu

\footnotetext{
${ }^{1075}$ Datuma šrifts uz oriǵinālā atzīšanas akta tiešām nedaudz atšķiras no pārējā teksta šrifta. - LVVA, 2570. f., 3. apr., 1148. 1., 33. 1p.

1076 Sk.: Dokumenti par Latvijas valsts starptautisko atzīšanu, neatkarības atjaunošanu un diplomātiskajiem sakariem... - 83. lpp.

1077 Kurjer Poranny. - 1921. - 29, 30, 31 stycz.; Latvijas Kareivis. - 1921. - 29. janv.; Źołnierz Polski. - 1921. - 2 luty.

1078 Kurjer Poranny. - 1921. - 1 luty.

1079 Łossowski P. Łotwa... - S. 18-19.

${ }^{1080}$ Kurjer Poranny. - 1921. - 31 stycz.
} 
ministrijas Preses nodaḷa neveikli mēǵināja situāciju glābt, lielākajiem laikrakstiem piesūtītā paskaidrojumā apgalvojot, ka tas "neatbilst patiesībai", bet "Kurjer Poranny" redakcija savā atbildē retoriski vaicāja: "Kas zina, vai Preses nodaḷa nedarītu labāk, noliedzot visu to patiesībai neatbilstošo [..] informāciju, kuru šajā lietā preses pārstāvjiem sniedza ministrijas ierēdnis Lukasēviča kungs?"1081

Latvijā Polijas puses izturēšanās atstāja jūtamu iespaidu. 7. februāra Ārlietu ministrija konstatēja, ka "poḷi ar savām intrigām de jure lietā nežēlīgi iekrita”. Par starptautisko atzīšanu Polijas pārstāvniecības darbinieki Rīgā nejauši uzzinājuši laikraksta "Jaunākās Ziṇas" redakcijā. Sekojis "liels apjukums, skraidīšana un runāšana". Pēc tam V. Kameneckis iesniedza aktu, kas bija parakstīts 31. decembri un kas Latvijas pusi pārliecināja, ka poli vienkārši gribējuši piespiest latviešus parakstīt "Latvijai citādi nepieņemamu konvenciju". Zīmīgi, ka Ārlietu ministrijas departamenta direktors L. Sēja piẹ̦āva varbūtību, ka Latvijai labvēlīgais J. Pilsudskis devis rīkojumu aktu iesniegt tūlìt, bet E. Sapeha "saziṇā ar saviem domubiedriem valdībā un Seimā" izlēmis to pagaidām uzglabāt. Viņš konstatēja, ka Polijas "izdaudzinātie" preses biroji ārvalstīs šoreiz nav bijuši uzdevumu augstumos un "ir notikusi liela Dieva žēlastība, jo mēs esam bijuši tikai pusotra soḷa no morāliskas verdzības: ja poḷi mūs būtu atzinuši jau 31. decembrī un to paziņojuši, viṇi visus nopelnus mūsu „de jure” lietā būtu pierakstījuši vienīgi sev un vinu uzpūtībai nebūtu robežu. Bet tagad, pēc Paderevska krokodila asarām Ženēvā un de jure grāmatas nodošanas tikai 27. janvārī, poḷu kungiem pret Latviju nav ar ko seviški lepoties; tiem nav arī iemesla mūs uzskatīt par savām kreatūrām [..]". ${ }^{1082}$

Katrā ziṇā liela daḷa taisnības bija Polijas Telegrāfa aǵentūras Rīgas biroja vadītājam J. Cinarskim, kurš 1921. gada aprīlī šādi, pat nedaudz pārspīlēti vērtēja Latvijas atzīšanu no Polijas puses: "Atzīšana [..] notika tik nelabvēlīgos apstākḷos, ka akta iesniedzēji tika padarìti smieklīgi, Polijas iespaids - ievērojami samazināts, bet latvieši - saērcināti un tiem iedvesta vēl lielāka nepatika pret Poliju."1083 To skaidri apliecina arī Lietuvas preses oficiozs „Lietuva”, kas uzsvēra Polijas „sakompromitēšanos” Latvijā. ${ }^{1084}$

$$
* * *
$$

Laika posmā no 1920. gada jūlija, kad Polijas armija pilnībā bija atstājusi Latvijas teritoriju, līdz 1921. gada janvārim, kad tā bija atzinusi Latvijas valstiskumu "de iure", abu valstu attiecībās bija vērojamas tendences, kuras uzskatāmi atklāja valdību ārpolitiskos pamatprincipus gan vienai pret otru, gan pret trešajām valstīm, pirmkārt, pret Lietuvu un Padomju Krieviju. Turklāt šajā periodā sevišḳi uzskatāmi izpaudās Latvijas un Polijas attiecību atkarība no globālajiem militārpolitiskiem procesiem reǵionā un Eiropā.

\footnotetext{
1081 Kurjer Poranny. - 1921. - 1 luty.

1082 LVVA, 2574. f., 1. apr., 23. 1., 283.-285. 1p.

1083 AAN, Kod, t. 2, k. 386.

${ }^{1084}$ Lietuva. - 1921. - 10 vas.
} 
Lai gan vēlākajos gados bija notikusi notu apmaina, 1920. gada jūlijā seši Ilūkstes apriņķa pagasti, kas līdz tam faktiski bija iekḷauti Polijā, tika pievienoti Latvijai, pateicoties notikumu attīstībai polu-padomju frontē. No Latvijas viedokḷa raugoties, tas bija pilnīgi likumīgi. Polija jūlijā bija gatava atzìt Latviju "de iure" un par labu Latvijai atteikties arī no šiem pagastiem, uz kuriem līdz šim un arī vēlāk tā izteica zināmas pretenzijas. Pretī tika prasīts militārs atbalsts cīṇā pret Padomju Krieviju. N̦emot vērā konkrētos militārpolitiskos apstākḷus reǵionā, uz šo atbalstu nevarēja cerēt. Šāda nostāja spilgti apliecina Polijas sarežğìto un pat smago militārpolitisko stāvokli šajā laikā.

Samērā krasa Latvijas un Polijas ārpolitisko nostādṇu maiṇa, no vienas puses, un Polijai labvēlīgā atmosfēra, kas valdīja Baltijas valstu konferencē Bulduros un ko noteica kārtējās izmaiṇas poḷu-padomju frontē un Latvijas teritoriālās nesaskaṇas ar Polijai naidīgo Lietuvu, no otras puses, skaidri parāda abu valstu politiskās intereses. Latvijas galvenais mērķis bija nodrošināt savu neatkarību un neiesaistīties karā Polijas pusē, tā bija ieinteresēta Polijas valstiskās neatkarības saglabāšanā apstākḷos, kad reāli kḷuva Sarkanās armijas uzvaras draudi. Latvija skaidri apzinājās, ka Polijas iznīcināšanas gadījumā "pasaules revolūcijas” idejas pārṇemtā Padomju Krievijas valdība un tās Sarkanā armija neapšaubāmi apdraudēs arī Baltijas valstu neatkarību. Tomēr tieši šajā Polijai tik kritiskajā laikā Latvijas valdība centās savas valsts neatkarību nodrošināt par katru cenu, līdzīgi Lietuvai - noslēdzot miera līgumu ar Padomju Krieviju (jāatzīst, ka Polijas puse, daḷēji savu interešu dēl, izturējās pret šo soli saprotoši). No šì brīža Latvijas neitralitāte tika formāli ievērota l,oti rūpīgi, turklāt ne tikai Polijas-Padomju Krievijas, bet arī Polijas-Lietuvas attiecībās un konfliktā.

1920. gada septembrī šķita, ka iespējama vismaz daḷēja attiecību noregulēšana starp Baltijas reǵiona valstīm, kā arī ar Padomju Krieviju. Par to liecināja gan Bulduru konferences pagaidām neratificētie līgumu projekti, gan Rīgā sāktās poḷu-padomju miera sarunas, gan poḷu-lietuviešu sarunas par savstarpējā konflikta noregulēšanu. Tomēr ǵenerāḷa Želigovska akcija Viḷnā un sekojošie notikumi izjauca trauslo līdzsvaru starp Poliju un Lietuvu un turpmākajos mēnešos zināmā mērā iesaistīja konfliktā arī Latviju kā abu minēto valstu tuvāko kaimiṇu ziemeḷos.

Tieši 1920. gada rudens notikumi īpaši uzskatāmi parādīja, pirmkārt, Latvijas ārpolitikas dienvidu virziena stratēǵiju - komplicētajā situācijā tā mēǵināja noturēties politiskā līdzsvarā starp Poliju un Lietuvu. Apstākḷos, kad ar Lietuvu joprojām pastāvēja nopietnas teritoriālas domstarpības, bet no Polijas tika gaidìts būtisks atbalsts, lai panāktu starptautisku atzīšanu "de iure", minētajam līdzsvaram bija tendence nosvērties nedaudz par labu Polijai. Kopumā šì Latvijas nostāja saglabājās līdz pat Otrā pasaules kara sākumam 1939. gadā. Turklāt atklājās Latvijas attieksme pret Viḷnas jautājumu, kas bija galvenais Lietuvas un Polijas nesaskaṇu cēlonis. Tā bija nenoteikta, šķietami neitrāla, taču faktiski ārkārtīgi piesardzīga un atsevišķos posmos pat zināmā mērā divkosīga, jo daḷēji apslēpti simpātijas tika izrādītas abām pusēm. Turklāt 1920. gadā jau minēto apstākḷu dēl Polijai - nedaudz vairāk (ar nosacījumu, ka Lietuvas neatkarība netiks iznīcināta). Protams, bija arī aprēķins, ka novājināta Lietuva būs izdevīgāks sarunu partneris, kad būs jāizšksir starp abām valstīm vēl neatrisinātie robežas jautājumi. Arī 
turpmākajos gados Latvija formāli palika neitrāla kaimiṇvalstu konfliktā un strīdā par Viḷnu, taču faktiski atzina šīs pilsētas atrašanos Polijā. Viḷnāā strādāja Latvijas konsulāts, no 30. gadu sākuma uz Viḷnu brauca dažādas delegācijas un sporta komandas no Latvijas. Polijas diplomāti šos pasākumus novērtēja kā lielu savu panākumu. ${ }^{1085}$

1920. gada rudenī bez Žel̦igovska akcijas izraisītajām problēmām Latvijas un Polijas attiecībās dominēja vēl divi būtiski jautājumi, kuru risinājums lielākā vai mazākā mērā jāuzskata par neveiksmīgu Polijas diplomātijai zemes reformas sākums Latvijā un Latvijas valsts atzišana "de iure". Pirmajā gadījumā vainojama bija Latgales poḷu muižniecības reakcionārākās daḷas un atsevišksu Polijas oficiālo aprindu darbība, lai panāktu īpašas, nepamatotas priekšrocības poḷu tautības lielajiem zemes îpašniekiem (sākotnēji gan Polijas politiskās aprindas, gan paši poḷu muižnieku vairākums kā pašu par sevi saprotamu risinājumu uzskatīja pilnīgi atšḳirīgu, poḷiem daudz labvēlīgāku vāciešu un poḷu muižniecības traktējumu no Latvijas valdības puses). Otrajā gadījumā vainīgs bija Polijas ārpolitiskais resors, kas vilcinājās atzīt Latviju, piekopjot pārspīlētu Antantes orientācijas politiku, kuras dēḷ atzīšanas akts no Polijas nāca ar novēlošanos un ievērojami vājināja Polijai labvēlīgo tendenci gan Latvijas oficiālajās aprindās, gan sabiedriskajā domā. Turklāt Bulduru konferencē parakstītās vienošanās neratificēja arī Polijas Seims, kurš to vienkārši tiesiski nevarēja izdarīt līdz paredzētajam termiņam, jo Polija līdz šim laikam nebija atzinusi Latviju un Igauniju „de iure”. ${ }^{1086}$

Sarežğìtās politiskās situācijas dēḷ reǵionā Baltijas valstu savienības ideja jau 1920. gada nogalē cieta pirmo nopietno neveiksmi lielā mērā nosacìtajā trīsstūrī Varšava-Kauņa-Rīga un dažu ārpus tā esošo faktoru ietekmē (Somijas, mazākā mērā Igaunijas nostāja). Tomēr "de iure" atzīšanas akts 1921. gada janvārī noslēdza to posmu Latvijas un Polijas attiecībās, kura laikā abu valstu attiecības bija pilnīgi izveidojušās. Turpmāk abas valstis attiecības veidoja jau uz tiesiski pilnīgi vienlīdzīgiem, starptautiski akceptētiem pamatiem.

\section{Nobeigums}

Latvijas attiecības ar Poliju neatkarības sākumposmā un arī vēlāk nav iespējams skatìt kā izolētu procesu. Tas jādara gan abu pušu, gan visa reǵiona zemju, gan pēc Pirmā pasaules kara izveidotās visas Versaḷas-Rīgas sistēmas valstu attiecību kontekstā. Baltijas reǵionā savstarpēju un daudzpusēju militāru konfliktu dēl šajā laikā norisa l̦oti sarežğìti procesi. Tādējādi šis Eiropas reǵions kḷuva par īpaši uzskatāmu piemēru jaunizveidotās robežu sistēmas trūkumiem (tā pastāvēja divus gadu desmitus līdz Otrajam pasaules

\footnotetext{
1085 Sk., piemēram: AAN, Sztab Główny, t. 616/151, k. 481.

1086 Jāpiezīmē, ka Polija nebūt nebija vienīgā, kura atzīšanas rakstu iesniedza ar novēlošanos un no kuras tas tika gaidīts ātrāk kaut vai iecerētās un nekad neīstenotās Baltijas valstu savienības vārdā. Arī Somijas valdība gaidīja Lielbritānijas rīcību Baltijas valstu atzīšanā, jo savas valsts drošību tāpat kā poḷi (vienīgi gaidot, pirmkārt, Francijas rīcību - Ē. J.) redzēja saistībā ar Rietumu lielvalstīm. - Ščerbinskis V. Somija Latvijas ārpolitikā 1918-1940. Promocijas darbs Dr. hist. grāda iegūšanai. - Rīga, 2002 (LU bibliotēka). - 55. lpp.
} 
karam). Latvijas ārpolitikas veidotājiem šajā laikā bija jādarbojas patiesi sarežǵìtos apstākḷos un jāṇem vērā šādi nosacījumi.

Pirmkārt, attiecības starp trijām Baltijas valstīm (Latviju, Igauniju un Lietuvu), kuras galvenajos vilcienos bija līdzīgā ǵeopolitiskajā situācijā un kurās uzskatāmi iezīmējās Lietuvas atškirīgā nostāja. To savukārt noteica Lietuvas un Polijas sarežğìtās, konfrontējošās attiecības, kurās Latvija tika iesaistīta tieši - kā kaimiņvalsts.

Otrkārt, attiecības ar Poliju un Somiju, kuras bija labākā ǵeopolitiskā stāvoklī un kuras arī pašas apzinājās šo atšķirību. Minētā iemesla dēḷ šo divu valstu intereses sakrita ar Latvijas un Igaunijas interesēm tikai daḷēji un šo valstu ārpolitiskie mērḳi un to īstenošanas metodes atšḳīrās ne tikai no Baltijas valstīm, bet arī savstarpēji.

Treškārt, attiecības ar Vāciju un Padomju Krieviju. Pirmā pasaules kara un iekšpolitisko pārmaiṇu dēḷ abas valstis reǵionā pagaidām bija zaudējušas pozīciju, kura, viṇuprāt, tām pienācās. Jau šajā laikā tās skaidri pauda savu vēlmi saglabāt maksimālu iespaidu reǵionā, lai nākotnē mainītu robežu sistēmu, ko uzskatīja par netaisnīgu. Lieki piebilst, ka arī Padomju Krievijas un Vācijas ārpolitiskās vadlīnijas sakrita vai bija līdzīgas tikai galvenajos vilcienos. Viena no būtiskākajām to izpausmēm bija vēlme jebkuriem iespējamajiem līdzekḷiem - no diplomātiskiem līdz militāriem - nepiel̦aut austrumeiropas valstu politisko un militāro vienotību, kas varētu traucēt pastāvošo robežu sistēmu maiṇu nākotnē. Pateicoties pašu centieniem un pieaugošajam iespaidam, kā arī prasmei izmantot Baltijas valstu atšķirīgās intereses, Padomju Krievijai un Vācijai tas izdevās gandrīz pilnībā. Izdosies arī vēlāk līdz pat Otrā pasaules kara sākumam un Versaḷas-Rīgas sistēmas pilnīgam sabrukumam 1939.-1940. gadā.

Ceturtkārt, karā uzvarējušo Rietumu lielvalstu (pirmkārt, Lielbritānijas un Francijas, mazākā mērā ASV) intereses reǵionā. Daudzos gadījumos par „sabiedrotajiem” dēvēto lielvalstu izturēšanos pret šķietami līdzīgā situācijā esošajām Baltijas valstīm noteica šauri savtīgas intereses, turklāt tās rīkojās bez konkrēta darbības plāna - šo valstu politika reǵionā bija haotiska, nesaskan,ota, un līdz ar to tā traucēja jaunajām valstīm nostiprināties un saprasties. Bija jāievēro arī Ukrainas Tautas Republikas un Baltkrievijas Tautas Republikas, arī Zviedrijas, mazāk - Norvēǵijas, Dānijas, kā arī pat Rumānijas intereses.

Tādējādi Baltijas reǵionā izveidojās Versaḷas-Rīgas sistēmai raksturīgs un ippaši sarežǵìts jauno un atdzimušo nacionālo valstu attiecību samezglojums. Tajā svarīga nozīme bija tam, ka visā Austrumeiropā un Centrāleiropā izveidotajai sistēmai piemita trūkumi - nebija iespējams izveidot starpvalstu robežas, kas pilnībā atbilstu etniskajam principam, un trūka demokrātijas pieredzes trūkums. Tas iespaidoja gan uz Igaunijas, Latvijas un Lietuvas, gan Polijas ārpolitiku, nerunājot par Padomju Krieviju, kur nebija pat demokrātijas iedīglu; tās galvenais mērķis bija kaimiņvalstu neatkarības iznīcināšana. Šādā situācijā attīstījās Latvijas attiecības ar Poliju. Neatkarības sākumā tās bija l̦oti sarežǵìtas, un tās var iedalīt vairākos laika posmos atkarībā no politiskās un militārās situācijas reǵionā. Visas reǵiona valstis bija spiestas sākt darbību kara un revolūciju izmainītā situācijā, ar jauniem kaimiṇiem un problēmām. Bija izveidojusies un veidojās jauna Eiropas politiskā karte, un šo procesu vēl arvien lielā mērā ietekmēja militārais faktors. 
Gan Latvijai, gan Polijai bija raksturīga diferencēta attieksme vienai pret otru. 1919. un 1920. gadā - kara un pēckara apstākḷos - tā izpaudās sevišḳi uzskatāmi un strauji, jo bija saistīta ar norisēm militārajā laukā. Šo attieksmi noteica arī attiecības ar citām reǵiona valstīm (pirmkārt, ar Lietuvu, Padomju Krieviju un Vāciju) un Antantes lielvalstīm, kā arī abu valstu atškirīgie politiskie un militārie mērḳi, kurus savukārt noteica dažādā vēsturiskā pieredze, dažādais valstu lielums, iedzīvotāju daudzums un valstu politiskā nozīme un mērk,i. Abu valstu savstarpējo attieksmi iespaidoja arī Latvijas poḷu minoritātes un Latgales poḷu muižniecības aktīvākās un Latvijas valstij nelabvēlīgākās daḷas darbība. Jāsecina, ka Polijas galvenie politiskie grupējumi 1919.-1920. gadā pret Baltijas valstīm izturējās augstprātīgi, protekcioniski un ar pārākuma apziṇu. Viṇi tās uzskatīja par mazām (līdz ar to - par vājām). Zinot Polijas iekšējās un ārējās problēmas, tas nebija pamatoti. Lai īstenotu savus ārpolitiskos mērķus, Polija bija ieinteresēta sadarboties ar Latviju, tādēḷ arī poḷu mērenākie jeb demokrātiskākie politiskie spēki (pie kuriem piederēja arī pie varas esošā J. Pilsudska nometne) centās sadarboties un dažkārt pat piekāpās. Tie pauda pārliecību, ka Polijai ir galvenā nozīme vinu iecerētajā federatīvajā valstī vai formāli neatkarīgu, bet ar Poliju cieši saistītu valstu savienībā. Ja nebūtu Polijas ieinteresētības, tā pret Latviju izturētos kā pret Lietuvu, kaut arī, atšķirībā no Lietuvas, tikai viena Latvijas daḷa (Latgale) l̦oti tālā pagātnē un pilnīgi atšķirīgos vēsturiskajos apstākḷos bija bijusi apvienotās Polijas-Lietuvas valsts sastāvā. Tādēḷ Latvijas sadarbībā ar Poliju jau pašā attiecību sākumā no Latvijas puses bija vērojama piesardzība, kas saglabāsies līdz pat Otrā pasaules kara sākumam un ko var apzīmēt ar terminu „piesardzīgā draudzība”.

Latvija un Polija bija ieinteresēta politiskā un militārā sadarbībā. Latvijai bija nepieciešams sabiedrotais, lai nodrošinātu savu neatkarību, Polijai - sabiedrotais, lai īstenotu mērķus attiecībās ar Padomju Krieviju, Lietuvu un 1919. gadā - arī ar Vāciju. Tādējādi 1919. gada rudenī Baltijā briestošā krīze ar reakcionārajiem vācu-krievu spēkiem Bermonta vadībā izraisīja noteiktu Latvijas tuvināšanos Polijai - tika nodibinātas diplomātiskas attiecības un jaunā Latvijas valsts saṇēma dažādu Polijas atbalstu.

Kopumā Latvijai sadarbība ar Poliju 1919. un 1920. gadā bija sevišḳi izdevīga. Ar šīs valsts atbalstu, kā arī tiešu diplomātisku un pat militāru palīdzību tika panākta Latvijas starptautiskā atzīšana (vispirms "de facto", pēc tam "de iure"), pilnīga Latvijas zemju atbrīvošana un apvienošana. Ar Polijas atbalstu lielā mērā tika neitralizētas otras kaimiṇvalsts - Lietuvas teritoriālās pretenzijas pret Latviju. Polijas palīdzība Latvijai lika pamatu labām kaiminattiecībām nākamajos gados. Tajos, runājot poḷu vēsturnieka P. Losovska vārdiem, abām valstīm, kurām nebija nekādas sadarbības pieredzes pagātnē, nācās pastāvēt blakus un pārvarēt šādām situācijām raksturīgo neuzticību. ${ }^{1087}$ Kaut arī dažādu apstākḷ dēḷ līdz pat Otrā pasaules kara sākumam Latvijas piesardzība pilnībā neizzuda, 1919. un 1920. gadā sniegtais Polijas atbalsts liecināja par šīs valsts labvēlīgo attieksmi pret Latvijas neatkarību.

1087 Łossowski P. Polska w Europie i świecie 1918-1939. - Warszawa, 1990. - S. 21. 
Galvenais šḳērslis ciešākai sadarbībai starp Baltijas valstīm, Somiju un Poliju bija minētās atšķirīgās valstiskās intereses un pretrunas, kas atsevišḳos brīžos izpaudās sevišḳi spilgti. To dēḷ ne 1920. gadā, ne arī vēlāk neizdevās izveidot Baltijas valstu savienību, kam būtu aizsardzības raksturs. Augstākā sasniegtā sadarbības forma starp tām bija samērā regulāri notiekošās konferences, kurās Baltijas valstu pārstāvji pārsvarā nesekmīgi centās vienoties par noteiktu kopēju nostāju, pirmkārt, pret Padomju Krieviju un starptautiskajās norisēs kopumā.

Attiecības ar Latviju minēto iemeslu dēḷ neattīstījās arī atbilstoši Polijas valsts vadītāja J. Pilsudska un valdības iecerēm. Pateicoties labvēlīgai militārpolitiskai situācijai, Polijai tomēr izdevās savās interesēs izmantot un pat veicināt Latvijas nesaskaņas ar tai naidīgo Lietuvu. Polija un Latvija pretēji Lietuvas interesēm panāca, ka tika izveidota kopīgas robeža, tādējādi uz diviem gadu desmitiem izolējot Lietuvu no Padomju Krievijas (tas bija gan Latvijas, gan Polijas interesēs). Tieši kopīgā 104 kilometrus garā robeža starp Latviju un Poliju pavēra iespējas abu valstu plašai sadarbībai starpkaru periodā. Lietuvas valdība bija neapmierināta ar šādu stāvokli, un lietuviešu un poḷu konflikts par Viḷṇu, kā arī Latvijas nenoteiktā nostāja konflikta laikā šo neapmierinātību vēl vairāk pastiprināja. Latvijai bija nepieciešams uzturēt labas attiecības ar abām savstarpēji naidīgām valstīm, jo tas garantēja Latvijas starptautiski neatzìto neatkarību un Latvijai bija svarīgi noturēties politiskā līdzsvarā starp savstarpēji konfliktējošām, lielākā vai mazākā mērā Latvijai draudzīgām kaimiṇvalstīm. Sadarbība ar tām nākotnē varēja garantēt ne tikai savu, bet pat visa reǵiona drošību. Katrā ziṇā Latvijas un Polijas attiecībās 1919.-1920. gadā skaidri atklājās cēloṇi, kuri arī turpmāk neḷāva pilnībā vienoties ne savstarpēji, ne visām Baltijas reǵiona valstīm kopumā. Tādēl netika izveidota minētā Baltijas valstu savienība, kas spētu vismaz ievērojami izmainīt, ja ne pilnībā novērst 1939.-1940. gada notikumus Eiropā kopumā.

Turpmākajos gados reǵiona valstu savstarpējās un daudzpusējās attiecībās saglabājās galvenās tendences, kas bija spilgti izpaudušās 1919.-1920. gadā: Padomju Krievijas tiesiskā mantiniece - Padomju Savienība - arī turpmāk tikpat sekmīgi centās nepieḷaut un faktiski nepiel̦āva Baltijas valstu un Polijas tuvināšanos, izveidojot aizsardzības savienību. Polijas konflikts ar Lietuvu turpināja attīstīties līdz pat 1938. gadam, kad tika ārēji, bet ne iekšejji atrisināts - Polija ar militāriem draudiem pieprasīja nodibināt diplomātiskas attiecības. Latvija šajā strīdā formāli turpināja ieņemt neitrālu pozīciju, bet faktiski tā atzina Viḷnas atrašanos Polijā - to lika darìt reālie apstākḷi.

1925. gadā ideja par Baltijas valstu savienības izveidi tika atmesta pilnībā, un turpmāk katra valsts darbojās vienīgi savās interesēs vēl atklātāk nekā līdz šim. Nelielas pārmaiṇas triju Baltijas valstu ārpolitikā bija vērojamas, sākot ar 1934. gadu, kad tika izveidota Baltijas Antante. Tā kā Vācija un Padomju Savienība bija noslēgusi vienošanos ar Poliju, Lietuva pilnīgi pārliecinājās par savas horizontālās orientācijas neefektivitāti, un Igaunija un Latvija ḷāva Lietuvai pievienoties Antantei, kaut arī tās nebija neieinteresētas „Lietuvas specifisko" problēmu - Viḷnas un Klaipēdas jautājumu - risināšanā. Tomēr arī šajā neefektīvajā savienībā katra dalībvalsts darbojās, ievērojot tikai savas intereses. Tā kā Versaḷas-Rīgas robežu sistēmai bija trūkumi un divu 
totalitāro kaimiṇvalstu iespaids pieauga, Baltijas valstu un Polijas liktenis faktiski bija izlemts.

Līdz pat Polijas valsts likvidēšanai, kas notika 1939. gada septembrī, Latvijas attiecībās ar Poliju izpaudās tendences, kas bija iezīmējušās jau 1919.-1920. gadā: atšķirības ārpolitiskajos mērķos un zināmā Polijas vēlme būt reĝ́ionā galvenajai noteicējai. Līdz pat 1929. gadam pastāvēja Polijas teritoriālās pretenzijas uz sešiem Ilūkstes apriṇka pagastiem un Grīvas pilsētu, kas tikai 1920. gada vasarā bija nonākuši Latvijas varā. Strīds formāli tika atrisināts līdz ar tirdzniecības un kuğniecības līguma parakstīšanu. Tas bija izdevīgs abām pusēm un sevišḳi Latvijai, un tam tika pievienota konfidenciāla vienošanās par naudas kompensāciju izmaksu Polijas pilsoniem - bijušajiem zemes īpašniekiem Latvijā (galvenokārt Latgalē un Ilūkstes apriṇkīi). Savukārt Polija piekrita robežas delimitācijai un atteicās no tālākām pretenzijām. Tiesa, neoficiāli tās laiku pa laikam bija. Latvijai periodiski tika pārmesta Latvijas poḷu minoritātes interešu neievērošana. 1931. gadā šī iemesla dēḷ Polijas sūtnis, gan oficiāli nepārtraucot diplomātiskās attiecības, gandrīz uz pusgadu atstāja Latvijas galvaspilsētu. Tomēr kopumā attiecības bija samērā labas, kaut arī no Latvijas puses bija vērojama piesardzība. Sevišk çi labas tās bija starp militārajiem resoriem, turklāt zināma sadarbība, īpaši izlūkdienestu jomā, tika sekmīgi ìstenota. Katrā ziṇā grāmatā aplūkotajā laika posmā tika likti pamati turpmākajām attiecībām, un tās bija loti daudzškautņainas - tām bija raksturīga draudzība, savstarpēja palīdzība un atbalsts, kā arī piesardzība, neuzticība, aizdomas un nepieciešamības gadijjumā pat otras puses interešu neievērošana savu interešu dēḷ. Tādas tās bija arī turpmāk, turklāt pamatā nemainījās, vienīgi tās noteica vēsturiskie apstākḷi un to attīstība. 


\section{Avoti un literatūra}

\section{Nepublicētie avoti}

\section{1) Latvijas Valsts vēstures arhīvs (Rīga)}

1. 1303. f., 1. apr. - Valsts prezidenta sekretariāts

2. 1304. f., 1. apr. - Lāčplēša Kara ordeña dome

3. 1313. f., 1., 2. apr. - Ārlietu ministrijas kanceleja

4. 1368. f., 1. apr. - Iekšlietu ministrijas sekretariāts

5. 1398. f., 2. apr. - Daugavpils apriņķa policijas iestādes

6. 1468. f., 1. apr. - Kara ministrijas sekretariāts

7. 1474. f., 1. apr. - Armijas štābs

8. 1491. f., 1. apr. - 3. Jelgavas kājnieku pulks

9. 1515. f., 1. apr. - Kurzemes divīzijas pārvalde

10. 1527. f., 1. apr. - Zemgales divīzijas pārvalde

11. 1532. f., 1. apr. - Satiksmes ministrijas Pasta-telegrāfa departaments

12. 1640. f., 1. apr. - Aizsargu organizācijas štābs

13. 2570. f., 1., 2., 3., 10. apr. - Ārlietu ministrijas Administratīvi juridiskais departaments

14. 2574. f., 1., 3. apr. - Ārlietu ministrijas Politiski ekonomiskais departaments

15. 2575. f., 1., 7., 8., 11, 15., 17. apr. - Diplomātiskās un konsulārās pārstāvniecības ārzemēs (Lielbritānijā, Igaunijā, Francijā, Lietuvā, Polijā, Somijā)

16. 3235. f., 1/14. apr. - Iekšlietu ministrijas Drošības policijas Politiskās policijas pārvalde (Armijas Virspavēlnieka štāba Iekšèjās izlūkošanas daḷas Daugavpils nodaļa)

17. 3444. f., 1. apr. - Daugavpils un apriņķa komandantūra

18. 3461. f., 1. apr. - Grīvas komandantūra

19. 3479. f., 1. apr. - Krāslavas komandantūra

20. 3485. f., 1. apr. - Kalkūnes stacijas komandantūra

21. 3601. f., 1., 9. apr. - Armijas Virspavēlnieka štābs

22. 3602. f., 1. apr. - Armijas Komandiera štābs

23. 3605. f., 1. apr. - Armijas Galvenā apgādības pārvalde

24. 3723. f., 2. apr. - Iekšlietu ministrijas Pašvaldību departaments

25. 4592. f., 3. apr. - Dzelzcel̦u virsvalde

26. 4917. f., 1. apr. - Robežsargu divīzijas štābs

27. 5192. f., 1. apr. - Galvenais štābs

28. 5434. f., 1. apr. - Kara muzejs

29. 5480. f.,1. apr. - Kārḷa Zariṇa personīgais fonds (arhīvs)

30. 5601. f., 1.-3. apr. - Armijas štāba personisko lietu kolekcija

31. 5604. f., 1. apr. - Policijas darbinieku personīgo lietu kolekcija

32. 5969. f., 1. apr. - K. Ulmaņa personīgais fonds

33. 6033. f., 1. apr. - Kara vēstures komisija

34. 6823. f., 2. apr. - Tirdzniecības un rūpniecības ministrija

35. 7473. f., 1. apr. - Studentu biedrība ,Zemgalija”

36. Latvijas armijas virspavēlnieka pavēles 1919. gadam//LVVA Zinātniskajā bibliotēkā

\section{2) Archiwum Akt Nowych (Varšava)}

1. Kolekcja opracowań i odpisów dokumentów dotyczących stosunków Polski z

2. Łotwą, Litwą, Estonią i Finlandią

3. Ministerstwo Spraw Zagranicznych 
4. Sztab Główny

5. Attachaty wojskowe Rzeczypospolitej Polskiej akredytowane przy państwach kapitalistycznych

6. Instytucje Wojskowe

7. Towarzystwo Straźy Kresowej

\section{3) Centralne Archiwum Wojskowe (Varšava)}

1. Akta osobiste (A. Myszkowski)

2. II oddział Naczelnego Dowództwa Wojska Polskiego

3. IV oddział Naczelnego Dowództwa Wojska Polskiego

4. Szefostwo lotnictwa

5. Teki Laudańskiego

6. Wojskowe Biuro Historyczne

4) Archiwum Polskiej Akademii Nauk (Varšava)

1. Świerzbiński M. Martyrologia Inflant Polskich

2. Djarjusz M. S. Kossakowskiego

5) Lietuvos Centrinis Valstybinis archivas (Vilְna)

1. 383 f., 7 ap. - Užsienio reikalų ministerija

2. 384 f., 3 ap. - Krašto apsaugos ministerija

3. 923 f., 1 ap. - Ministrių kabinetas

4. 929 f., 1, 3 ap. - Kariuomenès štabas

\section{6) Latvijas Kara muzejs (Rīga)}

1. Antens P. Pārskats par telegrāfa un telefona rotas darbību laikā no 1919. g. XI -1921. g. 1. IV

2. Artum-Hartmanis A. Zemgales divīzijas atsevišksā eskadrona vēsture

3. Caun̄ītis O. Vēsturisks pārskats par 2. Ventspils kājnieku pulka nodibināššnu, formēšanos un kara darbības gaitām Latvijas atbrīvošanās cīṇu laikmetā

4. 12. Bauskas kājnieku pulka vēsture

5. Kalniņš T. Īss pārskats par 10. Aizputes pulka nodibināšanu, formēšanos un kara darbības gaitām atbrīvošanās cīnu laikmetā 1919. un 1920. g.

6. Paulockis A. 3. bruṇotā vilciena kaujas apraksts par laiku no 3. līdz 20. janvārim 1920. g.

\section{7) Latvijas Kultūras fonda arhīvs (Rīga)}

1. Briņķis K. Autobiogrāfija

8) Wojskowy Instytut Historyczny Akademii Obrony Narodowej (Varšava)

1. Styliński J. Wspomnienia źołnierza 5 pp. Legionów 1915-1920.

\section{Prese}

1. Baltijas Vēstnesis (Rīga), 1919.-1920.

2. Brīvā Zeme (Rīga), 1919.-1921.

3. Czas (Krakova), 1920.

4. Dziennik Wileński (Viḷna), 1919.-1920.

5. Dzwon (Daugavpils), 1928., 1930.

6. Echo Litwy (Viḷna), 1920.

7. Gazeta Polska (Varšava), 1919. 
8. Gazeta Poranna (Varšava), 1919.-1920.

9. Gazeta Warszawska (Varšava), 1919.-1920.

10. Goniec Miński (Minska), 1919.-1920.

11. Jaunākās Ziņas (Rīga), 1919.-1921.

12. Kurjer Lwowski (Ļvova), 1920.

13. Kurjer Polski (Varšava), 1920.

14. Kurjer Poranny (Varšava), 1920.-1921.

15. Kurjer Powszechny (Varšava), 1920.

16. Kurjer Warszawski (Varšava), 1920.

17. Kurzemes Vārds (Liepāja), 1920.

18. Laisve (Kauña), 1919.-1920.

19. Latgales Vēstnesis (Daugavpils), 1939.

20. Latgalīts (Rēzekne), 1920.

21. Latgolas Words (Rēzekne), 1920.

22. Latvijas Kareivis (Rīga), 1920.-1921.

23. Latvijas Sargs (Rīga), 1919.-1920.

24. Lietuva (Kauña), 1919.-1921.

25. Naród (Varšava), 1920.

26. Nasz Głos (Daugavpils), 1933.

27. Nasz Kraj (Viḷna), 1919.-1920.

28. Przegląd Wieczorny (Kališa), 1920.

29. Republikas Sargs (Rīga), 1920.

30. Robotnik (Varšava), 1919.-1920.

31. Rząd i Wojsko (Varšava), 1920.

32. Rzeczpospolita (Varšava), 1920.

33. Słowo (Vil̦na), 1922, 1931.

34. Sociāldemokrāts (Rīga), 1919.-1920.

35. Strādnieku Avīze (Liepāja), 1920.

36. Tygodnik Polski (Rīga), 1927.

37. Tygodnik Wileński (Viḷņa), 1920.

38. Valdības Vēstnesis (Rīga), 1919.-1920.

39. Ziemia Wileńska (Viḷna), 1920.

40. Źołnierz Polski (Varšava), 1919.-1920., 1922.

41. Варшавская речь (Varšava), 1919.

42. Варшавское слово (Varšava), 1920.

43. Воля (Rīga), 1920.

44. Минский курьер (Minska), 1920.

45. Наша жизнь (Daugavpils), 1920.

46. Сегодня (Rīga), 1919.-1920.

47. Свобода (Varšava), 1920.

\section{Publicētie dokumenti}

1. Deruga A. Nieznane dokumenty do dziejów polityki wschodniej Polski 1918-1919//Z dziejów stosunków polsko - radzieckich. - T. VI. - Warszawa, 1970. - S. 231-246.

2. Dokumenti par Latvijas valsts starptautisko atzī̌sanu, neatkarības atjaunošanu un diplomātiskajiem sakariem 1918-1998. - Rīga, 1999. - 35.-39. lpp.

3. Dokumenti stāsta. Latvijas buržuāzijas nākšana pie varas/V. Bērziņa redakcijā. - Rīga, 1988.

4. Dokumenty do dziejów polskiej polityki zagranicznej 1918-1939. - T. I/Red. T. Jędruszczak, M. Nowak - Kielbikowa. - Warszawa, 1937. 
5. Likumu un valdības rīkojumu krājums. 1920.

6. Międzynarodowe aspekty wojny polsko - bolszewickiej 1919-1920. Antologia tekstow historycznych/Oprac. M. M. Drozdowski. - Warszawa, 1996.

7. Piłsudski J. Pisma zbiorowe. - T. V. - Warszawa, 1937.

8. Sąsiedzi wobec wojny 1920 roku. Wybór dokumentów/Oprac. J. Cisek. - Londyn, 1990.

9. Tajne rokowania polsko - radzieckie w 1919 r. - Warszawa, 1986.

10. Документы и материалы по истории советско-польских отношений. - Ч. II. - Москва, 1964.

11. Социалистическая Советская республика Латвии в 1919 г. и иностранная интервенция. Документы и материалы. - Том 2. - Рига, 1960.

\section{Atminas}

1. Balodis J. Ģenerāḷa Jāṇa Baloža atmiṇu burtnīcas//Neatkarīgā Rīta Avīze. - 1997. - 22. febr., 22., 29. marts, 26. apr., 17. maijs.

2. Broniewski W. Pamiętnik 1918-1922. - Warszawa, 1984.

3. Bržezinskis E. Cel̦ojums uz Daugavpili pirms 15 gadiem//Latgales Vēstnesis. - 1935. - 4. janv.

4. B. S. Jakeśmy Dźwińsk zafasowali//Źołnierz Polski. - 1921. - 31 lip., 7 sierp.

5. Cielēns F. dr. Miķelis Valters vēstures logatā. Viņa 90 gadu piemiṇai// Brīvība. - 1964. - Nr. 4/5.

6. Cielēns F. Laikmetu maiṇā. - 2. sēj. - Lidingö, 1963; Cielēns F. Laikmetu maiṇā. Atmiṇas un atziṇas. - 3. grām. - Stokholma, 1998.

7. Diparkē E. Latvju tautas augšāmcelšanās//Latvju varoṇu gaitas. - Rīga, 1938.

8. Dmowski R. Polityka polska i odbudowanie państwa. - T. II. - Warszawa, 1988.

9. Donass F. Politiskos krustcel̦os. - J. Šķirmanta apgāds, 1969.

10. Ezergailis J. Pirms 50 gadiem//Daugavas Vanagu Mēnešraksts. - 1971.- Nr. 3.-32. lpp.

11. Klimas P. Lietuvos diplomatineje tarnyboje. - Vilnius, 1991.

12. Klīve Ā. Latvijas neatkarības gadi. Latvijas politiskā veidošanās un augšana. - B. v., 1976.

13. Kurzemes muižniecības pilnvarotā - grāfa Paula Pālena dienas grāmata//Jaunākās Ziņas. 1921. - 12. jūl.

14. Kutzreba T. Wspomnienia źołnierskie w dzień niepodległości Łotwy//Przegląd Współczesny. T. XX. - 1927. - S. 113-120.

15. Līgotṇu J. Latvijas valsts dibināšana. - Rīga, 1925.

16. Mączewski P. Z podróźy na Łotwę//Gazeta Warszawska. - 1920. - 13, 14, 19 marzec.

17. Miškovskis A. Iz manām atmiṇām no Latvijas//Ģenerālis Jānis Balodis. Atmiṇu krājums no Latvijas brīvības cīṇu laika. - Rīga, 1931. - 70.-75. lpp.

18. Muižnieks O. Pirms piecpadsmit gadiem//Latgales Vēstnesis. - 1935. - 18. janv., 1. febr.

19. Myszkowski A. Z moich łotewskich wspomnień//Polska Zbrojna. - 1933. - 18 list.

20. Plensners A. Pret vētrām un negaisiem. - Grāmatu Draugs, 1982.

21. Punga H. Polija un viņas valsts darbinieki//Darba Balss. - 1921. - 31. dec.; [Punga H.] Pilsudskis kā revolucionārs un patriots//Latvijas Kareivis. - 1922. - 3. janv.

22. Ramats K. Virspavēlnieks//Ģenerālis Jānis Balodis. Atmiṇu krājums no Latvijas brīvības cīṇu laika. - Rīga, 1931. - 145.-158.

23. Seskis J. Latvijas valsts izcelšanās pasaules kara notikumu norisē. - Rīga, 1991.

24. Smaren-Svarinskis V. Manas atmiṇas//Latvju Nacionālā Kluba Biḷetens. - 1924. - Nr. 7; Nr. 8.

25. Smigly - Rydz E. Teicams karavīrs//Ģenerālis Jānis Balodis. Atmiṇu krājums. - Rīga, 1931. 68.-69. lpp.

26. Strautnieks Ž. Kāda jātnieka atmiņas//Kara Invalīds. - 1985. - Nr. 30. - 55.-60. lpp.

27. Valters M. Mūsu tautības jautājums//Daugavas gadagrāmata. 1932. - Rīga, 1932. - 120.-134. lpp.

28. Wasilewski L. Józef Piłsudski. Jakim go znałem. - Warszawa, 1935.

29. Zariņš K. 35 gadi Latvijas valsts darbā//Latviešu Almanahs 1954. gadam. - Londona, 1953. 


\section{Literatūra}

1. 2. Ventspils pulks. - Liepāja, 1936.

2. Albin J. Polski ruch narodowy na Łotwie w latach 1919-1940. - Wrocław, 1994.

3. Andersons E. Latvijas vēsture 1914-1920. - Daugava, 1967.

4. Andersons E. Sacensība par Daugavpili//Daugavas Vanagu Mēnešraksts. - 1965. - Nr. 2. 46.-51. lpp.

5. Apsītis A. Latgales atbrīvošana//Atbrīvošanās kara vēsture/Red. M. Peniķis. - Rīga, b. g. 256.-324. lpp.

6. Ārpolitika//Latvju Enciklopēdija/Red. A. Švābe. - 1. sēj. - Stokholma, 1950. - 99.-129. lpp.

7. Bąbiński K. Zarys historji wojennej 5 - go pułku piechoty Legjonów. - Warszawa, 1929.

8. Bebris R. Daugavpils atbrīvošana 1920. gada 3. janvārī//Militārais Apskats. - 1935. - Nr. 2. 214.-229. 1pp.

9. Bērziņš P. Latvijas brīvības cīņas 1918-1920. - Rīga, 1928.

10. Bērziņš V., Bambals A. Latvijas armija. - Rīga, 1991.

11. Borkiewicz A. Dzieje 1 - go pułku Legjonów. - Warszawa, 1929.

12. Boruta M. Wolni z wolnymi, równi z równymi, Polska i Polacy o niepodległośći wschodnich sąsiadów Rzeczypospolitej. - Kraków, 2002.

13. Butkus Z. Great Britain's mediation in establishing the Lithuanian - Latvian frontier, 1920-1921// Journal of Baltic Studies. - T. XXIV. - Nr. 4. - P. 359-368.

14. Butkus Z. Himansa projekts Polijas un Lietuvas attiecību risinājumā 1921. gadā: Latvijas nostāja// Latvijas vēsture. - 1995. - Nr. 1. - 15.-22. 1pp.

15. Butkus Z. Lietuvos ir Latvijos santykiai 1919-1929 metais. - Vilnius, 1993.

16. Cabanowski M. Generał Stanisław Bułak - Bałachowicz. - Warszawa, 1993.

17. Cynarski J. Łotwa//Bellona. - 1925. - T. XIX. - Zesz 1. - S. 1-23.

18. Cynarski J. Łotwa współczesna. - Warszawa, 1925.

19. Čepenas P. Naujuju laiku Lietuvos istorija. - II t. - Chikago, 1986.

20. Davies N. Orzeł biały, czerwona gwiazda. Wojna polsko - bolszewicka 1919-1920. - Kraków, 1998.

21. Dąb - Biernacki S. Grupy oporowe w świetle działań pierwszej dywizji piechoty legjonów//Bellona. - 1922. - T. VIII. - S. 230-246.

22. 9. Rēzeknes k. p. gaitas no 1919. g. 9. augusta līdz 1922. g. 9. augustam. - Rīga, 1923.

23. Dowgiałło W. Inflanty Polskie//Przegląd Dyplomatyczny. - 1919. - Nr. 1. - S. 29-36.

24. Dyneburg, Dźwina//Encyklopedja Wojskowa. T. II. - Warszawa, 1932. - S. 408-412, 476-481.

25. Feldmanis I. Latvijas valsts: rašanās, starptautiskā atz̄īsana un ārpolitiskās darbības galvenie vir zieni (1918-1940)//Dokumenti par Latvijas valsts starptautisko atzīšanu, neatkarības atjaunošanu un diplomātiskajiem sakariem 1918-1998. - Rīga, 1999. - 15.-57. lpp.

26. Gintel J. Zarys historji wojennej 2 - go pułku artylerii cięźkiej. - Warszawa, 1929.

27. Giza A. Latvijas un Polijas attiecības 1919. un 1920. gadā//Latvijas Vēsture. - 1992. - Nr. 1.

28. Herzog S. Historja wojenna 5 - go pułku artylerii cięźkiej. - Warszawa, 1930.

29. Historia Dyplomacji polskiej. T. IV 1918-1939/Red. P. Łossowski. - Warszawa, 1995.

30. Hłasko J. Polityka wewnętrzna//Przegląd Narodowy. - 1920. - T. XVII.

31. Hł[asko] J. Zaprzepaszczenie Inflant//Gazeta Warszawska. - 1920. - 29 czerw.

32. Hovi K. Alliance De Revers. - Turku, 1984.

33. Hovi K. Polish - Finnish Cooperation in Borderstate Policy, 1919-1922//Journal of Baltic Studies. - 1983. - Vol. XIV. - Nr. 2. - P. 121-127.

34. Inflanty//Encyklopedja Wojskowa. - T. III. - Warszawa, 1933. - S. 525-527.

35. Jankauskas V. Kario kelias. Generolas Kazimieras Ladiga nepriklausobybes kovose. - Vilnius, 2004.

36. Jātnieku pulks 10 gados. - Rīga, 1929. 
37. Jēkabsons Ē. ASV attieksme pret Latviju 1918.-1922. gadā//Vēsturnieks profesors Dr. phil. LZA ārzemju loceklis Andrievs Ezergailis. Bibliogrāfija. Darbabiedru veltījumi 70 gadu jubilejā/ Sast. J. Bērziņš. - Rīga: LU Latvijas vēstures institūts, 2000, 198.-263. lpp.

38. Jēkabsons Ē. Dienvidlatgales administratīvās pārvaldes veidošanās 20. gs. 20. gados//Acta Latgalica. - 9. sēj. - Daugavpiḷs, 1997. - 101.-113. lpp.

39. Jēkabsons Ē. Ģenerālis Jānis Balodis Polijas diplomātijas skatījumā//Latvijas Arhīvi. - 1995. Nr. 3. - 24.-28. lpp.

40. Jēkabsons Ē. Ģenerālis Staņislavs Bulak-Balahovičs un Latvija//Latvijas Arhīvi. - 1995. Nr. 1. - 16.-21. lpp.

41. Jēkabsons Ē. Jeńcy - Łotysze w niewoli polskiej (1918-1921)//Zeszyt Naukowy Muzeum Wojska. - 13.- Białystok, 2000. - S. 93-102.

42. Jēkabsons Ē. Latgales poḷu muižniecība un Latvijas valsts 1918.-1940. gados//Acta Latgalica. 11. sēj. - Daugavpiḷs, 2001, 82.-90. lpp.

43. Jēkabsons Ē. Latviešu tautības karagūstekņi Polijā//Latvijas Arhīvi. - 2006. - Nr. 2. 119-139. 1pp.

44. Jēkabsons Ē. Latvijas 1919. un 1920. gada vēstures materiāli Polijas arhīvos//Latvijas Arhīvi. 1995. - Nr. 2. - 79.-81. lpp.

45. Jēkabsons Ē. Latvijas attiecības ar Lietuvu 1919.-1921. gadā//Latvijas Vēsture. - 1997. Nr. 1. - 85.-91. lpp.; Nr. 2. - 25.-34. 1pp.

46. Jēkabsons $\bar{E}$. Latvijas attiecības ar Ukrainas Tautas Republiku (1919-1921)//Latvijas Vēsture. - 2003. - Nr. 4. - 56.-72. 1pp.

47. Jēkabsons $\bar{E}$. Latvijas diplomātija Bermonta uzbrukuma laikā 1919. gadā//Militārais Apskats. - 1994. - Nr. 2. - 73.-82. 1pp.

48. Jēkabsons Ē. Latvijas poḷi un Latgales poḷu muižniecība valsts neatkarības sākumposmā 1918.-1920. g.//Latvijas Vēstures Institūta Žurnāls. - 1995. - Nr. 3. - 78.-108. lpp.

49. Jēkabsons $\bar{E}$. Latvijas un Baltkrievijas Tautas Republikas attiecības (1919-1920)//Latvijas Arhīvi. - 1996. - Nr. 1/2. - 35.-41. lpp.

50. Jēkabsons Ē. Latvijas un Francijas militārie sakari//Militārais Apskats. - 1995. - Nr. 1. 79.-83. lpp.

51. Jēkabsons Ē. Latvijas un Polijas attiecības 1919. gadā//Latvijas Vēstures Institūta Žurnāls. 1994. - Nr. 1. - 93.-113. lpp.

52. Jēkabsons Ē. Latvijas un Polijas bruṇoto spēku kaujas ar Sarkano armiju Dienvidlatgalē 1920. gadā// Militārais Apskats. - 1994. - Nr. 1. - 59.-75. lpp.

53. Jēkabsons Ē. Latvijas un Polijas robeža 1919.-1939. gadā//Daugavpils Universitāte. Humanitārās fakultātes XII Zinātnisko lasījumu materiāli. Vēsture/History. Proceedings of the XIIth Scientific Readings of the Faculty of Humanities. - VI (I). - Daugavpils, 2003 - 69.-79. lpp. Publicēts arī: http://www.historia.lv/publikacijas/konf/daugp/012/1dala/jekabson.htm

54. Jēkabsons Ē. Latvijas varas iestāžu darbs Daugavpilī, Daugavpils apriņ̧̦̄ī un Grīvā 1920. gadā//Acta Latgalica. - 10. sēj. - Daugavpiḷs, 1999. - 83.-103. lpp.

55. Jēkabsons Ē. Latvija un Polija 1919. gadā: pirmie sakari//Latvijas Zinātņu Akadēmijas Vēstis. - 2003. - Nr. 1.-2. - 32.-53. lpp.

56. Jēkabsons Ē. Lietuvas karaspēks Ilūkstes apriṇḳī 1919.-1920. gadā//Latvijas Zinātṇu Akadēmijas Vēstis. A daḷa. Sociālās un humanitārās zinātnes. - 2005. - 59. sēj. - Nr. 2 - 49.-64. lpp.

57. Jēkabsons Ē. Łotewsko - polska współpraca wojskowa w maju-sierpniu $1920 \mathrm{roku} / / \mathrm{Księga} \mathrm{ju-}$ bileuszowa Muzeum Wojska 1968-1998. - Białystok: Muzeum Wojska w Białymstoku, 1999. S. 139-148.

58. Jēkabsons Ē. Pamiers Latgales frontē 1920. gadā//Latviešu Strēlnieks. - 1996. - Nr. 6.

59. Jēkabsons Ē. Pirmais, kurš brīdināja [Polijas militārais pārstāvis A. Miškovskis]//Latvijas Avīze. Mājas Viesis. - 2004. - 12. nov.

60. Jēkabsons Ē. Polijas armijas kaujas ar Sarkano armiju Ilūkstes apriṇk̦ī 1919. gada septemrī//Latvijas Kara muzeja gadagrāmata. - Rīga, 2000. - 46.-58. lpp.

61. Jēkabsons Ē. Poḷi Latvijā. - Rīga, 1996. 
62. Jēkabsons Ē. Poḷu karaspēks Krāslavā 1920. gadā//Acta Latgalica. Zinōtniski roksti. Dokumenti. Apceris. - 13. sēj. - Daugavpiḷs-Rēzekne: Latgolas Pētnīceibas instituts, 2004, 234.-240. lpp.

63. Jēkabsons Ē. Poḷu karavīru kapi Latvijā//Poḷu karavīru kapi (1919-1920) Latvijā/Red. J. Sozaņskis. - Rīga, 1995. - 38.-43. lpp.

64. Jēkabsons Ē. Sešu pagastu un Grīvas pilsētas problēma Latvijas un Polijas attiecībās 20. un 30. gados//Latvijas Vēstures Institūta Žurnāls. - 1995. - Nr. 1. - 80.-101. lpp.

65. Jēkabsons Ē. Varšavas kauja - brīnums pie Vislas 1920. g.//Militārais Apskats. - 1995. Nr. 2. - 49.-55. 1pp.

66. Jēkabsons Ē. Viḷṇas jautājums un Latvija 1920. gada rudenī//Latvija-Polija. Starptautiskas zinātniskas konferences materiāli. - Rīga, 1995. - 63.-88. lpp.

67. Jēkabsons Ē. Współpraca łotewskich pociągów pancernych z Wojskiem Polskim w 1920 roku// Pociągi pancerne 1918-1943. Organizacja-struktura-działania wojenne. - Białystok: Muzeum Wojska w Białymstoku, 1999, S. 28-40.

68. Jēkabsons E. Żołnierze polscy na Łotwie w lipcu-jesieni 1920 roku//Bitwa Niemeńska. - Białystok: Muzeum Wojska w Białymstoku, 2000, S. 121-127.

69. 3. Jelgavas kājnieku pulks 1919. 16. VIII-1919. 16. VIII. - Rīga, 1929.

70. Jeźewski B. Udział czołgów w akcji pod Dźwińskiem//Pregląd Wojskowo - Techniczny. - 1928. T. IV. - Zesz. 6.

71. Jędrzejewicz W. Kronika źycia Józefa Piłsudskiego. 1867-1935. - T. 1. - Londyn, 1986.

72. Juzwenko A. Postawa Polski wobec akcji Von Der Goltza i Bermondt - Awałowa w krajach Bałtyckich w 1919 roku//Komunikaty Mazursko - Warmińskie. - 1969. - Nr. 4. - S. 571-580.

73. Kamieniecki W. Polityka Bałtycka//Przegląd Współczesny. - 1922. - T. XVI. - S. 256-281.

74. Kampania “Zima”//Polska Zbrojna. - 1938. - 1, 3 stycz.

75. Karpus Z. Działalność gen. Stanisława Bułak - Bałachowicza i jego oddziału w Polsce podczas wojny 1920 r.//Zeszyt Naukowy Muzeum Wojska w Białymstoku. - 1990. - S. 89-101.

76. Karpus Z. Wschodni sojusznicy Polski w wojnie 1920 roku. Oddziały wojskowe ukraińskie, rosyjskie, kozackie i białoruskie w Polsce w latach 1919-1920. - Toruń, 1999.

77. Kiewisz L. Sprawy łotewskie w bałtyckiej polityce Niemiec w latach 1914-1919. - Poznań, 1970.

78. Kłopotowski M., Dobiecki J. Zarys historji wojennej 18 - go pułku ułanów pomorskich. - Warszawa, 1929.

79. Kopański T. 3. eskadra Wywiadowcza 1918-1920. - Warszawa, 1999.

80. Krzesławski J. Polacy na Łotwie//Rząd i Wojsko. - 1920. - 7 marzec.

81. Krsesławski J. Stosunki polsko - łotewskie. - Kraków, 1925.

82. Krzyźanowski B. Oddział wydzielony w działaniach obronnych na szerokim froncie// Bellona. - 1935. - Lipiec - grudzień. - S. 165-207.

83. K. L. Historja pułków i bataljonów saperskich w latach 1918-1928//Przegląd Wojskowo - Techniczny. Saper. - 1928. - T. IV. - Zesz. 6. - S. 319-411.

84. Lāčplēša Kara ordeņa kavalieri. Biogrāfiska vārdnīca. - Rīga, 1995.

85. Latvijas armija 20 gados. - Rīga, 1940.

86. Latvijas iekšējās drošǐbas nostiprināšanas vēsture. 1918-1925. - Rīga, 1925.

87. Latvijas statistiskā gada grāmata. 1920. - Rīga, 1921.

88. Laudyn W. Zarys historji wojennej 7 - go pułku ułanów lubelskich. - Warszawa, 1931.

89. Laurinavičius Č. Lietuvos - Sovietu Rusijos taikos sutartis. - Vilnius, 1992.

90. Lavenieks J. Bruņoto vilcienu pulks. - Izd. V. Laveniece, 1971.

91. Leščius V. Lietuvos kariuomene Nepriklausomybes kovose 1918-1920. Monografija. - Vilnius, 2004.

92. Lewicki R. Zarys historji wojennej 1 - go pułku artylerii polowej Legjonów. - Warszawa, 1929.

93. Lutosławski W. Unja Ludów//Kurjer Powszwechny. - 1920. - 9, 10 stycz.

94. Łatyszonek O. Białoruskie formacje wojskowe 1917-1923. - Białystok, 1995.

95. Łossowski P. Konflikt polsko - litewski 1918-1920//Warszawa, 1996.

96. Łossowski P. Łotwa nasz sąsiad. - Warszawa, 1990. 
97. Łossowski P. Nic nie dzieli - wszystko łączy//Polska Zbrojna. - 1992. - 21-23 luty.

98. Łossowski P. Stosunki polsko - estońskie. 1918-1939. - Gdańsk, 1992.

99. Łossowski P. Stosunki polsko - litewskie w latach 1918-1920. - Warszawa, 1966.

100. Łossowski P. Ustanowienie stosunków Polski z Estonią w latach 1918-1921//Z dziejów polityki i dyplomacji polskiej. - Warszawa, 1994.

101. Łossowski P. Wydarzenia militarne i polityczne wojny 1920 roku na ziemiach Północno - wschodnich//Wojna Polsko - sowiecka 1920 roku. - Warszawa, 1991. S. 41-58.

102. Łukomski G., Polak B. W obronie Wilna, Grodna i Mińska. Front Litewsko - Białoruski wojny polsko - bolszewickiej 1918-1920. - Koszalin - Warszawa, 1994.

103. Łukomski G., Polak B., Wrzosek M. Wojna Polsko - bolszewicka. - T. 1. - Koszalin, 1990.

104. Łukomski G. Walka Rzeczypospolitej o kresy Północno - wschodnie 1918-1920. - Poznań, 1994.

105. Machalski T. Wyzwolenie państw bałtyckich: Finlandii, Estonii i Łotwy//Bellona. - 1937. T. XX. - Zesz. 3. - S. 473-514.

106. Maliszewski E. Polacy na Łotwie. - Kraków, 1922.

107. Markiewicz F. Zarys historji wojennej 7 - go pułku piechoty Legjonów. - Warszawa, 1928.

108. Marszałek Edward Śmigły - Rydz. 1886-1986. - Londyn, 1986.

109. Mączewski P. Misya kap. A. Myszkowskiego//Tygodnik Ilustrowany. - 1920. - 17 kwiec.

110. Merwin [B.] Wzięcie Dźwińska//Nasz Kraj. - 1920. - 14, 15, 16, 17 stycz.

111. Michalczyk W. Zarys historji wojennej 1 - go pułku saperów kolejowych. - Warszawa, 1931.

112. Ms. Daugavpils ieņemšanas operācija 1920. gada 3. janvārī poḷu militārpreses apgaismojumā// Militārais Apskats. - 1938. - Nr. 2. - 250.-260. 1pp.

113. Mularczyk J. Zarys historji wojennej 1 - go pułku strzelców konnych. - Warszawa, 1931.

114. Myrek K. Zarys historji wojennej 3 - go pułku artylerii polowej Legjonów. - Warszawa, 1928.

115. Okulewicz P. Koncepcja „międzymorza” w myśli i praktyce politycznej obozu Józefa Piłsudskiego w latach 1918-1926. - Poznań, 2001.

116. O niepodległość i granice 1914-1921. - Warszawa, 1990.

117. Paluszyński T. Akcja polsko - łotewska w Łatgalii w styczniu 1920 roku//Wojskowy Pregląd Historyczny. - 1995. - Nr. 3-4. - S. 22-36.

118. Paluszyński T. Konflikty graniczne pomiędzy państwami Bałtyckimi: Litwa, Łotwa i Estonia w dobie ich walki o niepodległość w latach 1919-1921//Studia z Dziejów Rosji i Europy Środkowo - Wschodniej. - T. XXX. - 1996. - S. 37-46.

119. Paluszyński T. Podstawy polityki polskiej wobec Łotwy w latach 1919-1920//Łotwa - Polska. Materiały konferencji międzynarodowej. - Ryga, 1995. - S. 55-66.

120. Paluszyński T. Przejście oddziału generała Stanisława Bułak - Bałachowicza z Estonji do polski (marzec $1920 \mathrm{roku}) / /$ Polska i Europa w XIX - XX wieku. - Poznań, 1992. - S. 109-124.

121. Paluszyński T. Rola Leona Wasilewskiego w nawiązaniu stosunków pomiędzy Polską i państwami Bałtyckimi//Niepodległść Polski w 1918 roku a procesy państwowotwórcze w Europie Środkowo - Wschodniej. - Lublin, 1996. - S. 163-184.

122. Paluszyński T. Walka o niepodleglosc Lotwy 1914-1921. - Warszawa, 1999.

123. Pepłoński A. Wywiad a dyplomacja II Rzeczypospolitej. - Toruń, 2004.

124. Pepłoński A. Wywiad polski na ZSSR 1921-1939. - Warszawa, 1996.

125. Pepłoński A. Wywiad w wojnie polsko- bolszewickiej 1919-1920. - Warszawa, 1999.

126. Petruitis J. Mūsu žygiai. Atsiminimai iš kovu su bolševikas ir bermontininkais. - B. v., b. m.

127. Piwoszczik M. Zarys historji wojennej 1 - go pułku czołgów. - Warszawa, 1935.

128. Pobóg - Malinowski W. Najnowsza historia polityczna Polski 1864-1945. - T. II. - Londyn, 1956.

129. Pociej S. Walki 1 baonu 5 p. p. za Dźwiną//Źołnierz Polski. - 1920. - 10 marzec.

130. Počs K. Sanitārā kordona valgos. - R̄̄gā, 1971.

131. Polska w pierścieniu prób i ognia. Rok 1918-1926. - Warszawa, 1933.

132. Pomarański S. Zarys historji wojennej 1 - go pułku piechoty Legjonów. - Warszawa, 1931.

133. Pruszyński M. Dramat Piłsudskiego. Wojna 1920. - Warszawa, 1995. 
134. Pullat R. Od Wersalu do Westerplatte. Stosunki estońsko-polskie w okresie międzywojennym. - Kraków, 2003.

135. Radziņš P. Latvijas atbrīvošanas karš. - 2. d. - Rīga, 1922.

136. Schramm T. Działalność francuskich misji wojskowych w krajach Bałtyckich po I wojnie światowej// Studia i materiały di historii wojskowości. - T. XXVI. - 1983. - S. 263-291.

137. Sīpols V. Slepenā diplomātija. - Rīga, 1965.

138. Skarbek E. Zarys historji wojennej 6 - go pułku Legjonów. - Wilno, 1937.

139. Skirius J. Prof. Augustinas Voldemaras ir taptautinis Lietuvos valstybingumo įteisinimo procesas// Lietuvos užsienio reikalų ministrai 1918-1940. - Kaunas, 1999. - 13-38 p.

140. Skrzypek A. Stosunki polsko - łotewskie 1918-1939. - Gdańsk, 1997.

141. Skrzypek A. Zagadnienie polsko - łotewskiej konwencji wojskowej//Z dziejów stosunków polsko - radzieckich. - T. VI. - Warszawa, 1970. - S. 217-230.

142. Skrzypek A. Związek Bałtycki. - Warszawa, 1972.

143. Smoliński A. Jazda Rzeczypospolitej Polskiej w okresie od 12 X 1918 do 25 IV 1920. - Toruń, 2000.

144. Sołtan W. Polska a Łotwa//Przegląd Narodowy. - 1919. - Zesz. 5. - S. 564-569.

145. Staniewicz W. Zarys historji wojennej kompanji telegraficznej 1 dywizji piechoty Legjonów. - Wilno, 1930.

146. Stefan M. P. Polska a państwa Bałtyckie//Rząd i Wojsko. - 1920. - 7 marzec.

147. Stosunki polsko - łotewskie//Rodzina Polska. - 1938. - List. - S. 448.

148. Stranga A. Ceḷā uz mieru. Krievijas-Latvijas 1920. gada 11. augusta miera līgums//Pretstatu cīña. - Rīga, 1990. - 100.-122. lpp.

149. Stranga A. Latvijas-Padomju Krievijas miera līgums 1920. gada 11. augustā. Latvijas-Padomju Krievijas attiecības 1919.-1925. gadā. - Rīga, 2000.

150. Stranga A. O niektórych problemach polsko - łotewskich stosunków (przełom 1919 - 1920 r.)// Przegląd Zachodniopomorski. - T. 4. - 1989. - Zeszyt 3-4. - S. 147-154.

151. Strauss A. 2. Latvju strēlnieku pulks revolūcijas cīṇās//Latvju strēlnieku vēsture. - II sēj. 2. daḷa. - Strēlnieki Padomju Latvijā. Atmiņas un apraksti. - Maskava, 1934. - 285.-295. lpp.

152. Studnicki W. Zarys państw bałtyckich. Finlandja, Łotwa, Estonja. - Warszawa, 1928.

153. Sundbäk E. Finland in British Baltic Policy. British political and economic interesēts regarding Finland in the aftermath of the First World War. 1918-1925. - Saarijärvi, 2001.

154. Surgailis G. Lietuvas un Latvijas armiju sadarbība neatkarības cīṇu gados//Latvijas armija vēstures griežos. - Rīga, 1993.- 31.-36. 1pp.

155. Szatner Z. Zarys historji wojennej 9 - go pułku piechoty Legjonów. - Warszawa, 1928.

156. Szeptycki S. Front Litewsko - Białoruski. 10 marca 1919 - 30 lipca 1920. - Kraków, 1925.

157. Ščerbinskis V. Somija Latvijas ārpolitikā 1918-1940. Promocijas darbs Dr. hist. grāda iegūšanai. - Rīga, 2002 (LU bibliotēka).

158. Targowski M. Zarys historji wojennej 8 - gp pułku piechoty Legjonów. - Warszawa, 1928.

159. Tieslietu ministrijas un tiesu vēsture 1918-1938. - Rīga, 1939.

160. Vīgrabs J. Latvijas atzīšana “de jure” un uzņemšana Tautu savienībā//Latvijas Vēstures Institūta Žurnāls. - 1938. - Nr. 4. - 569.-612. lpp.

161. Wakar W. Rozwój terytorialny narodowości polskiej. - Cz. II. - Statystyka narodowościowa kresów wschodnich. - Kielce, 1917. - S. 154.

162. Wasilewski L. Wschodnia granica Polski// Bellona. - 1925. - T. XVII. - Zesz. 2. - S. 125-137.

163. Wejtko T. Zarys historji wojennej 3 - go pułku saperów wileńskich. - Warszawa, 1932.

164. Witkowski S. Zarys historji wojennej 23 - go pułku piechoty. - Warszawa, 1928.

165. Zaufał W. Zarys historji wojennej 3 - go pułku artylerii cięźkiej im. króla Stefana Batorego. - Warszawa, 1930.

166. Какурин Н., Меликов В. Гражданская война в России: война с белополяками. - Москва, 2002. 


\section{Personu rādītājs}

Ābols Pēteris (1885-pēc 1921), Latvijas armijas kara ierēdnis, 9. Rēzeknes pulka saimniecības daļas darbvedis 172

Albats Hermanis (1879-1942), Latvijas ārlietu ministra biedrs 205, 215

Aleksanders Herolds (Alexander, 1891-1969), Lielbritānijas armijas pulkvedis-leitnants, Latvijas armijas Vācu zemessargu komandieris. Vēlāk kara ministrs, generālfeldmaršals 72

Aḷbins Janušs (Albin, dz. 1936. g.), poḷu vēsturnieks 55, 56

Anaņjevs Marcians, Daugavpils apriņķa zemnieks 114

Andersons Edgars (1920-1989), latviešu izcelsmes ASV un latviešu trimdas vēsturnieks 17, 77,207

Ansbergs Jānis (1866-1937), jurists, A. Niedras valdības zemkopības ministrs 29

Ansons Eduards (1880-1928), latviešu agronoms 51

Antens Pauls (1893-1935), Latvijas armijas leitnants, atsevišķāas telegrāfa un telefona rotas komandieris. Vēlāk pulkvedis 15

Apsītis Aleksandrs (1887-1934), Latvijas armijas pulkvedis-leitnants, vēlāk pulkvedis 186

Apsītis-Apse Augusts (1895-1947), Latvijas armijas kapteinis, 3. Jelgavas kājnieku pulka bataljona komandieris. Vēlāk pulkvedis 81

Artum-Hartmanis Arnolds (1895-pēc 1939), Latvijas armijas kapteinis, Zemgales divīzijas atsevišşāa eskadrona komandieris. Vēlāk pulkvedis-leitnants 15

Asmanis Oskars (1878-pēc 1941), Latvijas armijas kapteinis, pulkvedis-leitnants, Rīgas pilsētas komandants. Vēlāk pulkvedis 33, 117

Aspazija (1865-1943), latviešu dzejniece 142

Bahs Žanis (1885-1941), Latvijas armijas pulkvedis-leitnants, Virspavēlnieka štāba Operatīvās daļas priekšnieka vietas izpildītājs. Vēlāk ǵenerālis 92

Balodis Jānis (1881-1965), Latvijas armijas virspavēlnieks, pulkvedis, pēc tam ǵenerālis 14, $45,46,49,53,63,65-67,73,92,99,118,126-129,136,142,149,150,152,162,197,199$, 203, 205, 207

Baļiņskis Jans (Baliński), Polijas pārstāvniecības I sekretārs Latvijā 43, 55, 184, 215

Bandrevičs Vilis (1875-1945), Latvijas pārstāvis Lietuvā 52, 61, 67, 117, 120, 134, 197, 198

Baranovskis Vladislavs (Baranowski, 1885-1939), Polijas diplomāts Šveicē 25

Barlickis Norberts (Barlicki, 1880-1941), Polijas Seima sociālistu frakcijas deputāts 195

Bartoševičs Joahims (Bartoszewicz, 1867-1938), Polijas delegācijas ǵenerālsekretāra vietnieks Parīzes Miera konferencē 42

Batorijs Stefans (Batory, 1533-1586), Polijas-Lietuvas valsts karalis 46

Bejnars Karols (Bejnar), Zarasu apriņķa zemnieks 114

Bekers Voldemārs (1881-1941), Latvijas armijas kapteinis, armijas Virspavēlnieka štāba Izlūkošanas dal̨as priekšnieks 100

Berbeckis Leons (Berbecki, 1875-1962), Polijas armijas 3. Leǵionu divīzijas komandieris, brigādes ǵenerālis. Vēlāk ieroču ǵenerālis $71,75,92,137$

Bergs Arveds (1875-1941), Latvijas politiķis, iekšlietu ministrs 190, 205

Berķis Kārlis (1879-pēc 1940), Daugavpils policijas prefekts 104

Berḳis Krišjānis (1884-1941), Latvijas armijas Latgales divīzijas komandieris, pulkvedis. Vēlāk ǵenerālis 74

Bermonts Pāvils (Bermondt, Бермондт, 1884-1973), Krievijas Rietumarmijas virspavēlnieks, ǵenerālmajors 12, 18, 30-34, 41-54, 62, 68, 69, 147, 148, 201, 220 
Berners Ignacijs (Boerner, 1875-1933), Polijas armijas Ģenerālštāba Izlūkošanas daļas kapteinis 30, 101, 103

Bērts Alfreds (Burt, 1876-1949), Anglijas armijas ǵenerālis, militārās misijas vadītājs Latvijā 122,127

Bērziņš Andrejs (1875-1941), Latgales apgabala priekšnieks 54, 105-107, 109, 112, 116, 149, 152,169

Bērziņš Pēteris (1882-1954), Latvijas armijas kara ierēdnis, militārais vēsturnieks 64

Bigge Krišjānis (1866-pēc 1921), Lodzas fabrikants, latvietis 143

Birks Adū (Birk, 1883-1942), Igaunijas valstsvīrs un diplomāts 125

Bisenieks Georgs (1885-1941), Latvijas diplomāts, diplomātiskais pārstāvis Anglijā 121

Blumbergs Eduards, Latvijas armijas Zemgales divīzijas atsevišksāa eskadrona kaprālis 179

Bocinskis (Bociński), Polijas vicekonsuls Harkovā 168

Boguslavskis (Bogusławski), Polijas armijas poručņiks 174

Bolšteins Ludvigs (1888-1940), Latvijas armijas 9. Rēzeknes kājnieku pulka komandieris, pulkvedis, vēlāk ǵenerālis 72

Borhs (Borch), A. Niedras valdības Ārlietu ministrijas ierēdnis 29

Borhs (Borch), Latgales poḷu muižnieks 112

Borhs (Borch), Rietumkrievijas apgabalu administratīvās padomes loceklis 49

Borkēvičs Adams (Borkiewicz, 1896-1958), Polijas armijas 1. Leǵionu pulka poručņiks. Vēlāk pulkvedis 16, 81, 90

Borovskis Stefans (Borowski), Polijas armijas pulkvedis 71

Borskis Jans Maurīcijs (Borski, 1889-1940), poḷu publicists, žurnālists 50

Bortnovskis Vladislavs (Bortnowski, 1891-1966), Polijas armijas 1. Leǵionu divīzijas štāba kapteinis. Vēlāk divīzijas ǵenerālis 74, 150, 152, 153

Boufals Broṇislavs (Bouffat, 1874-1947), Polijas pirmais diplomātiskais pārstāvis Latvijā 12, 43, 48, 54-56, 58, 115, 116, 118, 133, 148, 157-160, 164, 166, 176

Brašņevics Herberts (1892-1969), Latvijas armijas kapteinis, vēlāk pulkvedis-leitnants 122

Brencēns Rūdolfs (1882-pēc 1921), Latvijas armijas saimniecības pārvaldes vecākais sevišksu uzdevumu ierēdnis 96

Briāns Aristīds (Briand, 1862-1932), Francijas valstsvīrs, premjerministrs 214

Briņkis K., Latvijas armijas kareivis 182

Broņevskis Vladislavs (Broniewski, 1897-1962), Polijas armijas 1. Leǵionu pulka podporučņiks, dzejnieks 14, 100, 104

Brunners Pēteris (1889-1969), Apgādības ministrijas ierēdnis 60

Bržezinskis Eduards (1882-1935), Ilūkstes apriņ̧̧a latviešu sabiedriskais darbinieks 129

Budovskis Jānis (1893-pēc 1921), Latvijas armijas virsleitnants 178

Bulaks-Balahovičs Staņislavs (Bułak-Bałachowicz, Булак-Балахович, 1883-1940), Igaunijas armijas virspavēlniecībai pakḷautā Baltkrievu korpusa komandieris, generālmajors 126, $135,179,201$

Bundža Dāvids (1873-1901), latviešu sociāldemokrāts 22

Bušs Oktavians (Busz), Pol̦u grupas štāba Izlūkošanas dal̦as podhorunžijs 133

Butkēvičs (Butkiewicz), Polijas armijas 6. smagās artilērijas pulka poručñiks 107

Butkus Zenons (Butkus, dz. 1951. g.), lietuviešu vēsturnieks 66

Buzeks Juzefs (Buzek, 1873-1936), Polijas Seima deputāts no Mazpolijas 209

Bžezinskis Valeriušs (1875 -1947), Latvijas Tautas padomes loceklis-substitūts, zvērināts advokāts 55 
Caunītis Oskars (1899-1977), Latvijas armijas leitnants. Vēlāk kapteinis 199

Celmiņš Gustavs (1899-1968), Latvijas armijas leitnants, militārā pārstāvja Polijā palīgs. Vēlāk organizācijas "Pērkonkrusts" vadītājs 187, 188

Ceplītis Jānis (1881-1956), Latvijas armijas pulkvedis-leitnants, armijas Virspavēlnieka štāba virsnieks. Vēlāk pulkvedis 191

Cielēns Fēlikss (1888-1964), Latvijas Tautas padomes, Satversmes sapulces loceklis. Vēlāk diplomāts 14, 207

Cinarskis Jans (Cynarski, 1892-1943), Polijas Preses biroja vadītājs Rīgā 17, 166, 216

Čakste Jānis (1859-1927), Latvijas Tautas padomes, Satversmes sapulces priekšsēdētājs. Vēlāk Valsts prezidents 24, 25, 31, 33, 189, 204-207

Čarneckis Voldemars (Čarneckis, 1893-1946), Lietuvas valdības ministrs 47

Čičerins Georgijs (Чичерин, 1872-1936), Padomju Krievijas ārlietu tautas komisārs 123, 130, 161

Daniševskis Jūlijs (1884-1938), latviešu komunists, Padomju Krievijas delegācijas vadītājs 194, 195

Dankers Oskars (1883-1965), Latvijas armijas Zemgales divīzijas komandieris, pulkvedis. Vēlāk ǵenerālis 177, 181, 191

Daņiļēvičs-Čečots Zigmunts (Danilewicz-Czeczot), pirmais Polijas konsulārais aǵents Liepājā 54

Dašiņskis Ignacijs (Daszyński, 1866-1936), Polijas Seima deputāts no Sociālistu partijas 209

Daumanis Ansis (1885-1920), Sarkanās armijas Daugavpils garnizona komandieris. Krita Polijas frontē, būdams 10. divīzijas komandieris 35-37

Deiviss Normans (Davies, dz. 1939. g.) , angḷu vēsturnieks 19, 147

Denīns Marks (Dhenin), Francijas armijas lidotājs, leitnants 53

Deņikins Antons (Деникин; 1872-1947), Dienvidkrievijas Brīvprātīgo armijas virspavēlnieks 25

Diparkē Emanuels (Du Parquet, 1869-1933), Francijas armijas pulkvedis-leitnants, militārās misijas vadītājs Latvijā 58, 175

Dluskis Kazimežs (Dluski; 1855-1930), sociālists, ārsts, Polijas delegācijas loceklis Parīzes Miera konferencē 24

Dmovskis Romans (Dmowski, 1864-1939), vadošs Polijas politiķis, Poḷu Nacionālās komitejas priekšēēēājs Parīzē 26, 27, 124

Dobrodzickis Ježijs (Dobrodzicki, 1884-1934), Polijas armijas majors, 5. Leǵionu pulka komandieris, Daugavpils pilsētas pirmais komandants. Vēlāk brigādes ǵenerālis 99

Dombrovskis Jēkabs (1880-1949), Latvijas armijas 3. Jelgavas kājnieku pulka komandieris, pulkvedis-leitnants. Vēlāk pulkvedis 72, 92, 178

Dombs-Bernackis Stefans (Dąb-Biernacki, 1890-1959), Polijas armijas 1. Leǵionu brigādes komandieris, apakšpulkvedis. Vēlāk divīzijas ǵenerālis 16, 77

Dombskis Jans (Dambski, 1880-1931), Polijas ārlietu viceministrs 195, 196, 209, 211, 215

Donass Fēlikss (1882-1971), Latvijas pārstāvniecības darbvedis Polijā. Vēlāk konsuls Viḷnā $14,57,160$

Dovgjalo Vojcehs (Dowgiałto, 1866-pēc 1939), Latgales muižnieks, Polijas sabiedriskais darbinieks 28,212

Dzelzītis Hugo (1888-1941), Latvijas armijas leitnants. Vēlāk virsleitnants 95

Elksniņš Aleksandrs, kriminālnoziedznieks 101

Eņgélis Krišs, Latvijas armijas Zemgales divīzijas atsevišķā eskadrona kaprālis 179

Erdmanis (Erdmann), baltvācu sabiedriskais darbinieks Latvijā 29 
Everts Jānis (1892-1941, represēts), Latvijas armijas kapteinis, Daugavpils latviešu komandants 102

Feldmanis Jūlijs (1899-1953), Latvijas diplomāts 204

Fiḷipovičs Tituss (Filipowicz; 1873-1953), Polijas diplomāts 208

Firsovs Boriss (Фирсов), Krievijas Rietumu (Bermonta) armijas aviācijas priekšnieks, apakšpulkvedis 49

Gajs Gaja (Гай-Гая, 1887-1937), Sarkanās armijas 3. kavalērijas korpusa komandieris. Vēlāk korpusa komandieris 177

Galvanausks Ernests (Galvanauskas, 1882-1967), Lietuvas Ministru prezidents 47, 52, 117

Galvidis-Bikausks Jons (Galvydis-Bykauskas, 1864-1943), Lietuvas armijas ǵenerālleitnants 61

Gilis Vitauts (Gilys, 1886-1957), Lietuvas diplomāts, pārstāvis Somijā 125

Girdo Staņislavs (1889-1921), Latvijas armijas kapteinis, Daugavpils apriņķa komandants, vē̄āk Daugavpils izlūkošanas nodaļas vadītājs 101

Giza Antonijs (Giza, 1947-2005), poḷu vēsturnieks 18

Godḷevskis Juzefs (Godlewski, 1891-pēc 1926), Polijas armijas poručniks 30

Golbraihs Šajs, Daugavpils iedzīvotājs 114

Golmans,, Daugavpils tirgotājs 172

Gopers Kārlis (1876-1941), Latvijas Apsardzības ministrijas padomes priekšsēdētājs, generālis 204

Gordons Kastrians, Daugavpils iedzīvotājs 114

Grabskis Staņislavs (Grabski, 1871-1949), Polijas politiķis, Seima deputāts no Nacionālās Tautas savienības 195

Graudiņš Eduards (1890-1945), Latvijas armijas pulkvedis-leitnants, Daugavpils pilsētas komandants 102, 105, 108, 109, 111, 112, 151, 152, 155, 169, 172-175, 177

Grigorjevs Nikolajs (1883-pēc 1921), Latvijas policists Višķos 107

Grišāns Jānis (1891-1945), latviešu sabiedriskais darbinieks Latgalē, Latvijas Tautas padomes loceklis $45,47,52$

Grosvalds Jānis (1891-1933), Latvijas armijas 2. Ventspils kājnieku pulka bataljona komandieris, pulkvedis-leitnants. Vēlāk pulkvedis 199

Grosvalds Oḷgerts (1884-1962), Latvijas diplomāts 24, 42, 121, 124, 125

Grundmanis Žanis (1899-1941), Latvijas armijas virsleitnants, Daugavpils apriņķa komandants 116

Gurka Oḷǵgerds (Górka, 1887-1955), Polijas armijas majors, militārais pārstāvis Rumānijā 168

Gutovskis Staņislavs (Gutowski), Polijas Ārlietu ministrijas ierēdnis 138, 139, 142, 156, 157

Hallers Staņislavs (Haller, 1872-1940), Polijas armijas Ģenerālštāba priekšnieks, brigādes, vēlāk divīzijas gènerālis 49, 181, 184

Haņeckis Jakovs (Ганецикй, 1879-1937), Padomju Krievijas diplomāts 186

Hartmanis Mārtiņš (1882-1941), Latvijas militārais pārstāvis Polijā, pulkvedis-leitnants. Vēlāk generālis 45, 47, 48, 56, 59, 92, 157, 160, 166, 184, 186, 187, 202

Hermanovskis Teodors (1883-1964), Latvijas satiksmes un darba ministrs 93

Hickēvičs Ludvigs (Hickiewicz, ?-pēc 1939), Polijas armijas kapteinis, tehniskās grupas komandieris. Vēlāk pulkvedis 98,171

Holsti Rudolfs (Holsti, 1881-1945), Somijas ārlietu ministrs 125

Hovards E. (Hovard), angḷu diplomāts 25

Ičs Martins (Yčas, 1880-1931), Lietuvas politiķis 66 
Jakaitis Aleksandrs (Jakaitis, 1887-1933), Lietuvas armijas virsnieks 61

Jākobsons Aleksandrs (1871-1941), Latvijas konsuls Varšavā 195

Jakovḷevs Aleksandrs (1890-1939), Latvijas armijas kara ierēdnis 63

Janovskis Vitolds (Janowski, 1872-pēc 1922), Latvijas Tautas padomes loceklis 55

Jansons Arvīds (1887-pēc 1923), latviešu tautības Lietuvas armijas pulkvedis-leitnants 187

Jēkabsons Frīdrihs (1874-1941), Latvijas armijas pulkvedis-leitnants. Vēlāk pulkvedis 171

Jodko-Narkēvičs Vitolds (Jodko-Narkiewicz, 1864-1924), Polijas Ārlietu ministrijas ierēdnis. Vēlāk sūtnis Latvijā 24

Jofe Adolfs (Йоффe, 1883-1927), Padomju Krievijas diplomāts 186, 195, 196

Judeņičs Nikolajs (Юденич, 1862-1933), Krievijas Ziemeļrietumu armijas pavēlnieks, infantērijas ǵenerālis 32, 41, 47, 122, 135, 173

Juzvenko Adolfs (Juzwenko, dz. 1939. g.), poḷu vēsturnieks 18

Kalniņš Eduards (1876-1964), Latvijas armijas Galvenās artilērijas pārvaldes priekšnieks, pulkvedis. Vēlāk ǵenerālis 92, 138-140

Kambala Staņislavs (1893-1941), Latvijas Tautas padomes sekretārs, Satversmes sapulces priekšsēdētāja biedrs 29, 45, 47

Kameṇeckis Vitolds (Kamieniecki, 1883-1964), Polijas Seima deputāts, diplomātiskais pārstāvis Latvijā 14, 163-165, 184, 185, 188, 189, 195, 200, 205, 207, 208, 210, 212-216

Kaminskis Vilhelms (1875-1943), Latvijas armijas pulkvedis 186

Kasparsons Kārlis (1865-1962), Latvijas Tautas padomes, Satversmes sapulces loceklis 188

Kathe Maksims (Katche, 1879-1933), latviešu izcelsmes Lietuvas armijas ǵenerālis 187, 203

Kazens Jēkabs, Latvijas armijas kareivis 45

Kīnens Alfreds (Keenan, 1887-pēc 1921), Anglijas militārās misijas vadītājs Latvijā 175

Kerņiks Vladislavs (Kiernik, 1879-1971), Polijas Seima deputāts no Tautas partijas 195

Kersnovskis Aleksandrs (Kiersnowski), Polijas armijas majors, Poḷu likvidācijas komisijas priekšnieks un Daugavpils poḷu komandants 155, 171

Kevišs Leons (Kiewisz), poḷu vēsturnieks 18

Klepackis H. (Klepacki), Polijas Preses biroja vadītājs 54

Klīve Ādolfs (1888-1974), Latvijas Tautas padomes, Satversmes sapulces loceklis 204, 207

Klucis A., Latvijas Apgādības ministrijas ierēdnis 97

Klūge Eduards (1893-1941), Latvijas armijas virsleitnants, sakaru virsnieks pie Polijas 1. armijas. Vēlāk pulkvedis-leitnants 162, 185

Kḷims Petrs (Klimas, 1891-1969), Lietuvas diplomāts 25, 26, 52, 62, 66

Knolls Romans (Knoll, 1888-1946), Polijas diplomātiskās pārstāvniecības padomnieks Latvijā 215

Korks Augusts (Kork, 1887-1937), Padomju Krievijas 15. armijas komandieris. Vēlāk 2. ranga armijas komandieris 74

Korobovskis Vladimirs (1890-1941), Latvijas armijas Aviācijas parka virsleitnants. Vēlāk pulkvedis-leitnants 162

Kosakovskis Mihals Staņislavs (Kossakowski, 1883-1962), Polijas Austrumu zemju civilpārvaldes ǵenerālsekretāra vietnieks 11, 165, 186

Kraulis Andrejs (1898-1947), Latvijas armijas virsleitnants, militārais pārstāvis Lietuvā, vēlāk luterāṇu mācītājs 51, 52, 117

Kroders Pēteris, latvietis, fabrikas direktors Olkušāa, Polijā 59

Kropotkins Nikolajs (Кропоткин; 1872-1937), bijušais Kurzemes, tad Vidzemes vicegubernators, Rietumkrievijas apgabalu administratīvās padomes loceklis, kņazs 49,50 
Krūms Aleksis (1875-pēc 1930), Latvijas armijas kapteinis, pārstāvis gūstekṇu lietās Viḷnāa 59,185

Kšižanovskis Broņislavs (Krzyźanowski, 1876-1943), Viduslietuvas valdošās komisijas Ārlietu departamenta ierēdnis 204

Kšižanovskis Vlodimežs (Krzyźanowski, 1894 - pēc 1939), Polijas armijas 1. Leǵionu brigādes podporučniks. Vēlāk apakšpulkvedis 93

Kučeba Tadeušs (Kutrzeba, 1886-1947), Polijas armijas 1. Legíionu divīzijas un poḷu-latviešu karaspēka grupas štāba priekšnieks, majors. Vēlāk divīzijas ǵenerālis 16, 92, 99, 105, 109, $115,146,149,152,154$

Kučiņskis Zigmunds (1886-1948), Polijas armijas 1. Leǵionu brigādes kapteinis. Vēlāk majors 93

Kuks Aleksandrs (Kukk, 1886-1932), Padomju Krievijas 15. armijas štāba priekšnieks 74

Kuḷiņskis Mečislavs (Kuliński, 1871-1958), Polijas armijas Ģenerālštāba priekšnieka I vietnieks, brigādes, vēlāk divīzijas ǵenerālis 195

Kundziņa Elza, žēlsirdīgā māsa Pirmā pasaules kara laikā 202

Kvelbergs Kārlis (1876-1945), Latvijas Tiesu palātas prokurors 29

Ķēmanis Juris (1883-1937), Latvijas iekšlietu ministra biedrs, advokāts 137-140

Ķeniņš Atis (1874-1961), Latvijas diplomātiskais pārstāvis Polijā, dzejnieks 57-59, 60, 123, 124, 130-132, 138, 142-144, 156, 159, 160, 163, 167, 168, 176, 188, 200, 202, 210, 212, 215

Ķīselis Jānis (1897-1941), Latvijas armijas kapteinis, militārais pārstāvis Lielbritānijā 121

Ķūķis Krišs (1874-1945), Latvijas armijas 12. Bauskas kājnieku pulka komandieris, pulkvedis 191

Ladiga Kazis (Ladiga, 1893-1941), Lietuvas armijas pulkvedis-leitnants. Vēlāk ǵenerālis 35, 38,52

Laidoners Johans (Laidoner, 1883-1953), Igaunijas armijas ġenerālis 118

Laimiņš Eduards (1882-1982), Latvijas armijas pulkvedis, apsardzības ministra biedrs 92, 205

Lappa Sigismunds (1887-pēc 1941), Lietuvas militārā pārstāvja palīgs Latvijā 53

Launags Antons (1884-pēc 1940), Tirdzniecības un rūpniecības ministrijas Tirdzniecības departamenta direktors 45

Laurināvičs Česlovs (Laurinavičius, dz. 1952. g.), lietuviešu vēsturnieks 66, 67

LavenieksJānis(1890-1969),Latvijasarmijas 1.bruṇotādivizionakomandierapal̄̄gs, pulkvedisleitnants. Vēlāk ǵenerālis 83

Lazdiņš Roberts (1891-1932), Latvijas Preses biroja vadītājs Varšavā 123

Legzdiņš Aleksandrs, Polijas militārās žandarmērijas, vēlāk Latvijas armijas kareivis 45

Lejas-Sauss Eduards (1885-1922), Latvijas armijas kapteinis, vēlāk pulkvedis-leitnants 186

Lēvings Aleksandrs (1894-1975), Latvijas armijas rotmistrs, militārā pārstāvja pal̄̄gs Polijā 202, 204-206

Līkums Kārlis, Latvijas Apgādības ministrijas ierēdnis, pārstāvis pie Polijas armijas 97, 113,171

Lilienfelds (Lilienfeldt), baltvācu muižnieks 29

Loids Džordžs Deivids (Lloyd George, 1863-1945), Anglijas premjerministrs 121, 214

Lopato Valerians (Kopatto, 1888-pēc 1945), Polijas konsuls Liepājā. Vēlāk konsuls Rīgā 195

Losovskis Pjotrs (Lossowski, dz. 1925), poḷu vēsturnieks 18, 81, 126, 200, 212, 220

Luce-Birks Aleksandrs (Lutze-Birk, 1878-1974), Polijas konsuls Rīgā, inženieris 31, 43, 44, $55,60,63,136,143,163,164,188,213$ 
Lukasēvičs Juliušs (Eukasiewicz, 1892-1951), Polijas Ārlietu ministrijas Politiski ekonomiskā departamenta Austrumu nodą̧as vadītājs. Vēlāk sūtnis Latvijā 215, 216

L,atuks Prans (Liatukas, 1876-1945), Lietuvas armijas ǵenerālis 38, 51, 52, 81, 117, 118

Ļaudaņskis Staņislavs (Laudański), Polijas armijas majors, Ģenerālštāba Politiskās nodaļas priekšnieks, vēlāk pulkvedis 11, 50

Ļesņevskis Juzefs (Leśniewski, 1867-1921), Polijas armijas divīzijas ǵenerālis, kara lietu ministrs 48

Ļimanovskis Boḷeslavs (Limanowski, 1835-1935), poḷu sociālists 21

Ļisovskis Mikolajs (Lisowski), Drisas apriņķa muižnieks 180

L,ivickijs Andrijs (Лівицький, 1879-1954), Ukrainas Tautas Republikas valstsvīrs un diplomāts 140

Lutoslavskis Vincentijs (Lutosławski, 1863-1954), poḷu filozofs, docents 27

Mahaļskis Tadeušs (Machalski, 1893-1983), Polijas armijas rotmistrs, Lietuvas-Baltkrievijas frontes štāba IV nodą̧as priekšnieks. Vēlāk brigādes ǵenerālis 146

Maksimovs Pēteris (1894-pēc 1924), Latvijas armijas kapteinis, Krāslavas latviešu komandants 103, 109, 116, 153

Maļiševskis Edvards (Maliszewski, 1875-1928), poḷu žurnālists un vēsturnieks 146

Mannerheims Gustavs (Mannerheim, 1867-1951), Somijas armijas virspavēlnieks 125

Matuševskis Ignacijs (Matuszewski, 1891-1946), Polijas armijas Ģenerālštāba II daḷas priekšnieks, pulkvedis 194

Mečkovskis Adams (Mieczkowski, 1876-1953), Polijas Seima deputāts no Nacionālās apvienības 195

Meierovics Zigfrīds Anna (1887-1925), Latvijas valstsvīrs, ārlietu ministrs 23, 24, 30, 31, 34, $40,44,46-49,51,56,61,66,67,119-121,123,125,127,130,131,134,137,142,150,154$, $158,160,161,163,168,176,182,184,188,189,196,204,206,207,208,210,211$

Melderis V., Latvijas Izglītības ministrijas ierēdnis 155

Menders Fricis (1885-1971), Latvijas Tautas padomes, Satversmes sapulces loceklis 207

Merķis Antans (Merkys, 1887-1955), Lietuvas armijas pulkvedis, kara ministrs. Vēlāk Ministru prezidents 118

Mikuļskis (Mikulski), Polijas armijas majors 171

Miltovičs Ferdinands (1884-pēc 1948), Krāslavas miesta vecākais 99

Misiņš Jānis (1895-pēc 1945), Latvijas armijas virsleitnants. Vēlāk kapteinis 178

Miškovskis Aleksandrs (Myszkowski, 1892-1956), Polijas armijas kapteinis, majors, militārais pārstāvis Latvijā. Vēlāk pulkvedis 14, 32, 33, 48, 49, 52, 53, 65, 67, 68, 73-75, 86, 92, 94-96, 106, 115, 117, 118, 119, 122, 127, 129, 130, 133-135, 138, 142, 145, 149, 152, 155, $159,162,163,168,171,172,174,179-181,183,184,188,193-195,197-201,204,205$

Mokets H. B. (Mockett), Lielbritānijas militārās misijas majors 38

Mokžiņskis Juzefs (Mokrzyński), Poḷu Nacionālās komitejas pārstāvis Zviedrijā 23

Mols Heronims (Mohl), Latgales muižnieks, Polijas armijas virsnieks 112

Mončevskis Pšemislavs (Monczewski, 1879-1942), Polijas laikraksta "Gazeta Warszawska" žurnālists 104

Morozovs, policists Daugavpilī 107

Moscickis Ignācijs (Mościcki, 1867-1946), Polijas valstsvīrs, Valsts prezidents 22

Muižnieks Oskars (1884-1940), Latgales apgabala priekšnieks, jurists 103-106, 112

Nagujevskis Broṇislavs (1874-1942), Latvijas Tautas padomes, Tiesu palātas, Kara virstiesas loceklis 55 
Natkēvičs Vlads (Natkevičius, 1893-1945), Lietuvas armijas kapteinis, militārais pārstāvis Latvijā. Vēlāk diplomāts 46, 53, 168, 191

Niedra Andrievs (1871-1942), Latvijas provāciskās valdības vadītājs, mācītājs 29, 30, 47, 60,68

N̦edzjalkovskis Mečislavs (Niedziałkowski, 1893-1940), Polijas Seima deputāts no sociālistu partijas 209

Okenckis Zdzislavs (Okęcki, 1874-1940), Polijas Ārlietu ministrijas Politiski diplomātiskā departamenta direktors 57, 131

Oliņš Pēteris (1890-1962), Latvijas pārstāvniecības I sekretārs Polijā 57, 132, 154-157, 159$161,165,187,188,193,202,206,215$

Ol̦ševskis Antonijs (Olszewski, 1879-1942), Polijas rūpniecības un tirdzniecības ministrs 138

Oḷševskis Bohdans (Olszewski), Polijas armijas 7. Leǵionu pulka virsnieks 150

Oḷšina-Viḷčin̦skis Juzefs (Olszyna-Wilczyński, 1890-1939), Polijas armijas 3. Leǵionu brigādes komandieris. Vēlāk brigādes ġenerālis 71,76

O’Rurks Edvards (O’Rourke, 1876-1943), katoḷu mācītājs, Rīgas arhidiecēzes bīskaps. Vēlāk Dancigas (tag. Gdaņskas) bīskaps 141

Oše Arveds (1896-1989), Latvijas armijas leitnants, armijas virspavēlnieka II adjutants. Vēlāk kapteinis 138

Ozols Kārlis (1888-1948), Padomju Krievijas 15. armijas komisārs 74

Ozols Pēteris (1890-1942), Latvijas armijas Kara satiksmes pārvaldes priekšnieks, kapteinis. Vēlāk pulkvedis-leitnants 99

Ozols Voldemārs (1884-1949), Latvijas armijas pulkvedis-leitnants 61, 62, 186, 187, 198, 203 , 205

Pabērzs Juris (1891-1961), Latgales latviešu sabiedrisks darbinieks. Vēlāk valstsvīrs 167, 201

Paderevskis Ignacijs (Paderewski, 1860-1941), Polijas premjerministrs un komponists 29, 42, 43, 48, 57, 59, 210, 211, 216

Paļušiņskis Tomašs (Paluszyński, dz. 1967. g.), poḷu vēsturnieks 19, 32, 42, 50, 140

Pateks Stanisislavs (Patek, 1866-1944), Polijas ārlietu ministrs 124, 131, 138, 139, 142, 154 , 156,157

Paulockis Arnolds (1892-1934), Latvijas armijas 1. Brunotā diviziona vilciena komandieris, kapteinis. Vēlāk pulkvedis-leitnants 15, 84

Peniķis Mārtiņš (1874-1964), Latvijas armijas pulkvedis, vēlāk karaspēka inspektors, generālis 92,186

Peploņskis Andžejs (Pepłoński), poḷu vēsturnieks 133

Pētersons Herberts (1890-pēc 1940), Latvijas armijas Virspavēlnieka štāba virsleitnants 92

Pilsudskis Juzefs (Pitsudski, 1867-1935), Polijas valsts priekšnieks un armijas virspavēlnieks, maršals $5,6,14,20-22,24-27,29,30,32-34,42,43,45,48,52,53,55,60,63-65,67,69$, $91,92,99,100,103,109,110,117,124-129,132,136,140,141,149,158,159,165,167,176$, 194, 197, 200, 202, 212, 213, 216, 220, 221

Plāters-Broels Leons (Plater-Broel; 1897-1980), Latgales muižnieks, Polijas armijas poručniks. Vēlāk kapelāns apakšpulkvedis 116, 171, 179, 195

Plāters-Broels Mihals Heromims (Plater-Broel, 1834-1924), Latgales muižnieks 116

Pobugs-Maļinovskis V. (Pobóg-Malinowski, 1899-1962), poḷu vēsturnieks 18

Počs Kārlis (dz. 1936. g.), latviešu vēsturnieks 17, 19

Polis Jāzeps (1881-pēc 1934), Latvijas politiskais darbinieks un tirgotājs 60 
Popovičs Boḷeslavs (Popowicz, 1878-1937), Polijas armijas 6. Leǵionu pulka komandieris, majors. Vēlāk brigādes ǵenerālis 35,71

Poska Jāns (Poska, 1866-1920), Igaunijas valstsvīrs 25

Požerskis Mečislavs (Poźerski, 1884-1943), Polijas armijas pulkvedis, militārais pārstāvis Somijā 125

Preisbergs Jānis (1895-1967), Latvijas armijas virsleitnants 178

Pristors Aleksandrs (Prystor, 1874-1941), Polijas armijas kapteinis, valdības sakaru virsnieks Viduslietuvā 202

Pruss-Boguslavskis Stanislavs (Prus-Bogusławski), Polijas armijas rotmistrs 33, 34, 43, 61, 125

Puhal̦skis (Puchalski), Polijas armijas virsnieks 34

Punga Hermanis (1877-1941), latviešu sociāldemokrāts, vēlāk Latvijas diplomāts 22

Puriņš Jānis (1889-1944), Latvijas armijas Kurzemes divīzijas komandiera vietas izpildītājs, pulkvedis-leitnants. Vēlāk pulkvedis 72-75, 86-88, 90, 92-94, 130

Pusta Karels (Pusta, 1883-1964), Igaunijas diplomāts un valstsvīrs 23

Radziņš Pēteris (1880-1930), Latvijas armijas Virspavēlnieka štāba priekšnieks, pulkvedis, generālis $12,15,47,62,63,65,67,68,74,75,87,92-95,104,116-118,126,127,129,133$, 137, 138, 142, 162, 163, 174, 179, 182, 183, 188, 194, 198, 199, 202, 207

Radzivils Stanislavs (Radziwitt, 1880-1920), Polijas armijas rotmistrs, virspavēlnieka adjutants 33,63

Rainis (1865-1929), latviešu dzejnieks 142, 143, 188

Rajskis Ļudomils (Rayski, 1892-1977), Polijas armijas poručṇiks, lidotājs. Vēlāk brigādes generālis 30

Ramats Kārlis (1885-1931), Latvijas armijas pulkvedis-leitnants. Vēlāk pulkvedis 92, 162, 188, 194, 203, 207

Rambolds Horiss Džordžs (Rumbold, 1869-1941), Lielbritānijas sūtnis Polijā 64

Rapeports Leopolds (1889-pēc 1921), Latvijas tirgotājs 60

Ratnieks Edgars (1896-1949), Latvijas armijas 4. Valmieras kājnieku pulka kapteinis. Vēlāk pulkvedis-leitnants 20

Rati Ahils (Ratti, 1857-1939), Romas pāvesta nuncijs Polijā. Vēlāk pāvests Pijs XI 141

Rebūls Konstantins (Reboul), Francijas armijas pulkvedis-leitnants, militārās misijas vadītājs Lietuvā 118

Ridzs-Smiglijs Eduards (Rydz-Śmigły, 1886-1941), Polijas armijas 1. Leǵionu divīzijas un operatīvās grupas komandieris, brigādes ǵenerālis. Vēlāk maršals 10, 14, 20, 64, 65, 68, $71,74-77,81,82,84-87,89,90,92,93,96,101-103,105,106,109,112-116,119,123,127$, $128,133,136,138,141,149-155,163,168,172$

Rīkemans Vilhelms (Rückeman, 1894-1986), Polijas armijas 6. Leǵionu pulka bataljona komandieris, kapteinis. Vēlāk brigādes ǵenerālis 110

Romers Antons (Romer), Latgales poḷ muižnieks 116

Ronis Alfreds (1898-1942), Latvijas armijas Kurzemes divīzijas štāba virsseržants, vēlāk pulkvedis-leitnants 74

Rouens-Robinsons H. R. (Rowan-Robinson), Anglijas militārās misijas vadītājs Polijā 117

Rozenšteins Hugo (1892-1941), Latvijas armijas pulkvedis-leitnants, Virspavēlnieka štāba Operatīvās daļas ārējās izlūkošanas priekšnieks. Vēlāk generālis 92

Rozvadovskis Tadeušs (Rozwadowski, 1866-1928), Polijas armijas Ģenerālštāba priekšnieks, divīzijas, vēlāk ieroču ġenerālis 199, 215

Rudzītis Dāvids (1881-1939), Latvijas Valsts kancelejas direktors 29 
Rummels Juliuss (Rómmel, 1881-1967), Polijas armijas 1. Leǵionu artilērijas brigādes komandieris, pulkvedis. Vēlāk divīzijas ǵenerālis 76,92

Ruškēvičs Jēkabs (1883-1942), Latvijas armijas pulkvedis. Vēlāk generālis 186

Ružickis A. (Róźycki), Polijas armijas podporučņiks 172

Sahnovskis Zigmunds (Sachnowski), Polijas laikraksta "Kurjer Poranny” žurnālists 215

Salcēvičs Julians (Satcewicz, 1871-1937), Latvijas Tautas padomes loceklis, Polijas Goda konsulārais aǵents Rīgā 31, 55, 62, 195

Samsons-Himmelstjerna Mikolajs (Samson-Himmelstjerna, 1880-1931), Polijas diplomātiskais pārstāvis Somijā 125

Sapeha Eustahijs (Sapieha, 1881-1963), Polijas ārlietu ministrs 194, 196, 200, 209-212, $214-216$

Sausais Jānis (1890-1941, represēts), Latvijas armijas virsleitnants, Daugavpils Izlūkošanas nodą̧as priekšnieks 100, 101

Savinkovs Boriss (Савинков, 1879-1925), krievu revolucionārs, pretlieliniecisko spēku vadītājs 13

Seile Valerija (1891-1970), Latgales latviešu sabiedriskā darbiniece, politiķe, Tautas padomes locekle un Satversmes sapulces deputāte 29

Sēja Ludvigs (1877-1962), Latvijas Ārlietu ministrijas departamenta direktors, diplomāts $120,121,133,135,137,138,140,183,184,195,196,204,210,216$

Serejskis Marians (Serejski, 1897-1975), poḷu vēsturnieks 11

Seskis Jānis (1877-1941), Latvijas delegācijas loceklis Parīzes Miera konferencē, diplomāts 30,42

Sforca Karlo (Sforza, 1872-1952), Itālijas ārlietu ministrs 214

Siliņš Vilhelms, Zemgales divīzijas atsevišķā eskadrona seržants 162

Sīmansons Dāvis (1859-1933), Latvijas armijas virspavēlnieks, ǵenerālis 32, 33, 45

Simpsons Džeimss Jangs (Simpson, 1873-1934), skotu diplomāts, ǵeogrāfs 192, 208

Simsons Jānis, publicists 29, 157, 158

Sīpols Vilnis (1923-2001), padomju vēsturnieks 17

Sirevičs Staņislavs (Syrewicz, 1858-1926), Polijas Goda konsuls Daugavpilī, zvērināts advokāts 167, 195, 200

Skangelis Nikolajs (1880-1942), Latvijas Satversmes sapulces loceklis 116

Skrapce Pēteris (1884-1960), Latvijas armijas pulkvedis-leitnants. Vēlāk ǵenerālis 171

Skšinsskis Vladislavs (Skrzyński, 1873-1937), Polijas Ārlietu ministrijas valsts apakšsekretārs 45,48

Skšipeks Andžejs (Skrzypek), poḷu vēsturnieks 18, 138, 189

Skulskis Leopolds (Skulski, 1877-1939), Polijas premjerministrs 132, 212

Skurkēvičs Grigorijs (Skurkiewicz), Polijas armijas 36. pulka maksas aǵents, spekulants 181

Slaveks Valerijs (Stawek, 1879-1939), Polijas armijas kapteinis, Lietuvas-Baltkrievijas frontes štāba Izlūkošanas daḷas priekšnieks. Vēlāk premjerministrs 33, 47, 63

Slezevičs Mikols (Sleževičius, 1882-1939), Lietuvas valstsvīrs, Seima deputāts 66, 203

Smaren-Svarinskis Vilhelms (1887-1940), latviešu sociāldemokrāts, vēlāk Latvijas Nacionālā kluba aktīvists 22

Smetona Antans (Smetona, 1874-1944), Lietuvas Valsts prezidents 46

Sokoḷnickis Mihals (Sokolnicki, 1881-1967), Polijas sūtnis Somijā 125, 188

Soltans Vladislavs (Sołtan, 1877-1943), Latgales muižnieks, Polijas Austrumu nomaļu pārvaldes Latvijas nodaļas vadītājs. Vēlāk iekšlietu ministrs 28-30

Sorokovskis (Sorokowski), Polijas konsuls Odesā 168 
Spāde Kārlis (1880-1953), tirdzniecības kuğa kapteinis. Vēlāk rēderis 33, 45, 47, 51, 57, 59

Spariņš Vilhelms, Latvijas armijas kareivis 45

Springovičs Antonijs (1876-1958), katoḷu mācītājs, Rīgas arhidiecēzes bīskaps 141

Stange Ernests (1877-1944) Latvijas armijas Kurzemes divīzijas luterāņu mācītājs 169

Stankēvičs J. (Stankiewicz), Polijas armijas kapteinis 194

Staževskis M. (Starzewski), Polijas armijas Ģenerālštāba majors 140

Steinmanis Heinrihs (1875-1932), Latvijas pārstāvniecības tirdzniecības atašejs Polijā 57, 143

Stranga Aivars (dz. 1954. g.), latviešu vēsturnieks 17, 63, 161, 196

Strautnieks Žanis (1902-1993), Latvijas armijas kareivis 191

Strods Pēteris (1891-1941), Latvijas armijas leitnants, pilnvarotais gūstekņu lietās Polijā 58, 145

Studņickis-Gizberts Vladislavs (Studnicki-Gizbert, 1865-1953), Latgales muižnieks, Polijas politiķis $16,17,166,201,202$

Svencickis Tadeušs (Święcicki, 1893-1973), Polijas laikraksta “Gazeta Polska” žurnālists, virsnieks 42

Svežbiņskis Mihals (Świerzbiński), Latgales muižnieks, 1921.-1930. gadā Polijas konsuls Daugavpilī 11, 146, 168, 174

Šadurskis Vaclavs (Szadurski, 1878-1958), Latgales muižnieks, Polijas Braslavas apriņķa vecākais 166

Šahno Bohdans (Szachno, 1868-1955), Latgales muižnieks 166

Šeptickis Staņislavs (Szeptycki, 1867-1950), Polijas armijas Lietuvas-Baltkrievijas frontes pavēlnieks, divīzijas, pēc tam ieroču ǵenerālis 64, 76, 83, 92, 101, 123, 127, 162, 186

Šimkus Jons (Šimkus, 1873-1944), Lietuvas valstsvīrs 35

Šlıūps Jons (Šliūpas, 1861-1944), Lietuvas diplomāts 46, 53, 61

Špakovskis Antons, Daugavpils policists 107

Šūmanis Vilis (1887-1948), Latvijas Ārlietu ministrijas departamenta direktors 204

Švejcers Ludviks (Szwejcer), Polijas armijas poručņiks 162, 179

Švīders Kārlis (1876-1954), Latvijas armijas pulkvedis-leitnants. Vēlāk pulkvedis 150, 153

Talats-Kelpša Edvards (Tallat-Kelpša, 1896-1966), Lietuvas armijas kapteinis, militārais pārstāvis Latvijā. Vēlāk ǵenerālis 182, 191, 206

Talents Stīvenss (Tallents, 1884-1958), Anglijas pārstāvis sabiedroto misijā Baltijas valstīs, generālis 52, 122, 192

Tarnovskis Adams (Tarnowski, 1892-1956), Polijas Ārlietu ministrijas Politiskā departamenta ierēdnis $57,163,188$

Tenisons Jāns (Tönisson, 1875-1941), Igaunijas valstsvīrs 125, 126

Tepfers Herberts (1892-1966), Latvijas armijas virsleitnants, ārlietu ministra adjutants. Vēlāk kapteinis 47

Terners Arturs (Turner, 1878-1952), Anglijas pārstāvis sabiedroto misijā Baltijas valstīs, ġenerālis 121,133

Tone Augusts (1887-1949), Latvijas armijas kapteinis, Kurzemes divīzijas štāba priekšnieks. Vēlāk pulkvedis 92

Traubergs Eduards (1883-1965), Latvijas Tautas padomes loceklis, uzṇēmējs 60

Treimanis J., Latvijas uzņēmējs 60

Trockis Ļevs (Троикий, 1879-1940), Padomju Krievijas valstsvīrs 161

Trompčiņskis Vojcehs (Trąmpczyński, 1860-1953), Polijas Seima Senāta priekšsēdētājs 212, 213 
Tščin̦skis Boḷeslavs Kazimežs (Trzczyński), Polijas armijas 18. ulānu pulka poručņiks 179, 180

Turks Aleksandrs (1894-pēc 1922), Latvijas armijas virsleitnants, 1. Daugavpils garnizona rotas komandieris. Vēlāk kapteinis 77

Turovskis Vladislavs (Turowski, 1894-pēc 1923), Polijas armijas podporučniiks, 582. aviācijas eskadril̦as lidotājs 53

Ulmanis Indriķis (1894-pēc 1926), Latvijas armijas virsleitnants, 1919. g. oktobrī-decembrī - militārā pārstāvja palīgs Polijā 56

Ulmanis Kārlis (1877-1942), Latvijas Ministru prezidents. Vēlāk Valsts prezidents 29, 30, 35 , 47, 49, 52, 53, 55, 62, 67-69, 117, 129, 188-190, 204, 205, 207

Vaicuška Prans (Vaiciuška), ārsts, Lietuvas armijas ǵenerālis, Lietuvas pārstāvis Igaunijā 125

Vakars Vlodzimežs (Wakar, 1885-1933), poḷu demogrāfs 23

Valters Miķelis (1874-1968), Latvijas valstsvīrs un diplomāts 22, 210

Vangins Zenons (Wangin), Polijas armijas 36. pulka maksas aǵents, spekulants 181

Vardejns-Zagurskis Tadeušs (Wardejn-Zagórski), Polijas armijas podporučniks, vēlāk majors 32

Vasil̨evskis Leons (Wasilewski, 1870-1936), pirmais Polijas ārlietu ministrs, Valsts priekšnieka pilnvarotais Baltijas valstu lietās, diplomātiskais pārstāvis Igaunijā 11, 14, 24, 25, 29-31, $33,47,48,52,54,125,131,136,138,139,157,157,166,188,195,200,206,215$

Vasil̨evskis (Wasilewski), Viduslietuvas armijas poručņiks 204

Vaškēvičs Ludviks (Waśkiewicz, 1888-1976), Polijas Seima deputāts no Nacionālās strādnieku partijas 195

Veiss Aleksandrs (1889-1944), Latvijas armijas sakaru virsnieks poḷu-latviešu karaspēka grupas štābā, pulkvedis-leitnants. Vēlāk pulkvedis 74, 82, 91-94, 96, 99, 102, 103, 109, $112,136,150,151,153$

Velkme Jānis (1877-1963), Latgales latviešu katoḷu mācītājs, sabiedriskais darbinieks 29

Veḷoglovskis Felikss (Wielogłowski), Viduslietuvas Tirdzniecības un rūpniecības departamenta vicedirektors 204

Vennola Juho (Vennola, 1872-1938), Somijas premjerministrs 125

Veņava-Dlugoševskis Boḷeslavs (Wieniawa-Dlugoszewski, 1881-1942), Polijas armijas virspavēlnieka ǵenerāladjutants, apakšpulkvedis. Vēlāk brigādes ǵenerālis 202

Vesmanis Fridrihs (1875-1941), latviešu sociāldemokrāts, vēlāk Latvijas politiķis un diplomāts 22

Vihḷiņskis Mihals (Wichliński, 1882-1960), Polijas Seima deputāts no kristīgo demokrātu partijas 195

Vilsons Vudro (Vilson, 1856-1924), ASV prezidents 5

Virgoličs P. (Virgolich, Вирголич), Bermonta Krievijas Rietumarmijas korpusa komandieris Lietuvā, žandarmērijas pulkvedis 47

Virza Edvarts (1883-1940), latviešu dzejnieks 201

Višiņskis K. (Wiszyński), Polijas armijas podporučniks, pretizlūkošanas virsnieks 101

Višņevskis (Wiśniewski), Polijas armijas 1. Leǵionu brigādes podporučņiks 93

Vītols Jānis (1876-1952), Latvijas armijas pulkvedis-leitnants. Vēlāk pulkvedis 186

Vitoss Vincentijs (Witos, 1874-1945), Polijas politiķis, Seima deputāts no Tautas partijas. Vēlāk premjerministrs 209, 212

Vizbars Kazimirs (Vizbaras, 1872-1941), Latvijas lietuviešu sabiedriskais darbinieks, Lietuvas diplomāts 51,53 
Vojevudzkis Silvestrs (Wojewódzki, 1892-1937), Polijas armijas Lietuvas-Baltkrievijas frontes štāba poručņiks 153

Vojtovičs A. (Wojtowicz), Polijas militārā izlūkdienesta aǵents 119

Voldemars Augustins (Voldemaras, 1883-1942), Lietuvas ārlietu ministrs. Vēlāk premjerministrs $34,66,67,119,120,134$

Zālītis Jānis (1874-1919), Latvijas Tautas padomes loceklis 44-46, 56

Zaļeskis Vincents (Zaleski, 1873-1942), aptiekas īpašnieks Daugavpilī 128

Zaleskis Zigmunts (Zaleski, 1882-1967), poḷu literatūras vēsturnieks, dzejnieks, Polijas delegācijas loceklis Parīzes Miera konferencē 25

Zāmuels Voldemārs (1872-1948), Latvijas Tautas padomes, Satversmes sapulces loceklis 61, 125,188

Zariņš Kārlis (1879-1963), Latvijas Tautas padomes loceklis, vēlāk diplomāts 14, 33, 34, 40, 45,59

Zauņus Dovs (Zaunius, 1892-1940), Lietuvas diplomāts 125, 198, 204

Zeiferts Ābrams, Daugavpils uzṇēmējs 108

Zemgals Gustavs (1871-1939), Tautas padomes priekšsēdētāja biedrs. Vēlāk Valsts prezidents 29

Zimins K. (Зимин), Bermonta civilpārvaldes ierēdnis 52

Zinčenko, Daugavpils policists 107

Zinkels Eižens, Daugavpils pilsētas valdes priekšsēdētājs 104

Zīverts Kārlis (1897-1943), Latvijas armijas kapteinis. Vēlāk pulkvedis-leitnants 72

Želiigovskis Lucjans (Źeligowski, 1865-1947), Polijas armijas divīzijas, vēlāk ieroču ǵenerālis. Îstenoja Vilı̣nas ieņemšanas operāciju 9, 11, 197-211, 217, 218

Žukausks Silvestrs (Žukauskas, 1860-1937), Lietuvas armijas virspavēlnieks, ǵenerālis 34

Žuks Konstantins (Žukas, 1884-1962), Lietuvas armijas pulkvedis, apsardzības ministrs un armijas virspavēlnieks 198 
LU Akadēmiskais apgāds Baznīcas iela 5, Rīga, LV-1010

Tālrunis: 7034535

Iespiests

SIA "LATGALES DRUKA" 